\title{
Uranium in Coal
}

in the Western

United States

G E O L O G I C A L S U RVEY B U L L E T I N 1 O 55

This report concerns work done on behalf of the U. S. Atomic Energy Commission and is published with the permission of the Commission

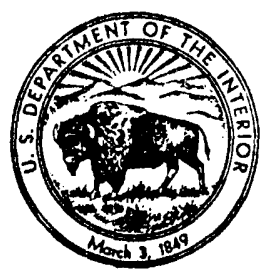





\section{Uranium in Coal}

\section{in the Western}

United States

GEOLOGICAL S U R VEY B U LLETIN 1055

Based on the joint and individual work of Norman M. Denson, George $O$. Buchman, James R. Gill, William J. Hail, Jr., Roy C. Kepferle, William J. Mapel, Harold Masursky, Robert E. Melin, George W. Moore, George N. Pipiringos, Charles B. Read, James $M$. Schopf, James D. Vine, and Howard D. Zeller

This report concerns work done on behalf of the U.S. Atomic Energy Commission and is published with the permission of the Commission

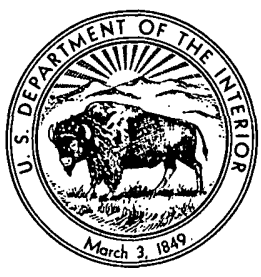




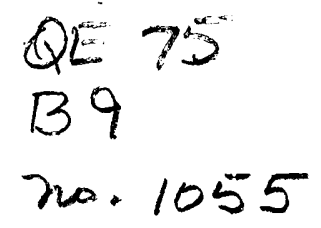

\section{UNITED STATES DEPARTMENT OF THE INTERIOR}

FRED A. SEATON, Secretary

\section{GEOLOGICAL SURVEY}

Thomas B. Nolan, Director 


\section{CONTENTS}

[The letters in parentheses preceding the titles designate individual chapters]

Page

(B) Uranium-bearing lignite in northwestern South Dakota and adjacent States, by N. M. Denson, G. O. Bachman, and H. D. Zeller

(C) Core drilling for uranium-bearing lignite in Harding and Perkins Counties, South Dakota, and Bowman County, North Dakota, by

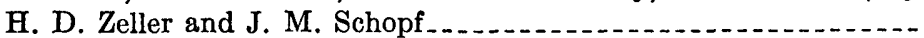

(D) Core drilling for uranium-bearing lignite, Mendenhall area, Harding County, South Dakota, by J. R. Gill, H. D. Zeller, and J. M. Schopf

(E) Uranium-bearing lignite in southwestern North Dakota, by G. W. Moore, R. E. Melin, and R. C. Kepferle........

(F) Reconnaissance for uranium in the Ekalaka lignite field, Carter County, Montana, by J. R. Gill

(G) Uranium-bearing coal in the Red Desert area, Sweetwater County, Wyoming, by Harold Masursky and G. N. Pipiringos.

(H) Tertiary geology of the Goose Creek district, Cassia County, Idaho, Box Elder County, Utah, and Elko County, Nevada, by W. J. Mapel, and W. J. Hail, Jr.

(I) Geology and uranium deposits in carbonaceous rocks of the Fall Creek area, Bonneville County, Idaho, by J. D. Vine

(J) Uranium-bearing coal and carbonaceous shale in the La Ventana Mesa area, Sandoval County, New Mexico, by G. O. Bachman, J. D. Vine, C. B. Read, and G. W. Moore

Index 


\section{Introduction}

By NORMAN M. DENSON

URANIUM IN COAL IN THE WESTERN UNITED STATES

GE OLOG I C A L S U R V E Y B U L L E T I N $1055-\mathrm{A}$

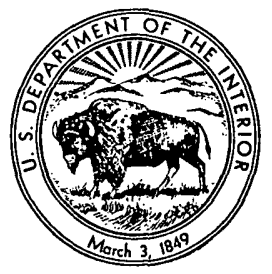





\section{CONTENTS}

General statement

Historical background..... 2

Source and accumulation of uranium

Possible economic value of uranium-bearing coal_...................... 4

Guides in evaluating evidence for uranium-bearing coal in unexplored areas_. $\quad 5$

Areas that may contain uranium-bearing coal_.

Literature cited. .

Index

\section{ILLUSTRATIONS}

Figure 1. Index map showing areas of uranium-bearing coal and carbonaceous shale in the western United States. . ......... 2. Areas that may have uranium-bearing coal in the western

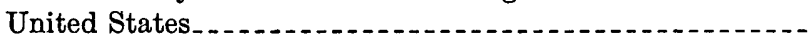

Page 



\title{
URANIUM IN COAL IN THE WESTERN UNITED STATES
}

\section{INTRODUCTION}

\author{
By Norman M. Denson
}

\section{GENERAL STATEMENT}

During the 5-year period 1950-1954, the United States Geological Survey made extensive investigations of the occurrence and distribution of uranium in coal and related carbonaceous materials throughout large areas in the western United States. By use of portable geiger and scintillation counters and carborne scintillation equipment, hundreds of exposures of coal were tested for radioactivity, and samples were collected for chemical and spectrographic analyses. Subsequently, exploratory core-drilling was carried out in several coalbearing areas in North Dakota, South Dakota, Wyoming, and Idaho, by the United States Bureau of Mines and the United States Geological Survey, to determine the uranium content of coal beds below the surface. These investigations have shown that several large coal deposits in the Tertiary basins of the Rocky Mountain and the Great Plains regions contain very low grade concentrations of uranium. The uranium content of the coal in these deposits is not uniform but ranges from about 0.005 to 0.02 percent. Within the low-grade uranium-bearing coal deposits, smaller irregular masses of coal containing 0.1 percent or more uranium have been found in places. A number of uranium minerals including autunite, zeunerite, torbernite, carnotite, becquerelite, and coffinite have been identified in the higher grade uraniferous coals, but much of the uranium is inconspicuously disseminated in the carbonaceous material. In the larger and lower grade deposits individual uranium minerals have not been identified. The uranium is disseminated in the carbonaceous material.

This chapter presents an outline of the history and extent of the Survey's investigations of uraniferous coal in the Western States and a short discussion of the origin of the uranium in the coal; subsequent chapters in this report deal with the geology and economic 
potentialities of those areas where uranium was found in sufficient amount in coal to be of possible future value. Briefly mentioned are other areas not examined in detail where the geologic setting is favorable for the occurrence of similar deposits.

This report is based on work undertaken as part of a program of exploration for radioactive materials for the U. S. Atomic Energy Commission and is published with the permission of the Commission.

\section{HISTORICAL BACKGROUND}

Although the association of uranium with carbonaceous material has been recognized for many years (Berthoud, 1875; Boutwell, 1905; Unkovskaya, 1940; Davidson and Bowie, 1951; and Gruner, 1954), it has long been known that most coal beds are some of the least radioactive of the common sedimentary strata for the uranium content of coal is generally very low (Russell, 1945; Newmarch, 1950; Couret, 1952 ; and Davidson and Ponsford, 1954). Little attention was given to the possibility that significant quantities of uranium occur in coal beds in the western United States until 1945, when Slaughter and Nelson of the Geological Survey discovered extensive low-grade deposits of uranium-bearing coal in the Great Divide Basin of southcentral Wyoming (Slaughter and Nelson, written communication, 1946). In 1948 and 1949 beds of coal in the Williston basin area of North and South Dakota were found to be uranium-bearing by Wyant and Beroni (written communication, 1949) and by Beroni and Bauer (written communication, 1952). In 1950 Denson, Bachman, and Zeller continued studies of uranium-bearing coals in the southern part of the basin to evaluate their economic possibilities and to determine the geologic factors controlling the accumulation of the uranium. Emphasis was placed on finding coal in beds of minable thickness and grade that could be used as fuel and from which uranium could be extracted from the ash as a by-product. From 1951 through 1954 the Geological Survey conducted extensive investigations for uraniumbearing coal and carbonaceous shale in many other areas in the Western States. These studies included brief examinations of several of the better known deposits of Cretaceous and Tertiary coal in the Rocky Mountain province from southern Montana to New Mexico, the Colorado Plateau, the Great Basin, and the Pacific Coast region. Results of some of these investigations, most of which were negative, have been briefly described in reports by Bachman and Read (1952); Beroni and McKeown (1952); Gude and McKeown ${ }^{1}$; Love (1952); Vine

\footnotetext{
1 Gude, A. J., 3rd, and McKeown, F. A., 1952, Results of exploration at the Old Leyden coal mine, Jefferson County, Colorado: U. S. Geol. Survey open-flle report.
} 
and Moore (1952) ; Bachman, Baltz, and O'Sullivan (written communication, 1953); Duncan (1953a); Hail and Gill (1953); Troyer and others (1953); Vine and Flege (1953); Griggs (1954); Moore and Stephens (1954); Staatz and Bauer (1954) ; Baltz (written communication, 1955) ; Zeller (1955); and Wyant, Sharp, and Sheridan (1956).

\section{SOURCE AND ACCUMULATION OF URANIUM}

Three hypotheses of source and accumulation have been advanced by geologists to explain the occurrence of uranium in coal of the Western States. They are:

1. Syngenetic.-Uranium was deposited from surface waters by living plants or in dead organic matter in swamps prior to coalification.

2. Diagenetic--Uranium was introduced into the coal during coalification by waters bringing the uranium from areas marginal to the coal deposits or from the consolidating enclosing sediments.

3. Epigenetic.-Uranium was introduced in the coal after coalification and after consolidation of the enclosing sediments by ground water deriving uranium from hydrothermal sources or from unconformably overlying volcanic rocks.

The source and manner of accumulation of uranium in coal are briefly discussed here, because a systematic search for additional deposits will be successful chiefly to the extent that it is guided by valid concepts of origin. The epigenetic hypothesis favored by the author and presented in greater detail in chapter $B$ is but one of the possible processes, as indicated above, by which uranium may be concentrated in coal. The author wishes, however, to emphasize that the accumulation of uranium in coal may vary markedly from place to place and that each newly discovered deposit should be objectively considered and interpreted in relation to the geologic history of the region in which each deposit occurs.

As a result of the investigation of uraniferous lignite in the Dakotas in 1948 and 1949, Gott, Wyant, and Beroni (1952) concluded that the uranium was probably of syngenetic origin, having been initially concentrated from swamp waters by the vegetation from which the coal was formed. Beroni and Bauer (written communication, 1952) recognized, however, that the lignite is interbedded with strata in the Dakotas that contain minerals of volcanic origin and suggested that the uranium might be of diagenetic origin, having been redistributed from volcanic materials during or shortly after the deposition of the lignite. Systematic sampling and regional studies of beds of radioactive lignite in the Dakotas and eastern Montana by Denson, Bachman, and Zeller in 1950 (see chapter B of this bulletin) led them to 
propose the theory that the uranium in these deposits is of epigenetic origin, secondarily derived by leaching of the volcanic materials in the Oligocene and Miocene rocks that at one time covered most of the region. They thought that the uranium was a primary constituent of volcanic ash and that the uranium was leached from it by ground water during weathering and devitrification. This concept was based largely on the fact that beds of uranium-bearing lignite, irrespective of age, closely underlie the unconformity at the base of tuffaceous rocks of the White River group, and that the greater concentrations of uranium occur in the upper parts of the stratigraphically highest lignite beds.

Application of this theory to the search for other deposits during 1950 led to the discovery of uranium-bearing coal in the Lost Creek coal field in the southern part of the Powder River Basin of eastern Wyoming (Love, 1952), and to similar discoveries in 1951 in the Ekalaka Hills area of Montana, the Fall Creek and Goose Creek areas of Idaho, and the La Ventana Mesa area of New Mexico, described in chapters $\mathrm{F}, \mathrm{I}, \mathrm{H}$, and $J$, respectively, and shown on figure 1 . In general, the uranium-bearing coal in each of these areas forms the topmost seam of a sequence overlain unconformably by layers of silicic volcanic materials or other strata from which uranium may have been leached by ground waters.

The fact that the most highly mineralized beds of coal are those adjacent to beds of coarse-grained permeable sandstone suggests that the latter acted as a conduit for the mineralizing solutions, which in some areas may have carried uranium great distances under hydrostatic head (Masursky and Pipiringos in Denson and others, 1952). The average range in uranium content of water from seeps and springs issuing from these volcanic rocks is about 10-100 times greater than that of normal ground water, which generally contains less than 3 parts per billion (Aberdeen, E. J., and others, written communication, 1952; Gill and Moore, 1955; Denson, Zeller, and Stephens, 1955 ; Fix, 1955). The uranium content of these ground waters and also the occurrence of carnotite, autunite, metatyuyamunite, and uranocircite in these volcanic rocks at several widely separated localities in the Rocky Mountain and Great Plains regions (Staatz and Bauer, 1951; Duncan, 1953b; Gill and Moore, 1955; and Moore and Levish, 1955) suggest that the volcanic rocks may be source beds of uranium. The uranium could have been leached out of these or similar source rocks and transported considerable distances downward and laterally by ground water, being deposited in favorable host materials in the underlying strata. 


\section{POSSIBLE ECONOMIC VALUE OF URANIUM-BEARING COAL}

Large quantities of uranium are contained in the low-rank coal of Cretaceous and Tertiary age in the basin areas of Wyoming, Idaho, and New Mexico, and the northern Great Plains region of eastern Montana and the Dakotas (fig. 1). In comparison with current sources of uranium, most of the uranium-bearing deposits herein described are very low grade. Detracting from their value as a possible source of uranium is the fact that, in general, the more highly uraniferous coals have greater ash and much lower heating value than nonuraniferous coals. Considered on this basis, utilization of the coals and the recovery of the uranium as a byproduct from the ash would depend upon the coals' suitability for use as fuel in competition with other coals. No efficient or inexpensive means of extracting small amounts of uranium from coal has yet been found, but the possible development of new metallurgical techniques and recovery processes may eventually lead to the utilization of some of the larger uraniferous coal deposits, many of which are suited to strip-mining methods.

Some of the uranium-bearing coal described in subsequent chapters have been found to contain small irregular occurrences of material containing 0.1 or more percent uranium, as for example those beds in the La Ventana (chapter J), Goose Creek (chapter H), and Fall Creek (chapter I) areas. In these areas a closer search might disclose some uranium-bearing coal that can be mined under present economic conditions.

Adding interest to coal as an important future source of uranium is the recent discovery of large tonnages of coal containing as much as 6 percent and averaging 0.7 percent uranium in beds as much as 24 inches thick on the southern flank of the Williston basin in the Cave Hills area of northwestern South Dakota (Gill, 1954). This discovery indicates that uranium-bearing coal of comparable grade may occur at other localities in the Western States.

\section{GUIDES IN EVALUATING EVIDENCE FOR URANIUM- BEARING COAL IN UNEXPLORED AREAS}

During the investigations of the occurrence and distribution of uranium in coal and related carbonaceous materials in the Western States, several thousand water samples, mostly of ground water sources from seeps, springs, and wells, were analyzed for uranium. These analyses served not only to delimit areas where the abnormally high uranium content of water reflects present leaching of ore deposits but also helped to evaluate the relative possibilities of widespread vol- 


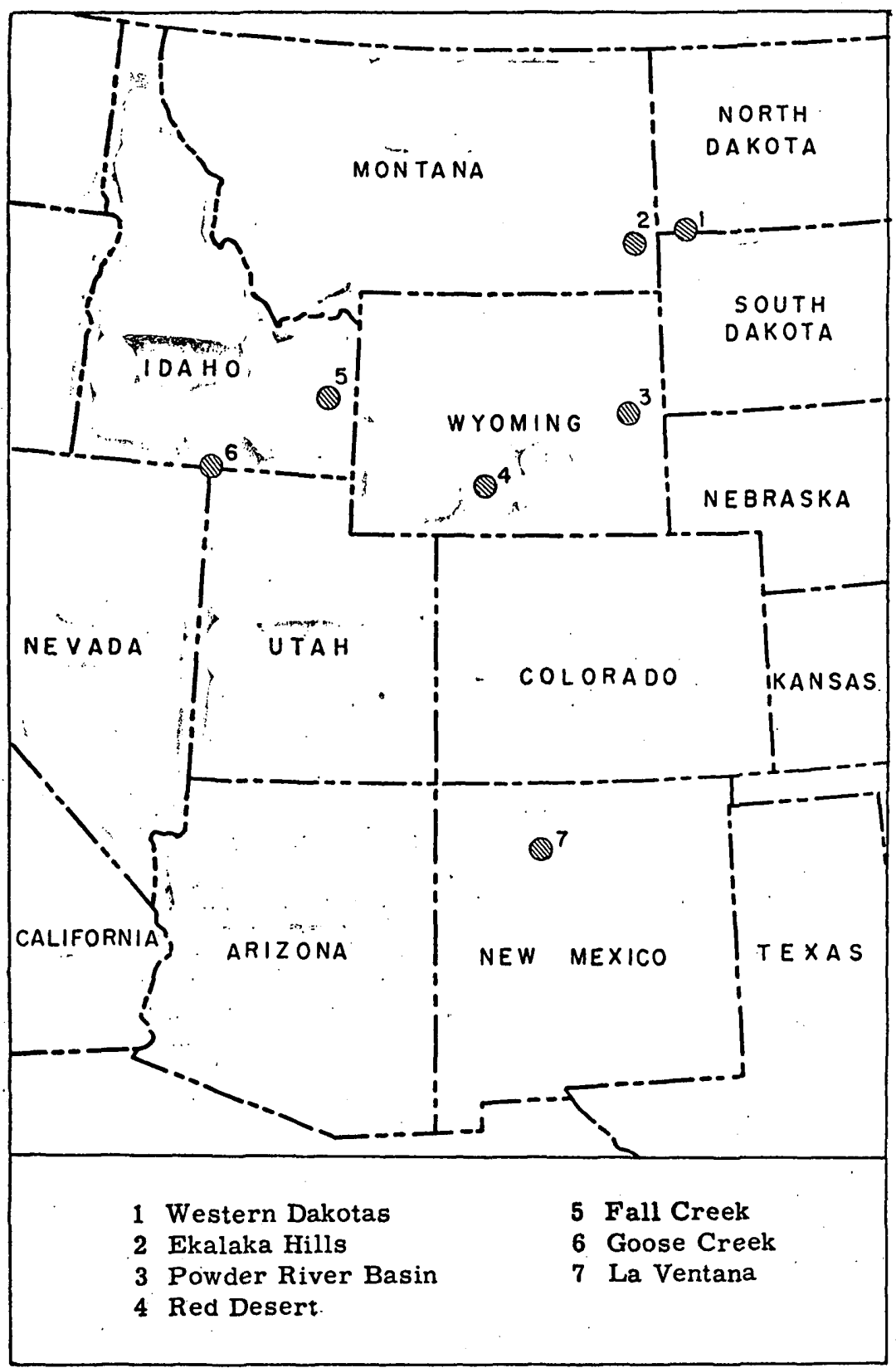

FIGORE 1.-Index map showing areas of uranium-bearing coal and carbonaceous shale in the western United States. 
canic-rock units which may have been an important primary source of uranium now present in deposits in the underlying sedimentary rocks. Although many volcanic rocks of Tertiary age contain small amounts of uranium, not all furnish uranium to the ground-water system in equal amounts. Analyses have been made of water samples from. volcanic rocks ranging in age from Late Cretaceous to Pliocene throughout the Rocky Mountain and Great Plains regions. Ground water issuing from rock units of Oligocene and Miocene age, irrespective of geographic location, is notable for its relatively great uranium content.

Although the factors controlling the solubility of uranium are imperfectly understood, it is probable that those causing the variations in physical, chemical, and climatic environments to which normal ground water is subjected affect its acidity, chemical composition, and colloidal content.' These factors may be significant in controlling the solubility of uranium by natural solutions. The average range in uranium content of ground water from the areas studied showed the following variation. The highest concentrations of uranium in ground water are found in areas of known deposits (about 70-300 parts per billion) and in ground water from silicic tuffs and tuffaceous rocks of Oligocene and Miocene age (about 20-45 parts per billion). The most highly mineralized water from tuffaceous terranes has an alkaline $\mathrm{pH}$ range of 7.5-9.5. In general, the greater the alkalinity of the waters from these rocks, the more uranium the waters contain. Analyses showing greater contents of uranium also show proportionately greater contents of sodium and calcium, the water from Oligocene rocks being more sodic and the water from the Miocene rocks being more calcic. The trace-metal content of these waters has not been related to their uranium content. Chemical and spectrographic analyses of residues obtained by evaporation of large samples of water from these units show that they contain more than normal amounts of molybdenum, vanadium, copper, phosphorus, zinc, and arsenic. There may be a genetic relationship between these rocks and those of the ore minerals (autunite, carnotite, torbernite, and zeunerite) associated with coal at some localities in the western interior.

In evaluating uranium possibilities of unexplored areas, groundwater sampling may be a useful means of prospecting, particularly in areas where thick overburden makes geiger and scintillation counters ineffective. 


\section{AREAS THAT MAY CONTAIN URANIUM-BEARING COAL}

In comparison with the areas known to contain uranium-bearing coal, there are several other areas, not described in the following chapters and perhaps not adequately examined for radioactive materials; where the geologic setting seems favorable for the occurrence of uranium deposits. These areas (fig. 2) contain coal-bearing rocks

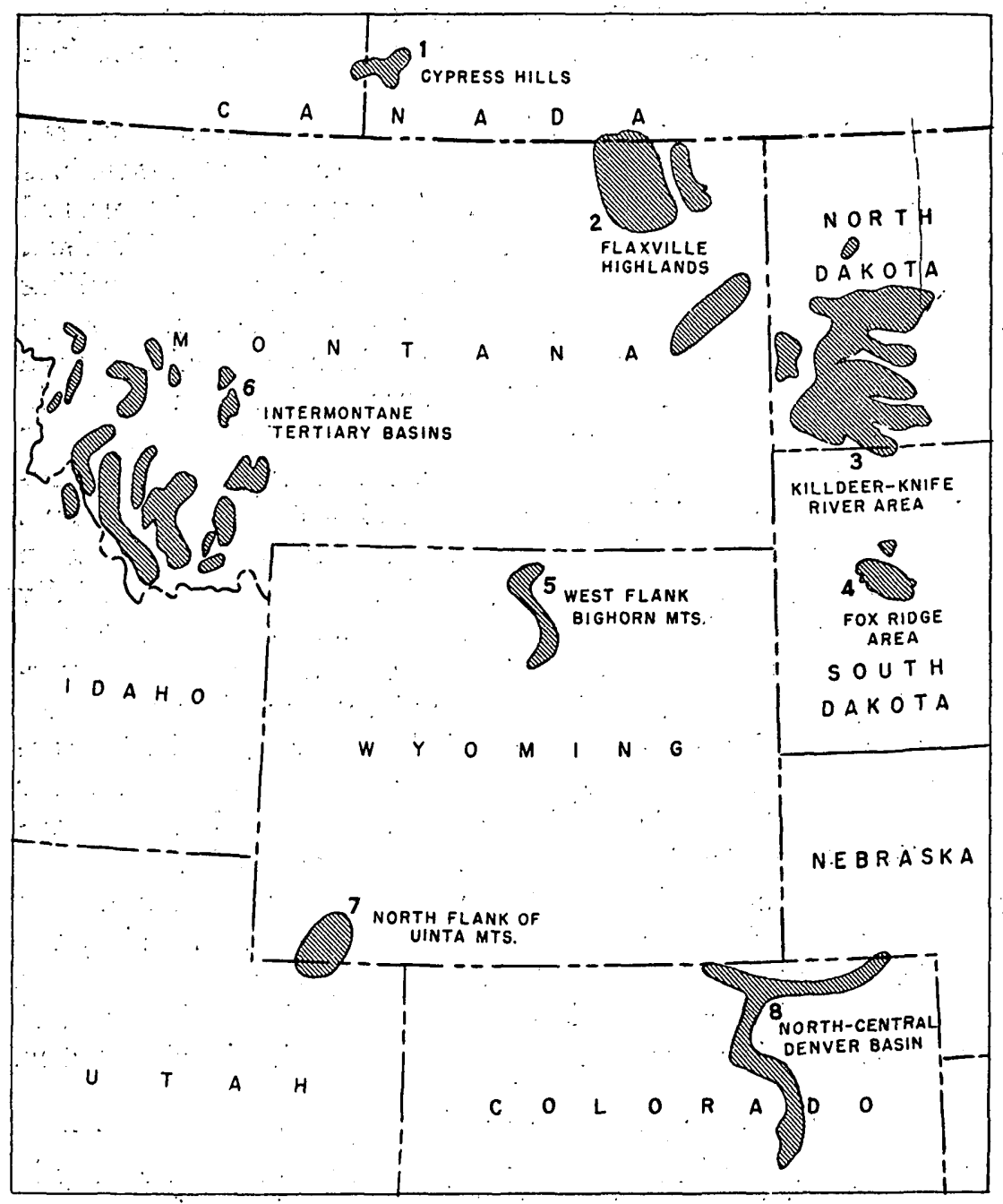

Figure 2.-Areas in western United States and adjacent Canada that may contain uranium-bearing coal. 
that are today or were once closely overlain by slightly uraniferous volcanic rock and may have significant deposits of uranium-bearing coal. They are the following:

No. on

fig. $\mathbb{Q}$,

Area

1 Cypress Hills in Canada (Saskatchewan and Alberta)

2 Flaxville Highlands in Montana

3 Killdeer-Knife River area in North Dakota

4 Fox Ridge area in South Dakota

5 . West flank of the Bighorn Mountains in Wyoming

6 Intermontane basins of Tertiary age in Montana

7 North flank of Uinta Mountains in Wyoming

8 North-central part of the Denver basin in Colorado

\section{LITERATURE CITED}

Bachman, G. O., and Read, C. B., 1952, Trace elements reconnaissance investigations in New Mexico and adjoining States in 1951: U. S. Geol. Survey TEM443A, U. S. Atomic Energy Comm., Tech. Inf. Serv., Oak Ridge.

Beroni, E. P., and McKeown, F. A., 1952, Reconnaissance for uraniferous rock in northwestern Colorado, southwestern Wyoming, and northeastern Utah : U. S. Geol. Survey TEI-308A, U. S. Atomic Energy Comm., Tech. Inf. Serv., Oak Ridge.

Berthoud, E. L., 1875, On the occurrence of uranium, silver, fron, etc., in the Tertiary formations of Colorado Territory: Acad. Nat. Sci. Phila. Proc., จ. 27, p. 363-365.

Boutwell, J. M., 1905, Vanadium and uranium in southeastern Utah: U. S. Geol. Survey Bull. 260, p. 200-210.

Couret, A. P., 1952, Bore-hole surveying by the Schlumberger methods and its application in the search for coal in Great Britain: Trans. Inst. Min. Surv., v. 32, p. 114-128.

Davidson, C. F., and Bowie, S. H. U., 1951, On thucolite and related hydrocarbon uraninite complexes: Great Britain Geol. Survey Bull. 3, p. 1-19.

Davidson, C. F., and Ponsford, D. R. A.,.1954, On the occurrence of uranium in coals: The Mining Magazine (London), v. 91, no. 5 (Nov.), p. 265-273.

Denson, N. M., 1952, Summary of uranium-bearing coal, lignite, and carbonaceous shale investigations in the Rocky Mountain region during 1951 , with description of deposits by Bachman, G. O., Gill, J. R., Hail, W. J., Jr., Love, J. D., Masursky, Harold, Denson, N. M., Moore, G. W., Pipiringos, G. N., Vine, J. D., and Zeller, H. D.: U. S. Geol. Survey TEM-341A, U. S. Atomic Energy Comm., Tech Inf. Serv., Oak Ridge.

Denson, N. M., Zeller, H. D., and Stephens, J. G., 1956, Water sampling as a guide in the search for uranium deposits and its use in evaluating widespread volcanic units as potential source beds for uranium: U. S. Geol.

: $\quad$ Survey Prof. Paper 300, p. 673-681.

Duncan, D..C., 1953a, Results of reconnaissance for uranium in nonmarine carbonaceous rocks in parts of California, Idaho, Nevada, Oregon, Utah, and Washington during 1951 and 1952: U. S. Geol. Survey TEM-444A; U. 'S. Atomic Energy Comm., Tech. Inf. Serv., Oak Ridge.

Duncan, D. C., 1953b, A uranium-bearing rhyolitic tuff deposit near Coaldale. Esmeralda County, Nev.; U. S. Geol. Survey Circ. 291.

Fix, P. P., 1955, Hydrogeochemical exploration for uranium : U. S. Geol. Survey. Prof. Paper 300, p. 667-671.

$469117-59-2$ 
Gill, J. R., 1954, Uranium in carbonaceous rocks, coal and lignite, in Geologic investigations of radioactive deposits, Semiannual Progress Report, June 1 to November 30, 1954: U. S. Geol. Survey TEI-490, U. S. Atomic Energy Comm., Tech. Inf. Serv., Oak Ridge.

Gill, J. R., and Moore, G. W., 1955, Carnotite-bearing sandstone in Cedar Canyon, Slim Buttes, Harding Co., S. Dak.: U. S. Geol. Survey Bull. 1009-I.

Gott, G. B., Wyant, D. G., and Beroni, E. P., 1952, Uranium in black shales, lignites, and limestones in the United States, in Selected papers on uranium deposits in the United States: U. S. Geol. Survey Circ. 220, p. 31-35.

Griggs, R. L., 1954, A reconnaissance for uranium in New Mexico, 1953: U. S. Geol. Survey Circ. 354.

Gruner, J. W., 1954, The origin of the uranium deposits of the Colorado Plateau and adjacent regions: Mines Mag., $\nabla .44$, p. 53-56.

Hail, W. J., Jr., and Gill, J. R., 1953, Results of reconnaissance for uraniferous coal, lignite, and carbonaceous shale in western Montana : U. S. Geol. Survey Circ. 251.

Love, J. D., 1952, Preliminary report on the uranium deposits in the Pumpkin Buttes area, Powder River Basin, Wyo.: U. S. Geol. Survey.Circ. 176.

Moore, G. W., and Levish, Murray, 1955, Uranium-bearing sandstone in the White River Badlands, Pennington County, S. Dak.: U. S. Geol. Survey Circ. 359.

Moore, G. W., and Stephens, J. G., 1954, Reconnaissance for uranium-bearing carbonaceous rocks in California and adjacent parts of Oregon and Nevada: U. S. Geol. Survey Circ. 313.

Newmarch, C. B., 1950, The correlation of Kootenay coal seams-radioactivity measurements: Bull. Canad. Min. Metall., v. 43, p. 143.

Russell, W. T., 1945, Relation of radioactivity, organic content, and sedimentation: Am. Assoc. Petroleum Geologists Bull., v. 29, p. 1470-1494.

Staatz, M. H., and Bauer, H. L., Jr., 1951, Virgin Valley opal district, Humboldt County, Nevada: U. S. Geol. Survey Circ. 142.

:Staatz, M. H., and Bauer, H. L., Jr., 1954, Gamma property, in Lovering, T. G., Radioactive deposits of Nevada: U. S. Geol. Survey Bull. 1009-C, p. 76-77.

Troyer, M. L., McKay, E. J., Soister, P. W., and Wallace, S. R., 1953, Summary of investigation of uranium deposits in the Pumpkin Buttes area, Johnson and Campbell Counties, Wyo.: U. S. Geol. Survey Circ. 338.

Unkovskaya, V., 1940, Determination de faibles quantite's d'uranium par le procédé de fluorescence: Acad. Sci. U. R. S. S. Comptes rendus (Doklady), v. 29, nos. 5-6, p. 380-383.

Vine, J. D., and Moore, G. W., 1952, Reconnaissance for uranium-bearing carbonaceous rocks in northwestern Colorado, southwestern Wyoming, and adjacent parts of Utah and Idaho: U. S. Geol. Survey TEI-281, U. S. Atomic Energy Comm., Tech. Inf. Serv., Oak Ridge.

Vine, J. D., and Flege, R. F., Jr., 1953, Reconnaissance during 1952 for uraniumbearing carbonaceous rocks in parts of Colorado, Utah, Idaho, and Wyoming: U. S. Geol. Survey TEI-336; U. S. Atomic Energy Comm., Tech. Inf. Serv., Oak Ridge.

Wyant, D. G., Sharp, W. N., and Sheridan, D. M., 1956, Reconnaissance study of uranium deposits in the Red Desert, Sweetwater County, Wyo.: U. S. Geol. Survey Bull. 1030-I [1957].

Zeller, H. D., 1955, Reconnaissance for uranium-bearing carbonaceous materials in southern Utah: U. S. Geol. Survey Circ. 349. 


\section{Uranium-Bearing Lignite in Northwestern}

\section{South Dakota and}

\section{Adjacent States}

By NORMAN M.: DENSON, GEORGE O. BACHMAN; and HOWARD D. ZELLER URANIUM IN COAL IN THE WESTERN UNITED STATES

GE OLOGICAL SUR VEY B U L L E T I N $1055-\mathrm{B}$

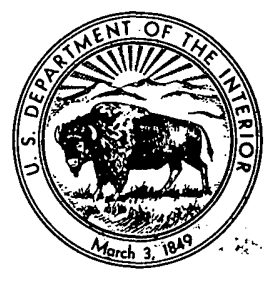





\section{CONTENTS}

\begin{tabular}{|c|c|}
\hline ict_. & $\begin{array}{r}\text { Page } \\
11\end{array}$ \\
\hline roduction. - & 12 \\
\hline - n-1 & 12 \\
\hline wledgments _. . . & 15 \\
\hline tig & 15 \\
\hline s system, Hell Creek formation & 16 \\
\hline ( & 17 \\
\hline ormation (Paleocene) & 17 \\
\hline group (Oligocene) & 20 \\
\hline formation (Miocene) & 23 \\
\hline Quaternary system & 28 \\
\hline ( & 28 \\
\hline ( & 28 \\
\hline of the uranium & 28 \\
\hline nulation & 29 \\
\hline syngenetic origin & 31 \\
\hline an epigenetic origin & 31 \\
\hline ncentration of uranium & 38 \\
\hline ring lignite............ & 40 \\
\hline - & 40 \\
\hline 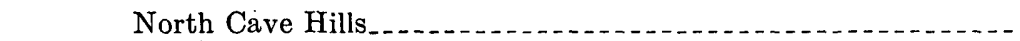 & 42 \\
\hline 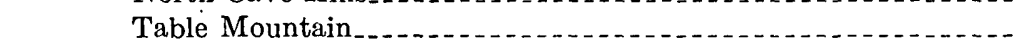 & 43 \\
\hline llls & 44 \\
\hline 只 & 45 \\
\hline ( & 45 \\
\hline S. & 45 \\
\hline s of uranium-bearing lignite & 47 \\
\hline 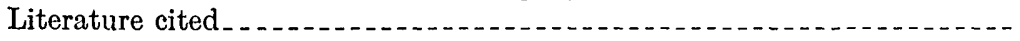 & 55 \\
\hline & 309 \\
\hline
\end{tabular}

\section{ILLUSTRATIONS}

[Plates 1 and 4-12 are in box]

Plate 1. Block diagram of northwestern South Dakota and adjacent areas showing relationship of uranium-bearing lignite deposits to regional setting.

2. Photomicrograph of thin-section of sandstone from Arikaree Page

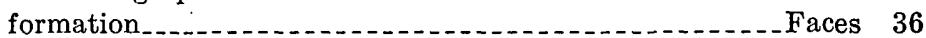

3. Photomicrograph of analcite rosettes from uranium-bearing lignite_._.

4. Geologic map of the Cave Hills and Table Mountain area, Harding County, S. Dak. 
Plate 5. Sections of lignite, South Cave Hills, Harding County, S. Dak.

6. Columnar sections showing stratigraphic relationships' of uranium-bearing lignite beds Cave Hills area.

7. Sections of lignite, Table Mountain and North Cave Hills, Harding County, S. Dak.

8. Geologic map of the Medicine Pole Hills area, Bowman County, N. Dak.

9. Sections of lignite, Lodgepole area, Medicine Pole Hills, and the Long Pine Hills, South Dakota, North Dakota, and Montana.

10. Geologic map of the Lodgepole area, Perkins County, S. Dak.

11. Geologic map of the Slim Buttes area, Harding County, S. Dak.

12. Sections of lignite, Slim Buttes area, Harding County, S. Dak.

13. West face of the Slim Buttes, showing badland topography --

14. Arikaree formation unconformably overlying the White River group at Reva Gap. Follows 44

15. Uranium-bearing lignite unconformably overlain by younger source beds of uranium at the Mendenhall strip mine, South Dakots. Follows 44

16. Mendenhall strip mine, showing distribution and concentration of uranium in lignite and siltstone roof . . . . . . . . . Faces 45

FIGURE 3. Index map showing areas of uranium-bearing lignite

4. Generalized columnar section showing stratigraphic position of principal lignite beds in northwestern South Dakota and adjacent areas. . . . . . . . . . . . .

5. Cross sections from the Short Pine Hills, S. Dak., to HT Butte, N. Dak., and from the Long Pine Hills, Mont., to White Butte, S. Dak

6. Generalized map showing areal distribution of the White River group and the Arikaree formation

7. Diagram showing distribution and concentration of uranium in lignite and lignite ash, South Dakota ........................

8. Diagram illustrating an interpretation of factors that control the

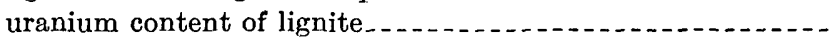

\section{TABLES}

TABLE 1. Minimum amounts of elements detectable with semiquanti-

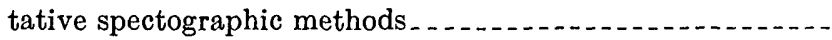

2. Analyses of core samples of the White River group and Arikaree formation, the Slim Buttes, S. Dak ...............................

3. Analyses of uranium, showing vertical distribution of uranium

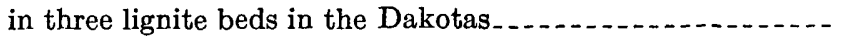

4. Tonnage of uranium-bearing lignite in the North Cave Hills, South Cave Hills, McKensie Butte, and Table Mountain areas.

5. Analyses of surface samples and auger cuttings of uraniumbearing lignite from northwestern South Dakota and adjacent areas. 


\title{
URANIUM IN COAL IN THE WESTERN UNITED STATES
}

\section{URANIUM-BEARING LIGNITE IN NORTHWESTERN SOUTH DAKOTA AND ADJAGENT STATES}

\author{
By Norman M. Denson, George O. Bachman, and Howard D. Zeller
}

\begin{abstract}
In northwestern South Dakota and adjacent areas, uranium-bearing lignite beds occur at many horizons in the Hell Creek formation of Late Cretaceous age and in the overlying Ludlow, Tongue River, and Sentinel Butte members of the Fort Union formation of Paleocene age. Analyses for uranium of 275 samples of lignite taken from outcrops or obtained by auger-drilling and of about 1,000 core samples of lignite show that many of the lignite beds contain $0.005-0.02$ percent uranium, and their ash contains $0.05-0.10$ percent. Analytical data also indicate that the region contains an aggregate of at least 47,500,000 tons of lignite having an average uranium content of slightly more than 0.008 percent. Almost a fifth of the lignite occurs in beds suitable for strip mining and averaging about 4 feet in thickness. Recent discoveries of ore-grade deposits of autunite-bearing lignite and of secondary minerals of uranium in carbonaceous sandstone at Cave Hills and Slim Buttes indicate that northwestern South Dakota and adjacent areas may contain important deposits of uranium minerals.

The stratigraphic units containing the uraniferous lignite beds have a combined thickness of about 1,500 feet and are unconformably overlain by a sequence of 300 feet or more of tuffaceous sandstone and bentonitic claystone of the White River group of Oligocene age and the Arikaree formation of Miocene age. The stratigraphically highest lignite beds in the area have the greatest content of uranium, and the concentration of uranium is greatest at the top of thick lignite beds, diminishing progressively downward to a vanishing point in their lower parts. Variations in permeability of the rocks overlying the mineralized lignite beds seem to be related to the concentration of uranium. Most of the known beds of uranium-bearing lignite in the region are closely overlain by rocks of the White River group and the Arikaree formation, which have about 12 times more uranium than the average sedimentary rock. Furthermore, the uranium content of spring water from these formations is 30 or more times that of normal ground water. The presence of uranium in the lignite is independent of the age of the formation in which the lignite occurs. Field relations thus suggest that the uranium is of secondary origin and has been introduced after the accumulation and marked regional uplift and warping of the lignite beds and associated rocks.
\end{abstract}


The uranium is believed to have been a finely disseminated constituent of the overlying mildly radioactive volcanic ash and was released or displaced during weathering, and carried-probably in the ionic form-by downward and laterally moving ground waters. Carbonaceous material-lignite or carbonaceous shaleis believed to have taken the uranium from solution by ion exchange or by the formation of organo-metallic compounds.

Geologic factors that seem most significant in controlling the distribution and concentration of uranium in these beds of lignite are the following: (1) Stratigraphic proximity of the lignite to the base of the White River group, (2) permeability of the rocks overlying the lignites, (3) adsorptive properties and porosities of the constituents of lignite, (4) present and past position of the ground-water table; and (5) the amount of uranium in the original White River and Arikaree sediments.

\section{INTRODUCTION}

The study of uranium-bearing lignite in northwestern South Dakota and adjacent areas was undertaken to evaluate its economic possibilities and to determine the geologic factors controlling the accumulation of uranium in lignite. Field work began in June 1950 and was completed in October 1950. Geiger-Mueller counters and a portable scaler were used in the field work as guides in the sampling program. A jeep-powered auger was employed to obtain samples of unweathered uranium-bearing lignite. During the field investigations, 275 other samples were collected for laboratory analysis. Radiometric and chemical analyses for uranium, and chemical and semiquantitative spectrographic analyses for other minor elements in these samples were made by the Geological Survey.

The validity of the theory herein presented on the origin and accumulation of the uranium in the lignite was tested during the latter part of the summer of 1950 in the Powder River Basin in eastern Wyoming and in other areas in the Rocky Mountain region during the summer of 1951; here its application led to the discovery of other concentrations of uranium-bearing carbonaceous materials.

\section{GEOGRAPHY}

The lignite field of northwestern South Dakota and adjacent areas of Montana and North Dakota includes about 5,000 square miles near the eastern margin of the Great Plains province and north of the Black Hills (fig. 3 ) in a region of rolling prairie, interrupted by small areas of badlands, or by rugged and precipitous buttes and ridges. The more prominent buttes are the Cave Hills and the Slim Buttes near the center of the area, and the Short Pine Hills (S. Dak.) and Long Pine Hills (Mont.) near the southwest corner of the area. These buttes stand 300-500 feet above the surrounding country and support a growth of yellow pine. Strata are well exposed in the cliffs rimming the buttes. The eastward-flowing Grand River and the northward-flowing Little Missouri River and their tributaries drain most 
of the region. Low sandy hills and broad sandy flats border the rivers, but the divides in many places are capped by small rock buttes or by red baked rock and clinker resulting from the burning of the lignite beds.

The altitude of the lignite field ranges from 2,100 feet above sea level, along the east border, to 4,019 feet, on the Short Pine Hills, giving a maximum relief of about 1,900 feet. Buffalo (population 400), the county seat of Harding County, is the largest town within the area in South Dakota. Many county roads and prairie trails, supplementing State and Federal highways, make most places fairly accessible. Bowman, N. Dak. (population 1,400), 50 miles north of Buffalo, is the nearest railroad shipping point.

The prominent topographic features in the region and their relationship to the general geologic setting are shown on plate 1 .

\section{ACKNOWLEDGMENTS}

Several members of the Geological Survey contributed information and advice that greatly aided this investigation. C. H. Dane, W. G. Pierce, and V. E. McKelvey made helpful suggestions in the field. D. G. Wyant and E. P. Beroni supplied analytical data and information on the uranium-bearing lignites in North Dakota and eastern Montana. W. E. Benson permitted the authors to use his then unpublished map showing the areal distribution of upper Tertiary formations in western North Dakota (Benson, 1951). R. W. Brown gave valuable assistance in the field, identifying plant collections and establishing the age relationships of the rock units mapped. W. E. Benson and D. G. Wyant also assisted during the early stages of the field work, and Howard A. Powers studied and interpreted thin sections of volcanic rocks.

\section{STRATIGRAPHY}

The stratigraphic section exposed in northwestern South Dakota and adjacent areas includes rocks of Cretaceous, Tertiary, and Quaternary age. Figure 4 is a generalized columnar section adapted from Winchester and others (1916) and Hares (1928), showing the average thicknesses, characteristics, and relations of the various formations and the stratigraphic position of the principal coal beds.

Beds of uranium-bearing lignite occur sporadically throughout the region at many horizons in the Ludlow, Tongue River, and Sentinel Butte members of the Fort Union formation of Paleocene age and in the underlying Hell Creek formation of Late Cretaceous age. The sequence of lignite-bearing stratigraphic units has a thickness of 1,500 feet or more and consists predominantly of fluviatile deposits of somber-colored, soft, sandy, clay shale and massive, thick-bedded, 


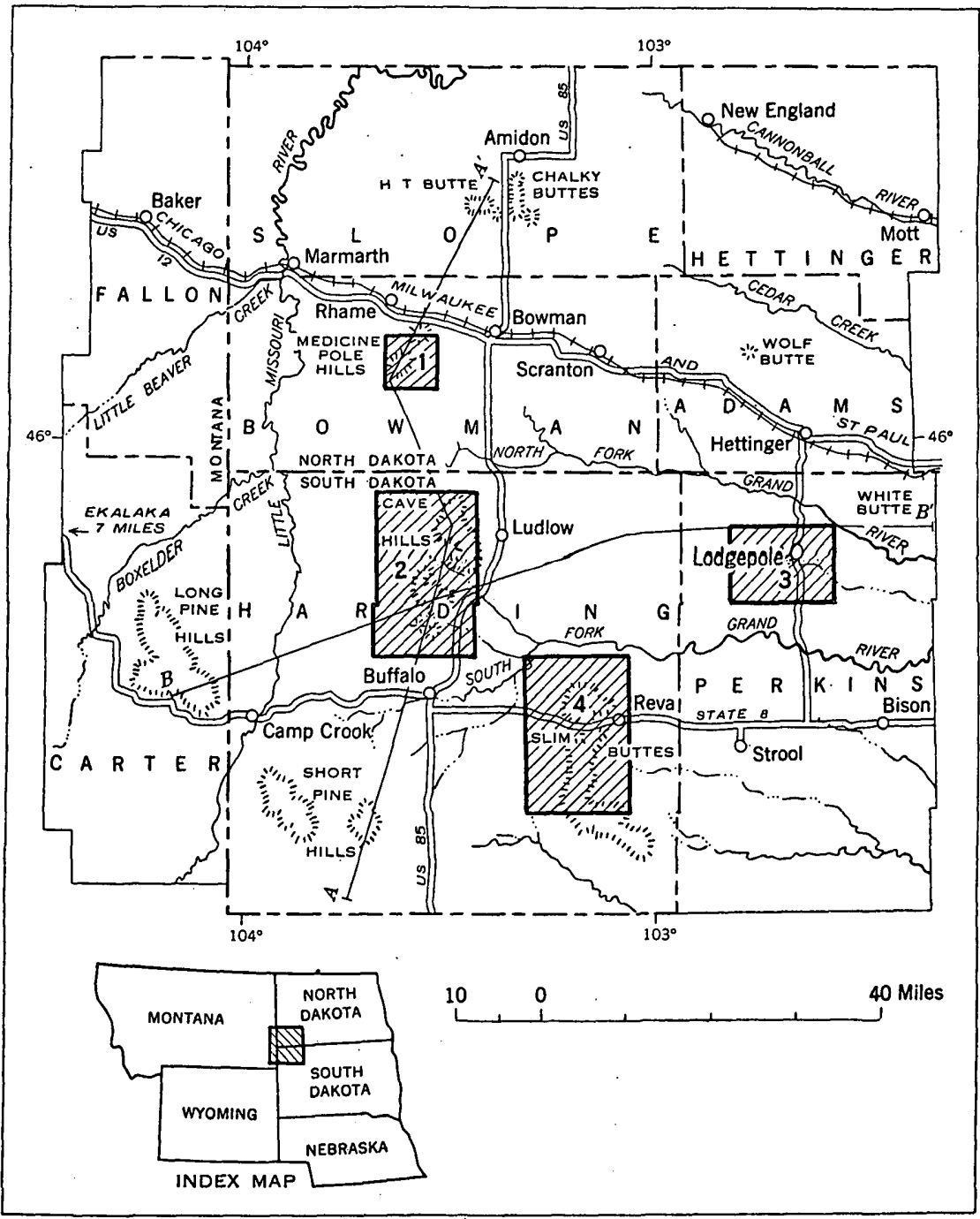

Figdne 3.-Index map showing areas of uranium-bearing lignite deposits described in this report.

tan, and buff-gray sandstone. A marked regional unconformity separates them from 300 feet or more of ash-gray, mildly radioactive tuffaceous sandstone and bentonitic clay of the overlying White River group of Oligocene age and the Arikaree formation of Miocene age. Remnants of the latter two units, which cap many of the high buttes and escarpments, indicate that they once covered most if not all the lignite-bearing rocks in western South Dakota and adjacent parts of North Dakota and Montana (pl.1). 


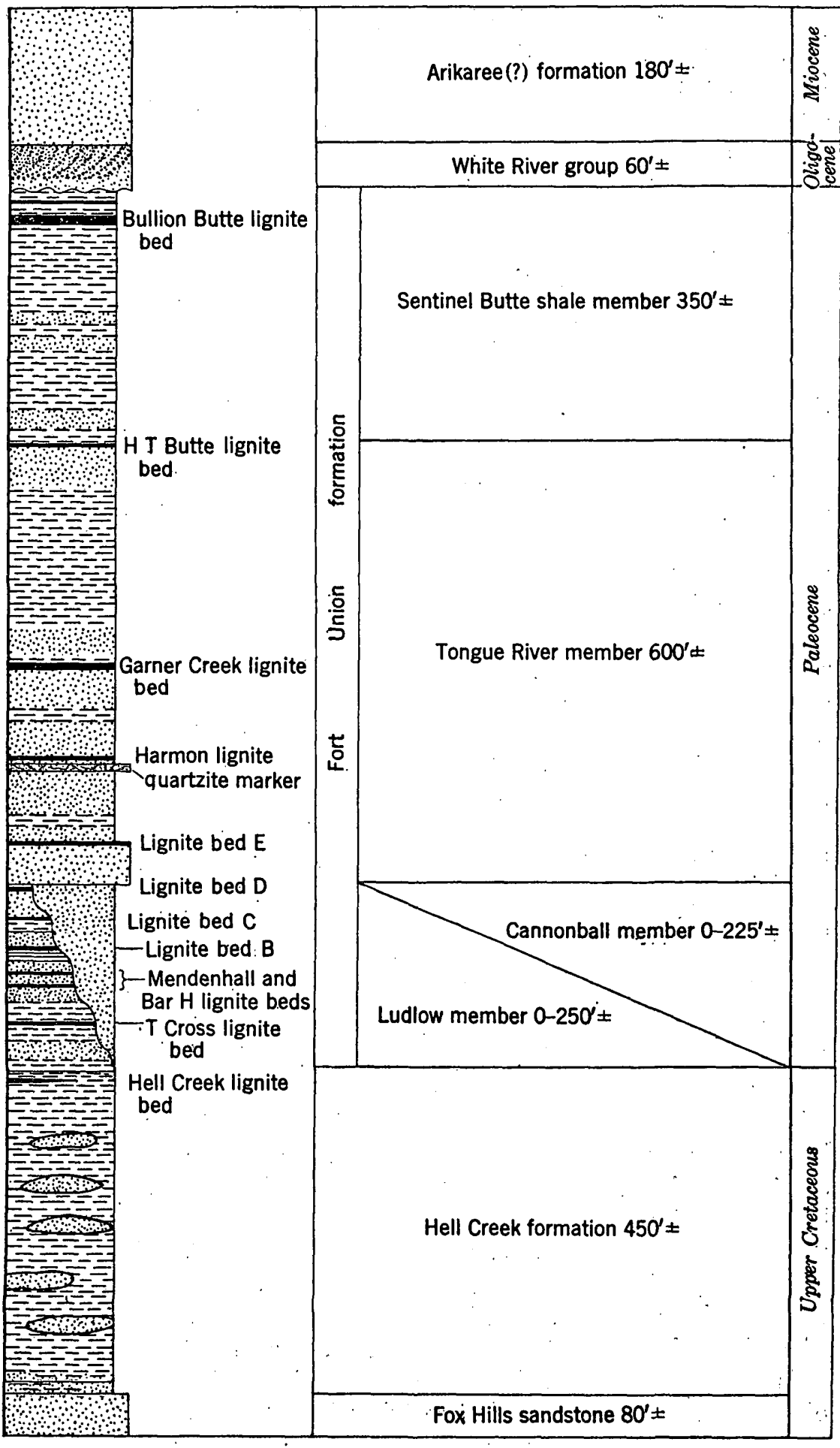

Figurm 4.-Generalized columnar section showing stratigraphic position of principal lignite beds in northwestern South Dakota and adjacent areas. 
The geology of the region has been described in detail in reports by Winchester and others (1916), Bauer (1924), Hares (1928), and Baker (1952), and therefore no attempt is made in this report to treat the geology in detail. The stratigraphy and general geology of the various areas underlain by significant deposits of uranium-bearing lignite are summarized.

\section{CRETACEOUS SYSTEM, HELI CREEK FORMATION}

The Hell Creek formation is the oldest stratigraphic unit of the thick sequence of lignite-bearing continental sediments exposed in Harding and Perkins Counties, S. Dak., and in the adjoining areas in Bowman County, N. Dak., and southeastern Montana. The formation overlies the Fox Hills sandstone, of marine origin, and crops out extensively in South Dakota south and west of Slim Buttes, Cave Hills, and Table Mountain, and in North Dakota along the east flank of the Cedar Creek anticline in southwest Bowman County.

The Hell Creek formation ranges from 300 to 575 feet in thickness and consists of fresh- and possibly some brackish-water deposits of sandstone, bentonitic claystone, and thin beds of lignite. In places the strata contain ellipsoidal, buff, or dirty-brown, iron-cemented sandstone concretions which range from an inch or less to 5-6 feet in diameter. Thin layers of bog iron and ferruginous masses formed by the weathering of iron carbonate are also present. The Hell Creek strata are heterogeneous and crossbedded. As a rule, single beds are not traceable more than a few miles, even where exposures are good. Although weakly cemented, the rocks are resistant to erosion, weathering into rounded and fluted surfaces having a rough, coarse, irregular appearance. They commonly produce a characteristic varied badland topography interspersed with broad flat areas. The uniformly dark, somber hues of gray, buff, olive green, and chocolate distinguish them at a distance from the overlying prevailing yellow sandy strata of the Ludlow member of the Fort Union formation. They are sparingly fossiliferous and have yielded species of turtles, dinosaurs, and poorly preserved plants of Late Cretaceous age.

The Hell Creek formation as a whole is barren of valuable lignite beds. Such lignite as occurs is usually in lenticular beds of small areal extent in the uppermost 100 feet of the formation. Uraniumbearing lignite was found at only two places in the formation in northwestern South Dakota: (1) in the E 1/2 sec. 13, T. 17 N., R. 3 E.; and (2) near the center of the south line of sec. 17, T. 19 N., R. 3 E. There the beds are thin, and the occurrence of uranium in them is only of academic interest. According to R. W. Brown (1952) the lignite beds here mapped as in the upper part of the Hell Creek should be placed in the lower part of the overlying Ludlow formation. Because 
there is no distinct lithologic difference between these rocks and the lower part of the Hell Creek they are here assigned to the Hell Creek formation.

\section{TERTIARY SYSTEM}

\section{FORT UNION FORMATION (PALEOCENE)}

In northwestern South Dakota and in the adjoining area to the north in North Dakota, the Fort Union formation, of Paleocene age, consists of 1,200 feet or more of lignite-bearing sandstone, shale, and claystone. The continental strata of the lower 300 feet of the formation are assigned to the Ludlow member, and intertongue to the east with marine strata not containing lignite and assigned to the Cannonball member of the formation. Overlying the Ludlow and Cannonball members with apparent conformity is the Tongue River member, in turn overlain by the Sentinel Butte member. The significant lithologic characteristics and stratigraphic relationships of each of the four members are described below.

Ludlow member.-The Ludlow member of the Fort Union formation, named from the town of Ludlow in Harding County, S. Dak., is well exposed at its type locality along the south face of the North Cave Hills (Winchester and others, 1916, p. 20). Rocks assigned to the member occur throughout much of the region as a thin cover on divides, particularly along the south fork of the Grand River north and east of Slim Buttes, and as belts around the higher buttes and mesas, as in the South Cave Hills, Table Mountain, and Long Pine Hills areas. Most of the rocks are loosely consolidated and easily disintegrated.

At its type locality the member consists of $300-350$ feet of interbedded sandstone, shale, and lignite, most of which is believed to be of fresh-water origin. The most prominent feature of typical Ludlow is the predominance of light-yellow sandstone. The Ludlow member is very similar to the overlying Tongue River member, but it is separated from that member throughout the eastern part of the area by the marine Cannonball member with which it intertongues (fig. 5). Although dinosaur remains are absent in the Ludlow and are commonly present in the underlying Hell Creek formation on which the Ludlow rests conformably, the differentiation of these stratigraphic units at many places is difficult because of the local similarity of the lithologic and color criteria by which the formations are distinguished. At most places, however, the lower limit of the Ludlow is placed where predominantly somber-colored shale of the Hell Creek is overlain by prominent yellow sandy strata characteristic of the Ludlow member of the Fort Union formation, and is marked in many places by a bed of lignite. 
Most of the lignite beds which occur throughout the Ludlow member are lenticular, and persist for only a few miles along their outcrop. Locally, the beds are thick, and have been mined to supply fuel for local use. Deposits of uranium-bearing lignite occur in the Ludlow member in the Bar $\mathrm{H}$ and Mendenhall areas, along the west-central and northeastern parts of Slim Buttes (pl. 11), and in the North and South Cave Hills and Table Mountain areas, Harding County, S. Dak. Slightly radioactive lignite also occurs in the Ludlow in the Long Pine Hills, Carter County, Mont.

Cannonball member.-The Cannonball member of the Fort Union formation is named for exposures along the Cannonball River in Grant County, N. Dak. (Tps. 132 and 133 N., R. 88 W.), about 50 miles northeast of the area of this report. It consists of sediments of a sea which extended from the east into northern Perkins and northeastern Harding Counties, S. Dak., and southern Adams and southwestern Bowman Counties, N. Dak. The Cannonball member is reported to be about 300 feet thick along the Cannonball River (Lloyd, 1914, p. 248-249), but thins as it interfingers to the west with the Ludlow. It has not been recognized west of R. $8 \mathrm{E}$. in the vicinity of Anarchist (Mud) Butte, northeastern Harding County, S. Dak. The Cannonball is composed largely of thick-bedded gray to buff, calcareous or ferruginous sandstone, and alternating beds of yellow to buff clay, and silty limestone. Concretions ranging in diameter from 6 inches to 10 feet are commonly present. Because the Cannonball member does not contain lignite beds, it was not studied in detail.

Tongue River member.-The Tongue River member of the Fort Union formation has been eroded from most of northwestern South Dakota and the adjacent areas in North Dakota and Montana. Where the rocks of this unit are present, they conformably overlie the Ludlow member or its marine equivalent, the Cannonball member. The Tongue River member caps Table Mountain, North and South Cave Hills, and forms the bedrock near Anarchist Butte and Lodgepole Buttes in northeastern Harding and northern Perkins Counties, S. Dak., and near the Medicine Pole Hills in Bowman County, N. Dak. At most places the Tongue River weathers to a gently rolling upland and to a fertile sandy loam.

An estimate of the original thickness of the Tongue River in South Dakota cannot be made because its upper part has been eroded. A maximum thickness of about 300 feet was measured by Winchester and others (1916, p. 27) near Anarchist Butte in the southeastern part of T. 22 N., R. 8 E., in Harding County, S. Dak. Hares (1928, p. 4748) describes a total of 600 feet of Tongue River strata to the north, in the Marmarth field where these rocks are overlain by the Sentinel Butte member. The rocks are light gray, tan, buff, and white and are 
predominantly sandstone, for the most part, fine grained and evenly thin bedded, though quite massive in places. The sandstone commonly resists erosion and forms vertical walls, to which is due the mesalike character of the Cave Hills and Table Mountain. The rocks of the Tongue River are lighter in color, contain a larger percentage of sandstone, and have thicker and more persistent beds of lignite than those of the underlying Ludlow member. The individual strata are also more persistent and regular.

On the southwest side of the North Cave Hills and stratigraphically about 170 feet above the base of the Tongue River, a 2-foot bed of quartzite, the lowest of such beds in the Fort Union formation, forms the top of the massive sandstone caprock. The quartzite is gray, very fine grained, and contains impressions of plant roots. Boulders of quartzite containing impressions of stems and roots and derived from this bed and from beds higher in the section are scattered over the surface of much of the area. Quartzite similar to that of the North Cave Hills has been described by Hares (1928, p. 34-36) and Brown (1948, p. 1268-1269) in adjacent areas of North Dakota. In Harding and Perkins Counties, S. Dak., the lowest quartzite bed persists for about 30 miles from the North Cave Hills eastward to the vicinity of Lodgepole Post Office. The bed forms the caprock on the prominent buttes east of the North Cave Hills. It is present in the Tepee Buttes, Anarchist Butte, and on the Johnson outlier in the Lodgepole area. (See pls. 1 and 10.) It normally occurs 10-20 feet below a widespread and persistent bed of lignite, referred to in this report as the Harmon lignite bed. In western Perkins County the quartzite may be within 100 feet of the base of the Tongue River member; however, the Tongue River rests on the Cannonball member and the stratigraphic position of the quartzite is difficult to determine because of poor exposures and the gradational boundary between the Cannonball and Tongue River members.

Plants of Paleocene age from the Tongue River member collected from beds above the Harmon lignite bed at Anarchist Butte in SW1/4 sec. 27, T. 22 N., R. 9 E., Harding County, S. Dak., were identified by R. W. Brown of the U. S: Geological Survey as follows:

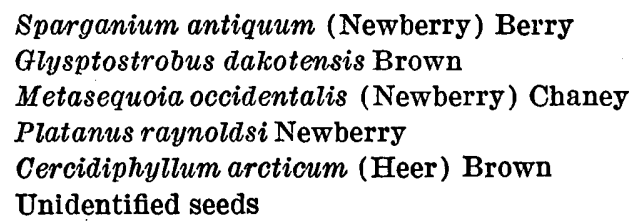

Deposits of uranium-bearing lignite occur in the Tongue River member of the Fort Union formation in three areas: (1) the Medicine Pole Hills area, Bowman County, N. Dak.; (2) the Lodgepole area 
of Perkins County, S. Dak. ; and (3) Cave Hills area, Harding County, S. Dak.

Sentinel Butte member.-The Sentinel Butte is the uppermost member of the Fort Union formation. It has been removed by erosion from all parts of northwestern South Dakota and is preserved only in the higher buttes in the adjoining area of North Dakota. There, it is unconformably overlain by claystone of probable Oligocene age. The Sentinel Butte member is about 350 feet thick and in lithology is similar to the Hell Creek formation of Late Cretaceous age. The member is composed chiefly of siltstone, clay shale, and thin beds of lignite. Somber shades of gray and brown predominate, but the upper part of the unit, directly underlying the White River group, is characteristically oxidized to a yellow or light tan.

Uranium-bearing lignite beds occur in the Sentinel Butte member at HT Butte near the central part of Slope County (fig. 5), but the beds of lignite are thin.

\section{WHITE RIVER GROUP (OLIGOCENE)}

The White River group crops out prominently in the Slim Buttes and Short Pine Hills in Harding County, S. Dak., and in the adjoining area to the west in the Long Pine Hills, Carter County, Mont. Many isolated hills in Perkins and Bowman Counties have thin remnants of the White River group capping them. The group lies unconformably on the Hell Creek formation in the Short Pine Hills, on the Ludlow member in the Slim Buttes and Long Pine Hills, on the Tongue River member in Cave Hills and Medicine Pole Hills, and on the Sentinel Butte member on HT Butte. At least 1,200 feet of older rocks were removed in the Short Pine Hills before the deposition of the White River (fig. 5).

The White River group is 40-200 feet thick. It commonly consists of a basal clastic unit of coarse-grained, tuffaceous sandstone and conglomerate succeeded by light-colored bentonitic clay, thin limestone lenses, and white calcareous grit. Locally these rocks exhibit slump structures (see Gill, Zeller, and Schopf, chapter D, this bulletin) and are commonly overlain by massive, nearly horizontal, cliff-forming sandstone of the Arikaree formation (pl. 14). The lower 25 feet or more of the White River group at many places consists of very finegrained sandstone and silty carbonaceous shale eroded from the weathered pre-Oligocene formations. Where present, these rocks are characteristically stained yellow or rusty tan. Volcanic material in the White River group consists of pebbles of pink porphyry in the basal clastic phases of the formation; glass shards are common in the succeeding finer-grained clastics. A persistent 10-40-foot bed of darkgray bentonitic clay occurs in the upper part of the sequence. Its 
言
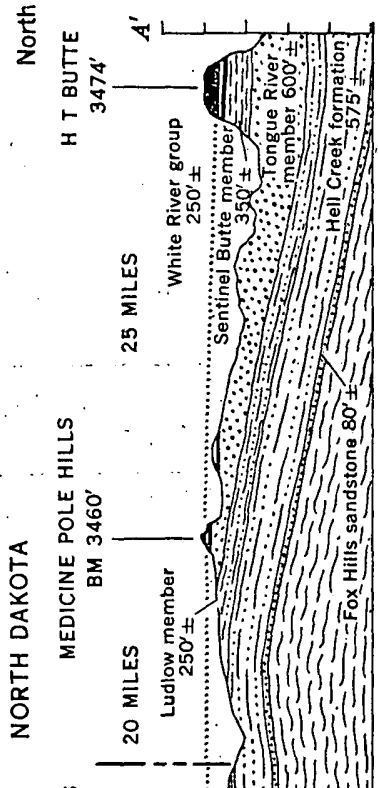

占
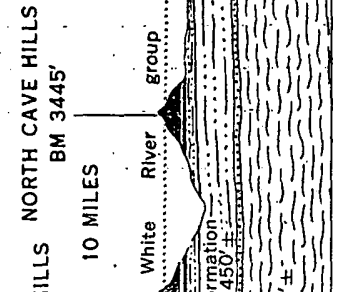

$\bar{x}$

岁售

工立

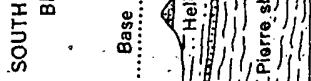

出

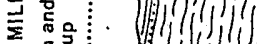

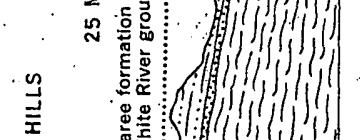

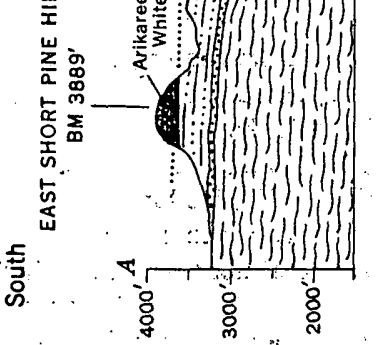

若 店
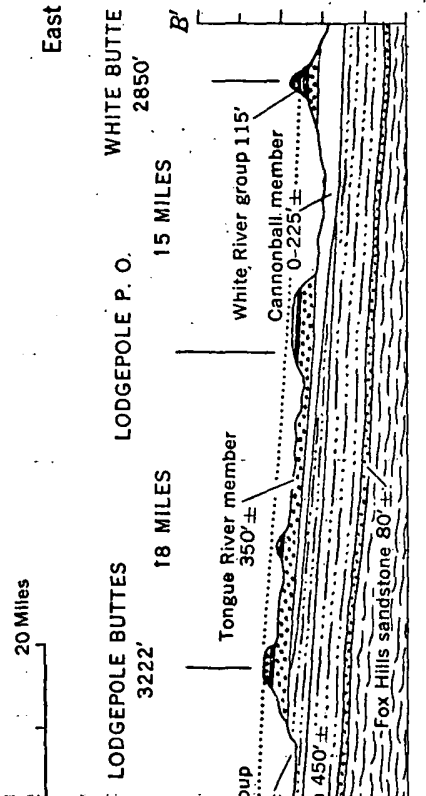

๑ั

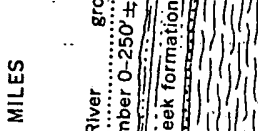

要

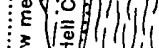

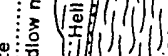

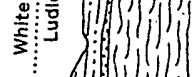

(lis)

至

工立

ด

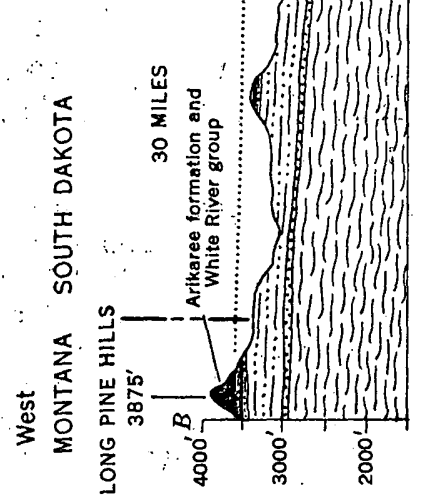

日ั

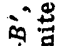

0

สำ

蒫

安是

点鸪

造

응.

量:

总

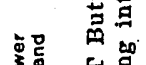

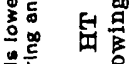

윻용

它完

คี

vं $\dot{0}$

舾

몽응

88

sot

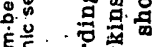

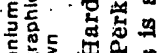

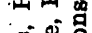

尝壳

的它的

究和

可 콩

당

ต ثิ

是定

崫

萿

i

总

矛。

on

号古

1 齿

เง

苦 
presence, particularly in Slim Buttes, controls the position of a perched water table marked by springs and seeps on the flanks of the buttes.

Analyses, in parts per million, of two water samples from the White River group taken at springs on the west flank of Slim Buttes, Harding County, S. Dak., in the Custer National Forest, made by the U. S. Geological Survey, are given below. Uranium analyses, in parts per million are included for comparison.

\begin{tabular}{|c|c|c|}
\hline & $\begin{array}{l}\text { Colonel Spring 1 } \\
\text { [Mendenhall } \\
\text { area] }\end{array}$ & $\begin{array}{l}\text { West Spring } \\
\text { [Bar } \mathrm{H} \text { area] }\end{array}$ \\
\hline 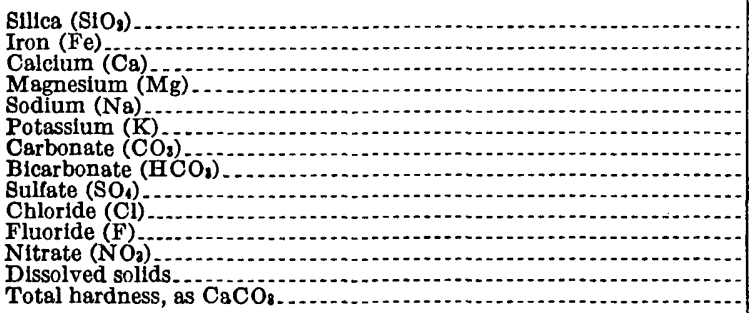 & $\begin{array}{r}29 \\
4.3 \\
1.3 \\
144 \\
4.5 \\
9 \\
367 \\
8.0 \\
2.5 \\
.6 \\
1.3 \\
398 \\
16\end{array}$ & $\begin{array}{l}24 \\
1.03 \\
27.0 \\
27 \\
2.8 \\
87 \\
544 \\
16 \\
3.0 \\
.6 \\
2.2 \\
698 \\
4\end{array}$ \\
\hline Specific conductance $\left(\right.$ micromhos at $\left.25^{\circ} \mathrm{C}\right) \ldots \ldots \ldots \ldots \ldots \ldots \ldots \ldots$ & 591 & 1,100 \\
\hline $\mathrm{pH}$ & 8.4 & 9.3 \\
\hline Uranium (parts per million) & $80.030-40.036$ & $80.030-40.045$ \\
\hline
\end{tabular}

1 Colonel Spring is in SE1/4 sec. 1, T. 17 N., R. 7 E., Harding County, S. Dak.

2 West Spring is in NE1/4 sec. 26, T. 19 N., R. 7 E., Harding County, S. Dak.

Uranium determinations made by the U. S. Geological Survey.

- Uranium determinations made by Oak Ridge National Laboratory, Oak RIdge, Tenn.

Gill and Moore (1955) report that the average uranium content of water from 26 springs in the White River group and Arikaree formation in the Slim Buttes area is 41 parts per billion.

Volcanic material forms an appreciable part of the White River group in other areas (Wanless, 1922; Wood, 1949). Various workers have noted that volcanic material in the White River may be absent or range in quantity from very little to the bulk of the unit. Wood $(1949$, p. 88$)$ summarized the volcanic nature of the White River group as follows:

... The ash falls became steadily heavier during the Oligocene and extended progressively east and north during this epoch. Thus, in eastern and northern White River deposits (Nebraska, South Dakota, North Dakota, and Montana) the Chadron is a true sedimentary rock with clays, silts, and sandstones. The Brule, in these same areas, is of composite origin; the Orella, its lower member, is still largely a sediment, with minor amounts of volcanic material; the Leptauchenia clays of the upper, Whitney member are almost a tuff. Much, but not quite all, of the ash was apparently reworked and deposited by water rather than as direct ash falls. To the west, in Colorado and eastern Wyoming, the ash content rises markedly in both Chadron and Brule, so that these units become progressively more difficult to distinguish from each other by color, 
erosional habit, or lithology. Still farther west, in central Wyoming, the whole White River is one nearly uniform, predominantly volcanic, tuff facies, which may locally be treated as a formation ...

The writers made no attempt to subdivide the Oligocene rocks in northwestern South Dakota into the Chadron and Brule formations as recognized in the Big Badlands of South Dakota (Bump, 1951).

Fossils of early Oligocene age (Chadronian) from the sandstone in the White River capping Medicine Pole Hills in secs. 1, 2, and 12, $\mathrm{T}$. 130 N., R. 104 W., Bowman County, N. Dak. (pl. 9), were identified by C. L. Gazin of the U. S. National Museum as follows:

Hyaenodon sp.

Dinictis sp.

Titanothere teeth
Hyracodon sp.

Proebrotherium sp.

Leptomeryx sp.

Winchester and others $(1916$, p. 33) report Oligocene fossils from the White River at many localities in the Slim Buttes and Short Pine Hills in northwestern South Dakota.

\section{ARIKAREE FORMATION (MIOCENE)}

The rocks referred to the Arikaree formation in northwest South Dakota and adjacent areas to the west in Carter County, Mont.; are so assigned because of their stratigraphic position and lithologic similarity to the middle Miocene Arikaree formation in the Big Badlands of southern South Dakota. On the basis of age determination of a beaver fossil collected in Carter County, Mont., Wood (1945, p. 5) interpreted the rocks assigned to the Arikaree in this area to be of upper rather than of middle Miocene age. The rocks, however, are lithologically more closely related to the Arikaree formation than to the Ogallala formation of the Great Plains. As the available evidence does not seem to justify renaming of the unit for purposes of this report, the writers follow Darton (1909, p. 31), Winchester and others $(1916$, p. 34), and Bauer $(1924$, p. 245$)$ in assigning them to the Arikaree. The age and stratigraphic relationships of the Arikaree and Ogallala formations in northwestern South Dakota and adjacent areas are discussed by Wood and others (1941) and Wood (1945).

The Arikaree formation in northwestern South Dakota and adjacent areas is predominantly a cliff-forming formation, about 200 feet thick, consisting almost wholly of chalky to greenish-gray sandy and quartzitic tuffaceous beds (pl.13). A distinctive zone, 20-30 feet thick, composed largely of concretions with concentric and columnar structure occurs at many places within 25 feet of the base of the formation. The zone is typically developed along the west face of Slim Buttes in the vicinity of the Mendenhall mine, sec. 1, T. 17 N., R. 7 E. (pl. 15). The Arikaree rests disconformably on the White River group in the 
Slim Buttes and the Short Pine Hills in Harding County, S. Dak., and the Long Pine Hills in Carter County, Mont. A bed of conglomerate 2-3 feet thick, composed of very fine grained tuffaceous sandstone pebbles as much as 3 inches in diameter, occurs at many places directly above the basal contact. In parts of the Long Pine Hills, the White River is absent and the Arikaree rests on the Ludlow member of the Fort Union formation. Volcanic material is abundant throughout the formation. Typical specimens contain angular feldspar, biotite, quartz, epidote, augite, hornblende, and fragments of glass, together with chloritic material. These rocks have been termed rhyolitic tuff by E. S. Larsen, Jr. (Winchester and others, 1916, p. 34-35). The Arikaree formation and the White River group are remarkably uniform in lithologic characteristics over large areas in western North and South Dakota, Nebraska, and eastern Wyoming. Their general areal distribution is shown on figure 6 .

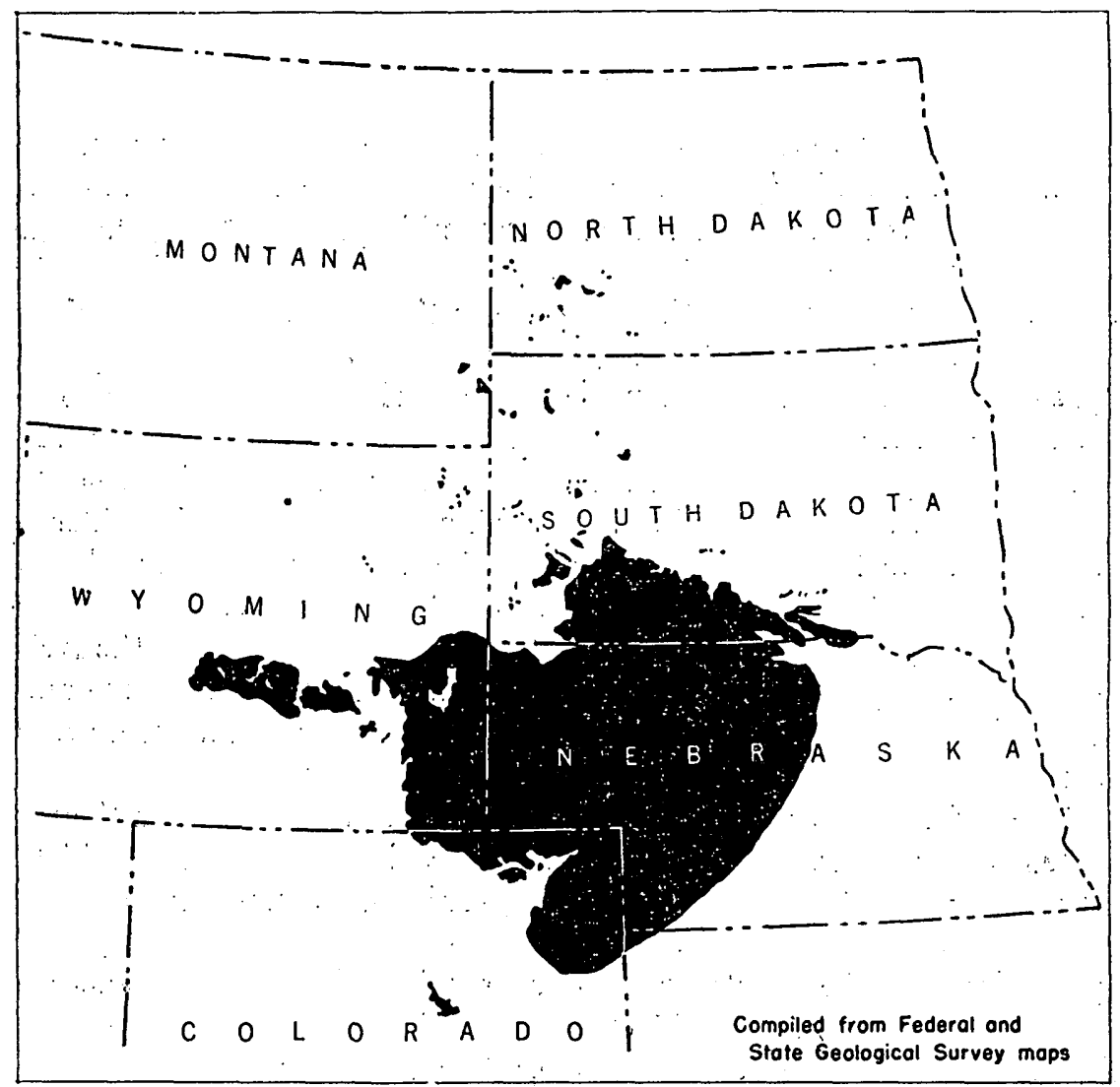

Frodn: 6.-Generalized map showing areal distribution (black areas) of the White River group of Oligocene age, and the Arlkaree formation of Mlocene age. 
Three hand specimens from the tuffaceous Arikaree formation in the Slim Buttes area (ZD-33, -40 , and -41$)$ and thin sections of two of these (ZD-33 and -40) were studied by Howard A. Powers. Field data on these specimens are:

\begin{tabular}{|c|c|}
\hline \multirow{3}{*}{$\begin{array}{l}\text { Specimen } \\
\text { ZD-33 }\end{array}$} & Source in A rikaree formation \\
\hline & \\
\hline & $\begin{array}{l}\text { Concretionary zone near base of formation, } \mathrm{SE} 1 / 4 \\
\text { sec. } 36, \text { T. } 18 \text { N., R. } 7 \mathrm{E} \text {. }\end{array}$ \\
\hline ZD-40 & $\begin{array}{l}\text { At depth of } 120 \text { feet in core hole } 16 \mathrm{~A} \text {, near base of } \\
\text { formation, NE1/4 sec. 12, T. } 17 \text { N., R. } 7 \mathrm{E} \text {. (from } \\
\text { same horizon as } \mathrm{ZD}-33 \text { ). }\end{array}$ \\
\hline-41 & $\begin{array}{l}\text { At depth of } 53 \text { feet in core hole } 17 \text {, near top of } \\
\text { formation, SW } 1 / 4 \text { sec. } 6 \text {, T. } 17 \text { N., R. } 8 \mathrm{E} \text {. (Gill } \\
\text { Zeller, and Schopf, chapter D, this bulletin, } \\
\text { pl. 26). }\end{array}$ \\
\hline
\end{tabular}

Mr. Powers reports the following data (written communication, July 1, 1952) :

Hand specimen notes: All three are sandstones containing well rounded to subangular mineral and rock fragments in matrix material. Samples ZD-33 and -40 are compacted but not in the least indurated; $\mathrm{ZD}-41$ is moderately indurated ; $\mathrm{ZD}-33$ is a concentrically banded nodule, 2 inches in diameter. $\mathrm{ZD}-40$ contains about 5 percent of fragments as much as $1 \mathrm{~mm}$. in diameter, about 35 percent fragments between 0.05 and $0.15 \mathrm{~mm}$., and 60 percent matrix; the other two samples contain about 60 percent of fragments ranging in diameter from 0.02 to $0.25 \mathrm{~mm}$. with the greatest number between 0.05 and $0.15 \mathrm{~mm}$. Sample ZD-41 owes its induration to opal in the matrix.

Microscopic determinations: All three rocks have essentially the same general composition, except for the larger fragments in sample ZD-40 and the opal in the matrix of sample ZD-41 mentioned above. The mineral and rock fragments range from well rounded to subangular in form, and are present in about the following relative proportions:

clear crystalline quartz

cloudy, yellowish to greenish, cryptocrystalline fragments of fine-grained altered material, perhaps altered mudstone.

clear, twinned, zoned plagioclase, composition about andesine.

clear, twinned microcline

green hornblende crystals.

biotite

brown hornblende crystals

zircon crystals and rounded grains

apatite crystals and rounded grains...........

iron oxide grains

black tourmaline, augite, and rounded grains rare of garnet. about half of the fragments about a third of the fragments

about an eighth of the fragments

\section{numerous}

numerous

common.

common

common

common

common

From 5 to 10 percent of shard-shaped bodies should also be listed with the fragments and not with the matrix material. These shapes are outlined in thin section by a thin film of a high-birefringent flakey mineral, which also mantles all of the mineral and rock fragments. The material composing the shard-shaped 
bodies is colorless, clear to cloudy, isotropic, soft material with index of refraction lower than balsam. It cannot be isolated and separated on a freshly broken rock surface, so that the material examined in index oils cannot with confldence be assigned to the shard-shapes rather than to some similar materials appearing in the matrix.

The matrix, except for the opal in $\mathrm{ZD}-41$, is an incoherent mass of at least three sorts of material; a clear, birefringent mineral which occurs in sheaves of fibers, a cloudy cryptocrystalline birefringent low index clay mineral (or minerals), and some clear isotropic interstitial material. The fibrous sheaf mineral has the habit of a zeolite, but its index of refraction, $1.464 \pm .003$ is low for most of the fibrous zeolites. Two hydrous aluminum sulphate minerals have an index in this range, i. e. mendozite, and aluminite, but both are described as uncommon, and I hesitate to suggest either one without much more determinative work. The clay minerals have an index of refraction that would permit them to be in the montmorillonite group. Some of the clear isotropic material has an index slightly below 1.480 (which I presume is that from the shard-shaped bodies) and some of it has an index about 1.562 .

Thoughts on the origin of the rock: In the nodule (ZD-33) nothing was discovered either in texture or in the observed mineral composition which apparently could account for the suggested concentric layering. The rock as a whole must be a mixture of materials from two different sources, and with two different erosion histories. Several different considerations force this conclusion. The presence of rounded microcline and rounded tourmaline grains requires a source of crystalline rock, and a history of strong mechanical erosion. The presence of rounded fragments of cryptocrystalline aggregate, probably chlorite, serpentine and chalcedony requires a source of metamorphosed fine sediments and some mechanical erosion. The presence of zoned and twinned plagioclase, in fragments subrounded to subangular, requires a source of extrusive volcanic rock, with not too strong mechanical erosion. The presence of many needleshaped crystals of green hornblende indicates very moderate mechanical erosion, and suggests a source in volcanic tuff or lava which was easily broken up. The

TABLE 2.-Analyses of core samples of the White River

[Analyst, Paul

Semiquantitative spectrographic analyses: range in percent: $A$, more for but not found: $\mathrm{P}, \mathrm{Ag}, \mathrm{As}, \mathrm{Au}, \mathrm{BI}, \mathrm{Cd}, \mathrm{Ce}, \mathrm{Ge}, \mathrm{In}, \mathrm{Ir}, \mathrm{Hf}, \mathrm{Hg}, \mathrm{Li}$,

\begin{tabular}{|c|c|c|c|c|c|c|c|c|c|c|c|c|c|c|}
\hline \multirow[b]{2}{*}{$\begin{array}{l}\text { Core } \\
\text { hole }\end{array}$} & \multicolumn{6}{|c|}{ Sample } & \multicolumn{8}{|c|}{$\begin{array}{l}\text { Semiquantitative spéctrographlc } \\
\text { analyses (see key) }\end{array}$} \\
\hline & $\begin{array}{l}\text { Field } \\
\text { No. }\end{array}$ & $\begin{array}{l}\text { Labo- } \\
\text { ra- } \\
\text { tory } \\
\text { No. }\end{array}$ & $\begin{array}{c}\text { Thick- } \\
\text { ness } \\
\text { (inches) }\end{array}$ & $\begin{array}{c}\text { Depth } \\
\text { in } \\
\text { hole } \\
\text { (feet) }\end{array}$ & Geologic unit & Rock type & $\mathrm{Si}$ & $A 1$ & $\mathrm{Fe}$ & $\mathrm{Mg}$ & $\mathrm{Ca}$ & $\mathrm{Na}$ & $\mathbf{K}$ & $\mathrm{Ba}$ \\
\hline 17 & ZD-41 & 62912 & 8 & 53 & $\begin{array}{l}\text { Arlkaree for- } \\
\text { mation. }\end{array}$ & $\begin{array}{l}\text { Quartzitic silt- } \\
\text { stone. }\end{array}$ & A & $\mathbf{B}$ & B & $\mathbf{C}$ & B & $\mathbf{B}$ & B & D \\
\hline $16 A:-$ & $\begin{array}{l}-40 \\
-39\end{array}$ & $\begin{array}{l}62911 \\
62910\end{array}$ & $\begin{array}{l}7 \\
6\end{array}$ & $\begin{array}{l}120 \\
137\end{array}$ & White River & $\begin{array}{l}\text { Siltstone } \\
\text { Bentonitic }\end{array}$ & A & $\underset{\mathbf{B}}{\mathbf{B}}$ & $\underset{\mathbf{B}}{\mathbf{B}}$ & $\underset{\mathbf{B}}{\mathbf{C}}$ & $\stackrel{\mathrm{B}}{\mathrm{C}}$ & $\stackrel{\text { B }}{\mathbf{C}}$ & B & $\stackrel{O}{D}$ \\
\hline $164:$ & -37 & 62908 & 8 & 173 & group. & $\begin{array}{l}\text { clay. } \\
\text { Calcareous }\end{array}$ & A & B & B & $\mathbf{C}$ & C & $\mathbf{B}$ & B & D \\
\hline $16:-$. & $\begin{array}{l}-38 \\
-36\end{array}$ & $\begin{array}{l}62909 \\
62907\end{array}$ & $\begin{array}{l}9 \\
8\end{array}$ & $\begin{array}{l}242 \\
240\end{array}$ & (...-do. & $\begin{array}{l}\text { Pink clay...-. } \\
\text { Green clay...- }\end{array}$ & $\mathbf{A}$ & $\underset{\mathbf{B}}{\mathbf{B}}$ & $\begin{array}{l}\text { B } \\
\mathbf{B}\end{array}$ & $\underset{\mathbf{B}}{\mathbf{B}}$ & $\underset{\mathrm{C}}{\mathrm{C}}$ & $\begin{array}{l}\mathbf{C} \\
\mathbf{B}\end{array}$ & $\stackrel{\mathrm{B}}{\mathrm{C}}$ & $\underset{D}{D}$ \\
\hline
\end{tabular}

- From Gill, Zeller, and Schopf, chapter D, this bulletin, pl. 22.

b From Zeller and Schopf, chapter C, this bulletin, pl. 17 . 
shard-shaped fragments most logically could be assumed to have been shards of volcanic glass which had undergone very little transportation and mechanical erosion. Probably the simplest proposed origin which can account for the observed mineralogy and petrography is that the rock is fluviatile or lacustrine sandstone derived from a crystalline and metamorphic country rock at some distance, mixed with crystal-vitric ash from a nearby source.

A photomicrograph of a thin section of a sandstone concretion (ZD-33) from the zone near the base of the Arikaree formation is shown in pl. 2. Semiquantitative spectrographic and chemical determinations on core samples of the White River group and Arikaree formation in the Slim Buttes area, Harding County, South Dakota, are listed in table 2. The minimum amounts of elements detectable with semiquantitative spectrographic methods are indicated in table 1.

TABLE 1.-Minimum amounts of elements detectable with semiquantitative spectrographic methods

[Revised May 22, 1952]

\begin{tabular}{|c|c|c|c|c|c|c|c|}
\hline Element & Percent & Element & Percent & Element & Percent & Element & Percent \\
\hline $\mathrm{Ag}_{-\ldots} \ldots$ & 0.0001 & $\mathrm{Fe} . . .$. & 0.001 & $\mathrm{Nb}$ & 0.005 & S1_...... & 0.001 \\
\hline Al...... & .001 & $\mathrm{Ca}$ & .001 & $\mathrm{Nd}$ & .01 & $\mathrm{Sm}$ & .01 \\
\hline As $\ldots$ & 1 & Gd... & .05 & Ni....... & .0005 & Sn & .001 \\
\hline $\mathrm{Au}$ & .005 & $\mathrm{Ge}$ & .0005 & Os. & .005 & $\mathrm{Sr}$ & .0005 \\
\hline B. & .005 & Hi & .1 & $\mathbf{P}$ & .5 & $\mathrm{Ta}$ & .05 \\
\hline $\mathrm{Ba} \ldots$ & .0001 & $\mathrm{Hg}$ & 1.0 & $\mathrm{~Pb}$ & .001 & $\mathrm{Te}$ & .5 \\
\hline $\mathrm{Be} \ldots$ & .0001 & In. & .001 & $\mathrm{Pd}$ & .0005 & $\mathrm{Th}$ & .05 \\
\hline$\overline{B i}$ & .001 & Ir & .005 & $\mathrm{Pr}_{-}$ & .005 & $\mathrm{~T} 1$ & .001 \\
\hline $\mathrm{Ca}$. & .001 & $\mathbf{K}$. & - $1.0(0.005)$ & Pt.. & .005 & Tl. & .05 \\
\hline Cd. & .005 & La. & .005 & $\mathrm{Rb}$ & $(0.01)$ & U. & .05 \\
\hline $\mathrm{Ce}_{--}$ & .05 & $\mathrm{LI}$ & $.01(0.0001)$ & Re.... & .005 & & .001 \\
\hline $\begin{array}{l}\mathrm{Co} .- \\
\text { Cr.. }\end{array}$ & $\begin{array}{r}.0005 \\
0005\end{array}$ & Mg..... & $\begin{array}{r}.005 \\
.001\end{array}$ & $\mathrm{Rh}_{\mathrm{R}} \ldots$ & .005 & $\underset{\mathbf{Y}}{\mathbf{W}}$ & .01 \\
\hline & $-1.0(0.05)$ & Mn. . . & .0005 & $\mathrm{Sb}$........ & .05 & $\mathrm{Zn}$ & .051 \\
\hline a & .0001 & $\mathrm{Na}$ & $.05(0.001)$ & $\mathrm{Sc}$ & .001 & $\mathrm{Zr}$ & .001 \\
\hline
\end{tabular}

- A second exposure is required for the high sensitivity listed.

group and Arikaree formation, the Slim Buttes, S. Dak.

R. Barnett]

than $10 ; \mathrm{B}, 1-10 ; \mathrm{C}, 0.1-1 ; \mathrm{D}, 0.01-0.1 ; \mathrm{E}, 0.001-0.01 ; \mathrm{F}, 0.0001-0.001$; looked Nb, Nd, Os, Pd, Pt, Re, Rh, Ru, Sb, Sm, Ta, Te, Th, T1, U, W, Zn

\begin{tabular}{|c|c|c|c|c|c|c|c|c|c|c|c|c|c|c|c|c|c|c|c|c|}
\hline \multirow{2}{*}{\multicolumn{18}{|c|}{ Semiquantitative spectrographic analyses (see key)-Continued }} & \multicolumn{3}{|c|}{ Analyses, In percent } \\
\hline & & & & & & & & & & & & & & & & & & \multirow{3}{*}{$\begin{array}{c}\begin{array}{c}\text { Radio- } \\
\text { metric }\end{array} \\
\begin{array}{l}\text { Equiva- } \\
\text { lent } \\
\text { uranium }\end{array}\end{array}$} & \multicolumn{2}{|c|}{ Chemical } \\
\hline \multirow[b]{2}{*}{$\mathrm{Sr}$} & \multirow[b]{2}{*}{ Mn } & \multirow[b]{2}{*}{ TI } & \multirow[b]{2}{*}{ B } & \multirow[b]{2}{*}{$\mathrm{Cu}$} & \multirow[b]{2}{*}{ Mo } & \multirow[b]{2}{*}{ V } & \multirow[b]{2}{*}{$\mathrm{Cr}$} & \multirow[b]{2}{*}{$\mathrm{N1}$} & \multirow[b]{2}{*}{$\mathrm{Pb}$} & \multirow[b]{2}{*}{ Co } & \multirow[b]{2}{*}{$\mathrm{Sc}$} & \multirow[b]{2}{*}{$\mathbf{Z r}$} & \multirow[b]{2}{*}{$\mathrm{Ga}$} & \multirow[b]{2}{*}{$\mathbf{Y}$} & \multirow[b]{2}{*}{ Sn } & \multirow[b]{2}{*}{ Be } & \multirow[b]{2}{*}{ La } & & & \\
\hline & & & & & & & & & & & & & & & & & & & $\begin{array}{l}\text { Ura- } \\
\text { nlum }\end{array}$ & $\underset{\text { rine }}{\text { Fluo- }}$ \\
\hline $\mathrm{D}$ & $\mathrm{D}$ & C & $\ldots$ & $\mathbf{E}$ & $\ldots$ & $\mathbf{E}$ & $\mathbf{E}$ & $\mathbf{E}$ & $\mathbf{F}$ & $\mathbf{F}$ & $\mathbf{F}$ & D & F & $\mathbf{E}$ & & & & 0.002 & 0.001 & 0.008 \\
\hline $\mathrm{D}$ & $\mathrm{D}$ & $\mathbf{C}$ & $\mathbf{E}$ & $\mathbf{E}$ & & $\mathbf{E}$ & $\mathbf{E}$ & $\mathbf{F}$ & $\mathrm{F}$ & $\mathbf{F}$ & $\mathbf{F}$ & $\mathrm{D}$ & $F$ & $\mathbf{E}$ & & & $\mathbf{E}$ & .002 & .001 & .005 \\
\hline D & $\mathrm{D}$ & C & $\mathbf{E}$ & $\mathbf{E}$ & $\mathbf{F}$ & $\mathbf{E}$ & $\mathbf{E}$ & $\mathbf{E}$ & $\mathrm{F}$ & $\mathbf{F}$ & $\mathbf{E}$ & $\vec{E}$ & $\mathrm{~F}$ & $\cdots$ & $\mathrm{F}$ & $\ldots$ & 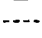 & .001 & .001 & .002 \\
\hline D & D & $\mathrm{C}$ & $\ldots$ & $\mathbf{E}$ & $\mathbf{E}$ & $\mathbf{E}$ & $\mathbf{E}$ & $\mathbf{E}$ & $F$ & $\ldots$ & -. & $\mathbf{E}$ & $F$ & $\mathbf{E}$ & $\ldots$ & -. & $\mathbf{E}$ & .001 & .001 & .008 \\
\hline$\underset{D}{D}$ & $\begin{array}{l}\mathrm{D} \\
\mathrm{D}\end{array}$ & $\begin{array}{l}\mathrm{C} \\
\mathrm{C}\end{array}$ & $\begin{array}{l}\mathbf{E} \\
\mathbf{E}\end{array}$ & $\underset{\mathrm{E}}{\mathrm{E}}$ & $\cdots$ & $\underset{E}{\mathrm{D}}$ & $\underset{\mathbf{E}}{\mathbf{E}}$ & $\underset{\mathrm{E}}{\mathrm{E}}$ & $\underset{\mathbf{E}}{\mathbf{E}}$ & $\underset{F}{F}$ & $\frac{\mathrm{E}}{\mathrm{F}}$ & $\stackrel{E}{D}$ & $\frac{\mathrm{F}}{F}$ & $\frac{\mathrm{E}}{\mathrm{E}}$ & $\mathbf{E}$ & F & $\mathrm{E}$ & $\begin{array}{l}.003 \\
.001\end{array}$ & $\begin{array}{l}.001 \\
.001\end{array}$ & $\begin{array}{l}.008 \\
.000\end{array}$ \\
\hline
\end{tabular}




\section{QUATERNARY SYSTEM}

Thin terrace deposits are distributed along the principal streams of the region here described. The material in these deposits ranges in size from sand grains to cobbles 3-5 inches in diameter, and is composed principally of quartzite, sandstone, limestone, and fossil wood. Sand dunes cover large areas along the Grand and Little Missouri Rivers, but since neither the dunes nor the terrace deposits seem to be related to the occurrence of uranium-bearing lignites, they were not studied in detail.

\section{STRUCTURE}

The lignite-bearing formations occupy the west limb of a very shallow structural trough, the Lemmon syncline, the axis of which trends approximately north and lies well to the eastern edge of the area (fig. 3). In general, the strike of the rocks is northwest and the regional dip is $10-40$ feet per mile to the northeast. The dominant structural feature effecting the regional dip is the plunging north end of the Black Hills uplift, the axis of which trends north-northwest and is just to the west of the Short Pine Hills in western Harding County, S. Dak., and the Long Pine Hills in eastern Carter County, Mont. All of the lignite-bearing formations are slightly deformed to an equal degree. The younger White River group, Arikaree formation and Quaternary terrace gravel lie almost horizontally on the truncated edges of the older formations. A few faults with stratigraphic displacement of less than 150 feet were observed at the north end of the Slim Buttes. At many places, however, landslides of Recent and of Miocene(?) age havie produced effects similar to faulting and folding.

\section{URANIUM-BEARING LIGNITE}

\section{MODE OF OCCURRENCE OF THE URANIUM}

Uranium minerals of megascopic size recently discovered in lignite and carbonaceous sandstones in the Cave Hills and Slim Buttes areas of northwestern South Dakota (J. R. Gill, written communication, 1954) are autunite, zeunerite, torbernite, and metatyuyamunite. These impregnate fractures and joints in thin impure lignite beds and in the enclosing sandstone.

Uranium minerals have not been found in the radioactive lignite deposits in the other Dakota areas. Detailed microscopic and analytical studies have not been completed on samples from the deposits herein described and the exact nature of the occurrence of uranium is not known. However, the common concept is that the uranium 
occurs as a disseminated constituent of carbonaceous material. Petrographic and mineralogic studies by the Battelle Memorial Institute (R. A. Ewing, written communication, 1950), the U. S. Geological Survey (Schopf and Gray, 1954; I. A. Breger and M. Deul, written communication, 1952) and Pennsylvania State University (T. F. Bates and others, written communication, 1952) of lignite from North and South Dakota demonstrate that the uranium, although not present as a distinct mineral, is closely associated with the organic carbonaceous material. Gypsum, analcite, jarosite, limonite, quartz, and other minerals were identified in decreasing order of abundance but had no observed relationship to the amount of uranium in the lignite. Semiquantitative spectrographic analyses of the ash from uranium-bearing lignite cores from South Dakota (see chapter C, this bulletin, table 4) show that most chemical elements are uniformly distributed through a vertical section of lignite. Uranium and molybdenum are among those which show a marked decrease downward from the top of the bed. The presence of small amounts of nickel, lead, vanadium, and arsenic is suggested by spectrographic data but the association and the distribution of these elements with uranium is less consistent.

Lignite from South Dakota has been shown to be a good extractor of uranium from solution (Moore, 1954). Nonradioactive lignite from the Slim Buttes, S. Dak., was immersed in a solution of uranyl sulfate containing 200 parts per million uranium. After 19 days the lignite contained 0.19 percent uranium and the solution contained 2.0 parts per million uranium. This confirms, in a striking manner, the affinities of carbonaceous material for uranium pointed out by Tolmachev (1943) and Szalay (1954). Similar adsorptive relationships have been postulated by McKelvey and Nelson (1950, p. 46) for the origin of uranium in marine black shale, and Frederickson (1948) has discussed the relation between uranium and other types of carbon.

\section{THEORIES OF ORIGIN AND ACCUMULATION}

The origin of uranium in the lignites in South Dakota cannot be conclusively demonstrated, although the writers believe an abundance of field evidence favors the epigenetic hypothesis, the third of three opposing concepts, numbered here as the (1) diagenetic, (2) syngenetic, and (3) epigenetic hypotheses of origin.

As the result of work in 1948 and 1949, D. G. Wyant and E. P. Beroni (written communication, 1950) proposed the following two hypotheses of origin :

1. That uranium was deposited with other detrital minerals in sediments overlying or marginal to the lignite and subsequently leached from them, carried downward, or laterally, and fixed by the carbon of the lignite; or, 
2. That uranium was deposited from surface waters by the action of living organisms or dead organic matter at the same time as the carbonaceous debris from which the lignite formed.

E. P. Beroni and H. L. Bauer, Jr. (written communication, 1952), as the result of more detailed work in 1949 , reiterated these two hypotheses, and stated: "Both of these hypotheses require that there was uraniferous source material being eroded and leached either at the time of deposition of the organic material of the lignite or shortly thereafter." They concluded as did Gott, Wyant, and Beroni (1952, p. 34) and L. R. Page (written communication, 1953) that the second, "syngenetic", origin was more probable.

The results of our work in 1950 led us to propose the third hypothesis: 3 . the uranium is epigenetic in origin, being derived from unconformably overlying tuffaceous source rocks and carried by ground water percolating downward or moving laterally along aquifers near the lignite beds and extracted by the lignite after coalification. The uranium ion is believed to have been held as a finely disseminated constituent in volcanic ash and other glassy extrusive rocks. Subsequent release or displacement of the uranium may have been accomplished by weathering and ultimate devitrification of the volcanic materials. Whatever the reason for the displacement, carbonaceous materials are believed to have acted as filters to concentrate and cause fixation of the uranium as a result of ion exchange or by the formation of organo-metallic compounds (I. A. Breger and M. Deul, written communication, 1952).

Subsequent field work, including extensive core drilling in the Dakotas, has provided data and confirmed this hypothesis, now termed the "ash-leach" or volcanic-ash theory (Thomas, 1954; Hager, 1954; and Miller and Gill, 1954). The concept has been applied in other areas, both as a guide in exploration and as an explanation of the distribution of known deposits. Love (1952) has attributed the origin of certain sandstone-type uranium deposits in Wyoming to the ash-leach process as has R. L. Griggs (1954) in New Mexico and J. W. Gruner (1954) in the Colorado Plateau and other areas. Koeberlin (1938) suggested that volcanic ash may have been the source of various metals in some deposits in southwestern United States where evidence of hydrothermal activity is obscure or lacking. The recent discoveries of ore-grade deposits of autunite-bearing lignite and of metatyuyamunite in carbonaceous sandstones closely underlying tuffaceous rocks in the Slim Buttes and North Cave Hills areas (J. R. Gill and G. W. Moore, written communication, 1954) offer additional confirmatory evidence 
for the theory. The origin of the uranium seems important because search for other deposits will be successful chiefly to the extent that it is guided by application of valid concepts of origin.

\section{EVIDENCE IN SUPPORT OF A SYNEGETIC THEORY OF ORIGIN}

The following observations were summarized by E. P. Beroni and H. L. Bauer (written communication, 1952) :

1. Uranium-bearing lignites are confined to a limited stratigraphic zone and uranium content is due to a process which operated only during the time of deposition of sediments of that zone.

2. Uranium content of individual lignite beds is remarkably uniform over wide areas indicating an environmental control.

3. Uranium is closely associated with analcite-bearing rocks. Both analcite and uranium are deemed to be syngenetically derived from the breakdown of volcanic material deposited in the coal swamps.

4. An autoradiograph suggests a homogeneous distribution of uranium in lignite, which in turn suggests introduction of the uranium before coalification.

5. In some areas, as at Sentinel Butte, N. Dak., the lignite nearest the unconformity at the base of the White River does not have the highest uranium content as it should if the uranium were coming from downward moving solutions.

6. There is little evidence of radioactive materials in the overlying White River group which could make it a source bed for the radioactive materials in the lignite.

EVIDENCE IN GUPPORT OF AN EPIGENETIC THEORY OF ORIGIN

There is much field evidence which supports the theory that the uranium in the Dakota lignites was secondarily derived by groundwater leaching of the volcanic materials in the White River group and Arikaree formation, of which the following relationships are believed to be of particular significance:

1. All uranium-bearing lignite deposits reported from eastern Montana and the Dakotas are stratigraphically near the unconformity at the base of the Oligocene and bear no apparent relationship to the age of the formation in which they occur:

Areal relationships of the uranium-bearing lignite beds in wide areas in the Dakotas, eastern Montana, and Wyoming indicate that the uranium in the lignite is independent of the age of the formation in which the lignite occurs but is very closely related to the topographic position of the widespread unconformity at the base of a thick sequence of tuffaceous rocks which at one time covered most of the region (pl. 1). Because lignite beds of successively younger age are uranium-bearing adjacent to the unconformity it seems logical to assume that uraniummineralization occurred after the tilting and truncation of the lignitebearing rocks. 
A summary of the uranium-bearing lignite deposits in the Dakotas and eastern Montana, all in the Fort Union formation of Paleocene age, are listed below by formation and stratigraphic proximity to the base of the White River group (or Arikaree formation)

\begin{tabular}{|c|c|c|}
\hline Location & $\begin{array}{l}\text { Unit of the Fort Union formation in which } \\
\text { deposit occurs }\end{array}$ & $\begin{array}{l}\text { Stratigraphic prox- } \\
\text { imity of deposits } \\
\text { to base of White } \\
\text { River group or } \\
\text { Arikaree forma- } \\
\text { tion }\end{array}$ \\
\hline 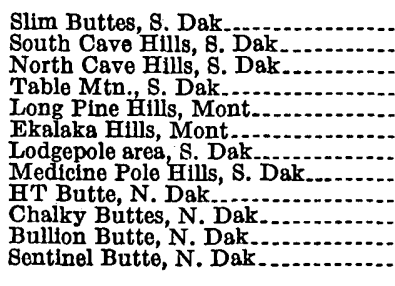 & $\begin{array}{l}\text { Ludlow member } \\
\text { Ludlow and Tongue River members } \\
\text { Ludlow member } \\
\text { Tongue River member } \\
\text { Sentinel Butte member }\end{array}$ & $\begin{array}{l}5-40 \text { feet. } \\
75-160 \text { feet. } \\
135-150 \text { feet. } \\
150-160 \text { feet. } \\
75-150 \text { feet. } \\
10-85 \text { feet. } \\
25-75 \text { feet. } \\
25-60 \text { feet. } \\
160-180 \text { feet. } \\
10-80 \text { feet. } \\
160-180 \text { feet. } \\
80-100 \text { feet. }\end{array}$ \\
\hline
\end{tabular}

Indicated projected position of base of the White River group in areas where White River has been removed by erosion.

In addition to the Paleocene units listed above, thin beds of uranium-bearing lignite are found in the Hell Creek formation of Late Cretaceous age near the East Short Pine Hills, Harding County, S. Dak., and in the Golden Valley formation of Eocene age in the Little Badlands, Stark County, N. Dak. At both localities, the beds are within 10-20 feet of the base of the White River group.

If the uranium in the lignite is syngenetic, it is difficult to explain why uranium-bearing lignite occurs only on the flanks of the highest buttes capped with volcanic materials. Many lignite beds are exposed along the low plains and stream valleys throughout the Dakotas and Gastern Montana and many have been sampled or tested for radioactivity. However, none are uranium bearing. Much of the information gathered during the course of the investigation is not presented in this report. Such data, however, are pertinent and were critically evaluated in developing working hypotheses to explain the origin of the uranium and to determine the factors controlling its accumulation.

2. Most of the lignite beds having the most uranium are highest in the stratigraphic section:

Within a series of nearly flat-lying carbonaceous beds the stratigraphically and topographically higher beds, in general, have more uranium. The uranium content of succeeding lower beds decreases to the vanishing point. This suggests that the uranium probably was derived from an overlying source. This relationship is noted at a majority of the localities where a sufficient number of samples has been collected from each stratigraphic section. Locality 84 (pls. 11, 12, and 16) at the Mendenhall mine in the Slim Buttes is an excellent 
example. There the highest bed of lignite in the stratigraphic section contains 0.030 percent uranium. The second highest bed of lignite contains 0.010 percent uranium, while the third highest bed contains 0.005 percent uranium in the upper half and only 0.002 percent uranium in the lower half. The fourth highest bed of lignite sampled at this locality contains only 0.002 percent uranium. Beds lower in the stratigraphic section in this area were tested for radioactivity but did not show appreciable amounts. Many localities which show this relationship may be cited: for example, localities $82,88,92,96$, and 97 (pl. 12) in the Slim Buttes; locality 9 (pl. 7), at Table Mountain; localities 36, 38, 39, 40, 44, 45, and 46 (pl. 7), in the North Cave. Hills; and localities 66 and 68 (pl. 5) in the South Cave Hills. Anomalies may be explained by the presence and the position of the permeable zones which, in some places, may have carried ground water laterally for a considerable distance under hydrostatic head. For example, at locality 7 (pl. 7) at Table Mountain the stratigraphically highest bed of lignite contains only 0.003 percent uranium; whereas the second highest contains 0.036 percent uranium. The highest bed of lignite in this stratigraphic section is a thin lens enveloped in shale. The relatively impermeable shale would prevent access of the uranium-bearing solutions to the lignite. The second highest bed of lignite in this section is somewhat more continuous and is overlain by a relatively thick, poorly cemented, coarse-grained sandstone. This sandstone may have served as an aquifer for the lateral movement of uranium-bearing solutions. Other notable exceptions to the relationship also occur at localities 52 and 63 (pl. 5) in the South Cave Hills.

3. Uranium concentrations are highest at the top of thick lignite beds, diminishing progressively downward to a vanishing point in their lower parts:

In general the uranium content within a uranium-bearing lignite bed 3 feet or more thick is greater at the top and diminishes progressively downward. This suggests that the uranium was derived from an overlying source. The analyses in table 3 (p. 34) show the progressive decrease downward in distribution of uranium, characteristic of thick beds of radioactive lignite in the Dakotas.

At those places where the stratigraphically highest lignite is less than 3 feet thick, the uranium in general is concentrated in the lower part of the bed. Examples of this "inverted" pattern were noted by Zeller and Schopf (chapter C, this bulletin, p. 68), who concluded that the higher concentration in the lower rather than the upper parts of these beds might be explained by the lateral movement of uraniumbearing ground water along the base of these generally incompetent and highly fractured beds which normally overlie thick, impervious 
underclays. Analyses showing the "inverted" pattern are listed below:

\begin{tabular}{|c|c|c|c|c|c|}
\hline \multirow{3}{*}{ Lignite bed in Fort Union formation } & \multirow{3}{*}{ Interval } & \multicolumn{4}{|c|}{ Analyses, in percent } \\
\hline & & \multirow{2}{*}{ Ash } & \multicolumn{2}{|c|}{ Uranium } & \multirow{2}{*}{$\begin{array}{c}\text { Equiva } \\
\text { lent } \\
\text { uranium }\end{array}$} \\
\hline & & & In ash & $\underset{\text { sample }}{\text { In }}$ & \\
\hline $\begin{array}{l}\text { A: lignite bed, } 12 \text { inches thlck, near top of } \\
\text { Sentinel Butte member, north side of } \\
\text { Sentinel Butte, SE1/4. sec. 6, T. 39 N., } R \text {. } \\
104 \text { W., Golden Valley County, N. Dak. } \\
\text { B: lignite bed, } 19 \text { inches thick, near top of } \\
\text { Ludlow meniber, east side of Table } \\
\text { Mountoin, SEY, sec. 5, T. 22 N., R. } 4 \text { E., } \\
\text { Harding County, S. Dak. (locality } 9 \text {, } \\
\text { pl. 4). }\end{array}$ & 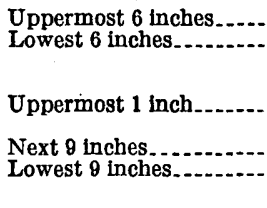 & $\begin{array}{r}50.5 \\
41.7 \\
38.1 \\
22.8 \\
28.6\end{array}$ & $\begin{array}{l}.004 \\
.035 \\
.078\end{array}$ & $\begin{array}{r}.001 \\
.008 \\
.022\end{array}$ & $\begin{array}{r}.003 \\
.008 \\
.017\end{array}$ \\
\hline
\end{tabular}

TABLE 3.-Analyses of uranium, in percent, showing vertical distribution of uranium in three lignite beds, in the Dakotas

[Analysts: M. Delevaux, S. Furman, S. Lundine, W. Tucker, and J. Wilson]

\begin{tabular}{|c|c|c|}
\hline $\begin{array}{l}\text { Harmon(?) bed in } \\
\text { Perkins County, } \\
\text { S. Dak. } \\
\text { Core hole } 14{ }^{1} \\
\text { (Pl. 20) }\end{array}$ & $\begin{array}{l}\text { Mendenhall bed in } \\
\text { Harding County, } \\
\text { S. Dak. } \\
\text { Auger hole } 86^{2} \\
\text { (Pl. 12) }\end{array}$ & $\begin{array}{l}\text { Sllde Butte bed in } \\
\text { Slope County, } \\
\text { N. Dak. } \\
\text { Surface sectlon } 30 \\
\text { (Fig. 27) }\end{array}$ \\
\hline $\begin{array}{l}\text { Sampled-interval, } \\
\text { thickness, } 6 \text { inches }\end{array}$ & $\begin{array}{l}\text { For sampled-interval } \\
\text { thickness, see footnotes }\end{array}$ & $\begin{array}{l}\text { Sampled-interval, } \\
\text { thickness, } 12 \text { inches }\end{array}$ \\
\hline $\begin{array}{c}\text { (Top of bed) } \\
0.036 \\
.028 \\
.021 \\
.013 \\
.008 \\
.002 \\
.001 \\
\text { (Base of bed) }\end{array}$ & $\begin{array}{c}\text { (Top of bed) } \\
0.010 \\
5.006 \\
0.003 \\
7.002 \\
\text { (Base of bed) }\end{array}$ & $\begin{array}{c}\text { (Top of bed) } \\
0.022 \\
.013 \\
.010 \\
.006 \\
.004 \\
.001 \\
.005 \\
\text { (Base of bed) }\end{array}$ \\
\hline
\end{tabular}

1 After Zeller and Schopf, chapter $\mathbf{C}$, this bulletin.

- Contamination makes analyses of cuttings $25-45$ percent less than their true values.

After Moore, Melin, and Kepferle, chapter E, this bulletin.

4 Uppermost 2 feet.

8 Two to 4 feet below top of bed.

- Four to $\theta$ feet below top of bed.

7 Nine to 11 feet below top of bed.

The order of magnitude and normal pattern of distribution of uranium in the Dakota lignites are shown on figure 7. Due to contamination of lignite cuttings by the wall rock, the uranium analyses shown for the lignite from auger holes in figure 7 are approximately 25-45 percent below their true values.

4. Variations in the permeability of the rock overlying the mineralized bed are reflected in the intensity of uranium mineralization. 
Where a uranium-bearing lignite bed is directly overlain by permeable sandstone, the lignite is more highly mineralized than where it is overlain by clay or shale. An excellent example of the effect of the permeability of the roof rock on the distribution of uranium in a lignite bed is shown by the data from localities 111 and 112 (pl. 12) in the northeast corner of Slim Buttes. At locality 111, the Bar H lignite bed is directly overlain by at least 30 feet of coarse-grained permeable sandstone, which grades laterally within half a mile into a thick impervious clay shale at locality 112. At locality 111, where the sandstone rests directly on the lignite, the upper bench of the Bar $\mathrm{H}$ lignite bed is about 5 feet thick and contains at least 0.011 percent uranium; the lower bench is about 7 feet thick and contains 0.007

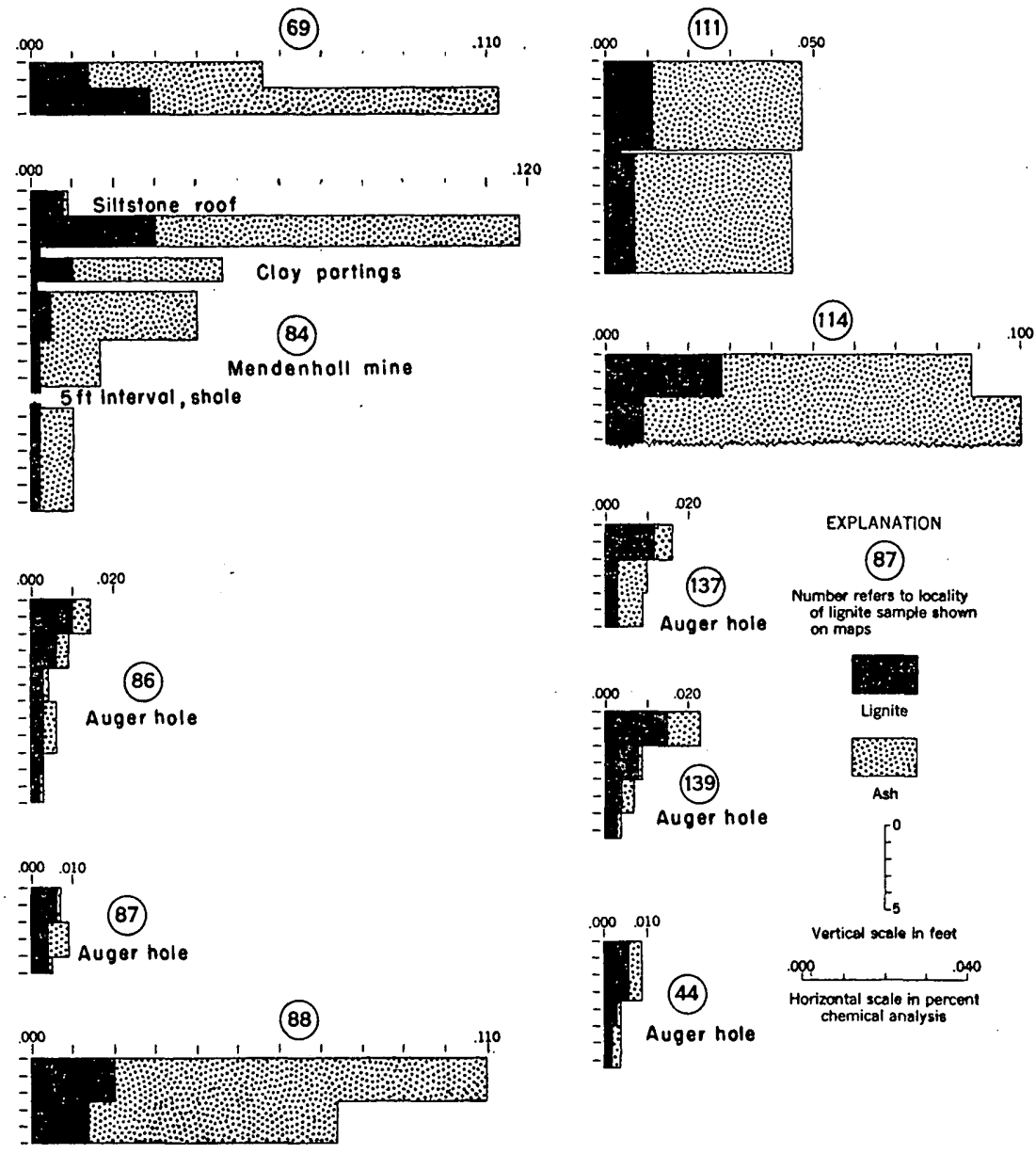

FIodre 7.-Diagram showing pattern of distribution and order of magnitude of uranium concentrations in lignite and lignite ash, Harding and Perkins Counties, S. Dak. (Note.-Locallty 44 should be No. 49) 
percent uranium. At the Bar $\mathrm{H}$ mine (locality 112) the same lignite bed is directly overlain by 25 feet.or more of impervious clay shale, and the uranium content of the upper bench is only 0.001 percent; the lower bench is not uranium bearing.

5. Volcanic materials in the White River group and Arikaree formation show appreciable radioactivity and at some localities are associated with uranium minerals:

The radioactivity of the source beds in the. White River and Arikaree unconformably overlying the uranium-bearing lignites on Slim Buttes was measured in four core holes with a scaler equipped with a GeigerMueller-counter tube and a 400-foot coaxial cable (Gill, Zeller, and Schopf, chapter D, this bulletin, p. 115). Logs obtained by this method show radioactivity greater than background throughout most of the rocks entered by the holes.

Chemical analyses of representative samples from the White River group and Arikaree formation show a maximum content of 0.0030 percent and an average of about 0.0015 percent uranium, indicating a uranium content of about 12 times that of the average sedimentary rock (Evans and Goodman, 1941). Analyses of these rocks also show concentrations of about 0.04 percent vanadium (Davidson, 1953). These analyses and the occurrence of carnotite, a potassium uranyl vanadate; metatyuyamunite(?), a calcium uranyl vanadate; and uranocircite, a barium uranyl phosphate; in the White River group at several widely separated localities in South Dakota (Gill and Moore, 1955; and Moore and Levish, 1955) suggest that these volcanic materials may be source beds of uranium.

6. Water analyses show large uranium content for spring water now issuing from the White River group and Arikaree formation indicating that uranium as well as other elements are being leached today from these volcanic materials:

Gill and Moore (1955) have shown that spring water issuing from the White River and Arikaree in the Slim Buttes area of Harding County, S. Dak., contains 10-30 times more uranium than water from the Fort Union and Hell Creek formations. Chemical analyses show that the water from the White River group also contains significant concentrations of vanadium. The average uranium content of water from 26 springs in the White River and Arikaree is 41 parts per billion, whereas water from 8 springs in the underlying formations averages 4 parts per billion. The uranium content of the water from the Fort Union and Hell Creek formations is even smaller in areas distant from known sources of uranium. The average uranium content of the ocean is about 1.5 parts per billion (Rankama and Sahama, 1950).

Concerning the role of volcanism in the geochemistry of uranium Farrington Daniels (written communication, 1953) concludes: 


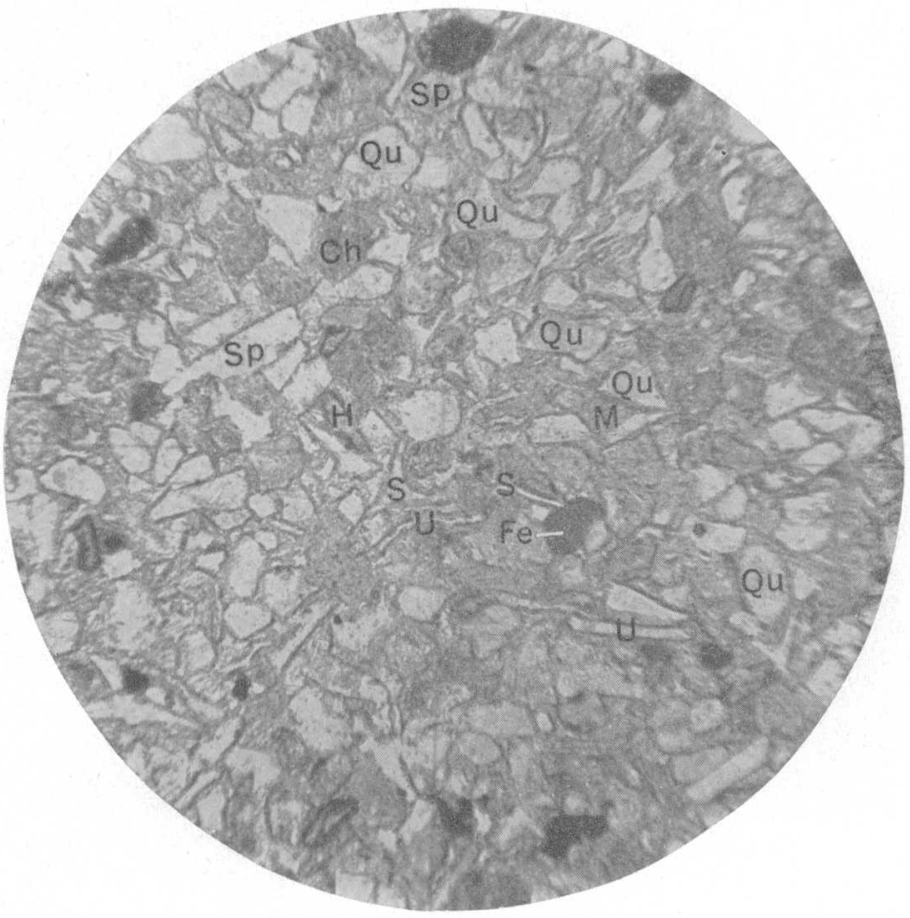

PHOTOMICROGRAPH OF A THIN SECTION OF SANDSTONE FROM THE ARIKAREE FORMATION

$U$, High-index (greater than 1.60), isotropic, somewhat brownish, scaly-shaped, secondary mineral; $M$, matrix of isotropic, low index (less than 1.48) secondary material, clear in transmitted and white in reflected light; $Q u$, quartz; $S p$, andesine; $C h$, chalcedony; $H$, brown or green hornblende; $F e$, opaque iron oxide; $S$, shard. A common fibrous, low-index (less than 1.48) secondary mineral of low birefringence and rounded grains of microcline can not be seen in the photograph $(X 60)$. Identifications by Howard A. Powers. 


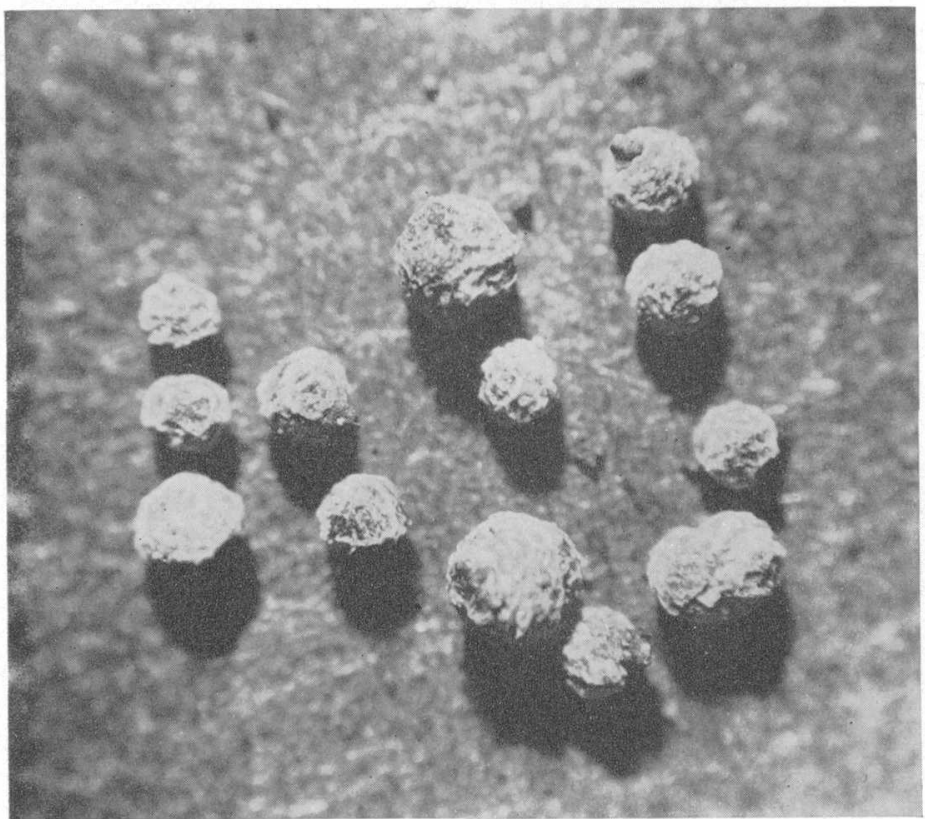

PHOTOMICROGRAPH OF A GROUP OF ANALCITE (NaAlSi $\left.\mathrm{O}_{6} \cdot \mathrm{H}_{2} \mathrm{O}\right)$ ROSETTES ISOLATED FROM URANIUM-BEARING LIGNITE, SOU'TH CAVE HILLS, HARDING COUNTY, S. DAK. $\left(\begin{array}{ll}X & 13\end{array}\right)$. 
We believe that the distribution of uranium in volcanic dust and ashes is an important factor in providing the preliminary source of uranium for later concentration into secondary deposits in sedimentary rocks. The volcanic ash has a very large surface area and uranium can be leached out rather quickly by water passing through porous material of this type.

If uranium can be leached by ordinary ground water. today, it is logical to assume that ground water in the past could have leached the uranium out of these or similar rocks, transported it along aquifers in the underlying strata, and deposited it in favorable host materials. Favorable host material, in addition to the lignite underlying the White River group and Arikaree formation, would include carbonaceous sandstone which E. P. Beroni and H. L. Bauer (written communication, 1952) predicted would be favorable for the localization of secondary uranium minerals if the tuffaceous rocks in the White River were a significant source of uranium. A recent discovery of a bed of such carbonaceous sandstone, 3.2 feet thick and containing as much as 3.9 percent and averaging 0.68 percent uranium, in the Ludlow member of the Fort Union formation underlying the pre-Oligocene unconformity at Reva Gap in the Slim Buttes (J. R. Gill and G. W. Moore, written communications, 1954), seems to substantiate Beroni and Bauer's prediction and adds supporting evidence to the theory that the uranium may have been derived from the overlying volcanic materials.

At many places in some of the most highly radioactive lignite, analcite $\left(\mathrm{NaAlSi}_{2} \mathrm{O}_{6} \mathrm{H}_{2} \mathrm{O}\right)$ is a common impurity (R. A. Ewing, written communication, 1950 ; E. P. Beroni and H. L. Bauer, written communication, 1952; Gill, chapter F, this bulletin). The mineral occurs as finely disseminated minute white particles or rosettes $0.5-1 \mathrm{~mm}$ in diameter (pl. 3) or as minute trapezohedral crystals and generally in such abundance as to give the lignite a characteristic "salt and pepper" appearance. As analcite occurs only rarely in sedimentary mineral deposits (Ross, 1928; Bradley, 1930), and has been reported in few coal deposits (Foster and Feicht, 1946, p. 359; Tourtelot, 1946), its occurrence in the lignite deposits of South Dakota is worthy of some discussion.

Foster and Feicht (1946) point out that analcite must form in alkaline water, although coal accumulates in acidic water. It therefore is improbable that the analcite is syngenetic in origin or that it could have been formed in the acidic waters characteristic of the deposition of coal. As both clastic and hydrothermal hypotheses for its origin are inadequate to explain its occurrence and the spring waters issuing from the White River group and Arikaree formation are soda rich and alkaline in character ( $\mathrm{pH}$ of 8.5-9.5), it is possible that the analcite was derived from the overlying volcanic materials and introduced into the lignite by ground water after coalification.

$469.117-59 \longrightarrow 4$ 
In a report on the occurrence of uranium in coal Davidson and Ponsford (1954) conclude:

A syngenetic origin for the mineralization fails, however, to explain why it is that in the uraniferous coal deposits which have been studied in some detail, high values are commonly restricted to a single seam, usually the highest in the local sequence. Further, the geological evidence tends to suggest that uraniumrich coals are only found where there is direct access to overlying sedimentary, volcanic or pyroclastic rocks likely to form sources for uraniferous ground-water solutions. The close relation between uranium-bearing coals and ancient surfaces truncating them, and the manner in which a higher coal protects an underlying coal from becoming mineralized, can best be explained by the epigenetic introduction of the mineralization by means of descending meteoric water.

From the foregoing statements and the detailed description of the deposits which follow, it is reasonable to conclude that most of the uranium in the lignite is of secondary origin, being derived from tuffaceous materials of Oligocene and Miocene age in which lignite is absent.

\section{FACTORS CONTROLLING CONCENTRATION OF URANIUM}

The distribution of uranium in the lignite in the area is controlled by a combination of factors, none of which has absolute control but all of which are potentially complementary. The factors listed below are believed to be of primary importance (letters $A-B$ referred to below are shown on fig. 8 ).

1. Stratigraphic proximity of lignite to base of the White River group of Oligocene age $(A)$, or to the projected position of its base in areas where the White River has been removed by erosion $(B)$ :

Lignite 200 feet or more below this base is not uranium bearing. This observation is in general accordance with the work of D. G. Wyant and E. P. Beroni (written communication, 1950) who report that radioactive lignite in North Dakota appears to be limited to a zone 40-140 feet below the White River group.

2. Permeability of the rocks overlying the lignite, whether the permeability is inherent as in sandstone $(C)$ or induced by jointing $(D)$, fracturing or faulting $(E)$ :

Greatest concentrations of uranium are present in a lignite bed where directly overlain by sandstone. The same bed where overlain by beds of shale or clay contains little or no uranium. Lignite adjacent to joints, in general, shows greater concentrations of uranium than that farther from joints.

3. Adsorptive properties and porosities of the organic lignitic constituents.

The writers believe that soft porous lignite is a much better host material for the adsorption and fixation of uranium than is dense, 


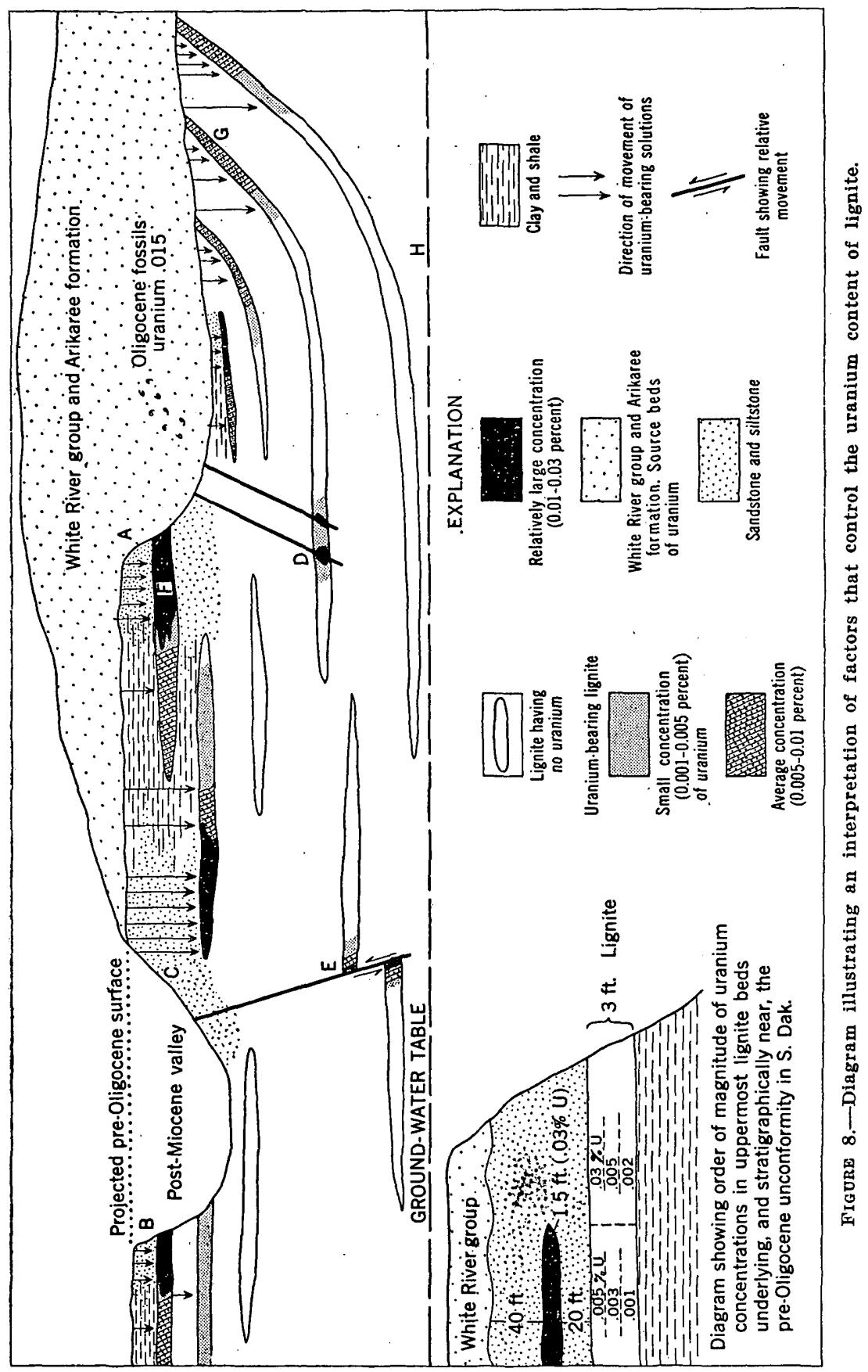


hard, impervious, semibituminous coal and anthracite, and that the amount of uranium extracted from solution may be directly proportional to the presence of certain specific lignitic constituents.

4. Attitude of the beds:

Horizontal or very gently dipping lignite beds $(F)$ are more radioactive than beds having greater dips $(G)$.

5. The position both present and past of the water table in relation to lignite and its effects on active ground-water circulation $(H)$.

6. Amount of uranium originally present in the White River and Arikaree and the nature and degree of its dissemination and distribution:

Studies of drill cores by Farrington Daniels of the University of Wisconsin (oral communication, 1952) indicate that the uranium content is fairly uniform throughout most of the White. River and Arikaree. Whether the uranium content of these rocks was uniform. over wide areas is not known, but if a considerable variation did occur, it seems reasonable to conclude, other conditions being equal, that this variation would be reflected in the degree of mineralization in the underlying lignite.

\section{AREAS OF URANIUM-BEARING LIGNITE}

SOUTH CAVE HWLLS

The South Cave Hills is a conspicuous mesa that occupies about 9 square miles in parts of Tps. 20 and 21 N., Rs. 4 and 5 E., 12 miles north of Buffalo in Harding County, S. Dak. (pl. 4). The mesa rises several hundred feet above the surrounding country in almost impassable cliffs. Several flat-topped ridges separated by deep box canyons extend; outward from the main area of the mesa. Below the massive-sandstone cap rock a steep talus slope of large blocks of slumped sandstone makes the top of the mesa almost inaccessible but it can be reached by way of a few cattle trails and by narrow secondary Forest Service roads. Directly to the south, across the valley of Jones Creek, are many small buttes, the largest being McKensie Butte. Some of the buttes are capped with clinker resulting from the burning of lignite. Their brick-red colors are very distinctive and they are visible many miles.

The lower part of the South Cave Hills mesa and the surrounding country consists of soft sandstone and shale of the Ludlow member of the Fort Union formation, but the cap rock of the prominent McKensie and Rattlesnake Buttes and of the main area of the South Cave Hills mesa is a massive well-indurated sandstone 125 feet thick, in the lower part of the Tongue River member of the Fort Union formation. "A remnant of the White River group, 50 feet or less in thickness, caps the mesa over an area of about 160 acres in parts of sec. 31 and 32, T. 
21 N., R. 5 E. The pre-Oligocene surface in the Cave Hills area was apparently close to the present mesa top. At most places, beds of the Fort Union dip uniformly about 40 feet per mile to the northeast.

Because of the heavy cover of talus and scarcity of lignite outcrops, most of the correlations between lignite beds in the Cave Hills and Table Mountain areas are at best tentative.

The lignite bed having the greatest uranium content in the South Cave Hills is not more than 50 feet below the top of the Ludlow member of the Fort Union formation and is referred to in this report as Bed $D$ (pls. 5 and 6). The bed has a maximum measured thickness of 4.2 feet at locations 55 and 60, and an average thickness, based on 17 measured sections, of about 2.5 feet. A thin bed of lignite or a carbonaceous zone, tentatively referred to as Bed $E$, occurs 30 to 40 feet above the base of the Tongue River member, but its lenticular character and poor quality make it only of local importance. Because the autunite occurs in lignite in bed $E$ in the North Cave Hills (J. R. Gill, written communication, 1954) and the bed is near the base of the overlying White River group, significant deposits of secondary minerals of uranium may be found in this bed in the South Cave Hills. The thickest and most persistent beds of lignite in the South Cave Hills are in the middle and lower parts of the Ludlow member. These beds are not radioactive and were not mapped or studied in detail.

The three areas in the South Cave Hills underlain by significant deposits of uranium-bearing lignite, at least 3 feet thick, are listed here in order of their apparent importance: (1) SW1/4 sec. 28 and NW1/4 sec. 33 , T. 21 N., R. 5 E., locations 57-61; (2) NE1/4 sec. 5, T. 20 N., R. 5 E., location 63 ; and (3) S1/2 sec. 13, T. 21 N., R. 4 E., and SW1/4 sec. 18 and SW $1 / 4$ sec. 16, T. 21 N., R. 5 E., locations 55 and 56. These areas, with a combined total of about 600 acres, are estimated to contain 3.15 million tons of uranium-bearing lignite (table 4).

A small area of about 50 acres at McKensie Butte in SE1/4 sec. 20, T. 20 N., R. 5 E., may also contain an additional 262,000 tons of uranium-bearing lignite (pl. 5, location 69 and table 4). Although bed $D$ is persistent and may contain significant tonnages of uranium-bearing lignite in other areas in the South Cave Hills than those listed, the poor exposures and wide spacing of localities sampled make a closer estimate of the potentialities of the area impossible without trenching or coring.

There is no strippable uranium-bearing lignite in the South Cave Hills. There, because of the thickness and character of the overburden, all the lignite will require underground-mining methods. Bowman, N. Dak., the nearest railroad shipping point, is $25-30$ miles to the north along U.S. Highway 85. 
TaBle 4.-Tonnage of uranium-bearing lignite in the North Cave Hills, South Cave Hills, McKensie Butte, and Table Mountain areas, Harding County, S. Dak.

\begin{tabular}{|c|c|c|c|c|}
\hline Area & $\begin{array}{l}\text { Extent } \\
\text { (acres) }\end{array}$ & $\begin{array}{c}\text { Average } \\
\text { thickness } \\
\text { (feet) }\end{array}$ & $\begin{array}{l}\text { Uranium } \\
\text { content } \\
\text { (percent) }\end{array}$ & $\begin{array}{c}\text { Tonnage of } \\
\text { lignite } 1 \\
\text { (short tons) }\end{array}$ \\
\hline
\end{tabular}

In beds suitable for strip-mining methods

$\begin{aligned} & \text { North Cave Huls, } 2 \text { center of sec. 19, T. } 22 \text { N., R. 5 E., } \\ & \text { Harding County...1. }\end{aligned}$
Total

In beds accessible by underground-mining methods

\begin{tabular}{|c|c|c|c|c|}
\hline 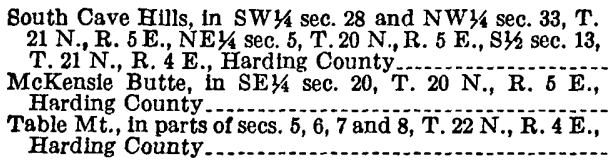 & $\begin{array}{r}600 \\
50 \\
500^{\circ}\end{array}$ & $\begin{array}{l}3.0 \\
3.0 \\
2.0\end{array}$ & $\begin{array}{l}0.009 \\
.01 \\
.008\end{array}$ & $\begin{array}{r}3,150,000 \\
262,000 \\
1,750,000\end{array}$ \\
\hline Totsl & $\ldots$ & -............... & - & $5,162,000$ \\
\hline Grand total & -- & $\ldots$ & $\ldots$ & $5,337,000$ \\
\hline
\end{tabular}

1 Tonnage estimates based on 1,750 tons of lignite per acre foot, net result rounded to nearest 1,000 tons. 2 Tonnage data for the minerallzed bed $E$ in parts of secs. 22, 26, and 27, T. 22 N., R. $5 \mathrm{E}$., in the North Cave Hills are not included.

\section{NORTH CAVE HILLS}

The North Cave Hills occupy about 15 square miles in Tps. 21 and 22 N., R. 5 E., in north-central Harding County, S. Dak. (pls. 1 and 4). Topographically and structurally they resemble the South Cave Hills and are separated from that mesa by about 4 miles of low rolling country and the valley of Bull Creek. From a distance the North Cave Hills appear to be a single mesa rising 300-400 feet above the surrounding country, but in reality they are a series of narrow flattopped ridges separated by narrow canyonlike gullies. They are capped by about 200 feet of thick-bedded sandstone which in most places forms sheer cliffs, and the Tongue River-Ludlow contact is placed at the base of this sandstone. Two small remnants of conglomerate from the White River group overlie the Tongue River in secs. 21 and 28, T. 22 N., R. 5 E., but throughout the rest. of the area the White River has been removed by erosion. In some parts of the North Cave Hills two distinct cliffs are formed by two sandstone units of the Tongue River member (Winchester and others, 1916, p. 27), separated by $40-125$ feet of light-gray friable sandstone and whitish-gray clay. A thin bed of carbonaceous shale or clayey lignite rests on the lower unit of sandstone. This bed, which is also present at some places in the sandstone cap rock in the South Cave Hills, is referred to as bed $E$ (pl. 6). The lower sandstone unit in the North Cave Hills is 75-100 feet thick and is gray to buff. The upper sandstone unit is commonly 
pink, crossbedded and at some places contains clay pellets and rounded pebbles of sandstone. A two-foot bed of quartzite, described on page 19, occurs on top of the massive sandstone cap rock (pl. 6, locations 33,34 , and 40 ). At many places wind action along joints and on the unequally indurated sandstone has developed characteristically pitted and cavernous surfaces in the cliff faces. The beds in the North Cave Hills, in general, dip about 25 feet per mile to the northeast (Winchester and others, 1916, p. 73).

Only two lignite beds of minable thickness, beds $B$ and $C$, are mildly radioactive in the North Cave Hills area (pl. 7). These beds occur in the upper 100 feet of the Ludlow member of the Fort Union formation. Lack of exposures and marked variability in thickness and quality make an exact correlation of the beds in many places doubtful. The samples, taken from 36 localities, indicate there are few, if any, places where the uranium content of these beds is sufficient to warrant underground mining. An area of about 15 acres near the center of sec. 19, T. 22 N., R. 5 E., may be favorable for strip mining. Here, bed $B$ is 5-10 feet thick and is overlain by about 35 feet of soft sandstone. Analyses of 14 samples of contaminated auger cuttings from 3 auger holes indicate that the area may contain 175,000 tons of uranium-bearing lignite (pl. 4, locations 47,48 , and 49 , and table 4 ). Bed $E$, absent in most of the North Cave Hills, is present in parts of secs. 22,26 , and 27, T. 22 N., R. 5 E., where it ranges from 6 inches to 2 feet in thickness and locally contains as much as 5 percent uranium. Where the bed is most highly radioactive, visible uranium minerals, autunite and torbernite, occur (J. R. Gill, written communication, 1954). The reason for the small uranium content of lignite in other parts of the North Cave Hills is not known but probably is due to the presence of 40-75 feet of impervious shale directly above the stratigraphically highest beds of lignite (beds $B$ and $C$ ). The shale may have prevented downward-moving uranium-bearing ground water from reaching the lignite.

\section{TABLE MOUNTANN}

Table Mountain is a high butte with steep and rocky slopes which occupies about 500 acres in northwestern Harding County, S. Dak. (pl. 4). The butte is capped by about 125 feet of tan and buff massive sandstone of the Tongue River member of the Fort Union formation and underlain by 250 feet or more of poorly indurated yellowishand light-gray sandstone and shale of the Ludlow member. At the south end of the butte, thin lenses of fine-grained, chalky, gray tuffaceous sandstone containing shards are present within the cap rock. These lenses are rarely more than a foot thick, but are quite con- 
spicuous by their color and by the indentation which they form in the cliff. The regional eastward dip at Table Mountain and vicinity is about 50 feet to the mile.

The uranium-bearing lignite at Table Mountain occurs in the uppermost 40 feet of the Ludlow member. It is found in two beds referred to as beds $D$ and $C$, which average about 2 and 2.5 feet in thickness, respectively (pls. 6 and 7 ). The lack of exposures and the prevalence of slumping along the steep sides of the butte make their indentification and correlation at many places very difficult. The uranium-bearing lignite of bed $C$ is thicker and less variable in thickness than that of bed $D$. The average uranim content of bed $C$, however, is not as great as that of bed $D$. This is probably due to the fact that bed $C$ is overlain at most places by bed $D$ and also by relatively impervious shale. The lignite beds stratigraphically below bed $C$ show little or no radioactivity (pl. 7). From 17 measured sections and as many analyses at least 1.75 million tons of uranium-bearing lignite (table 4) in beds averaging about 30 inches thick are estimated to underlie about 500 acres on Table Mountain (secs. 5, 6, 7, and 8, T. 22 N., R. 4 E.). The character and thickness of the overburden will require that the lignite be recovered by underground mining.

\section{MEDICINE POLE HOLLS}

The Medicine Pole Hills, mapped and described in detail by Hares (1928, p. 95, 98), are part of a hilly divide separating the Little Missouri and Grand River drainage basins in the southwestern part of the Marmarth lignite field, Bowman County, N. Dak. (pl. 1). The general geology and a brief description of the stratigraphy in the Medicine Pole Hills area are given by Zeller and Schopf in chapter C of this bulletin. Data obtained from 6 auger holes and 4 surface sections indicate that there are about 360 acres underlain by approximately 3 million tons of uranium-bearing lignite in beds $3-4.5$ feet thick (pls. 8 and 9 ).

Hares $(1928$, p. 97$)$ estimates that there are 4.48 million tons of lignite in the Harmon lignite bed, which underlies the low hills three miles to the northeast of Medicine Pole Butte, but significant amounts of uranium were not found in samples of lignite taken at surface exposures or from auger holes (pls. 8 and 9). In this area the Harmon bed is at least 20 feet thick and throughout most of the area is overlain by less than 75 feet of soft sandstone and shale. Although uranium in the Harmon lignite bed at the four localities (nos. 129-132) sampled is not of commercial significance, there is a good possibility that there are other places in the area where conditions for mineralization were much more favorable. The inadequacy of the exposures 


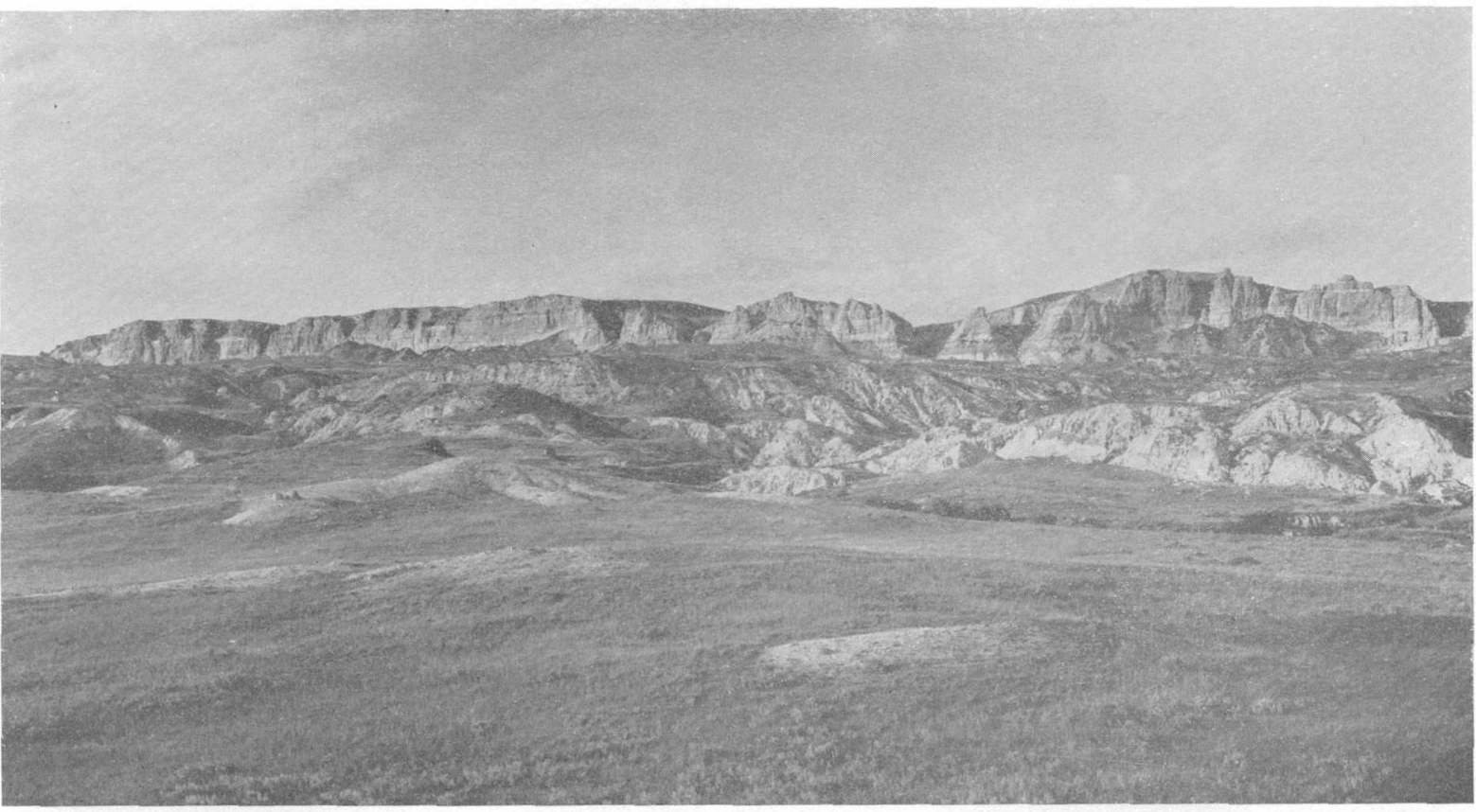

West face of the Slim Buttes in T. 16 N., R. 7 E., showing badland topography formed by landslides and slumping in the White River group and the Arikaree formation. 


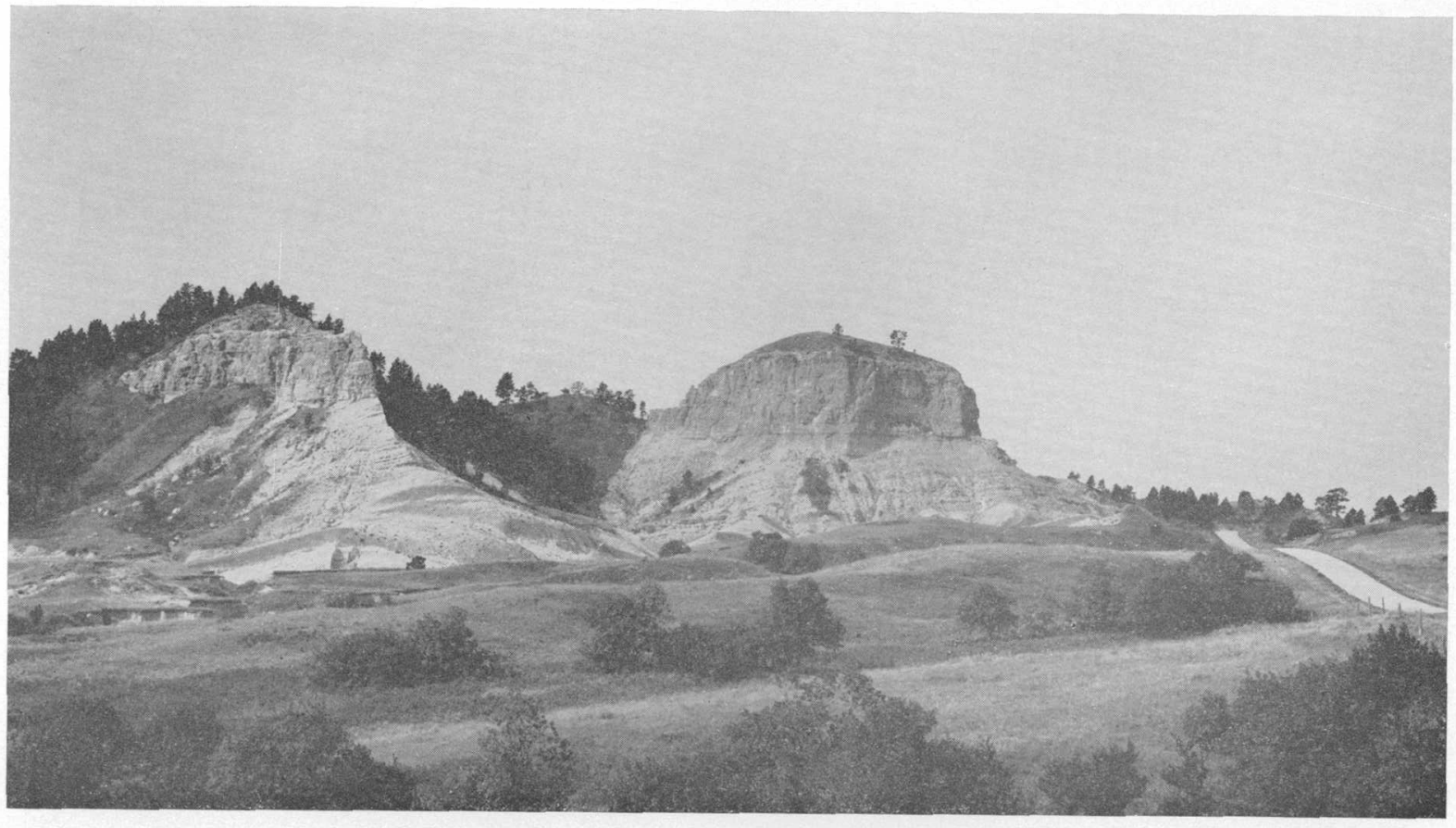

Cliff-forming tuffaceous sandstone of the Arikaree formation unconformably overlying bentonitic clay and siltstone of the White River group at Reva Gap, SW11/4 sec. 8, T. 18 N., R. 8 E., Harding County, S. Dak. 


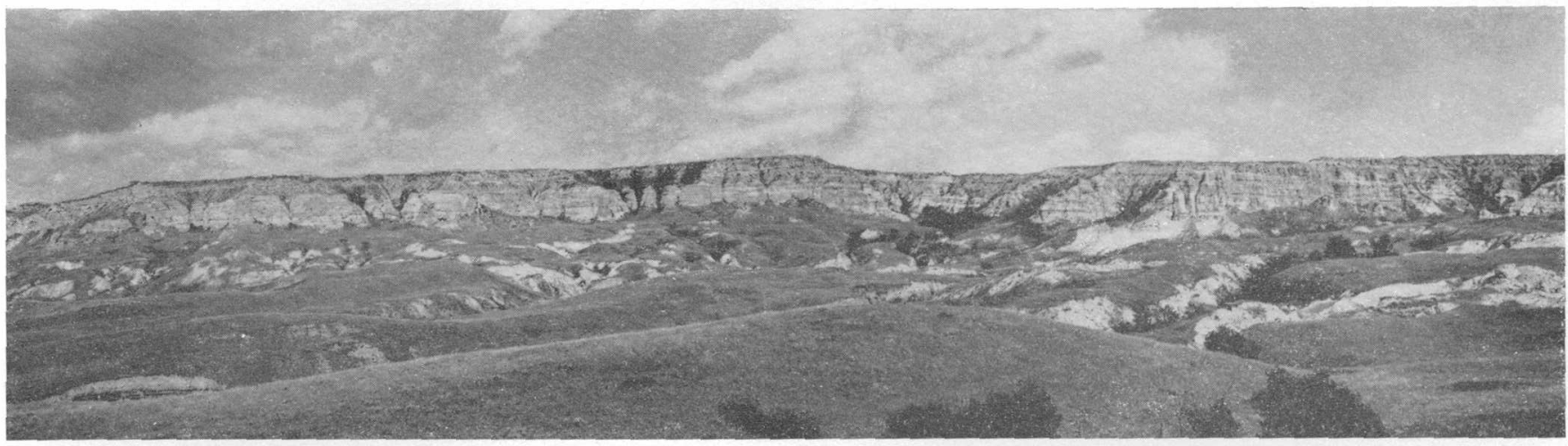

Uranium-bearing lignite in the Fort Union formation unconformably overlain by source beds of uranium in the White River group and Arikaree formation in $\mathrm{T}$. $17 \mathrm{~N}$., R. 7 E., Harding County, S. Dak. Mendenhall strip mine (see plate 16) is in the left foreground, 


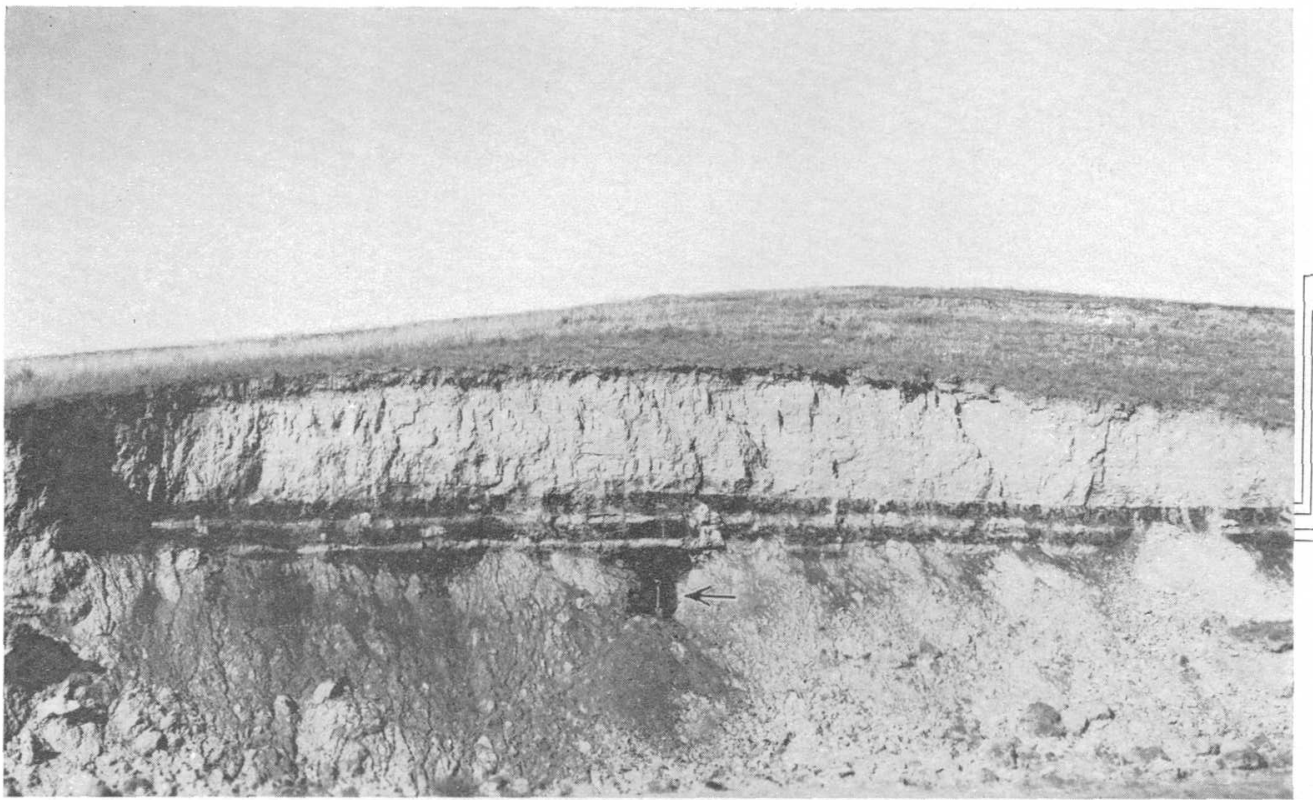

Percent 
make necessary additional trenching and drilling before the area's potentialities can be fully appraised:

\section{LODGEPOLE AREA}

The Lodgepole area is part of an upland surface between the North and South Forks of the Grand River in T. 21 N., Rs. 11 and 12 E., northwestern Perkins County, S. Dak. (fig. 3 and pl. 10). A brief description of the stratigraphy and general geology of the area underlain by uranium-bearing lignite is presented in chapter C. Data from 5 auger and 8 surface sections indicate that there are at least 120 acres underlain by approximately 680,000 tons of strippable uranium-bearing lignite in beds 3-6 feet thick (pl. 9).

A mile northeast of the Lodgepole Post Office the Harmon lignite bed averages 6 feet in thickness and underlies approximately 1,000 acres (Winchester, 1916, pl. 10). In this area the lignite is directly overlain by thick impervious clay and at the two localities sampled contains only a trace of uranium in its upper 2 feet (locations 142 and $143, \mathrm{pl} .10)$. It is possible, however, that secondary uranium minerals may be localized in the massive coarse-grained sandstone capping the buttes.

\section{SLIM BUTTES}

Slim Buttes is a timber-covered steep sided mesa $1 / 2-7$ miles wide and 20 miles long in southeastern Harding County, S. Dak. (fig. 3, and pls. 11 and 12). The mesa is composed chiefly of massive, chalky gray, tuffaceous sandstone of the Arikaree formation, which in places forms sheer cliffs 200 feet or more high. Slumped rocks that Recent erosion has dissected into nearly impassable badlands are present at many places around the mesa (pl. 13). Slumping and landslides have so greatly disturbed and covered the zones in which lignite beds crop out along the edges of the mesa that at many places it is very difficult to correlate beds or correctly interpret geologic structure. Many good springs issue from rocks along the edge of the mesa, but the surface in their vicinity is so rugged that few stock ranches can be located to take advantage of the excellent water. The top of the mesa, at a mean elevation of about 3,600 feet, is 400 to 600 feet above the general level of the surrounding plains and is gently rolling. A few pine trees grow about its margin. The central part of Slim Buttes is most easily accessible along the top of the buttes by a U.S. Forest Service road that extends north from J-B Pass road half a mile east of the divide. The northern part is most easily accessible from the top of the buttes by 6 miles of Forest Service road extending northeastward from State Route 8 at a point 2 miles west of Reva.

The oldest rocks in the Slim Buttes area are exposed at its southern 
margin, where the White River group and Arikaree formation unconformably overlie the Hell Creek formation of Late Cretaceous age. To the north the pre-Oligocene unconformity bevels progressively younger beds, and in the central and northern parts of Slim Buttes the Oligocene rocks rest on the lignite-bearing Ludlow member of the Fort Union formation of Paleocene age (pl. 11), which dips northeastward at about 20 feet or less per mile.

The lignite beds and associated strata are relatively undisturbed except at the north end of the buttes, where the rocks are broken by a pre-White River fault (pl. 11) and pre-Arikaree landsliding. The fault trends $\mathrm{N} .75^{\circ} \mathrm{W}$. for an inferred distance of about a mile in sec. 28, T. 19 N., R. 8 E., and has a maximum stratigraphic displacement of about 150 feet. The only other place examined in the Slim Buttes area where pre-White River faulting may have occurred is in the vicinity of Reva Gap, sec. 8, T. 18 N., R. 8 E. There, however, the exposures are so poor and Recent slumping so prevalent that the preWhite River faults and pre-Arikaree landslides were not differentiated.

The two areas in the Slim Buttes where core and surface samples are adequate for estimation of resources are along the west-central part of the buttes in the vicinity of the Mendenhall mine, locations 83-96 (pls. 11, 15, and 16) and in the Bar $\mathrm{H}$ area at the northeast tip of the buttes, locations 110 to 118 . The uranium-bearing beds in these areas average 6-12 feet in thickness (pl. 12) and are of excellent quality lignite. The content of uranium is not uniform and appears to be most closely controlled by the nearness of the lignite bed to the base of the White River group and to the permeability of the rocks directly overlying the bed.

Uranium-bearing lignite at widely separated localities $(79,81,101$, 107 , and 108, pl. 11) indicate that beds of such lignite 5 feet or more in thickness probably underlie most of the 60 square miles of White River and Arikaree strata that cap the Slim Buttes. Surface and core data were considered adequate for estimating tonnage of lignite for only 7 square miles. On the basis of the surface and core hole data, it is estimated that there are at least 5.25 million tons of strippable lignite in beds 5 feet or more in thickness in the Mendenhall area and a combined total of 33.25 million tons of lignite in the Mendenhall and the $\mathrm{Bar} \mathrm{H}$ areas which will require underground mining. The potential resources of uranium-bearing lignite underlying all of Slim Buttes are estimated to be 340 million tons.

\section{LONG PINE HILLS}

The Long Pine Hills are a high mesa, 2-5 miles wide and 14 miles long from north to south, in the eastern part of Carter County, Mont. 
Throughout the length of the mesa, chalky-gray sandstone and bentonitic clay of the White River group and Arikaree formation unconformably overlie the lignite-bearing Ludlow member of the Fort Union formation (pl.1). These stratigraphic units make up the main body of the mesa, which rises 500 feet or more above the general level of the surrounding plains. Beds of lignite 30 inches or more thick occur at few places around the mesa and are generally overlain by 100 feet or more of impervious shale. Reconnaissance examination of most of the lignites exposed along the flanks of the mesa did not find significant deposits of radioactive carbonaceous materials. At the abandoned Chuning mine at the southern tip of the mesa, in the NE1/4 sec. 21, T. 3 S., R. 62 E., a lignite bed 5 feet thick occurs 150 feet below the base of the White River (Bauer, 1924, pl. 23, locality 287). The impure character of the bed and its small uranium content (pl. 9, locality 121) makes the occurrence of academic interest only. The lignite at the Chuning mine thins to the west and in the NW1/4 sec. 19, T. 3 S., R. 62 E. (locality 291 of Bauer) ranges from 6 inches to 2 feet in thickness. The lignite is only mildly radioactive (pl. 9, locality 120). At the northern tip of the mesa in the NE1/4 sec. 20, T. 1 S., R. 61 E. (pl. 9, locality 122) the same bed, or one at about the same stratigraphic horizon contains a significant amount of uranium but is 1 foot or less in thickness at most places.

The massive coarse-grained sandstone of the Ludlow member directly beneath the base of the Oligocene rocks in the Long Pine Hills, however, may at some places act as a favorable host rock for the concentration of secondary minerals of uranium. The discovery of such minerals in sandstone underlying the White River group at Reva Gap in Slim Buttes is evidence that they may be found in the Long Pine Hills.

\section{POTENTIAL RESOURCES OF URANIUM-BEA RING LIGNITE}

Available data from northwestern South Dakota and the adjacent areas indicate that the region as a whole contains an aggregate of at least 47.5 million tons of uranium-bearing lignite. Almost a fifth of this lignite is strippable and in beds averaging 4 feet in thickness. Analyses of about 275 channel and auger samples (table 5) and 1,000 samples from drill cores indicate that the lignite contains an average of slightly more than 0.008 percent uranium. In some areas the uranium content ranges from 0.015 to 0.03 percent. The ash content of the lignites ranges from 10 percent or less to about 20 percent; the uranium content of the ash thus is at least 5 times and generally 7-10 times that of the lignite. Proximate and ultimate analyses of the lignite cores by the U. S. Bureau of Mines are tabulated in chapters C and $\mathrm{D}$ of this bulletin. 
The uranium-bearing lignite deposits in the Slim Buttes are of Harding County, S. Dak., are perhaps the most promising of those examined in the Dakotas. The lignite beds underlying the Slim Buttes average ten feet or more in thickness and closely underlie the base of the White River group, thus being in a favorable position for widespread mineralization by ground water.

Approximately 880 feet of core-drilling in 8 shallow holes along the northeast side of Slim Buttes was completed late in July 1952 (see chapter $\mathrm{C}$, this bulletin). The core-drilling, however, is not adequate to appraise the area's potential resources of uranium-bearing lignite. The incomplete data at hand indicate the Slim Buttes may be underlain by 340 million tons of uranium-bearing lignite in beds averaging 5 feet or more in thickness. A total of 15-20 core holes, each 375-400 feet deep, would provide a more complete and accurate appraisal of the area's potentialities. At most places in the Slim Buttes area, below the uppermost bed of uranium-bearing lignite are large deposits of nonuraniferous lignite that require underground mining methods. Additional large deposits of such lignite, some of which are strippable, are present 7-9 miles north of the Slim Buttes along the South Fork of the Grand River in the vicinity of the Shirley mine (sec. 35, T. 21 N., R. 8 E.). The Slim Buttes area, therefore, seems particularly well adapted for providing large tonnages of lignite for lignite-consuming industrial installations.

In Harding County, S. Dak., estimates of uranium-bearing lignite for the Mendenhall area of the Slim Buttes total 5.25 million tons in strippable beds and 28 million tons in beds requiring underground mining; in the Bar $\mathrm{H}$ area there are 5.25 million tons in beds that require underground mining (see chapter $\mathrm{C}$ ).

In Perkins County, S. Dak., 682,000 tons of strippable uraniumbearing lignite are reported in the Lodgepole and Johnson outlier areas, and in Bowman County, N.Dak., 3.045 million tons of strippable uranium-bearing lignite are estimated in the Medicine Pole Hills area (see chapter $\mathrm{C}$, this bulletin).

In addition to the estimates of uranium-bearing lignite listed herein for northwestern South Dakota and adjacent areas, other resources in beds averaging 2.5-4.5 feet in thickness at Bullion Butte, Billings County, and at Sentinel Butte, Golden Valley County; in the southwest corner of North Dakota and 38 and 52 miles north of the Medicine Pole Hills respectively, are reported by Moore, Melin, and Kepferle (see chapter $\mathrm{E}$, this bulletin). They report about 5 million tons of uranium-bearing lignite with an average grade of 0.007 percent of uranium underlying an area of about 1,200 acres at Sentinel Butte 
and about 4.2 million tons of the same grade underlying 500 acres at Bullion Butte. The thickness and the character of the White River group which caps these buttes makes underground mining necessary.

They estimate that in the vicinity of the Chalky Buttes, in Slope County, N. Dak., about 5 miles north of Bowman, a total of about 18 million tons of uranium-bearing lignite underlie about 5,200 acres. The grade is estimated to be about 0.017 percent, but the beds average 2.5 feet or less in thickness and most will require underground mining methods. Approximately 600 acres are beds of lignite averaging 0.016 percent uranium and at least 2 feet thick and beneath no more than 30 feet of overburden which can be worked by strip mining.

In the Ekalaka Hills, Carter County, Mont., Gill (chapter F, this bulletin) estimates that 16.5 million tons of lignite having a moderate content of uranium (average grade 0.005 percent) underlies about 2,000 acres. The beds average about 5 feet in thickness and at most places are overlain by 200 feet or more of massive-bedded sandstone.

TABLE 5.-Analyses of surface samples and auger cuttings of uranium-bearing lignite from northwestern South Dakota and adjacent areas in North Dakota and Montana

[Chemical analyses by F. Cuttitta, A. Dufour, E. Mallori, J. J. McGee, W. P. Tucker, Jr., and H. W. Worthing; radioactivity analysés by C. Cox, B. A. McCall, J. N. Rosholt; and J. J. Warr, Jr., U. S. Geological Surveyl

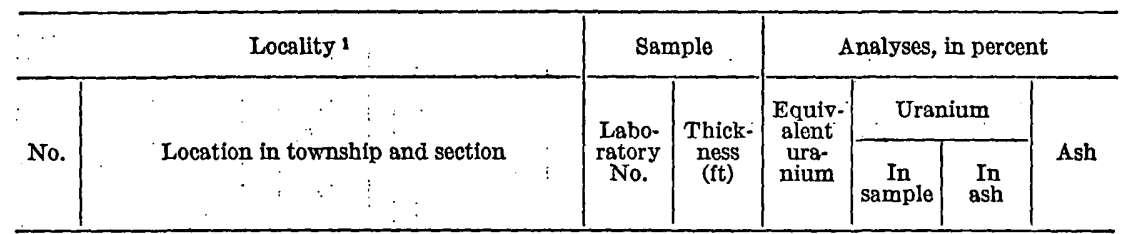

TABLE MOUNTAIN AND ADJACENT OUTLIERS, HARDING COUNTY, S. DAK. (LOCALITIES 1-15, PL. 7)

T. 22 N., R. 4 E.

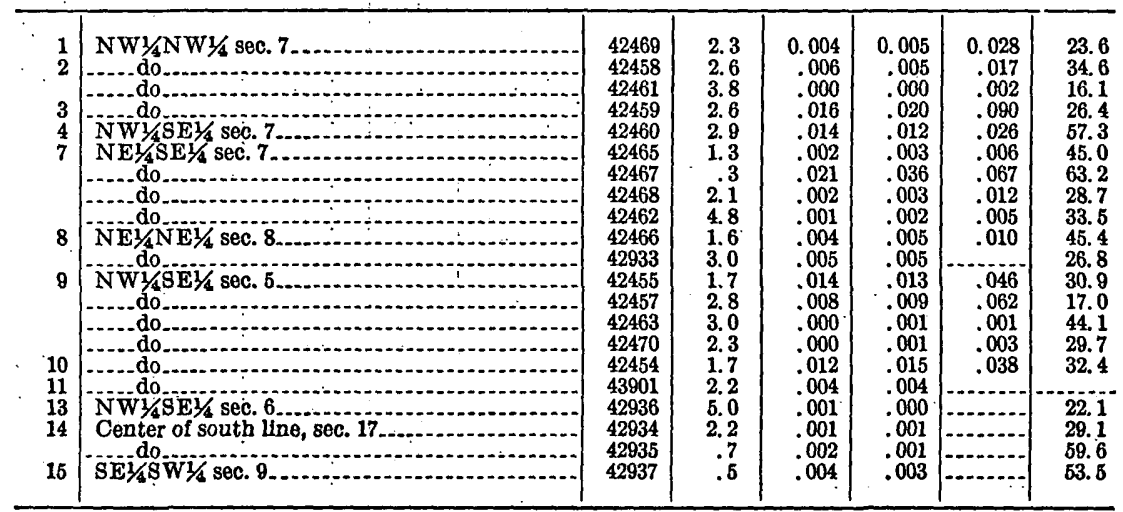

1 At localitles 5, 6, and 12, lignite is not radioactive and was not sampled. 
TABLE 5.-Analyses of surface samples and auger cuttings of uranium-bearing lignite from northwestern South Dakota and adjacent areas in North Dakota and Montana-Continued

\begin{tabular}{|c|c|c|c|c|c|c|c|}
\hline \multirow[b]{3}{*}{ No. } & Locality ! & \multicolumn{2}{|c|}{ Sample } & \multicolumn{4}{|c|}{ Analyses, in percent } \\
\hline & \multirow[b]{2}{*}{ Location in township and section } & \multirow{2}{*}{$\begin{array}{c}\text { Labo- } \\
\text { ratory } \\
\text { No. }\end{array}$} & \multirow{2}{*}{$\begin{array}{c}\text { Thick- } \\
\text { ness } \\
\text { (ft) }\end{array}$} & \multirow{2}{*}{$\begin{array}{c}\text { Equiv- } \\
\text { slent } \\
\text { urs- } \\
\text { nium }\end{array}$} & \multicolumn{2}{|c|}{ Uranium } & \multirow[b]{2}{*}{ Ash } \\
\hline & & & & & $\underset{\text { sample }}{\text { In }}$ & $\underset{\text { ash }}{\text { In }}$ & \\
\hline
\end{tabular}

NORTH CAVE hILLS, HARDING COUNTY, S. DAK. (LOCALITIES 16-51, PL. 7)

T. 21 N., R. 6 E.

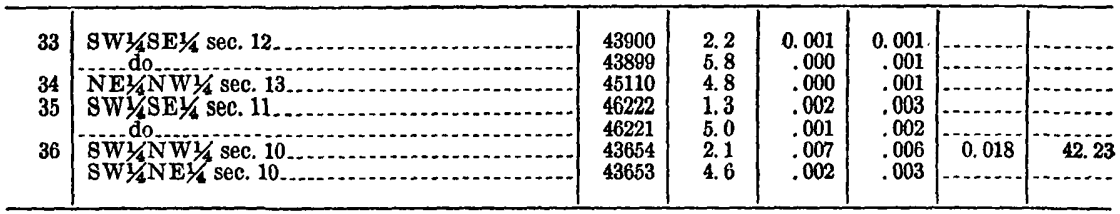

T. 22 N., R. 4 E.

\begin{tabular}{|c|c|c|c|c|c|c|c|}
\hline $\begin{array}{l}43 \\
44\end{array}$ & $\begin{array}{l}\text { NW1/NE1/4 sec. } 25 \\
\text { SE1/4NE1/4 sec. } 24\end{array}$ & $\begin{array}{l}44267 \\
43649 \\
43650\end{array}$ & $\begin{array}{r}1.2 \\
3.6 \\
1.1\end{array}$ & $\begin{array}{r}0.005 \\
.003 \\
.014\end{array}$ & $\begin{array}{r}0.003 \\
.005 \\
.010\end{array}$ & $\begin{array}{r}0.028 \\
.043\end{array}$ & $\begin{array}{l}19.96 \\
27.13\end{array}$ \\
\hline
\end{tabular}

T. 22 N., R. 5 E.

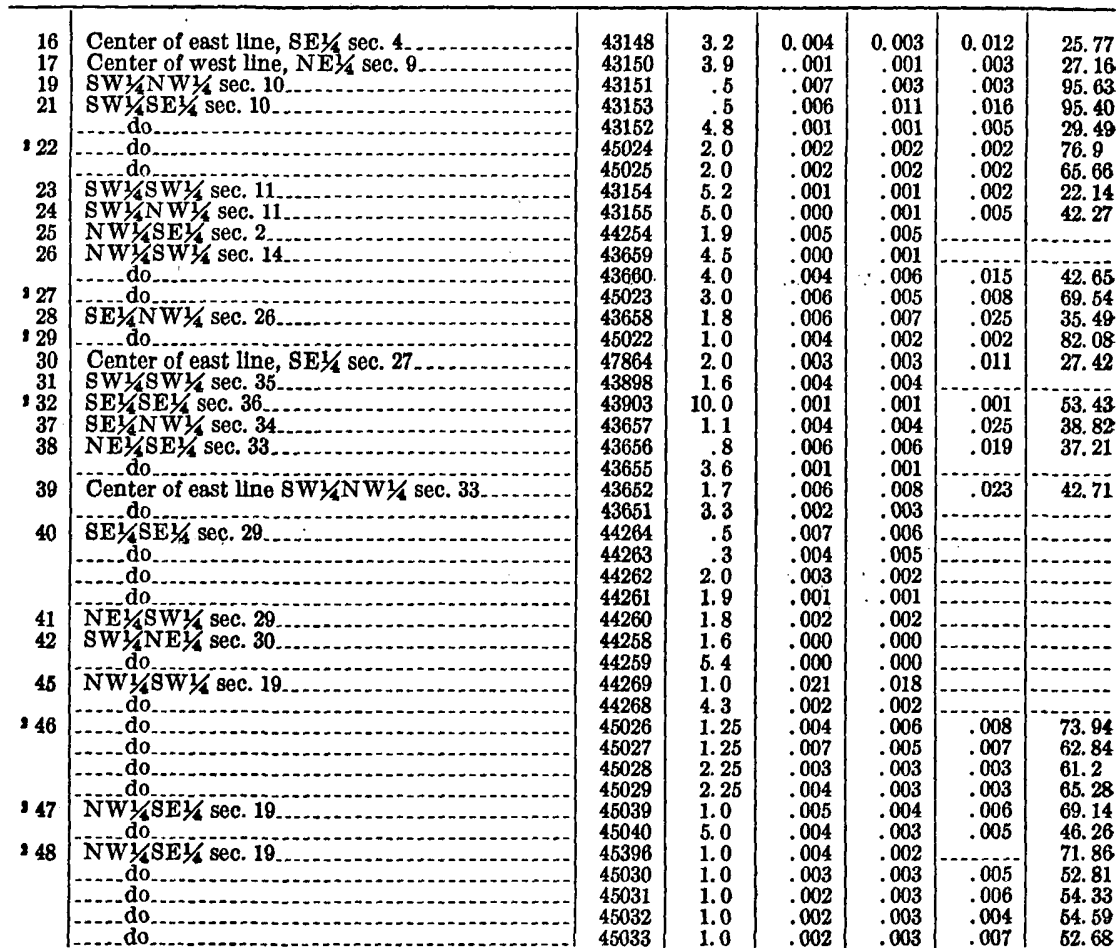

1 At locallties 5,6 , and 12, lignite is not radioactive and was not sampled.

2 Auger hole. Owing to contamination of wall rock with lignite cuttings, uranium analyses are 25 to 45 percent less than their true values. 
TABLE 5.-Analyses of surface samples and auger cuttings of uranium-bearing lignite from northwestern South Dakota and adjacent areas in North Dakota and Montana-Continued

\begin{tabular}{|c|c|c|c|c|c|c|c|}
\hline \multirow{3}{*}{ No. } & Locality 1 & \multicolumn{2}{|c|}{ Sample } & \multicolumn{4}{|c|}{ Analyses, in percent } \\
\hline & \multirow{2}{*}{ Location in township and section } & \multirow{2}{*}{$\begin{array}{l}\text { Labo- } \\
\text { ratory } \\
\text { No. }\end{array}$} & \multirow{2}{*}{$\begin{array}{l}\text { Thick- } \\
\text { ness } \\
\text { (ft) }\end{array}$} & \multirow{2}{*}{$\begin{array}{l}\text { Equiv- } \\
\text { alent } \\
\text { ura- } \\
\text { nium }\end{array}$} & \multicolumn{2}{|c|}{ Uranium } & \multirow[b]{2}{*}{ Ash } \\
\hline & & & & & $\underset{\text { sample }}{\text { In }}$ & $\underset{\text { ash }}{\text { In }}$ & \\
\hline
\end{tabular}

NORTH CAVE HILLS, HARDING COUNTY, S. DAK. (LOCALITIES 16-51, PL. 7)-continued T. 22 N., R. 5 E. - Continued

\begin{tabular}{|c|c|c|c|c|c|c|c|}
\hline $\begin{array}{l}48 \\
49 \\
50 \\
51\end{array}$ & 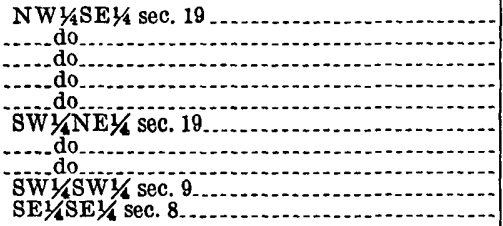 & $\begin{array}{l}45034 \\
45035 \\
45036 \\
45037 \\
45038 \\
45397 \\
45041 \\
45042 \\
44256 \\
44255\end{array}$ & $\begin{array}{l}1.0 \\
1.0 \\
1.0 \\
1.0 \\
1.0 \\
2.5 \\
4.0 \\
1.5 \\
2.0 \\
4.5\end{array}$ & $\begin{array}{l}0.003 \\
.002 \\
.002 \\
.003 \\
.002 \\
.006 \\
.001 \\
.003 \\
.004 \\
.001\end{array}$ & $\begin{array}{l}0.003 \\
.003 \\
.002 \\
.003 \\
.003 \\
.005 \\
.003 \\
.003 \\
.004 \\
.002\end{array}$ & $\begin{array}{r}0.005 \\
.004 \\
.004 \\
.005 \\
.006 \\
-006 \\
.003 \\
\\
\end{array}$ & $\begin{array}{l}54.94 \\
58.42 \\
42.61 \\
45.0 \\
55.73 \\
40.80 \\
32.85 \\
70.63 \\
\\
\end{array}$ \\
\hline
\end{tabular}

SOUTH CAVE hills AND ADJACENT OUTLIERS, HaRding COUNTY, S. DAK. (LOCALITIES $52-75$, PL. 5)

T. 20 N., R. 4 E.

\begin{tabular}{|c|c|c|c|c|c|c|c|}
\hline $\begin{array}{l}72 \\
73 \\
74 \\
75\end{array}$ & $\begin{array}{l}\text { SE1/SW1/4 sec. } 13 \\
\text { NE1/4NE1/4 sec. } 21.19 \\
\text { Center of south line, sec. } 21 \\
\text { NE1/4NE1/4 sec. } 28\end{array}$ & $\begin{array}{l}47926 \\
47930 \\
47931 \\
47928 \\
47929\end{array}$ & $\begin{array}{l}2.3 \\
.5 \\
1.5 \\
1.6 \\
1.6\end{array}$ & $\begin{array}{l}0.003 \\
.017 \\
.018 \\
.003 \\
.001\end{array}$ & $\begin{array}{l}0.005 \\
.018 \\
.025 \\
.002 \\
.003\end{array}$ & $\begin{array}{r}0.019 \\
.046 \\
\end{array}$ & $\begin{array}{r}94.93 \\
54.93 \\
\\
\end{array}$ \\
\hline 276 & $\mathrm{SE} 1 / 4 \mathrm{sW} / / 4 \mathrm{sec} .23$ & & 5.5 & & .002 & & \\
\hline
\end{tabular}

T. 20 N., R. 5 E.

\begin{tabular}{|c|c|c|c|c|c|c|c|}
\hline $\begin{array}{l}62 \\
63\end{array}$ & $\begin{array}{l}\text { SE1/4NW1/4 sec. } 9 \\
\text { SW1/4NE1/4 sec. } 5\end{array}$ & $\begin{array}{l}43889 \\
43888\end{array}$ & $\begin{array}{l}1.0 \\
2.0\end{array}$ & $\begin{array}{r}0.011 \\
.006\end{array}$ & $\begin{array}{r}0.014 \\
.007\end{array}$ & $\begin{array}{r}0.039 \\
.013\end{array}$ & $\begin{array}{l}39.59 \\
49.8\end{array}$ \\
\hline 64 & $\mathrm{NE} 1 / 4 \mathrm{NE} 1 / 4$ sec. 6 & $\begin{array}{l}43887 \\
43890\end{array}$ & $\begin{array}{l}\text { 3. } 3 \\
\text { 3. } \\
1\end{array}$ & $\begin{array}{l}.008 \\
.006\end{array}$ & $\begin{array}{l}.013 \\
.006\end{array}$ & .031 & $\begin{array}{l}40.42 \\
38.8\end{array}$ \\
\hline $\begin{array}{l}65 \\
66\end{array}$ & 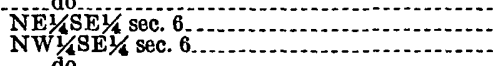 & $\begin{array}{l}43891 \\
44715 \\
43893\end{array}$ & $\begin{array}{l}1.0 \\
3.0 \\
1.7\end{array}$ & $\begin{array}{l}.003 \\
.001 \\
.011\end{array}$ & $\begin{array}{l}.007 \\
.001 \\
.006\end{array}$ & $\begin{array}{ll}.021 \\
.011\end{array}$ & $\begin{array}{l}42.13 \\
60.01\end{array}$ \\
\hline 69 & NEY/ASWY/4 sec. 20 & $\begin{array}{l}43892 \\
47934 \\
47933 \\
47932\end{array}$ & $\begin{array}{l}\text { 6. } 0 \\
1.75 \\
1.75 \\
3.0\end{array}$ & $\begin{array}{l}.001 \\
.015 \\
.016 \\
.003\end{array}$ & $\begin{array}{l}.001 \\
.014 \\
.029 \\
.002\end{array}$ & $\begin{array}{l}.056 \\
.116\end{array}$ & $\begin{array}{l}25.17 \\
25.07\end{array}$ \\
\hline 70 & NE1/NEY// sec. $1 \theta^{2}$ & 47937 & $\begin{array}{r}.7 \\
.7\end{array}$ & .023 & .018 & .020 & 94.87 \\
\hline 71 & SW $1 / 4 \mathrm{SE} Y / 4 \mathrm{sec}$ 30 & $\begin{array}{l}47935 \\
47925 \\
47927\end{array}$ & $\begin{array}{l}.8 \\
.5 \\
.8\end{array}$ & $\begin{array}{l}.020 \\
.14 \\
.018\end{array}$ & $\begin{array}{l}.024 \\
.19 \\
.020\end{array}$ & $\begin{array}{l}.031 \\
.22 \\
.022\end{array}$ & $\begin{array}{l}85.74 \\
88.94\end{array}$ \\
\hline
\end{tabular}

T. 21 N., R. 4 E.

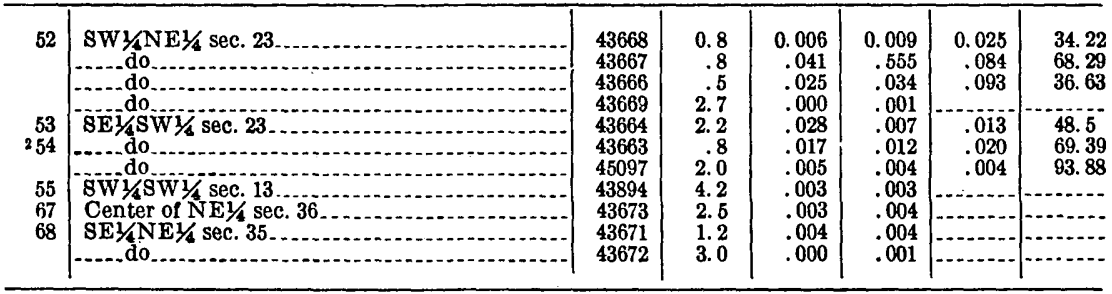

1 At localities 5, 6, and 12, lignite is not radioactive and was not sampled.

2 Auger hole. Owing to contamination of wall rock with lignite cuttings, uranium analyses are 25 to 45 percent less than their true values. 
TABLE 5.-Analyses of surface samples and auger cuttings of uranium-bearing

I lignite from northwestern South Dakota and adjacent areas in North Dakota and Montana-Continued

\begin{tabular}{|c|c|c|c|c|c|c|c|}
\hline \multirow[b]{3}{*}{ No. } & Locality 1 & \multicolumn{2}{|c|}{ Sample } & \multicolumn{4}{|c|}{ Analyses, in percent } \\
\hline & \multirow[b]{2}{*}{ Location in townshlp and section } & \multirow{2}{*}{$\begin{array}{c}\text { Labo- } \\
\text { ratory } \\
\text { No. }\end{array}$} & \multirow{2}{*}{$\begin{array}{l}\text { Thick- } \\
\text { ness } \\
\text { (ft) }\end{array}$} & \multirow{2}{*}{$\begin{array}{l}\text { Equiv- } \\
\text { alent } \\
\text { ura- } \\
\text { nium }\end{array}$} & \multicolumn{2}{|c|}{ Uranium } & \multirow[b]{2}{*}{ Ash } \\
\hline & & & & & $\underset{\text { sample }}{\text { In }}$ & $\underset{\text { ash }}{\text { In }}$ & \\
\hline
\end{tabular}

SOUTH CAVE HILLS AND ADJACENT OUTLIERS, HARDING COUNTY, S. DAK. (LOCALITIES 52-75, PL. 5)-continued

T. 21 N., R. 5 E.

\begin{tabular}{|c|c|c|c|c|c|c|c|}
\hline $\begin{array}{l}56 \\
57 \\
58 \\
59 \\
60 \\
61\end{array}$ & $\begin{array}{l}\text { Center of SW1/4 sec. } 18 \\
\text { NW1 } 14 \text { SW1 } 1 / 4 \text { sec. } 28 \\
\text { NW } 1 / 4 \text { NW } 1 / 4 \text { sec. } 33 \\
\text { Center of south line, sec. } 28 \\
\text { Center of south line, sec. } 28\end{array}$ & $\begin{array}{l}44716 \\
44717 \\
47866 \\
44719 \\
44718 \\
43670\end{array}$ & $\begin{array}{l}3.5 \\
1.0 \\
2.5 \\
1.5 \\
4.2 \\
1.1\end{array}$ & $\begin{array}{r}0.007 \\
.042 \\
.020 \\
.029 \\
.014 \\
.006\end{array}$ & $\begin{array}{r}0.009 \\
.045 \\
.024 \\
.030 \\
.015 \\
.013\end{array}$ & 0.108 & $\begin{array}{l}21.93 \\
82.20 \\
22.12 \\
70.13 \\
29.33 \\
51.18\end{array}$ \\
\hline
\end{tabular}

SLIM BUTTES, HARDING COUNTY, S. DAK. (LOCALITIES 77-119, PL. 12)

T. 16 N., R. 7 E.

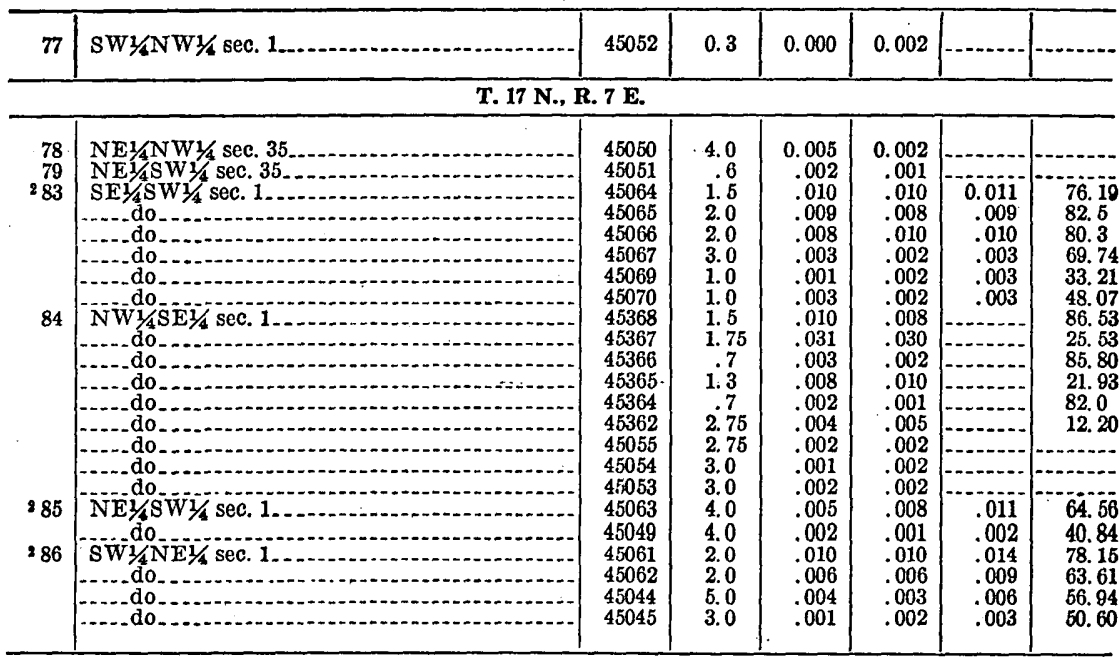

T. 17 N., R. 8 E.

\begin{tabular}{|c|c|c|c|c|c|c|c|}
\hline $\begin{array}{l}80 \\
81 \\
82\end{array}$ & \begin{tabular}{l} 
NW1/4SE1/4 sec.8 \\
SW1/4SE1/4 sec. 8. \\
SE1/4NE1/4 sec. 5 \\
\hdashline do
\end{tabular} & $\begin{array}{l}47851 \\
47 \$ 52 \\
47853 \\
47854\end{array}$ & $\begin{array}{l}1.0 \\
4.9 \\
2.1 \\
2.7\end{array}$ & $\begin{array}{r}0.003 \\
.009 \\
.009 \\
.005\end{array}$ & $\begin{array}{r}0.002 \\
.007 \\
.010 \\
.005\end{array}$ & $\begin{array}{r}0.039 \\
.029 \\
.017\end{array}$ & $\begin{array}{l}43.79 \\
17.85 \\
34.30 \\
29.47\end{array}$ \\
\hline
\end{tabular}

T. 18 N., R. 7 E.

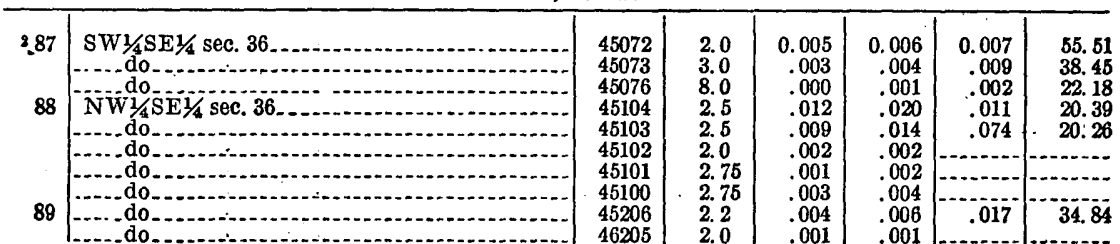

1 At localities 5,6 , and 12, lignite is not radioactive and was not sampled:

Auger hole. Owing to contamination of wall rock with lignite cuttings uranium analyses are 25 to 45 percent less than their true values. 
TABLE 5.-Analyses of surface samples and auger cuttings of üranium-bearing lignite from northwestern South Dakota and adjacent areas in North'Dakota and Montana-Continued

\begin{tabular}{|c|c|c|c|c|c|c|c|}
\hline \multirow{3}{*}{ No. } & \multirow{3}{*}{$\frac{\text { Locality } 1}{\vdots}$ Location in township and section } & \multicolumn{2}{|c|}{ Sample } & \multicolumn{4}{|c|}{ Analyses, in percent } \\
\hline & & \multirow{2}{*}{$\begin{array}{l}\text { Labo- } \\
\text { ratory } \\
\text { No. }\end{array}$} & \multirow{2}{*}{$\begin{array}{c}\text { Thick- } \\
\text { ness } \\
\text { (ft) }\end{array}$} & \multirow{2}{*}{$\begin{array}{c}\text { Equiv- } \\
\text { alent } \\
\text { ura- } \\
\text { nium }\end{array}$} & \multicolumn{2}{|c|}{ Uranium } & \multirow{2}{*}{ Ash } \\
\hline & & & & & $\underset{\text { somple }}{\text { In }}$ & $\underset{\text { ash }}{\text { In }}$ & \\
\hline
\end{tabular}

SLIM BUTTES, HARDING COUNTY, S. DAK. (LOCALITIES 77-119, PL. 12)-continued T. 18 N., R. 7 E.-Continued

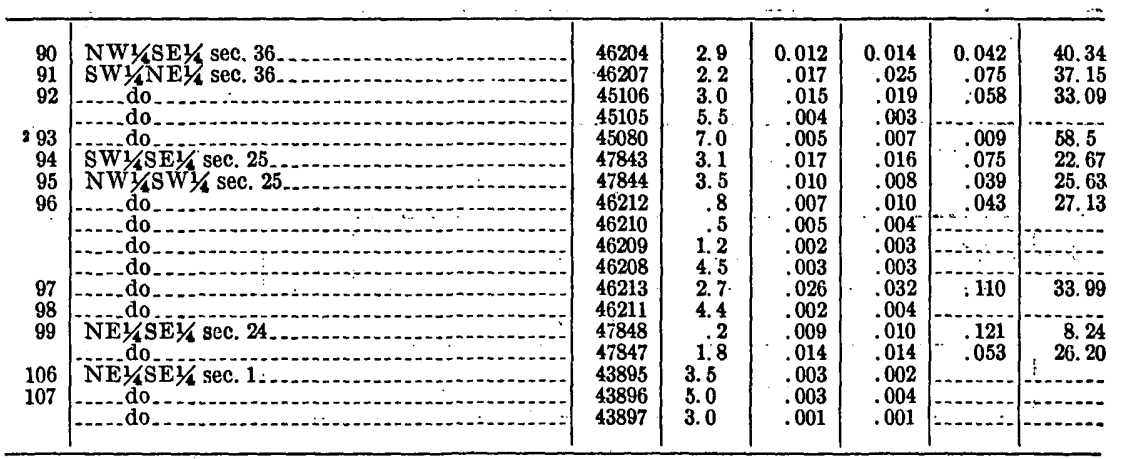

T. 18 N., R. 8 E.

\begin{tabular}{|c|c|c|c|c|c|c|c|}
\hline 100 & SE1/4SW $1 / 4$ seç. 20. & \multirow{13}{*}{$\begin{array}{r}47849 \\
47850 \\
.47855 \\
\mathbf{4 7 8 5 6} \\
\mathbf{4 7 8 5 7} \\
47859 \\
\mathbf{4 7 8 5 8} \\
\mathbf{4 7 8 6 0} \\
.47943 \\
47944 \\
.47945 \\
47946 \\
47947 \\
\mathbf{4 7 9 4 8} \\
47949 \\
\mathbf{4 7 9 5 3} \\
\mathbf{4 7 9 5 4} \\
\mathbf{4 7 9 5 6}\end{array}$} & \multirow{13}{*}{$\begin{array}{l}3.0 \\
2.5 \\
3.7 \\
3.5 \\
4.2 \\
1.7 \\
3.1 \\
.4 \\
1.0 \\
2.0 \\
2.0 \\
2.0 \\
2.0 \\
2.0 \\
8.0 \\
2.0 \\
4.0 \\
1.5\end{array}$} & \multirow{13}{*}{$\begin{array}{r}0.009 \\
.006 \\
.005 \\
.007 \\
.002 \\
.004 \\
.003 \\
.012 \\
.002 \\
.002 \\
.001 \\
.002 \\
.001 \\
.001 \\
.002 \\
.003 \\
.002 \\
.002\end{array}$} & \multirow{13}{*}{$\begin{array}{l}0.010 \\
.006 \\
.008 \\
.009 \\
.002 \\
.004 \\
.002 \\
.011 \\
.005 \\
.003 \\
.002 \\
.003 \\
.002 \\
.003 \\
.003 \\
.004 \\
.003 \\
.004\end{array}$} & \multirow{5}{*}{$\begin{array}{r}0.050 \\
.034 \\
.020 \\
.025 \\
.011 \\
.014\end{array}$} & \multirow{6}{*}{$\begin{array}{r}19.87 \\
17.61 \\
25.05 \\
35.80 \\
17.93 \\
28.07 \\
12.55 \\
80.13\end{array}$} \\
\hline 101 & NW $1 /$ Swi $1 / 1 / \sec 28$ & & & & & & \\
\hline 102 & SW1/4SW1/4 sec. 29. & & & & & & \\
\hline 103 & SE $1 / 4$ SE $1 / 4$ sec. 8 & & & & & & \\
\hline 104 & NE $1 / 4$ NE $1 / 4$ sec. 17 & & & & & & \\
\hline 105 & $-\ldots-d_{0}$ & & & & & .014 & \\
\hline 2108 & $\mathrm{SE} 1 / 4 \mathrm{SE} 1 / 4$ sec. 8 & & & & & & \\
\hline . & 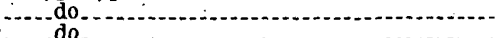 & & & & & & \\
\hline. & - & & & & & & \\
\hline & 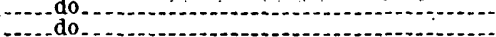 & & & & & & 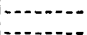 \\
\hline 2109 & $\mathrm{SE} 1 / 4 \mathrm{NW} 1 / 4$ sec. 8 & & & & & & \\
\hline & .... do do............ & & & & & & \\
\hline & $\begin{array}{l}\text { do } \\
\text { do }\end{array}$ & & & & & & \\
\hline
\end{tabular}

T. 19 N., R. 8 E.

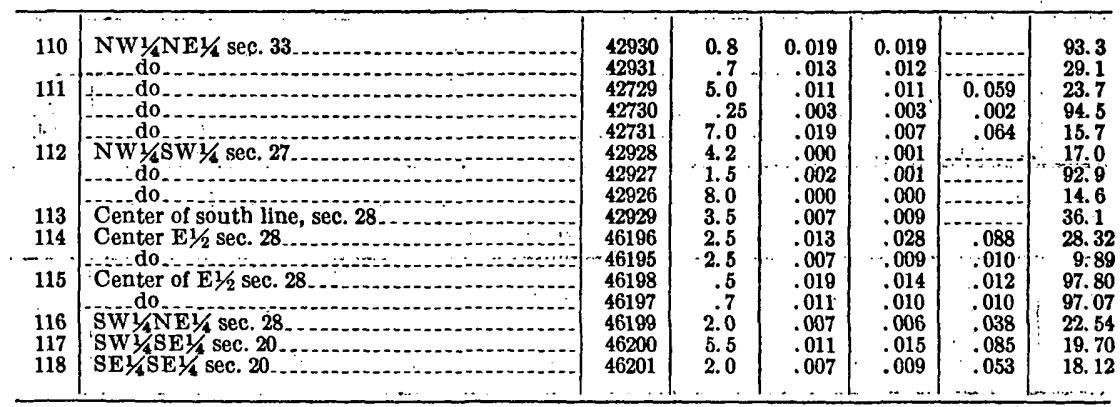

1 At localities 5, 6, and 12, lignite is not radioactive and was not sampled.

2 Auger hole. Owing to contamination of wall rock with lignite cutting, uranium analyses are 25 to 45 percent less than their true values.

$469117-59-5$ 
TABLE 5.-Analyses of surface samples and auger cuttings of uranium-bearing lignite from northwestern South Dakota and adjacent areas in North Dakota and Montana-Continued

\begin{tabular}{|c|c|c|c|c|c|c|c|}
\hline \multirow[b]{3}{*}{ No. } & Locality 1 & \multicolumn{2}{|c|}{ Sample } & \multicolumn{4}{|c|}{ Analyses, in percent } \\
\hline & \multirow[b]{2}{*}{ Location in township and section } & \multirow{2}{*}{$\begin{array}{c}\text { Labo- } \\
\text { ratory } \\
\text { No. }\end{array}$} & \multirow{2}{*}{$\begin{array}{c}\text { Thick- } \\
\text { ness } \\
\text { (ft) }\end{array}$} & \multirow{2}{*}{$\begin{array}{l}\text { Equiv- } \\
\text { alent } \\
\text { urs- } \\
\text { numm }\end{array}$} & \multicolumn{2}{|c|}{ Uranium } & \multirow[b]{2}{*}{ Ash } \\
\hline & & & & & $\begin{array}{l}\text { In } \\
\text { sample }\end{array}$ & $\operatorname{In}_{\text {ash }}$ & \\
\hline
\end{tabular}

SLIM. BUTTES, HARDING COUNTY, S. DAK. (LOCALITIES 77-119, PL. 12)-continued T. 21 N., R. 8 E.

\begin{tabular}{|c|c|c|c|c|c|c|c|}
\hline 119 & \begin{tabular}{|c|c|} 
SW1/4 sec. 20 & \\
do & do
\end{tabular} & $\begin{array}{l}42923 \\
42924 \\
42925\end{array}$ & $\begin{array}{l}0.7 \\
3.2 \\
2.2\end{array}$ & $\begin{array}{r}0.005 \\
.001 \\
.001\end{array}$ & $\begin{array}{r}0.003 \\
.001 \\
.001\end{array}$ & 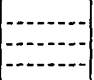 & $\begin{array}{l}36.5 \\
19.4 \\
18.0\end{array}$ \\
\hline
\end{tabular}

LONG PINE HILLS, CARTER COUNTY, MONT. (LOCALITIES 120-123, PL. 9) T. 1 N., R. 48 E.

\begin{tabular}{r|r|r|r|r|r|r|r|r|}
\hline 123 & SW1/4SW1/4 sec. 13 & $\vdots$ & 46217 & 0.8 & 0.002 & 0.003 & $\ldots \ldots$ \\
\hline
\end{tabular}

T. 1 S., R. 61 E.

\begin{tabular}{r|r|r|r|r|r|r|r}
\hline 122 & NE1/4NE1/4 sec. 20 & & \\
\hline
\end{tabular}

T. 3 S., R. 62 E.

\begin{tabular}{|c|c|c|c|c|c|c|c|}
\hline $\begin{array}{l}120 \\
121\end{array}$ & $\begin{array}{l}\text { NW1/4NW1/4 sec. 19. } \\
\text { SW1/4NE1/4 sec. } 21\end{array}$ & $\begin{array}{l}42472 \\
46215 \\
46214\end{array}$ & $\begin{array}{l}2.0 \\
2.5 \\
2.5\end{array}$ & $\begin{array}{r}0.004 \\
.005 \\
.005\end{array}$ & $\begin{array}{r}0.004 \\
.004 \\
.003\end{array}$ & 0.006 & $\begin{array}{r}70.6 \\
\hdashline-1\end{array}$ \\
\hline
\end{tabular}

MEDICINE POLE HILLS, BOWMAN COUNTY, N. DAK. (LOCALITIES 125-132, 147-148, PL. 9) T. 130 N., R. 104 W.

\begin{tabular}{|c|c|c|c|c|c|c|c|}
\hline $\begin{array}{l}125 \\
147 \\
148\end{array}$ & $\begin{array}{l}\text { NE1/4NW1/4 sec. } 12 \\
\text { NE1/4SE1/4 sec. } 2 \\
\text { SW1/4NW1/4 sec. } 1 .\end{array}$ & $\begin{array}{l}42474 \\
45391 \\
45392\end{array}$ & $\begin{array}{l}4.0 \\
3.5 \\
5.0\end{array}$ & $\begin{array}{r}0.005 \\
.019 \\
.003\end{array}$ & $\begin{array}{r}0.005 \\
.019 \\
.003\end{array}$ & 0.015 & $\begin{array}{l}45.1 \\
58.40 \\
60.66\end{array}$ \\
\hline
\end{tabular}

T. 131 N., R. 103 E.

\begin{tabular}{|c|c|c|c|c|c|c|c|}
\hline $\begin{array}{r}129 \\
130 \\
131 \\
2132\end{array}$ & \begin{tabular}{l} 
NW1/4NW1/4 sec. 29 \\
SW1/4SW1/4 sec. 20 \\
NE1/4NE1/4 sec. 21.04 \\
\hdashline do
\end{tabular} & $\begin{array}{l}45056 \\
45394 \\
45369 \\
45395 \\
45060\end{array}$ & $\begin{array}{l}2.0 \\
8.0 \\
2.0 \\
5.0 \\
5.0\end{array}$ & $\begin{array}{r}0.001 \\
.002 \\
.008 \\
.002 \\
.003\end{array}$ & $\begin{array}{r}0.001 \\
.001 \\
.010 \\
.001 \\
.002\end{array}$ & $\mid$\begin{tabular}{|c|}
-102 \\
\hdashline 0.002
\end{tabular} & $\begin{array}{l}55.46 \\
34.26 \\
59.60 \\
54.20\end{array}$ \\
\hline
\end{tabular}

T. 131 N., R. 104 W.

\begin{tabular}{|c|c|c|c|c|c|c|c|}
\hline $\begin{array}{l}126 \\
127 \\
128 \\
\end{array}$ & $\begin{array}{l}\text { SE1/4SW1/4 sec. } 35 \ldots \\
\text { NW1/4SE1/4 sec. } 35 \ldots \ldots\end{array}$ & $\begin{array}{l}45390 \\
45393 \\
\mathbf{4 5 3 9 8}\end{array}$ & $\begin{array}{l}5.0 \\
4.5 \\
5.5\end{array}$ & $\begin{array}{r}0.005 \\
.008 \\
.007\end{array}$ & $\begin{array}{r}0.004 \\
.010 \\
.009\end{array}$ & 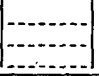 & $\begin{array}{l}61.33 \\
64.0 \\
17.33\end{array}$ \\
\hline
\end{tabular}

LODGEPOLE AREA, PERKINS COUNTY, S. DAK. (LOCALITIES 133-145, PL. 90) T. 21 N., R. 11 E.

\begin{tabular}{|c|c|c|c|c|c|c|c|}
\hline $\begin{array}{l}144 \\
145\end{array}$ & 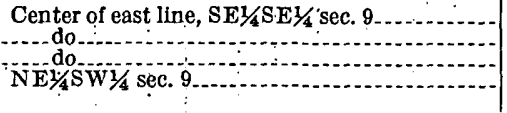 & $\begin{array}{l}45093 \\
45094 \\
45095 \\
44272\end{array}$ & $\begin{array}{l}3.5 \\
1.5 \\
2.5 \\
5.5\end{array}$ & $\begin{array}{r}0.006 \\
.003 \\
.002 \\
.003\end{array}$ & $\begin{array}{r}0.006 \\
.003 \\
.002 \\
.004\end{array}$ & $\begin{array}{r}0.009 \\
.004 \\
.004 \\
\end{array}$ & $\begin{array}{r}64.75 \\
53.05 \\
52.53 \\
\end{array}$ \\
\hline
\end{tabular}

1 At localities 5, 6, and 12, lignite is not radioactive and was not sampled.

2 A uger hole. Owing to contamination of wall rock with lignite cutting, uranium analyses are 25 to 45 percent less than their true values. 
TABLE 5.-Analyses of surface samples and auger cutings of uranium-bearing lignite from northwestern South Dakota and adjacent areas in North Dakota and Montana-Continued

\begin{tabular}{|c|c|c|c|c|c|c|c|c|c|c|}
\hline \multirow{3}{*}{$\begin{array}{l}\therefore \\
\text { No. } \\
\therefore\end{array}$} & . & $\quad$ Locality 1 & Locality 1 & & \multicolumn{2}{|c|}{ Sample } & \multicolumn{4}{|c|}{ Analyses, in percent } \\
\hline & \multirow{2}{*}{$\therefore$} & \multirow{2}{*}{\multicolumn{2}{|c|}{ Location in township and section }} & & \multirow{2}{*}{$\begin{array}{l}\text { Labo- } \\
\text { ratory } \\
\text { No. }\end{array}$} & \multirow{2}{*}{$\begin{array}{c}\text { Thick- } \\
\text { ness } \\
\text { (ft) } \\
- \\
\end{array}$} & \multirow{2}{*}{$\begin{array}{c}\text { Equiv- } \\
\text { alent } \\
\text { urg- } \\
\text { nium } \\
\end{array}$} & \multicolumn{2}{|c|}{ Uranium } & \multirow[b]{2}{*}{ Asho } \\
\hline & & & & & & & & $\underset{\text { sample }}{\text { In }}$ & $\underset{\text { ash }}{\text { In }}$ & \\
\hline
\end{tabular}

LOdGEPOLE AREA, PERKINS COUNTY, S. DAK. (LOCALITIES 133-145, PL. 9)-continued T. 21 N., R. 12 E.

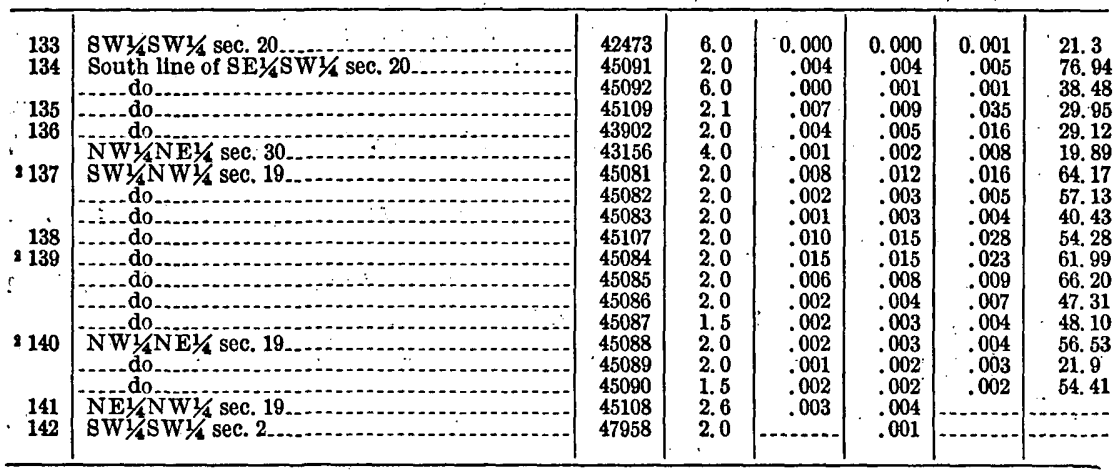

T. 22 N., R. 12 E.

\begin{tabular}{r|r|r|r|r|r|r|r}
\hline 143 & NW1/4SW1/4 sec. 33.......................... & 43157 & 3.0 & 0.001 & 0.001 & 0.003 & 23.41 \\
\hline
\end{tabular}

1 At localities 5, 6, and 12, lignite is not radioactive and was not sampled.

2 Auger hole. Owing to contamination of wall rock with lignite cutting, uranium analyses are 25 to 45 percent less than their true values.

\section{LITERATURE CITED}

Baker, C. L., 1952, Geology of Harding County: South Dakota Geol. Survey Rept. Inv. No. 68.

Bauer, C. M., 1924, The Ekaläka lignite field, southeastern Montana: U. S. Geol. Survey Bull. 751-F, p. 231-267.

Benson, W: E., 1951, Geologic map of North Dakota southwest of the Missouri . . River: U. S.Geol. Survey map.

Bradley, W. H., 1930, The occurrence and origin of analcite and meerschaum beds in the Green River formation of Utah, Colorado, and Wyoming :' U. S. Geol. Survey Prof. Paper 158-A, p. 1-7.

Brown, R. W., 1948, Correlation of Sentinel Butte shale in western North Dakota: Am. Assoc. Petroleum Geologists Bull., v. 32, no. 7, p. 1265-1274.

1952, Tertiary strata in eastern Montana and western North and South Dakota : Billings Geol. Soc. Guidebook, 3d ann. conference, p. 89-92.

Bump, J. D., '1951, The White River badlands of South Dakota: Soc. of Vertebrate Paleontology; 5th fleld conference, p.'35-46.

Darton, N. H., 1909, Geology and underground waters of South Dakota: 'U. S. Geol. Survey Water-Supply:Paper 227, p. 1-156.

Davidson, C. F., and Ponsford, D. R. A., 1954, On. the occurrence of uranium in coals: Mining Magazine (London), v. 91, no. 5, p. 265-273. 
Davidson, D. F., 1953, Reconnaissance for uranium in the Powder River Basin; Wyo.: U. S. Geol. Survey TEM-677, U. S. Atomic Energy Comm., Tech. Inf. Serv., Oak Ridge.

Dobbin, C. E., and Erdmann, C. E., 1946, Structure contour map of the Montana Plains: U. S. Geol. Survey Oil and Gas Inv. Map OM 165.

Evans, R. D., and Goodman, Clark, 1941, Radioactivity of rocks: Bull. Geol. Soc. America, v. 52, p. 459:

Foster, W. D., and Feicht, F. L., 1946, Mineralogy of concretion from Pittsburgh coal seam, with special reference to analcite: Am. Mineralogist, $\nabla$. 31, p. $357-364$.

Frederickson, A. F., 1948, Some mechanisms for the flxation of uranium in certain sediments: Science, v. 108, p. 184-185.

Gill, J. R., and Moore, G. W., 1955, Carnotite-bearing sandstone in Cedar Canyon, Slim Buttes, Harding County, S. Dak. : U. S. Geol: Survey Bull. 1009-I.

Gott, G. B., Wyant, D. C., and Beroni, E. P., 1952, Uranium in black shales, lignites, and limestones in the United States: U. S. Geol. Survey. Circ. 220, p. 31-35.

Griggs, R. L., 1954, Reconnaissance for uranium in New Mexico in 1953: U. S. Geol. Survey Circ. 354.

Gruner, J. W., 1954, The origin of the uranium deposits of the Colorado Platean and adjacent regions: Mines Mag., v. 44, p. 53-56.

Hager, Dorsey, 1954, Uranium-the volcanic ash theory: Uranium, v. 1, no. 1, p. 12-13, 38.

Hares, C. J., 1928, Geology and lignite resources of the Marmarth field, southwestern North Dakota :..U. S. Geol. Survey Bull. 775.

Koeberlin, F. R., 1938, Sedimentary copper, vanadium-uranium, and silver in southwestern United States: Econ. Geology, v. 33, no. 4, p. 458-461.

Lloyd, E. R., 1914, The Cannonball River lignite fleld, Morton; Adams, and Hettinger Counties, N. Dak.: U. S. Geol. Survey Bull. 541, p. 243-291.

Love, J. D., 1952, Preliminary report on uranium in the Pumpkin Buttes area, Powder River Basin, Wyo. : U. S. Geol. Survey Circ: 176.

McKelvey, V. E., and Nelson, J. M., 1950, Characteristics of marine uraniumbearing sedimentary rocks : Econ. Geology, v. 45, no. 1, p. 35-53.

Miller, R. L., and Gill, J. R., 1954, Uranium from coal: Scientific American; v. 191, no. 4, p. 36-39.

Moore; G: W., 1954, Extraction of uranium from aqueous solution by coal and some other materials : Econ. Geology, v. 49, no. 6, p. 652-658.

Moore, G. W., and Levish, Murray, 1955, Uranium-bearing sandstone in the Chadron formation, White River badlands, Pennington County, S. Dak.: U. S. Geol. Survey Circ. 359.

Rankama, K., and Sahama, T. G., 1950, Geochemistry: The University of Chicago Press.

Ross, C. S., 1928, Sedimentary analcite : Am. Mineralogist, v. 13, no. 5, p. 195-197.

Schopf, J. M., and Gray, R. J., 1954, Microscopic studies of uraniferous coal deposits: U. S. Geol. Survey Circ. 343.

Szalay, S., 1954, The enrichment of uranium in some brown coals in Hungary : Acta Geologica, Magyar Tudomanyos Akademia, v. 2, nos. 3-4, p. 299-310.

Thomas, H. D., 1954, Wyoming's uranium prospects: Uranlum, จ. 1, no. 1, p. $8,46-47$.

Tolmachev, I. M., 1943, Adsorption of urangl salts on solid adsorbents: U. S. S. R. Acad. Sci. Bull. 1, p. 28-34. 
Tourtelot, H. A., 1946, Tertiary stratigraphy in the northeastern part of the Wind River Basin, Wyoming: U. S. Geol. Survey Oil and Gas Inv. Prelim. Chart 22. Wanless, H. R., 1922, Lithology of the White River sediments: Am. Philos. Soc., Proc., v. 61, p. 184-203.

Winchester, D. E., Hares, C. J., Lloyd, E. R., and Parks, E. M., 1916, The lignite field of northwestern South Dakota : U. S. Geol. Survey Bull. 627.

Wood, H. E., 2d, Chaney, R. W., Clark, John, Colbert, E. H., Jepson, G. L., Reeside, J. B., and Stock, Chester, 1941, Nomenclature and correlation of the North American Continental Tertiary: Geol. Soc. America Bull., v. 52, p. 1-48.

Wood, H. E., 2d, 1945, Late Miocene Beaver from southeastern Montana : Am. Museum Novitates, no. 1299.

1949, Oligocene faunas, facies, and formations, in Longwell, C. R., Sedimentary facies in geologic history: Geol. Soc. America Mem. 39, p. 83-92. 


\section{Core Drilling for Uranium-}

Bearing Lignite in Harding and Perkins Counties, South Dakota and Bowman County

North Dakota

By HOWARD D. ZELLER and JAMES M. SCHOPF

URANIUM IN COAL IN THE WESTERN UNITED STATES

GE OLOG I CAL SUR VEY BULLETIN $1055-\mathrm{C}$ 



\section{CONTENTS}

Abstract.....

Introduction

Geology

Bar $\mathrm{H}$ area $\ldots . . .62$

Lodgepole area and Johnson outlier.

Medicine Pole Hills area._. 65

Relationships between uranium and other trace elements in lignite in the Dakotas _. . . 68

Tonnage and grade of uranium-bearing lignite. 69

Literature cited. . . 70

Index ... 309

\section{ILLUSTRATIONS}

[Plates are in box]

Plate 17. Geologic map of the Bar $\mathrm{H}$ area, South Dakota, showing location of core holes.

18. Stratigraphic chart showing correlation of uranium-bearing lignite beds in core holes, Bar $\mathrm{H}$ area, South Dakota.

19. Distribution and concentration of uranium in lignite cores, Bar H area, South Dakota.

20. Distribution and concentration of uranium in lignite cores, Lodgepole area and Johnson outlier, South Dakota.

21. Distribution and concentration of uranium in lignite cores, Medicine Pole Hills area, North Dakota.

Figure 9. Index map showing the areas of core drilling for uraniumbearing lignite described in this report . . . . . . . . . . ...

10. Geologic map of the Lodgepole area, South Dakota, showing

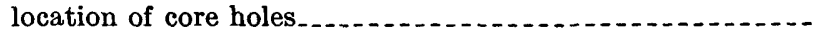

11. Stratigraphic chart showing correlation of uranium-bearing lignite beds in core holes, Medicine Pole Hills area, North Dakota, and Lodgepole area and Johnson outlier, South

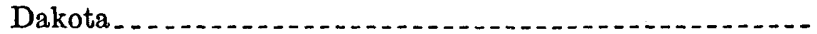

12. Geologic map of the Medicine Pole Hills area, North Dakota, showing location of core holes.......................

\section{TABLES}

TABLE 1. Data on core holes

2. Estimated tonnage of uranium-bearing lignite ...........

3. Threshold values of elements included in semiquantitative method . . . . .

4. Semiquantitative analyses of ash from lignite cores.........

5. Proximate and ultimate analyses of lignite cores.........

6. Lithologic descriptions of lignite cores.... 



\title{
GORE DRILLING FOR URANIUM-BEARING LIGNITE IN HARDING AND PERKINS COUNTIES, SOUTH DAKOTA, AND BOWMAN COUNTY, NORTH DAKOTA
}

\author{
By Howard D. Zeller and James M. Schopf
}

\section{ABSTRACT}

Twenty core holes having a total footage of 1,907 feet were drilled and from them 94 feet of lignite were taken for analyses for uranium during part of the summers of 1951 and 1952 in northwestern South Dakota and southwestern North Dakota.

About 9 million tons of lignite averaging 0.01 percent uranium are estimated to be present in the areas covered by this report. The results of 191 chemical determinations for uranium show that generally the greatest concentrations of uranium are in the upper parts of uranium-bearing lignite beds 3 feet or more in thickness and that the uranium content decreases downward to near the vanishing point in succeeding lower beds." The results of 191 semiquantitative spectrographic analyses of the ash from the lignite cores reveal that molybdenum closely parallels uranium in distribution and concentration and may possibly be significant as an indicator element in prospecting for uranium.

\section{INTRODUCTION}

The main objective of the core-drilling program in the Dakotas was to determine the quality of unweathered uranium-bearing lignite, particularly from those areas where surface sampling had indicated that significant concentrations of uranium might be present. A secondary objective was to collect unweathered samples from, and to measure the radioactivity of, the White River group of Oligocene age and the Arikaree formation of Miocene age that overlie the lignite. The uranium in the lignite is believed to have been derived from these formations.

Core holes were drilled by a private contractor, for the U.S. Geological Survey, in four major areas: the Mendenhall and Bar $\mathrm{H}$ areas of the Slim Buttes, Harding County, S. Dak.; the Lodgepole area and Johnson outlier, Perkins County, S. Dak.; and the Medicine Pole 
Hills area, Bowman County, N. Dak. The locations of these areas are shown on figure 9, and the data on core holes are given in table 1 , except for the Mendenhall area, the data for which are presented in chapter D.

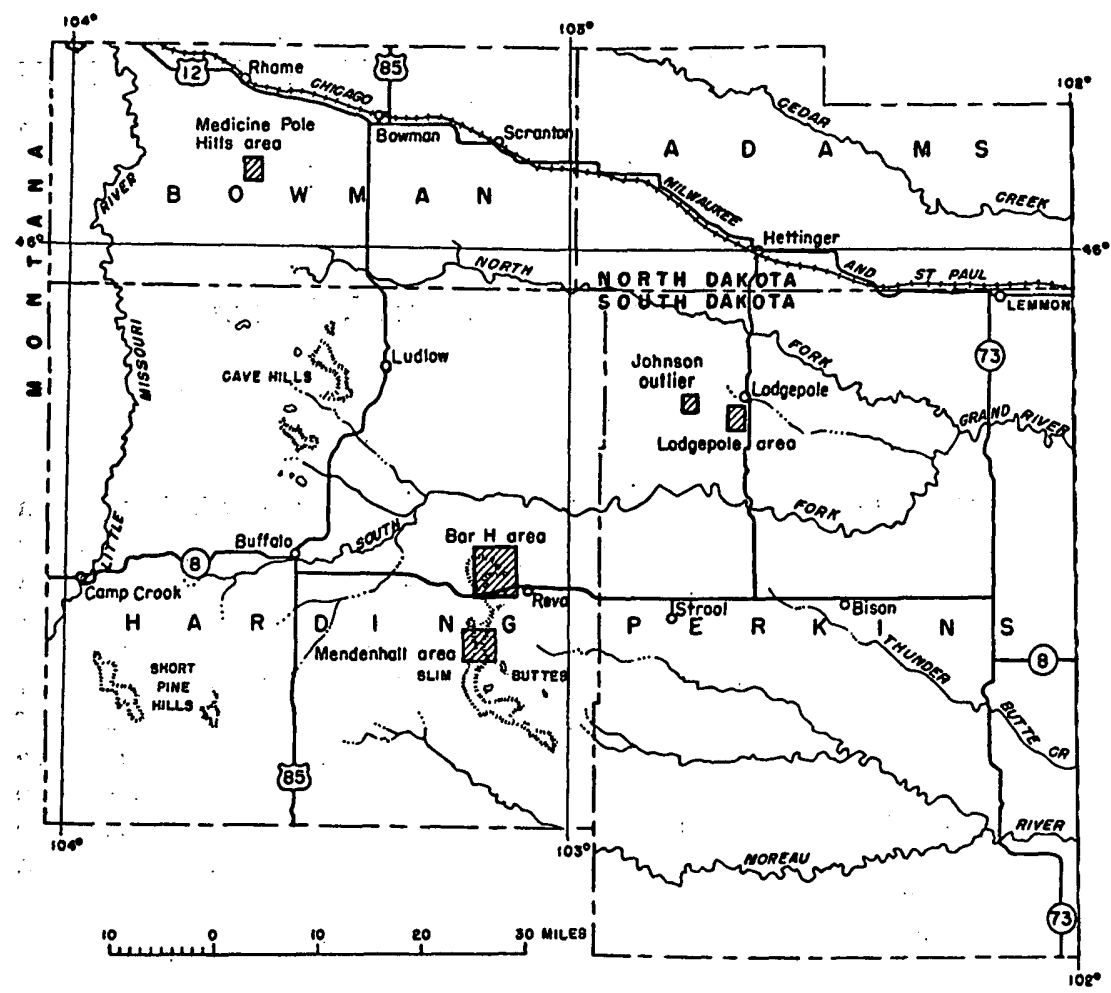

Figure 9.-Index map, showing the areas of core drilling for uranium-bearing lignite described in thls report.

The detailed description of lignite cores (table 6) and the selection of samples for uranium and semiquantitative spectrographic analyses (TE) (table 4) and for fuel analyses (table 5) were made at the Geological Survey laboratory at Columbus, Ohio, under the direction of James M. Schopf. Chemical determination of percent uranium and semiquantitative spectrographic analyses for other elements in the lignite (table 4) were made by the U. S. Geological Survey and the proximate and ultimate fuel analyses (table 5) by the U.S. Bureau of Mines at Pittsburgh, $\mathrm{Pa}$.

TE samples were sawed to include about one-fourth the volume of the core. A similar quadrant of the coal in the core constituted the Bureau of Mines analytic sample of the lignite. The remainder of the core was reserved for the preparation of thin sections and for more 
TABLE 1.-Summary of core holes drilled in North and South Dakota

\begin{tabular}{|c|c|c|c|c|c|c|c|}
\hline \multirow{2}{*}{$\begin{array}{l}\text { Core } \\
\text { hole }\end{array}$} & \multirow{2}{*}{ Location } & \multirow{2}{*}{$\begin{array}{c}\text { Eleva- } \\
\text { tion (feet } \\
\text { above } \\
\text { sea level) }\end{array}$} & \multicolumn{2}{|c|}{$\begin{array}{c}\text { Depth to } \\
\text { lignite }\end{array}$} & \multicolumn{2}{|c|}{$\begin{array}{l}\text { Thickness } \\
\text { of lignite }\end{array}$} & \multirow{2}{*}{$\begin{array}{l}\text { Depth } \\
\text { of hole } \\
\text { (ft) }\end{array}$} \\
\hline & & & $\mathrm{Ft}$ & In & $\mathrm{Ft}$ & In & \\
\hline
\end{tabular}

Bar $\mathrm{H}$ area, Harding County, S. Dak.

\begin{tabular}{|c|c|c|c|c|c|c|c|}
\hline $\begin{array}{l}19 \\
20 \\
21 \\
22 \\
23 \\
24 \\
25 \\
26 \\
27\end{array}$ & 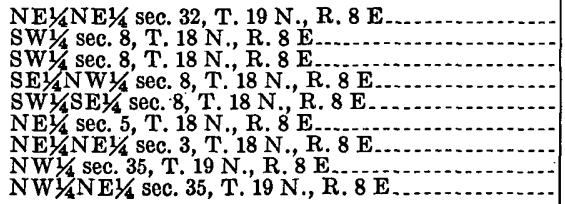 & $\begin{array}{l}3503 \\
3320 \\
3285 \\
3260 \\
3216 \\
3270 \\
3177 \\
3100 \\
3085\end{array}$ & $\begin{array}{r}379 \\
10 \\
28 \\
21 \\
105 \\
27 \\
30 \\
10\end{array}$ & \begin{tabular}{r|}
$41 / 2$ \\
0 \\
6 \\
10 \\
8 \\
10 \\
5 \\
0
\end{tabular} & $\begin{array}{r}6 \\
20 \\
4 \\
8 \\
9 \\
9 \\
10 \\
3\end{array}$ & \begin{tabular}{r|}
$1 / 2$ \\
4 \\
10 \\
0 \\
0 \\
4 \\
0 \\
0
\end{tabular} & $\begin{array}{r}412 \\
146 \\
100 \\
105 \\
100 \\
190 \\
100 \\
75 \\
69\end{array}$ \\
\hline
\end{tabular}

Lodgepole area and Johnson outlier, Perkins County, S. Dak.

\begin{tabular}{|c|c|c|c|c|c|c|c|}
\hline $\begin{array}{l}10 \\
11 \\
12 \\
13 \\
14 \\
15\end{array}$ & 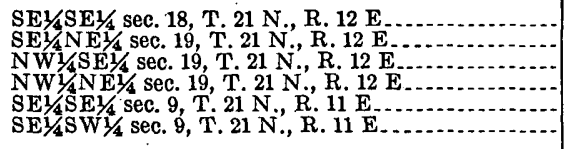 & $\begin{array}{l}2970 \\
2959 \\
2961 \\
2949 \\
3015 \\
3017\end{array}$ & $\begin{array}{l}41 \\
53 \\
33 \\
14 \\
18\end{array}$ & $\begin{array}{c}7 \\
111 / 2 \\
41 / 2 \\
8 \\
2\end{array}$ & $\begin{array}{l}8 \\
7 \\
4 \\
7 \\
5\end{array}$ & $\begin{array}{c}51 / 2 \\
71 / 2 \\
2 \\
9 \\
101 / 2\end{array}$ & $\begin{array}{r}100 \\
67 \\
65 \\
42 \\
25 \\
30\end{array}$ \\
\hline
\end{tabular}

Medicine Pole Hills area, Bowman County, N. Dak.

\begin{tabular}{|c|c|c|c|c|c|c|c|}
\hline \multirow[t]{2}{*}{$\begin{array}{l}5 \\
6 \\
7 \\
8 \\
9\end{array}$} & 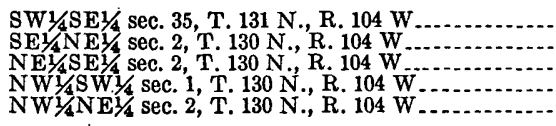 & $\begin{array}{l}3427 \\
3427 \\
3417 \\
3414 \\
3422\end{array}$ & $\begin{array}{l}68 \\
58 \\
20 \\
29 \\
53\end{array}$ & $\begin{array}{l}91 / 2 \\
5 \\
0 \\
6 \\
0\end{array}$ & $\begin{array}{r}4 \\
5 \\
-2 \\
2 \\
5\end{array}$ & $\begin{array}{l}1 / 2 \\
81 / 2 \\
6 \\
.1 / 2\end{array}$ & $\begin{array}{l}73 \\
66 \\
45 \\
36 \\
61\end{array}$ \\
\hline & Tot & & & & 121 & $101 / 2$ & 1,907 \\
\hline
\end{tabular}

detailed study of radioactive-material distribution in lignite constituents.

\section{GEOLOGY}

No attempt is made in this report to describe the geology in detail; only a brief account of the geology of each area is given. A detailed description of the regional geology may be found in Winchester and others (1916), and Hares (1928). Darton (1909), Toepelman (1923), and Wood (1942) have also briefly described the geology of small areas within Harding and Perkins Counties. Uranium-bearing lignite in this region was reported by D. G. Wyant and E. P. Beroni (written communication, 1950).

Details on the geology and origin of the uranium-bearing lignite in the areas are given by Denson, Bachman, and Zeller in chapter B. In most respects the data obtained by core drilling in the Dakotas substantiate the theory presented in that report. Generally the analyses of the lignite cores show greater concentrations of uranium in the upper parts of uranium-bearing beds 3 feet or more thick, the uranium content decreasing progressively downward to near the 
vanishing point in the lower parts and in the succeeding lower beds (pls. 19, 20, and 21).

Gamma counts recorded with a portable scaler equipped with a geiger tube and a 400-foot coaxial cable showed marked radioactivity in the source beds of the White River group and the Arikaree formation, which unconformably overlie the uranium-bearing lignite beds at the Slim Buttes.

\section{BAR H AREA}

The Bar $\mathrm{H}$ area is at the northeast tip of the Slim Buttes in eastcentral Harding County, S. Dak. (fig. 9). The outcrops are accessible only from the top of the buttes by 6 miles of the U.S. Forest Service dirt road that joins State Route 8 at a point 2 miles west of Reva. The bedrock in the area is divided into 3 geologic units. The oldest, the lignite-bearing Ludlow member of the Fort Union formation of Paleocene age, crops out along the base of the buttes and consists predominantly of soft, light-buff and tannish-gray sandstone, gray shale, and lignite. It is unconformably overlain by 150 feet or more of tuffaceous sandstone and bentonitic clay of the White River group of Oligocene age. The youngest unit, the Arikaree formation of Miocene age, consists of greenish-gray, chalky, tuffaceous sandstone, and forms imposing cliffs 200 feet high along the margins of the Slim Buttes that rise 300-400 feet above the surrounding country. The geologic map (pl. 17) shows the locations of the core holes and the areal distribution of the rock units described above.

The Bar $\mathrm{H}$ lignite bed is believed to be the stratigraphically highest persistant lignite in most of the area, although in some places a thin lignite bed, the Bar $\mathrm{H}$ rider bed, lies 60 feet or more above it. The Bar $\mathrm{H}$ bed has an average thickness of about 12 feet and is exposed at many places along the north base of the Slim Buttes. Erosion before deposition of the White River group removed the Bar $\mathrm{H}$ lignite in much of the southern part of the area. In this area, only beds stratigraphically below the Bar $\mathrm{H}$ bed were drilled; a possible exception is the upper lignite in hole 21 (pl. 18), which may be a correlative of the Bar H bed.

Structure.-High-angle normal faults cut the lignite beds in several places along the east margin of the buttes and trend N. $60-80^{\circ} \mathrm{W}$. The more prominent ones are shown on the geologic map (pl. 17). Between core holes 20 and 21, in. Reva Gap, there is a fault with a displacement of about 55 feet (pls. 17 and 18). Strata of the Ludlow member dip steeply where adjacent to faults, because of drag along the faults. Large-scale slumping in Recent time, especially along the north face of the Slim Buttes, complicates the mapping of individual 
lignite beds. The rocks in the greater part of the area are almost horizontal but the regional dip appears to be northeast.

Distribution and concentration of uranium.-As shown by samples from core hole 19 (pl. 19), the uranium is distributed in the Bar H rider lignite bed in the pattern observed in most of the other lignite beds, with the greatest amount in the upper part-here the uppermost of three seams-and decreasing amounts in the lower two seams. This upper seam, 2 feet 10 inches thick, averages 0.02 percent uranium and 0.10 percent uranium in its ash; this is the greatest concentration of uranium found in the Bar $\mathrm{H}$ area during drilling.

The lignite cores from holes $21,22,26$, and 27 contain only a small amount of uranium, although the uppermost foot of the highest bed of lignite cored in hole 22 contains 0.001 percent uranium and almost 0.01 percent in the ash. Upper lignite seams, ranging from 6 to 18 inches in thickness, in holes 23,24 , and 25 contain from 0.005 to 0.01 percent uranium. The two uppermost seams in hole 25, aggregating 2 feet 8 inches in thickness, contain $0.005-0.008$ percent uranium, with $0.03-0.066$ percent in the ash ( $\mathrm{pl} .19$ ). In most of the more highly uraniferous beds, the uranium content is greatest at the top of the bed, and the lignite beds in the upper part of the stratigraphic section contain more uranium than beds in the lower part.

The upper lignite bed reached by core hole 21 is 10 feet thick, but no core was recovered. However, it is estimated the uppermost three feet of the bed contains about 0.01 percent uranium, a figure based on comparison of the gamma-ray log of the hole with those from other core holes in the Slim Buttes area from which the uranium content has been determined by chemical analysis.

Quality of the lignite.-Fuel analyses by the U. S. Bureau of Mines show that the lignite of cores from the $\mathrm{Bar} \mathrm{H}$ area contain an average of 24.7 percent fixed carbon, 12 percent ash, and 1.3 percent sulfur, and has an average heating value of 5,470 $\mathrm{Btu}$. These figures represent analyses of lignite in the "as received" condition. Analyses of individual beds are given in table 5 .

\section{IODGEPOIE AREA AND JOHNSON OUTLIER}

The Lodgepole area and the Johnson outlier are in northwestern Perkins County, S. Dak. The areas are readily accessible by 17 miles of graveled road extending north from State Route 8 about 9 miles west of Bison, S. Dak. Hettinger, N. Dak., the nearest shipping point, is 17 miles to the north (fig. 9). A low grassy butte a mile south of Lodgepole Post Office is the main topographic feature in the Lodgepole area. A smaller butte, referred to in this report as the Johnson outlier, is 3 miles to the west. The lignite beds in both areas were mapped and described by Winchester (1916, p. 138, 142). A map 
compiled from aerial photographs at a scale of $1: 20,000$ (fig. 10) shows the areal distribution of the beds and the location of the core holes in the Lodgepole area.

The beds of uranium-bearing lignite in these areas occur about 150 feet above the base of the Tongue River member of the Fort Union. formation of Paleocene age, which has a regional dip of about 24 feet

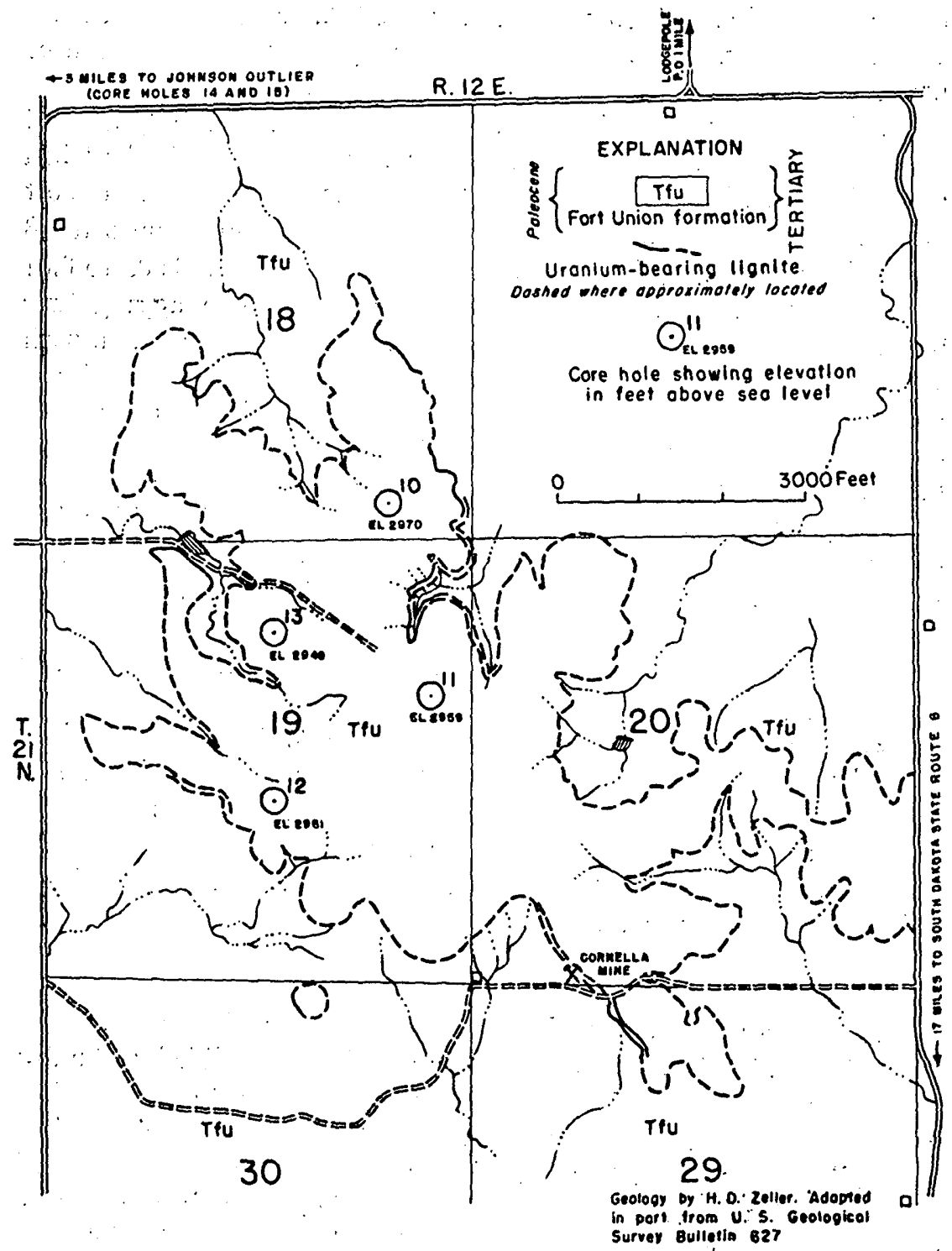

Fradze 10.-Geologle map of the Lodgepole area, Perkins County, S. Dak., showing locations of core holes. 
per mile to the northeast. The Tongue River member consists of pink sandstone and siltstone, with interbedded gray shale and lignite. The main lignite bed averages 6 feet or more in thickness and is believed to be the Harmon lignite bed (fig. 11). With it is commonly associated the Harmon rider lignite bed, 10-15 feet stratigraphically higher, which ranges from a few inches to 6 feet in thickness in short distances along the outcrop. The only bed exposed in the Johnson outlier may be either of these beds.

Distribution and concentration of uranium.-The lignite cored in holes 11,12 , and 13 in the Lodgepole area contains only a small percentage of uranium. Only the uppermost 1-2 feet of the Harmon rider lignite bed contains more than 0.001 percent uranium and the underlying Harmon lignite bed was not uranium-bearing. The only lignite bed exposed in the Johnson outlier, however, contains larger amounts of uranium (pl. 20). The analyses of the lignite cores from hole 14 demonstrate ideally the pattern of distribution and concentration in most of the uranium-bearing parts of lignite beds sampled in 1950 (see chapter B, table 3). Uranium decreased in concentration downward within a $31 / 2$-foot interval from 0.036 percent at the top of the bed to 0.001 percent at the base of the interval.

The lignite in the Harmon lignite bed of the Lodgepole area, as shown by fuel analyses of samples in the "as received" condition, averages 28 percent fixed carbon, 11 percent ash, and 1.5 percent sulfur, and has an average heating value of $6,940 \mathrm{Btu}$. This is the best grade of lignite found in drilling (table 5). On the Johnson outlier the lignite is of a poorer quality; it averages 16 percent fixed carbon, 12.4 percent ash, and 1.5 percent sulfur, and has a heating value of $4,160 \mathrm{Btu}$ ("as received" condition).

\section{MEDICINE POLE HILLS AREA}

The Medicine Pole Hills, in Bowman County, N. Dak., are on a hilly divide separating the Little Missouri River and Grand River drainage basins. The Tongue River member of the Fort Union formation of Paleocene age, which includes ledge-forming beds of hard sandstone and quartzite, underlies the main part of the hills (fig. 12). The hills are capped by a thin veneer of the White River group of Oligocene (Chadronian) age (C. L. Gazin, written communication, 1950) which unconformably overlies the Tongue River member. The hills are nearly flat topped and are easily accessible by a dirt road that leaves the main graveled road 8 miles south of Rhame, N. Dak., the nearest rail shipping point. The Medicine Pole Hills are in the southwestern part of the Marmarth lignite field, which was mapped and described in detail by Hares $(1928$, p. 95, 98).

$469117-59 \longrightarrow 6$ 


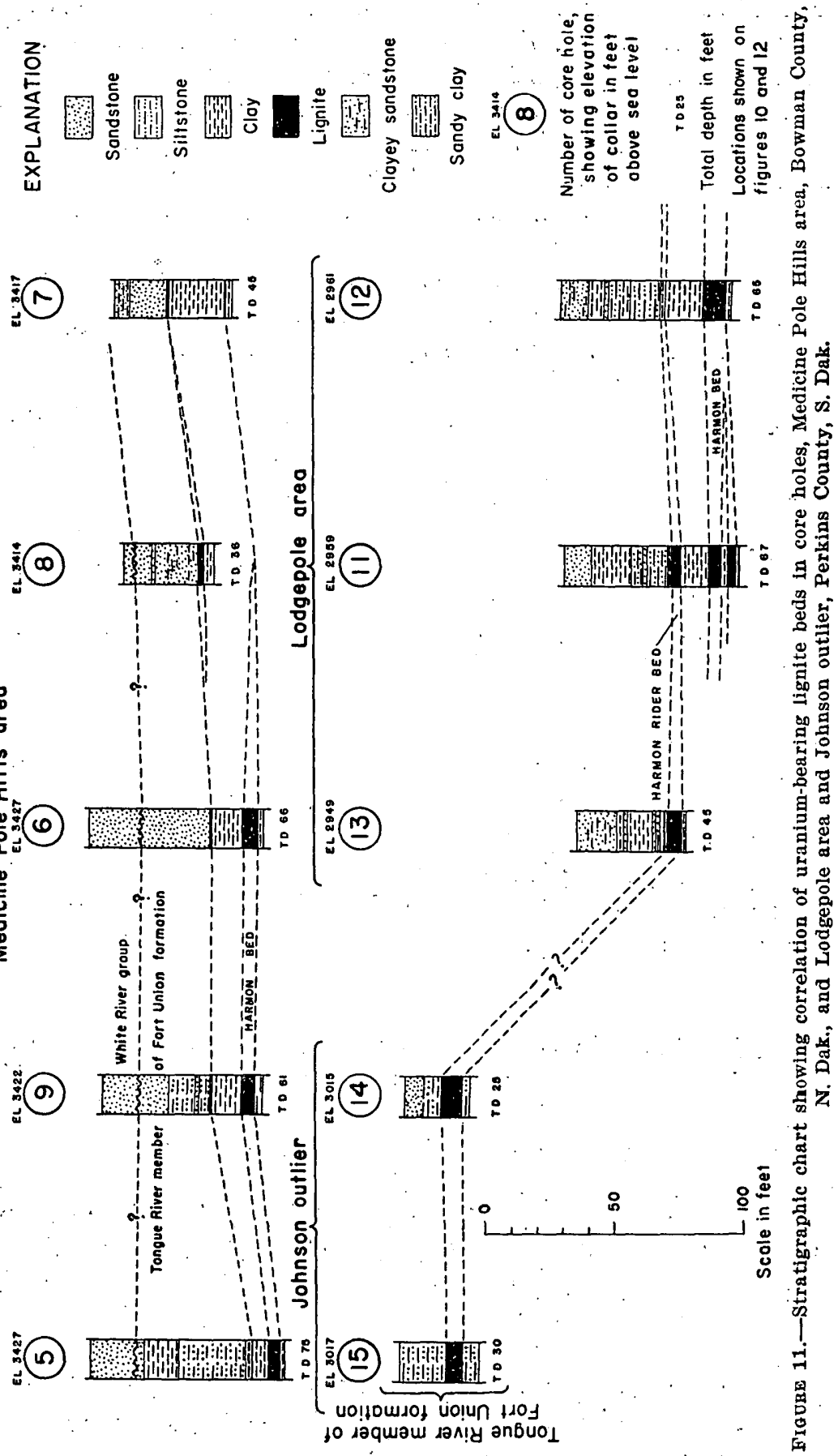



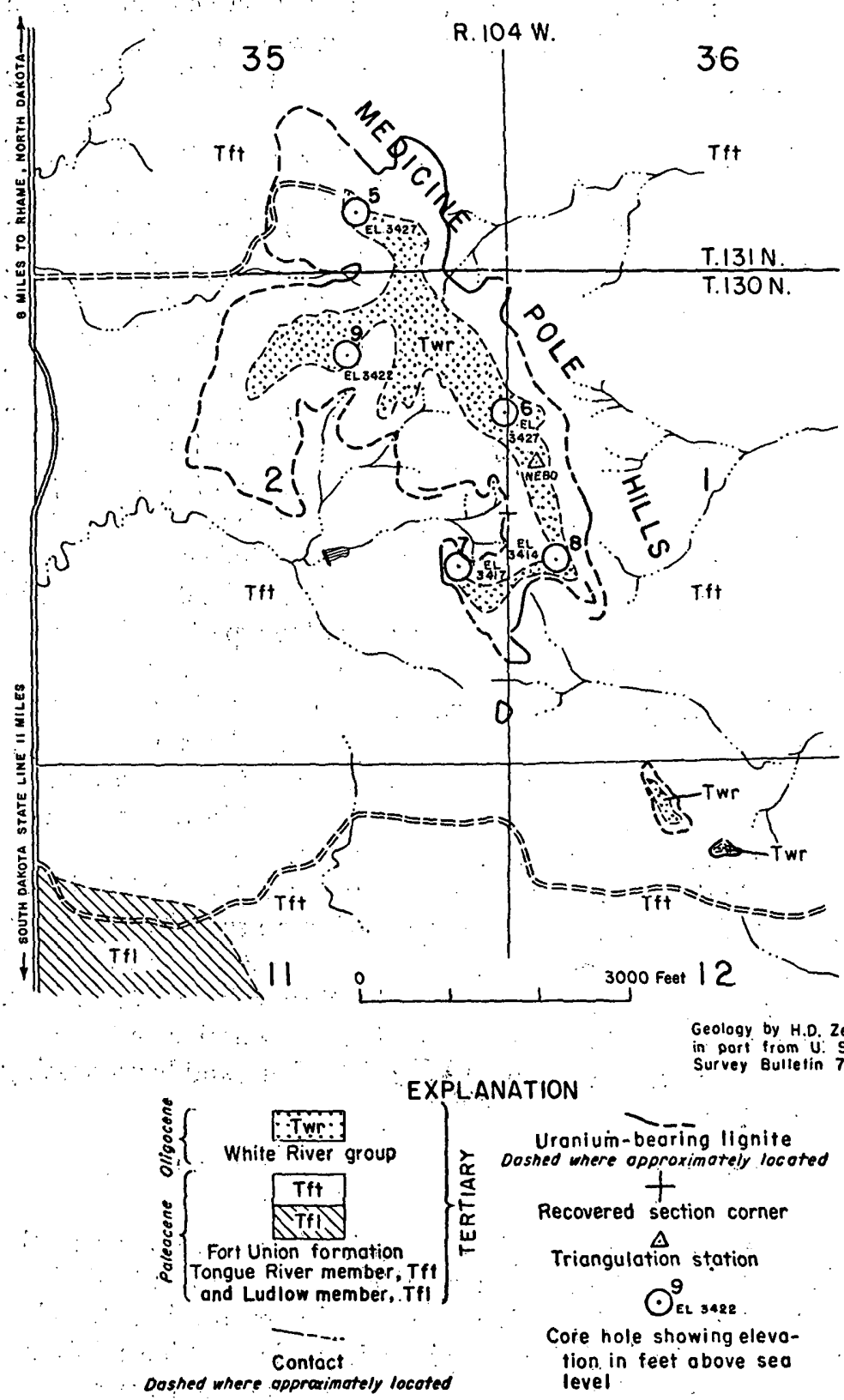

Frodro 12.-Geologic map of the Medicine Pole Hills area, Bowman County, N. Dak., showing locations of core holes.

A widespread persistent lignite bed, the Harmon lignite bed, underlies most of the area (fig. 11). This bed and the associated Harmon rider lignite bed were mapped on aerial photographs at a scale of 
approximately $1: 20,000$. Figure 12, the geologic map compiled from the photographs, shows the locations of the core holes which reached the uranium-bearing Harmon lignite bed in the Medicine Pole Hills area.

Distribution and concentration of uranium.-The distribution of uranium in the lignite cored at hole 5 (pl. 21) follows the general pattern of uranium distribution in which the concentration of uranium decreases progressively downward from the top of the lignite bed. The concentration and distribution of uranium in lignite from other core holes in the Medicine Pole Hills, however, differ from the pattern observed in other areas. In the lignite from core holes 6 and 9, for example, the uranium is fairly uniformly distributed throughout the bed, with perhaps a slightly greater concentration at its base. This distribution pattern has not been observed in uranium-bearing lignite elsewhere in the Dakotas, either in cores or in surface samples. The Harmon rider lignite bed is 30 inches thick at core hole 8 and contains 0.005 percent uranium in the uppermost 6 inches and 0.016 percent in the basal 12 inches of the bed. This "inverted" pattern is a very common feature of uranium-bearing lignite beds not more than $2 \frac{1}{2}$ feet thick where they have been examined in the Dakotas. A possible explanation for the greater concentrations of uranium in the lower rather than the upper parts of these beds is that uranium-bearing ground water moved laterally along the base of thin and fractured beds which normally overlie impervious underclays.

Quality of lignite.--The lignite in the Harmon lignite bed (table 5) in core holes 5,6 , and 9 , based on analyses of samples in "as received" condition, averages 21.2 percent fixed carbon, 10.3 percent ash, and 1.4 percent sulfur, and has an average heating value of 5,400 Btu. The Harmon rider lignite bed at hole 8 (fig. 11) contains 15.1 percent fixed carbon, 16.5 percent ash, and 0.3 percent sulfur, and has a heating value of $3,730 \mathrm{Btu}$.

\section{RELATIONSHIP BETWEEN URANIUM AND OTHER TRACE ELEMENTS IN LIGNITE IN THE DAKOTAS}

Semiquantitative spectrographic determinations were made of the ash of most of the lignite core samples from the Dakotas to find the vertical distribution and possible relationship of uranium to other trace elements. These results are given in table 4. The minimum amounts of elements detectable with the semiquantitative spectrographic methods used are indicated in table 3.

Preliminary work on the occurrence and distribution of the various elements as determined by spectrographic analyses indicates that only one element, molybdenum, shows a consistent relationship to uranium. In the upper parts of the beds, where the uranium content commonly 
is greater, the molybdenum content is also greater, and conversely, in the lower parts of the beds, where the uranium content is small, the molybdenum content is also small. The notable correlation between the amounts of uranium and molybdenum in various parts of uraniumbearing.lignite beds is believed to be due to the close chemical similarity of these elements (Clarke, 1924, p. 722).

There is no apparent correlation between the distribution of uranium and vanadium in lignite of the Dakotas, although these elements commonly occur together in the deposits of the Colorado Plateau. Their chemical characteristics, however, do not seem to indicate that the two should necessarily occur together.

The net result of the preliminary spectrographic studies of uraniumbearing lignite to date seems to indicate that greater importance and attention should be given to the presence of molybdenum as a possible geologic indicator for the presence of uranium. Considerably more data and work are necessary to establish its validity, but it seems possible that the association of molybdenum and uranium may prove valuable in the search for uranium.

\section{TONNAGE AND GRADE OF URANIUM-BEARING LIGNITE}

On the basis of the drilling done at the time of the investigation of the areas in northwestern South Dakota and southwestern North Dakota described in this report, it is estimated that there were about 9 million tons of lignite (table 2). Approximately half the lignite is at

TABLE 2.-Estimated tonnage of uranium-bearing lignite, Harding and Perkins Counties, S. Dak., and Bowman County, N. Dak.

\begin{tabular}{|c|c|c|c|c|c|c|}
\hline Area & $\begin{array}{c}\text { Location in area } \\
\therefore\end{array}$ & $\begin{array}{l}\text { Extent } \\
\text { (acres) }\end{array}$ & $\begin{array}{l}\text { Thick- } \\
\text { ness } \\
\text { (feet) }\end{array}$ & $\begin{array}{l}\text { Ura- } \\
\text { nium } \\
\text { (per- } \\
\text { cent) }\end{array}$ & $\begin{array}{l}\text { Resources }{ }^{1} \\
\text { (short tons) }\end{array}$ & $\begin{array}{l}\text { Num: } \\
\text { ber of } \\
\text { core } \\
\text { holes }\end{array}$ \\
\hline \multicolumn{7}{|c|}{ Strippable lignite } \\
\hline $\begin{array}{l}\text { Lodgepole area, Perkins: } \\
\text { County. } \\
\text { Johnson outlier, Perkins } \\
\text { County. } \\
\text { Medicine Pole Hills, Bow- } \\
\text { man County. }\end{array}$ & 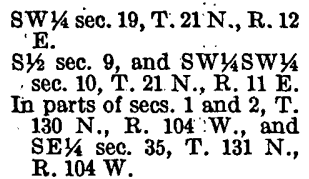 & $\begin{array}{r}30 \\
90 \\
360 \\
40\end{array}$ & $\begin{array}{r}4.0 \\
3.0 \\
4.5 \\
3.0\end{array}$ & $\begin{array}{r}0.010 \\
.010 \\
.006 \\
.013\end{array}$ & $\begin{array}{r}210,000 \\
472,000 \\
2,835,000 \\
210,000\end{array}$ & $\begin{array}{l}4 \\
2 \\
5\end{array}$ \\
\hline Total. & & & & & $3,727,000$ & - \\
\hline
\end{tabular}

Lignite requiring underground mining

\begin{tabular}{|c|c|c|c|c|c|c|}
\hline \multirow{2}{*}{$\begin{array}{c}\text { Bar H area, Harding County. } \\
\text { Grand total............ }\end{array}$} & $\begin{array}{l}\text { In parts of secs. } 20,21,28,29, \\
\text { and } 33, T .19 \text { N., R. } 8 \text { E. }\end{array}$ & 600 & & 0.010 & $5,250,000$ & 8 \\
\hline & . & & - - & $\ldots$ & $8,977,000$ & .......... \\
\hline
\end{tabular}

1 Tonnage estimates based on 1,750 tons of lignite per acre foot.

1 Uppermost 3 feet of 6 -foot bed of lignite. 
depths shallow enough for strip mining and in beds averaging more than 4 feet thick. Analyses of 200 samples from cores, in addition to analyses of 175 samples obtained during the previous season's fieldwork, indicate that the uranium content of the lignite averages about 0.01 percent, although the content is highly variable. The average grade of the uranium in small parts of the areas may be as much as 0.03 percent. The ash content of the lignite ranges from 10 percent or less to about 20 percent, which indicates that after ignition of the lignite the uranium content of the ash is at least 5 times and generally 7-10 times the uranium content of the lignite. Proximate and ultimate analyses (table 5) show a sulfur content of 2 percent or less and the heating value of samples in the "as received" condition ranges from 4,200 to $6,900 \mathrm{Btu}$.

\section{LITERATURE CITED}

Clarke, F. W., 1924, The data of geochemistry : U. S. Geol. Survey Bull. 770, 840 p. Darton, N. H., 1909, Geology and underground waters of South Dakota: U. S: Geol. Survey Water-Supply Paper 227, $156 \mathrm{p}$.

Hares, C. J., 1928, Geology and lignite resources of the Marmarth field, southwestern North Dakota: U. S. Geol. Survey Bull. 775, 110 p.

Toepelman, W. C., 1923, The possibilities of oil in eastern Harding County : South Dakota Geol. and Nat. Hist. Survey Circ. 12, p. 1-12.

Winchester, D. E., Hares, C. J., Lloyd, E. R., and Parks, E. M., 1916, The lignite field of northwestern South Dakota: U. S. Geol. Survey Bull. 627, 169 p.

Wood, H. E., 2d, 1942, Problems of our continental Tertiary: New York Acad. Sci. Trans., ser. 2, v. 4, p. 135-144.

TABLE 3.-Threshold values of elements included in the semiquantitative spectrographic method (revised June 4, 1951).

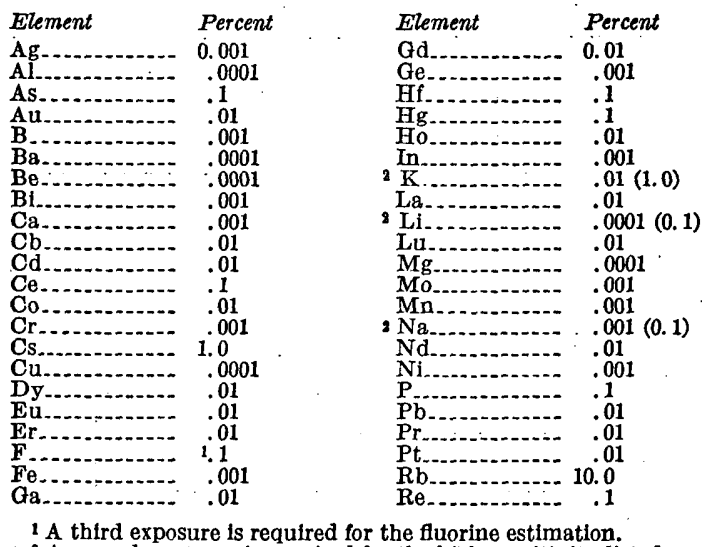

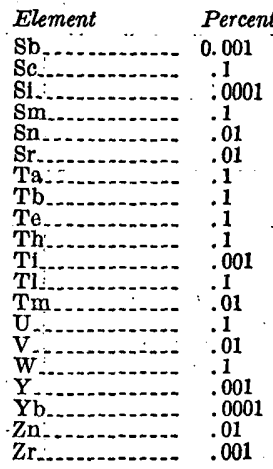

2 A second exposure is required for the high sensitivitÿ listed. 


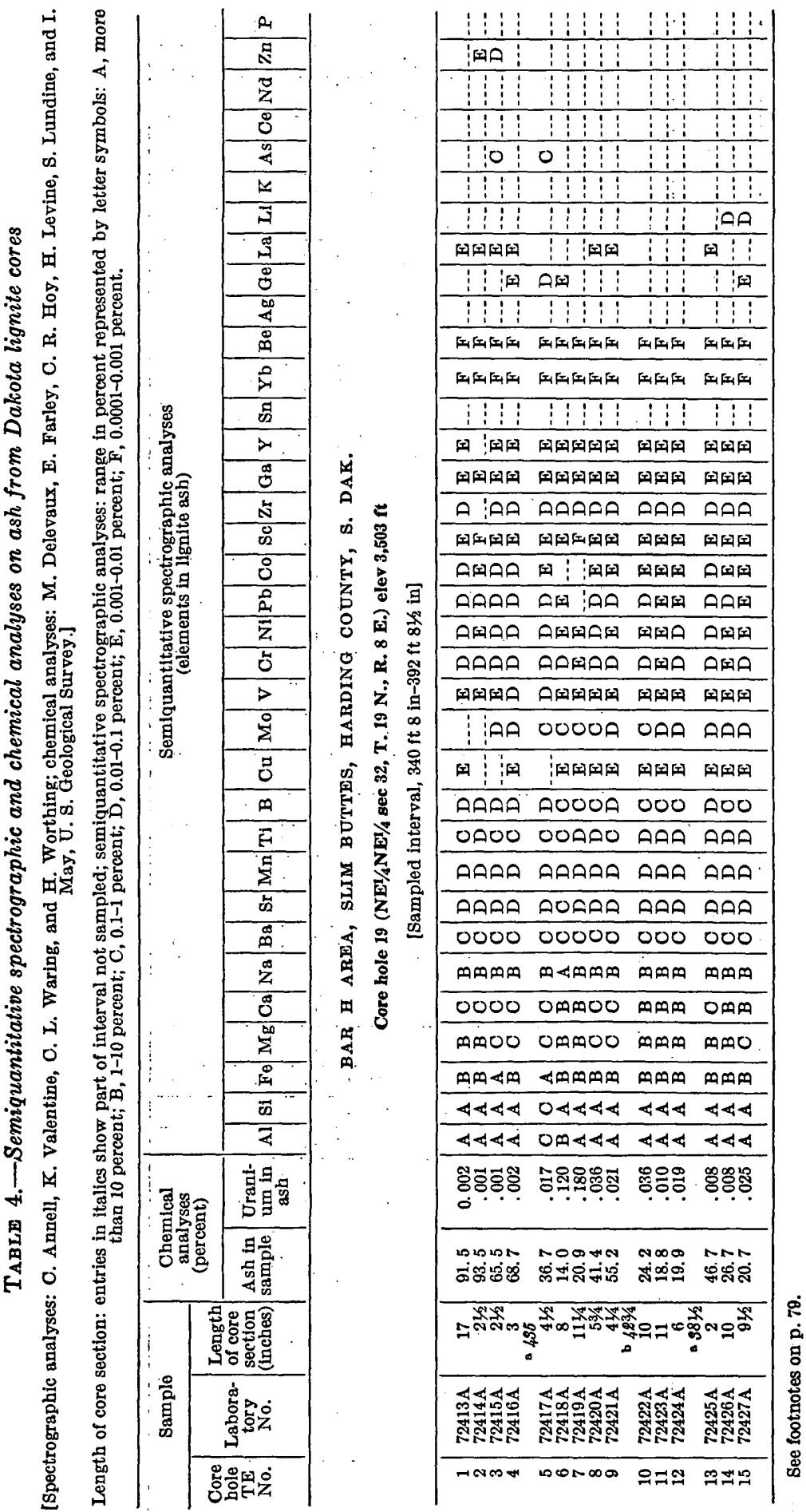




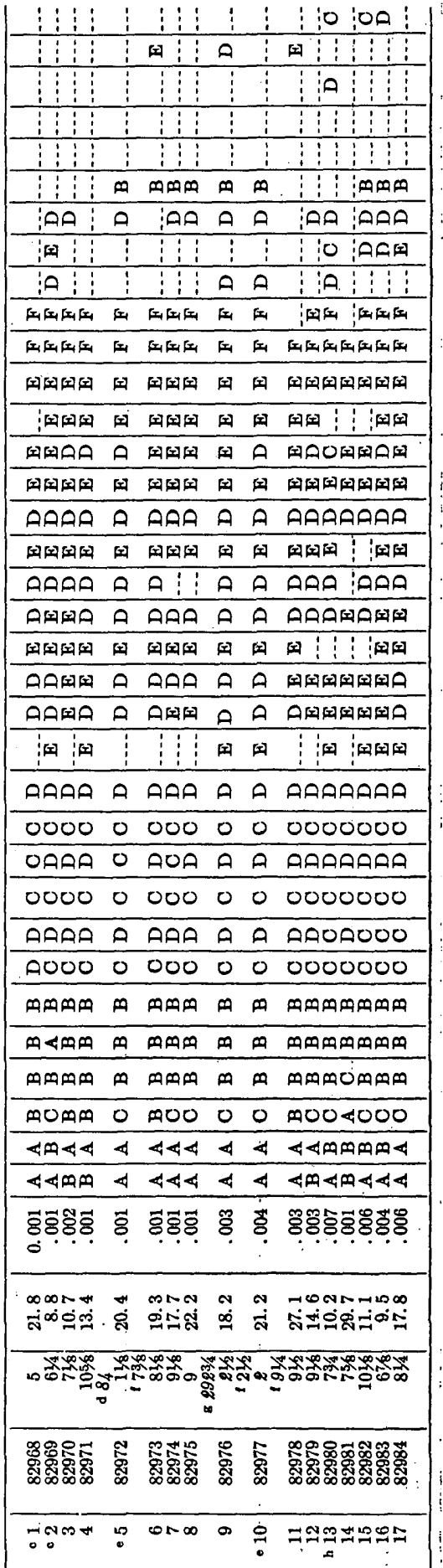




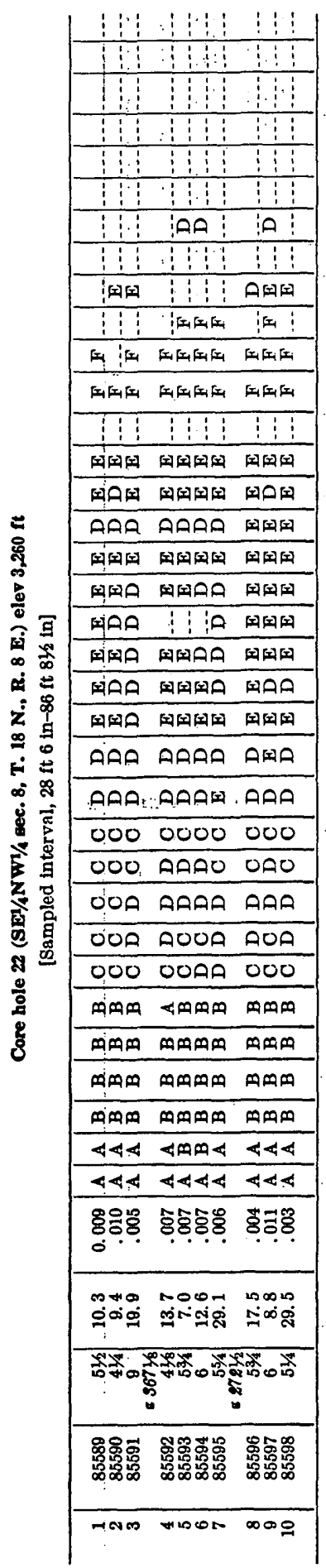

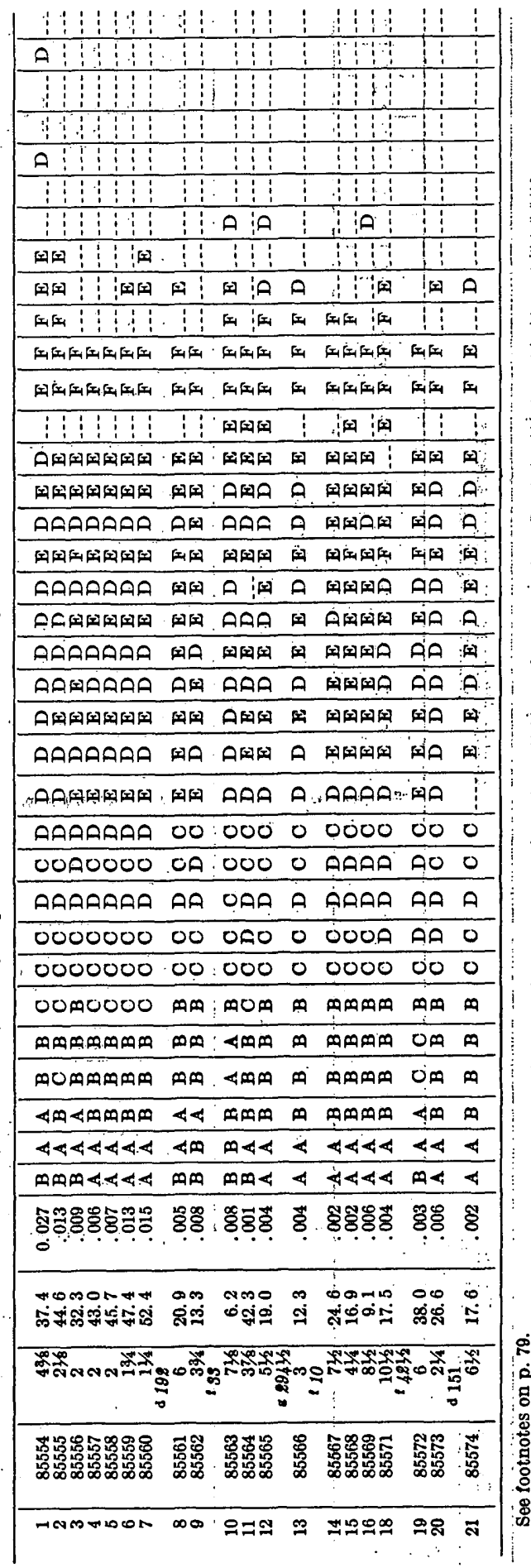




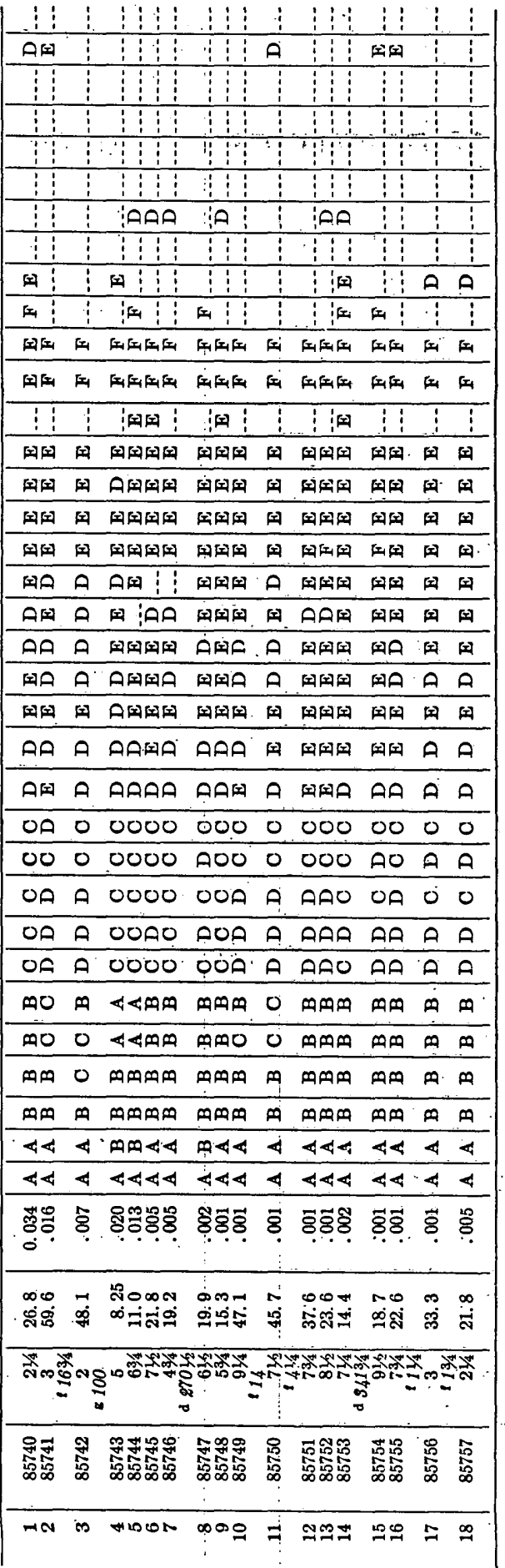




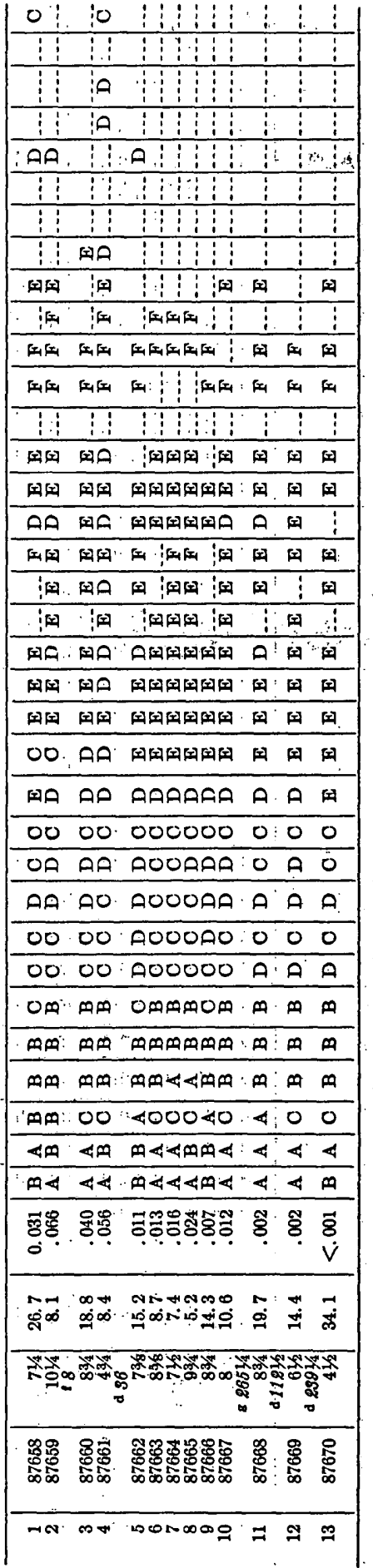

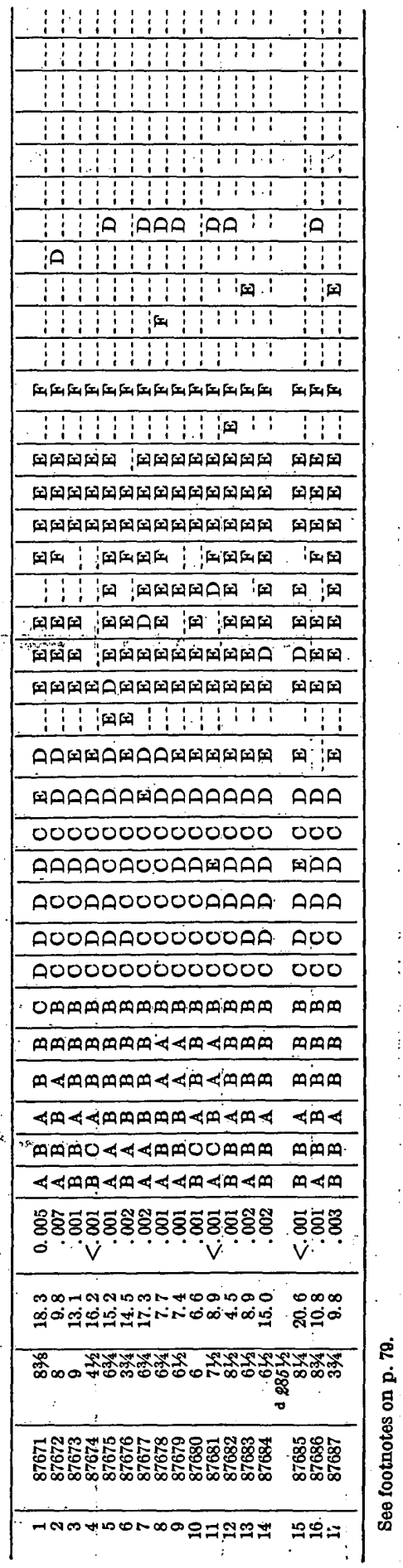




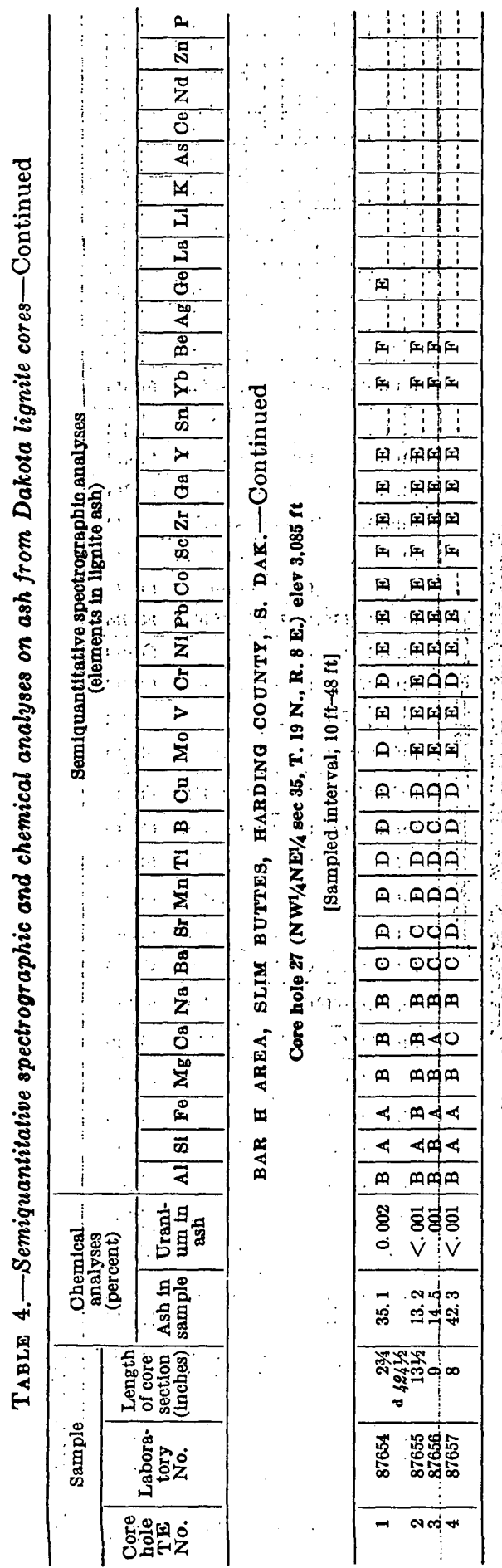

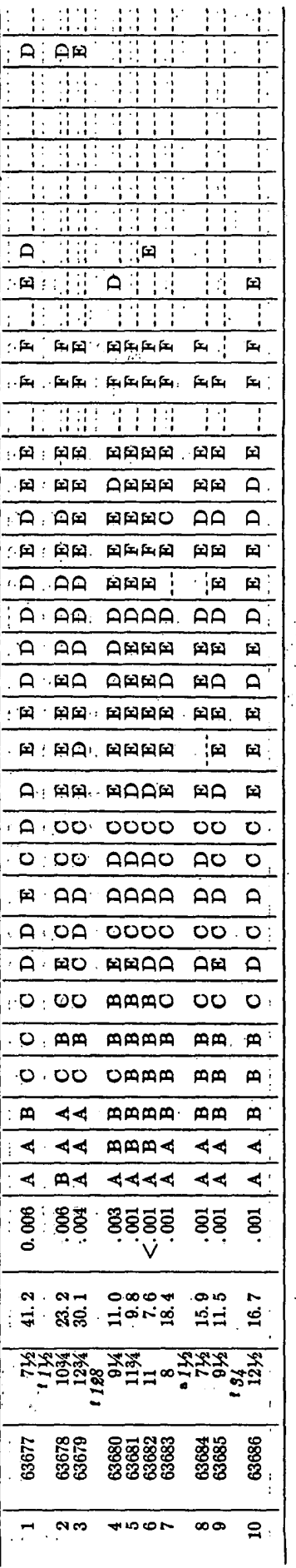




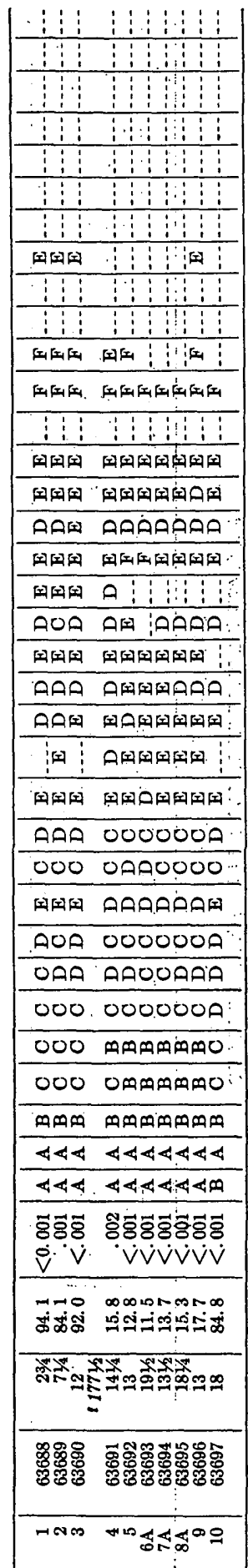

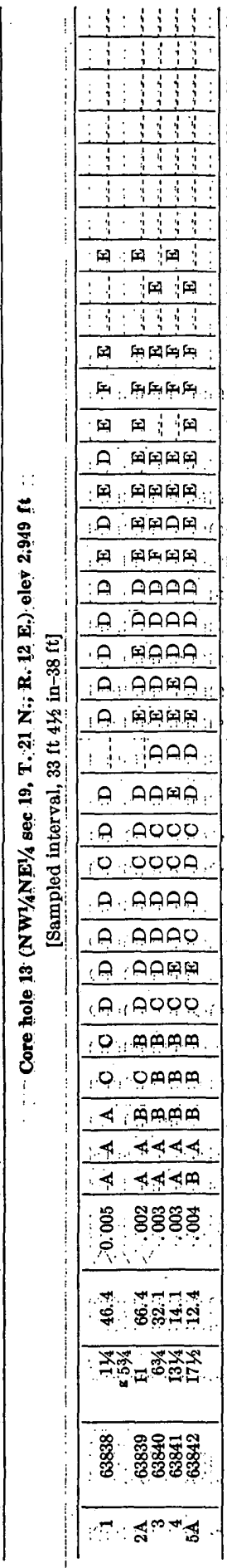

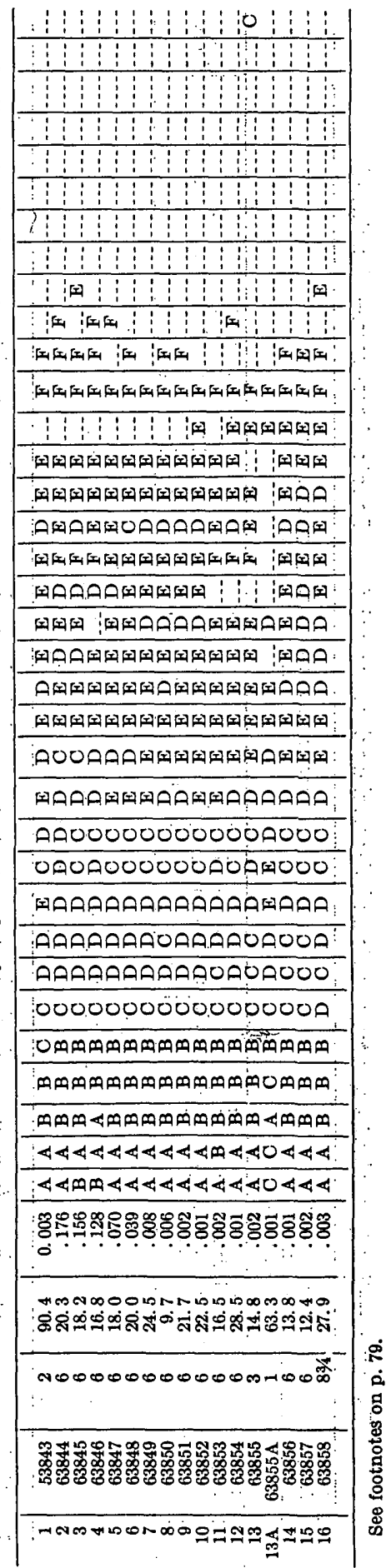



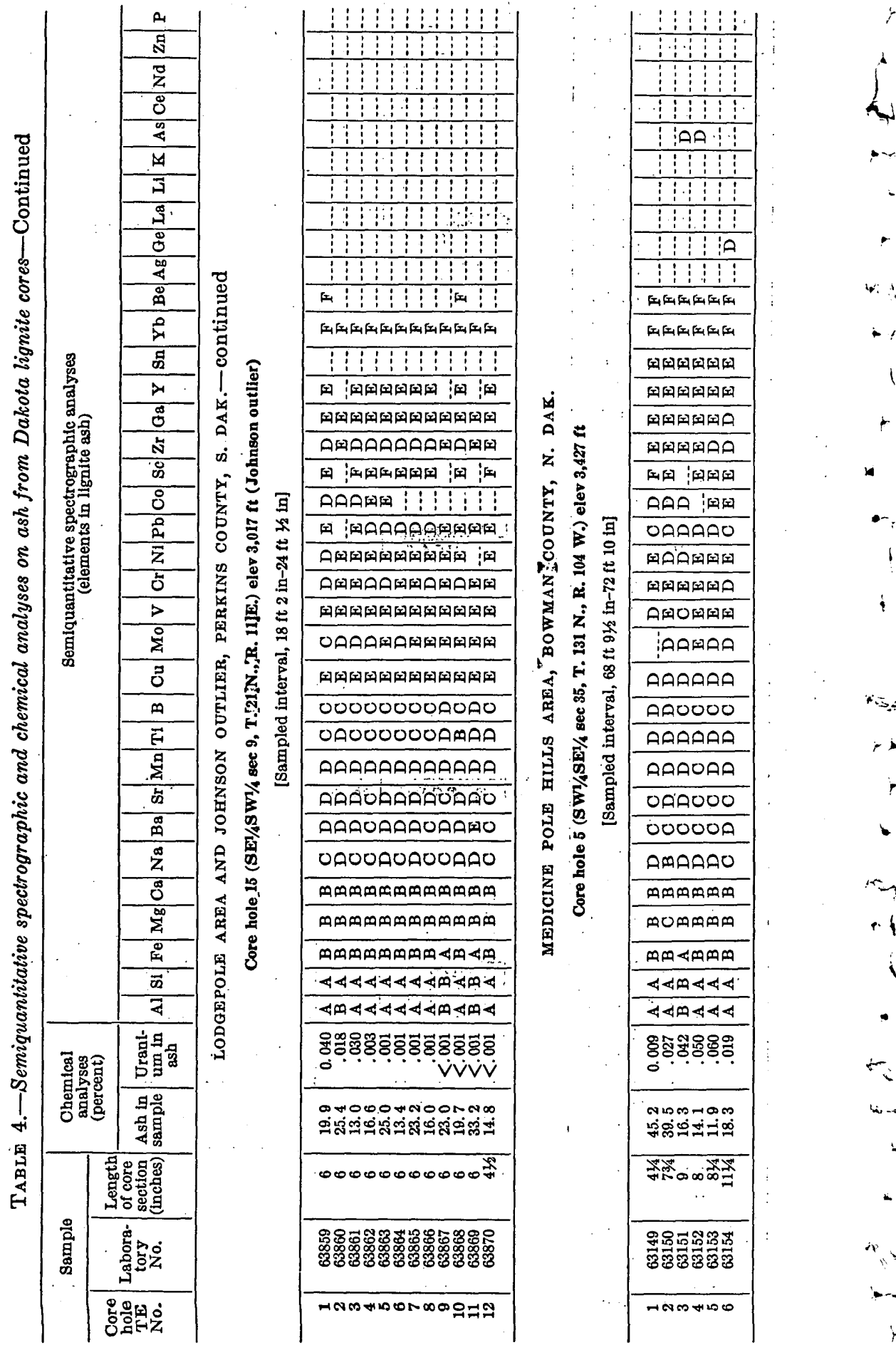

5

c.

‡

.

옥

$\stackrel{-1}{-1}$

$\sum_{m}$

. .

के

兽

5 


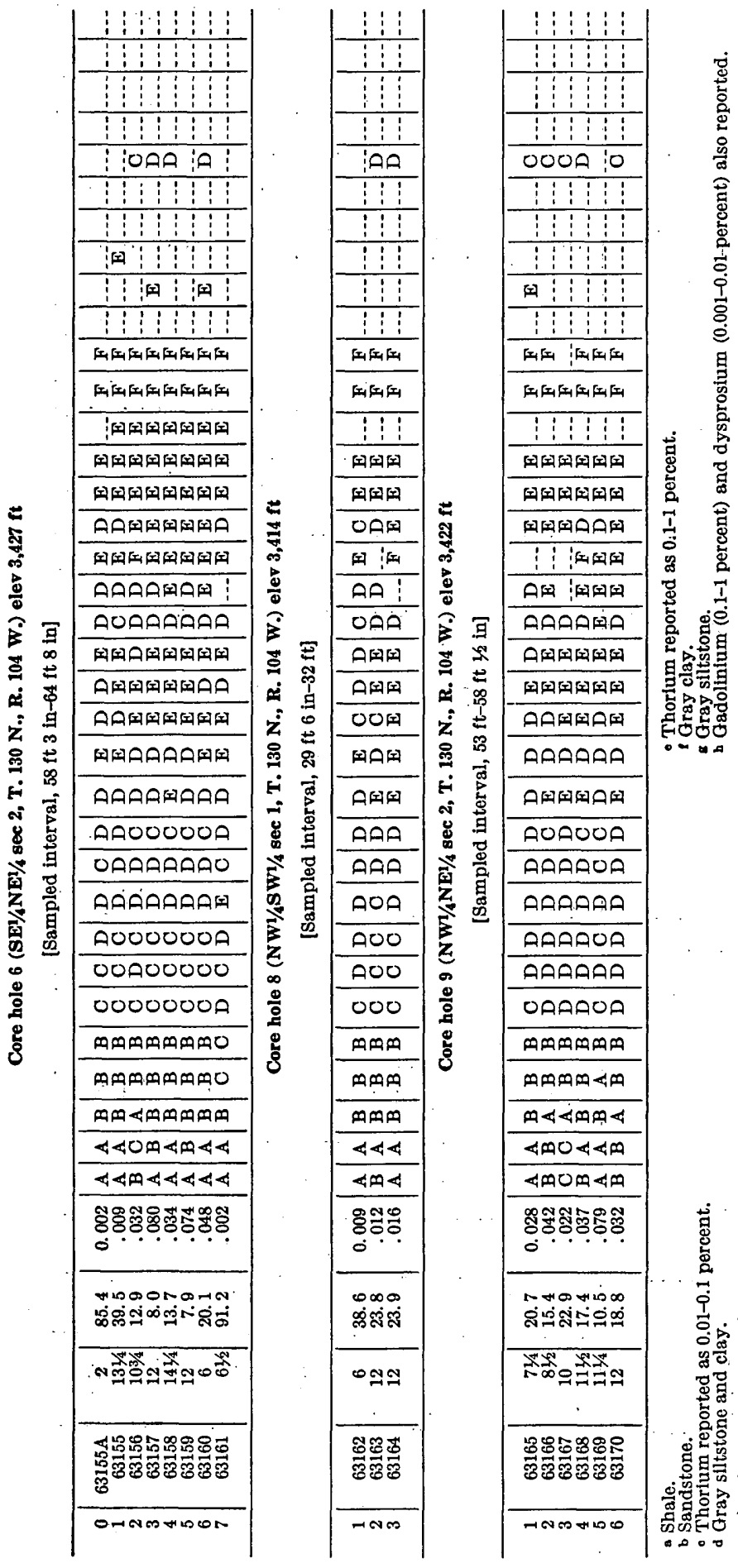




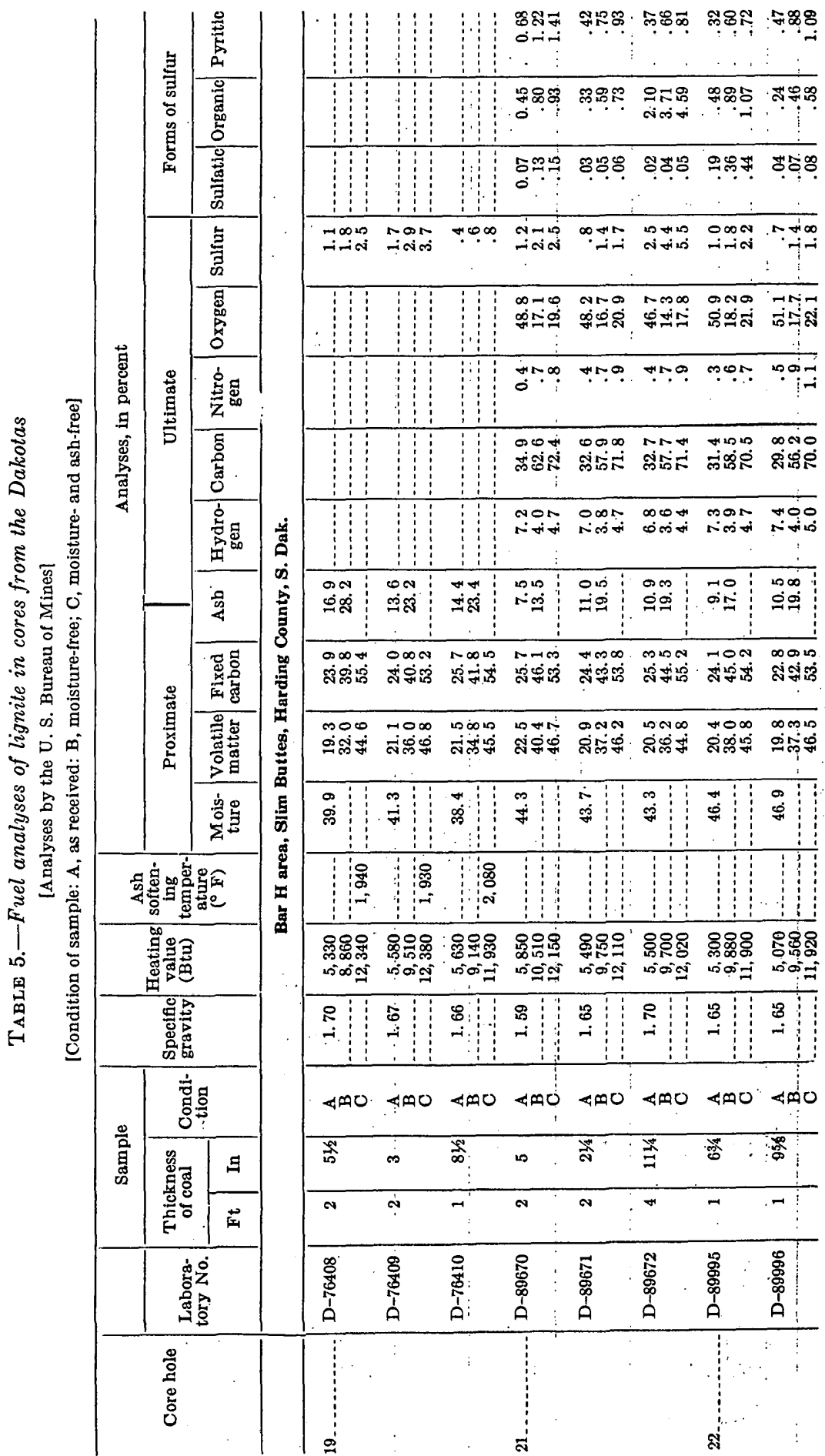




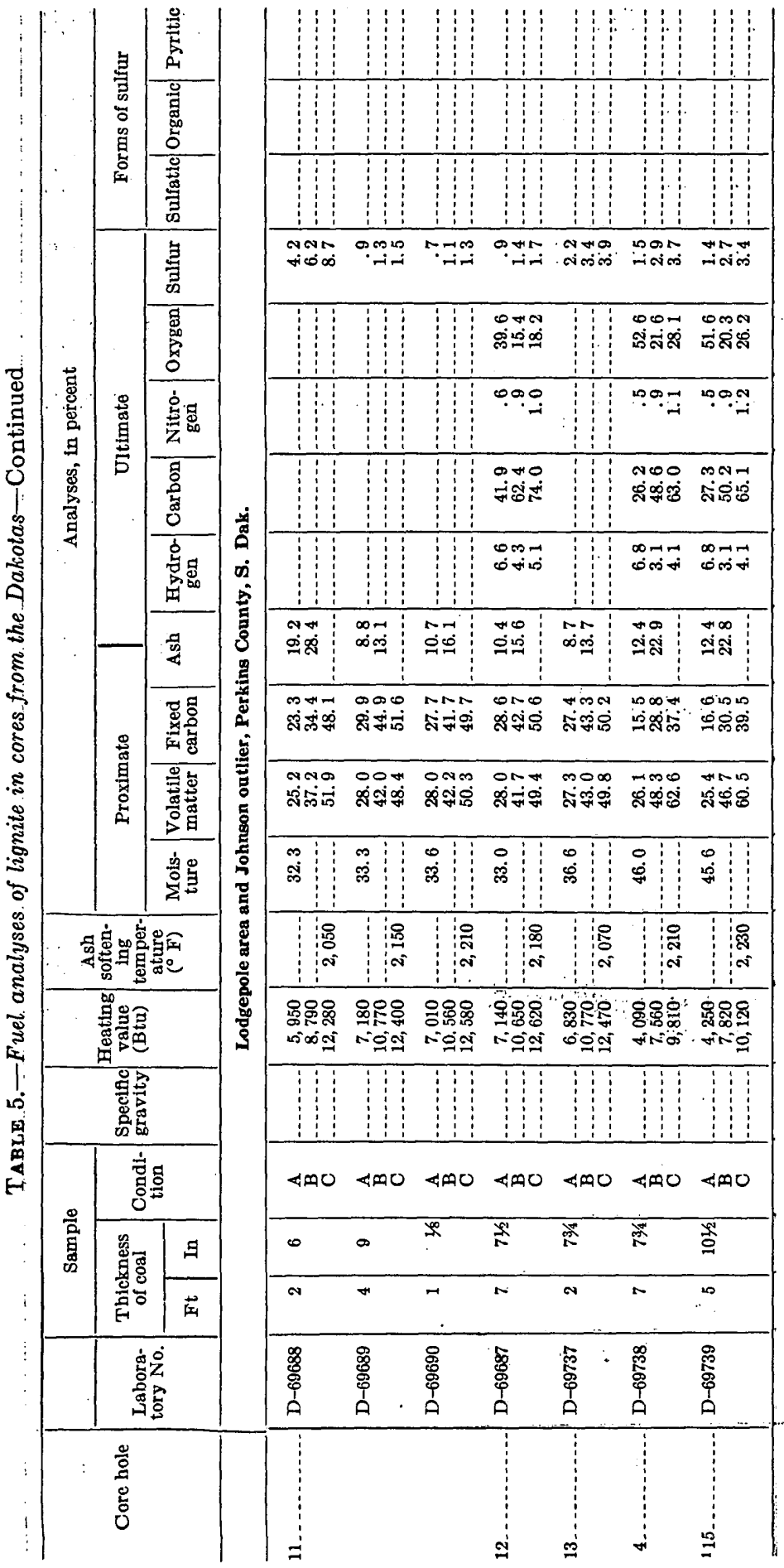




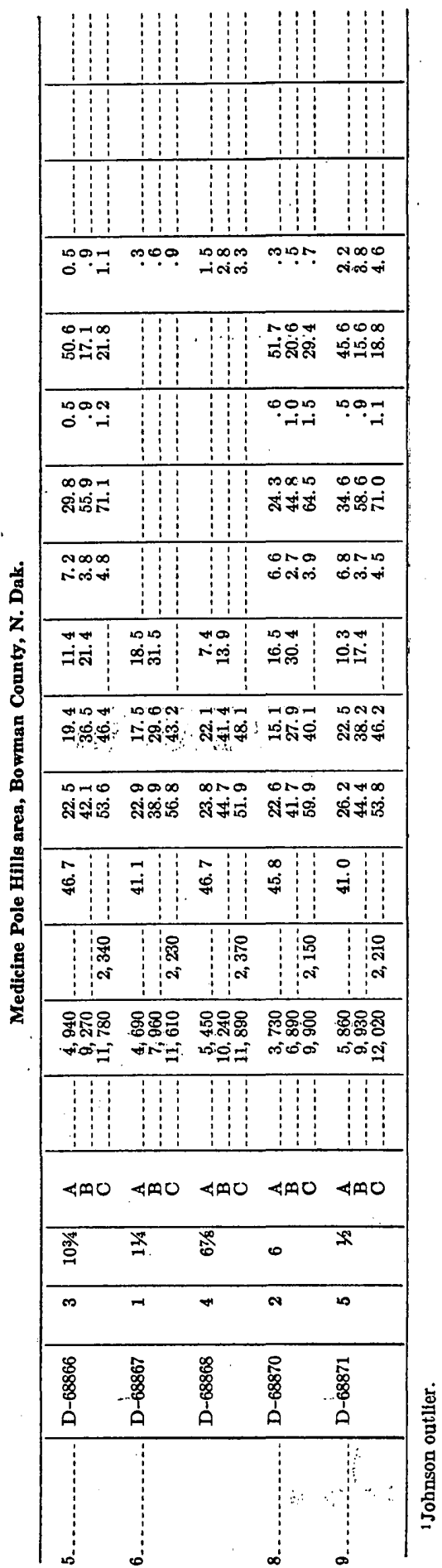


TABLE 6.-Lithologic descriptions of lignite cores from the Bar $H$ area, Harding County, S. Dak., the Lodgepole area and Johnson outlier, Perkins County, S. Dak., and the Medicine Pole Hills area, Bowman County, N. Dak.

The lignites discussed in this report are dominantly banded coals. The banding is primarily a function of the occurrence of elongate lenses of large fragments of woody trunks and roots of ancient plants. In describing banded coals the important features are (1) the thickness of bands, and (2) the frequency of occurrence of these bands. Thickness and frequency are described in this table using the terms according to the following definitions:

(1) Thickness of woody bands (wocdy

bands less than about $1 / 50$ inch, or $0.5 \mathrm{~mm}$, thick are regarded as a part of attrital coal)

Thin bands.....- about $1 / 50-1 / 12$ in. $(0.5-2.0 \mathrm{~mm})$

Medium bands.... about $1 / 12-1 / 5$ in. $(2.0-5.0 \mathrm{~mm})$

Thick bands ...... about $1 / 5-2$ in $(5.0-50.0 \mathrm{~mm})$

Very thick bands.. more than 2 in. (more than 50.0 $\mathrm{mm}$ )
(2) Frequency of occurrence (percentage of the layer)

Sparse...... less than 15 percent Moderate . . 15-30 percent

Abundant . . - 30-60 percent

Dominant.... more than 60 per. cent

\begin{tabular}{|c|c|c|c|c|c|c|}
\hline \multirow{3}{*}{$\begin{array}{c}\text { Core } \\
\text { hnle } \\
\text { TE } \\
\text { sample } \\
\text { No. }\end{array}$} & \multirow{3}{*}{$\begin{array}{l}\text { Tra- } \\
\text { nium } \\
\text { (per- } \\
\text { cent) }\end{array}$} & \multicolumn{4}{|c|}{ Core section } & \multirow{3}{*}{ Lithologic description and remarks } \\
\hline & & \multicolumn{2}{|c|}{$\begin{array}{c}\text { Depth in } \\
\text { hole }\end{array}$} & \multicolumn{2}{|c|}{ Length } & \\
\hline & & $\mathrm{Ft}$ & in & $\mathrm{Ft}$ & in & \\
\hline
\end{tabular}

BAR H AREA, SLIM BUTTES, HARDING COUNTY, B. DAK.

Cere hole 19 (NE1/4NE1/4 sec. 32 , T. 19 N., R. 8 E.) elev 3,503 ft

\begin{tabular}{|c|c|c|c|c|c|c|}
\hline & & 337 & 6 & & $31 / 2$ & (Top of core sent to laboratory.) Clay, light-gray, silty, \\
\hline & & 337 & $91 / 2$ & 1 & $31 / 2$ & $\begin{array}{l}\text { Clay, as in above sample, but silty and interbedded with } \\
\text { streaks of fine-grained sandstone. commonly ferruginous }\end{array}$ \\
\hline & & 338 & 1 & & 3 & \\
\hline & & 33 & 11 & & & $\begin{array}{l}\text { mo } \\
\text { Silts }\end{array}$ \\
\hline & & & & & 2 & -tan to light-brown, becomi \\
\hline $\begin{array}{l}1 \\
2\end{array}$ & $\begin{array}{r}0.002 \\
.001\end{array}$ & $\begin{array}{l}340 \\
342\end{array}$ & $\begin{array}{l}8 \\
1\end{array}$ & 1 & $\begin{array}{l}5 \\
21 / 2\end{array}$ & $\begin{array}{l}\text { oxidized zone } \\
\text { oxided. }\end{array}$ \\
\hline $\begin{array}{l}3 \\
4\end{array}$ & $\begin{array}{l}.001 \\
.001\end{array}$ & $\begin{array}{l}342 \\
342 \\
342\end{array}$ & $31 / 2$ & & $\begin{array}{l}21 / 2 \\
3 \\
9\end{array}$ & aly shale. \\
\hline & & & 9 & & & Shal \\
\hline & & $\begin{array}{l}34 \\
34\end{array}$ & $\begin{array}{r}6 \\
10\end{array}$ & 1 & 4 & \\
\hline & & & 0 & 34 & & \\
\hline 5 & .006 & 37 & 0 & & 41 & $\begin{array}{r}\text { Sha } \\
\text { lo }\end{array}$ \\
\hline 6 & .01 & 37 & $41 / 2$ & & 8 & $83 / 2$ \\
\hline 7 & 037 & 380 & $1 / 2$ & & 113 & lid- \\
\hline 8 & 015 & 380 & $113 / 4$ & & & Coal, m \\
\hline 9 & .012 & 381 & $51 / 2$ & & $41 / 4$ & -brown; 3/4-in woody bar \\
\hline & & $\begin{array}{l}381 \\
381\end{array}$ & $\begin{array}{r}93 / 4 \\
111 / 4\end{array}$ & & $\begin{array}{l}1136 \\
214\end{array}$ & $\mathrm{~m}$ \\
\hline & & 384 & $11 / 2$ & & 11 & $\begin{array}{l}\text { y, dark-gray to black, somewhat sandy, with occasional } \\
\text { mall pyritic nodules toward the base. } \\
\text { ddstone, medium-gray, soft, clayey, fine-to medium-grained. }\end{array}$ \\
\hline
\end{tabular}


TABLE 6.-Lithologic descriptions of lignite cores from the Bar $H$ area, Harding County, S. Dak., the Lodgepole area and Johnson outlier, Perkins County, S. Dak., and the Medicine Pole Hills area, Bowman County, N. Dak.-Continued

\begin{tabular}{|c|c|c|c|c|c|c|}
\hline \multirow{3}{*}{$\begin{array}{c}\text { Core } \\
\text { hole } \\
\text { TE } \\
\text { sample } \\
\text { No. }\end{array}$} & \multirow{3}{*}{$\begin{array}{l}\text { Ura- } \\
\text { nium } \\
\text { (per- } \\
\text { cent) }\end{array}$} & \multicolumn{4}{|c|}{ Core section } & \multirow{3}{*}{ Lithologie description and remarks } \\
\hline & & \multicolumn{2}{|c|}{$\underset{\text { Dopth in }}{\text { Delo }}$} & \multicolumn{2}{|c|}{ Length } & \\
\hline & & Ft & in & Ft & in & \\
\hline
\end{tabular}

BAR H AREA, SLIM BUTTES, HARDing COUNTT, s. DAK.-continued

Core hole 19-Continued

\begin{tabular}{|c|c|c|c|c|c|c|}
\hline 10 & .009 & 385 & $43 / 2$ & & 10 & Coal, sparsely to moderately thin- and medium-banded; \\
\hline 11 & .002 & 386 & 2162 & & 11 & Coal, moderstely medium- to thick-banded. \\
\hline 12 & .004 & 387 & $11 / 2$ & & 6 & Coal, mostly dull luster, attrital, very sparsely banded. \\
\hline & & 387 & $71 / 2$ & & $101 / 2$ & Sandy clay, gray, soft, becoming more shaly downward. \\
\hline & & 388 & 10 & 2 & 0 & Shale, sandy, gray to dark-gray, a few woody lenticles in the \\
\hline 13 & $0 \Omega$ & 300 & 10 & & & lower part. \\
\hline 14 & .002 & 391 & 10 & & 11 & Coal, sparsely thin- and medium-banded. Mostly dull, \\
\hline 15 & .005 & 391 & 11 & & $91 / 2$ & Coal, moderately thin- and medium-banded; 1/8-in fusain \\
\hline & & 392 & 836 & 5 & $81 / 2$ & 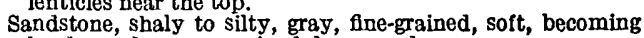 \\
\hline & & 398 & 5 & & & $\begin{array}{l}\text { harder and coarser grained downw } \\
\text { (Base of core sent to laboratory.) }\end{array}$ \\
\hline
\end{tabular}

Fuel samples (U. S. Bureau of Mines): D-76408 includes TE samples 5-8. D-76409 includes TE samples 10-12. D-76410 includes TE samples 14 and 15.

Core hole 21 (SW1/4 sec 8, T. 18 N., R. 8 E.) elev 3,285 ft

\begin{tabular}{|c|c|c|c|c|c|c|}
\hline & & 0 & 0 & 10 & 0 & urface de \\
\hline & & 10 & 0 & av & 0 & (Badly weathered coal at drill hole but not sent to laboratory.) \\
\hline & & 20 & 0 & 10 & 10 & (No core sent to laboratory; described at drill site as gray \\
\hline & & ? & 10 & & 53 & siltstone.) \\
\hline & & 30 & 10 & & $5 \% / 4$ & (Top of core sent to laporatory.) Snale, gray, with tam \\
\hline & & 31 & $33 / 4$ & & $7 / 4$ & Thin pyritic layer. \\
\hline 1 & $<0.001$ & 31 & 4 & & 5 & $\begin{array}{l}\text { Coal, sparsely medium-banded, matrix is earthy; lower half } \\
\text { was broken in drilling. }\end{array}$ \\
\hline 2 & $<.001$ & 31 & 9 & & 634 & Coal; upper 4 in almost entirely woody; earthy below. \\
\hline 3 & & 32 & $31 / 4$ & & $71 / 8$ & $\begin{array}{l}\text { Coal, dominantly woody, medium- to thick-banded, 18-in } \\
\text { fusain bleb at } 32 \mathrm{ft} 834 \text { in. }\end{array}$ \\
\hline 4 & $<.001$ & 32 & 1038 & & 1058 & $\begin{array}{l}\text { Coal, sparsely to moderately woody, medium- and thick- } \\
\text { banded, 1/2-in pyritic bleb at } 32 \mathrm{ft} 113 / 4 \text { in; core was partly } \\
\text { broken in drilling. }\end{array}$ \\
\hline & & 33 & 9 & & 3 & (Loss in coring interval from $31 \mathrm{ft} 4 \mathrm{fn}-34 \mathrm{ft}$.) \\
\hline & & 34 & $\mathbf{0}$ & 1 & 2 & Clay, \\
\hline & & 35 & 2 & 5 & 10 & (No core sent to laboratory; described at drill site as gray \\
\hline 5 & $<.001$ & 41 & 0 & & $11 / 8$ & ably impure. \\
\hline & & & 118 & & 3 & rading downward $t$ \\
\hline 6 & $<.001$ & 41 & $81 / 2$ & & 818 & Coal, moderately woody, thin- and medium-banded; $1 / 4$-in \\
\hline 7 & $<.001$ & 42 & 458 & & 938 & $\begin{array}{l}\text { Coal, moderately woody, medium- to thick-banded; } 21 / 2 \text {-in } \\
\text { woody layer below } 42 \mathrm{ft} 10 \mathrm{in} \text {; thin fusain bleb at top of } \\
\text { section. }\end{array}$ \\
\hline 8 & $<.001$ & 43 & $18 / 4$ & & 9 & Coal, 21/2-in woody piece at top; lower part dominantly at- \\
\hline & & 43 & $10 \%$ & & $11 / 4$ & ing interval from $41 \mathrm{ft} 81 / 2 \mathrm{in}-4$ \\
\hline & & 44 & & & 10 & $\begin{array}{l}\text { Clay, dark-gray; somewhat lignitic, soft and plastic; woody } \\
\text { lenses at the top; } 1 / 4 \text {-in pyrite bleb below } 44 \mathrm{ft} 4 \mathrm{in} \text {. }\end{array}$ \\
\hline & & 44 & 10 & 23 & 2 & $\begin{array}{l}\text { (No core sent to laboratory; described at drill site as gray } \\
\text { siltstone.) }\end{array}$ \\
\hline 9 & .001 & $\begin{array}{l}68 \\
68\end{array}$ & $\begin{array}{l}0 \\
43\end{array}$ & & $\begin{array}{l}43 / 4 \\
2 \%\end{array}$ & $\begin{array}{l}\text { medium-gray, soft and plastic. } \\
\text { dominantly woody; irregular contact } w\end{array}$ \\
\hline & & 68 & 71 & & $21 / 2$ & $\begin{array}{l}\text { Clay, dark gray, soft and plastic; irregular contact with coal } \\
\text { below; contains some coal fragments from samples above and } \\
\text { below, }\end{array}$ \\
\hline 10 & .001 & 68 & $93 / 4$ & & 2 & Coal, dominantly woody; earthy in lower portion. \\
\hline & & & & & & dark-gray, soft and plastic. \\
\hline
\end{tabular}


TABLE 6.-Lithologic descriptions of lignite cores from the Bar $H$ area, Harding County, S. Dak., the Lodgepole area and Johnson outlier, Perkins County, S. Dak., and the Medicine Pole Hills area, Bowman County, N. Dak.-continued

\begin{tabular}{c|c|c|c|c|}
\hline & \multicolumn{3}{|c|}{ Core section } \\
$\begin{array}{c}\text { Core } \\
\text { hole } \\
\text { TE } \\
\text { sample } \\
\text { No. }\end{array}$ & \begin{tabular}{c} 
Ura- \\
nium \\
\cline { 2 - 4 } \\
cent)
\end{tabular} & \multicolumn{2}{|c|}{$\begin{array}{c}\text { Depth in } \\
\text { hole }\end{array}$} & $:$ Length \\
\cline { 3 - 5 } & Ft & in & Ft & in \\
\hline
\end{tabular}

BAR H AREA, SLIM BUTTES, HARDING COUNTY, S. DAK.-continued

Core hole 21-Continued

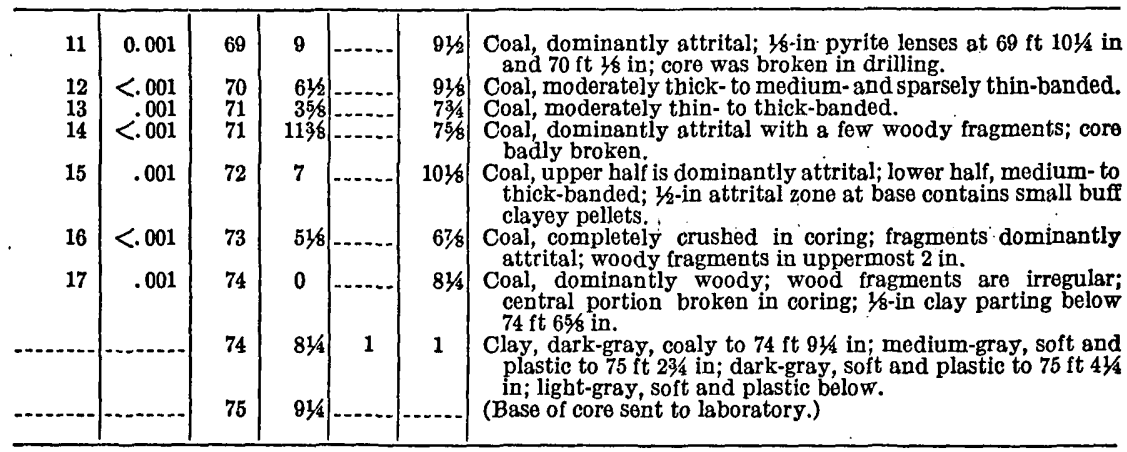

Fuel samples (U. S. Bureau of Mines): D-89670 includes TE samples 1-4. D-89671 includes TE samples 6-8. D-89672 includes TE samples 11-17.

Core hole 22 (SE $1 / 4$ NW1/4 sec 8 , T. 18 N., R. 8 E.) elev 3,260 ft

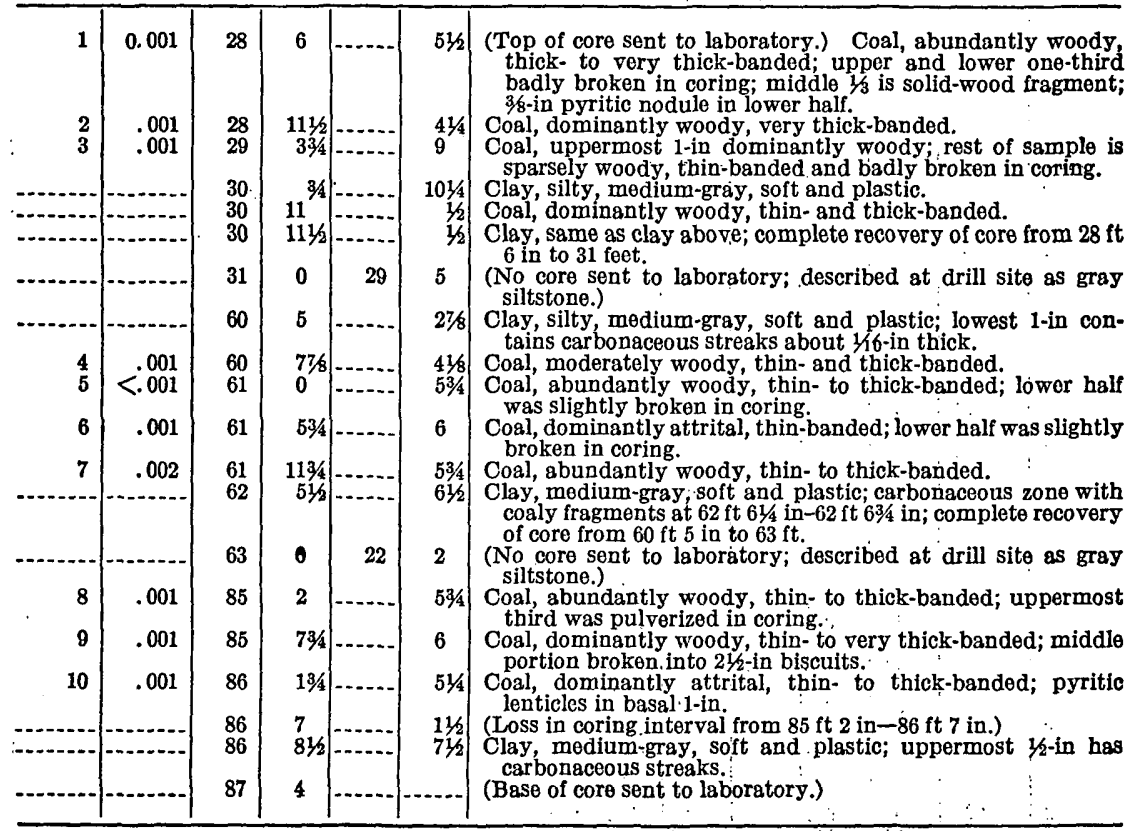

Fuel samples (U. S. Bureau of Mines): D-88995 includes TE samples 1-3. D-89996 includes TE samples 4-7. D-89997 includes TE samples 8-10. 
TABLE 6.-Lithologic descriptions of lignite cores from the Bar $H$ area, Harding County; S. Dak., the Lodgepole area and Johnson outlier, Perkins County, 'S: Dak., and the Medicine Pole Hills area, Bowman County, N. Dak.-Continued

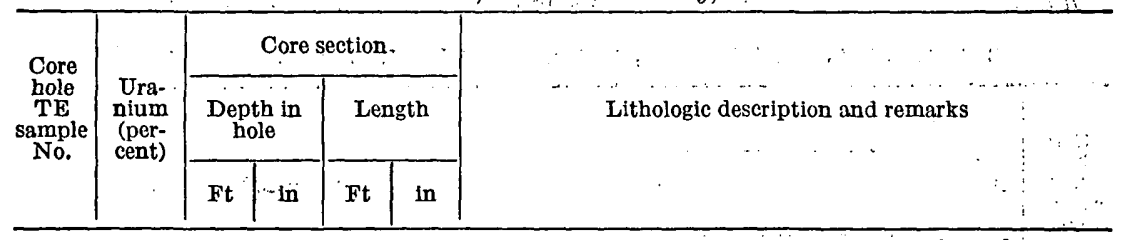

BAR h AREA, SLIM BUTTES, HARDING COUNTY, s. DAK.-continued

Core hole 23 (SW1/4SEl/4 sec 8 , T. 18 N., R. 8 E.) elev 3,216 ft

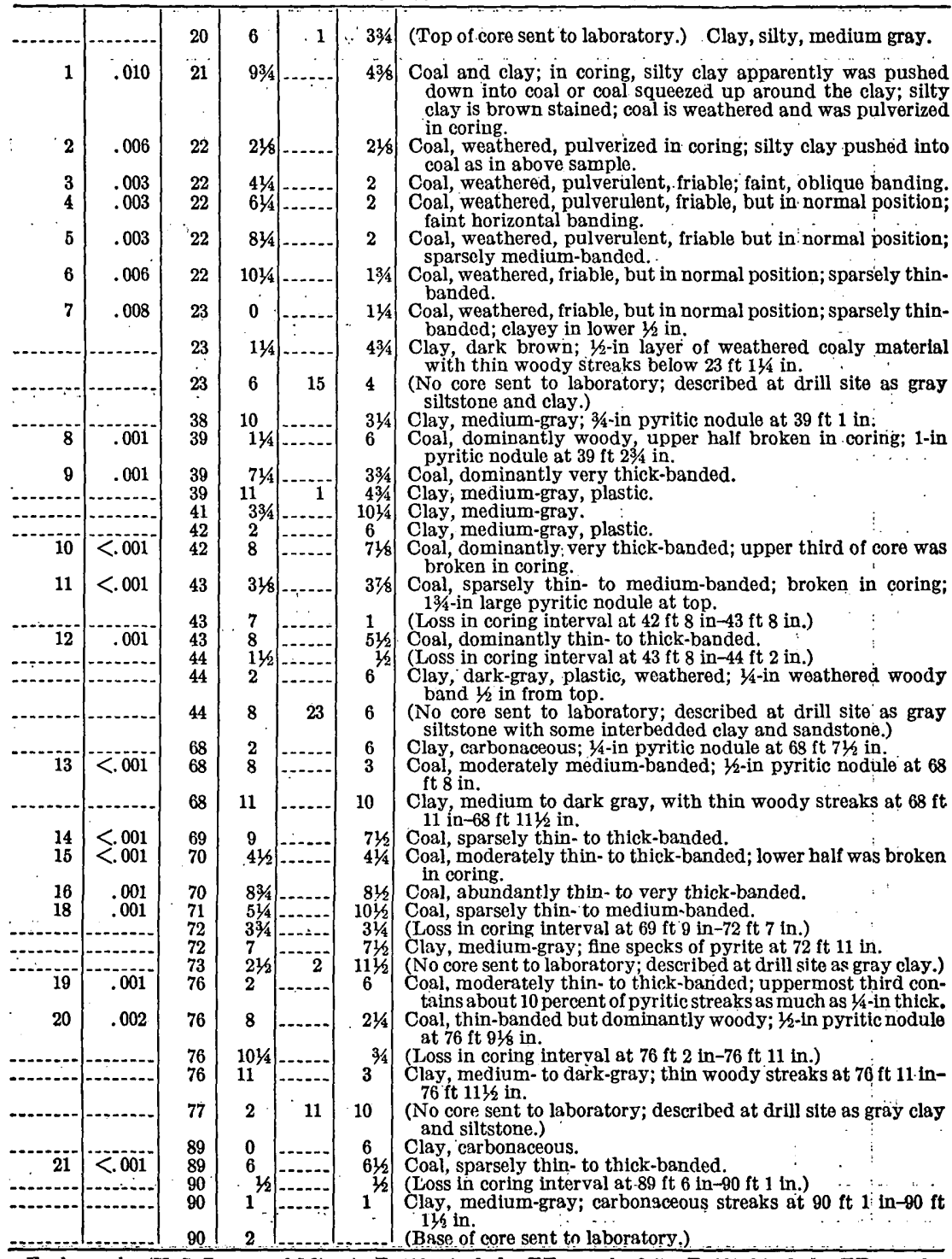

Fuel samples (U. S. Bureau of Mines): D-90065 includes TE samples 3-7., D-90066 includes TE samples 10-12. D-90067 includes TE-samples 14-16 and 18. 
TABLE 6.-Lithologic descriptions of lignite cores from the Bar $H$ area, Harding County, S. Dak., the Lodgepole area and Johnson outlier, Perkins County, S. Dak., and the Medicine Pole Hills area, Bowman County, N. Dak.-Continued

BAR h AREA, SLIM BUTTES, HARDING COUNTY, S. DAK.-continued

\begin{tabular}{|c|c|c|c|c|c|c|}
\hline \multirow{3}{*}{$\begin{array}{c}\text { Core } \\
\text { hole } \\
\text { TE } \\
\text { sample } \\
\text { No. }\end{array}$} & \multirow{3}{*}{$\begin{array}{l}\text { Ura- } \\
\text { nium } \\
\text { (per- } \\
\text { cent) }\end{array}$} & \multicolumn{4}{|c|}{ Core section } & \multirow{3}{*}{ Lithólogic description and remarks } \\
\hline & & \multicolumn{2}{|c|}{$\begin{array}{c}\text { Depth in } \\
\text { hole }\end{array}$} & \multicolumn{2}{|c|}{ Length } & \\
\hline & & Ft & in & Ft & in & \\
\hline
\end{tabular}

Core hole 24 (NE1/4 sec 5, T. 18 N., R. 8 E.) elev 3,270 ft

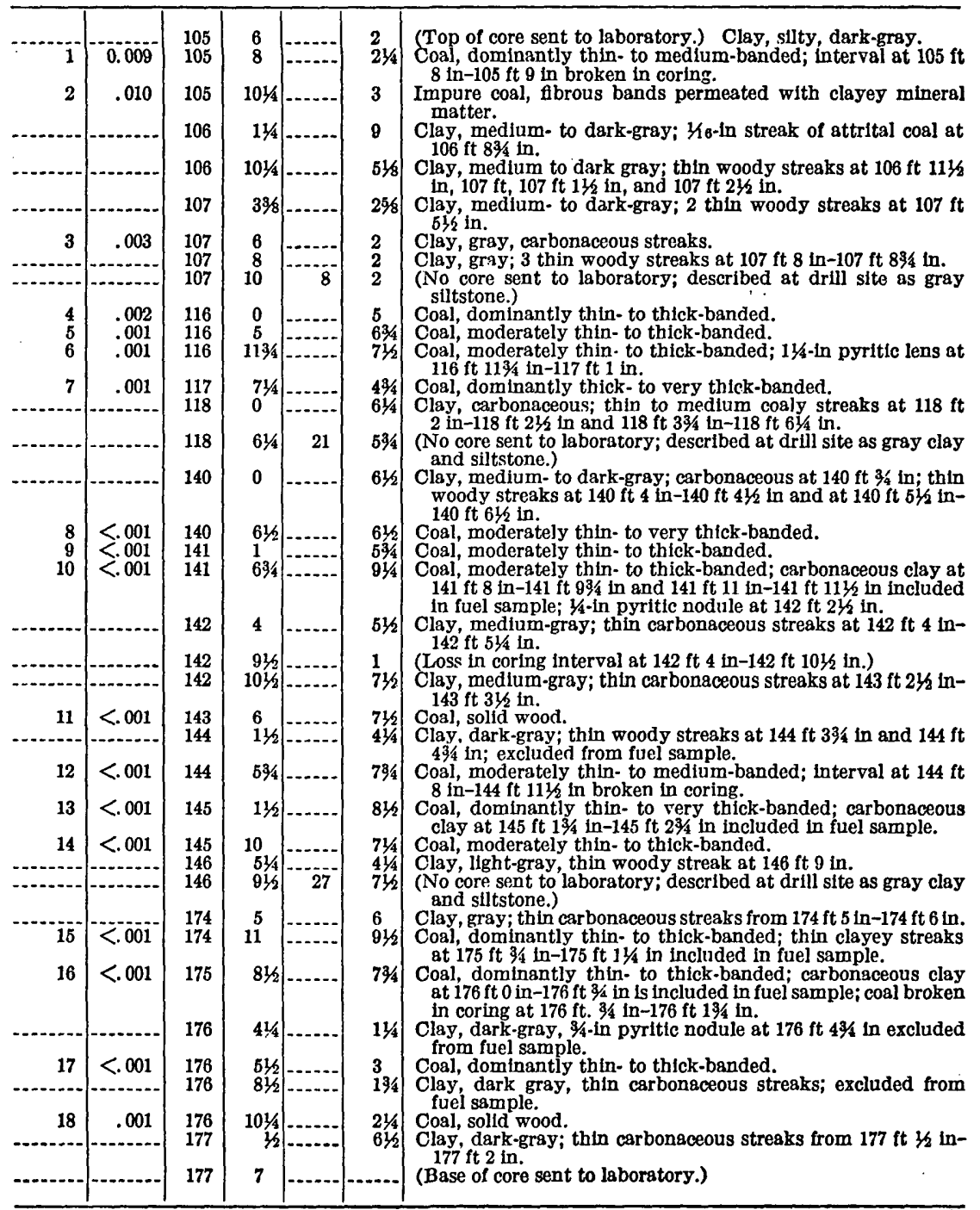

Fuel samples (U. 8. Bureau of Mines): D-90297 includes TE samples 4-7. D-90298 includes TE samples 8-10. D-90299 includes TE samples 11-14. D-80300 includes TE samples 15-18. 
TABLE 6.-Lithologic descriptions of lignite cores from the Bar $H$ area, Harding County, S. Dak., the Lodgepole area and Johnson outlier, Perkins County, S. Dak., and the Medicine Pole Hills area, Bowman County, N. Dak.-Continued

\begin{tabular}{|c|c|c|c|c|c|c|}
\hline \multirow{3}{*}{$\begin{array}{c}\text { Core } \\
\text { hole } \\
\text { TE } \\
\text { sample } \\
\text { No. }\end{array}$} & \multirow{3}{*}{$\begin{array}{l}\text { Ura- } \\
\text { nium } \\
\text { (per- } \\
\text { cent) }\end{array}$} & \multicolumn{4}{|c|}{ Core section } & \multirow{3}{*}{ Lithologic description and remarks } \\
\hline & & \multicolumn{2}{|c|}{$\underset{\text { Dole }}{\text { Depth in }}$} & \multicolumn{2}{|c|}{ Length } & \\
\hline & & Ft & in & Ft & in & \\
\hline
\end{tabular}

BAR h AREA, SLIM BUTTES, HARDING COUNTY, S. DAK.-continued

Core hole $25\left(\mathrm{NE}^{1 / 4} / \mathrm{NE} 1 / 4 \sec 3\right.$, T. 18 N., R. 8 E.) elev. $3,177 \mathrm{ft}$

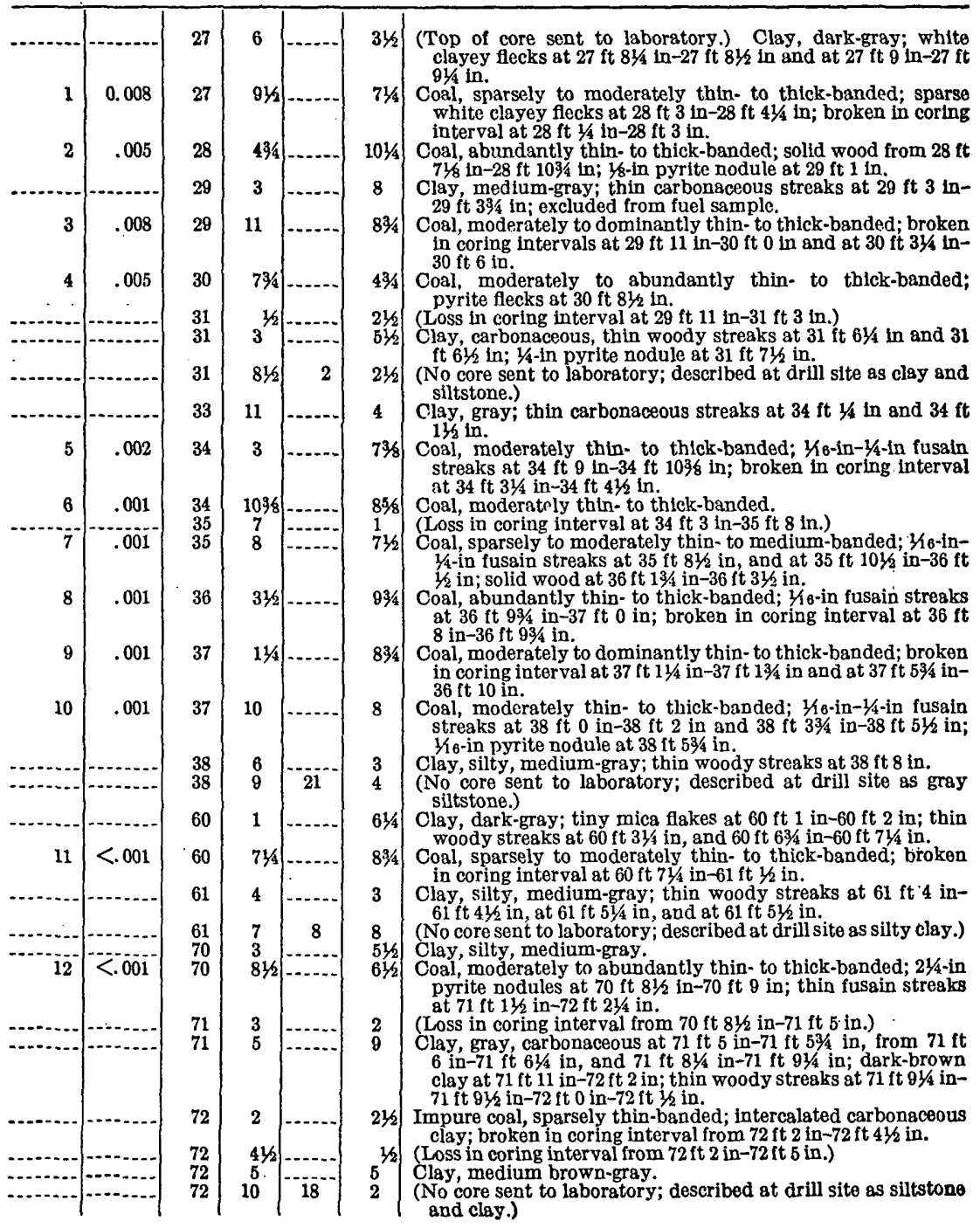


TABLE 6.- Lithologic descriptions of lignite cores from the Bar $H$ area, Harding County, -S. Dak., the Lodgepole area and Johnson outlier, Perkins County, S. Dak., and the Medicine Pole Hills area, Bowman County, 'N. Dak.-Continued

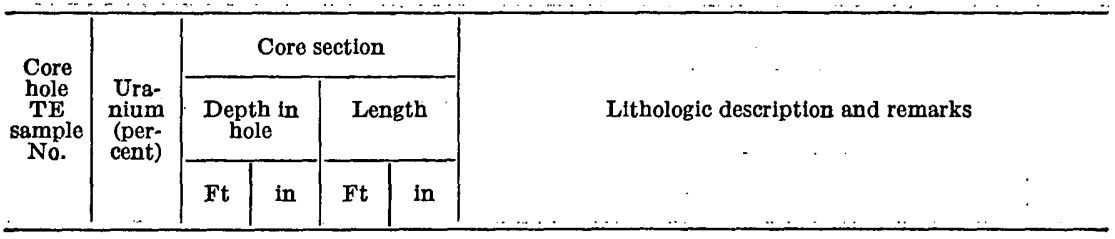

BAR H AREA, SLIM BUTTES, HARDING CoUNTY, s. DAK.-continued

Core hole 25-Continued

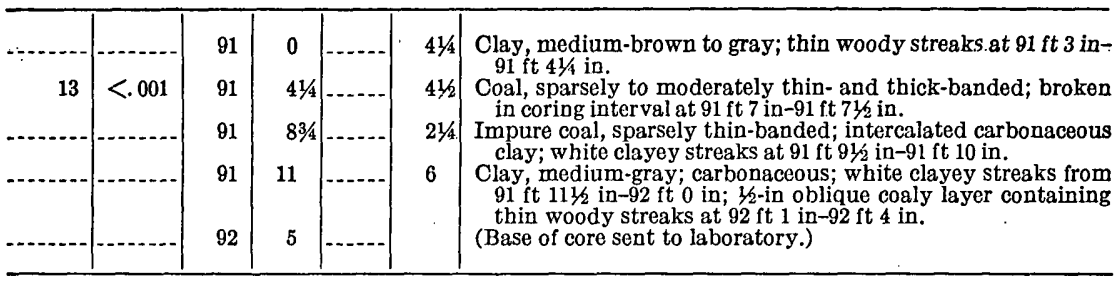

Fuel samples (U. S. Bureau of Mines): D-90758 includes TE samples 1-4. D-90759 includes TE samples 6-10.

Core hole 26 (NWt/4 sec 35, T. 19 N., R. 8 E.) elev $3,100 \mathrm{ft}$

\begin{tabular}{|c|c|c|c|c|c|c|}
\hline & & 29 & 9 & & $75 \%$ & of core sent to laboratory. \\
\hline & & & & & & \\
\hline 1 & 01 & 30 & 458 & & $83 \%$ & $\begin{array}{l}\text { Coal, sparsely thin- and moderately medium-banded; solid } \\
\text { wood at } 30 \mathrm{ft} 45 / 8 \text { in- } 30 \mathrm{ft} 51 / 2 \text { in; } 1 \text {-in pyrite nodule at } 30 \mathrm{ft} \\
9 \text { in- } 30 \mathrm{ft} 10 \mathrm{in} \text {; broken in coring interval at } 30 \mathrm{ft} 61 / 2 \text { in- } \\
31 \mathrm{ft} 1 \mathrm{in} \text {. }\end{array}$ \\
\hline 2 & .001 & 31 & 1 & & 8 & Sely thin- to medium-banded; broken in coring \\
\hline 3 & $<.001$ & 31 & 9 & & 9 & - to medium-banded; $1 / 16$ in-1/4 in fusain \\
\hline 4 & $<.001$ & 32 & 6 & & $41 / 2$ & anded; 1 -in pyrite nodule at \\
\hline 5 & $<.001$ & 32 & $101 / 2$ & & $63 / 4$ & Coal, s \\
\hline 6 & $<.001$ & 33 & $51 / 4$ & & $33 / 4$ & anded; broken in coring \\
\hline & & 33 & 9 & & 634 & (Lo \\
\hline 7 & $<.001$ & 33 & 10 & & $63 / 4$ & $\begin{array}{l}\text { Coal, s } \\
33 \mathrm{ft} \\
10 \mathrm{in}\end{array}$ \\
\hline 8 & $<.001$ & 34 & $43 / 4$ & & $63 / 4$ & derately thin- and medium-banded, sparsely thick- \\
\hline 9 & $<.001$ & 34 & $111 / 2$ & & $61 / 2$ & Ided; \\
\hline : & $<.001$ & 35 & 6 & & 6 & banded; $1 / 16$-in-1/4-in fusain \\
\hline 11 & $<.001$ & 36 & 0 & & $71 / 2$ & y thin- or \\
\hline$\therefore \quad \therefore 12$ & 001 & 36 & $71 / 2$ & & $81 / 2$ & $36 \mathrm{ft}$ \\
\hline 13 & 01 & 37 & 4 & & $61 / 2$ & $\begin{array}{l}\text { hin- and thick- } \\
7 \mathrm{ft} 5 \mathrm{in} ; \mathrm{K}_{\mathrm{\theta}} \text {-in- }\end{array}$ \\
\hline 14 & $<.001$ & 37 & $101 / 2$ & & $61 / 2$ & $\begin{array}{l}\text { to thick-banded; } 1 \text {-in pyrite nodule at } \\
\text { in. }\end{array}$ \\
\hline & & $\begin{array}{l}38 \\
38\end{array}$ & $\begin{array}{l}5 \\
61\end{array}$ & & $\begin{array}{l}11 / 2 \\
61 / 2\end{array}$ & $\begin{array}{l}\text { Clay, carbonaceo } \\
\text { Clay, medium-g }\end{array}$ \\
\hline & & & & & & \\
\hline & & 35 & 1 & 21 & & $\begin{array}{l}\text { Clay, medium-gray; 1/8-in pyrite nodule at } 39 \text { ft } 51 / 2 \text { in. } \\
\text { (No core sent to laboratory; described at drill site as gray } \\
\text { siltstone.) }\end{array}$ \\
\hline & & 61 & 2 & & 6 & $\begin{array}{l}\text { Clay, silty, medium dark-gray; 1/16-in gray sandy streaks } \\
\text { throughout sample. }\end{array}$ \\
\hline & & 61 & 8 & & $61 / 2$ & $\begin{array}{l}\text { n. } \\
\text { inm- to dark-gray; carbonaceous at } 62 \mathrm{ft} \\
\end{array}$ \\
\hline
\end{tabular}


TABLE 6.-Lithologic descriptions of lignite cores from the Bar $H$ area, Harding County, S. Dak., the Lodgepole area and Johnson outlier, Perkins County, S. Dak., and the Medicine Pole Hills area, Bowman County, N. Dak.-Continued

\begin{tabular}{|c|c|c|c|c|c|c|c|}
\hline \multirow{3}{*}{$\begin{array}{c}\text { Core } \\
\text { hole } \\
\text { TE } \\
\text { sample } \\
\text { No. }\end{array}$} & \multirow{3}{*}{$\begin{array}{c}\text { Ura- } \\
\text { nium } \\
\text { (per- } \\
\text { cent) }\end{array}$} & \multicolumn{4}{|c|}{ Core section } & \multirow{3}{*}{ Lithologic description and remarks } & \multirow{3}{*}{$\cdots$} \\
\hline & & \multicolumn{2}{|c|}{$\begin{array}{c}\text { Depth in } \\
\text { hole }\end{array}$} & \multicolumn{2}{|c|}{ Length } & & \\
\hline & & Ft & in & Ft & in & & \\
\hline
\end{tabular}

BAR H AREA, SLIM BUTTES, HARDiNg COUNTY, 8. DAK.-continued

Core hole 26-Continued

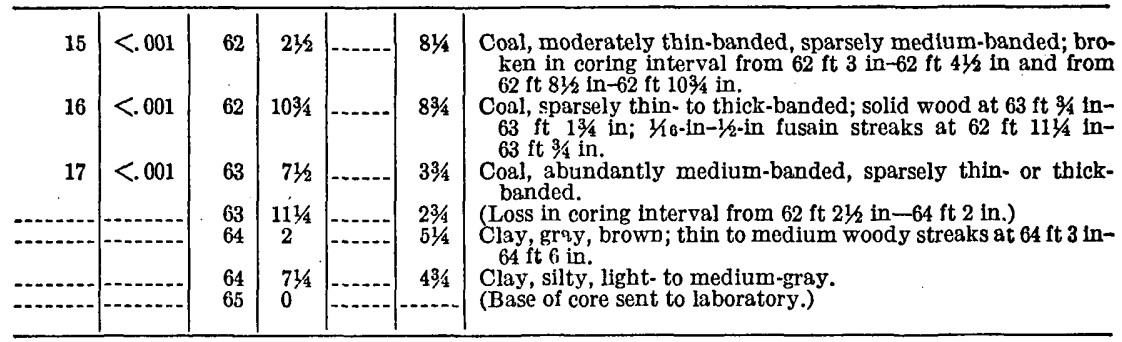

Fuel samples (U. S. Bureau of Mines): D-90760 includes TE samples 1-14. D-90761 includes TE samples 15-17.

Core hole $27\left(\mathrm{NW}^{1} \frac{1}{4} \mathrm{NE}^{1 / 4} / 4 \sec 35\right.$, T. 19 N., R. 8 E.) elev $3,085 \mathrm{ft}$

\begin{tabular}{|c|c|c|c|c|c|c|}
\hline 1 & 0.001 & 1 & 0 & & 234 & op of \\
\hline & & & 234 & & 21 & and mixed with choc \\
\hline & & 10 & 5 & & 3 & Clay, ehocolate-brown; thin jarosite streaks at $10 \mathrm{ft} 51 / 2$ in and \\
\hline & & 10 & 8 & & $21 / 4$ & ained, stained \\
\hline & & 10 & $101 / 4$ & & 734 & w sandy streaks. \\
\hline & & 11 & 6 & & 9 & is gray silt- \\
\hline & & 45 & 3 & & $41 / 4$ & Clay, silty, dark-gray. \\
\hline & & & & & 74 & $\begin{aligned} C o a l, \\
46 \mathrm{ft}\end{aligned}$ \\
\hline 3 & $<.001$ & 46 & 5 & & 9 & Coal, sparsely thin- to thick-banded; $1 / 2$-in pyrite nodule at 46 \\
\hline 4 & $<.001$ & 47 & $\begin{array}{r}2 \\
10\end{array}$ & & 8 & $\begin{array}{l}\text { Cosl, moderately thin-banded, sparsely medium-banded; } 1 \text { - } \\
\text { regular } 134 \text {-in pyrite nodule at } 47 \mathrm{ft} 2 \mathrm{in} \text {. } \\
\text { (Loss in coring interval from } 45 \mathrm{ft} 7 \mathrm{in}-48 \mathrm{ft} \text {.) }\end{array}$ \\
\hline & & 48 & $\begin{array}{l}0 \\
7\end{array}$ & & 7 & Clay, dark-gray; carbonaceous streaks in uppermost 1/2-in. \\
\hline & & 49 & 2 & & $21 / 2$ & Clay, dark \\
\hline & & 49 & 412 & & & Do. \\
\hline & & 50 & $11 / 2$ & & $21 / 2$ & Coal, sparsely thin- and medium-banded; broken in coring. \\
\hline & & $\begin{array}{l}50 \\
50\end{array}$ & $\begin{array}{l}4 \\
61 / 2\end{array}$ & & $21 / 2$ & $\begin{array}{l}\text { Clay, gray. } \\
\text { (Base of core sent to laboratory.) }\end{array}$ \\
\hline
\end{tabular}

Fuel sample (U. S. Bureau of Mines): D-90762 includes TE samples 2-4.

LODGEPOLE AREA AND JOHNSON OUTLIER, PERKINS COUNTY, S. DAK.

Core hole $11\left(\mathrm{SE}^{1 / 4} \mathrm{NE} 1 / 4 \sec 19\right.$, T. 21 N., R. $12 \mathrm{E}$.) elev $2,959 \mathrm{ft}$

\begin{tabular}{|c|c|c|c|c|c|c|}
\hline & & 40 & & & & (Ton of core sent to laboratorv) Glay buff plastic \\
\hline & & 41 & $51 / 2$ & & 0 & $\begin{array}{l}\text { Clay, black, plastic. } \\
\text { Clay, Dum, plastic. }\end{array}$ \\
\hline & & 41 & 6 & $\ldots$ & 1 & Clay, brown, silty. \\
\hline & 0.002 & 41 & & & $71 / 2$ & Coal, moderately woody; core is broken, reserved for petro- \\
\hline$\cdots$ & & 42 & $21 / 2$ & & $34^{3}$ & Clay \\
\hline & & 42 & $31 / 4$ & $-\cdots$ & $3 / 4$ & Shale, carbonaceous. \\
\hline 2 & .001 & 42 & 4 & $\mid . . .$. & $103 / 4$ & $\begin{array}{l}\text { Coal, upper part moderately wood-banded, lower part is } \\
\text { abundantly woody; pyritic areas at } 42 \mathrm{ft} 51 / 2 \mathrm{in}, 42 \mathrm{ft} 8 \mathrm{in} \text {, } \\
42 \mathrm{ft} 10 \mathrm{in}, 43 \mathrm{ft} \text {, and } 43 \mathrm{ft} 1 \mathrm{ln} \text {. }\end{array}$ \\
\hline
\end{tabular}


TABLE 6.-Lithologic descriptions of lignite cores from the Bar $H$ area, Harding County, S. Dak., the Lodgepole area and Johnson outlier, Perkins County, S. Dak., and the Medicine Pole Hills area, Bowman County, N. Dak.-Continued

\begin{tabular}{c|c|c|c|c|}
\hline & \multicolumn{3}{|c|}{ Core section } & \multicolumn{3}{|c|}{$\begin{array}{c}\text { Core } \\
\text { hole } \\
\text { TE } \\
\text { sample } \\
\text { No. }\end{array}$} & $\begin{array}{c}\text { Urs- } \\
\text { nium } \\
\text { (per- } \\
\text { cent) }\end{array}$ & $\begin{array}{c}\text { Depth in } \\
\text { hole }\end{array}$ & Length & Lithologic description and remarks \\
\cline { 3 - 5 } & Ft & in & Ft & in \\
\hline
\end{tabular}

LODGePole AREA AND JOHNSON OUTLIER, PERKINS COUNTY, S. DAK.-continued Core hole 11-Continued

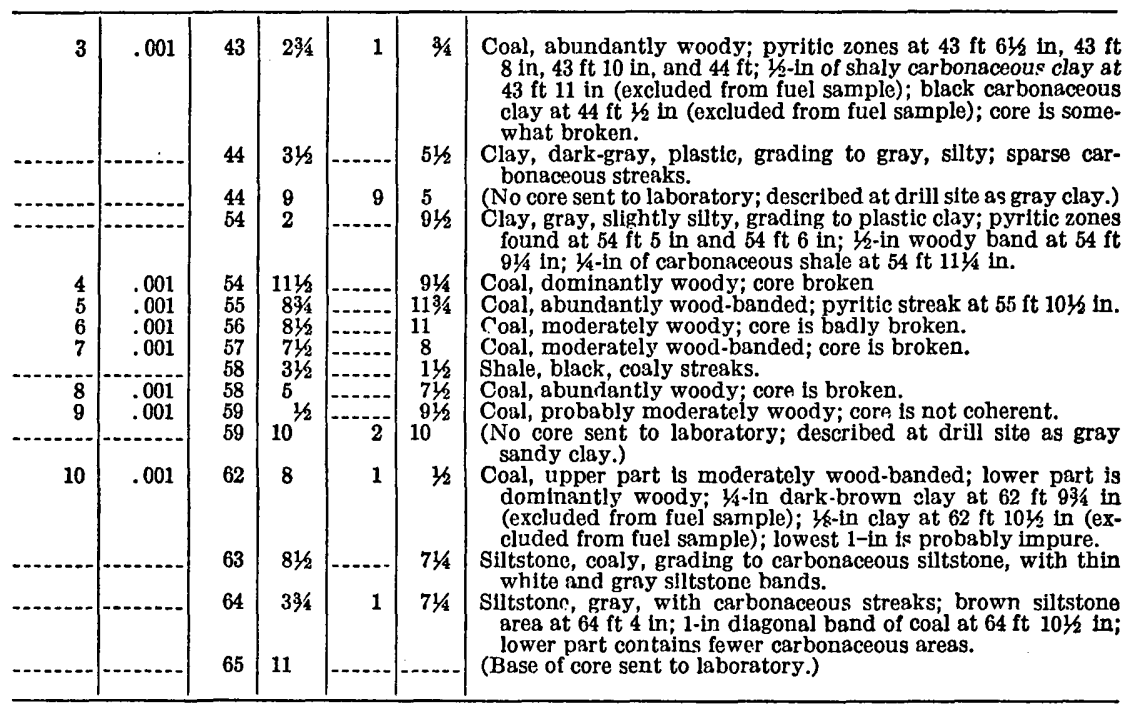

Fuel samples (U. S. Bureau of Mines): D-69688 includes TE samples 1-3. D-69689.includes TE samples 4-9. D-69690 includes TE sample 10.

Core hole 12 (NW1/4SE1/4 $\sec 19$, T. 21 N., R. 12 E.) elev 2,961 ft

\begin{tabular}{|c|c|c|c|c|c|c|}
\hline 1 & $<0.001$ & 37 & 4 & & $23 / 4$ & ent to laboratory.) Shale, yellow, sllty, very \\
\hline 2 & .001 & 37 & 634 & & $71 / 4$ & $\begin{array}{l}\text { sparse lignitic spots. } \\
\text { Clay; upper part is plastic, buff, gray and yellow clay; middle } \\
\text { part is shaly clay; lower part is dark-brown clay; } 1 \text {-in of }\end{array}$ \\
\hline 3 & $<.001$ & 38 & 2 & 1 & 0 & $\begin{array}{l}\text { Shale, gray, silty at top; upper part is silty clay; middle and } \\
\text { lower parts are shaly silty clay with diffuse carbonaceous } \\
\text { streaks; } 11 \text {-in carbonaceous shale, grading to coaly shale at } \\
\text { bottom. }\end{array}$ \\
\hline & & 39 & 2 & 13 & 7 & (No core sent to laboratory; described at drill site as gray clay.) \\
\hline 4 & $<.001$ & $\begin{array}{l}52 \\
53\end{array}$ & $\stackrel{9}{11 / 2}$ & 1 & $\begin{array}{l}21 / 2 \\
21 / 4\end{array}$ & $\begin{array}{l}\text { Clay, gray, somewhat plastic; } 21 / 4 \text {-In of coaly shale at bottom. } \\
\text { Coal; upper half is dominantly woody; lower half is abun- } \\
\text { dantly woody; thin pyritic streak at } 54 \mathrm{ft} 11 / 4 \text { in; fusain } \\
\text { streaks in middle part; } 1 / 4 \text {-in fusain streak at } 54 \text { ft } 734 \text { in; } \\
\text { impure specks and thin impure streaks of fusain in lower } \\
\text { port. }\end{array}$ \\
\hline 5 & $<.001$ & 55 & $1 \%$ & 1 & 1 & $\begin{array}{l}\text { Coal, sparsely woody b } \\
\text { out; } 1,2 \text {-in fusain strea }\end{array}$ \\
\hline 6 & $<.001$ & 56 & 234 & 1 & $71 / 2$ & $\begin{array}{l}\text { Coal, moderately wood-banded; } 1 / 8 \text {-in fusain streak at } 56 \mathrm{ft} \\
33 / 4 \text { in, thin flusain streaks in lower part; } 1 / 4 \text {-in pyritic rosette } \\
\text { at } 56 \mathrm{ft} 4 \mathrm{in} \text {, 16-in pyritic band at } 56 \mathrm{ft} 6 \text { in. }\end{array}$ \\
\hline 7 & $<.001$ & 57 & 1014 & 1 & $11 / 2$ & $\begin{array}{l}\text { Coal, moderately wood-banded; } 1 / 4-1 \text { in fusain band at } 57 \mathrm{ft} \\
103 / 4 \text { in; } 1 / 4 \text {-in fusain rosette at } 57 \mathrm{ft} 111 / 4 \text { in and } 58 \mathrm{ft} 3 / 4 \mathrm{in} \text {; } \\
\text { fusain streak at } 58 \mathrm{ft} 73 / 4 \text { in. }\end{array}$ \\
\hline
\end{tabular}


TABLE 6--Lithologic descriptions of lignite cores from the Bar $H$ area, Harding County, S. Dak., the Lodgepole area and Johnson outlier, Perkins County, S. Dak., and the Medicine Pole Hills area, Bowman County, N. Dak.-Continued

\begin{tabular}{c|c|c|c|c}
\hline & \multicolumn{2}{|c|}{ Core section } \\
$\begin{array}{c}\text { Core } \\
\text { hnle } \\
\text { TE } \\
\text { sample } \\
\text { No. }\end{array}$ & $\begin{array}{c}\text { Ura- } \\
\text { nium } \\
\text { (per- } \\
\text { cent) }\end{array}$ & $\begin{array}{c}\text { Depth in } \\
\text { hole }\end{array}$ & Length & Lithologic description and remarks \\
\cline { 3 - 5 } & Ft & in & Ft & in \\
\hline
\end{tabular}

LODGEPOLE AREA AND JOHNSON OUTLIER, PERKINS COUNTY, S. DAK.-continued Core hole 12-Continued

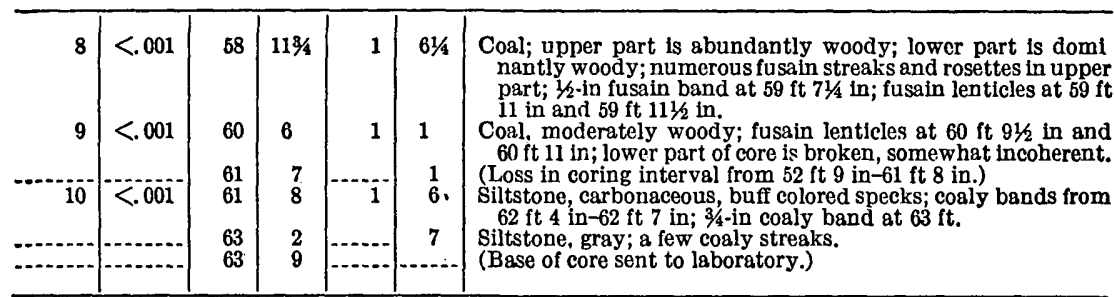

Fuel sample (U. S. Bureau of Mines): D-69687 includes TE samples 4-9.

Core hole $13\left(\mathrm{NW}^{1} / 4 \mathrm{NE} 1 / 4 \mathrm{sec} 19\right.$, T. 21 N., R. 12 E.) elev 2,949 ft

\begin{tabular}{|c|c|c|c|c|c|c|}
\hline & & 32 & 11 & & $51 / 2$ & $\begin{array}{l}\text { (Top of core sent to laboratory.) Clay, silty, gray, grading to } \\
\text { plastic clay; pyritic specks throughout clay; } 3 / 4 \text {-in gypsum } \\
\text { crystal at } 32 \mathrm{ft} 111 / 2 \text { in. }\end{array}$ \\
\hline 1 & 0.002 & 33 & $\begin{array}{l}41 / 2 \\
53 / 4\end{array}$ & & $\begin{array}{l}11 / 4 \\
53 / 4\end{array}$ & Coal. \\
\hline 2 & .001 & 33 & $111 / 2$ & & $10^{7 / 4}$ & $\begin{array}{l}\text { Coal, impure, weathered, with gypsum crystal and pyritic } \\
\text { specks; lower part is coaly clay; } 3 / 4 \text {-in pyritic rosette at } 34 \\
\text { ft } 43 / 4 \text { in; } 1 / 2 \text {-in tabular crystal of gypsum at } 34 \mathrm{ft} 61 / 4 \text { in. }\end{array}$ \\
\hline 3 & . 001 & 34 & $91 / 2$ & & $63 / 4$ & $\begin{array}{l}\text { Coal, woody, weathered, irregular thin clay streaks; lower } \\
\text { part is dominantly woody. }\end{array}$ \\
\hline $\begin{array}{l}4 \\
5\end{array}$ & $<.001$ & $\begin{array}{l}35 \\
36\end{array}$ & $\begin{array}{l}41 / 4 \\
51 / 2\end{array}$ & 1 & $\begin{array}{l}11 / 4 \\
61 / 2\end{array}$ & $\begin{array}{l}\text { Coal, dominantly woody, highly weathered. } \\
\text { Coal, dominantly woody, highly weathered. }\end{array}$ \\
\hline & & 38 & 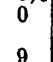 & & 0 & $\begin{array}{l}\text { Shale, clayey; coaly at top; plastic brown clay in middle part; } \\
\text { lower part is gray silty clay. }\end{array}$ \\
\hline & & 38 & $y$ & & & (Base of core sent to laboratory.) \\
\hline
\end{tabular}

Fuel sample (U. S. Bureau of Mines): D-69737 includes TE samples 4 and 5.

Core hole 14 (SE1/4SE1/4 sec 9, T. 21 N., R. 11 E.) elev 3,015 ft (Johnson outlier)

\begin{tabular}{|c|c|c|c|c|c|c|}
\hline $\begin{array}{r}1 \\
2 \\
3 \\
4 \\
5 \\
6 \\
7 \\
8 \\
9 \\
10 \\
11 \\
12 \\
13\end{array}$ & $\begin{array}{r}0.003 \\
.036 \\
.028 \\
.021 \\
.013 \\
.008 \\
.002 \\
.001 \\
<.001 \\
<.001 \\
<.001 \\
<.001 \\
<.001\end{array}$ & $\begin{array}{l}14 \\
14 \\
15 \\
15 \\
16 \\
16 \\
17 \\
17 \\
18 \\
18 \\
19 \\
19 \\
20\end{array}$ & $\begin{array}{l}6 \\
8 \\
2 \\
8 \\
2 \\
8 \\
2 \\
8 \\
2 \\
8 \\
2 \\
8 \\
2\end{array}$ & 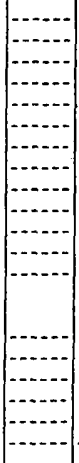 & $\begin{array}{l}2 \\
6 \\
6 \\
6 \\
6 \\
6 \\
6 \\
6 \\
6 \\
6 \\
6 \\
6 \\
6\end{array}$ & $\begin{array}{l}\text { (Top of core sent to laboratory.) Clay, plastic, gray. } \\
\text { Coal, highly weathered, pulverulent and crumbly. } \\
\text { Do. } \\
\text { Do. } \\
\text { Do. } \\
\text { Do. } \\
\text { Do. } \\
\text { Do. } \\
\text { Do. } \\
\text { Do. } \\
\text { Do. } \\
\text { Do. } \\
\text { Coal, highly weathered, pulverulent and crumbly, but a 1-in } \\
\text { hard impure band at } 20 \text { ft } 5 \text { in (sent for TE analyses but } \\
\text { excluded from fuel sample). } \\
\text { Coal, highly weathered, pulverulent and crumbly. } \\
\text { Do. } \\
\text { Do. } \\
\text { Siltstone, hard. } \\
\text { Sandstone, clayey, hard. } \\
\text { (Base of core sent to laboratory.) }\end{array}$ \\
\hline
\end{tabular}

Fuel sample (U. S. Bureau of Mines): D-69738 includes TE samples 2-16. 
TABLE 6.-Lithologic descriptions of lignite cores from the Bar $H$ area, Harding County, S. Dak., the Lodgepole area and Johnson outlier, Perkins County, S: Dak., and the Medicine Pole Hills area, Bowman County, N. Dak.-Continued

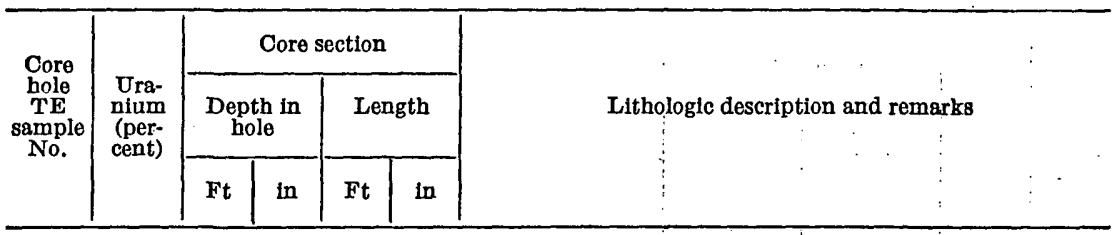

LODGEPOLE AREA AND JOHNSON OUTLIER, PERKINS COUNTY, S. DAK.-continued Core hole 15 (SE $1 / 4$ SW $1 / 4$ sec. 9, T. 21 N., R. 11. E.) elev 3,017 ft (Johnson outller)

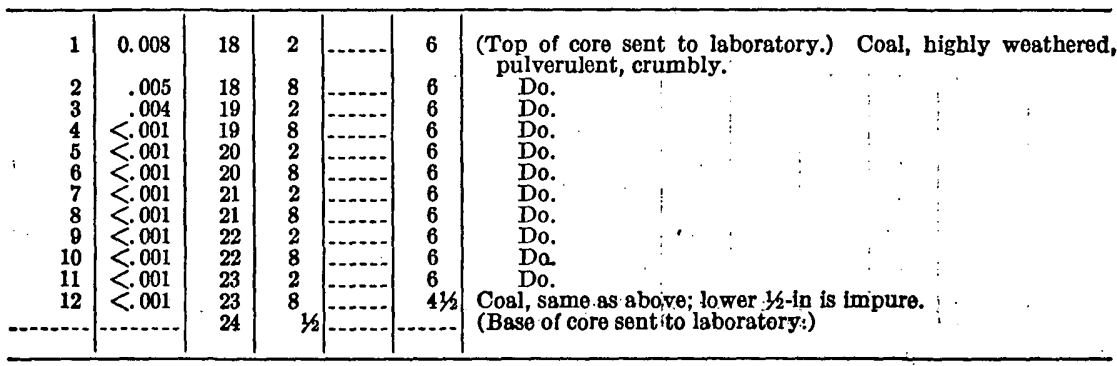

Fuel sample (U. S. Bureau of Mines): D-69739 includes TE samples 1-12.)

\begin{tabular}{|c|c|c|c|c|c|c|}
\hline \multicolumn{7}{|c|}{$\begin{array}{l}\text { MEDICINE POLE HILLS AREA, BOWMAN COUNTY, N. DAK. } \\
\text { Core hole } 5 \text { (SW } / 4 \text { SEL } / 4 \text { sec. } 35, T .131 \text { N., R. 104:W.) elev } 3,427 \text { it }\end{array}$} \\
\hline & & 64 & 4 & 4 & $51 / 2$ & $\begin{array}{l}\text { (Top of core sent to laboratory.) Clisy, brown, a little silt, } \\
\text { blocky irregular fracturg joints at } 68 \text { ft, grading to a less } \\
\text { silty clay at } 68 \text { ft } 5 \text { in, then grading to highly plastic soft } \\
\text { slightly darker brown clay; oblique irregular joints stlll } \\
\text { present. }\end{array}$ \\
\hline $\mathbf{1}$ & $\begin{array}{r}0.004 \\
.011\end{array}$ & $\begin{array}{l}68 \\
69\end{array}$ & $\begin{array}{l}91 / 2 \\
1 \% 4\end{array}$ & & $7 \%$ & $\begin{array}{l}\text { Coal badly crushed, } \\
\text { Coal, attrital, a few woody streaks; upper part is coherent but } \\
\text { weakened by horizontal and vertical cracks; lower part is } \\
\text { broken. }\end{array}$ \\
\hline $\begin{array}{l}\mathbf{3} \\
\mathbf{4} \\
\mathbf{5} \\
\mathbf{6}\end{array}$ & $\begin{array}{l}.007 \\
.007 \\
.006 \\
.003\end{array}$ & $\begin{array}{l}69 \\
70 \\
71 \\
71\end{array}$ & $\begin{array}{r}91 / 2 \\
612 \\
21 \% \\
1034\end{array}$ & 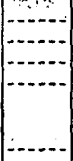 & $\begin{array}{l}9 \\
8 \\
844 \\
1134\end{array}$ & $\begin{array}{l}\text { Coal, sparsely thin- to medium-banded; dominantly attrital. } \\
\text { Coal, moderately wood-banded; very dull attrital coal. } \\
\text { Coal, similar to that in sample above, 2-in wood band at base. } \\
\text { Coal, badly crushed, including one woody piece l-in thick at } \\
\text { about the middle; lower 6-in of crushed cosl dried out in } \\
\text { shipment; most of the coal appears to be attrital. } \\
\text { (Base of core sent to laboratory.) }\end{array}$ \\
\hline
\end{tabular}

Fuel samples (U: S. Bureau of, Mines): D-68866 includes TE samples 1-6.

Core hole 6 (SE $1 / 4$ NE $1 / 4$ sec 2, T. 130 N., R. 104 W.) elev 3,247 ft

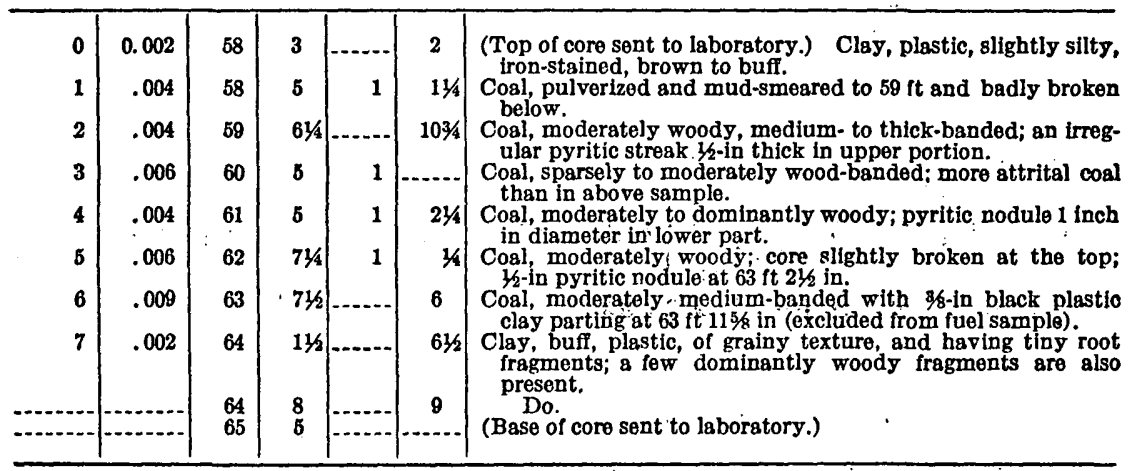

Fuel sample (U. 8. Bureau of Mines): D-68867 includes TE sample 1. D-68868 includes TE samples 2-6. 
TABLE 6.-Lithologic descriptions of lignite cores from the Bar $H$ area, Harding County, S. Dak., the Lodgepole area and Johnson outlier, Perkins County, S. Dak., and the Medicine Pole Hills area, Bowman County, N. Dak.-Continued

\begin{tabular}{|c|c|c|c|c|c|c|}
\hline \multirow{3}{*}{$\begin{array}{c}\text { Core } \\
\text { hole } \\
\text { TE } \\
\text { sample } \\
\text { No. }\end{array}$} & \multirow{3}{*}{$\begin{array}{l}\text { Ura- } \\
\text { nium } \\
\text { (per- } \\
\text { cent) }\end{array}$} & \multicolumn{4}{|c|}{ Core section } & \multirow{3}{*}{ Lithologic description and remarks } \\
\hline & & \multicolumn{2}{|c|}{$\begin{array}{l}\text { Depth in } \\
\text { hole }\end{array}$} & \multicolumn{2}{|c|}{ Length } & \\
\hline & & $\mathrm{Ft}$ & in & Ft & in & \\
\hline
\end{tabular}

MEDICINE POLE hILLS AREA, BOWMAN COUNTY, N. DAK.-continued

Core hole $8(\mathrm{NW} 1 / 4 \mathrm{SW} 1 / 4 \sec 1$, T. 130 N., R. $104 \mathrm{~W}$.) elev 3,414 ft

\begin{tabular}{|c|c|c|c|c|c|c|}
\hline $\begin{array}{r}2 \\
3 \\
-\end{array}$ & $\begin{array}{r}.012 \\
.016 \\
\end{array}$ & $\begin{array}{l}30 \\
31 \\
32\end{array}$ & $\begin{array}{l}0 \\
0 \\
0\end{array}$ & $\begin{array}{l}1 \\
1 \\
2\end{array}$ & $\begin{array}{r}0 \\
0 \\
11\end{array}$ & $\begin{array}{l}\text { (Top of core sent to laboratory.) Coal apparently banded, } \\
\text { probably mostly attrital, very badly weathered, too friable } \\
\text { to saw. } \\
\text { Do. } \\
\text { Do. } \\
\text { Clay, silty, grading downward to clayey siltstone at about } \\
34 \text { ft; the clay and siltstone are brown, of grainy texture, and } \\
\text { having a few small root traces and coaly lenticles. } \\
\text { (Base of core sent to laboratory.) }\end{array}$ \\
\hline
\end{tabular}

Fuel sample (U. s. Bureau of Mines): D-68870 includes TE samples 1-3.

$\therefore$.

Core hole $9(\mathrm{NW} 1 / 4 \mathrm{NE} 1 / 4 \sec 2$, T. 130 N., R. 104 W.) elev $3,422 \mathrm{ft}$

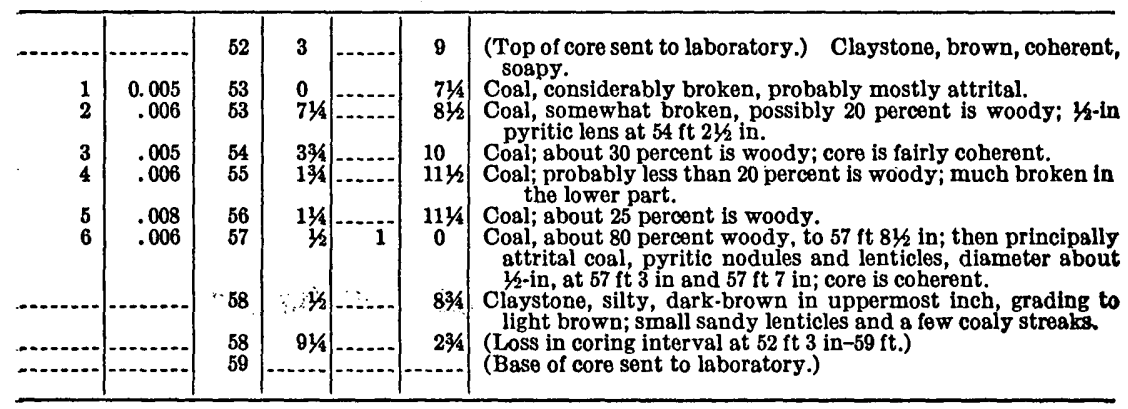

Fuel sample (U. S. Bureau of Mines): D-68871 includes TE samples 1-6. 


\section{Core Drilling for Uranium-}

\section{Bearing Lignite, Mendenhall}

\section{Area, Harding County}

South Dakota

By J. R. GILL, H. D. ZELLER, and J. M. SCHOPF

URANIUM IN COAL IN THE WESTERN UNITED STATES

GEOLOGICAL S U R VEY B ULLETIN 1055-D

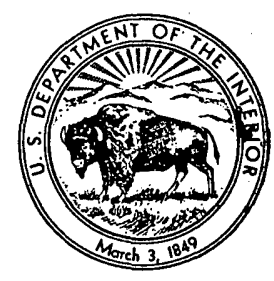





\section{CONTENTS}

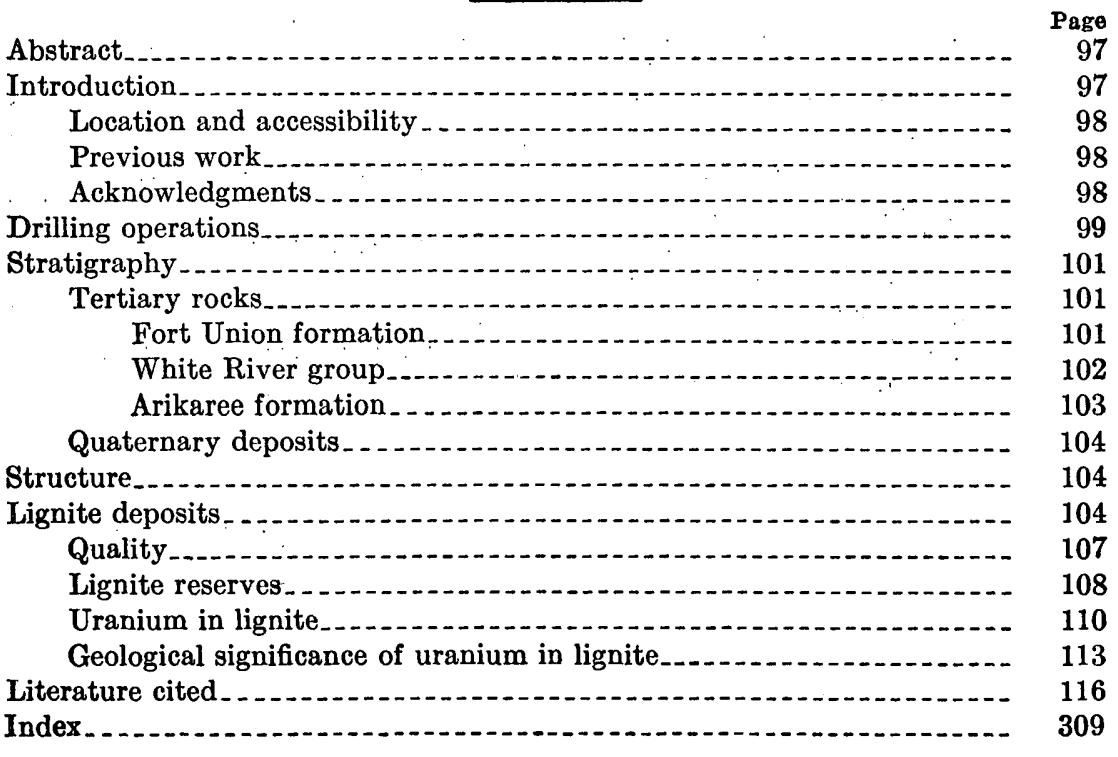

\section{ILLUSTRATIONS}

[Plates are ln ibox]

Puate 22. Geologic map showing location of core holes.

23. Fence diagram showing correlation and thickness of lignite beds.

24. Distribution and concentration of uranium in lignite cores at core holes GS 1-4, and SD 1, 3-8.

25. Distribution and concentration of uranium in lignite cores at core holes GS 18 and'SD 2, 10, 11; 15; 19, 24 and 25 .

26. Distribution and concentration of uranium in lignite cores at core holes GS 16-17, and SD 9A, 12, 14, 16, 20, 23, and 35 .

27. Distribution and concentration of uranium in lignite cores at core holes SD 13, 17, 21, 22, 30-32, and 39.

28. Distribution and concentration of uranium in lignite cores at core holes SD 18A, 26, 28, 29, 33, 36, and 38 .

29. Thickness, grade, and distribution of lignite beds.

Fradre 13. Index map showing location of Mendenhall area

14. Areal distribution, of uranium-bearing lignite

15. Index map showing location of bulk-sample pits and selected core holes

16. Uranium content and thickness of lignite in bulk-sample pits_

17. Areas of potentially strippable uranium-bearing lignite......

18. Radioactivity $\log$ of the Arikaree formation ............... 


\section{TABLES}

TABLE 1. Summary of data for holes drilled in the Mendenhall area...

3. Comparison of analyses of weathered lignite with unweathered lignite from the same bed............ 108

4. Summary of lignite reserves..... 109

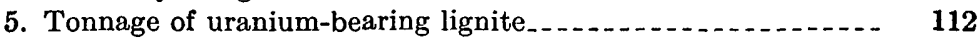

6. Threshold values of elements in semiquantitative spectro-

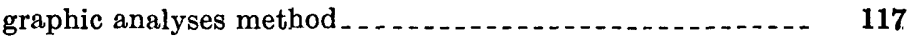

7. Semiquantitative spectrographic analyses and chemical analyses of ash from lignite.......

8. Fuel analyses of lignite cores......

9. Lithologic description's of lignite cores from core holes GS 1-4,

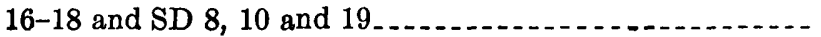




\title{
URANIUM IN COAL IN THE WESTERN UNITED STATES
}

\section{CORE DRILLING FOR URANIUM-BEARING LIGNITE, MEN- DENHALL AREA, HARDING COUNTY, SOUTH DAKOTA}

\author{
By James R. Girl, Howard D. Zhuler, and James M. Schopf
}

\begin{abstract}
Core drilling for data on uranium-bearing lignite in the Mendenhall area, near the center of the Slim Buttes, Harding County, S. Dak., was conducted by the Geological Survey in the summer of 1951 and by the Bureau of Mines during the period October 1952-July 1953. Samples from 49 core holes having a total footage of 11,146 feet, drilled in an area of about 9 square miles, indicate a reserve of about 127 million tons of lignite, of which about 49 million tons contain an average of 0.005 percent uranium or more. The uranium-bearing lignite uverages 5.4 feet in thickness and occurs in the Ludlow member of the Fort Union formation of Paleocene age.

Fuel analyses of about 130 samples indicate that the lignite contains about 15 percent ash, 37 percent moisture, 24 percent fixed carbon, 24 percent volatile matter, and 1.5 percent sulfur and has a heating value of about $5,800 \mathrm{Btu}$ (as received condition).

In the Slim Buttes, exclusive of the Mendenhall area, approximately 60 square miles are underlain by uranium-bearing lignite having an average thickness of five feet and an average uranium content of 0.007 percent or more, and having a potential reserve of 340 million tons of uranium-bearing lignite.

The core samples indicate only the stratigraphically highest lignite bed beneath the unconformity at the base of the Chadron formation of Oligocene age contains appreciable quantities of uranium. Data indicate that the uranium in the lignite is of secondary origin, having been leached and transported by ground water from the mildly radioactive tuffaceous rocks that unconformably overlie the lignite-bearing strata.
\end{abstract}

\section{INTRODUCTION}

Seven core holes were drilled for uranium-bearing lignite in the Mendenhall area, Harding Co., S. Dak., by a contractor for the U. S. Geological Survey during the summer of 1951 ; additional drilling was carried on by the U. S. Bureau of Mines, between October 1952 and July 1953, in the same area under the direction of Glen Walker, Bureau of Mines Mine Examination and Exploration Engineer. Forty-nine holes having a total footage of about 11,146 feet were drilled. Uranium-bearing lignite was found in cores from 38 holes. 


\section{IOCATION AND ACCESSIBIITTY}

The Mendenhall area includes 9 square miles in the central part of the Slim Buttes (fig. 13) in southeastern Harding County, and about 18 miles airline southeast of Buffalo, S. Dak. The west part of the area may be reached from Buffalo by traveling 12 miles east on State Route 8 , then 7 miles south on a county road, and 4 miles east on an unimproved road. The central part of the Mendenhall area, occupying the flat tableland at the top of the Slim Buttes, can best be reached from $J$ B Pass by a Forest Service dirt road that extends north along the crest of the divide for 4 miles. The nearest rail-shipping points are Reeder, N. Dak., 55 miles to the north, and Newell, S. Dak., 70 miles to the south.

\section{PREVIOUS WORK}

The geology and lignite deposits of the Slim Buttes area have been described by Winchester and others (1916), the structural geology in relation to oil and gas by Toepelman (1923), and the general geology by Baker (1952). In 1949, uraniferous lignite was discovered by Beroni and Bauer (written communication, 1952) in the vicinity of Reva Gap, about 4 miles north of the Mendenhall area. The following year, the work of Denson, Bachman, and Zeller (see chapter B, this bulletin) extended the area of known occurrence in the Slim Buttes and elsewhere in the Dakotas. As a result of this work, an exploratory drilling program was started in the Slim Buttes area in 1951.

Concurrently with exploratory drilling a petrographic examination of the uranium-bearing lignite was undertaken by Schopf (Schopf and Gray, 1954) and Koppe (T. F. Bates, written communication, 1952). The geochemistry of the lignite was investigated by I. A. Breger, Maurice Deul and Samuel Rubinstein (1955).

\section{ACKNOWLEDGMENTS}

George W. Moore logged cores and cuttings from the drilling in February 1953 and returned to the area in June to assist in the completion of the geologic studies related to the drilling. Roy C. Kepferle, Murray Levish, and Robert E. Melin joined the project in July and assisted J. R. Gill until its completion in August 1953.

James M. Schopf and other members of the Geological Survey laboratory at Columbus, Ohio, provided detailed descriptions and radioactivity logs of several of the lignite cores (table 9). Chemical analyses, radioactivity measurements, and semiquantitative spectographic determinations were made in the Washington, D. C., and Denver, Colo., laboratories of the Geological Survey (table 7). Proximate and ultimate analyses of lignite cores were made by the U. S. Bureau of Mines (table 8). 


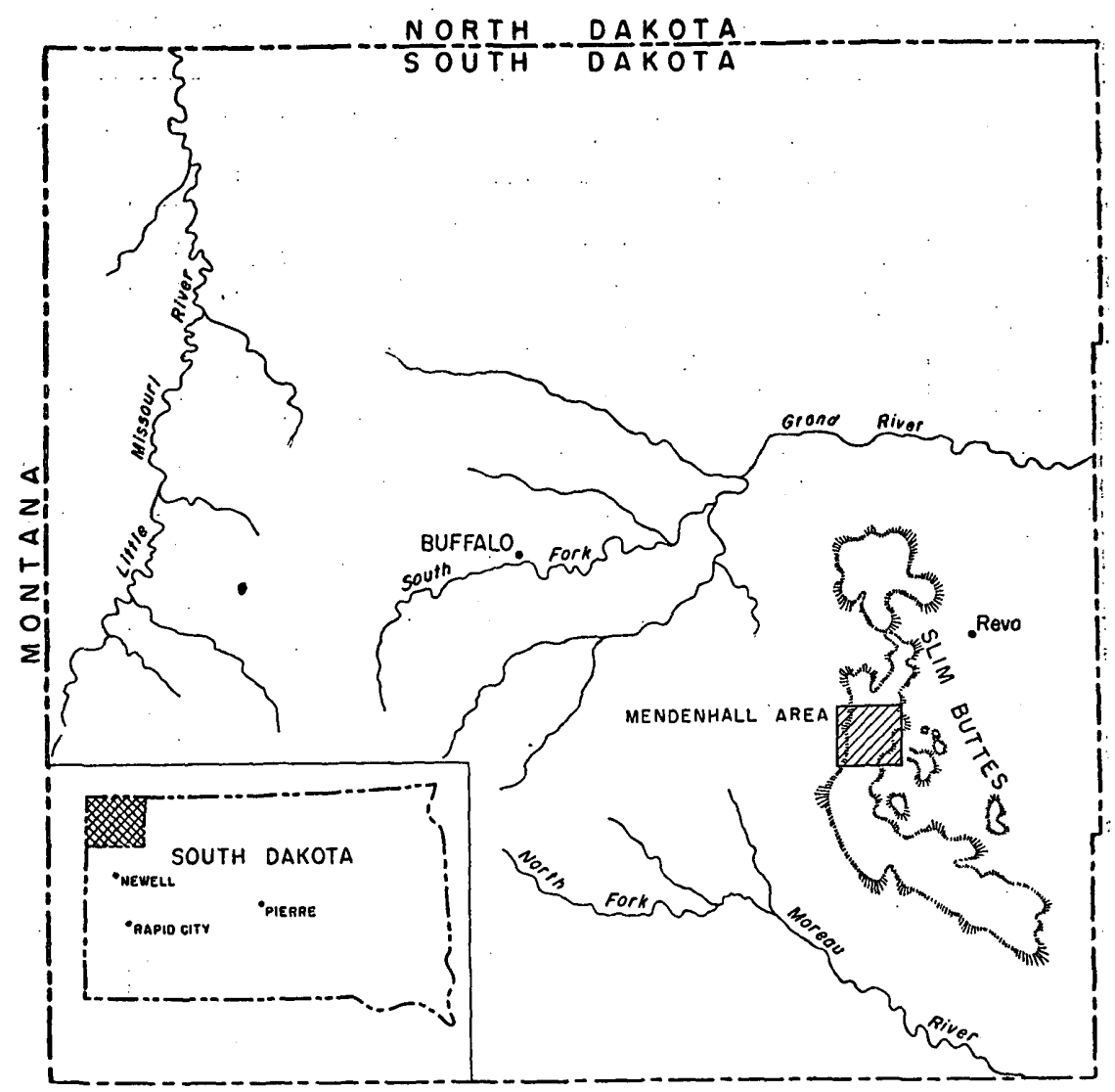

Figure 13.-Index map of Harding County, S. Dak., showing location of the Mendenhall area.

The writers express their appreciation to the local ranchers, particularly Vernon, William, and Esther Wammen, for the many courtesies extended.

\section{DRILLING OPERATIONS}

In the summer of 1951,7 holes totaling 1,464 feet were drilled in the Mendenhall area, by a contractor for the Geological Survey, underthe supervision of H. D. Zeller. The cores from these holes were split and described by James M. Schopf. Information obtained from this. drilling indicated that the lignites in the Slim Buttes were potential sources of uranium and fuel. More extensive drilling exploration foruraniferous lignite in this area (pl. 22) was begun in October 1952 by the U. S. Bureau of Mines in cooperation with the U. S. Geological Survey. Forty-two holes totaling 9,682 feet were drilled. Drilling was completed in July 1953. Table 1 shows the location, surface ele-- 
TABLE 1.-Summary of data for core holes drilled in the Mendenhall area, Harding County, South Dakota

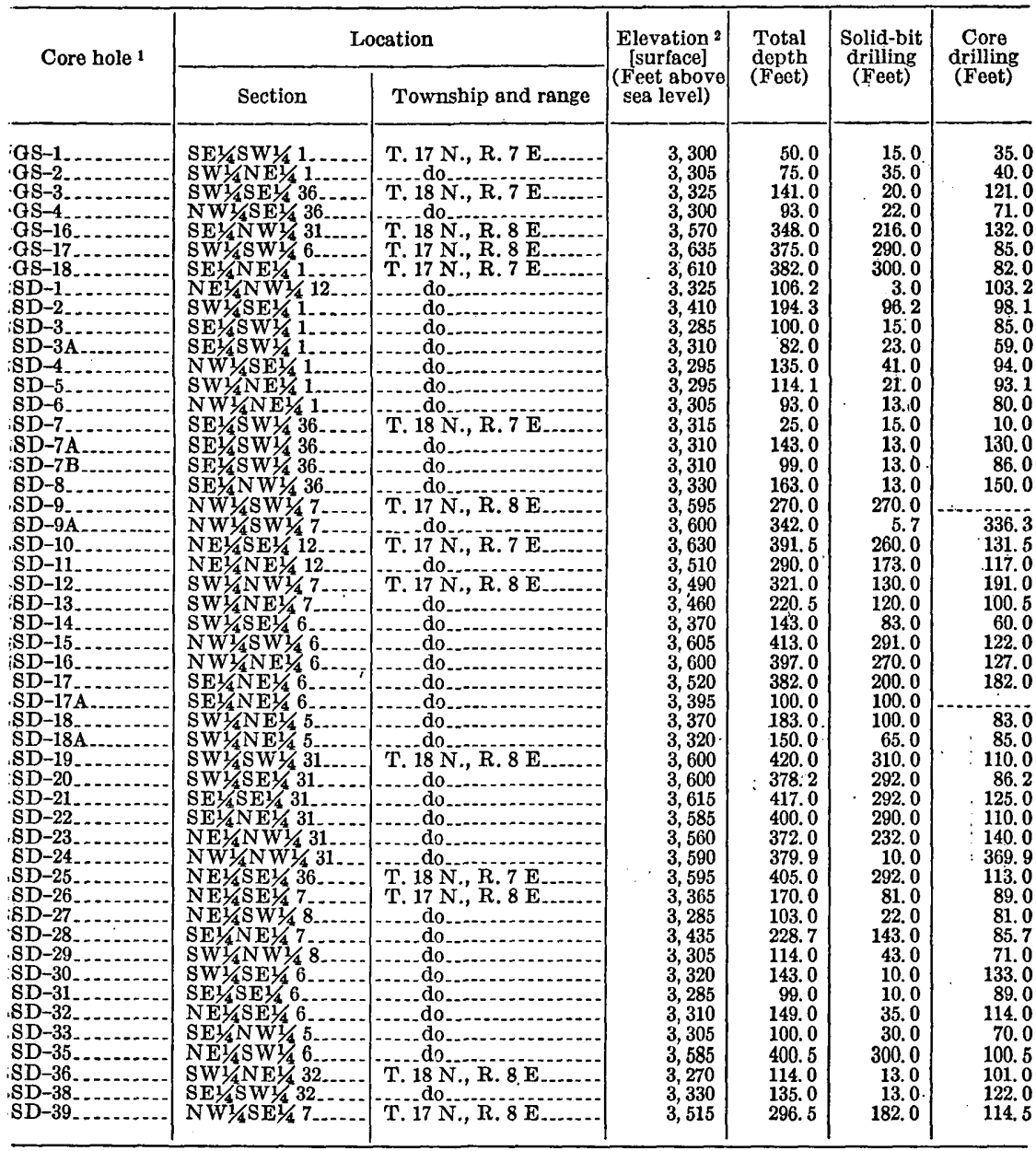

1 Prefix GS denotes core holes drilled for the U. S. Geological Survey in 1951; prefix SD denotes holes drilled by the U. S. Bureau of Mines in 1952-53.

2 Elevations established by single-base altimetry.

vation, total depth, and footage of core and solid-bit drilling done.by the Geological Survey in 1951 and by the Bureau of Mines in 1952-53.

In drilling beds of uranium-bearing lignite, coring was started 20 feet or more above the stratigraphically highest bed of lignite and stopped at a depth of 60 feet below its base. All lignite beds, regardiess of stratigraphic position, were sampled and analyzed. The lignite cores were securely wrapped in waxed paper and sample intervals, approximately one foot in length, for uranium analyses were indicated. Lignite cores from holes $\mathrm{SD}-8,-10$, and -19 were split and described 
by James M. Schopf, with the remaining cores being split at the $\mathrm{Bu}$ reau of Mines laboratory at Grand Forks, N. Dak. Half of the core was forwarded to the Geological Survey laboratories for uranium determination; the other half was used by the Bureau for proximate and ultimate fuel analysis.

In this report the description of the geology of the area drilled includes an interpretation of the geological significance of the distribution of the uranium in the receptor beds, the structure and correlation. of the lignite beds and associated strata, the vertical and areal extent of active aquifiers, and estimates of tonnage of uranium-bearing and' other lignite.

\section{STRATIGRAPHY}

Lignite-bearing strata in the Mendenhall area are of Paleocene age. They are unconformably overlain by beds of bentonitic clay and tuffaceous sandstone of Oligocene and Miocene age and conformably overlie Cretaceous strata. The rocks are all of continental origin, but sedimentation ranged from the deposition of material to form lignite to the deposition of volcanic ash. The sequence of sedimentation was broken by at least two periods of uplift and erosion; one is indicated by the unconformity at the base of rocks of Oligocene age; the other, by the unconformity at the base of rocks of Miocene age.

\section{TERTIARY ROCKS}

\section{FORT UNION FORMATION}

Ludlow member.-The Ludlow member of the Fort Union formation conformably overlies the Hell Creek formation of Cretaceous age. The Ludlow member, the lowermost member of the Fort Union formation, is the only unit of Paleocene age in the Mendenhall area, as it is unconformably overlain by rocks of the Chadron formation of Oligocene age. In the northern part of Harding County, the Ludlow grades: into the marine Cannonball formation and is conformably overlain by the Tongue River member of the Fort Union formation.

Rocks of the Ludlow member include poorly indurated yellowishbrown fine-grained sandstone and siltstone; gray clay shale; and: lignite, in part, uranium bearing. The Ludlow is estimated to beabout 200 feet thick in the Mendenhall area. At the type locality near the Ludlow Post Office (sec. 28, T. 22 N., R. 6 E.), S. Dak., its. thickness is about 350 feet.

The rocks of the Ludlow member are covered at most places by vegetation and by landslide debris from the overlying White River group and Arikaree formation. The lignite beds are traceable for only short distances along the face of the Slim Buttes, but core-hole data indicate that they are the most persistent beds in the Ludlow. 
However, closely spaced surface sections or core holes are necesșary to avoid miscorrelation ( $\mathrm{pl} .23$ ), because they differ considerably in thickness throughout the area and may either diverge or join within short distances. The sandstone, siltstone, and shale are lenticular and are not reliable for correlation (pls. 24-28).

Most of the sandstone and siltstone is poorly consolidated, and attempts to core these rocks were not always successful because the drilling water had a tendency to wash away the core. The lignite was cored with satisfactory core recovery, except in shallow holes where it is weathered. The determination of rock where cores were lost was difficult, as the water return was generally poor and cuttings could not be recovered. For shallow holes, determinations of loss in coring could generally be made by extrapolation from nearby surface exposures or adjacent core holes. Consistent loss of water in uncased holes made the determination of aquifers in the Ludlow member impossible.

The Ludlow member of the Fort Union formation is unconformably overlain by the Chadron formation of Oligocene age. The contact between the two formations is difficult to identify because the uppermost beds of the Ludlow are yellow stained and reworked material of a similar color occurs in the basal few feet of the Chadron.

\section{WHATE RIVER GROUP}

The White River group of Oligocene age is divided into the Chadron and Brule formations. The Chadron formation is present throughout the area, but the Brule formation is preserved only in dropped blocks (pl. 22) that represent landslides occurring before deposition of the overlying Arikaree formation.

Chadron formation. - The Chadron formation of Oligocene age unconformably overlies the Ludlow member of the Fort Union formation. In normal succession the Chadron is conformably overlain by the Brule formation. However, at most places in the Mendenhall area the Brule is absent and the Chadron is unconformably overlain by the Arikaree formation. The basal part of the Chadron formation consists of bright-yellow to dark yellowish-orange sandstone and siltstone reworked from the underlying rocks. The rest of the formation is composed of white fine- to coarse-grained pebbly sandstone and light olive-gray bentonite. Lenticular beds of tuffaceous sandstone and opalized clay are present locally.

The thickness of the Chadron formation ranges from 60 feet in the northeastern part of the area to more than 150 feet in the southwest. Impervious beds of bentonite near or at the top of the formation form the base of a perched water table. Springs issue at the top of these 
beds along the margins of the buttes. In the southern part of the Slim Buttes, carnotite-bearing sandstone has been found at this stratigraphic position (Gill and Moore, 1955). The sandstone and bentonite of the Chadron contain about 0.001 percent uranium, as compared to the average for sandstone of 0.00012 (Rankama and Sahama, 1950). The water from springs that issue from the Chadron formation contains from 10 to 200 parts per billion of uranium.

Brule formation.-The Brule formation of Oligocene age is exposed only as narrow northwest-trending pre-Arikaree landslide blocks in the northeast part of the Mendenhall area. The formation is composed of thin-bedded to massive, pink to tan, sandy, tuffaceous claystone, siltstone, and sandstone, and is similar in lithology and age to the Brule formation as exposed in the Big Badlands of Pennington County, South Dakota. The thickness of the Brule formation ranges from 20 to more than 140 feet, a part of the formation, of unknown thickness, having been eroded:-: .

Valleys more than 300 feet deep were cut into the Brule, Chadron and Ludlow rocks of this area before deposition of the Arikaree formation. After valley cutting, large-scale landsliding occurred, massive blocks of Brule and Chadron rocks sliding into the valleys. These landslide blocks average about 300 yards in width and at many places are several miles long. The trend of the blocks is consistently northwest, with dips toward the plane of movement ranging from $5^{\circ}$ to $30^{\circ}$. The Chadron rocks involved in the slumping are generally highly contorted; the more indurated Brule rocks show little evidence of movement other than having steep uniform dips.

Tuffaceous claystone, siltstone and sandstone of the Brule formation contain on the average about 0.001 percent uranium, and vertebrate fossils from these rocks commonly contain more than 0.01 percent uranium. At many places the fossils are coated with a yellow nonfluorescent uranium:mineral. .

\section{ARIKAREE FORMATION}

The Arikaree formation of Miocene age is composed dominantly of yellowish-gray very fine-grained tuffaceous sandstone. In the Mendenhall area it has a thickness of about 200 feet. The basal 50 feet contains much material reworked from the underlying Brule and Chadron formations and is thin-bedded, in contrast with the more massive upper part. Locally, one or more beds of conglomerate occur at or near the base of the formation. These beds of conglomerate are usually made up of claystone pebbles and cobbles averaging 2 inches in diameter, most of which appear to have been derived from the Brule formation. 
Tuffaceous sandstone of the Arikaree formation forms the caprock and the steep upper cliffs at Slim Buttes. No fossils have been found in the Arikaree formation in the Slim Buttes region. However, Wood (1945) has described a beaver of late Miocene age from similar rocks in southeastern Montana which probably are correlative with the Arikaree formation in the Slim Buttes.

Rocks of the Arikaree formation, as well as those of the Chadron and Brule formations, contain an average of about 0.001 percent. uranium. It is thought that this uranium is in the volcanic material which composes the greater part of the formation.

\section{QUATERNARY DEPOSITS}

Deposits of probable Pleistocene age consist of (1) alluvial fans. extending outward from the bases of cliffs, (2) terraces along stream valleys, and (3) landslide material. Many of these deposits are similar in appearance to rocks in the White River group because much of their material was derived from those rocks. The terrace deposits have relatively flat upper surfaces, but recent erosion has cut into these surfaces at many places, leaving the deposits as isolated "tables." These deposits were not mapped. Landslides are extensive around the periphery of the Slim Buttes. The landslide blocks and masses are made up largely of Arikaree and White River rocks but at a few places may contain rocks of the Ludlow member of the Fort Union formation.

\section{STRUCTURE}

The broad regional structure of the Ludlow member of the Fort Union formation is that of a gentle homocline that dips about $1^{\circ}$ to the northeast into the Williston basin. Structure contours on the top of the upper bench of the Olesrud lignite bed in the Mendenhall area show the presence of minor structures that are alined normal to the regional dip (pl. 22). These minor structures are small anticlines and synclines, the axes of which strike northeast. The Arikaree formation is essentially horizontal, as are the Chadron and Brule formations except where they form landslide blocks.

\section{LIGNITE DEPOSITS}

The Mendenhall area is underlain by four important lignite seams in the Ludlow member of the Fort Union formation. From top to bottom these are the Mendenhall rider lignite bed, the Mendenhall lignite bed, and the upper and lower benches of the Olesrud lignite bed. The lignite beds dip gently to the north and are truncated by rocks of the overlying Chadron formation. Therefore, the areal extent of the stratigraphically highest bed, the Mendenhall rider bed, is 
confined to the northern one-third of the area, the Mendenhall bed underlies the northern half of the area, and the upper and lower benches of the Olesrud bed underlie all of the area (fig. 14). Each bed is uranium bearing; however, only where it is the stratigraphically highest bed. Two beds occur below the lower bench of the Olesrud and are here designated the $Y$ and $Z$ lignite beds (pls. 24-28). They are present throughout much of the area, and at a few places are as much as 2.5 feet thick. In hole SD-6 (fig. 24) where the lignite beds are close together, lignite constitutes 30 feet of a stratigraphic interval of 34 feet.

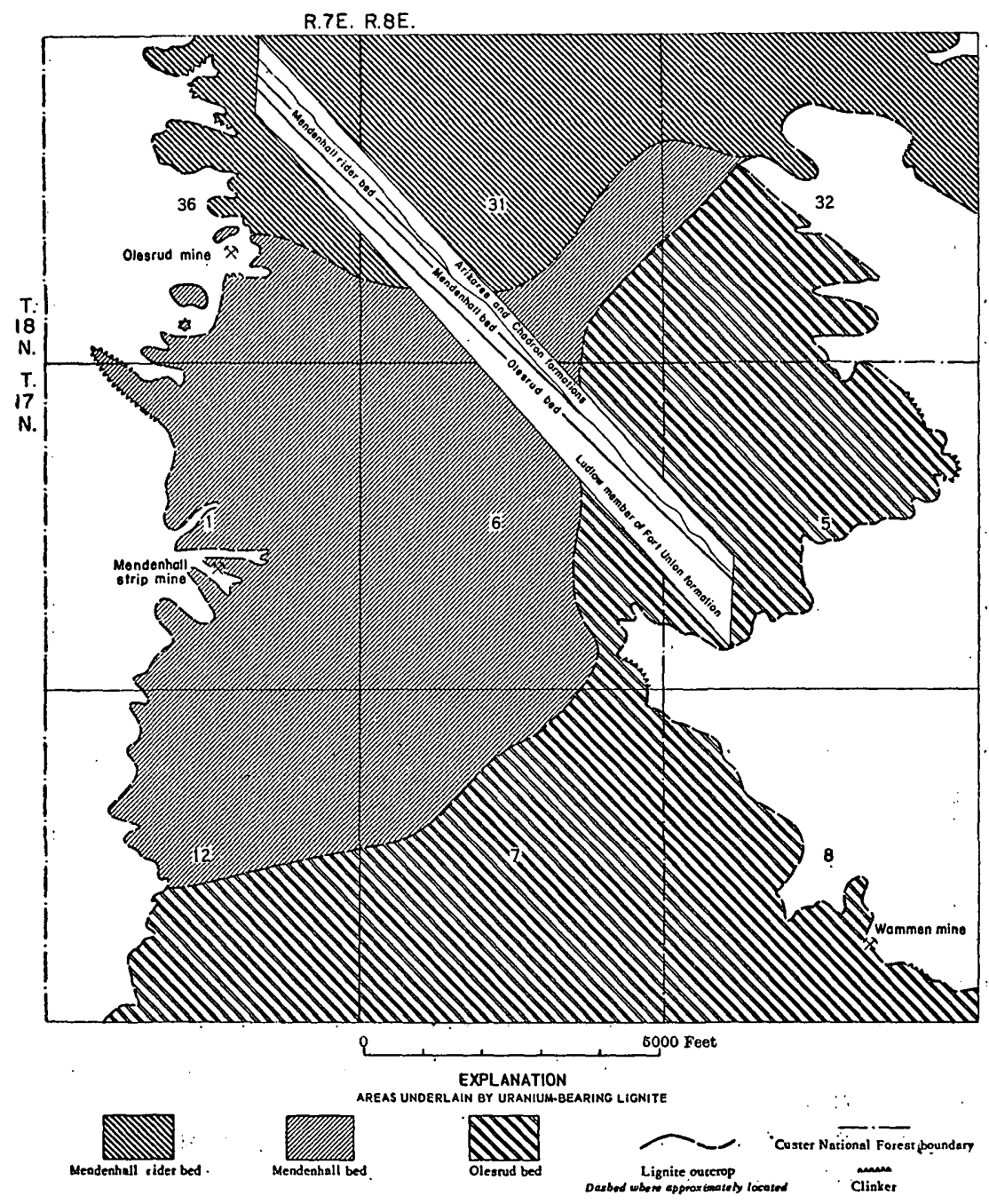

Figure 14.- Sketch map showing areal distribution of uranium-bearing lignite in the Mendenhall area; Slim Buttes, Harding County, S. Dak. 
The lignites of the Mendenhall area are dominantly banded coals. The banding is primarily a function of the occurrence of elongate lenses of large fragments of woody trunks and roots of ancient plants. In describing: (see table 9) banded coals the important features are (1) the thickness of bands, and (2) the frequency of occurrence of these bands. Thickness and frequency are described using the terms according to the following definitions:

(1) Thickness of woody bands ${ }^{1}$ Thin bands_- about $1 / 50-1 / 12$ inch (0.5$2.0 \mathrm{~mm}$ )

Medium bands_- about $1 / 12-1 / 6$ inch $(2.0-5.0 \mathrm{~mm})$

Thick bands_- about $1 / 5-2$ inches (5.0$50.0 \mathrm{~mm}$ )

Very thick bands_- more than 2 inches (more than $50.0 \mathrm{~mm}$ )
(2) Frequency of occurrence (percentage of the layer)

Sparse

Moderate-_-_-_-_-_---- 15-30 percent Abundant_._._._._-_-_- 30-60 percent

Dominant_._-_--- more than 60 percent

1 Woody bands less than about 350 inch $(0.5 \mathrm{~mm})$ thick are regarded as a part of attrital coal.

The lithologic description of lignite cores (table 9) and the selection of samples for uranium and semiquantitative spectrographic analyses (TE) and for fuel analyses were made at the Geological Survey läboratory at Columbus, Ohio, under the direction of James $\mathbf{M}$. Schopf. Chemical determination of percent uranium and semiquantitative spectrographic analysis for other elements in the lignite (table 7) was made by the U. S. Geological Survey, and the proximate and ultimate fuel analysis by the U. S. Bureau of Mines at Pittsburgh, Pa.

Cores were sawed to include about one-fourth the volume of the core in samples for chemical and semiquantitative spectrographic analyses. A similar quadrant of the coal in the core constituted the Bureau of Mines sample for fuel analysis of the lignite. The remainder of the core was reserved for the preparation of thin sections and for more detailed study of radioactive-material distribution in lignite constituents.

Semiquantitative spectrographic determinations were made of the ash of lignite and carbonaceous shale to determine vertical distribution and possible relationship of uranium to other trace metals. Preliminary study of spectrographic data indicates that only molybdenum shows consistent relationship to uranium. In samples of lignite ash with a large uranium content the molybdenum content is large and in samples of small uranium content the molybdenum content is small.

Table 7 lists semiquantitative spectrographic analyses of ash of lignite and carbonaceous shale from cores and bulk-sample pits. The minimum amounts of elements detectable with semiquantitative spectrographic methods are listed in table 6. 
In conjunction with petrographic work on the lignite, the staff of the coal geology laboratory made a preliminary investigation of the plant microfossil assemblages. Their work indicates a distinctive group of plant spores and pollen is present in the lower bench of the Olesrud lignite bed and helps confirm correlations made in the field:

\section{QUALITY}

The lignite of the Mendenhall area is dark brown to black and has a dull luster on a fresh surface. On exposure to air the lignite loses moisture and slacks in a short time. Weathering also results in a change in luster from dull to vitreous. A detailed study of the various lignite constituents and their relationship to uranium was undertaken by the Geological Survey's coal geology laboratory (Schopf and Gray, 1954).

A total of 135 samples of lignite from the six beds in Mendenhall area were submitted to the U.S. Bureau of Mines for proximate and ultimate fuel analyses (table 8). Proximate and ultimate analyses for each bed have been averaged and are summarized in table 2 . Five samples of lignite from Mendenhall rider lignite bed, E-32880, E-24658, E-24659, D-68859, and D-68860, were excluded from these averages because the lignite in these samples obviously was weathered; analyses of these samples show ash contents that are greater than in unweathered lignite and Btu measurements that are smaller.

TABLE 2.-Average fuel analyses, in percent, of lignite 1 beds cored in the Mendenhail area

\begin{tabular}{|c|c|c|c|c|c|c|c|c|}
\hline Bed & . & Moisture & \multicolumn{2}{|c|}{$\begin{array}{l}\text { Volatile } \\
\text { matter }\end{array}$} & $\begin{array}{c}\text { Fixed } \\
\text { carbon }\end{array}$ & Ash. & $\begin{array}{c}\text { Heating } \\
\text { value } \\
\text { (Btu) }\end{array}$ & $\begin{array}{l}\text { Number } \\
\text { of } \\
\text { samples }\end{array}$ \\
\hline $\begin{array}{l}\text { Mendenhall rider lignite bed } \\
\text { Mendenhall lignite bed } \\
\text { Olesrud lignite bed (upper bench) } \\
\text { Olesrud lighite bed (lower bench) } \\
Y \text { lignite bed } \\
Z \text { lignite bed. }\end{array}$ & (n) & $\begin{array}{l}36 . \\
37 . \\
34 . \\
36 . \\
33 . \\
35 .\end{array}$ & : & $\begin{array}{l}4 \\
3 \\
3 \\
\text { 3. } \\
\text { 3. } \\
\text { 3. } \\
7\end{array}$ & $\begin{array}{l}24.3 \\
26.7 \\
25.7 \\
25.6 \\
26.0 \\
27.0\end{array}$ & $\begin{array}{l}14.3 \\
12.3 \\
15.9 \\
14.0 \\
17.3 \\
13.6\end{array}$ & $\begin{array}{l}5,590 \\
5,870 \\
5,930 \\
5,630 \\
5,830 \\
5,990\end{array}$ & $\begin{array}{l}25 \\
33 \\
38 \\
29 \\
11 \\
11\end{array}$ \\
\hline \multicolumn{9}{|c|}{ Ultimate analyses } \\
\hline Bed & $\underset{\text { gen }}{\text { Hydro- }}$ & $\begin{array}{l}\text { Car- } \\
\text { bon }\end{array}$ & $\begin{array}{l}\text { Nitro- } \\
\text { gen }\end{array}$ & $\begin{array}{l}\text { Ox } \\
\text { ger }\end{array}$ & Sulfur & Ash & $\begin{array}{l}\text { Ash sof- } \\
\text { tening } \\
\text { tempera- } \\
\text { ture }\left({ }^{\circ} \mathrm{F}\right)\end{array}$ & $\begin{array}{c}\text { Number } \\
\text { of } \\
\text { samples }\end{array}$ \\
\hline $\begin{array}{l}\text { Mendenhall rider lignite bed } \\
\text { Mendenhall lignite bed } \\
\text { Olesrud lignite bed (upper bench) } \\
\text { Olesrud lignite bed (lower bench) } \\
Y \text { lignite bed. } \\
Z \text { lignite bed. }\end{array}$ & $\begin{array}{l}5.8 \\
6.1 \\
5.9 \\
6.3 \\
5.9 \\
6.1\end{array}$ & $\begin{array}{l}30.9 \\
35.4 \\
34.8 \\
33.4 \\
34.4 \\
35.9\end{array}$ & $\begin{array}{r}0.4 \\
\therefore \quad .4 \\
\therefore \quad .4 \\
.4 \\
.4 \\
.5\end{array}$ & $\begin{array}{r}43 \\
42 \\
.41 \\
.43 \\
39 \\
41\end{array}$ & \begin{tabular}{r|r}
.1 & 1.7 \\
.3 & 1.9 \\
.6 & 1.1 \\
.2 & 1.6 \\
.8 & 1.4 \\
.7 & 1.5
\end{tabular} & $\begin{array}{l}18.1 \\
13.9 \\
16: 2 \\
15.1 \\
18.1 \\
14.3\end{array}$ & $\begin{array}{r}2,180 \\
1,990 \\
\quad 2,060 \\
2,150 \\
2,140 \\
i \quad 2,080\end{array}$ & $\begin{array}{l}34 \\
28 \\
10 \\
10\end{array}$ \\
\hline
\end{tabular}

\footnotetext{
1 Analyses are on samples of lignite in the "as received" condition.

2 Samples E-32880, E-24658, E-24659, D-68859 and D-68860 were excluded from the average because the lignite in these samples was highly weathered.
} 
The Bureau of Mines analyses show that the lignite samples of the six beds in the Mendenhall area range from 35 to 38 percent in moisture content, 14 to 18 percent in ash, 20 to 27 percent in fixed carbon, and 1.4 to 1.9 percent in sulfur, with heating values ranging from 4,480 to $5,930 \mathrm{Btu}$. These are based on the "as received" condition.

Concurrently with drilling operations in the Mendenhall area, the Bureau of Mines collected five 5-ton bulk samples of lignite to test for ash and heating qualities. Location and graphic logs of Bureau of Mines sample pits are shown in figures 15 and 16 . Table 3 shows the comparison between analyses of weathered lignite from sample pits with unweathered lignite from the same bed reached by nearby core holes.

TABLE 3.-Comparison of fuel analyses, in percent, of samples ${ }^{1}$ of weathered lignite

$(A)$ with those of unweathered lignite $(B)$ from the same bed

[Weathered-lignite (A) samples are from U. S. Bureau of Mines bulk-sample pits, unweathered-lignite (B) samples are from nearby core holes]

\begin{tabular}{|c|c|c|c|c|c|c|c|c|c|c|}
\hline & \multicolumn{4}{|c|}{ Mendenhall bed } & \multicolumn{2}{|c|}{$\begin{array}{l}\text { Mendenhall } \\
\text { rider bed }\end{array}$} & \multicolumn{4}{|c|}{ Olesrud bed (upper bench) } \\
\hline & $\mathbf{A}$ & $\mathbf{B}$ & A & $\mathbf{B}$ & A & $\mathbf{B}$ & A & $\mathbf{B}$ & A & $\mathbf{B}$ \\
\hline & $|\mathrm{USBM}-1|$ & $\mathrm{SD}-1$ & USBM-2 & $|\mathrm{SD}-4|$ & USBM-3 & $\mid \mathrm{SD}-8$ & $|\mathrm{USBM}-4|$ & $|\operatorname{si}-33|$ & $\mid$ OSBM-5 & $\mathrm{SD}-27$ \\
\hline \multicolumn{11}{|c|}{ Proximate analysees } \\
\hline $\begin{array}{l}\text { Moisture } \\
\text { Volatile matter. } \\
\text { Fixed carbon } \\
\text { Ash............. }\end{array}$ & $\begin{array}{l}44.3 \\
24.3 \\
12.5 \\
18.9\end{array}$ & $\begin{array}{l}36.3 \\
23.6 \\
30.0 \\
10.1\end{array}$ & $\begin{array}{l}45.1 \\
25.5 \\
14.5 \\
14.9\end{array}$ & $\begin{array}{l}24.9 \\
26.0 \\
35.4 \\
13.7\end{array}$ & $\begin{array}{l}43.9 \\
24.2 \\
18.3 \\
13.6\end{array}$ & $\begin{array}{r}39.0 \\
25.5 \\
29.5 \\
6.0\end{array}$ & $\begin{array}{l}49.0 \\
19.0 \\
16.0 \\
16.0\end{array}$ & $\begin{array}{l}34.6 \\
24.0 \\
25.4 \\
16.0\end{array}$ & $\begin{array}{l}45.8 \\
20.8 \\
15.6 \\
17.8\end{array}$ & $\begin{array}{l}35.8 \\
23.7 \\
25.5 \\
15.0\end{array}$ \\
\hline \multicolumn{11}{|c|}{ Ultimate analyses } \\
\hline $\begin{array}{l}\text { Hydrogen } \\
\text { Carbon. } \\
\text { Nitrogen } \\
\text { Oxygen } \\
\text { Sulfur } \\
\text { Ash } \\
\text { Btu.... }\end{array}$ & $\begin{array}{r}6.1 \\
22.0 \\
.4 \\
50.7 \\
1.9 \\
18.9 \\
3,110\end{array}$ & $\begin{array}{r}6.2 \\
36.7 \\
.4 \\
44.4 \\
2.2 \\
10.1 \\
6,120\end{array}$ & $\begin{array}{r}6.2 \\
23.8 \\
.4 \\
52.6 \\
2.1 \\
14.9 \\
3,370\end{array}$ & $\begin{array}{r}5.5 \\
43.8 \\
.6 \\
34.6 \\
1.8 \\
13.7 \\
7,450\end{array}$ & $\begin{array}{r}6.2 \\
26.4 \\
51.7 \\
1.7 \\
13.6 \\
3,920\end{array}$ & $\begin{array}{r}6.9 \\
39.2 \\
.5 \\
46.4 \\
1.0 \\
6.0 \\
6,510\end{array}$ & $\begin{array}{r}6.7 \\
23.2 \\
.5 \\
53.3 \\
.3 \\
16.0 \\
3,480\end{array}$ & $\begin{array}{r}6.0 \\
33.0 \\
.5 \\
42.5 \\
1.1 \\
16.0 \\
5,430\end{array}$ & $\begin{array}{r}6.3 \\
23.0 \\
.5 \\
51.6 \\
17.8 \\
3,420\end{array}$ & $\begin{array}{r}6.2 \\
34.0 \\
.4 \\
43.6 \\
.8 \\
15.0 \\
5,590\end{array}$ \\
\hline
\end{tabular}

1 "As received" condition.

\section{LIGNITE RESERVES}

In estimating the reserves of lignite in the Mendenhall area the authors have used the coal-reserve estimation procedures of the U.S. Geological Survey (Averitt and Berryhill, 1950). Maps showing thickness and distribution of the four mineable lignite beds in the area are shown on plate $29, A, B, C$, and $D$. The continuity of the lignite beds and close spacing of core holes indicate that the computed 
tonnage is probably accurate to within 20 percent. A summary of lignite reserves for each of the four beds is given in table 4 below.

TABLE 4,-Summary of lignite reserves, Mendenhall area, Harding County, S. Dak.

\begin{tabular}{|c|c|c|c|}
\hline Bed & $\begin{array}{l}\text { Average } \\
\text { thickness } \\
\text { (ft) }\end{array}$ & $\begin{array}{c}\text { Area } \\
\text { (acres) }\end{array}$ & $\begin{array}{c}\text { Lignito } 1 \\
\text { (short tons) }\end{array}$ \\
\hline Mendenhall rider bed............ & 5. $3\left\{\begin{array}{r}3.3 \\
8.1 \\
11.0\end{array}\right.$ & $\begin{array}{l}140 \\
275 \\
165\end{array}$ & $\begin{array}{r}808,000 \\
3,898,000 \\
3,177,000\end{array}$ \\
\hline Total & $-\ldots \ldots \ldots+\ldots$ & 580 & $7,883,000$ \\
\hline Mendenhall bed.............. & 8. $5\left\{\begin{array}{r}3.8 \\
7.3 \\
12.2\end{array}\right.$ & $\begin{array}{r}220 \\
1,210 \\
705\end{array}$ & $\begin{array}{r}1,463,000 \\
15,458,000 \\
15,052,000\end{array}$ \\
\hline Total & - & 2,135 & $31,973,000$ \\
\hline Olesrud bed (upper bench) & $6.8\left\{\begin{array}{r}4.0 \\
7.4 \\
12.4\end{array}\right.$ & $\begin{array}{r}730 \\
3,110 \\
45\end{array}$ & $\begin{array}{r}5,110,000 \\
40,858,000 \\
976,000\end{array}$ \\
\hline 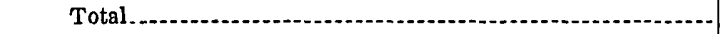 & - & 3,885 & $46.944,000$ \\
\hline Olesrud bed (lower bench) & 5. $7\left\{\begin{array}{l}3.8 \\
6.7\end{array}\right.$ & $\begin{array}{l}1,320 \\
2,705\end{array}$ & $\begin{array}{r}8,778,000 \\
31,716,000\end{array}$ \\
\hline Grand total & -........... & 4,025 & $40,494,000$ \\
\hline Grand total & & & $127,294,000$ \\
\hline
\end{tabular}

1 Calculations based on 1,750 sbort tons per acre foot-net result rounded to nearest 1,000 tons.

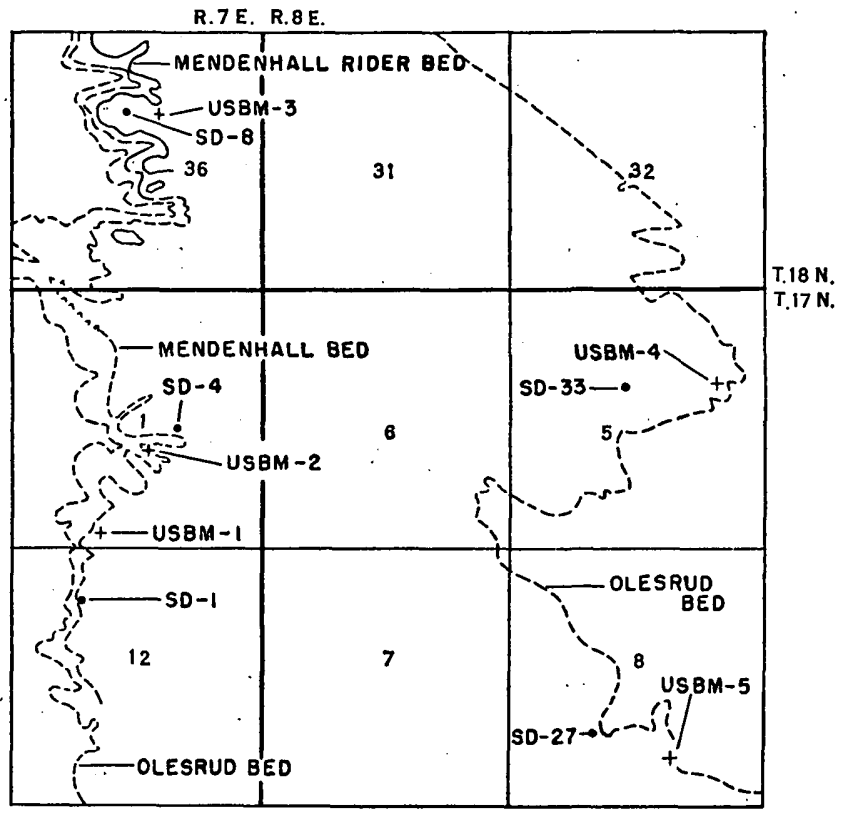

Figdre 15.-Index map showing location of United States Bureau of Mines bulk-sample pits and selected core holes. 


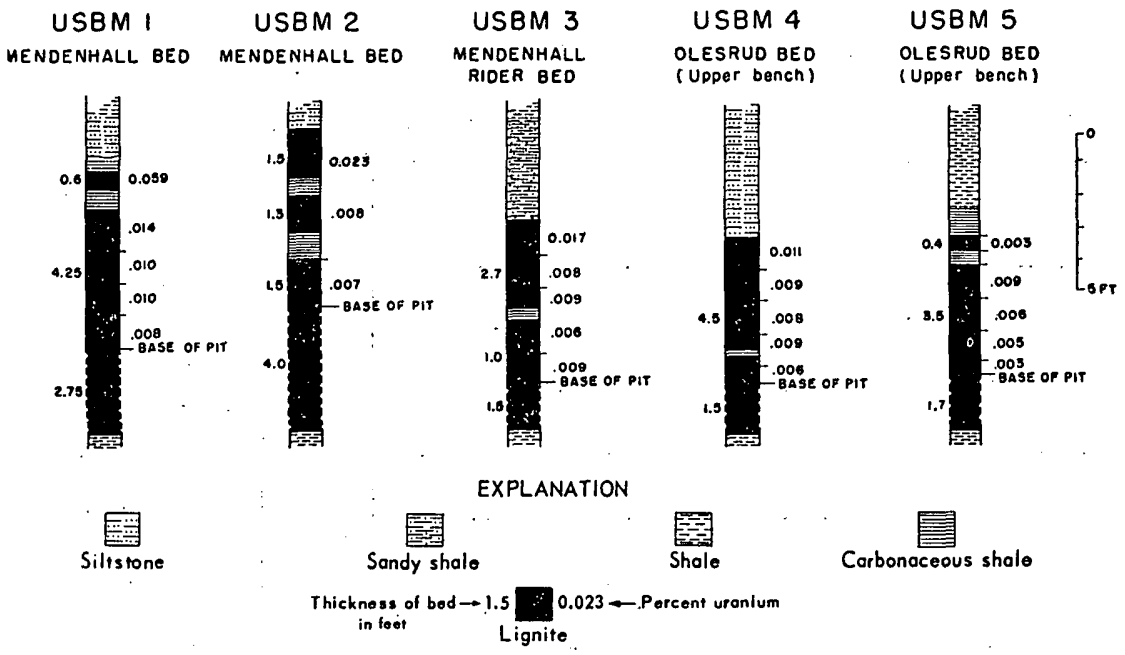

FIGURB 16.-Graphic logs showing uranium content and thickness of lignite in United States Bureau of Mines bulk sample pits.

\section{URANIUM IN LIGNITE}

The Mendenhall area is underlain by three beds of uranium-bearing lignite; they are, going downward in stratigraphic position, the Mendenhall rider bed, the Mendenhall bed, and the upper bench of the Olesrud bed. In most-localities, the lignite nearest the base of the Chadron formation is the only lignite that contains much uranium (see pl. 29, $E, F, G$, and $H$, cross section). In the northern part of the area the Mendenhall rider bed, the stratigraphically highest lignite bed, occupies this position; in the central part of the area it is the Mendenhall bed. Although the upper bench of the Olesrud underlies all of the area, it is uranium bearing only in the southern part, where the Mendenhall rider and Mendenhall bed have been removed by erosion prior to the deposition of the overlying Chadron formation. Similarly the Mendenhall bed is uranium bearing only in the central part where the Mendenhall rider has been removed by erosion. Correlation of the lignite beds in the drill holes and the relationship of the beds to the unconformity at the base of the Chadron are shown in the correlation charts (pls. 24-28) and fence diagram (pl. 23).

In estimating the amount of uranium-bearing lignite, five categories showing different amounts of uranium in the lignite and in the ash of the lignite were used. Although the extent and thickness of the lignite beds are accurately known the uranium content is variable and the estimates of uranium content are only roughly approximate. These 
estimates are given in table 5. A thickness-of-overburden map (fig. 17) shows that an area of 680 acres is overlain by 60 feet or less of overburden.

In the Slim Buttes it is conservatively estimated that 60 square miles are underlain by uranium-bearing lignite beds that have an

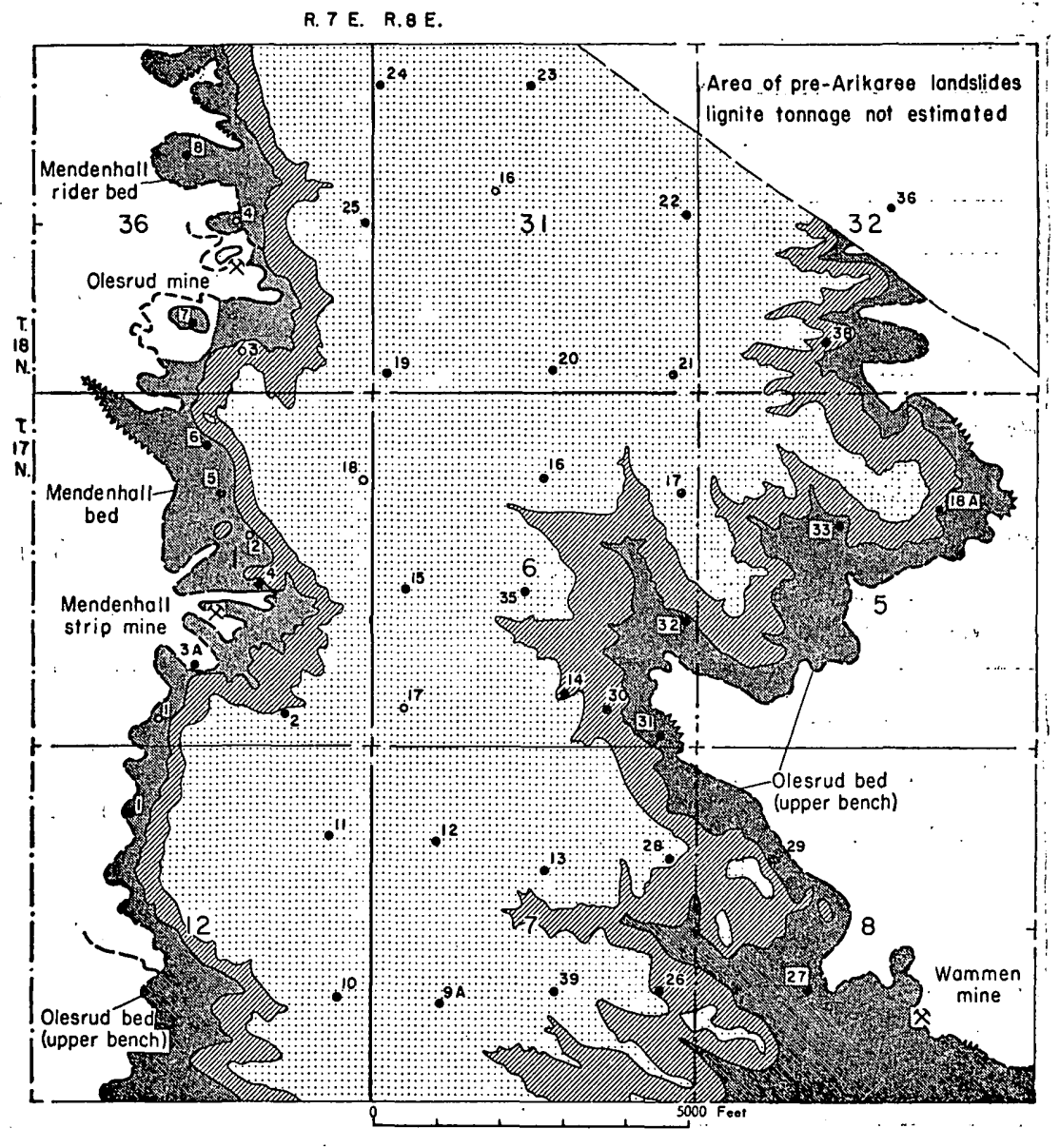

EXPLANATION

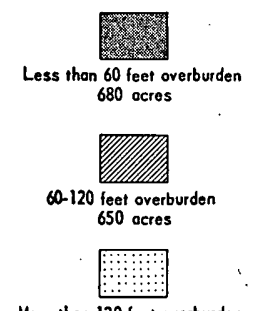

More than 120 feet overburden

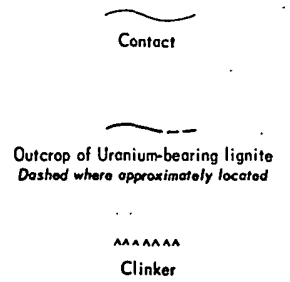

Core hole 1951

.5

Core hole 1952.53

Figure 17.-Map showing areas of potentially strippable uranium-bearing lignite in the Mendenhall area, Slim Buttes, Harding County, s. Dak. . 
average thickness of 5 feet and a uranium content of 0.007 percent. Therefore, the Slim Buttes, exclusive of the Mendenhall area, perhaps is underlain by about 300 million tons of lignite that contains a few thousandths to a few hundredths percent uranium. These large lowgrade concentrations of uranium might be of future interest as a pos-

TABLE 5.-Estimates of tonnage of uranium-bearing lignite and approximate uranium content of the lignite in the Mendenhall area, Harding County, S. Dak.

\begin{tabular}{|c|c|c|c|c|c|}
\hline Bed & $\begin{array}{c}\text { Averages } \\
\text { thickness } \\
\text { (ft) }\end{array}$ & $\begin{array}{l}\text { Extent } \\
\text { (acres) }\end{array}$ & $\begin{array}{l}\text { Uranium } \\
\text { (percent) }\end{array}$ & $\underset{\text { (percent) }}{\text { Ash }}$ & $\begin{array}{c}\text { Lignite } t \\
\text { (short } \\
\text { tonș) }\end{array}$ \\
\hline \multicolumn{6}{|c|}{ Lignite containing at least 0.005 percent uranium } \\
\hline Mendenhall rider & 4. $9\left\{\begin{array}{r}3.4 \\
6.9 \\
10.6\end{array}\right.$ & $\begin{array}{r}340 \\
235 \\
10\end{array}$ & $\left.\begin{array}{r}0.015 \\
.007 \\
.012\end{array}\right\} 0.012$ & & $\left\{\begin{array}{r}2,023,000 \\
2,837,000 \\
186,000\end{array}\right.$ \\
\hline Total & - & 585 & 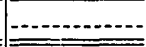 & $\cdots$ & $5,046,000$ \\
\hline \multirow{2}{*}{$\begin{array}{l}\text { Mendenhall } \\
\vdots \\
\vdots\end{array} \quad$ Total } & $6.1\left\{\begin{array}{r}4.2 \\
7.1 \\
11.0\end{array}\right.$ & $\begin{array}{r}465 \\
645 \\
40\end{array}$ & $\left.\begin{array}{l}.005 \\
.008 \\
.008\end{array}\right\} .007$ & - & $\left\{\begin{array}{r}3,418,000 \\
8,014,000 \\
770,000\end{array}\right.$ \\
\hline & 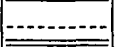 & 1,150 & $-\cdots$ & & $12,202.000$ \\
\hline \multirow[t]{2}{*}{ Olesrud (upper bench) } & $5.2\left\{\begin{array}{l}3.9 \\
6.3\end{array}\right.$ & $\begin{array}{l}635 \\
770 \\
\end{array}$ & $.008\} .007$ & -- & $\left\{\begin{array}{l}4,334,000 \\
8,489,000\end{array}\right.$ \\
\hline & $\ldots$ & 1,405 & -.... & $\cdots$ & $12,823,000$ \\
\hline Grand total. & $\cdots$ & 3,140 & -... & $-\cdots$ & $30,071,000$ \\
\hline \multicolumn{6}{|c|}{ Lignite containing at least 0.010 percent urạium } \\
\hline \multirow{2}{*}{$\begin{array}{l}\text { Mendenball rider } \\
\vdots \\
\vdots\end{array} \quad$ Total. } & 5. $6\left\{\begin{array}{r}3.1 \\
8.0 \\
10.6\end{array}\right.$ & $\begin{array}{l}60 \\
45 \\
10\end{array}$ & $\left.\begin{array}{r}0.025 \\
.010 \\
.012\end{array}\right\} 0.018$ & & $\left\{\begin{array}{l}325,000 \\
630.000 \\
186,000\end{array}\right.$ \\
\hline & - & 115 & . & $\ldots$ & $1,141,000$ \\
\hline \multirow{3}{*}{$\begin{array}{l}\text { Mendenball... } \\
\text { Total } \\
\text { Olesrud }\end{array}$} & 4.5 $\left\{\begin{array}{r}3.5 \\
7.2 \\
10.5\end{array}\right.$ & $\begin{array}{r}390 \\
130 \\
10 \\
\end{array}$ & $\left.\begin{array}{r}0.010 \\
.010 \\
.010\end{array}\right\} 0.010$ & & $\left\{\begin{array}{r}2,389.000 \\
1,638.000 \\
184,000\end{array}\right.$ \\
\hline & - & 530 & .................. & $\ldots$ & $4,211,000$ \\
\hline & 3.3 & 795 & .010 & & $4,591,000$ \\
\hline Grand total. . & $\ldots-$ & 1,440 & & & $9,843,000$ \\
\hline
\end{tabular}

Lignite furnishing ash containing at least 0.030 percent uranium

\begin{tabular}{|c|c|c|c|c|c|}
\hline Mendenhall rider & 6. $1\left\{\begin{array}{r}3.3 \\
7.9 \\
10.6\end{array}\right.$ & $\begin{array}{r}140 \\
190 \\
10\end{array}$ & {$\left[\begin{array}{c}0.054 \\
.030 \\
.128\end{array}\right\} 0.042$} & $\left\{\begin{array}{rl}29 . & 0 \\
23 . & 0 \\
9.4 & 4\end{array}\right\} 2.1$ & {$\left[\begin{array}{r}809.000 \\
2,627,000 \\
185,000\end{array}\right.$} \\
\hline Total. & & 340 &.- & & $3,621,000$ \\
\hline Mendenhall... & $6.1\left\{\begin{array}{r}4.0 \\
6.7 \\
10.9\end{array}\right.$ & $\begin{array}{r}370 \\
690 \\
50\end{array}$ & $\left.\begin{array}{l}.036 \\
.043 \\
.047\end{array}\right\} .041$ & $\left\{\begin{array}{l}16.7 \\
16.6 \\
15.9\end{array}\right\} 16.6$ & $\left\{\begin{array}{r}2,590.000 \\
8,090.000 \\
954,000\end{array}\right.$ \\
\hline Total. & -- & 1,110 & 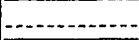 & - & $11,634,000$ \\
\hline Olesrud (upper bench) & 5. $0\left\{\begin{array}{l}3.8 \\
6.6\end{array}\right.$ & $\begin{array}{l}770 \\
560\end{array}$ & $.049\} .046$ & $\left\{\begin{array}{l}18.6 \\
17.3\end{array}\right\} 18.0$ & $\left\{\begin{array}{l}5,120,000 \\
6,468,000\end{array}\right.$ \\
\hline Total & -........... & 1,330 & - & $\therefore \ldots$ & $11,588,000$ \\
\hline Grand total. & $--\cdot$ & 2,780 & & & $26,843,000$ \\
\hline
\end{tabular}

Footnote on p. 113. 
TABLE 5.-Estimates of tonnage of uranium-bearing lignite and approximate uranium content of the lignite in the Mendenhall area, -Harding County, S. Dak.Continued

\begin{tabular}{c|c|c|c|c|c|c}
\hline$-\quad$ Bed & $\begin{array}{c}\text { Average } \\
\text { thickness } \\
\text { (it) }\end{array}$ & $\begin{array}{c}\text { Extent } \\
\text { (acres) }\end{array}$ & $\begin{array}{l}\text { Uranium } \\
\text { (percent) }\end{array}$ & $\begin{array}{c}\text { Ash } \\
\text { (percent) }\end{array}$ & $\begin{array}{c}\text { Lignite 1 : } \\
\text { (short } \\
\text { tons) }\end{array}$ \\
\hline
\end{tabular}

Lignite furnishing ash containing at least 0.050 percent uranium

\begin{tabular}{|c|c|c|c|c|c|}
\hline 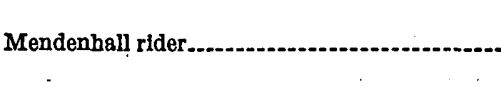 & 4.0 $\begin{array}{r}3.3 \\
7.5 \\
10.6\end{array}$ & $\begin{array}{r}165 \\
15 \\
10\end{array}$ & $\left.\begin{array}{c}0.063 \\
.050 \\
.128\end{array}\right\} 0.065$ & $\left.\begin{array}{r}26.9 \\
15.0 \\
9.4\end{array}\right\} 25.5$ & $\begin{array}{l}953,000 \\
197,000 \\
185,000 \\
\end{array}$ \\
\hline Total... & -.......... & 190 & ................... & -................... & $1,335,000$ \\
\hline Mendenhall... & $5.0\left\{\begin{array}{r}4.0 \\
7.6 \\
10.8\end{array}\right.$ & $\begin{array}{r}565 \\
200 \\
10 \\
\end{array}$ & $\left.\begin{array}{l}.050 \\
.057 \\
.050\end{array}\right\} 0.052$ & $\left.\begin{array}{l}14.9 \\
16.3 \\
17.0\end{array}\right\} 15.3$ & $\left\{\begin{array}{r}3,955,000 \\
2,660,000 \\
189,000\end{array}\right.$ \\
\hline Total. & $\ldots . .$. & 775 & ................ & - & $6,804,000$ \\
\hline Olesrud. & $4.3\left\{\begin{array}{l}3.6 \\
6.4\end{array}\right.$ & $\begin{array}{l}675 \\
215\end{array}$ & $.059\} 0.058$ & $\left.\begin{array}{l}16.2 \\
15.0\end{array}\right\}^{15.9}$ & $\left\{\begin{array}{l}4,252,000 \\
2,408,000 \\
\end{array}\right.$ \\
\hline Total... & 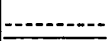 & 890 & $\ldots$ & & $6,660,000$ \\
\hline Grand total. & - -.-....... & 1,855 & - & ..... & $14,799,000$ \\
\hline
\end{tabular}

Total uranium-bearing lignite

\begin{tabular}{|c|c|c|c|c|c|c|}
\hline $\begin{array}{l}\text { Mendenhall rider } \\
\text { Mendenhall } \\
\text { Olesrud (upper bench) }\end{array}$ & $\begin{array}{l}7.5 \\
9.2 \\
5.8\end{array}$ & $\begin{array}{r}585 \\
1,555 \\
1,750\end{array}$ & $\begin{array}{r}0.010 \\
.003 \\
.006\end{array}$ & - & $\begin{array}{l}22.6 \\
14.1 \\
18.0\end{array}$ & $\begin{array}{l}i \\
27,580,000 \\
24,150,000 \\
17,800,000\end{array}$ \\
\hline Grand total & - & 3,890 & $-\ldots$ & & - & $49,530,000$ \\
\hline
\end{tabular}

1 Calculations based on 1,750 tons per acre foot; net result rounded to nearest 1,000 tons.

sible byproduct source of uranium. Relatively small parts of these: deposits were found to contain higher grade uranium accumulations containing more than 0.1 percent uranium in the lignite, after the field and laboratory work of this report were completed. The small highgrade uranium occurrences are not discussed in this report.

\section{GEOLOGICAL SIGNIFICANCE OF URANIUM IN IIGNITE}

A brief consideration of the origin of the uranium in the lignite is necessary to understand the distribution of mineralized lignite.

A scaler equipped with a Geiger-Mueller counter tube and 400 -foot coaxial cable was used to measure the radioactivity of the source beds in the Chadron and Arikaree formations unconformably overlying the uranium-bearing lignites in the core holes drilled in the Slim Buttes." Unfortunately most of the holes caved soon after the lignite was cored and a complete record of the radioactivity of wallrock in all the holes penetrating the Chadron and Arikaree formations was not obtained. The most complete log of radioactivity obtained by this method was for hole GS-17, the gamma counts of which are plotted and shown in figure 18. Although the Arikaree formation is litho- 
logically uniform throughout its thickness at the drill hole, the radioactivity is above background throughout most of the wallrock of the hole and is notably higher near the base of the Arikaree formation. As water was reached in the hole a few feet above the Chadron-Arikaree contact, readings of the Chadron formation could not be calibrated for comparison with those taken higher in the section. The reason for the apparently higher concentration of uranium or other radioactive elements near the base of the Arikaree formation may be due to the occurrence of a widespread and persistent 10-40 foot thick bed

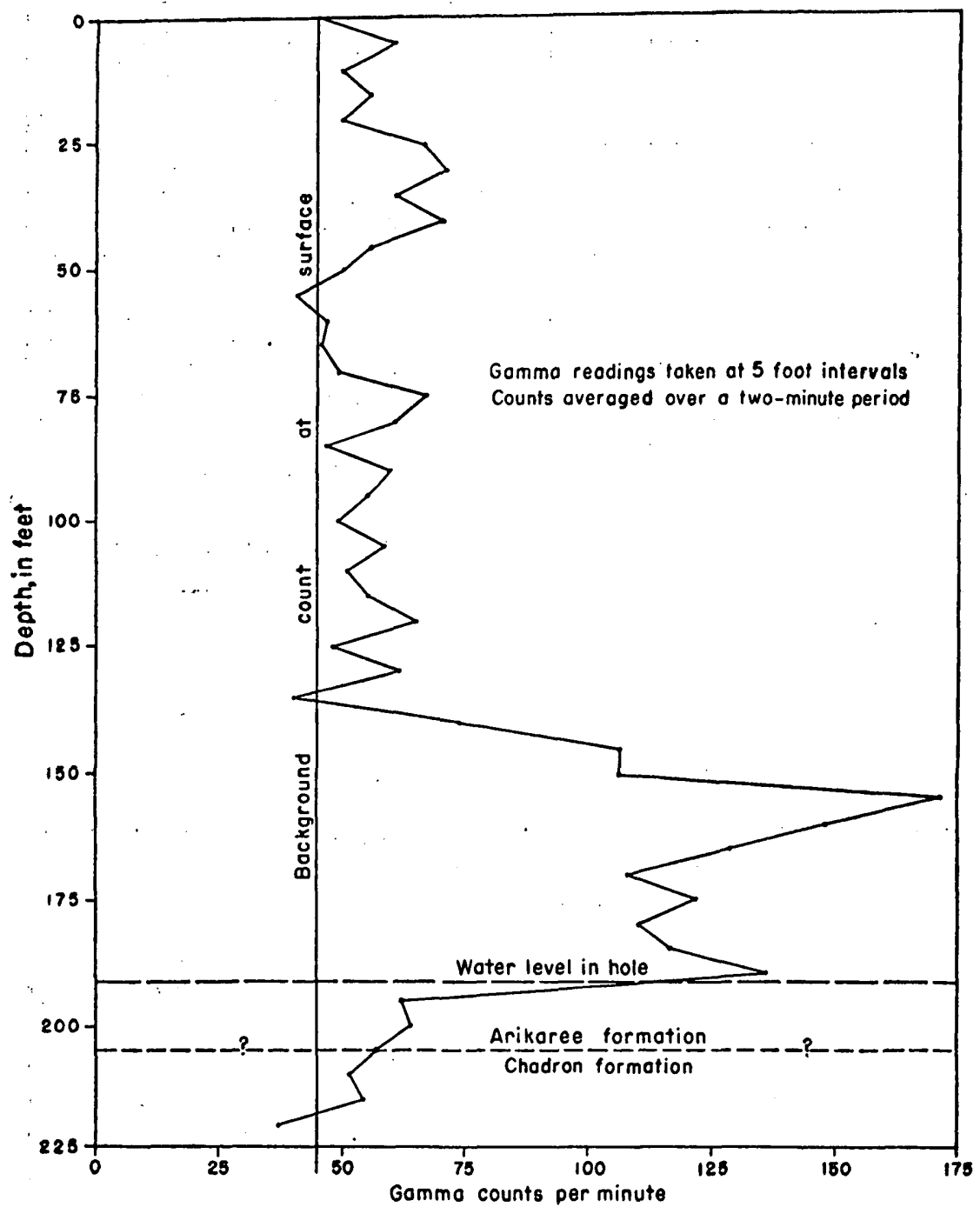

Froore 18.- - Log showing radioactivity of Arikaree formation in core hole GS-17, Mendenhall area, Slim Buttes, Harding County, S. Dak. 
of impervious bentonitic clay at the top of the Chadron formation which supports a perched water table.

It may be significant that gamma counts recorded in 3 of 4 deep holes showed a similar higher concentration of radioactivity in the lower part of the Arikaree formation. Leaching of uranium from the upper part of the Arikaree formation and concentration of uranium in the lower part of the formation, which seems to be uniform lithologically, is suggested but cannot yet be confirmed.

The uranium in the lignite of the Mendenhall area is believed to have been introduced into the lignites long after their formation. Enrichment may be going on today. Denson, Bachman, and Zeller (chapter B, this bulletin) first suggested that the uranium was leached by ground water from the Oligocene and Miocene tuffaceous rocks that unconformably overlie the lignite-bearing strata of the Ludlow member of the Fort Union formation. The ground water brought the uranium into contact with the lignite beds in which the uranium combined with carbon compounds to form a metallo-organic complex (I. A. Breger and Maurice Deul, written communication, 1952).

In the Slim Buttes area the Chadron and Arikaree formations contain on the average, about 0.001 percent uranium, in comparison with the average uranium content of the earth's crust of 0.0004 percent (Mason, 1952) and in comparison with the average for sedimentary rocks of 0.00012 (Rankama and Sahama, 1950). Therefore these formations contain nearly 10 times the average concentration of uranium and seem to be logical source beds for the uranium. It is estimated that a cubic mile of the Chadron and Arikaree formations with a uranium content of 0.001 percent would contain about 130,000 tons of uranium. Springs issuing from the Chadron and Arikaree formations contain 10 to 200 parts per billion of uranium, as compared to the average uranium content of the ocean of 1.5 parts per billion (Rankama and Sahama, 1950).

The distribution of uranium in uranium-bearing lignite beds (pls. 24-28) appears to be related to the accessibility of the beds to uraniumbearing solutions coming from the overlying Oligocene and Miocene rocks rather than to such features as changes in physical character of the lignite. The observed distribution does not appear to correspond to any reasonable interpretation of the conditions under which the lignites were deposited (Schopf and Gray, 1954).

The geologic factors that appear to control the occurrence of uranium in the lignites in the Mendenhall area are the following:

1. Stratigraphic proximity of lignite to the base of the Chadron formation.

2. Permeability of rocks directly overlying the lignite.

3. Physical character and adsorptive qualities of the lignite and 
porosities of its constituents. In areas where the lignites have weathered and have greater permeability, there appears to be an increase in the uranium content. The thickness map of uranium-bearing lignite containing at least 0.005 percent uranium (pl. 29, $E, F, G, H$ ) shows that the areas of lignite with the greatest uranium content are generally in the areas of the least overburden. This may indicate that lignite of these areas is being enriched by uranium-bearing ground water draining from the Chadron and Arikaree formations.

4. Position of past and present water tables. Little is known about past ground-water conditions, but it is reasonable to expect that major fiuctuations have taken place in past geologic time. Aside from the perched water table in the upper part of the Chadron and the lower part of the Arikaree formations in the Slim Buttes area the present water table is below the uranium-bearing lignite.

Data obtained during this study indicate that the uranium in the lignite is of secondary origin, having been introduced after formation of the lignite, and that the uranium has been and is being leached by ground water from the mildly radioactive tuffaceous rocks of the Chadron and Arikaree formations.

\section{LITERATURE CITED}

Averitt, Paul, and Berryhill, L. R., 1950, Coal resources of the United States: U. S. Geol. Survey Circ. 94.

Baker, C. L., 1952, Geology of Harding County: South Dakota Geol. Survey Rept. Inv. 68.

Breger, I. A., Deul, Maurice, and Rubinstein, Samuel, 1955, Geochemistry and mineralogy of a uraniferous lignite : Econ. Geology, 50, p. 206-226.

Gill, J. R., and Moore, G. W., 1955, Carnotite-bearing sandstone in Cedar Canyon, Slim Buttes, Harding County, S. Dak.: U. S. Geol. Survey Bull. 1009-I.

Mason, Brian, 1952, Principles of geochemistry, New York, John Wiley and Sons.

Rankama, K., and Sahama, T. G., 1950, Geochemistry, The University of Chicago Press.

Schopf, J. M., and. Gray, R. J., 1954, Microscopic 'studies of uraniferous coal deposits : U. S. Geol. Survey Circ. 343.

Toepelman, W. C., 1923, The possibilities of oil in eastern Harding County, S. Dak. : South Dakota Geol. and Nat. Hist. Survey Circ. 12.

Winchester, D. E., Hares, C: J., Lloyd, E. R., and Parks, E. N., 1916, The lignite field of northwestern South Dakota: U. S. Geol. Survey Bull. 627.

Wood, H. E., 2d, 1945, Late Miocene beaver from southeastern Montana : Am. Mus. Novitates, no. 1299. 
CORE DRILLING, MENDENHALL AREA, SOUTH DAKOTA 117

TABLE 6.-Threshold values in percent of elements included in the semi-quantitative spectrographic method

[Revised June 4, 1951]

\begin{tabular}{|c|c|c|c|c|c|c|c|}
\hline Element & Percent & Element & Percent & Element & Percent & Element & Percent \\
\hline $\begin{array}{l}\text { Ag. } \\
\text { Al } \\
\text { As } \\
\mathbf{A u} \\
\mathbf{B} \\
\mathbf{B a}\end{array}$ & $\begin{array}{l}0.001 \\
.0001 \\
.1 \\
.01 \\
.001 \\
.0001 \\
.0001 \\
.001 \\
.001 \\
.01 \\
.01 \\
.1 \\
.01 \\
.001 \\
1.0 \\
.0001\end{array}$ & 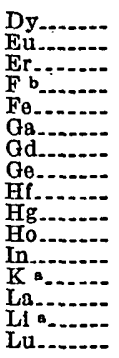 & $\begin{array}{l}0.01 \\
.01 \\
.01 \\
.1 \\
.001 \\
.01 \\
.01 \\
.001 \\
.1 \\
.1 \\
.01 \\
.001 \\
.01(1.0) \\
.01 \\
.0001(0.1) \\
.01\end{array}$ & $\begin{array}{l}\mathrm{Mg} \\
\mathrm{Mo} \\
\mathrm{Mn} \\
\mathrm{Ng} \\
\mathrm{Nd} \\
\mathrm{Ni} \\
\mathrm{P} \\
\mathrm{Pb}\end{array}$ & $\begin{array}{c}0.0001 \\
.001 \\
.001 \\
.001(0.1) \\
.01 \\
.001 \\
.1 \\
.01 \\
.01 \\
.01 \\
10.0 \\
.1 \\
.001 \\
.1 \\
.0001 \\
.1\end{array}$ & 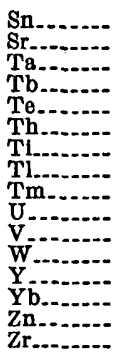 & $\begin{array}{l}0.01 \\
.01 \\
.1 \\
.1 \\
.1 \\
.1 \\
.001 \\
.1 \\
.01 \\
.1 \\
.01 \\
.1 \\
.001 \\
.0001 \\
.01 \\
.001\end{array}$ \\
\hline
\end{tabular}

- A second exposure is required for the high sensitivity test.

b A third exposure is required for the fluorine estimation. 


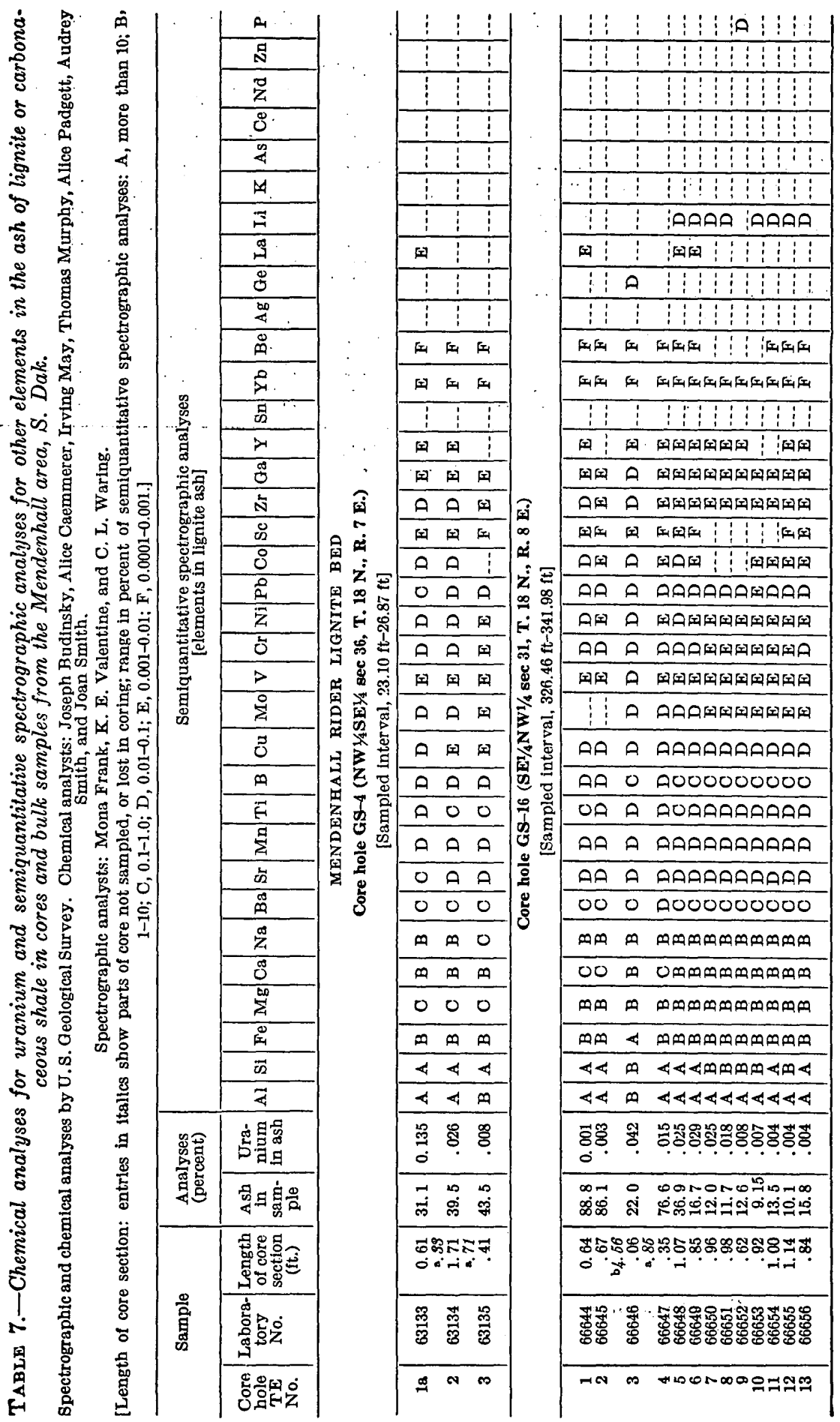



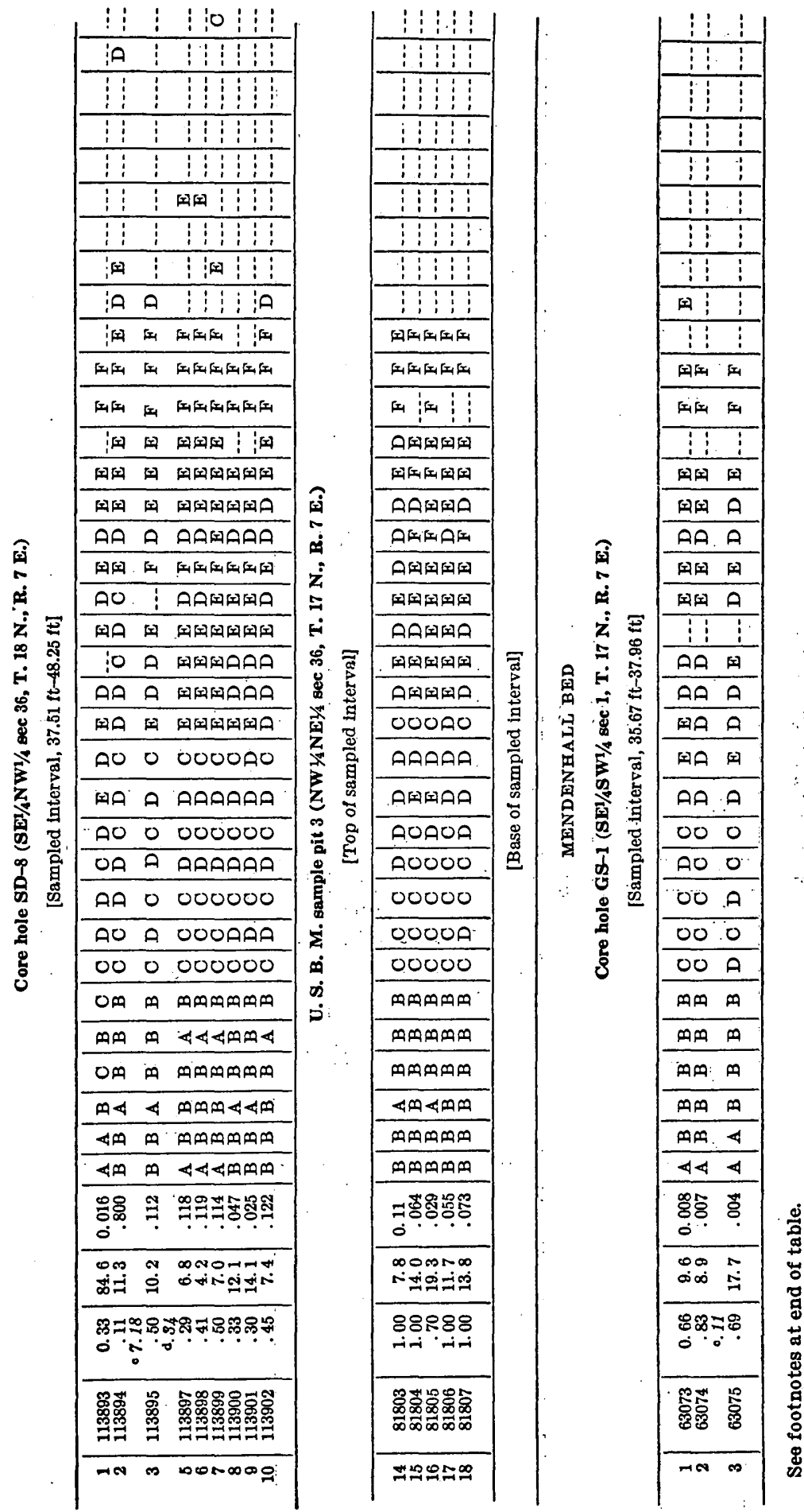


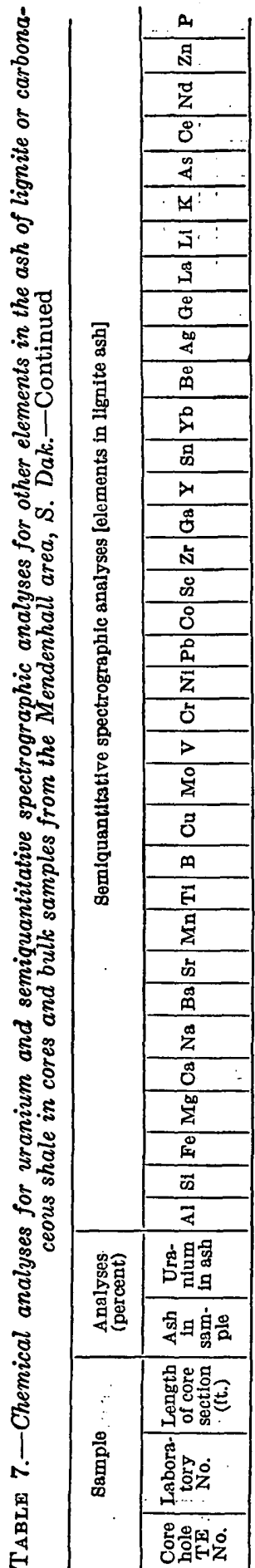

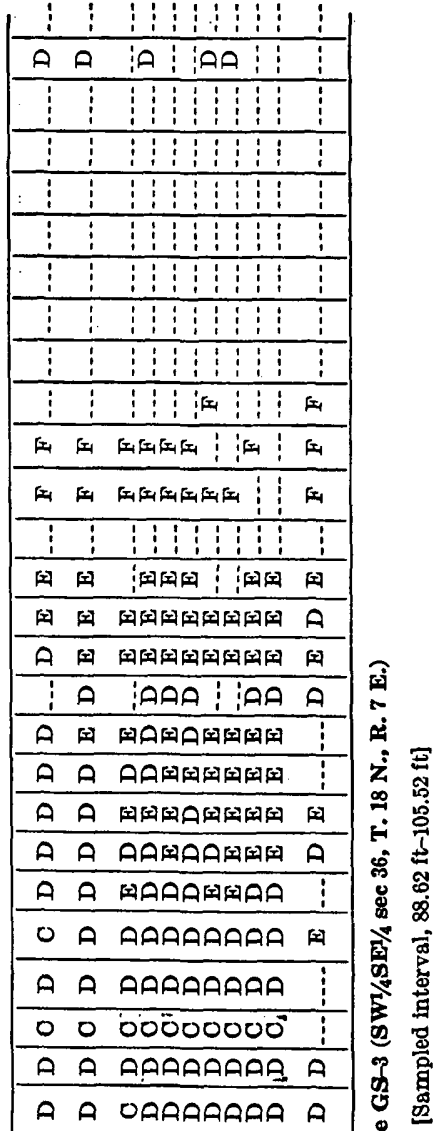

\begin{tabular}{lllll}
$A$ & 0 & 00000000 & 0 \\
\hline & 0 & 00000000 & 0
\end{tabular}

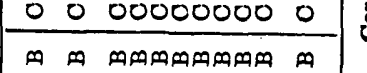

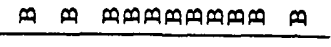

$4 M$ MMM

$4 \varangle$ ४MMM $4 M M M \square$

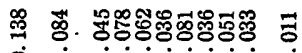
$\circ$

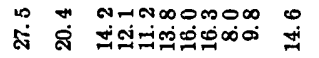

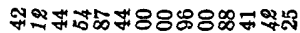

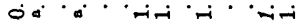

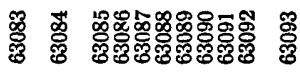

$\rightarrow$ a nhonoso

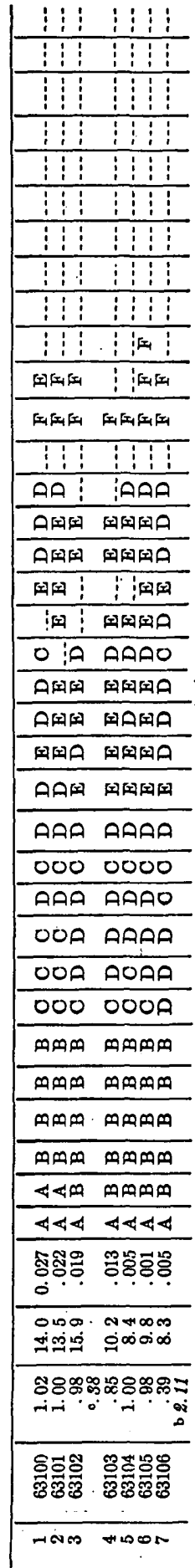




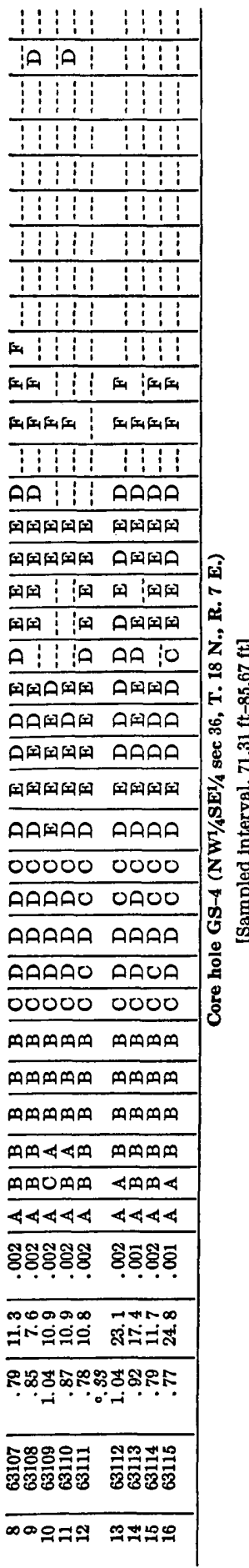

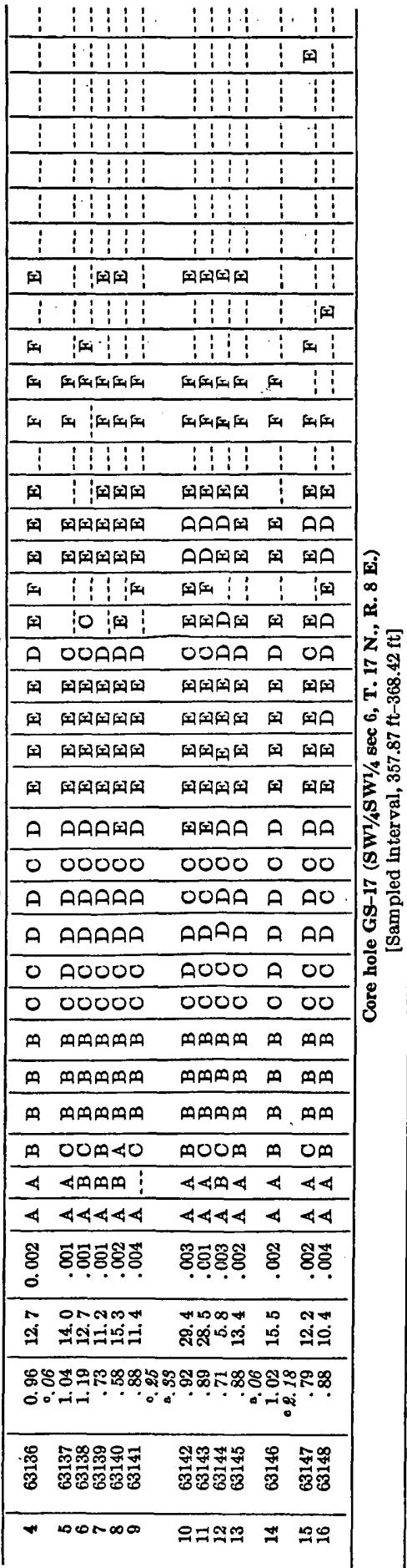

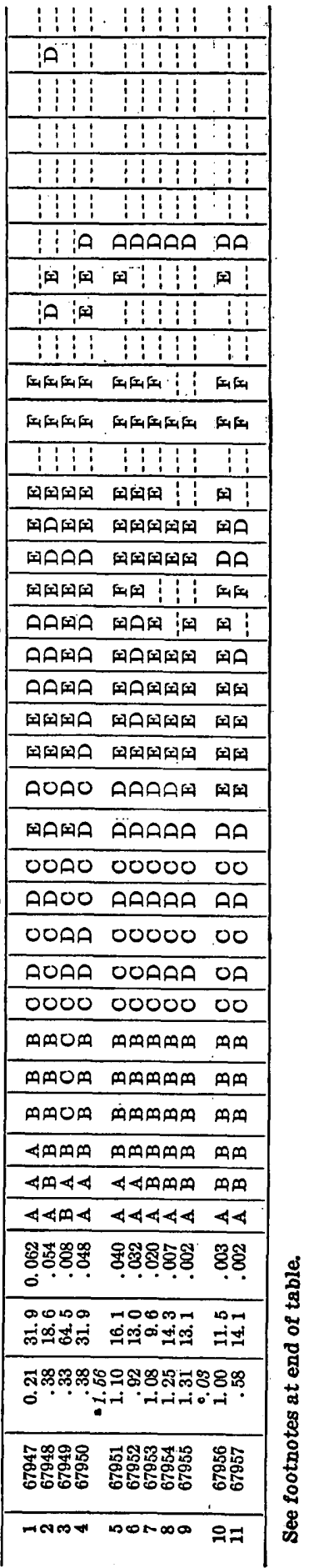




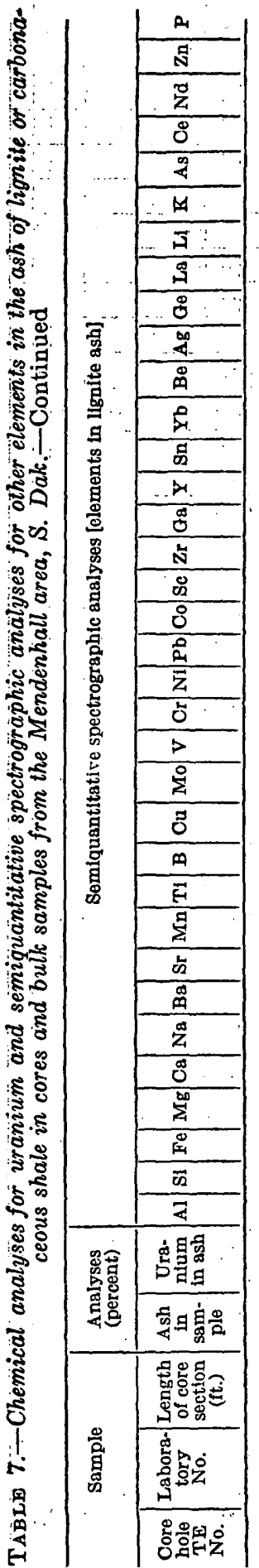

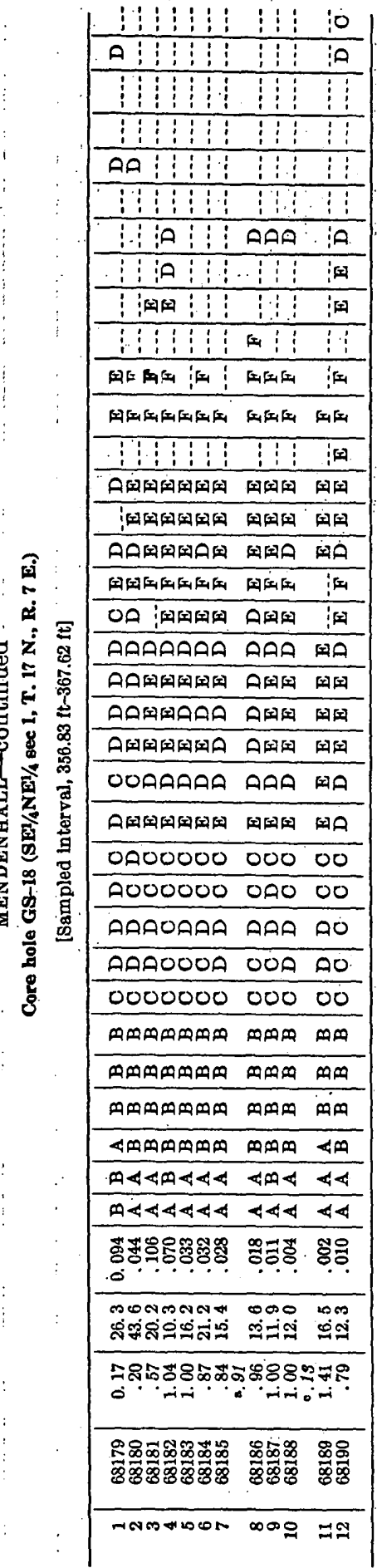



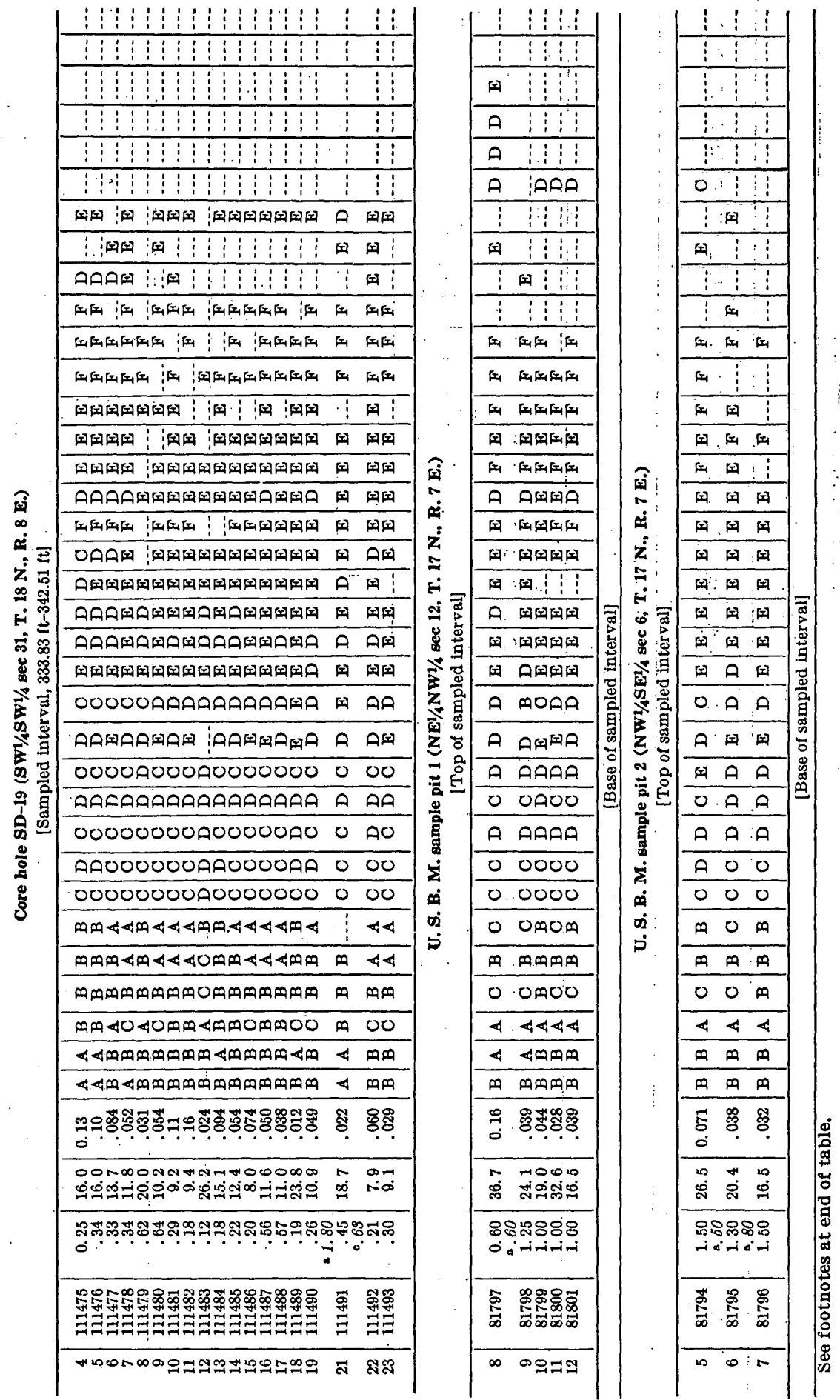
124 URANIUM IN COAL. IN : THE WESTERN UNITED STATES

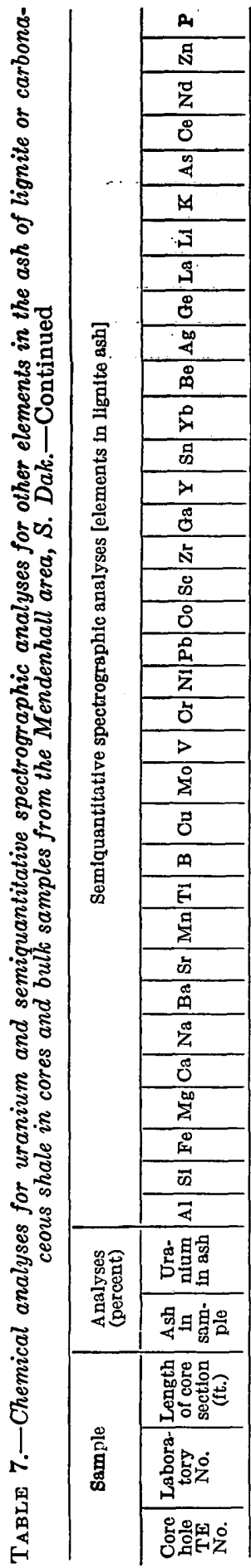

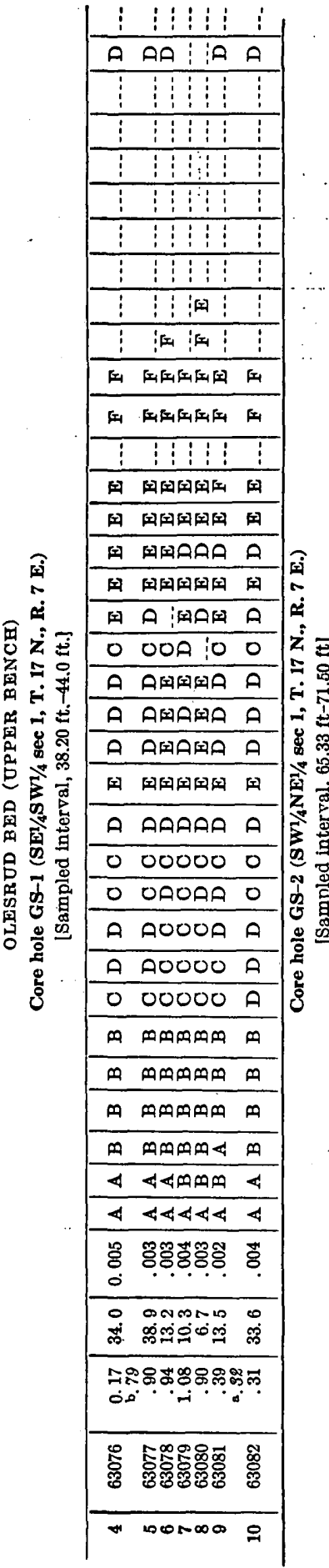

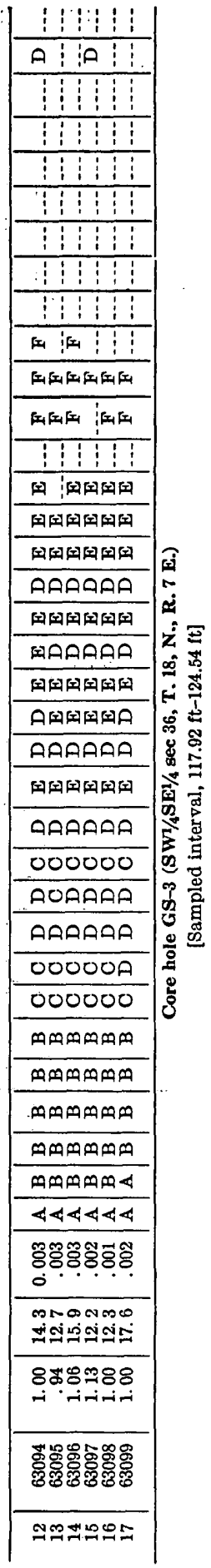

\begin{tabular}{|c|}
\hline $\begin{array}{l::l::} & \text { : } \\
\end{array}$ \\
\hline 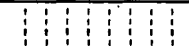 \\
\hline 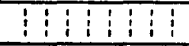 \\
\hline 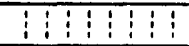 \\
\hline 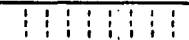 \\
\hline 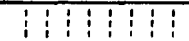 \\
\hline 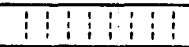 \\
\hline 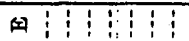 \\
\hline $\begin{array}{ll}! \\
\vdots\end{array}$ \\
\hline 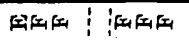 \\
\hline 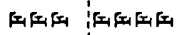 \\
\hline 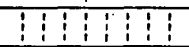 \\
\hline О日: \\
\hline 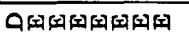 \\
\hline 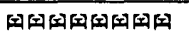 \\
\hline 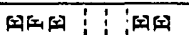 \\
\hline 由: \\
\hline AOOARAAR \\
\hline 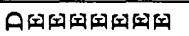 \\
\hline A四A夋A四的A \\
\hline 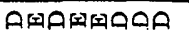 \\
\hline 国国由界 \\
\hline AAAAAAAA \\
\hline 00000000 \\
\hline AAAFOAFO \\
\hline OOOOAAAA \\
\hline 00000000 \\
\hline 00000000 \\
\hline 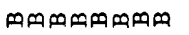 \\
\hline ロロロロロロறロロ \\
\hline ロறロறロறロறロற \\
\hline MMMU $4 M M M$ \\
\hline 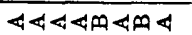 \\
\hline 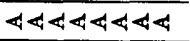 \\
\hline 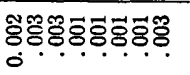 \\
\hline 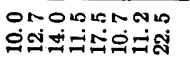 \\
\hline ஜோ8 \\
\hline 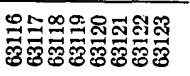 \\
\hline 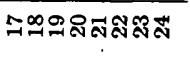 \\
\hline
\end{tabular}




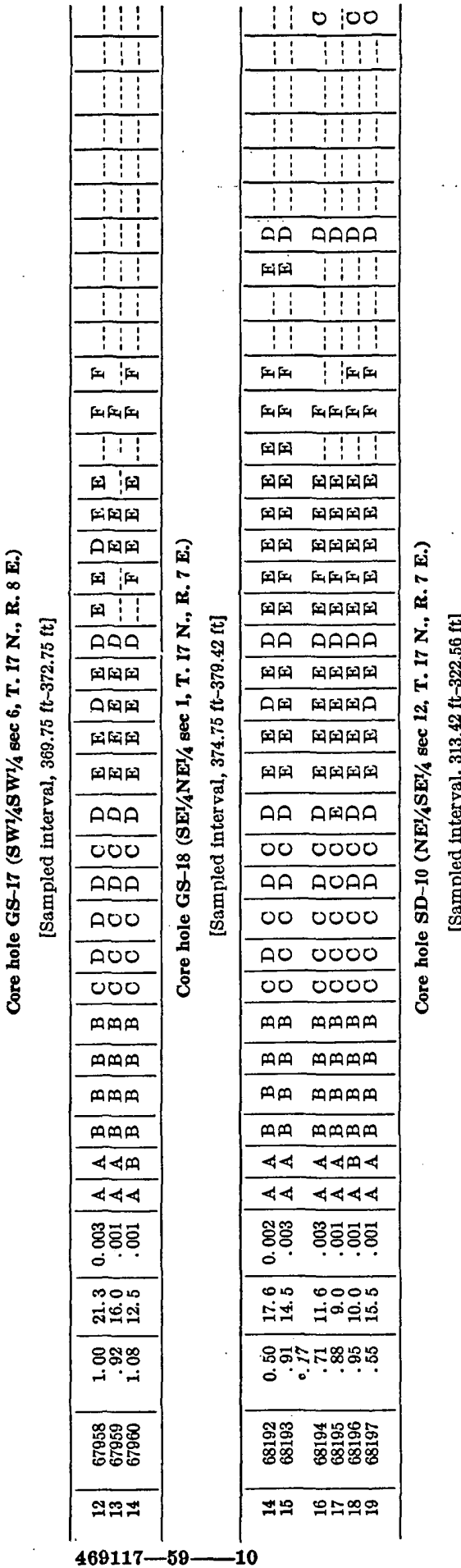

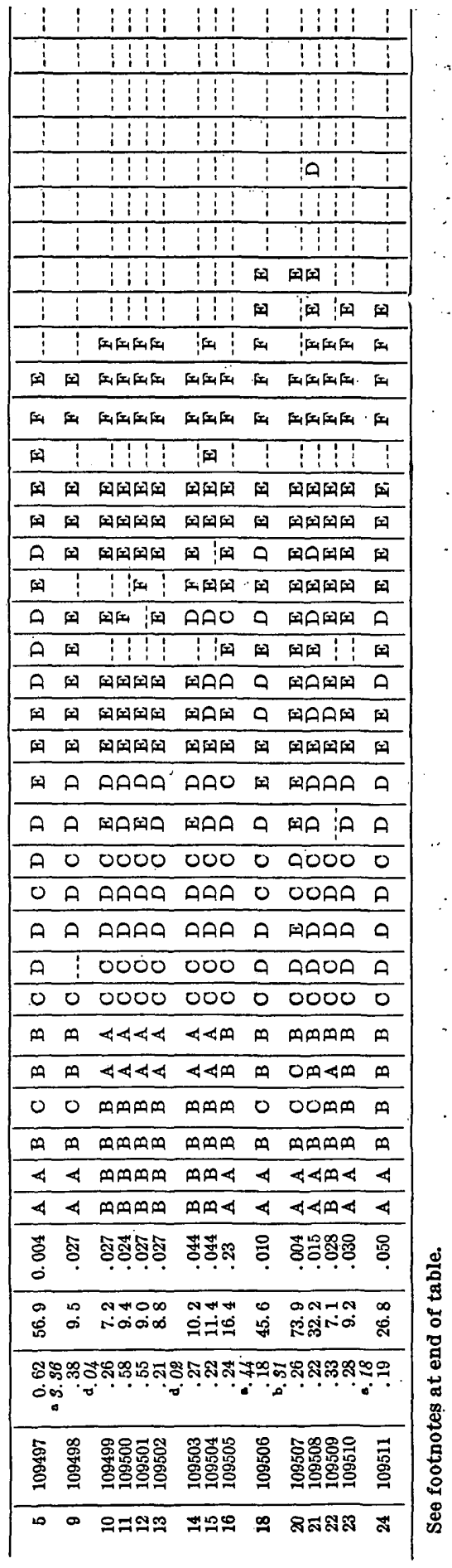




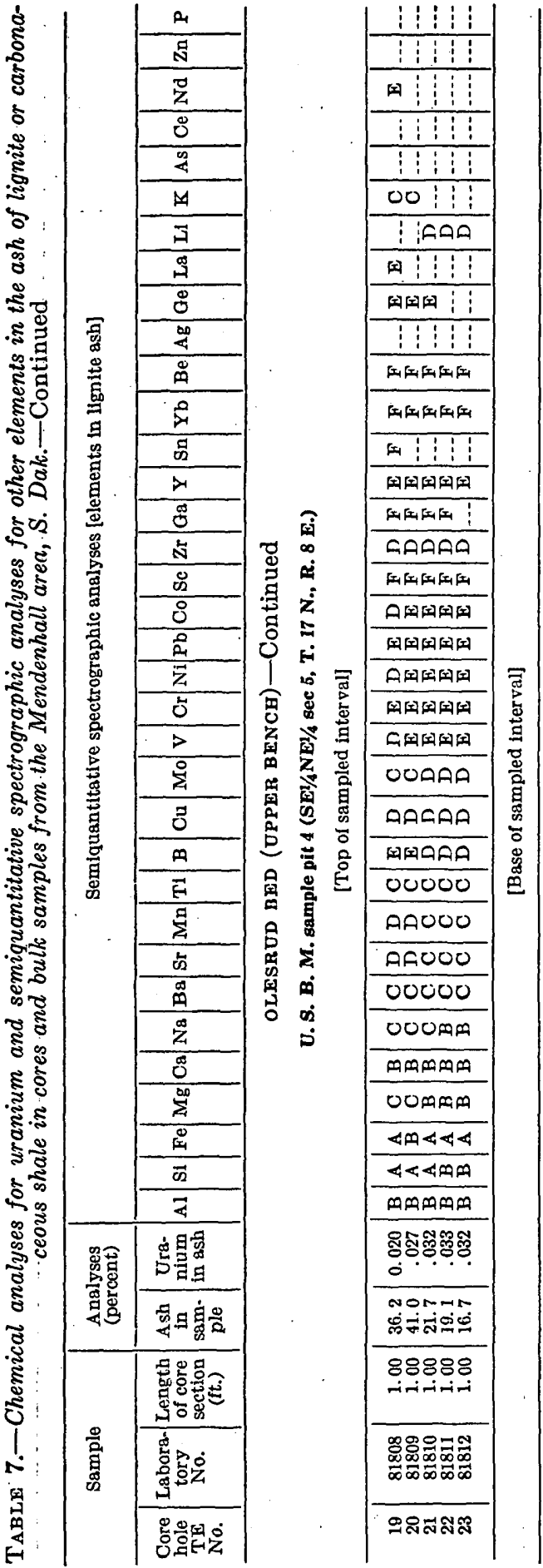

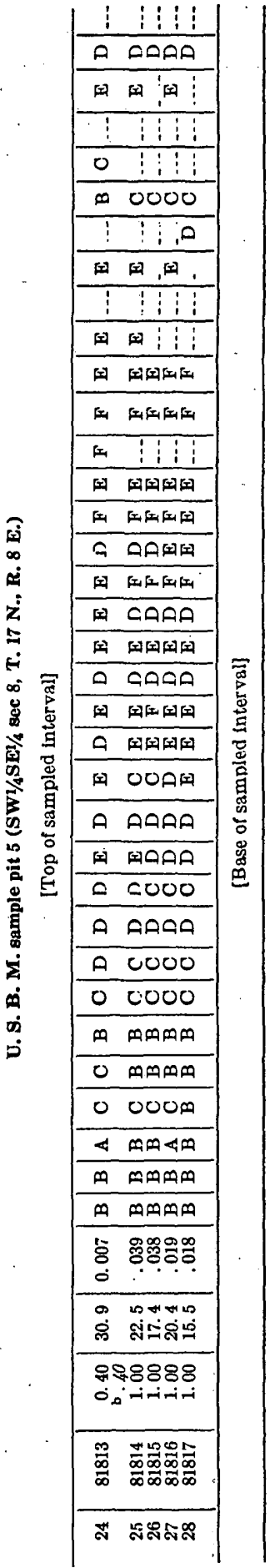




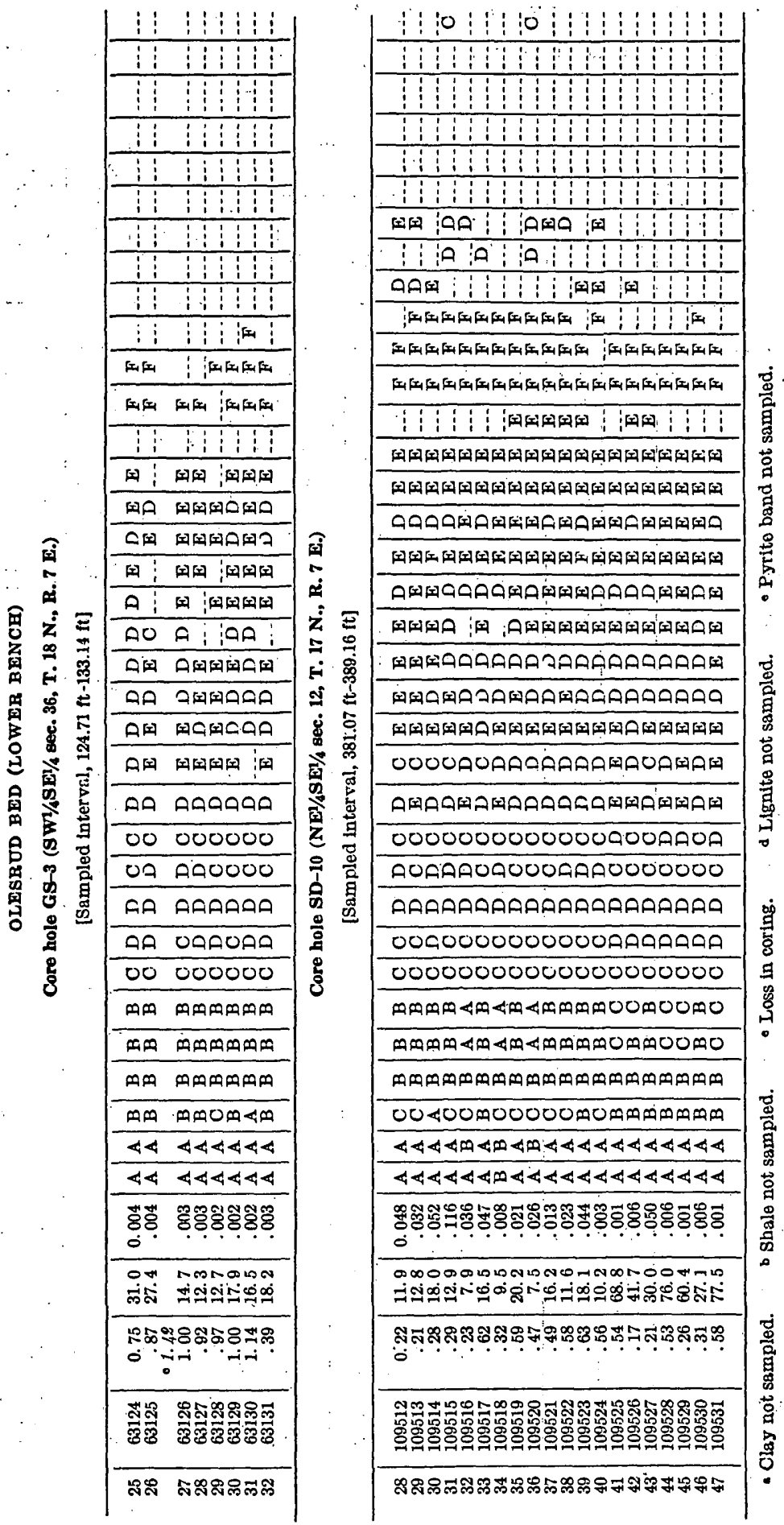




\section{URANIUM IN COAL IN THE WESTERN UNITED STATES}

TABLE 8.-Fuel analyses of lignite from the Mendenhall area, South Dakota

[Analyses by the United States Bureau of Mines. Condition of sample: A, as recelved; B, molsture-free; $C$, moisture- and ash-free]

\begin{tabular}{|c|c|c|c|c|c|c|c|c|c|c|c|c|c|c|}
\hline \multirow{3}{*}{$\begin{array}{l}\text { Core } \\
\text { hole }\end{array}$} & \multicolumn{3}{|c|}{ Sample } & \multicolumn{9}{|c|}{ Analyses, in percent } & \multirow{3}{*}{$\begin{array}{l}\text { Heat- } \\
\text { ing } \\
\text { value } \\
\text { (Btu) }\end{array}$} & \multirow{3}{*}{$\begin{array}{c}\text { Ash } \\
\text { soften- } \\
\text { ring } \\
\text { tem- } \\
\text { pers- } \\
\text { ture } \\
\text { of. }\end{array}$} \\
\hline & \multirow[b]{2}{*}{$\begin{array}{l}\text { Thick- } \\
\text { ness } \\
\text { (feet) }\end{array}$} & \multirow[b]{2}{*}{$\begin{array}{c}\text { Labora- } \\
\text { tory } \\
\text { No. }\end{array}$} & \multirow[b]{2}{*}{$\begin{array}{c}\text { Con- } \\
\text { di- } \\
\text { tion }\end{array}$} & \multicolumn{3}{|c|}{ Proximate } & \multicolumn{6}{|c|}{ Ultimate } & & \\
\hline & & & & $\begin{array}{c}\text { Mois- } \\
\text { ture }\end{array}$ & $\begin{array}{l}\text { Vol- } \\
\text { atile } \\
\text { mat- } \\
\text { ter }\end{array}$ & $\begin{array}{c}\text { Fixed } \\
\text { car- } \\
\text { bon }\end{array}$ & Ash & $\begin{array}{l}\text { Hy- } \\
\text { dro- } \\
\text { gen }\end{array}$ & $\begin{array}{l}\text { Car- } \\
\text { bon }\end{array}$ & $\begin{array}{l}\text { Ni- } \\
\text { tro- } \\
\text { gen }\end{array}$ & $\begin{array}{l}\text { Oxy- } \\
\text { gen }\end{array}$ & $\begin{array}{l}\text { Sul- } \\
\text { fur }\end{array}$ & & \\
\hline
\end{tabular}

Mendenhall rider bed

\begin{tabular}{|c|c|c|c|c|c|c|c|c|c|c|c|c|c|c|}
\hline SD-7...- & 0.65 & E-32880 & $\begin{array}{l}\mathbf{A} \\
\mathbf{B} \\
\mathbf{C}\end{array}$ & $\begin{array}{c}20.5 \\
-20 \\
-\cdots\end{array}$ & $\begin{array}{l}29.5 \\
37.1 \\
67.7\end{array}$ & $\begin{array}{l}14.0 \\
17.7 \\
32.3\end{array}$ & $\begin{array}{c}36.0 \\
45.2 \\
-\ldots . .\end{array}$ & $\begin{array}{l}3.7 \\
1.8 \\
3.3\end{array}$ & $\begin{array}{l}25.2 \\
31.7 \\
57.9\end{array}$ & $\begin{array}{r}0.5 \\
.6 \\
1.2\end{array}$ & $\begin{array}{l}32.3 \\
17.8 \\
32.2\end{array}$ & $\begin{array}{l}2.3 \\
2.9 \\
5.4\end{array}$ & $\begin{array}{l}3,590 \\
4 ; 510 \\
8,240\end{array}$ & $\begin{array}{r}2,380 \\
-\end{array}$ \\
\hline SD-8..... & $\begin{array}{l}3.1 \\
4.0\end{array}$ & $\begin{array}{l}\text { E-19298 } \\
\text { E-19299 }\end{array}$ & $\begin{array}{l}\mathbf{A} \\
\mathbf{B} \\
\mathbf{C} \\
\mathbf{A} \\
\mathbf{B} \\
\mathbf{C}\end{array}$ & \begin{tabular}{c}
39.0 \\
\hdashline 45.0 \\
-.0 \\
\end{tabular} & $\begin{array}{l}25.5 \\
41.8 \\
46.4 \\
21.9 \\
39.9 \\
44.3\end{array}$ & $\begin{array}{l}29.5 \\
48.4 \\
53.6 \\
27.6 \\
50.0 \\
55.7\end{array}$ & $\begin{array}{r}6.0 \\
9.8 \\
5.5 \\
10.1 \\
-\end{array}$ & $\begin{array}{l}6.9 \\
4.2 \\
4.7 \\
7.2 \\
4.1 \\
4.5\end{array}$ & $\begin{array}{l}39.2 \\
64.3 \\
71.3 \\
35.5 \\
64.2 \\
71.3\end{array}$ & $\begin{array}{l}.5 \\
.7 \\
.8 \\
.4 \\
.8 \\
.9\end{array}$ & $\begin{array}{l}46.4 \\
19.3 \\
21.3 \\
50.9 \\
19.5 \\
21.9\end{array}$ & $\begin{array}{l}1.0 \\
1.7 \\
1.9 \\
.7 \\
1.3 \\
1.4\end{array}$ & $\begin{array}{r}6 ; 510 \\
10.670 \\
11,840 \\
5 ; 850 \\
10,640 \\
11,830\end{array}$ & $\begin{array}{r}2,260 \\
2,250 \\
\end{array}$ \\
\hline K-26 $1 \ldots$ & $\begin{array}{l}2.4 \\
3.5\end{array}$ & $\begin{array}{l}\text { E-24658 } \\
\text { E-24659 }\end{array}$ & $\begin{array}{l}\mathbf{A} \\
\mathbf{B} \\
\mathbf{C} \\
\mathbf{A} \\
\mathbf{B} \\
\mathbf{C}\end{array}$ & \begin{tabular}{c}
40.1 \\
\hdashline 39.6 \\
\hdashline-1 \\
\hdashline-
\end{tabular} & $\begin{array}{l}29.9 . \\
50.0 \\
63.6 \\
24.8 \\
41.0 \\
62.8\end{array}$ & \begin{tabular}{l|}
17.2 \\
28.6 \\
36.4 \\
14.7 \\
24.3 \\
37.2
\end{tabular} & \begin{tabular}{r}
12.8 \\
21.4 \\
\hdashline 20.9 \\
34.7 \\
-
\end{tabular} & $\cdots$ & - & & 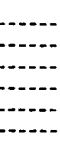 & $\begin{array}{l}1.9 \\
3.1 \\
4.0 \\
1.6 \\
2.7 \\
4.1\end{array}$ & $\begin{array}{l}4,130 \\
6,880 \\
8,760 \\
3,320 \\
5,490 \\
8,410\end{array}$ & - \\
\hline SD-24... & $\begin{array}{l}1.1 \\
6.3\end{array}$ & $\begin{array}{l}\text { E-33312 } \\
\text { E-33313 }\end{array}$ & $\begin{array}{l}\mathbf{A} \\
\mathbf{B} \\
\mathbf{C} \\
\mathbf{A} \\
\mathbf{B} \\
\mathbf{C}\end{array}$ & \begin{tabular}{|c|}
27.6 \\
29.8 \\
-2 \\
-2. \\
\end{tabular} & $\begin{array}{l}22.8 \\
31.5 \\
58.0 \\
25.2 \\
35.9 \\
47.1\end{array}$ & $\begin{array}{l}16.4 \\
22.7 \\
42.0 \\
28.4 \\
40.4 \\
52.9\end{array}$ & $\begin{array}{l}33.2 \\
45.8 \\
-16.6 \\
23.7 \\
-.-1\end{array}$ & $\begin{array}{l}4.3 \\
1.7 \\
3.1 \\
5.6 \\
3.3 \\
4.4\end{array}$ & $\begin{array}{l}24.8 \\
34.2 \\
63.2 \\
37.4 \\
53.3 \\
69.8\end{array}$ & $\begin{array}{r}.5 \\
.7 \\
1.3 \\
.4 \\
.6 \\
.8\end{array}$ & $\begin{array}{l}35.2 \\
14.9 \\
27.3 \\
38.3 \\
16.6 \\
21.8\end{array}$ & $\begin{array}{l}2.0 \\
2.7 \\
5.1 \\
1.7 \\
2.5 \\
3.2\end{array}$ & $\begin{array}{r}3,560 \\
4,920 \\
9,070 \\
6,250 \\
8,900 \\
11,660\end{array}$ & $\begin{array}{r}2,220 \\
\hdashline 2,030 \\
\hdashline\end{array}$ \\
\hline GS-4.... & $\begin{array}{r}.6 \\
1.7\end{array}$ & $\begin{array}{l}D-68859 \\
D-68860\end{array}$ & $\begin{array}{l}\mathbf{A} \\
\mathbf{B} \\
\mathbf{C} \\
\mathbf{A} \\
\mathbf{B} \\
\mathbf{C}\end{array}$ & $\begin{array}{c}43.8 \\
45.9 \\
-0 . \\
-0 . \\
\end{array}$ & $\begin{array}{l}24.1 \\
42.9 . \\
64.1 \\
20.7 \\
38.3 \\
63.4\end{array}$ & $\begin{array}{l}13.5 \\
24.0 \\
35.9 \\
11.9 \\
22.0 \\
36.6\end{array}$ & \begin{tabular}{c}
18.6 \\
33.1 \\
\hdashline 21.5 \\
39.7 \\
..--
\end{tabular} & \begin{tabular}{l}
$-\cdots$ \\
\hdashline 6.2 \\
\hdashline 2.1 \\
3.5
\end{tabular} & $\begin{array}{l}0.6 \\
18.6 \\
34.5 \\
57.2\end{array}$ & $\begin{array}{r}.3 \\
.6 \\
1.0\end{array}$ & $\begin{array}{l}0 . .5 \\
19.7 \\
32.6\end{array}$ & $\begin{array}{l}1.7 \\
3.1 \\
4.6 \\
1.9 \\
3.4 \\
\text { 5. }\end{array}$ & $\begin{array}{l}3,100 \\
5,510 \\
8,230 \\
2,680 \\
4,950 \\
8,200\end{array}$ & $\begin{array}{r}2,180 \\
2,130 \\
\end{array}$ \\
\hline GS-16..- & 8.4 & D-71570 & $\begin{array}{l}\mathbf{A} \\
\mathbf{B} \\
\mathbf{C}\end{array}$ & \begin{tabular}{c}
41.8 \\
\hdashline-1 \\
\hdashline.-
\end{tabular} & $\begin{array}{l}22.0 \\
37.9 \\
45.8\end{array}$ & $\begin{array}{l}26.1 \\
44.8 \\
54.2\end{array}$ & \begin{tabular}{c}
10.1 \\
17.3 \\
\hdashline...
\end{tabular} & $\begin{array}{l}6.9 \\
3.8 \\
4.6\end{array}$ & $\begin{array}{l}34.7 \\
59.7 \\
72.2\end{array}$ & $\begin{array}{l}.4 \\
.8 \\
.9\end{array}$ & $\begin{array}{l}47.1 \\
17.0 \\
20.6\end{array}$ & $\begin{array}{r}.8 \\
1.4 \\
1.7\end{array}$ & $\begin{array}{r}5,790 \\
9,950 \\
12,030\end{array}$ & $\begin{array}{r}2,100 \\
0\end{array}$ \\
\hline
\end{tabular}

Mendenhall bed

\begin{tabular}{|c|c|c|c|c|c|c|c|c|c|c|c|c|c|c|}
\hline SD-1... & $\begin{array}{l}2.1 \\
8.7\end{array}$ & $\begin{array}{l}\text { E-32380 } \\
\text { E-32381 } \\
\text { E-32382 }\end{array}$ & $\begin{array}{l}\mathbf{A} \\
\mathbf{B} \\
\mathbf{C} \\
\mathbf{A} \\
\mathbf{B} \\
\mathbf{C} \\
\mathbf{A} \\
\mathbf{B} \\
\mathbf{C}\end{array}$ & $\begin{array}{c}34.4 \\
36.3 \\
41.0 \\
-2 \\
-\ldots\end{array}$ & $\begin{array}{l}23.5 \\
35.9 \\
44.3 \\
23.6 \\
37.1 \\
44.1 \\
23.7 \\
40.1 \\
46.0\end{array}$ & $\begin{array}{l}29.6 \\
45.1 \\
55.7 \\
30.0 \\
47.1 \\
55.9 \\
27.8 \\
47.1 \\
54.0\end{array}$ & \begin{tabular}{c}
12.5 \\
19.0 \\
\hdashline 10.1 \\
15.8 \\
7.5 \\
12.8 \\
$-\ldots .$.
\end{tabular} & $\begin{array}{l}6.0 \\
3.3 \\
4.1 \\
6.2 \\
3.4 \\
4.1 \\
6.8 \\
3.8 \\
4.4\end{array}$ & $\begin{array}{l}36.2 \\
55.2 \\
68.2 \\
36.7 \\
57.6 \\
68.4 \\
35.9 \\
60.8 \\
69.7\end{array}$ & $\begin{array}{l}0.5 \\
.8 \\
.9 \\
.4 \\
.7 \\
.8 \\
.4 \\
.7 \\
.8\end{array}$ & $\begin{array}{l}42.3 \\
17.8 \\
22.0 \\
44.4 \\
19.1 \\
22.6 \\
48.0 \\
19.5 \\
22.4\end{array}$ & $\begin{array}{l}2.5 \\
3.9 \\
4.8 \\
2.2 \\
3.4 \\
4.1 \\
1.4 \\
2.4 \\
2.7\end{array}$ & $\begin{array}{r}6,090 \\
9,280 \\
11,460 \\
6,120 \\
9,600 \\
11,410 \\
6,060 \\
10,270 \\
11,770\end{array}$ & $\begin{array}{r}1,990 \\
1,970 \\
2,140 \\
\end{array}$ \\
\hline SD-2 & $\begin{array}{l}1.45 \\
5.3\end{array}$ & $\begin{array}{l}\text { E-32387 } \\
\text { E-32388 }\end{array}$ & $\begin{array}{l}\mathbf{A} \\
\mathbf{B} \\
\mathbf{C} \\
\mathbf{A} \\
\mathbf{B} \\
\mathbf{C}\end{array}$ & \begin{tabular}{c}
18.0 \\
\hdashline 32.5 \\
\hdashline..- \\
$-\cdots$
\end{tabular} & $\begin{array}{l}23.4 \\
28.5 \\
44.4 \\
26.8 \\
39.6 \\
45.9\end{array}$ & $\begin{array}{l}29.2 \\
35.7 \\
55.6 \\
31.5 \\
46.7 \\
54.1\end{array}$ & $\begin{array}{r}29.4 \\
35.8 \\
9.2 \\
13.7 \\
-. .2\end{array}$ & $\begin{array}{l}4.2 \\
2.6 \\
4.1 \\
6.2 \\
3.8 \\
4.4\end{array}$ & $\begin{array}{l}37.0 \\
45.1 \\
70.3 \\
41.5 \\
61.5 \\
71.2\end{array}$ & $\begin{array}{r}.5 \\
.6 \\
1.0 \\
.5 \\
.7 \\
.8\end{array}$ & $\begin{array}{l}26.4 \\
12.8 \\
19.8 \\
41.1 \\
18.1 \\
21.1\end{array}$ & $\begin{array}{l}2.5 \\
3.1 \\
4.8 \\
1.5 \\
2.2 \\
2.5\end{array}$ & $\begin{array}{r}6,070 \\
7,400 \\
11,530 \\
6,900 \\
10,220 \\
11,830\end{array}$ & $\begin{array}{r}2,210 \\
2,050 \\
\end{array}$ \\
\hline SD-4.... & $\begin{array}{l}4.75 \\
6.55\end{array}$ & $\begin{array}{l}\text { E-32401 } \\
\text { E-32402 }\end{array}$ & $\begin{array}{l}\mathbf{A} \\
\mathbf{B} \\
\mathbf{C} \\
\mathbf{A} \\
\mathbf{B}\end{array}$ & \begin{tabular}{c}
24.9 \\
\hdashline 29.6 \\
\hdashline.- .6 \\
\hdashline
\end{tabular} & $\begin{array}{l}26.0 \\
34.6 \\
42.3 \\
28.5 \\
40.5 \\
46.2\end{array}$ & $\begin{array}{l}35.4 \\
47.2 \\
57.7 \\
33.2 \\
47.2 \\
53.8\end{array}$ & $\begin{array}{r}13.7 \\
18.2 \\
-8.7 \\
12.3\end{array}$ & $\begin{array}{l}5.5 \\
3.7 \\
4.5 \\
6.1 \\
3.9 \\
4.5\end{array}$ & $\begin{array}{l}43.8 \\
58.3 \\
71.4 \\
43.1 \\
61.3 \\
69.9\end{array}$ & $\begin{array}{l}.6 \\
.7 \\
.9 \\
.5 \\
.7\end{array}$ & $\begin{array}{l}34.6 \\
16.7 \\
20.3 \\
40.4 \\
20.1 \\
22.8\end{array}$ & $\begin{array}{l}1.8 \\
2.4 \\
2.9 \\
1.2 \\
1.7 \\
2.0\end{array}$ & $\begin{array}{r}7,450 \\
9,910 \\
12,120 \\
7,180 \\
10,210 \\
11,640\end{array}$ & $\begin{array}{r}2,100 \\
2,220 \\
\\
\end{array}$ \\
\hline
\end{tabular}

I (Burface sample at SD-8). 
TABLE 8.-Fuel analyses of lignite from the Mendenhail area, South Dakota-Con.

\begin{tabular}{|c|c|c|c|c|c|c|c|c|c|c|c|c|c|c|}
\hline \multirow{3}{*}{$\begin{array}{c}\text { Core } \\
\text { hole }\end{array}$} & \multicolumn{3}{|c|}{ Sample } & \multicolumn{9}{|c|}{ Analyses, in percent } & \multirow{3}{*}{$\begin{array}{c}\text { Heat- } \\
\text { ing } \\
\text { value } \\
\text { (Btu) }\end{array}$} & \multirow{3}{*}{$\begin{array}{l}\text { Ash } \\
\text { solten- } \\
\text { ing } \\
\text { tem- } \\
\text { pera- } \\
\text { turo } \\
\text { of. }\end{array}$} \\
\hline & \multirow[b]{2}{*}{$\mid \begin{array}{c}\text { Thick- } \\
\text { ness } \\
\text { (feet) }\end{array}$} & \multirow[b]{2}{*}{$\begin{array}{c}\text { Labora- } \\
\text { tory } \\
\text { No. }\end{array}$} & \multirow[b]{2}{*}{$\begin{array}{c}\text { Con- } \\
\text { di- } \\
\text { tion }\end{array}$} & \multicolumn{3}{|c|}{ Proximate } & \multicolumn{6}{|c|}{ Ultimate } & & \\
\hline & & & & $\begin{array}{c}\text { Mois- } \\
\text { ture }\end{array}$ & $\begin{array}{c}\text { Vol- } \\
\text { atile } \\
\text { mat- } \\
\text { ter }\end{array}$ & $\begin{array}{l}\text { Fixed } \\
\text { car- } \\
\text { bon }\end{array}$ & Ash & $\begin{array}{l}\text { Hy- } \\
\text { dro- } \\
\text { gen }\end{array}$ & $\begin{array}{l}\text { Car- } \\
\text { bon }\end{array}$ & $\begin{array}{l}\text { N1- } \\
\text { tro- } \\
\text { gen }\end{array}$ & $\begin{array}{l}\text { Oxy- } \\
\text { gen }\end{array}$ & $\begin{array}{l}\text { Sul- } \\
\text { fur }\end{array}$ & & \\
\hline \multicolumn{15}{|c|}{ Mendenhall bed-Continued } \\
\hline SD-6 & $\begin{array}{l}5.75 \\
7.85\end{array}$ & $\begin{array}{l}\text { E-32807 } \\
\text { E-32871 }\end{array}$ & $\begin{array}{l}\mathbf{A} \\
\mathbf{B} \\
\mathbf{C} \\
\mathbf{A} \\
\mathbf{B} \\
\mathbf{C}\end{array}$ & \begin{tabular}{|c|}
39.3 \\
\hdashline 37.4 \\
..- \\
\end{tabular} & $\begin{array}{l}23.8 \\
39.2 \\
45.2 \\
24.2 \\
38.7 \\
44.7\end{array}$ & $\begin{array}{l}28.8 \\
47.5 \\
54.8 \\
30.1 \\
48.0 \\
55.3\end{array}$ & $\begin{array}{r}8.1 \\
13.3 \\
\hdashline 8.3 \\
13.3 \\
\hdashline-\end{array}$ & $\begin{array}{l}6.7 \\
3.9 \\
4.5 \\
6.5 \\
3.7 \\
4.3\end{array}$ & $\begin{array}{l}38.3 \\
63.0 \\
72.7 \\
39.3 \\
62.7 \\
72.4\end{array}$ & $\begin{array}{l}0.5 \\
.8 \\
.9 \\
.5 \\
.8 \\
.9\end{array}$ & $\begin{array}{l}45.2 \\
17.0 \\
19.6 \\
44.4 \\
18.0 \\
20.6\end{array}$ & $\begin{array}{l}1.2 \\
2.0 \\
2.3 \\
1.0 \\
1.5 \\
1.8\end{array}$ & $\begin{array}{r}6,360 \\
10,480 \\
12,100 \\
6,500 \\
10,390 \\
11,980\end{array}$ & 2,130 \\
\hline $\mathrm{SD}-1$ & $\begin{array}{l}1.1 \\
6.0\end{array}$ & $\begin{array}{l}\text { E-32888 } \\
\text { E-32889 }\end{array}$ & $\begin{array}{l}\mathbf{A} \\
\mathbf{B} \\
\mathbf{C} \\
\mathbf{A} \\
\mathbf{B} \\
\mathbf{C}\end{array}$ & 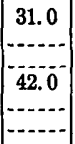 & $\begin{array}{l}19.8 \\
28.7 \\
50.2 \\
23.2 \\
40.0 \\
47.1\end{array}$ & \begin{tabular}{|l|}
19.6 \\
28.4 \\
49.8 \\
26.1 \\
45.0 \\
52.9
\end{tabular} & \begin{tabular}{r}
29.6 \\
42.0 \\
\hdashline 8.7 \\
15.0 \\
..--
\end{tabular} & $\begin{array}{l}4.8 \\
2.0 \\
3.5 \\
6.8 \\
3.6 \\
4.3\end{array}$ & $\begin{array}{l}25.1 \\
36.4 \\
63.8 \\
35.0 \\
60.3 \\
71.0\end{array}$ & $\begin{array}{r}.4 \\
.6 \\
1.1 \\
.4 \\
.7 \\
.8\end{array}$ & \begin{tabular}{|l|}
36.9 \\
13.4 \\
23.4 \\
48.1 \\
18.6 \\
21.8
\end{tabular} & $\begin{array}{l}3.2 \\
4.7 \\
8.2 \\
1.0 \\
1.8 \\
2.1\end{array}$ & $\begin{array}{r}3,920 \\
5,680 \\
9,940 \\
5,690 \\
9,810 \\
11,550\end{array}$ & $\begin{array}{r}2,040 \\
\hdashline 1,070 \\
\\
\hdashline\end{array}$ \\
\hline SD-15 & 2.2 & & $\begin{array}{l}\mathbf{A} \\
\mathbf{B}\end{array}$ & 39.7 & $\begin{array}{l}23.7 \\
39.2\end{array}$ & $\begin{array}{l}26.2 \\
43.5\end{array}$ & $\begin{array}{l}10.4 \\
17.3\end{array}$ & $\begin{array}{l}6.6 \\
3.7\end{array}$ & $\begin{array}{l}35.9 \\
59.5\end{array}$ & .5 & $\begin{array}{l}45.6 \\
17.0\end{array}$ & $\begin{array}{l}1.0 \\
1.7\end{array}$ & $\begin{array}{l}5,880 \\
9,740\end{array}$ & 1,960 \\
\hline & $\begin{array}{l}1.25 \\
5.8\end{array}$ & $\begin{array}{l}\text { E-32892 } \\
\text { E-32893 }\end{array}$ & $\begin{array}{l}\text { C } \\
\mathbf{A} \\
\mathbf{B} \\
\mathbf{C} \\
\mathbf{A} \\
\mathbf{B} \\
\mathbf{O}\end{array}$ & \begin{tabular}{c}
38.4 \\
\hdashline 40.5 \\
\hdashline-1. \\
\end{tabular} & $\begin{array}{l}47.5 \\
22.0 \\
35.6 \\
45.7 \\
23.1 \\
38.8 \\
46.7\end{array}$ & \begin{tabular}{|l|}
52.5 \\
26.0 \\
42.4 \\
54.3 \\
26.4 \\
44.4 \\
53.3
\end{tabular} & \begin{tabular}{c}
-13.6 \\
22.0 \\
\hdashline 10.0 \\
16.8 \\
\hdashline.-
\end{tabular} & $\begin{array}{l}4.4 \\
6.3 \\
3.3 \\
4.2 \\
6.7 \\
3.6 \\
4.4\end{array}$ & $\begin{array}{l}71.9 \\
33.1 \\
53.7 \\
68.8 \\
35.1 \\
59.0 \\
70.8\end{array}$ & $\begin{array}{l}.9 \\
.3 \\
.5 \\
.7 \\
.4 \\
.7 \\
.8\end{array}$ & $\begin{array}{l}20.7 \\
44.0 \\
16.1 \\
20.6 \\
46.8 \\
18.2 \\
21.9\end{array}$ & $\begin{array}{l}2.1 \\
2.7 \\
4.4 \\
5.7 \\
1.0 \\
1.7 \\
2.1\end{array}$ & $\mid \begin{array}{r}11,780 \\
5,560 \\
9,020 \\
11,570 \\
5,760 \\
9,690 \\
11,640\end{array}$ & $\begin{array}{r}-1,910 \\
1,970 \\
\end{array}$ \\
\hline SD- & $\begin{array}{l}5.3 \\
6.38\end{array}$ & $\begin{array}{l}\text { E-12615 } \\
\text { E-12616 }\end{array}$ & $\begin{array}{l}\mathbf{A} \\
\mathbf{B} \\
\mathbf{C} \\
\mathbf{A} \\
\mathbf{B} \\
\mathbf{O}\end{array}$ & \begin{tabular}{c}
42.7 \\
\hdashline 44.9 \\
\hdashline-1 \\
-0
\end{tabular} & $\begin{array}{l}22.0 \\
38.3 \\
46.4 \\
21.9 \\
39.8 \\
46.3\end{array}$ & \begin{tabular}{|l|}
25.3 \\
44.2 \\
53.6 \\
25.5 \\
46.1 \\
53.7
\end{tabular} & \begin{tabular}{r}
10.0 \\
17.5 \\
\hdashline 7.7 \\
14.1 \\
\end{tabular} & $\begin{array}{l}6.9 \\
3.8 \\
4.7 \\
7.2 \\
4.0 \\
4.6\end{array}$ & $\begin{array}{l}34.0 \\
59.3 \\
71.9 \\
34.1 \\
61.8 \\
71.9\end{array}$ & $\begin{array}{r}.5 \\
.8 \\
1.0 \\
.4 \\
.8 \\
.9\end{array}$ & $\begin{array}{l}46.9 \\
15.6 \\
18.8 \\
49.8 \\
17.9 \\
21.0\end{array}$ & \begin{tabular}{|l|}
1.7 \\
3.0 \\
3.6 \\
.8 \\
1.4 \\
1.6
\end{tabular} & $\begin{array}{r}5,790 \\
10,110 \\
12,250 \\
5,720 \\
10,380 \\
12,070\end{array}$ & $\begin{array}{r}2,010 \\
2,140 \\
\end{array}$ \\
\hline SD-2 & $\begin{array}{l}1.25 \\
. \\
5.5\end{array}$ & $\begin{array}{l}E-33310 \\
E-33311\end{array}$ & $\begin{array}{l}\mathbf{A} \\
\mathbf{B} \\
\mathbf{C} \\
\mathbf{A} \\
\mathbf{B} \\
\mathbf{C}\end{array}$ & \begin{tabular}{c}
37.4 \\
\hdashline 42.0 \\
\\
\hdashline
\end{tabular} & $\begin{array}{l}22.0 \\
35.2 \\
45.7 \\
22.8 \\
39.3 \\
45.9\end{array}$ & $\begin{array}{l}26.1 \\
41.7 \\
54.3 \\
26.8 \\
46.3 \\
54.1\end{array}$ & $\begin{array}{r}14.5 \\
23.1 \\
8.4 \\
14.4 \\
\end{array}$ & $\begin{array}{l}6.2 \\
3.2 \\
4.2 \\
6.9 \\
3.8 \\
4.5\end{array}$ & $\begin{array}{l}33.3 \\
53.2 \\
69.1 \\
35.3 \\
60.9 \\
71.1\end{array}$ & $\begin{array}{l}.4 \\
.6 \\
.8 \\
.4 \\
.7 \\
.8\end{array}$ & \begin{tabular}{|l}
42.5 \\
14.9 \\
19.5 \\
47.8 \\
18.2 \\
21.3
\end{tabular} & \begin{tabular}{|l|}
3.1 \\
5.0 \\
6.4 \\
1.2 \\
2.0 \\
2.3
\end{tabular} & $\begin{array}{r}5,610 \\
8,960 \\
11,650 \\
5,900 \\
10,180 \\
11,890\end{array}$ & $\begin{array}{r}1,940 \\
2,020 \\
\end{array}$ \\
\hline & 8.3 & E-33314 & $\begin{array}{l}\mathbf{A} \\
\mathbf{B} \\
\mathbf{C}\end{array}$ & $\mid$\begin{tabular}{c}
29.7 \\
\hdashline.. \\
\hdashline.--
\end{tabular} & $\begin{array}{l}25.3 \\
36.0 \\
46.4\end{array}$ & $\begin{array}{l}29.2 \\
41.5 \\
53.6\end{array}$ & \begin{tabular}{c}
15.8 \\
22.5 \\
\hdashline.--
\end{tabular} & $\begin{array}{l}5.7 \\
3.3 \\
4.3\end{array}$ & $\begin{array}{l}38.6 \\
54.9 \\
70.8\end{array}$ & $\begin{array}{l}.5 \\
.6 \\
.8\end{array}$ & \begin{tabular}{|l|}
38.3 \\
17.1 \\
22.1
\end{tabular} & $\begin{array}{l}1.1 \\
1.6 \\
2.0\end{array}$ & $\begin{array}{r}6,420 \\
9,130 \\
11,780\end{array}$ & $\begin{array}{r}2,080 \\
\end{array}$ \\
\hline SD-30. & 13.4 & $\begin{array}{l}E-33800 \\
E-33801\end{array}$ & $\begin{array}{l}\mathbf{A} \\
\mathbf{B} \\
\mathbf{C} \\
\mathbf{A} \\
\mathbf{B} \\
\mathbf{C}\end{array}$ & $\begin{array}{c}21.6 \\
39.0 \\
-\end{array}$ & $\begin{array}{l}23.8 \\
30.4 \\
55.6 \\
23.8 \\
39.0 \\
47.3\end{array}$ & $\begin{array}{l}19.1 \\
24.3 \\
44.4 \\
26.5 \\
43.5 \\
52.7\end{array}$ & \begin{tabular}{c}
35.5 \\
45.3 \\
\hdashline 10.7 \\
17.5 \\
\hdashline$\ldots$
\end{tabular} & $\begin{array}{l}3.6 \\
1.5 \\
2.8 \\
6.6 \\
3.7 \\
4.5\end{array}$ & $\begin{array}{l}28.0 \\
35.7 \\
65.3 \\
35.3 \\
57.9 \\
70.2\end{array}$ & $\begin{array}{r}.8 \\
1.1 \\
2.0 \\
.4 \\
.7 \\
.9\end{array}$ & $\begin{array}{l}28.3 \\
11.5 \\
21.0 \\
45.6 \\
17.9 \\
21.6\end{array}$ & $\begin{array}{l}3.8 \\
4.9 \\
8.9 \\
1.4 \\
2.3 \\
2.8\end{array}$ & $\begin{array}{r}4,210 \\
5,370 \\
9,820 \\
5,870 \\
9,630 \\
11,670\end{array}$ & $\begin{array}{r}1,970 \\
1,990 \\
\end{array}$ \\
\hline ת חס & 8.95 & $\mathrm{E}-33297$ & $\begin{array}{l}\text { A } \\
B \\
\text { C }\end{array}$ & $\mid$\begin{tabular}{c}
39.3 \\
\hdashline \\
\hdashline..- \\
\end{tabular} & $\begin{array}{l}22.5 \\
37.0 \\
47.2\end{array}$ & $\begin{array}{l}25.0 \\
41.3 \\
52.8\end{array}$ & $\begin{array}{l}13.2 \\
21.7\end{array}$ & $\begin{array}{l}6.4 \\
3.3 \\
4.3\end{array}$ & $\begin{array}{l}32.3 \\
53.1 \\
67.8\end{array}$ & $\begin{array}{r}.5 \\
.8 \\
1.0\end{array}$ & $\begin{array}{l}46.0 \\
18.4 \\
23.5\end{array}$ & $\begin{array}{l}1.6 \\
2.7 \\
3.4\end{array}$ & $\begin{array}{r}5,330 \\
8,770 \\
11,200\end{array}$ & \begin{tabular}{r}
2,040 \\
\hdashline$\ldots$ \\
\end{tabular} \\
\hline 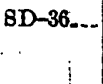 & $\begin{array}{l}2.2 \\
. .\end{array}$ & E-33810 & $\begin{array}{l}\mathbf{A} \\
\mathbf{B} \\
\mathrm{O}\end{array}$ & 32.7 & $\begin{array}{l}23.5 \\
34.8 \\
47.8\end{array}$ & \begin{tabular}{l|}
25.6 \\
38.1 \\
52.2
\end{tabular} & $\begin{array}{l}18.2 \\
27.1\end{array}$ & $\begin{array}{l}5.5 \\
2.8 \\
3.8\end{array}$ & $\begin{array}{l}31.6 \\
47.0 \\
64.4\end{array}$ & $\begin{array}{l}.4 \\
.5 \\
.7\end{array}$ & $\begin{array}{l}39.7 \\
15.8 \\
21.8\end{array}$ & $\begin{array}{l}4.6 \\
6.8 \\
9.3\end{array}$ & $\begin{array}{r}5,250 \\
7,800 \\
10,690\end{array}$ & $\begin{array}{r}1,940 \\
\end{array}$ \\
\hline GS-2 & 9.5 & $D-68851$ & $\begin{array}{l}\mathbf{A} \\
\mathbf{B} \\
\mathbf{C}\end{array}$ & 37.8 & $\begin{array}{l}24.2 \\
39.0 \\
46.6\end{array}$ & $\begin{array}{l}27.8 \\
44.7 \\
53.4\end{array}$ & $\begin{array}{l}10.2 \\
16.3\end{array}$ & & & & & $\begin{array}{l}1.6 \\
2.6 \\
3.1\end{array}$ & $\begin{array}{r}6,150 \\
9,880 \\
11,800\end{array}$ & $\begin{array}{r}2,060 \\
\hdashline \ldots\end{array}$ \\
\hline QS-3_- & $\begin{array}{r}6.2 \\
7.8\end{array}$ & $\begin{array}{l}D-68853 \\
D-68854\end{array}$ & $\begin{array}{l}\mathbf{A} \\
\mathbf{B} \\
\mathbf{C} \\
\mathbf{A} \\
\mathbf{B} \\
\mathbf{C}\end{array}$ & \begin{tabular}{c}
40.8 \\
\hdashline 40.3 \\
\end{tabular} & $\begin{array}{l}24.0 \\
40.5 \\
46.7 \\
24.7 \\
41.4 \\
48.5\end{array}$ & $\begin{array}{l}27.4 \\
46.4 \\
53.3 \\
26.2 \\
43.9 \\
51.5\end{array}$ & $\begin{array}{r}7.8 \\
13.1 \\
8.8 \\
14.7\end{array}$ & $\ldots$ & & $\cdots$ & & $\begin{array}{l}1.1 \\
1.8 \\
2.1 \\
1.6 \\
2.6 \\
3.1\end{array}$ & $\mid \begin{array}{r}6,260 \\
10,570 \\
12,160 \\
6,030 \\
10,100 \\
11,840\end{array}$ & $\begin{array}{l}2,070 \\
2,080\end{array}$ \\
\hline
\end{tabular}


TABLE 8.-Fuel analyses of lignite from the Mendenhall area, South Dakota-Con.

\begin{tabular}{|c|c|c|c|c|c|c|c|c|c|c|c|c|c|c|}
\hline \multirow{3}{*}{$\begin{array}{l}\text { Core } \\
\text { hole }\end{array}$} & \multicolumn{3}{|c|}{ Sample } & \multicolumn{9}{|c|}{ Analyses, in percent } & \multirow{3}{*}{$\begin{array}{c}\vdots \\
\text { Heat- } \\
\text { ing } \\
\text { value } \\
\text { (Btu) }\end{array}$} & \multirow{3}{*}{$\begin{array}{c}\text { Ash } \\
\text { soften } \\
\text { ing } \\
\text { tem- } \\
\text { pers- } \\
\text { ture } \\
\text { of. }\end{array}$} \\
\hline & \multirow[b]{2}{*}{$\begin{array}{l}\text { Thick- } \\
\text { ness } \\
\text { (feet) }\end{array}$} & \multirow[b]{2}{*}{$\begin{array}{c}\text { Labora- } \\
\text { tory } \\
\text { No. }\end{array}$} & \multirow[b]{2}{*}{$\begin{array}{c}\text { Con- } \\
\text { di- } \\
\text { tion }\end{array}$} & \multicolumn{3}{|c|}{ Proximate } & \multicolumn{6}{|c|}{ Ultimate } & & \\
\hline & & & & $\begin{array}{c}\text { Mols- } \\
\text { ture }\end{array}$ & $\begin{array}{l}\text { Vol- } \\
\text { atile } \\
\text { mat- } \\
\text { ter }\end{array}$ & $\begin{array}{c}\text { Fixed } \\
\text { car- } \\
\text { bon }\end{array}$ & Ash & $\begin{array}{l}\text { Hy- } \\
\text { dro- } \\
\text { gen }\end{array}$ & $\begin{array}{l}\text { Car- } \\
\text { bon }\end{array}$ & $\begin{array}{l}\text { N1- } \\
\text { tro- } \\
\text { gen }\end{array}$ & $\begin{array}{c}\text { Oxy- } \\
\text { gen }\end{array}$ & $\begin{array}{l}\text { Sul- } \\
\text { fur }\end{array}$ & & \\
\hline
\end{tabular}

Mendenhall bed-Continued

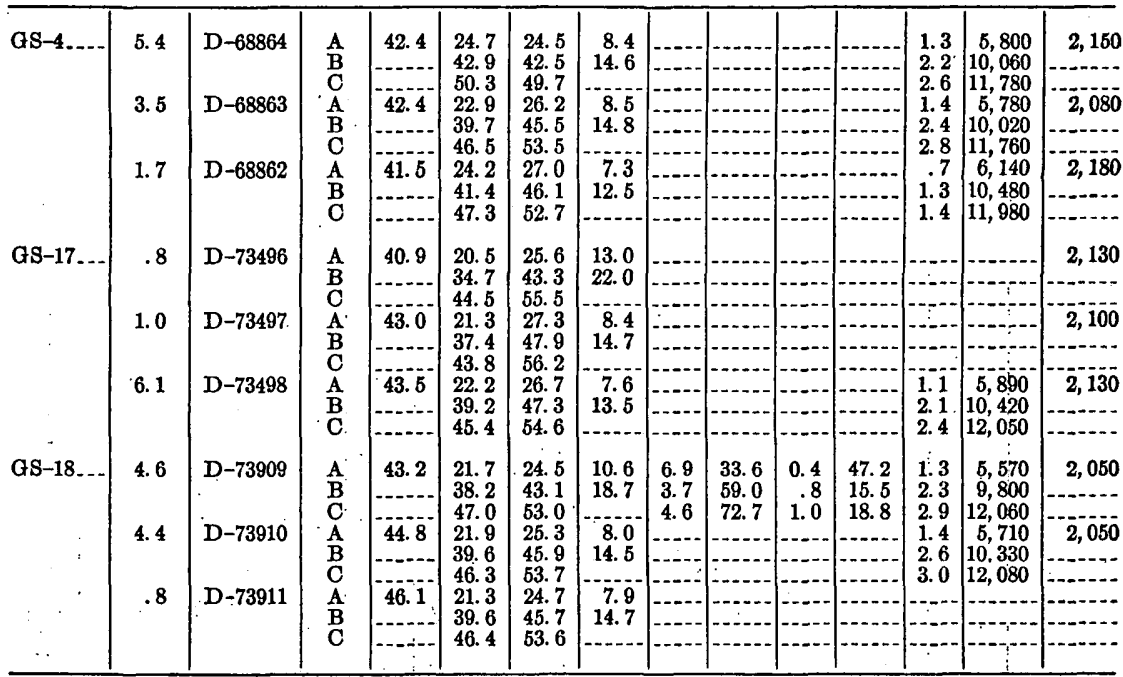

Olesrud lignite bed (upper bench)

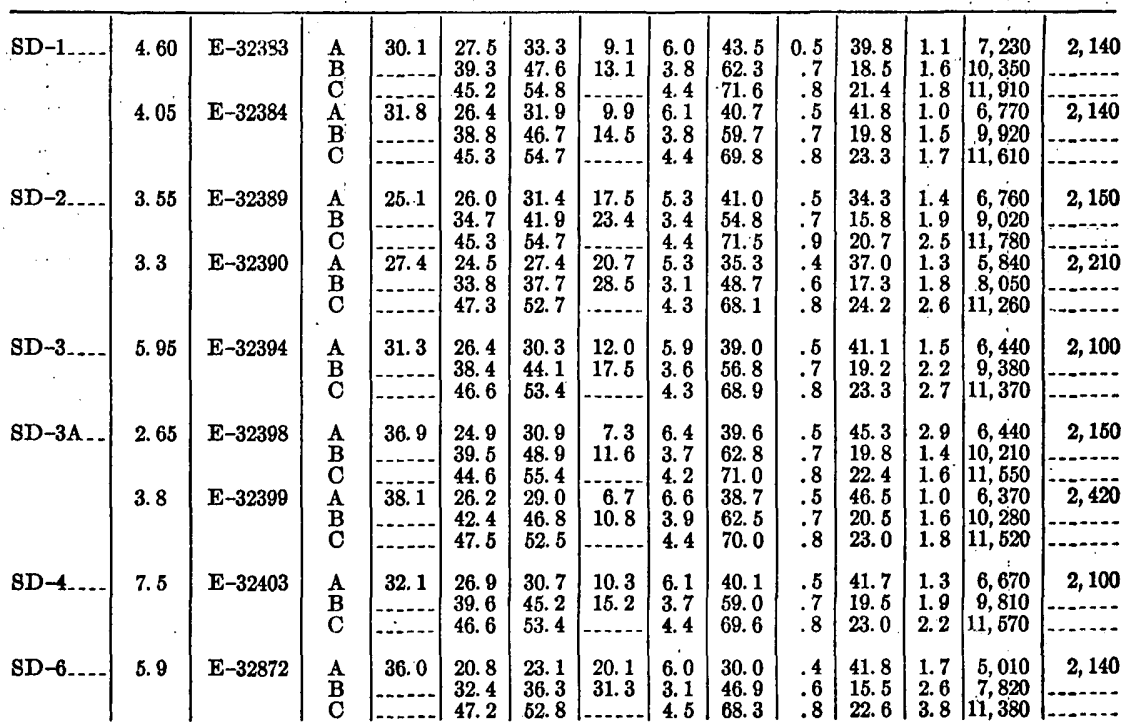


TABLE 8.-Fuel analyses of lignite from the Mendenhall area, South Dakota-Con.

\begin{tabular}{|c|c|c|c|c|c|c|c|c|c|c|c|c|c|c|}
\hline \multirow{3}{*}{$\begin{array}{l}\text { Core. } \\
\text { hole }\end{array}$} & \multicolumn{3}{|c|}{ Sample } & \multicolumn{9}{|c|}{ Analyses, in percent } & \multirow{3}{*}{$\begin{array}{c}\text { Heat- } \\
\text { ing } \\
\text { value } \\
\text { (Btu) }\end{array}$} & \multirow{3}{*}{$\begin{array}{c}\text { Ash } \\
\text { soften } \\
\text { ing } \\
\text { tem- } \\
\text { pera- } \\
\text { ture } \\
\text { or. }\end{array}$} \\
\hline & \multirow[b]{2}{*}{$\begin{array}{c}\text { Thick- } \\
\text { ness } \\
\text { (feet) }\end{array}$} & \multirow[b]{2}{*}{$\begin{array}{c}\text { Labora- } \\
\text { tory } \\
\text { No. }\end{array}$} & \multirow[b]{2}{*}{$\begin{array}{c}\text { Con- } \\
\text { di- } \\
\text { tion }\end{array}$} & \multicolumn{3}{|c|}{ Proximate } & \multicolumn{6}{|c|}{ Ultimate } & & \\
\hline & & & & $\begin{array}{c}\text { Mois- } \\
\text { ture }\end{array}$ & $\begin{array}{l}\text { Vol- } \\
\text { atile } \\
\text { mat- } \\
\text { ter }\end{array}$ & $\begin{array}{c}\text { Fixed } \\
\text { car- } \\
\text { bon }\end{array}$ & Ash & $\begin{array}{l}\text { Hy- } \\
\text { dro- } \\
\text { gen }\end{array}$ & $\begin{array}{l}\text { Car- } \\
\text { bon }\end{array}$ & $\begin{array}{l}\text { Ni- } \\
\text { tro- } \\
\text { gen }\end{array}$ & $\begin{array}{l}\text { Oxy } \\
\text { gen }\end{array}$ & $\begin{array}{l}\text { Sul- } \\
\text { fur }\end{array}$ & & \\
\hline
\end{tabular}

Olesrud lignite bed (upper bench) - Continued

\begin{tabular}{|c|c|c|c|c|c|c|c|c|c|c|c|c|c|c|}
\hline SD- & 5.65 & E-32875 & $\begin{array}{l}\mathrm{A} \\
\mathrm{B} \\
\mathrm{C}\end{array}$ & \begin{tabular}{|c|}
38.3 \\
\hdashline \\
\hdashline
\end{tabular} & $\begin{array}{l}24.5 \\
39.7 \\
46.4\end{array}$ & $\begin{array}{l}28.2 \\
45.7 \\
53.6\end{array}$ & $\begin{array}{r}9.0 \\
14.6 \\
-\end{array}$ & $\begin{array}{l}6.6 \\
3.8 \\
4.4\end{array}$ & \begin{tabular}{|l}
37.3 \\
60.5 \\
70.8
\end{tabular} & $\begin{array}{r}0.4 \\
.7 \\
.8\end{array}$ & $\begin{array}{l}45.7 \\
18.8 \\
22.1\end{array}$ & $\begin{array}{l}1.0 \\
1.6 \\
1.9\end{array}$ & $\begin{array}{r}6,180 \\
10,020 \\
11,730\end{array}$ & \begin{tabular}{r}
2,210 \\
\hdashline- \\
\end{tabular} \\
\hline SD-7B.. & 5.6 & E-32881 & $\begin{array}{l}\mathrm{A} \\
\mathrm{B} \\
\mathbf{C}\end{array}$ & 40.1 & $\begin{array}{l}23.9 \\
39.9 \\
47.8\end{array}$ & $\begin{array}{l}26.1 \\
43.5 \\
52.2\end{array}$ & $\begin{array}{r}9.9 \\
16.6 \\
\end{array}$ & $\begin{array}{l}6.8 \\
3.8 \\
4.6\end{array}$ & $\begin{array}{l}35.0 \\
58.4 \\
70.0\end{array}$ & $\begin{array}{l}.5 \\
.8 \\
.9\end{array}$ & $\begin{array}{l}46.4 \\
18.0 \\
21.7\end{array}$ & $\begin{array}{l}1.4 \\
2.4 \\
2.8\end{array}$ & $\begin{array}{r}5,830 \\
9,730 \\
\mathrm{u}, 660\end{array}$ & $\begin{array}{r}2,040 \\
\hdashline-. \\
\hdashline\end{array}$ \\
\hline SD-8. & 5. 34 & E-19300 & $\begin{array}{l}\mathrm{A} \\
\mathbf{B} \\
\mathbf{C}\end{array}$ & 44.1 & $\begin{array}{l}23.1 \\
41.2 \\
46.4\end{array}$ & $\begin{array}{l}26.6 \\
47.7 \\
53.6\end{array}$ & $\begin{array}{r}6.2 \\
11.1 \\
-\end{array}$ & $\begin{array}{l}7.3 \\
4.2 \\
4.7\end{array}$ & $\begin{array}{l}35.5 \\
63.4 \\
71.3\end{array}$ & $\begin{array}{l}.4 \\
.8 \\
.9\end{array}$ & $\begin{array}{l}49.6 \\
18.7 \\
21.0\end{array}$ & $\begin{array}{l}1.0 \\
1.8 \\
2.1\end{array}$ & $\begin{array}{r}5,920 \\
10,580 \\
11,900\end{array}$ & $\begin{array}{r}2,190 \\
\hdashline\end{array}$ \\
\hline \multirow[t]{3}{*}{ SD-9A. } & .7 & E-32885 & $\begin{array}{l}\mathrm{A} \\
\mathrm{B} \\
\mathbf{C}\end{array}$ & 19.2 & $\begin{array}{l}17.6 \\
21.7\end{array}$ & $\begin{array}{l}10.0 \\
12.5\end{array}$ & $\begin{array}{l}53.2 \\
65.8\end{array}$ & $\begin{array}{l}3.3 \\
1.4\end{array}$ & $\begin{array}{l}15.5 \\
19.2\end{array}$ & $\begin{array}{l}.3 \\
.4\end{array}$ & $\begin{array}{l}27.6 \\
13.1\end{array}$ & .1 & - & 2,700 \\
\hline & .4 & E-32886 & $\stackrel{\mathrm{A}}{\mathrm{B}}$ & 12.4 & $\begin{array}{l}14.5 \\
16.6\end{array}$ & $\begin{array}{l}10.9 \\
12.4\end{array}$ & $\begin{array}{l}62.2 \\
71.0\end{array}$ & $\begin{array}{l}2.7 \\
1.5\end{array}$ & $\begin{array}{l}15.9 \\
18.1\end{array}$ & .2 & $\begin{array}{r}18.6 \\
8.6\end{array}$ & $\begin{array}{l}.4 \\
.5\end{array}$ & - & 2,520 \\
\hline & 3.65 & E-32887 & $\begin{array}{l}\mathrm{A} \\
\mathrm{B} \\
\mathrm{C}\end{array}$ & 36.2 & $\begin{array}{l}-33.9 \\
37.5 \\
46.0\end{array}$ & $\begin{array}{l}28.0 \\
43.9 \\
54.0\end{array}$ & $\begin{array}{r}11.9 \\
18.6 \\
-\end{array}$ & $\begin{array}{l}6.2 \\
3.3 \\
4.1\end{array}$ & $\begin{array}{l}36.9 \\
57.9 \\
71.2\end{array}$ & $\begin{array}{l}.4 \\
.7 \\
.8\end{array}$ & $\begin{array}{l}42.4 \\
16.1 \\
19.7\end{array}$ & $\begin{array}{l}2.2 \\
3.4 \\
4.2\end{array}$ & $\begin{array}{r}6,060 \\
9,510 \\
11,680\end{array}$ & $\begin{array}{r}2,040 \\
\end{array}$ \\
\hline SD-10... & 5.17 & E-9832 & $\begin{array}{l}\mathbf{A} \\
\mathbf{B} \\
\mathbf{C}\end{array}$ & 44.2 & $\begin{array}{l}20.2 \\
36.3 \\
44.1\end{array}$ & $\begin{array}{l}25.7 \\
46.0 \\
55.9\end{array}$ & $\begin{array}{r}9.9 \\
17.7 \\
-\end{array}$ & $\begin{array}{l}7.0 \\
3.7 \\
4.5\end{array}$ & $\begin{array}{l}32.8 \\
58.8 \\
71.4\end{array}$ & $\begin{array}{l}.4 \\
.7 \\
.8\end{array}$ & $\begin{array}{l}49.3 \\
18.1 \\
22.1\end{array}$ & $\begin{array}{l}.6 \\
1.0 \\
1.2\end{array}$ & $\begin{array}{r}5,470 \\
9,790 \\
11,890\end{array}$ & $\begin{array}{r}2,020 \\
\hdashline\end{array}$ \\
\hline $\begin{array}{c}\text { SD-14 } \\
+\end{array}$ & 9.2 & E-32890 & $\begin{array}{l}\mathrm{A} \\
\mathbf{B} \\
\mathbf{C}\end{array}$ & 38.7 & $\begin{array}{l}24.3 \\
39.7 \\
47.5\end{array}$ & $\begin{array}{l}27.0 \\
44.0 \\
52.5\end{array}$ & $\begin{array}{l}10.0 \\
16.3\end{array}$ & $\begin{array}{l}6.5 \\
3.6 \\
4.3\end{array}$ & $\begin{array}{l}36.1 \\
58.9 \\
70.3\end{array}$ & $\begin{array}{l}.4 \\
.7 \\
.8\end{array}$ & $\begin{array}{l}45.4 \\
17.8 \\
21.4\end{array}$ & $\begin{array}{l}1.6 \\
2.7 \\
3.2\end{array}$ & $\begin{array}{r}5,950 \\
9,710 \\
11,600\end{array}$ & $\begin{array}{r}2,040 \\
\end{array}$ \\
\hline SD-15... & 8.5 & $\begin{array}{c}\text { E-32894 } \\
-\end{array}$ & $\begin{array}{l}\mathrm{A} \\
\mathrm{B} \\
\mathbf{C}\end{array}$ & 39.8 & $\begin{array}{l}22.6 \\
37.6 \\
47.7\end{array}$ & $\begin{array}{l}24.8 \\
41.2 \\
52.3\end{array}$ & $\begin{array}{l}12.7 \\
21.2\end{array}$ & $\begin{array}{l}6.6 \\
3.5 \\
4.5\end{array}$ & $\begin{array}{l}32.7 \\
54.5 \\
69.1\end{array}$ & $\begin{array}{l}.4 \\
.6 \\
.8\end{array}$ & $\begin{array}{l}46.5 \\
18.3 \\
23.2\end{array}$ & $\begin{array}{l}1.1 \\
1.9 \\
2.4\end{array}$ & $\begin{array}{r}5,390 \\
8,970 \\
11,380\end{array}$ & $\begin{array}{r}2,070 \\
\end{array}$ \\
\hline SD-18. & .6 & E-33304 & $\begin{array}{l}\mathrm{A} \\
\mathbf{B}\end{array}$ & 29.9 & $\begin{array}{l}17.9 \\
25.5\end{array}$ & $\begin{array}{r}9.6 \\
13.8\end{array}$ & $\begin{array}{l}42.6 \\
60.7\end{array}$ & $\begin{array}{l}4.4 \\
1.5\end{array}$ & $\begin{array}{l}17.0 \\
24.2\end{array}$ & .5 & $\begin{array}{l}35.3 \\
12.6\end{array}$ & .2 & $\because-$ & $\begin{array}{r}2,150 \\
\end{array}$ \\
\hline $8 D-19$ & 7.8 & E-12617 & $\begin{array}{l}\mathbf{A} \\
\mathbf{B} \\
\mathbf{C}\end{array}$ & \begin{tabular}{c}
45.5 \\
\hdashline- \\
\hdashline
\end{tabular} & $\begin{array}{l}21.5 \\
39.4 \\
44.7\end{array}$ & $\begin{array}{l}26.5 \\
48.7 \\
55.3\end{array}$ & $\begin{array}{r}6.5 \\
11.9 \\
-\end{array}$ & $\begin{array}{l}7.2 \\
4.0 \\
4.5\end{array}$ & $\begin{array}{l}34.7 \\
63.6 \\
72.2\end{array}$ & $\begin{array}{l}.4 \\
.8 \\
.8\end{array}$ & $\begin{array}{l}50.5 \\
18.4 \\
20.9\end{array}$ & $\begin{array}{r}.7 \\
1.3 \\
1.5\end{array}$ & $\begin{array}{r}5,820 \\
10,660 \\
12,100\end{array}$ & $\begin{array}{r}2,180 \\
\end{array}$ \\
\hline & & & $\stackrel{A}{B}$ & & $\begin{array}{l}23.3 . \\
29.8\end{array}$ & $\begin{array}{l}14.7 \\
18.7\end{array}$ & $\begin{array}{l}40.3 \\
51.5\end{array}$ & $\begin{array}{l}3.6 \\
1.5\end{array}$ & $\begin{array}{l}24.3 \\
31.0\end{array}$ & $\begin{array}{l}.5 \\
.7\end{array}$ & $\begin{array}{l}29.8 \\
13.4\end{array}$ & $\begin{array}{l}1.5 \\
1.9\end{array}$ & $\begin{array}{l}3,200 \\
4,090\end{array}$ & 2,280 \\
\hline & .95 & E-33308 & $\begin{array}{l}\mathrm{C} \\
\mathrm{A} \\
\mathrm{B} \\
\mathbf{C}\end{array}$ & \begin{tabular}{|c|}
-33.1 \\
\end{tabular} & $\begin{array}{l}61.5 \\
24.0 \\
35.8 \\
48.5\end{array}$ & $\begin{array}{l}38.5 \\
25.5 \\
38.1 \\
51.5\end{array}$ & $\begin{array}{l}17.4 \\
26.1\end{array}$ & $\begin{array}{l}3.0 \\
5.4 \\
2.6 \\
3.5\end{array}$ & $\begin{array}{l}64.0 \\
33.2 \\
49.7 \\
67.2\end{array}$ & $\begin{array}{r}1.3 \\
.5 \\
.8 \\
1.1\end{array}$ & $\begin{array}{l}27.9 \\
4 C .5 \\
16.3 \\
22.1\end{array}$ & $\begin{array}{l}3.8 \\
3.0 \\
4.5 \\
6.1\end{array}$ & $\begin{array}{r}8,440 \\
5,300 \\
7,920 \\
10,720\end{array}$ & $\begin{array}{r}1,030 \\
\end{array}$ \\
\hline SD-26.. & 5.2 & E-33315 & $\mathbf{A}$ & 38.5 & 24.1 & 27.6 & 9.8 & 6.5 & 36.7 & .5 & 45.8 & .7 & 6,110 & 2,130 \\
\hline & 4.0 & E-33316 & $\begin{array}{l}\mathbf{B} \\
\mathbf{C} \\
\mathbf{A} \\
\mathbf{B} \\
\mathbf{C}\end{array}$ & {$\left[\begin{array}{c}--\cdots \\
-35.1 \\
\cdots\end{array}\right.$} & $\begin{array}{l}39.2 \\
46.6 \\
21.5 \\
33.1 \\
49.4\end{array}$ & $\begin{array}{l}44.9 \\
53.4 \\
21.9 \\
33.8 \\
50.6\end{array}$ & $\mid$\begin{tabular}{c}
15.9 \\
\hdashline 21.5 \\
33.1
\end{tabular} & $\begin{array}{l}3.7 \\
4.4 \\
6.0 \\
3.2 \\
4.8\end{array}$ & $\begin{array}{l}59.8 \\
71.1 \\
29.8 \\
45.9 \\
68.6\end{array}$ & $\begin{array}{r}.8 \\
1.0 \\
.4 \\
.6 \\
.9\end{array}$ & $\begin{array}{l}18.7 \\
22.1 \\
41.4 \\
15.7 \\
23.5\end{array}$ & $\begin{array}{l}1.1 \\
1.4 \\
.9 \\
1.5 \\
2.2\end{array}$ & $\begin{array}{r}9,950 \\
11,830 \\
5,010 \\
7,730 \\
11,660\end{array}$ & 2,160 \\
\hline BD-27. & 3. 35 & E-33792 & $\begin{array}{l}\mathbf{A} \\
\mathbf{B} \\
\mathbf{C}\end{array}$ & 35.8 & $\begin{array}{l}23.7 \\
36.9 \\
48.1\end{array}$ & $\begin{array}{l}25.5 \\
39.8 \\
51.9\end{array}$ & $\begin{array}{c}15.0 \\
23.3 \\
\end{array}$ & $\begin{array}{l}6.2 \\
3.5 \\
4.6\end{array}$ & $\begin{array}{l}34.0 \\
52.9 \\
69.0\end{array}$ & $\begin{array}{l}.4 \\
.7 \\
.9\end{array}$ & $\begin{array}{l}43.6 \\
18.4 \\
23.9\end{array}$ & $\begin{array}{r}.8 \\
1.2 \\
1.6\end{array}$ & $\begin{array}{r}5,590 \\
8,720 \\
11,370\end{array}$ & 2,100 \\
\hline 8D-28.- & 4.6 & E-33796 & $\begin{array}{l}\mathbf{A} \\
\mathbf{B} \\
\mathbf{C}\end{array}$ & \begin{tabular}{c}
36.9 \\
\hdashline-
\end{tabular} & $\begin{array}{l}22.3 \\
35.3 \\
47.8\end{array}$ & $\begin{array}{l}24.4 \\
38.6 \\
52.2\end{array}$ & $\begin{array}{c}16.4 \\
26.1 \\
-\end{array}$ & $\begin{array}{l}6.2 \\
3.3 \\
4.5\end{array}$ & $\begin{array}{l}31.1 \\
49.3 \\
66.6\end{array}$ & $\begin{array}{l}.4 \\
.6 \\
.8\end{array}$ & $\begin{array}{l}44.3 \\
18.2 \\
24.8\end{array}$ & $\begin{array}{l}1.6 \\
2.5 \\
3.3\end{array}$ & $\begin{array}{r}5,310 \\
8,420 \\
11,380\end{array}$ & $\begin{array}{r}2,080 \\
\end{array}$ \\
\hline 8D-29... & 6.4 & E-33798 & $\begin{array}{l}\mathbf{A} \\
\mathbf{B} \\
\mathbf{C}\end{array}$ & 35.1 & $\begin{array}{l}25.1 \\
38.7 \\
45.9\end{array}$ & $\begin{array}{l}29.6 \\
45.6 \\
54.1\end{array}$ & $\begin{array}{l}10.2 \\
15.7\end{array}$ & $\begin{array}{l}6.4 \\
3.8 \\
4.5\end{array}$ & $\begin{array}{l}39.2 \\
60.3 \\
71.6\end{array}$ & $\begin{array}{l}.5 \\
.7 \\
.8\end{array}$ & $\begin{array}{l}43.1 \\
18.5 \\
21.9\end{array}$ & $\begin{array}{r}.6 \\
1.0 \\
1.2\end{array}$ & $\begin{array}{r}6,480 \\
9,980 \\
11,840\end{array}$ & 2,090 \\
\hline
\end{tabular}


TABLt 8.-Fuel analyses of lignite from the Mendenhaill area, South Dakota-Con.

\begin{tabular}{|c|c|c|c|c|c|c|c|c|c|c|c|c|c|c|}
\hline \multirow{3}{*}{$\begin{array}{l}\text { Core } \\
\text { hole }\end{array}$} & \multicolumn{3}{|c|}{ Sample } & \multicolumn{9}{|c|}{ Analyses, in percent } & \multirow{3}{*}{\begin{tabular}{|c|} 
Heat- \\
ing \\
value \\
(Btu)
\end{tabular}} & \multirow{3}{*}{$\begin{array}{c}\text { Ash } \\
\text { soften } \\
\text { ing } \\
\text { tem- } \\
\text { pera- } \\
\text { ture } \\
\text { of. }\end{array}$} \\
\hline & \multirow[b]{2}{*}{$\begin{array}{c}\text { Thick- } \\
\text { ness } \\
\text { (feet) }\end{array}$} & \multirow[b]{2}{*}{$\begin{array}{c}\text { Labora- } \\
\text { tory } \\
\text { No. }\end{array}$} & \multirow[b]{2}{*}{$\begin{array}{l}\text { Con- } \\
\text { di- } \\
\text { tion }\end{array}$} & \multicolumn{3}{|c|}{ Proximate } & \multicolumn{6}{|c|}{ Ultimate } & & \\
\hline & & & & $\begin{array}{c}\text { Mois- } \\
\text { ture }\end{array}$ & $\begin{array}{l}\text { Vol- } \\
\text { atile } \\
\text { mat- } \\
\text { ter }\end{array}$ & $\begin{array}{c}\text { Fixed } \\
\text { car- } \\
\text { bon }\end{array}$ & Ash & $\begin{array}{l}\text { Hy- } \\
\text { dro- } \\
\text { gen }\end{array}$ & $\begin{array}{l}\text { Car- } \\
\text { bon }\end{array}$ & $\begin{array}{l}\text { Ni- } \\
\text { tro- } \\
\text { gen }\end{array}$ & $\begin{array}{c}\text { Oxy- } \\
\text { gen }\end{array}$ & $\begin{array}{l}\text { Sul- } \\
\text { fur }\end{array}$ & & \\
\hline & \multicolumn{13}{|c|}{ Olesrud bed (upper bench) -Continued } & . \\
\hline SD-30. & 13.4 & E-33801 & $\begin{array}{l}\mathbf{A} \\
\mathbf{B} \\
\mathbf{C}\end{array}$ & \begin{tabular}{|c|}
39.0 \\
\hdashline$-\ldots$ \\
\end{tabular} & $\begin{array}{l}23.8 \\
39.0 \\
47.3\end{array}$ & $\begin{array}{l}26.5 \\
43.5 \\
52.7\end{array}$ & $\begin{array}{r}10.7 \\
17.5 \\
-. .\end{array}$ & $\begin{array}{l}6.6 \\
3.7 \\
4.5\end{array}$ & $\begin{array}{l}35.3 \\
57.9 \\
70.2\end{array}$ & $\begin{array}{l}0.4 \\
.7 \\
.9\end{array}$ & $\begin{array}{l}45.6 \\
17.9 \\
21.6\end{array}$ & $\begin{array}{l}1.4 \\
2.3 \\
2.8\end{array}$ & $\begin{array}{r}5,870 \\
9,630 \\
11,670\end{array}$ & $\begin{array}{r}1,890 \\
\hdashline\end{array}$ \\
\hline SD-32. & 2.0 & E-33804 & $\begin{array}{l}\mathbf{A} \\
\mathbf{B} \\
\mathbf{C}\end{array}$ & $\mid$\begin{tabular}{c}
34.0 \\
\hdashline..- \\
\hdashline
\end{tabular} & $\begin{array}{l}23.0 \\
34.9 \\
48.3\end{array}$ & $\begin{array}{l}24.6 \\
37.3 \\
51.7\end{array}$ & $\begin{array}{r}18.4 \\
27.8 \\
\hdashline-. .\end{array}$ & $\begin{array}{l}5.7 \\
2.9 \\
4.0\end{array}$ & $\begin{array}{l}32.8 \\
49.7 \\
68.9\end{array}$ & $\begin{array}{r}.6 \\
.9 \\
1.2\end{array}$ & $\begin{array}{l}41.4 \\
17.0 \\
23.6\end{array}$ & $\begin{array}{l}1.1 \\
1.7 \\
2.3\end{array}$ & $\begin{array}{r}5,200 \\
7,820 \\
10,910\end{array}$ & 2,300 \\
\hline & 3.0 & E-33805 & $\begin{array}{l}\mathbf{A} \\
\mathbf{B} \\
\mathbf{C}\end{array}$ & $\mid$\begin{tabular}{c}
37.7 \\
\hdashline..- \\
\hdashline
\end{tabular} & $\begin{array}{l}24.4 \\
39.1 \\
47.4\end{array}$ & $\begin{array}{l}27.0 \\
43.4 \\
52.6\end{array}$ & \begin{tabular}{c}
10.9 \\
17.5 \\
\hdashline..
\end{tabular} & $\begin{array}{l}6.5 \\
3.7 \\
4.5\end{array}$ & $\begin{array}{l}36.3 \\
58.2 \\
70.5\end{array}$ & $\begin{array}{l}.4 \\
.7 \\
.8\end{array}$ & $\begin{array}{l}44.3 \\
17.4 \\
21.1\end{array}$ & $\begin{array}{l}1.6 \\
2.5 \\
3.1\end{array}$ & $\begin{array}{r}6,030 \\
9,680 \\
11,730\end{array}$ & $\begin{array}{r}2,000 \\
\hdashline\end{array}$ \\
\hline SD- & 4.6 & E-33808 & $\begin{array}{l}\mathbf{A} \\
\mathbf{B} \\
\mathbf{C}\end{array}$ & \begin{tabular}{c}
34.6 \\
\hdashline..- \\
\hdashline$-\ldots$
\end{tabular} & \begin{tabular}{|l|}
24.0 \\
36.7 \\
48.6
\end{tabular} & $\begin{array}{l}25.4 \\
38.8 \\
51.4\end{array}$ & $\begin{array}{l}16.0 \\
24.5 \\
-\end{array}$ & $\begin{array}{l}6.0 \\
3.2 \\
4.3\end{array}$ & $\begin{array}{l}33.9 \\
51.8 \\
68.6\end{array}$ & $\begin{array}{l}.5 \\
.8 \\
1.0\end{array}$ & $\begin{array}{l}42.5 \\
18.0 \\
23.9\end{array}$ & $\begin{array}{l}1.1 \\
1.7 \\
2.2\end{array}$ & $\begin{array}{r}5,430 \\
8,300 \\
10,990\end{array}$ & $\begin{array}{r}2,030 \\
\end{array}$ \\
\hline $\mathrm{SD}$ & 6.85 & E-33811 & $\begin{array}{l}\mathbf{A} \\
\mathbf{C}\end{array}$ & \begin{tabular}{c}
38.7 \\
\hdashline..- \\
-2
\end{tabular} & $\begin{array}{l}24.4 \\
39.7 \\
45.4\end{array}$ & $\begin{array}{l}29.2 \\
47.8 \\
54.6\end{array}$ & $\begin{array}{r}7.7 \\
12.5 \\
\hdashline-. .\end{array}$ & $\begin{array}{l}6.6 \\
3.8 \\
4.3\end{array}$ & $\begin{array}{l}38.4 \\
62.7 \\
71.6\end{array}$ & $\begin{array}{l}.5 \\
.7 \\
.8\end{array}$ & $\begin{array}{l}46.0 \\
19.0 \\
21.7\end{array}$ & $\begin{array}{r}.8 \\
1.3 \\
1.5\end{array}$ & $\begin{array}{r}6,290 \\
10,260 \\
11,730\end{array}$ & $\begin{array}{r}2,100 \\
\hdashline\end{array}$ \\
\hline 8D-38... & 6.1 & E-33813 & $\begin{array}{l}\mathbf{A} \\
\mathbf{B} \\
\mathbf{O}\end{array}$ & 37.0 & $\begin{array}{l}25.2 \\
39.9 \\
47.2\end{array}$ & $\begin{array}{l}28.1 \\
44.8 \\
52.8\end{array}$ & $\begin{array}{r}9.7 \\
15.3 \\
\hdashline-.\end{array}$ & $\begin{array}{l}6.4 \\
3.5 \\
4.2\end{array}$ & $\begin{array}{l}38.1 \\
60.5 \\
71.4\end{array}$ & $\begin{array}{l}.5 \\
.8 \\
.9\end{array}$ & $\begin{array}{l}44.3 \\
18.3 \\
21.6\end{array}$ & $\begin{array}{l}1.0 \\
1.6 \\
1.9\end{array}$ & $\begin{array}{r}6,230 \\
9,890 \\
11,680\end{array}$ & $\begin{array}{r}2,060 \\
\hdashline\end{array}$ \\
\hline GS-1. & 1.7 & $\begin{array}{l}D-68847 \\
D-68848\end{array}$ & $\begin{array}{l}\mathbf{A} \\
\mathbf{B} \\
\mathbf{O} \\
\mathbf{A} \\
\mathbf{B} \\
\mathbf{C}\end{array}$ & \begin{tabular}{|c|}
29.2 \\
39.7 \\
\end{tabular} & $\begin{array}{l}29.1 \\
41.1 \\
45.8 \\
25.0 \\
41.5 \\
48.4\end{array}$ & $\begin{array}{l}34.4 \\
48.7 \\
54.2 \\
26.6 \\
44.2 \\
51.6\end{array}$ & $\begin{array}{r}7.3 \\
10.2 \\
8.7 \\
14.3 \\
\hdashline-\end{array}$ & $\cdots$ & & -- & & $\begin{array}{l}1.2 \\
1.6 \\
1.8 \\
1.1 \\
1.9 \\
2.2\end{array}$ & $\begin{array}{r}7,560 \\
10,680 \\
11,900 \\
6,100 \\
10,100 \\
11,790\end{array}$ & $\begin{array}{r}2,420 \\
2,110 \\
\end{array}$ \\
\hline GB-2.. & 6.1 & D-68850 & $\begin{array}{l}\mathbf{A} \\
\mathbf{B} \\
\mathbf{C}\end{array}$ & 36.0 & $\begin{array}{l}26.1 \\
40.8 \\
48.7\end{array}$ & $\begin{array}{l}27.5 \\
42.9 \\
51.3\end{array}$ & $\begin{array}{l}10.4 \\
16.3\end{array}$ & & & & & $\begin{array}{l}1.3 \\
2.1 \\
2.5\end{array}$ & $\begin{array}{r}6,370 \\
9,960 \\
11,890\end{array}$ & 2,150 \\
\hline G8-3.. & 7.8 & D-68855 & $\begin{array}{l}\mathbf{A} \\
\mathbf{B} \\
\mathbf{C}\end{array}$ & \begin{tabular}{c}
38.2 \\
\hdashline-
\end{tabular} & $\begin{array}{l}26.0 \\
42.0 \\
50.7\end{array}$ & $\begin{array}{l}25.2 \\
40.9 \\
49.3\end{array}$ & \begin{tabular}{l}
10.6 \\
17.1 \\
\hdashline
\end{tabular} & $\cdots$ & & 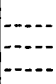 & & $\begin{array}{l}1.4 \\
2.2 \\
2.7\end{array}$ & $\begin{array}{r}6,040 \\
9,760 \\
11,790\end{array}$ & $\begin{array}{r}2,080 \\
\hdashline\end{array}$ \\
\hline G8-17... & 2.7 & D-73499 & $\begin{array}{l}\mathbf{A} \\
\mathbf{B} \\
\mathbf{O}\end{array}$ & \begin{tabular}{c}
43.4 \\
\hdashline- \\
\hdashline
\end{tabular} & $\begin{array}{l}21.0 \\
37.1 \\
45.0\end{array}$ & $\begin{array}{l}25.7 \\
45.5 \\
55.0\end{array}$ & $\begin{array}{r}9.9 \\
17.4\end{array}$ & & & & & & & $\begin{array}{r}2,150 \\
\hdashline\end{array}$ \\
\hline GS-18... & 4.5 & D-73912 & $\begin{array}{l}\mathbf{A} \\
\mathrm{B} \\
\mathbf{O}\end{array}$ & \begin{tabular}{c}
44.8 \\
\hdashline.- \\
\end{tabular} & $\begin{array}{l}21.9 \\
39.7 \\
46.0\end{array}$ & $\begin{array}{l}25.7 \\
46.5 \\
54.0\end{array}$ & $\begin{array}{r}7.6 \\
13.8 \\
-.\end{array}$ & $\begin{array}{l}7.2 \\
4.0 \\
4.7\end{array}$ & $\begin{array}{l}34.2 \\
61.9 \\
71.8\end{array}$ & $\begin{array}{l}.4 \\
.8 \\
.9\end{array}$ & $\begin{array}{l}49.7 \\
17.9 \\
20.8\end{array}$ & $\begin{array}{l}.9 \\
1.6 \\
1.8\end{array}$ & $\begin{array}{r}5,690 \\
10,310 \\
11,950\end{array}$ & $\begin{array}{r}2,130 \\
\end{array}$ \\
\hline
\end{tabular}

Olesrud bed (lower bench)

\begin{tabular}{|c|c|c|c|c|c|c|c|c|c|c|c|c|c|c|}
\hline SD-1 & 15 & 35 & $\begin{array}{l}\mathrm{A} \\
\mathrm{B} \\
\mathrm{O}\end{array}$ & \begin{tabular}{|c|}
34.2 \\
\hdashline \\
\hdashline
\end{tabular} & $\begin{array}{l}24.9 \\
37.9 \\
46.4\end{array}$ & $\begin{array}{l}28.9 \\
43.9 \\
53.6\end{array}$ & $\begin{array}{r}12.0 \\
18.2\end{array}$ & $\begin{array}{l}6.2 \\
3.7 \\
4.5\end{array}$ & $\begin{array}{l}37.1 \\
56.4 \\
68.9\end{array}$ & $\begin{array}{r}0.5 \\
.7 \\
.9\end{array}$ & $\begin{array}{l}42.9 \\
19.0 \\
23.3\end{array}$ & $\begin{array}{l}1.3 \\
2.0 \\
2.4\end{array}$ & $\begin{array}{r}6,220 \\
9,460 \\
11,570\end{array}$ & 2,050 \\
\hline D-2 & 4.0 & E-32391 & $\begin{array}{l}\mathbf{A} \\
\mathbf{B} \\
\mathbf{C}\end{array}$ & 29.3 & $\begin{array}{l}26.0 \\
36.7 \\
47.3\end{array}$ & $\begin{array}{l}28.9 \\
40.9 \\
52.7\end{array}$ & $\begin{array}{l}15.8 \\
22.4\end{array}$ & $\begin{array}{l}5.7 \\
3.4 \\
4.4\end{array}$ & $\begin{array}{l}36.9 \\
52.2 \\
67.3\end{array}$ & $\begin{array}{l}.5 \\
.6 \\
.8\end{array}$ & & $\begin{array}{l}2.5 \\
3.5 \\
4.6\end{array}$ & $\begin{array}{r}6,190 \\
8,750 \\
11,270\end{array}$ & 2,080 \\
\hline D. & 7 & 5 & $\begin{array}{l}\mathbf{A} \\
\mathbf{B} \\
\mathbf{C}\end{array}$ & & $\begin{array}{l}25.3 \\
38.4 \\
47.6\end{array}$ & $\begin{array}{l}27 . \\
42 . \\
52 .\end{array}$ & $\begin{array}{l}12.9 \\
19.5\end{array}$ & $\begin{array}{l}6.1 \\
3.6 \\
4.4\end{array}$ & & $\begin{array}{l}.5 \\
.8 \\
.9\end{array}$ & & $\begin{array}{l}2.3 \\
3.4 \\
4.2\end{array}$ & & 2,000 \\
\hline & 15 & E-32400 & $\begin{array}{l}\mathbf{A} \\
\mathbf{B} \\
\mathbf{C}\end{array}$ & 35.7 & $\begin{array}{l}25.0 \\
39.0 \\
46.4\end{array}$ & $\begin{array}{l}29.0 \\
44.9 \\
53.6\end{array}$ & $\begin{array}{l}10.3 \\
16.1\end{array}$ & $\begin{array}{l}6.4 \\
3.7 \\
4.4\end{array}$ & $\begin{array}{l}37.8 \\
58.8 \\
70.0\end{array}$ & .4 & $\begin{array}{l}43.8 \\
18.7 \\
22.4\end{array}$ & $\begin{array}{l}1.3 \\
2.0 \\
2.4\end{array}$ & & 2,060 \\
\hline
\end{tabular}


TABLE 8.-Fuel analyses of lignite from the Mendenhall area, South Dakota-Con.

\begin{tabular}{|c|c|c|c|c|c|c|c|c|c|c|c|c|c|c|}
\hline \multirow{3}{*}{$\begin{array}{l}\text { Core } \\
\text { hole }\end{array}$} & \multicolumn{3}{|c|}{ Sample } & \multicolumn{9}{|c|}{ Analyses, in percent } & \multirow{3}{*}{$\begin{array}{l}\text { Heat- } \\
\text { ing } \\
\text { value } \\
\text { (Btu) }\end{array}$} & \multirow{3}{*}{$\begin{array}{c}\text { Ash } \\
\text { soitten } \\
\text { ing } \\
\text { tem. } \\
\text { pera- } \\
\text { ture } \\
\text { \%. }\end{array}$} \\
\hline & \multirow[b]{2}{*}{$\begin{array}{c}\text { Thick- } \\
\text { ness } \\
\text { (feet) }\end{array}$} & \multirow[b]{2}{*}{$\begin{array}{l}\text { Labora- } \\
\text { tory } \\
\text { No. }\end{array}$} & \multirow[b]{2}{*}{$\begin{array}{c}\text { Con- } \\
\text { di- } \\
\text { tion }\end{array}$} & \multicolumn{3}{|c|}{ Proximate } & \multicolumn{6}{|c|}{ Ultimate } & & \\
\hline & & & & $\begin{array}{c}\text { Mois- } \\
\text { ture }\end{array}$ & $\begin{array}{l}\text { Vol- } \\
\text { atile } \\
\text { mat- } \\
\text { ter }\end{array}$ & $\begin{array}{c}\text { Fixed } \\
\text { car- } \\
\text { bon }\end{array}$ & Ash & $\begin{array}{l}\text { Hy- } \\
\text { dro- } \\
\text { gen }\end{array}$ & $\begin{array}{l}\text { Car- } \\
\text { bon }\end{array}$ & $\begin{array}{l}\text { Ni- } \\
\text { tro- } \\
\text { gen }\end{array}$ & $\begin{array}{l}\text { Oxy- } \\
\text { gen }\end{array}$ & $\begin{array}{l}\text { Sul- } \\
\text { fur. }\end{array}$ & & \\
\hline \multicolumn{15}{|c|}{ Olesrud lignite bed (Iower bench)-Continued } \\
\hline D-4 & 7.1 & E-32404 & $\begin{array}{l}\mathbf{A} \\
\mathbf{B} \\
\mathbf{C}\end{array}$ & \begin{tabular}{c}
28.6 \\
\hdashline..- \\
\hdashline--
\end{tabular} & $\begin{array}{l}27.6 \\
38.7 \\
47.3\end{array}$ & $\begin{array}{l}30.8 \\
43.1 \\
52.7\end{array}$ & $\begin{array}{l}13.0 \\
18.2 \\
-\end{array}$ & $\begin{array}{l}5.7 \\
3.6 \\
4.4\end{array}$ & $\begin{array}{l}40.6 \\
56.9 \\
69.6\end{array}$ & $\begin{array}{r}0.5 \\
.7 \\
.8\end{array}$ & $\begin{array}{r}38.8 \\
18.5 \\
22.8\end{array}$ & $\begin{array}{l}1.4 \\
2.0 \\
2.4\end{array}$ & $\begin{array}{r}6,740 \\
9,440 \\
11,540\end{array}$ & $\begin{array}{r}2,130 \\
\hdashline\end{array}$ \\
\hline D-6.. & 8.7 & E-32873 & $\begin{array}{l}\mathbf{A} \\
\mathbf{B} \\
\mathbf{C}\end{array}$ & $\mid$\begin{tabular}{c}
39.8 \\
\hdashline- \\
\hdashline-
\end{tabular} & $\begin{array}{l}23.1 \\
38.4 \\
46.6\end{array}$ & $\begin{array}{l}26.6 \\
44.1 \\
53.4\end{array}$ & $\begin{array}{l}10.5 \\
17.5 \\
\cdots\end{array}$ & $\begin{array}{l}6.7 \\
3.8 \\
4.6\end{array}$ & $\begin{array}{l}35.0 \\
58.2 \\
70.5\end{array}$ & $\begin{array}{l}.4 \\
.6 \\
.8\end{array}$ & $\begin{array}{l}46.3 \\
18.0 \\
: 21.8\end{array}$ & $\begin{array}{l}1.1 \\
1.9 \\
2.3\end{array}$ & $\begin{array}{r}5,850 \\
9,710 \\
11,770\end{array}$ & 2,080 \\
\hline D-7-.. & 5.1 & E-32876 & $\begin{array}{l}\mathbf{A} \\
\mathbf{B} \\
\mathbf{O}\end{array}$ & $\mid$\begin{tabular}{c}
37.9 \\
\hdashline.- \\
\hdashline-- \\
\end{tabular} & $\begin{array}{l}24.6 \\
39.6 \\
47.9\end{array}$ & $\begin{array}{l}26.8 \\
43.2 \\
52.1\end{array}$ & \begin{tabular}{l}
10.7 \\
17.2 \\
\hdashline-
\end{tabular} & $\begin{array}{l}6.6 \\
3.9 \\
4.7\end{array}$ & $\begin{array}{l}35.4 \\
57.0 \\
68.8\end{array}$ & $\begin{array}{l}.4 \\
.6 \\
.8\end{array}$ & $\begin{array}{l}45.0 \\
18.3 \\
22.1\end{array}$ & $\begin{array}{l}1.9 \\
3.0 \\
3.6\end{array}$ & $\begin{array}{r}6,020 \\
9,700 \\
11,710\end{array}$ & $\begin{array}{r}1,980 \\
\end{array}$ \\
\hline D-7B.. & 6.8 & E-32882 & $\begin{array}{l}\mathbf{A} \\
\mathbf{B} \\
\mathbf{C}\end{array}$ & \begin{tabular}{c}
40.1 \\
\hdashline- \\
\hdashline
\end{tabular} & $\begin{array}{l}23.7 \\
39.5 \\
47.6\end{array}$ & $\begin{array}{l}26.1 \\
43.6 \\
52.4\end{array}$ & $\begin{array}{l}10.1 \\
16.9 \\
-\end{array}$ & $\begin{array}{l}6.9 \\
4.0 \\
4.8\end{array}$ & $\begin{array}{l}35.1 \\
58.6 \\
70.5\end{array}$ & $\begin{array}{l}.4 \\
.7 \\
.8\end{array}$ & $\begin{array}{l}46.3 \\
17.7 \\
21.4\end{array}$ & $\begin{array}{l}1.2 ; \\
2.1 \\
2.5\end{array}$ & $\begin{array}{r}5,860 \\
9,790 \\
11,780\end{array}$ & 2,080 \\
\hline D-8.... & $5.46^{\prime}$ & E-19301 & $\begin{array}{l}\mathbf{A} \\
\mathbf{B} \\
\mathbf{C}\end{array}$ & $\mid$\begin{tabular}{c}
43.4 \\
\hdashline.- \\
\hdashline-
\end{tabular} & $\begin{array}{l}23.1 \\
40.9 \\
47.8\end{array}$ & $\begin{array}{l}25.4 \\
44.7 \\
52.2\end{array}$ & $\begin{array}{r}8.1 \\
14.4 \\
\end{array}$ & $\begin{array}{l}7.2 \\
4.3 \\
5.0\end{array}$ & $\begin{array}{l}34.9 \\
61.7 \\
72.1\end{array}$ & $\begin{array}{r}.5 \\
.8 \\
1.0\end{array}$ & $\begin{array}{l}48.4 \\
17.1 \\
20.0\end{array}$ & $\begin{array}{l}.9 \\
1.7 \\
1.9\end{array}$ & $\begin{array}{c}5,900 \\
10,430 \\
12,180\end{array}$ & $\begin{array}{r}2,210 \\
\hdashline-\end{array}$ \\
\hline 8 & 5.5 & E-9833 & $\begin{array}{l}\mathbf{A} \\
\mathbf{B} \\
\mathbf{C}\end{array}$ & 43.9 & $\begin{array}{l}21.6 \\
38.4 \\
45.8\end{array}$ & $\begin{array}{l}25.5 \\
45.5 \\
54.2\end{array}$ & $\begin{array}{r}9.0 \\
16.1 \\
\hdashline\end{array}$ & $\begin{array}{l}7.1 \\
3.9 \\
4.6\end{array}$ & $\begin{array}{l}33.4 \\
59.5 \\
70.9\end{array}$ & $\begin{array}{l}.4 \\
.8 \\
.9\end{array}$ & $\begin{array}{l}49.3 \\
18.2 \\
21.8\end{array}$ & $\begin{array}{r}.8 \\
1.5 \\
1.8\end{array}$ & $\begin{array}{r}5,640 \\
10,050: \\
11,970\end{array}$ & \begin{tabular}{r}
2,020 \\
\hdashline \\
\end{tabular} \\
\hline D-14-.- & 9.2 & $\mathrm{E}-32890$ & $\begin{array}{l}\stackrel{\dot{A}}{\mathrm{~B}} \\
\mathrm{C}\end{array}$ & \begin{tabular}{c}
38.7 \\
\hdashline$-\cdots$ \\
-
\end{tabular} & $\begin{array}{l}24.3 \\
39.7 \\
47.5\end{array}$ & $\begin{array}{l}27.0 \\
44.0 \\
52.5\end{array}$ & $\begin{array}{l}10.0 \\
16.3\end{array}$ & $\begin{array}{l}6.5 \\
3.6 \\
4.3\end{array}$ & $\begin{array}{l}36.1 \\
58.9 \\
70.3\end{array}$ & $\begin{array}{l}.4 \\
.7 \\
.8\end{array}$ & $\begin{array}{l}45.4 \\
17.8 \\
21.4\end{array}$ & $\begin{array}{l}1.6 \\
2.7 \\
3.2\end{array}$ & $\begin{array}{r}5,950 \\
8,710 ! \\
11,600\end{array}$ & $\begin{array}{r}2,040 \\
\end{array}$ \\
\hline D-15..- & 6.65 & E-32895 & $\begin{array}{l}\mathbf{A} \\
\mathbf{B} \\
\mathbf{O}\end{array}$ & \begin{tabular}{c}
39.7 \\
\hdashline-1 \\
\hdashline-
\end{tabular} & $\begin{array}{l}21.4 \\
35.5 \\
46.4\end{array}$ & $\begin{array}{l}24.6 \\
40.8 \\
53.6\end{array}$ & $\begin{array}{r}14.3 \\
23.7 \\
\end{array}$ & $\begin{array}{l}6.4 \\
3.4 \\
4.4\end{array}$ & $\begin{array}{l}31.9 \\
52.9 \\
69.4\end{array}$ & $\begin{array}{l}.4 \\
.6 \\
.8\end{array}$ & $\begin{array}{l}45.6 \\
17.0 \\
22.3\end{array}$ & $\begin{array}{l}1.4 \\
2.4 \\
3.1\end{array}$ & $\begin{array}{r}5,290 \\
8,770 \\
11,490\end{array}$ & 2,070 \\
\hline D-16... & 5.5 & E-33301 & $\begin{array}{l}\text { A } \\
B \\
\text { C }\end{array}$ & 38.0 & $\begin{array}{l}22.0 \\
35.5 \\
47.7\end{array}$ & $\begin{array}{l}24.1 \\
38.8 \\
52.3\end{array}$ & $\begin{array}{l}15.9 \\
25.7 \\
\end{array}$ & $\begin{array}{l}6.3 \\
3.3 \\
4.5\end{array}$ & $\begin{array}{l}31.2 \\
50.3 \\
67.6\end{array}$ & $\begin{array}{l}.4 \\
.6 \\
.8\end{array}$ & $\begin{array}{l}44.5 \\
17.4 \\
23.5\end{array}$ & $\begin{array}{l}1.7 \\
2.7 \\
3.6\end{array}$ & $\begin{array}{r}5,250 \\
8,470 \\
11,400\end{array}$ & $\begin{array}{r}2,130 \\
\end{array}$ \\
\hline 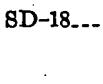 & 2.35 & E-33305 & $\begin{array}{l}\mathbf{A} \\
\mathbf{B} \\
\mathbf{C}\end{array}$ & \begin{tabular}{c}
37.1 \\
\hdashline$-\cdots$ \\
\hdashline
\end{tabular} & $\begin{array}{l}22.9 \\
36.4 \\
48.6\end{array}$ & $\begin{array}{l}24.3 \\
38.6 \\
51.4\end{array}$ & $\begin{array}{l}15.7 \\
25.0\end{array}$ & $\begin{array}{l}6.4 \\
3.5 \\
4.7\end{array}$ & $\begin{array}{l}32.6 \\
51.8 \\
69.1\end{array}$ & $\begin{array}{l}.4 \\
.6 \\
.8\end{array}$ & $\begin{array}{l}43.2 \\
16.3 \\
21.7\end{array}$ & $\begin{array}{l}1.7 \\
2.8 \\
3.7\end{array}$ & $\begin{array}{r}5,460 \\
8,680 \\
11,570\end{array}$ & {$\left[\begin{array}{r}2,110 \\
0\end{array}\right.$} \\
\hline & $1 . \theta$ & E-33306 & $\begin{array}{l}\mathbf{A} \\
\mathbf{B} \\
\mathbf{C}\end{array}$ & 26.4 & $\begin{array}{l}17.1 \\
23.2\end{array}$ & $\begin{array}{l}14.9 \\
20.3\end{array}$ & \begin{tabular}{|l|}
41.6 \\
56.5
\end{tabular} & $\begin{array}{l}4.6 \\
2.3\end{array}$ & $\begin{array}{r}20.8 \\
28.3\end{array}$ & $\begin{array}{l}.3 \\
.3\end{array}$ & $\begin{array}{l}30.9 \\
10.1\end{array}$ & $\begin{array}{l}1.8 \\
2.5\end{array}$ & & $\begin{array}{r}2,310 \\
\end{array}$ \\
\hline D-19. & 5.46 & E-13500 & $\begin{array}{l}\mathrm{A} \\
\mathrm{B} \\
\mathrm{O}\end{array}$ & {$\left[\begin{array}{c}44.2 \\
\hdashline-. . \\
\end{array}\right.$} & $\begin{array}{l}22.2 \\
39.8 \\
46.6\end{array}$ & \begin{tabular}{|l|}
25.5 \\
45.7 \\
53.4
\end{tabular} & $\begin{array}{r}8.1 \\
14.5 \\
\end{array}$ & $\begin{array}{l}7.2 \\
4.1 \\
4.8\end{array}$ & $\begin{array}{l}.33 .8 \\
60.7 \\
71.0\end{array}$ & $\begin{array}{l}.4 \\
.8 \\
.9\end{array}$ & \begin{tabular}{|l|}
49.6 \\
18.2 \\
21.3
\end{tabular} & $\begin{array}{r}.9 \\
1.7 \\
2.0\end{array}$ & $\begin{array}{r}5,790 \\
10,370 \\
12,140\end{array}$ & $\begin{array}{r}2,130 \\
\end{array}$ \\
\hline D-21_.. & 3.95 & E-33309 & $\begin{array}{l}\dot{\mathrm{A}} \\
\mathbf{B} \\
\mathbf{C}\end{array}$ & \begin{tabular}{c}
35.7 \\
\hdashline- \\
\end{tabular} & $\begin{array}{l}22.9 \\
35.6 \\
48.6\end{array}$ & $\begin{array}{l}24.2 \\
37.7 \\
51.4\end{array}$ & \begin{tabular}{l}
17.2 \\
26.7 \\
\hdashline
\end{tabular} & $\begin{array}{l}6.2 \\
3.4 \\
4.7\end{array}$ & $\begin{array}{l}32.0 \\
49.8 \\
67.9\end{array}$ & $\begin{array}{l}.4 \\
.7 \\
.9\end{array}$ & \begin{tabular}{|l|}
43.0 \\
17.6 \\
24.0
\end{tabular} & $\begin{array}{l}1.2 \\
1.8 \\
2.5\end{array}$ & $\begin{array}{r}5,380 \\
8,360 \\
11,410\end{array}$ & 2,180 \\
\hline SD-26. & 3.6 & E-33317 & $\begin{array}{l}\mathrm{A} \\
\mathrm{B} \\
\mathrm{C}\end{array}$ & \begin{tabular}{c}
36.5 \\
\hdashline \\
\hdashline
\end{tabular} & $\begin{array}{l}21.5 \\
33.8 \\
48.6\end{array}$ & \begin{tabular}{|l|}
22.7 \\
35.9 \\
51.4
\end{tabular} & $\begin{array}{l}19.3 \\
30.3\end{array}$ & $\begin{array}{l}6.2 \\
3.3 \\
4.7\end{array}$ & $\begin{array}{l}30.4 \\
47.8 \\
68.7\end{array}$ & $\begin{array}{l}.4 \\
.6 \\
.8\end{array}$ & $\begin{array}{l}42.5 \\
16.0 \\
23.0\end{array}$ & \begin{tabular}{|l|}
1.2 \\
2.0 \\
2.8
\end{tabular} & $\begin{array}{r}5,130 \\
8,070 \\
11,590\end{array}$ & 2,180 \\
\hline D-27. & 3.1 & E-33794 & $\begin{array}{l}\mathrm{A} \\
\mathrm{B} \\
\mathrm{C}\end{array}$ & 34.4 & $\begin{array}{l}21.6 \\
32.9 \\
49.3\end{array}$ & $\begin{array}{l}22.2 \\
33.8 \\
50.7\end{array}$ & $\begin{array}{l}21.8 \\
33.3\end{array}$ & $\begin{array}{l}5.8 \\
3.0 \\
4.5\end{array}$ & $\begin{array}{l}.28 .7 \\
43.7 \\
65.4\end{array}$ & $\begin{array}{l}.4 \\
.6 \\
.9\end{array}$ & $\begin{array}{l}41.5 \\
16.6 \\
25.0\end{array}$ & \begin{tabular}{l|}
1.8 \\
2.8 \\
4.2
\end{tabular} & $\begin{array}{r}4,870 \\
7,420 \\
11,120\end{array}$ & 2,130 \\
\hline D-28. & 3.9 & E-33797 & $\begin{array}{l}\mathrm{A} \\
\mathrm{B} \\
\mathrm{C}\end{array}$ & 35.1 & $\begin{array}{l}23.4 \\
36.0 \\
47.4\end{array}$ & $\begin{array}{l}25.9 \\
39.9 \\
52.6\end{array}$ & $\begin{array}{l}15.6 \\
24.1\end{array}$ & $\begin{array}{l}6.0 \\
3.3 \\
4.3\end{array}$ & $\begin{array}{l}36.0 \\
55.4 \\
73.0\end{array}$ & $\begin{array}{l}.4 \\
.6 \\
.8\end{array}$ & \begin{tabular}{|l|}
40.6 \\
14.4 \\
18.0
\end{tabular} & $\begin{array}{l}1.4 \\
2.2 \\
2.9\end{array}$ & $\begin{array}{l}\mathbf{5}, 750 \\
8,850 \\
11,500\end{array}$ & $\begin{array}{r}1,980 \\
\end{array}$ \\
\hline 8D-29. & 2.9 & E-33799 & $\underset{\mathrm{B}}{\mathrm{A}}$ & 39.7 & $\begin{array}{l}22.8 \\
37.9 \\
47.2\end{array}$ & $\begin{array}{l}25.6 \\
42.4 \\
52.8\end{array}$ & $\begin{array}{l}11.9 \\
19.7\end{array}$ & $\begin{array}{l}6.6 \\
3.6 \\
4.5\end{array}$ & $\begin{array}{l}33.5 \\
55.7 \\
69.3\end{array}$ & $\begin{array}{l}.4 \\
.6 \\
.8\end{array}$ & $\begin{array}{l}46.1 \\
17.9 \\
22.3\end{array}$ & $\left|\begin{array}{l}1.5 \\
2.5 \\
3.1\end{array}\right|$ & $\left|\begin{array}{r}5,620 \\
9,320 \\
11,610\end{array}\right|$ & 1,980 \\
\hline
\end{tabular}


134 URANIUM IN COAL IN THE WESTERN UNITED STATES

TABLE 8.-Fuel analyses of lignite from the Mendenhall area, South Dakota-Con:

\begin{tabular}{|c|c|c|c|c|c|c|c|c|c|c|c|c|c|c|}
\hline \multirow{3}{*}{$\begin{array}{l}\text { Core } \\
\text { hole }\end{array}$} & \multicolumn{3}{|c|}{ Sample } & \multicolumn{9}{|c|}{ Analyses, in percent } & \multirow{3}{*}{$\begin{array}{l}\text { Heat- } \\
\text { ing } \\
\text { value } \\
\text { (Btu) }\end{array}$} & \multirow{3}{*}{$\begin{array}{c}\text { Ash } \\
\text { soften } \\
\text { ing } \\
\text { tem- } \\
\text { pera- } \\
\text { ture } \\
\circ \mathrm{F} .\end{array}$} \\
\hline & \multirow[b]{2}{*}{$\begin{array}{c}\text { Thick- } \\
\text { ness } \\
\text { (feet) }\end{array}$} & \multirow[b]{2}{*}{$\begin{array}{c}\text { Labora- } \\
\text { tory } \\
\text { No. }\end{array}$} & \multirow[b]{2}{*}{$\begin{array}{l}\text { Con- } \\
\text { di- } \\
\text { tion }\end{array}$} & \multicolumn{3}{|c|}{ Proximate } & \multicolumn{6}{|c|}{ Ultimate } & & \\
\hline & & & & $\underset{\text { Mois- }}{\text { Mure }}$ & $\left\{\begin{array}{l}\text { Vol- } \\
\text { atile } \\
\text { mat- } \\
\text { ter }\end{array}\right.$ & $\begin{array}{c}\text { Fixed } \\
\text { car- } \\
\text { bon }\end{array}$ & Ash & $\begin{array}{l}\text { Hy- } \\
\text { dro- } \\
\text { gen }\end{array}$ & $\begin{array}{l}\text { Car- } \\
\text { bon }\end{array}$ & $\begin{array}{l}\text { Ni- } \\
\text { tro- } \\
\text { gen }\end{array}$ & $\begin{array}{c}\text { Oxy- } \\
\text { gen }\end{array}$ & $\begin{array}{l}\text { Sul- } \\
\text { fur }\end{array}$ & & \\
\hline
\end{tabular}

Olesrud bed (lower bench)-Continued

\begin{tabular}{|c|c|c|c|c|c|c|c|c|c|c|c|c|c|c|}
\hline$S D-30$ & 4.3 & E-33802 & $\underset{\mathbf{O}}{\mathbf{A}}$ & \begin{tabular}{c}
36.5 \\
\hdashline-2. \\
\hdashline-2.
\end{tabular} & $\begin{array}{l}23.2 \\
36.6 \\
48.5\end{array}$ & $\begin{array}{l}24.7 \\
38.9 \\
51.5\end{array}$ & $\begin{array}{r}15.6 \\
24.5 \\
\hdashline-.-\end{array}$ & $\begin{array}{l}6.2 \\
3.4 \\
4.5\end{array}$ & $\begin{array}{l}32.7 \\
51.4 \\
68.2\end{array}$ & $\begin{array}{r}0.4 \\
.6 \\
.8\end{array}$ & $\begin{array}{l}43.5 \\
17.6 \\
23.1\end{array}$ & $\begin{array}{l}1.6 \\
2.5 \\
3.4\end{array}$ & $\begin{array}{r}5,470 \\
8,610 \\
11,410\end{array}$ & 2,120 \\
\hline SD-31 $\ldots$ & 4.45 & $\mathbf{E}-33803$ & $\begin{array}{l}\mathbf{A} \\
\mathbf{B} \\
\mathbf{C}\end{array}$ & \begin{tabular}{c}
36.8 \\
\hdashline-2 \\
\hdashline.--
\end{tabular} & $\begin{array}{l}24.0 \\
37.8 \\
47.8\end{array}$ & $\begin{array}{l}26.1 \\
41.4 \\
52.2\end{array}$ & $\begin{array}{r}13.1 \\
20.7 \\
-\ldots . . .\end{array}$ & $\begin{array}{l}6.4 \\
3.7 \\
4.6\end{array}$ & $\begin{array}{l}34.4 \\
54.4 \\
68.6\end{array}$ & $\begin{array}{l}.4 \\
.6 \\
.7\end{array}$ & $\begin{array}{l}44.0 \\
17.9 \\
22.7\end{array}$ & $\begin{array}{l}1.7 \\
2.7 \\
3.4\end{array}$ & $\begin{array}{r}5,800 \\
9,190 \\
11,580\end{array}$ & 2,060 \\
\hline $8 \dot{D}-$ & 4. 4 & E-33806 & $\begin{array}{l}\mathbf{A} \\
\mathbf{B}\end{array}$ & \begin{tabular}{c}
39.2 \\
\hdashline-2 \\
\hdashline-2
\end{tabular} & $\begin{array}{l}23.1 \\
38.0 \\
47.8\end{array}$ & $\begin{array}{l}25.2 \\
41.4 \\
62.2\end{array}$ & $\begin{array}{c}12.5 \\
20.6 \\
-\ldots .-\end{array}$ & $\begin{array}{l}6.5 \\
3.5 \\
4.4\end{array}$ & $\begin{array}{l}33.4 \\
55.0 \\
69.3\end{array}$ & $\begin{array}{l}.4 \\
.6 \\
.8\end{array}$ & $\begin{array}{l}45.3 \\
17.2 \\
21.6\end{array}$ & $\begin{array}{l}1.9 \\
3.1 \\
3.9\end{array}$ & $\begin{array}{r}5,610 \\
9,230 \\
11,640\end{array}$ & 1,940 \\
\hline SD-33... & 3.25 & $\mathbf{E}-33809$ & $\begin{array}{l}\mathbf{A} \\
\mathbf{B}\end{array}$ & \begin{tabular}{c}
28.2 \\
\hdashline-2 \\
\hdashline..- \\
\end{tabular} & $\begin{array}{l}23.8 \\
33.2 \\
50.6\end{array}$ & $\begin{array}{l}23.3 \\
32.4 \\
49.4\end{array}$ & $\begin{array}{r}24.7 \\
34.4 \\
\hdashline-.-\end{array}$ & $\begin{array}{l}5.2 \\
2.9 \\
4.5\end{array}$ & $\begin{array}{l}30.2 \\
42.0 \\
64.1\end{array}$ & $\begin{array}{l}.4 \\
.6 \\
.8\end{array}$ & $\begin{array}{l}36.1 \\
15.3 \\
23.3\end{array}$ & $\begin{array}{l}3.4 \\
4.8 \\
7.3\end{array}$ & $\begin{array}{r}5,110 \\
7,120 \\
10,850\end{array}$ & 2,010 \\
\hline \&D-35 & 2.25 & $\mathbf{E}-33298$ & $\underset{\mathbf{C}}{\mathbf{B}}$ & \begin{tabular}{c}
39.6 \\
\hdashline..- \\
\hdashline-
\end{tabular} & $\begin{array}{l}22.4 \\
37.1 \\
44.6\end{array}$ & $\begin{array}{l}27.9 \\
46.2 \\
55.4\end{array}$ & $\begin{array}{l}10.1 \\
16.7 \\
-\ldots . .\end{array}$ & $\begin{array}{l}6.5 \\
3.5 \\
4.3\end{array}$ & $\begin{array}{l}35.9 \\
59.5 \\
71.4\end{array}$ & $\begin{array}{l}.4 \\
.7 \\
.8\end{array}$ & $\begin{array}{l}46.5 \\
18.6 \\
22.3\end{array}$ & $\begin{array}{r}.6 \\
1.0 \\
1.2\end{array}$ & $\begin{array}{r}5,920 \\
9,790 \\
11,760\end{array}$ & 2,130 \\
\hline SD-36. & 3.8 & E-33812 & $\begin{array}{l}\mathbf{A} \\
\mathbf{B} \\
\mathbf{C}\end{array}$ & \begin{tabular}{c}
35.8 \\
\hdashline-1. \\
\hdashline-2
\end{tabular} & $\begin{array}{l}22.0 \\
34.3 \\
48.6\end{array}$ & $\begin{array}{l}23.4 \\
36.4 \\
51.4\end{array}$ & $\begin{array}{r}18.8 \\
29.3 \\
-. . . .\end{array}$ & $\begin{array}{l}6.1 \\
3.3 \\
4.7\end{array}$ & $\begin{array}{l}30.9 \\
48.2 \\
68.2\end{array}$ & $\begin{array}{l}.3 \\
.5 \\
.7\end{array}$ & $\begin{array}{l}42.4 \\
16.4 \\
23.2\end{array}$ & $\begin{array}{l}1.5 \\
2.3 \\
3.2\end{array}$ & $\begin{array}{r}5,170 \\
8,060 \\
11,410\end{array}$ & 2,170 \\
\hline SD-38... & 3. 7 & E-33814 & $\begin{array}{l}\mathbf{A} \\
\mathbf{B} \\
\mathbf{O}\end{array}$ & \begin{tabular}{c}
32.9 \\
\hdashline-2 \\
\hdashline-2
\end{tabular} & $\begin{array}{l}23.1 \\
34.5 \\
48.5\end{array}$ & $\begin{array}{l}24.6 \\
36.6 \\
51.5\end{array}$ & \begin{tabular}{c}
19.4 \\
28.9 \\
\hdashline..-
\end{tabular} & $\begin{array}{l}6.2 \\
3.7 \\
5.3\end{array}$ & $\begin{array}{l}31.3 \\
46.7 \\
65.6\end{array}$ & $\begin{array}{l}.4 \\
.6 \\
.8\end{array}$ & $\begin{array}{l}39.5 \\
15.3 \\
21.5\end{array}$ & $\begin{array}{l}3.2 \\
4.8 \\
6.8\end{array}$ & $\begin{array}{r}5,270 \\
7,860 \\
11,040\end{array}$ & $\begin{array}{r}2,020 \\
0\end{array}$ \\
\hline GS-3.... & 5. 3 & $D-68856$ & $\underset{\mathbf{C}}{\mathbf{A}}$ & \begin{tabular}{c}
40.8 \\
\hdashline$\ldots$
\end{tabular} & $\begin{array}{l}22.6 \\
38.3 \\
45.8\end{array}$ & $\begin{array}{l}26.8 \\
45.2 \\
54.2\end{array}$ & $\begin{array}{r}9.8 \\
16.5 \\
\hdashline-.\end{array}$ & & & & & $\begin{array}{l}1.2 \\
2.1 \\
2.5\end{array}$ & $\begin{array}{r}5,040 \\
10,030 \\
12,020\end{array}$ & 2,070 \\
\hline
\end{tabular}

$\boldsymbol{Y}$ lignite bed

\begin{tabular}{|c|c|c|c|c|c|c|c|c|c|c|c|c|c|c|}
\hline SD-1 & 1.7 & E-32386 & $\begin{array}{l}\mathbf{A} \\
\mathbf{B} \\
\mathbf{C}\end{array}$ & $\begin{array}{c}39.7 \\
\\
\end{array}$ & $\begin{array}{l}24.6 \\
40.7 \\
46.5\end{array}$ & $\begin{array}{l}28.2 \\
46.9 \\
53.5\end{array}$ & $\begin{array}{r}7.5 \\
12.4 \\
-. . .-\end{array}$ & $\begin{array}{l}6.8 \\
3.9 \\
4.4\end{array}$ & $\begin{array}{l}37.6 \\
62.4 \\
71.2\end{array}$ & $\begin{array}{r}0.4 \\
.7 \\
.8\end{array}$ & $\begin{array}{l}47.0 \\
19.4 \\
22.2\end{array}$ & $\begin{array}{r}.7 \\
1.2 \\
1.4\end{array}$ & $\begin{array}{r}6,260 \\
10,370 \\
11,840\end{array}$ & 2,1 \\
\hline 8D & 1.05 & E-32392 & $\begin{array}{l}\mathbf{A} \\
\mathbf{B} \\
\mathbf{C}\end{array}$ & \begin{tabular}{|c|}
22.3 \\
$-2 .-$
\end{tabular} & $\begin{array}{l}26.5 \\
34.1 \\
43.9\end{array}$ & $\begin{array}{l}33.8 \\
43.5 \\
56.1\end{array}$ & \begin{tabular}{c}
17.4 \\
22.4 \\
\hdashline$\ldots .$.
\end{tabular} & $\begin{array}{l}5.2 \\
3.5 \\
4.6\end{array}$ & $\begin{array}{l}43.9 \\
56.5 \\
72.9\end{array}$ & $\begin{array}{r}.6 \\
.8 \\
1.0\end{array}$ & $\begin{array}{l}32.1 \\
15.8 \\
20.2\end{array}$ & $\begin{array}{r}.8 \\
1.0 \\
1.3\end{array}$ & $\begin{array}{r}7,350 \\
9,460 \\
12,190\end{array}$ & 2 \\
\hline 8D & .95 & E-32396 & $\stackrel{\mathbf{A}}{\mathbf{B}}$ & \begin{tabular}{c}
22.8 \\
\hdashline.-- \\
-
\end{tabular} & $\begin{array}{l}24.2 \\
31.4 \\
47.7\end{array}$ & $\begin{array}{l}26.7 \\
34.5 \\
52.3\end{array}$ & $\begin{array}{c}26.3 \\
34.1 \\
\cdots \ldots . .\end{array}$ & $\begin{array}{l}4.9 \\
3.0 \\
4.6\end{array}$ & $\begin{array}{l}35.3 \\
45.7 \\
69.4\end{array}$ & $\begin{array}{r}.5 \\
.7 \\
1.0\end{array}$ & $\begin{array}{l}32.3 \\
15.6 \\
23.6\end{array}$ & $\begin{array}{r}.7 \\
.9 \\
1.4\end{array}$ & $\begin{array}{r}5,900 \\
7,650 \\
11,610\end{array}$ & 2,4 \\
\hline 8D & .9 & E-32874 & $\begin{array}{l}\mathbf{A} \\
\mathbf{B} \\
\mathbf{C}\end{array}$ & \begin{tabular}{c}
37.3 \\
\hdashline$-\ldots$ \\
\hdashline..- \\
\end{tabular} & $\begin{array}{l}23.7 \\
37.8 \\
47.2\end{array}$ & $\begin{array}{l}26.6 \\
42.3 \\
52.8\end{array}$ & \begin{tabular}{c}
12.4 \\
19.9 \\
\hdashline$\ldots .$.
\end{tabular} & $\begin{array}{l}6.6 \\
3.9 \\
4.9\end{array}$ & $\begin{array}{l}35 \\
56 \\
70\end{array}$ & $\begin{array}{l}.4 \\
.6 \\
.7\end{array}$ & $\begin{array}{l}44.4 \\
17.8 \\
22.3\end{array}$ & $\begin{array}{r}.9 \\
1.5 \\
1.8\end{array}$ & $\begin{array}{r}5,990 \\
9,560 \\
11,930\end{array}$ & $\begin{array}{r}2, \\
\hdashline-\end{array}$ \\
\hline SD-7 & 1.1 & $\mathbf{E}-\mathbf{3 2 8 7 7}$ & $\begin{array}{l}\mathbf{A} \\
\mathbf{B} \\
\mathbf{C}\end{array}$ & \begin{tabular}{c}
36.9 \\
\hdashline-1 \\
\hdashline-
\end{tabular} & $\begin{array}{l}21.9 \\
34.7 \\
48.2\end{array}$ & $\begin{array}{l}23.6 \\
37.4 \\
51.8\end{array}$ & \begin{tabular}{c}
17.6 \\
27.9 \\
\hdashline$\ldots .$.
\end{tabular} & $\begin{array}{l}6.3 \\
3.5 \\
4.9\end{array}$ & $\begin{array}{l}31.4 \\
49.7 \\
69.0\end{array}$ & $\begin{array}{l}.3 \\
.5 \\
.7\end{array}$ & $\begin{array}{l}43.5 \\
16.9 \\
23.3\end{array}$ & $\begin{array}{r}.9 \\
1.5 \\
2.1\end{array}$ & $\begin{array}{r}5,340 \\
8,470 \\
11,750\end{array}$ & $\begin{array}{r}2,2 \\
-\end{array}$ \\
\hline 8D & .5 & $\mathrm{E}-32883$ & $\begin{array}{l}\mathbf{A} \\
\stackrel{\mathbf{B}}{\mathbf{C}}\end{array}$ & \begin{tabular}{|c|}
283 \\
\hdashline$\ldots$ \\
\hdashline$-2 .-$ \\
\end{tabular} & $\begin{array}{l}21.5 \\
30.0 \\
49.7\end{array}$ & $\begin{array}{l}21.9 \\
30.5 \\
50.3\end{array}$ & \begin{tabular}{c}
28.3 \\
39.5 \\
\hdashline...
\end{tabular} & $\begin{array}{l}5.2 \\
2.9 \\
4.8\end{array}$ & $\begin{array}{l}29.4 \\
41.0 \\
67.8\end{array}$ & $\begin{array}{l}.4 \\
.5 \\
.9\end{array}$ & $\begin{array}{l}34.2 \\
12.7 \\
20.8\end{array}$ & $\begin{array}{l}2.5 \\
\text { 3. } 4 \\
\text { 5. } 7\end{array}$ & $\begin{array}{r}5,010 \\
6,980 \\
11,540\end{array}$ & 2,0 \\
\hline GD-15 & .95 & $E-32896$ & $\begin{array}{l}\mathbf{A} \\
\mathbf{B}\end{array}$ & $\begin{array}{c}373 \\
-\ldots\end{array}$ & $\begin{array}{l}22.4 \\
35.7 \\
46.6\end{array}$ & $\begin{array}{l}256 \\
40.9 \\
53.4\end{array}$ & $\begin{array}{l}14.7 \\
23.4\end{array}$ & $\begin{array}{l}6.2 \\
3.3 \\
4.3\end{array}$ & $\begin{array}{l}32.5 \\
51.7 \\
67.5\end{array}$ & $\begin{array}{l}.4 \\
.7 \\
.9\end{array}$ & $\begin{array}{l}43.0 \\
15.8 \\
20.7\end{array}$ & $\begin{array}{l}3.2 \\
5.1 \\
6.6\end{array}$ & $\begin{array}{r}5,490 \\
8,760 \\
11,430\end{array}$ & 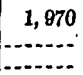 \\
\hline
\end{tabular}


TABLE 8.-Fuel analyses of lignite from the Mendenhall area, South Dakota-Con.

\begin{tabular}{|c|c|c|c|c|c|c|c|c|c|c|c|c|c|c|}
\hline \multirow{3}{*}{$\begin{array}{l}\text { Core } \\
\text { hole }\end{array}$} & \multicolumn{3}{|c|}{ Sample } & \multicolumn{9}{|c|}{ Analyses, in percent } & \multirow{3}{*}{$\begin{array}{l}\text { Heat- } \\
\text { ing } \\
\text { value } \\
\text { (Btu) }\end{array}$} & \multirow{3}{*}{$\begin{array}{l}\text { Ash } \\
\text { soften- } \\
\text { ing } \\
\text { tem- } \\
\text { pera- } \\
\text { ture } \\
\text { of. }\end{array}$} \\
\hline & \multirow[b]{2}{*}{$\begin{array}{c}\text { Thick- } \\
\text { ness } \\
\text { (feet) }\end{array}$} & \multirow[b]{2}{*}{$\begin{array}{c}\text { Labora- } \\
\text { tory } \\
\text { No. }\end{array}$} & \multirow[b]{2}{*}{$\begin{array}{l}\text { Con- } \\
\text { di- } \\
\text { tion }\end{array}$} & \multicolumn{3}{|c|}{ Proximate } & \multicolumn{6}{|c|}{ Ultimate } & & \\
\hline & & & & $\begin{array}{c}\text { Mois- } \\
\text { ture }\end{array}$ & $\begin{array}{l}\text { Vol- } \\
\text { atile } \\
\text { mat- } \\
\text { ter }\end{array}$ & $\begin{array}{l}\text { Fixed } \\
\text { car- } \\
\text { bon }\end{array}$ & Ash & $\begin{array}{l}\text { Hy- } \\
\text { dro- } \\
\text { gen }\end{array}$ & $\begin{array}{l}\text { Car. } \\
\text { bon }\end{array}$ & $\begin{array}{l}\text { Ni- } \\
\text { tro- } \\
\text { gen }\end{array}$ & $\underset{\substack{\text { Oxy- } \\
\text { gen }}}{ }$ & $\begin{array}{l}\text { Sul- } \\
\text { fur }\end{array}$ & & \\
\hline
\end{tabular}

Y lignite bed-Continued

\begin{tabular}{|c|c|c|c|c|c|c|c|c|c|c|c|c|c|c|}
\hline SD-16... & 1.0 & E-33302 & $\begin{array}{l}\mathrm{A} \\
\mathrm{B} \\
\mathrm{C}\end{array}$ & 30.4 & $\begin{array}{l}27.8 \\
39.9 \\
48.0\end{array}$ & $\begin{array}{l}30.1 \\
43.2 \\
52.0\end{array}$ & $\begin{array}{l}11.7 \\
16.9\end{array}$ & $\begin{array}{l}6.1 \\
3.9 \\
4.7\end{array}$ & $\begin{array}{l}40.3 \\
57.9 \\
69.6\end{array}$ & $\begin{array}{l}.5 \\
.7 \\
.9\end{array}$ & $\begin{array}{l}38.8 \\
16.8 \\
20.2\end{array}$ & $\begin{array}{l}2.6 \\
3.8 \\
4.6\end{array}$ & $\begin{array}{r}6,810 \\
9,780 \\
11,760\end{array}$ & \begin{tabular}{c}
2,010 \\
\hdashline
\end{tabular} \\
\hline $\begin{array}{c}D-27 \ldots \\
\therefore !\end{array}$ & 3.75 & E-33795 & $\begin{array}{l}\mathbf{A} \\
\mathbf{B} \\
\mathbf{C}\end{array}$ & \begin{tabular}{c}
34.0 \\
\hdashline .0 \\
\end{tabular} & $\begin{array}{l}19.3 \\
29.3 \\
49.2\end{array}$ & $\begin{array}{l}20.0 \\
30.2 \\
50.8\end{array}$ & $\begin{array}{l}26.7 \\
40.5\end{array}$ & \begin{tabular}{|l}
5.6 \\
2.8 \\
4.7
\end{tabular} & $\begin{array}{l}26.8 \\
40.6 \\
68.3\end{array}$ & $\begin{array}{l}.4 \\
.6 \\
.9\end{array}$ & $\begin{array}{l}39.5 \\
14.1 \\
23.7\end{array}$ & $\begin{array}{l}1.0 \\
1.4 \\
2.4\end{array}$ & $\begin{array}{r}4,530 \\
6,860 \\
11,530\end{array}$ & 2,190 \\
\hline 8D-36... & 1.3 & E-33299 & $\begin{array}{l}\mathrm{A} \\
\mathrm{B} \\
\mathrm{C}\end{array}$ & & $\begin{array}{l}22.1 \\
35.1 \\
47.4\end{array}$ & $\begin{array}{l}24.4 \\
38.9 \\
52.6\end{array}$ & \begin{tabular}{|l|}
16.4 \\
26.0
\end{tabular} & \begin{tabular}{|l}
6.3 \\
3.5 \\
4.7
\end{tabular} & $\begin{array}{l}32.1 \\
51.1 \\
69.0\end{array}$ & $\begin{array}{l}.4 \\
.6 \\
.9\end{array}$ & \begin{tabular}{|l}
43.6 \\
16.9 \\
22.9
\end{tabular} & $\begin{array}{l}1.2 \\
1.9 \\
2.5\end{array}$ & $\begin{array}{r}5,380 \\
8,550 \\
11,560\end{array}$ & 2,110 \\
\hline $8-3 \ldots$ & 1.0 & D-68857 & $A$ & 39.1 & $\begin{array}{l}25.1 \\
41.2 \\
49.4\end{array}$ & $\begin{array}{l}25.7 \\
42.2 \\
50.6\end{array}$ & $\begin{array}{l}10.1 \\
16.6\end{array}$ & 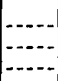 & 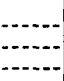 & $\ldots .$. & $\cdots$ & $\begin{array}{l}1.5 \\
2.4 \\
2.8\end{array}$ & $\begin{array}{r}6,100 \\
10,020 \\
12,020\end{array}$ & 2,050 \\
\hline
\end{tabular}

$\boldsymbol{Z}$ lignite bed

\begin{tabular}{|c|c|c|c|c|c|c|c|c|c|c|c|c|c|c|}
\hline 8D-2 & 1.5 & E-32393 & $\begin{array}{l}\mathbf{A} \\
\mathbf{B} \\
\mathbf{O}\end{array}$ & $\mid \begin{array}{c}31.3 \\
\cdots\end{array}$ & $\begin{array}{l}28.2 \\
41.0 \\
47.2\end{array}$ & $\begin{array}{l}31.5 \\
45.9 \\
52.8\end{array}$ & $\begin{array}{r}9.0 \\
13.1 \\
-\end{array}$ & $\begin{array}{l}6.2 \\
4.0 \\
4.5\end{array}$ & $\begin{array}{r}42.3 \\
61.5 \\
70.8\end{array}$ & $\begin{array}{l}.5 \\
.8 \\
.9\end{array}$ & $\begin{array}{l}40.4 \\
18.3 \\
21.2\end{array}$ & $\begin{array}{l}1.6 \\
2.3 \\
2.6\end{array}$ & $\begin{array}{r}7,080 \\
10,310 \\
11,850\end{array}$ & 2,070 \\
\hline SD-3.... & 2.1 & E-32397 & $\begin{array}{l}\mathbf{A} \\
\mathbf{B} \\
\mathbf{C}\end{array}$ & 30.3 & $\begin{array}{l}25.9 \\
37.2 \\
45.6\end{array}$ & $\begin{array}{l}30.9 \\
44.3 \\
54.4\end{array}$ & \begin{tabular}{c}
12.9 \\
18.5 \\
\hdashline-5
\end{tabular} & $\begin{array}{l}6.7 \\
3.4 \\
4.2\end{array}$ & $\begin{array}{l}39.2 \\
56.2 \\
68.9\end{array}$ & $\begin{array}{l}.5 \\
.7 \\
.8\end{array}$ & $\begin{array}{l}38.0 \\
15.9 \\
19.5\end{array}$ & $\begin{array}{l}3.7 \\
6.3 \\
6.5\end{array}$ & $\begin{array}{r}6,600 \\
9,460 \\
11,600\end{array}$ & $\begin{array}{r}2,030 \\
-\end{array}$ \\
\hline $\begin{array}{c}\text { BD-4... } \\
\therefore \ldots\end{array}$ & 2.3 & E-32405 & $\underset{\mathbf{B}}{\mathbf{A}}$ & $\begin{array}{c}28.4 \\
- \\
-\end{array}$ & $\begin{array}{l}26.5 \\
37.0 \\
47.0\end{array}$ & $\begin{array}{l}29.8 \\
41.7 \\
53.0\end{array}$ & $\begin{array}{c}15.3 \\
21.3 \\
\cdots\end{array}$ & $\begin{array}{l}5.7 \\
3.6 \\
4.5\end{array}$ & $\begin{array}{l}39.6 \\
55.3 \\
70.3\end{array}$ & $\begin{array}{l}.5 \\
.7 \\
.9\end{array}$ & $\begin{array}{l}37.4 \\
17.0 \\
21.6\end{array}$ & $\begin{array}{l}1.5 \\
2.1 \\
2.7\end{array}$ & $\begin{array}{r}6,650 \\
9,280 \\
11,800\end{array}$ & 2,050 \\
\hline $\mathbf{O}$ & 2.2 & $\mathbf{E}-\mathbf{3 2 8 7 8}$ & $\begin{array}{l}\mathbf{A} \\
\mathbf{B}\end{array}$ & \begin{tabular}{c}
39.2 \\
\hdashline-2
\end{tabular} & $\begin{array}{l}22.2 \\
36.5 \\
44.0\end{array}$ & $\begin{array}{l}28.2 \\
46.4 \\
56.0\end{array}$ & $\begin{array}{l}10.4 \\
17.1 \\
-\end{array}$ & $\begin{array}{l}6.6 \\
3.6 \\
4.4\end{array}$ & $\begin{array}{l}36.7 \\
60.4 \\
72.8\end{array}$ & $\begin{array}{l}.5 \\
.8 \\
.9\end{array}$ & $\begin{array}{l}45.2 \\
17.1 \\
20.6\end{array}$ & $\begin{array}{r}.6 \\
1.1 \\
1.3\end{array}$ & $\begin{array}{r}5,980 \\
9,840 \\
11,870\end{array}$ & 2,100 \\
\hline & 0.6 & E-32879 & $\begin{array}{l}\mathbf{A} \\
\mathbf{B} \\
\mathbf{C}\end{array}$ & \begin{tabular}{c}
37.8 \\
- \\
\hdashline$-0-$
\end{tabular} & $\begin{array}{l}21.5 \\
34.5 \\
49.7\end{array}$ & $\begin{array}{l}21.7 \\
34.9 \\
50.3\end{array}$ & $\begin{array}{c}19.0 \\
30.6 \\
-\end{array}$ & $\begin{array}{l}6.2 \\
3.3 \\
4.7\end{array}$ & $\begin{array}{l}28.9 \\
46.5 \\
66.9\end{array}$ & $\begin{array}{r}.4 \\
.7 \\
1.0\end{array}$ & $\begin{array}{l}43.7 \\
16.0 \\
23.3\end{array}$ & $\begin{array}{l}1.8 \\
2.9 \\
4.1\end{array}$ & $\begin{array}{r}4,870 \\
7,830 \\
11,280\end{array}$ & 2,080 \\
\hline 8D-8... & 2.0 & E-32884 & $\begin{array}{l}\mathbf{A} \\
\mathbf{B} \\
\mathbf{C}\end{array}$ & $\begin{array}{c}40.8 \\
\cdots\end{array}$ & $\begin{array}{l}22.7 \\
38.4 \\
45.9\end{array}$ & $\begin{array}{l}26.7 \\
45.1 \\
54.1\end{array}$ & $\begin{array}{r}9.8 \\
16.5 \\
-\end{array}$ & $\begin{array}{l}6.7 \\
3.6 \\
4.3\end{array}$ & $\begin{array}{l}36.2 \\
61.1 \\
73.2\end{array}$ & $\begin{array}{r}.5 \\
.9 \\
1.0\end{array}$ & $\begin{array}{l}45.5 \\
15.6 \\
18.8\end{array}$ & $\begin{array}{l}1.3 \\
2.3 \\
2.7\end{array}$ & $\begin{array}{r}5,960 \\
10,070 \\
12,060\end{array}$ & $\begin{array}{r}2,040 \\
0\end{array}$ \\
\hline 8D-15... & 1.65 & E-32897 & $\begin{array}{l}\mathbf{A} \\
\mathbf{B}\end{array}$ & $\begin{array}{c}36.7 \\
\cdots\end{array}$ & $\begin{array}{l}25.4 \\
40.1 \\
46.4\end{array}$ & $\begin{array}{l}29.3 \\
46.3 \\
53.6\end{array}$ & $\begin{array}{r}8.6 \\
13.6\end{array}$ & $\begin{array}{l}6.5 \\
3.8 \\
4.4\end{array}$ & $\begin{array}{l}39.5 \\
62.5 \\
72.3\end{array}$ & $\begin{array}{l}.5 \\
.8 \\
.9\end{array}$ & $\begin{array}{l}44.3 \\
18.3 \\
21.2\end{array}$ & $\begin{array}{l}.6 \\
1.0 \\
1.2\end{array}$ & $\left\{\begin{array}{r}6,510 \\
10,280 \\
11,890\end{array}\right.$ & 2,110 \\
\hline SD-16... & $\begin{array}{l}2.0 \\
\end{array}$ & E-33303 & $\begin{array}{l}\mathbf{A} \\
\mathbf{B} \\
\mathbf{C}\end{array}$ & $\begin{array}{c}31.4 \\
\cdots\end{array}$ & $\begin{array}{l}22.5 \\
32.8 \\
48.9\end{array}$ & $\begin{array}{l}23.5 \\
34.2 \\
51.1\end{array}$ & $\begin{array}{c}22.6 \\
33.0\end{array}$ & $\begin{array}{l}5.7 \\
3.2 \\
4.8\end{array}$ & $\begin{array}{l}31.2 \\
45.4 \\
67.8\end{array}$ & $\begin{array}{l}.4 \\
.6 \\
.9\end{array}$ & $\begin{array}{l}38.5 \\
15.4 \\
23.0\end{array}$ & $\begin{array}{l}1.6 \\
2.4 \\
3.5\end{array}$ & $\begin{array}{r}5,300 \\
7,720 \\
11,530\end{array}$ & 2,140 \\
\hline 8D-19. & 1.83 & $\mathbf{E}-13501$ & $\begin{array}{l}\mathbf{A} \\
\mathbf{B} \\
\mathbf{C}\end{array}$ & 44.9 & $\begin{array}{l}22.9 \\
41.5 \\
45.9\end{array}$ & $\begin{array}{l}26.9 \\
48.9 \\
\text { b4. } 1\end{array}$ & $\begin{array}{l}5.3 \\
9.6\end{array}$ & & & & & $\begin{array}{l}.6 \\
1.1 \\
1.3\end{array}$ & $\begin{array}{r}6,180 \\
11,200 \\
12,390\end{array}$ & \\
\hline BD-32... & 1.7 & E-33807 & $\begin{array}{l}\mathbf{A} \\
\mathbf{B} \\
\mathbf{C}\end{array}$ & $\begin{array}{c}34.0 \\
-\end{array}$ & $\begin{array}{l}20.1 \\
30.4 \\
49.7\end{array}$ & $\begin{array}{l}20.2 \\
30.7 \\
50.3\end{array}$ & $\begin{array}{c}25.7 \\
38.9 \\
-\end{array}$ & $\begin{array}{l}5.6 \\
2.8 \\
4.6\end{array}$ & $\begin{array}{l}27.4 \\
41.5 \\
67.9\end{array}$ & $\begin{array}{l}.4 \\
.5 \\
.9\end{array}$ & $\begin{array}{l}39.6 \\
14.4 \\
23.5\end{array}$ & $\begin{array}{l}1.3 \\
1.9 \\
3.1\end{array}$ & $\begin{array}{r}4,520 \\
6,840 \\
11,190\end{array}$ & 2,150 \\
\hline 8D-35. & 2.0 & E-33300 & $\begin{array}{l}\mathbf{A} \\
\mathbf{B} \\
\mathbf{C}\end{array}$ & 38.3 & $\begin{array}{l}24.7 \\
40.1 \\
46.9\end{array}$ & $\begin{array}{l}28.0 \\
45.4 \\
53.1\end{array}$ & $\begin{array}{r}9.0 \\
14.5 \\
-\cdots\end{array}$ & $\begin{array}{l}6.6 \\
3.8 \\
4.5\end{array}$ & $\begin{array}{l}37.8 \\
61.4 \\
71.8\end{array}$ & $\begin{array}{l}.5 \\
.8 \\
.9\end{array}$ & $\begin{array}{l}44.8 \\
17.4 \\
20.3\end{array}$ & $\begin{array}{l}1.3 \\
2.1 \\
2.5\end{array}$ & $\begin{array}{r}6,280 \\
10,190 \\
11,920\end{array}$ & 2,030 \\
\hline
\end{tabular}




\section{URANIUM IN COAL IN THE WESTERN UNITED STATES}

TABLE 9.-Lithologic description of lignite cores from core holes GS-1-4,-16-18, and $S D-8,-10$, and -19, Mendenhall area, Harding County, South Dakota

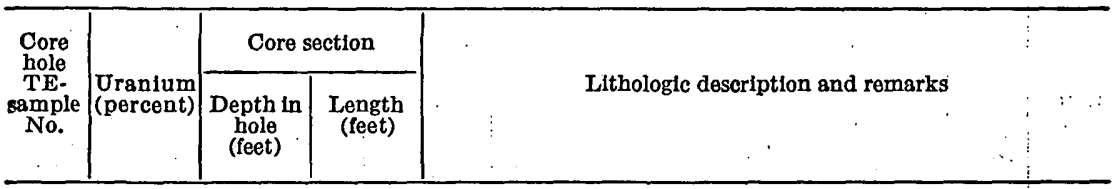

Core hole GS-1 (SE $1 / 4$ SW1/4 sec 1, T. 17 N., R. 7 E.) elev 3,300 ft

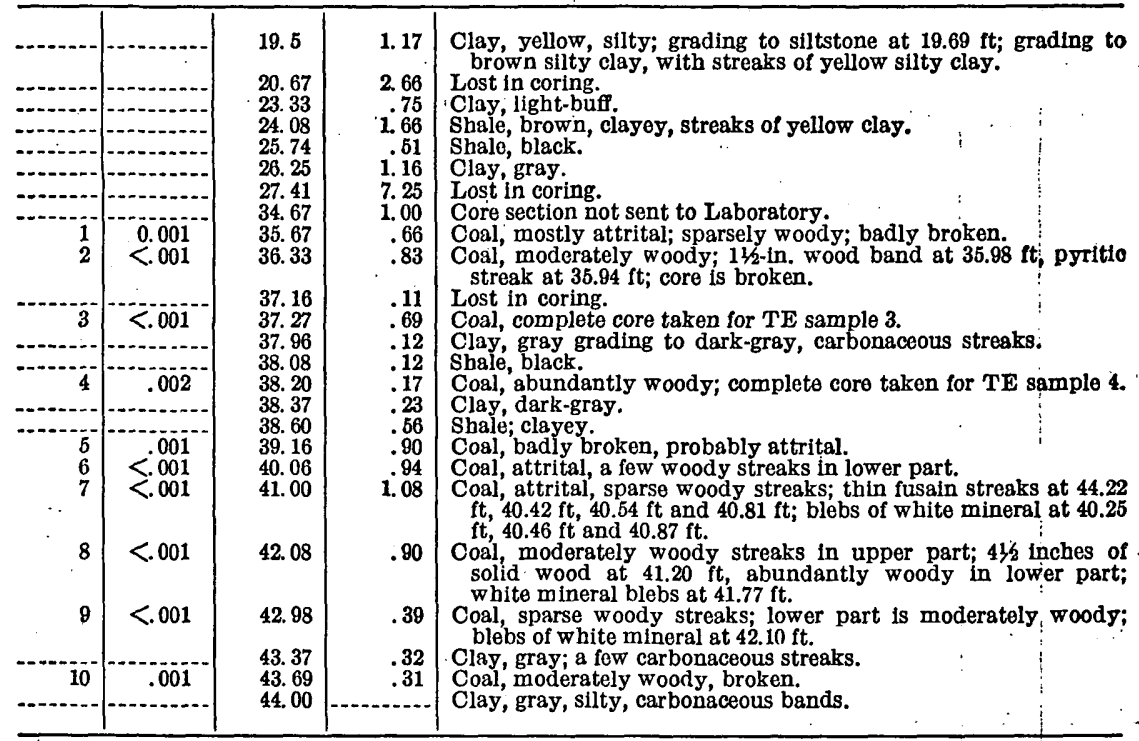

Fuel samples (U. S. Bureau of Mines): D-68847 includes TE samples 1 and 2. D-68848 includes TE samples 5-10.

\begin{tabular}{|c|c|c|c|c|c|c|}
\hline & & \multicolumn{3}{|c|}{ Core hole GS-2 (SW $1 / 4$ NE $1 / 4$ sec. 1, T. 17 N., R. 7 E.) elev 3,305 ft } & $:$ & \\
\hline $\begin{array}{r}1 \\
2 \\
3 \\
4 \\
5 \\
6 \\
7 \\
8 \\
9 \\
10 \\
11\end{array}$ & $\begin{array}{l}0.038 \\
.017 \\
.006 \\
.010 \\
.007 \\
.005 \\
.013 \\
.006 \\
.004 \\
.003 \\
.002\end{array}$ & $\begin{array}{l}51.00 \\
51.42 \\
51.54 \\
51.98 \\
52.52 \\
53.39 \\
53.83 \\
54.83 \\
55.83 \\
56.79 \\
57.79 \\
58.67 \\
59.08 \\
60.50 \\
61.75 \\
64.46 \\
65.37 \\
66.37 \\
67.31 \\
68.37 \\
69.50 \\
70.50 \\
71.50\end{array}$ & $\begin{array}{r}0.42 \\
.12 \\
.44 \\
.54 \\
.87 \\
.44 \\
1.00 \\
1.00 \\
.96 \\
1.00 \\
.88 \\
.41 \\
1.42 \\
1.25 \\
2.71 \\
.91 \\
1.00 \\
.94 \\
1.06 \\
1.13 \\
1.00 \\
1.00\end{array}$ & $\begin{array}{l}\text { Coal, moderately woody, badly broken. } \\
\text { Clay, dark-gray. } \\
\text { Coal, abundantly woody; badly broken. } \\
\text { Clay, gray, sparse wood bands. } \\
\text { Coal, abundantly woody; broken into biscuits. } \\
\text { Do. } \\
\text { Do. } \\
\text { Coal, moderately woody; broken into biscuits. } \\
\text { Coal, abundant woody bands; badly broken. } \\
\text { Do. } \\
\text { Coal, dominantly woody; badly broken. } \\
\text { Coal, pulverized. } \\
\text { Lost in coring. } \\
\text { Coal, pulverized. } \\
\text { Clay, dark-gray; a few streaks of woody coal; } 11 / 2 \\
\text { woody coal at } 62.50 \text { ft and } 64.33 \text { ft. } \\
\text { Clay, dark-gray, thin carbonaceous streaks. } \\
\text { Coal, attrital, sparse woody bands. } \\
\text { Coal, attrital, sparse woody bands; lower par } \\
\text { woody, badly broken. } \\
\text { Coal, pulverized. } \\
\text { Do. } \\
\text { Coal, attrital, sparse woody bands; a thin im } \\
\text { at } 69.52 \text { ft; core is badly broken. } \\
\text { Coal, probably attrital; evidences of impure coa } \\
\text { broken and dry. } \\
\text { Base of core sent to laboratory. }\end{array}$ & $\begin{array}{l}\text { inches of } \\
\text { rt is mo } \\
\text { ipture-cos } \\
\text { al streaks }\end{array}$ & $\begin{array}{l}\text { f impure } \\
\text { derately } \\
\text { s; coreats }\end{array}$ \\
\hline
\end{tabular}

Fuel samples (U. S. Bureau of Mines): D-68851 includes TE samples 3-11. D-68850 includes TE samples 12-17. 
TABLE 9.-Lithologic description of lignite cores from core holes $G S-1-4,-16-18$, and $S D-8,-10$, and -19, Mendenhall area, Harding County, South Dakota-Continued

\begin{tabular}{c|c|c|c|c}
\hline $\begin{array}{c}\text { Core } \\
\text { hole } \\
\text { TE- } \\
\text { sample } \\
\text { No. }\end{array}$ & $\begin{array}{c}\text { Uranium } \\
\text { (percent) }\end{array}$ & $\begin{array}{c}\text { Core section } \\
\text { Depth in } \\
\text { hole } \\
\text { (feet) }\end{array}$ & $\begin{array}{c}\text { Length } \\
\text { (feet) }\end{array}$ & Lithologic description and remarks \\
\hline
\end{tabular}

Core hole GS-3 (SW $1 / 4 \mathrm{SE}^{1 / 4} / 4$ sec 36 , T. 18 N., R. 7 E.) elev $3,325 \mathrm{ft}$

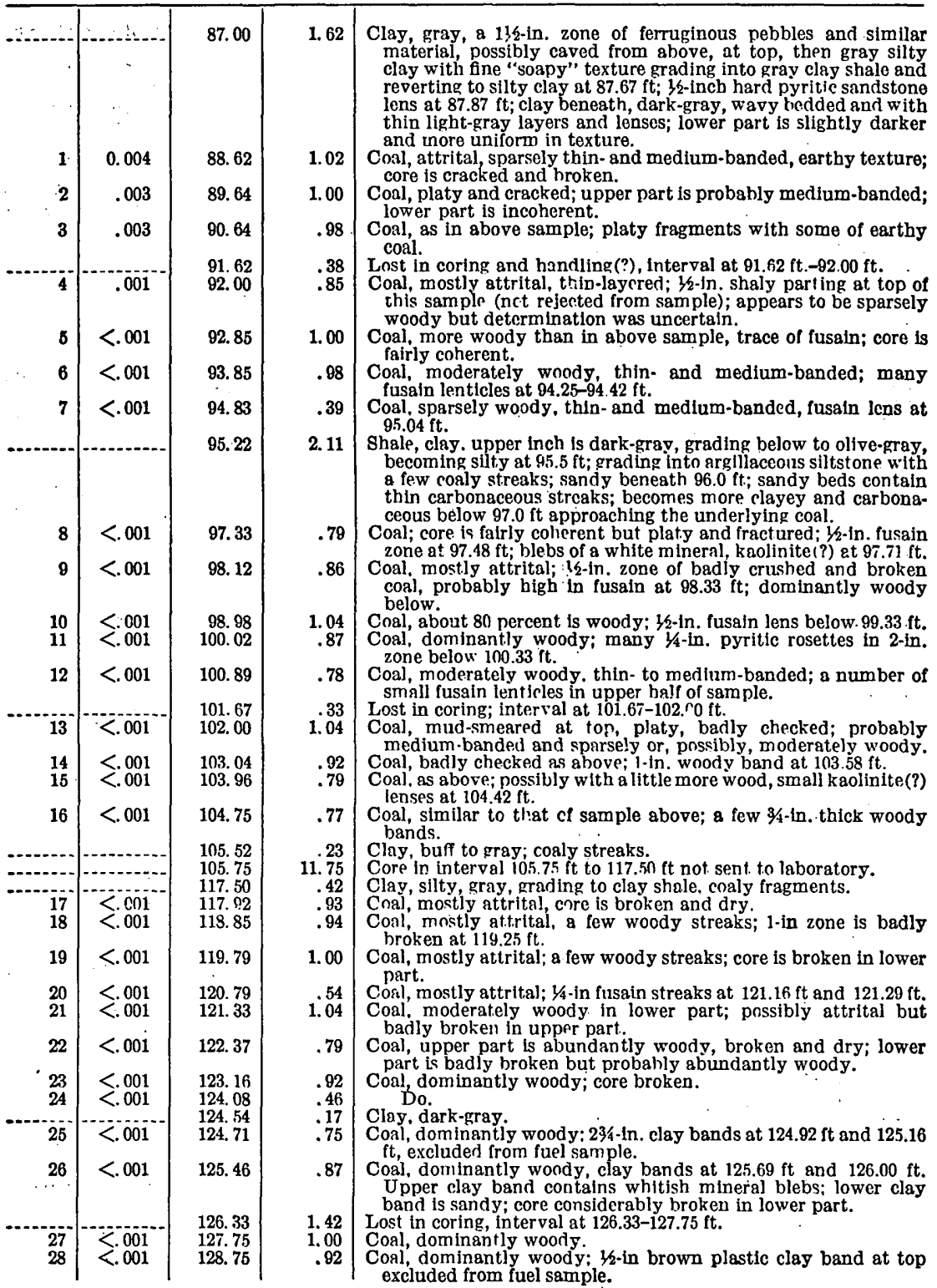


TABLE 9.-Lithologic description of lignite cores from core holes $G S-1-4,-16-18$, and $S D-8,-10$, and -19 , Mendenhall area, Harding County, South Dakota-Continued

\begin{tabular}{|c|c|c|c|c|c|}
\hline \multirow{2}{*}{$\begin{array}{c}\text { Core } \\
\text { hole } \\
\text { TE- } \\
\text { sample } \\
\text { No. }\end{array}$} & \multirow[b]{2}{*}{\begin{tabular}{|} 
Uranium \\
(percent)
\end{tabular} \mid} & \multicolumn{2}{|c|}{ Core section } & & \\
\hline & & $\begin{array}{c}\text { Depth in } \\
\text { hole } \\
\text { (feet) }\end{array}$ & $\begin{array}{c}\text { Length } \\
\text { (feet) }\end{array}$ & Lithologic description and remarks & \\
\hline
\end{tabular}

Core hole GS-3-Continued

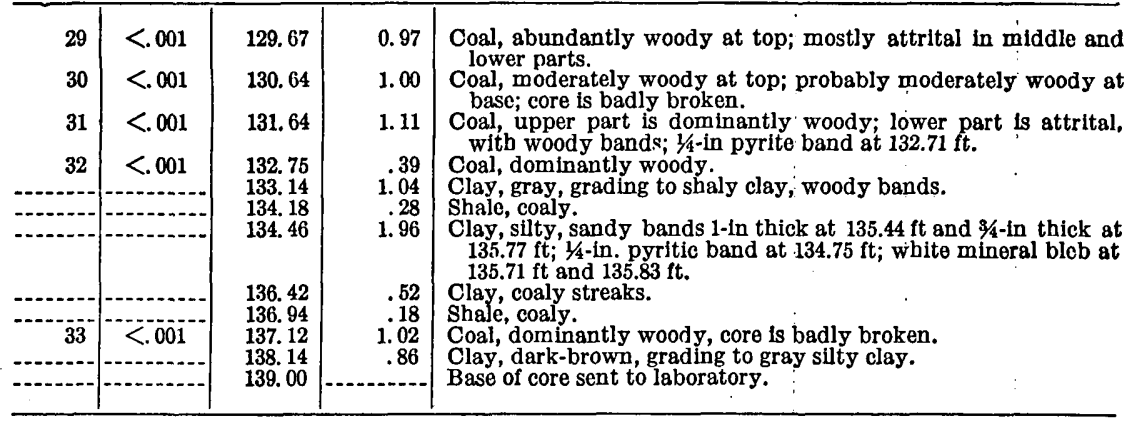

Fuel samples (U. S. Bureau of Mines): D-68853 includes TE samples 1-7; D-68854 includes TE samples 8-16; D-6885 includes TE samples 17-26; D-68856 includes TE samples 27-32; D-68857 includes TE samplo 33.

Core hole GS-4 (NW1/4SE1/4, sec 36, T. 18 N., R. 7 E.) elev 3,300 ft

\begin{tabular}{|c|c|c|c|c|}
\hline & & 22.42 & & MgLl-Dum \\
\hline & & & .12 & Sandstone, medium-grained, unconsolid \\
\hline & & 22.81 & .21 & Clay, light-buff, plastic. \\
\hline & 0.044 & $\begin{array}{l}23.02 \\
23.10\end{array}$ & .08 & $\begin{array}{l}\text { Coal, pulverulent, when hroken apart carefully it seems evident } \\
\text { that it is mostly in place but badly shrunken and cracked from }\end{array}$ \\
\hline & & 23.71 & . 33 & $\begin{array}{l}\text { underground weatnering. } \\
\text { Clay, brown, sbaly; small lenticles of light-yellow clay possibly }\end{array}$ \\
\hline 2 & .010 & 24.04 & 1.71 & $\begin{array}{l}\text { Coal, pulverulent, extremely oxidized and weathered; light- } \\
\text { yellow pellets in coal are probably a result of pyritic oxidation. }\end{array}$ \\
\hline & & $\begin{array}{l}25.75 \\
26.33\end{array}$ & .58 & $\begin{array}{l}\text { Lost in coring; in terval at } 25.75-26.33 \mathrm{ft} \text {. } \\
\text { Clay, light-buff to yellow, semifluid consistency. }\end{array}$ \\
\hline & .003 & 26.46 & .41 & $\begin{array}{l}\text { Coal, weathered; too weak to be sawed, but apparently in normal } \\
\text { relationship; excluded from fuel sample. }\end{array}$ \\
\hline & & $\begin{array}{l}26.87 \\
27.08\end{array}$ & .21 & $\begin{array}{l}\text { Coaly shale. } \\
\text { Clay shale, gray, slightly silty; bedding irregular, a few coaly } \\
\text { lenticles. }\end{array}$ \\
\hline & & $\begin{array}{l}27.83 \\
70.58\end{array}$ & $\begin{array}{r}42.75 \\
.67\end{array}$ & $\begin{array}{l}\text { Core in interval } 27.83-70.58 \mathrm{ft} \text { not sent to laboratory, } \\
\text { Shale, light-gray, grades to darker gray shale at } 7 \mathrm{ft} \text {; well-pre- } \\
\text { served plant fossils. }\end{array}$ \\
\hline & & 71.25 & .06 & Clay, gray, plastic. \\
\hline 4 & 01 & 71 & .96 & $\begin{array}{l}\text { Coal, broken and shaly at top; woody between } 71.50 \mathrm{ft} \text { and } 71.67 \\
\mathrm{ft} \text {; earthy to } 72 \mathrm{ft} \text {; moderately woody at base. }\end{array}$ \\
\hline 5 & $<.001$ & 72. & $\begin{aligned} .06 \\
1.04\end{aligned}$ & $\begin{array}{l}\text { Lost in coring; interval at 72.27-72.33 ft. } \\
\text { Coal, earthy, attrital; badly broken except for a } 2 \text {-in. woody band } \\
\text { at } 72.83 \mathrm{ft} \text {. }\end{array}$ \\
\hline 6 & $<.001$ & 73. 37 & 1.19 & $\begin{array}{l}\text { Coal, dominantly attrital; less than } 10 \text { percent woody coal; 3/2-in. } \\
\text { fusain streak at } 74.5 \mathrm{ft} \text {. }\end{array}$ \\
\hline 7 & $<: 001$ & 74.56 & .73 & $\begin{array}{l}\text { Coal, moderately woody, thin-banded with many small fusain } \\
\text { chips in upper part; more woody in lower part. }\end{array}$ \\
\hline 8 & $<.001$ & 75.29 & .58 & $\begin{array}{l}\text { Coal, moderately woody, thin-and medium-banded, with pyritic } \\
\text { lenticle at } 75.3 \mathrm{ft} \text {. }\end{array}$ \\
\hline 9 & $<.001$ & 75.87 & .88 & $\begin{array}{l}\text { Coal, moderately woody, thin- and medium-banded; a fow fusain } \\
\text { lenticles in middle part; core split and broken. }\end{array}$ \\
\hline & & $\begin{array}{l}76.75 \\
77.00\end{array}$ & .25 & $\begin{array}{l}\text { Lost in coring; interval at } 76: 75-77.00 \mathrm{ft} \text {. } \\
\text { Clay, brown, shaly; a few plant fragments. }\end{array}$ \\
\hline 10 & .001 & 77.33 & .92 & $\begin{array}{l}\text { Shaly coal(?), earthy; blebs of buff clay in basal } 1 \text { inch; core } \\
\text { broken into small biscuits; excluded from fuel sample. }\end{array}$ \\
\hline 11 & $<.001$ & 78. 25 & .89 & $\begin{array}{l}\text { Coal, dominantly attrital, impure; } 1 \text {-in woody band at } 78.48 \mathrm{ft} \\
\text { and } 1 / 2-\text { in woody band at } 78.83 \mathrm{ft} \text {. }\end{array}$ \\
\hline $\begin{array}{l}12 \\
13\end{array}$ & $<.001$ & $\begin{array}{l}79.14 \\
79.85\end{array}$ & .71 & $\begin{array}{l}\text { Coal, solid wood, grain highly contorted. } \\
\text { Coal, dominantly woody coal in middle part; upper part is mostly } \\
\text { attrital coal with thin fusain lenticles; 38-in. pyritic lens at } \\
80.42 \mathrm{ft} \text {. }\end{array}$ \\
\hline
\end{tabular}


TABLE 9.-Lithologic description of lignite cores from core holes $6 S-1-4,-16-18$, and $S D-8,-10$, and -19, Mendenhall area, Harding County, South Dakota-Continued

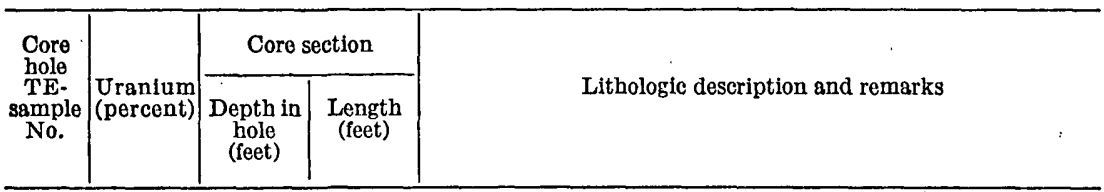

\section{Core hole GS-4-Continued}

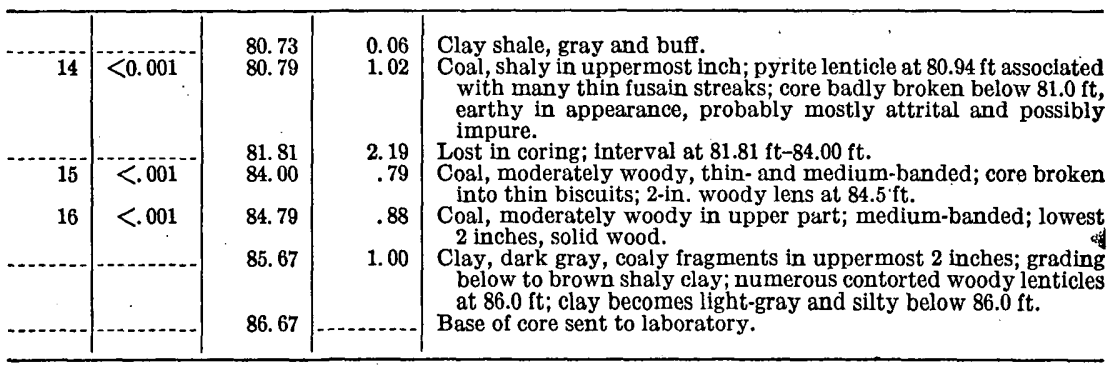

Fuel samples (U. S. Bureau of Mines): D-68359 includes TE sample 1. D-68860 includes TE sample 2. D-68864 includes TE samples 4-9. D-68863 includes TE Samples 11-14. D-68862 includes TE samples 15 and 16.

Core hole GS-16 (SE1/4NW14 sec. 31 T. 18 N. R. 8 E.) elev. 3,570 ft.

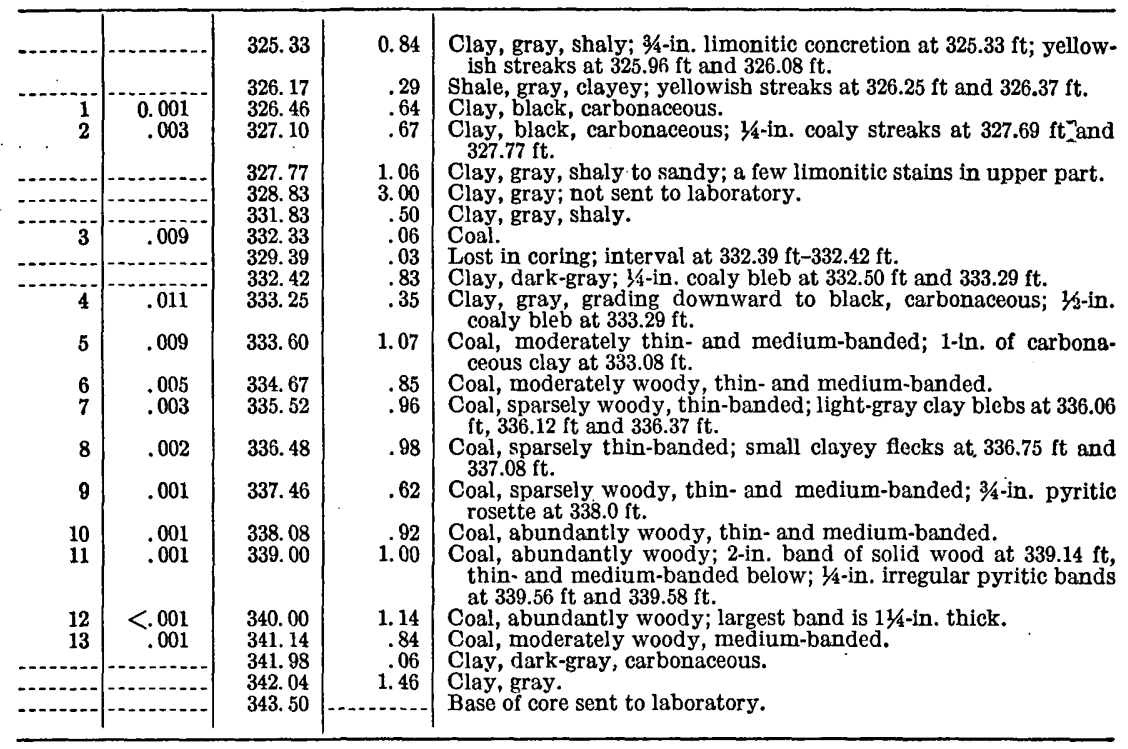

Fuel sample (U. S. Bureau of Mines): D-71570 includes TE samples 5-13.

Core hole GS-17 (SW1/4SW1/4 sec. 6 T. 17 N. R. 8 E.) elev. 3,635 ft.

\begin{tabular}{r|c|c|}
\hline & & \\
1 & 0.020 & 357.50 \\
2 & .010 & 357.87 \\
3 & .005 & 358.08 \\
4 & .015 & 358.79 \\
\hdashline & 359.17 \\
\hdashline 5 & .006 & 360.73
\end{tabular}

0.37 Clay, dark-gray, plastic.

.21 Coal, impure.

.38 Coal, moderately woody.

.33 Coal, impure; rejected from fuel sample.

.38 Coal, dominantly woody.

1. 33 Clay, gray to dark-gray; 3 -2-in. coaly streak at $359.25 \mathrm{ft}$.

.08 Clay, black, carbonaceous.

15 Shale, coaly.

1. 10 Coal, attrital; 14 -in. pyritic lenticle at $361.81 \mathrm{ft}$; 1 -in. zone of impure coal at $360.96 \mathrm{ft}$, rejected from fuel sample. 
TABLE 9. - Lithologic description of lignite cores from core holes $7 S-1-4,-16-18$, and SD-8,-10, and-19, Mendenhall area, Harding County, South Dakota-Continued

\begin{tabular}{c|c|c|c}
\hline $\begin{array}{c}\text { Core } \\
\text { hole } \\
\text { TE. } \\
\text { sample } \\
\text { No. }\end{array}$ & $\begin{array}{c}\text { Uranium } \\
\text { (percent) }\end{array}$ & $\begin{array}{c}\text { Core section } \\
\text { Depth in } \\
\text { bole } \\
\text { (feet) }\end{array}$ & $\begin{array}{c}\text { Length } \\
\text { (fcet) }\end{array}$ \\
\hline
\end{tabular}

Core hole GS-17-Continued

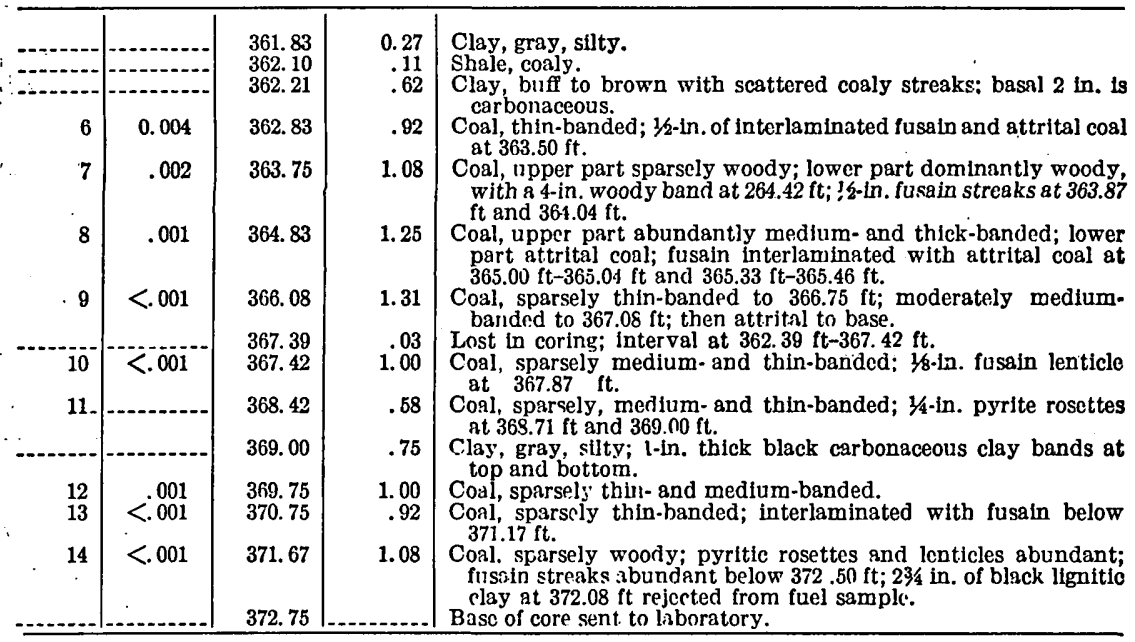

Fuel samples (U. S. Burean of Mines): D-73496 Includes TE samples 2-4. D-73497 includes TE sample 5 D-73498 includes TE samplrs f-11. D-73499 includes TE samples 12-14.

Core hole GS-18 (SE1/4NE34 sec. 1, T. 17 N., R. 7 E.) elev. 3,610 ft.

\begin{tabular}{|c|c|c|c|c|}
\hline & & & 1.37 & Siltstone, gray, soft: more clayey in basal 6 in \\
\hline 1 & 0.025 & 356. 83 & .17 & $\begin{array}{l}\text { Co.l, soft and pulverulent in uppermost } 3 / 4 \text { in., the rest is coherent } \\
\text { and dominantly attrital. }\end{array}$ \\
\hline $\mathbf{2}$ & .017 & $\begin{array}{l}357.00 \\
357.20\end{array}$ & .20 & $\begin{array}{l}\text { Coal, attrital, small mineral flecks. } \\
\text { Coal, moderately thin and medium-banded, w'th thin clayey }\end{array}$ \\
\hline $\begin{array}{l}4 \\
5\end{array}$ & .007 & $\begin{array}{l}357.67 \\
358.71\end{array}$ & $\begin{array}{l}1.04 \\
1.00\end{array}$ & $\begin{array}{l}\text { Coal, sparsely medium-banded, a fow flecks of attrital fusain. } \\
\text { Coal, moderately medium- and thin-banded, associnted fusain } \\
\text { and clayev flecks at } 359.00 \text { ft; fusain interlaminated with at trital } \\
\text { coal at } 359.16 \text { ft. }\end{array}$ \\
\hline 6 & .007 & 359.71 & .87 & $\begin{array}{l}\text { Coal, douninantly attrital in upper part. moderately thin- and } \\
\text { medlum-banded in lower part; attrital part has many fusain }\end{array}$ \\
\hline 7 & .004 & 360.58 & .84 & $\begin{array}{l}\text { Conl, moderately to abundantly woody; } 16 \text {-inch band of fusain } \\
\text { with attrital coal partings at } 361.04 \text { fit; } 16 \text { - in. pyritic lenticles } \\
\text { beneath th:ck woody bands in lower part. }\end{array}$ \\
\hline & & 361.42 & .91 & $\begin{array}{l}\text { Clay, grayish-buff, wondy bands in the uppermost and basal } \\
\text { inchee; slickensides developed along the woody fragments and } \\
\text { larger slip planes opposed at about } 45 \text { drgrens in middle rart; } \\
\text { mlddle and lower parts show some evidence of bedding. }\end{array}$ \\
\hline 8 & .002 & 362.33 & .96 & $\begin{array}{l}\text { Coal, somewhat clayey in the uppermost inch; dominantly } \\
\text { (about } 95 \text { percent) wood in middlo part; moderatcly thin-banded } \\
\text { in lower part, a few fusain lenticles. }\end{array}$ \\
\hline 9 & .001 & 363.29 & 1.00 & $\begin{array}{l}\text { Coal, moderately thin- to thick-banded in upper balf: dominantly } \\
\text { woody in lower half. }\end{array}$ \\
\hline 10 & $<.001$ & 364.29 & 1.00 & Coal, moderately thin- to thick-banded; zones of fusain flecks \\
\hline 11 & .001 & $\begin{array}{l}365.29 \\
365.42\end{array}$ & .13 & $\begin{array}{l}\text { Lost in coring; interval at } 365.29 \text { ft-365.42. ft. } \\
\text { Coal, sparsely medium-banded in uppermost foot; badly broken } \\
\text { in lower part. }\end{array}$ \\
\hline 12 & .001 & $\begin{array}{l}366.83 \\
367.62 \\
371.83\end{array}$ & $\begin{array}{l}.79 \\
4.21 \\
1.96\end{array}$ & $\begin{array}{l}\text { Coal, badly broken. } \\
\text { Lost in coring, presumed to be coal; } 367.62 \mathrm{ft}-371.83 \mathrm{ft} \text {. } \\
\text { Clay, brown, shaly, a few thin coaly streaks, becomes clayey } \\
\text { shale at about } 373 \mathrm{ft} \text { and more carbonaceous, well-preserved } \\
\text { plant fossils in lower } 4 \text { in. }\end{array}$ \\
\hline
\end{tabular}


TABLE 9.-Lithologic description of lignite cores from core holes $7 \mathrm{~S}-1-4,-16-18$, and $S D-8,-10$, and -19 , Mendenhall area, Harding County, South Dakota-Continued

\begin{tabular}{c|c|c|c|}
\hline $\begin{array}{c}\text { Core } \\
\text { hole } \\
\text { TE- } \\
\text { sample } \\
\text { No. }\end{array}$ & $\begin{array}{l}\text { Uranium } \\
\text { (percent) }\end{array}$ & $\begin{array}{c}\text { Core section } \\
\begin{array}{c}\text { Depth in } \\
\text { hole } \\
\text { (feet) }\end{array}\end{array}$ & $\begin{array}{c}\text { Length } \\
\text { (feet) }\end{array}$ \\
\hline
\end{tabular}

Core hole GS-18-Continuéd

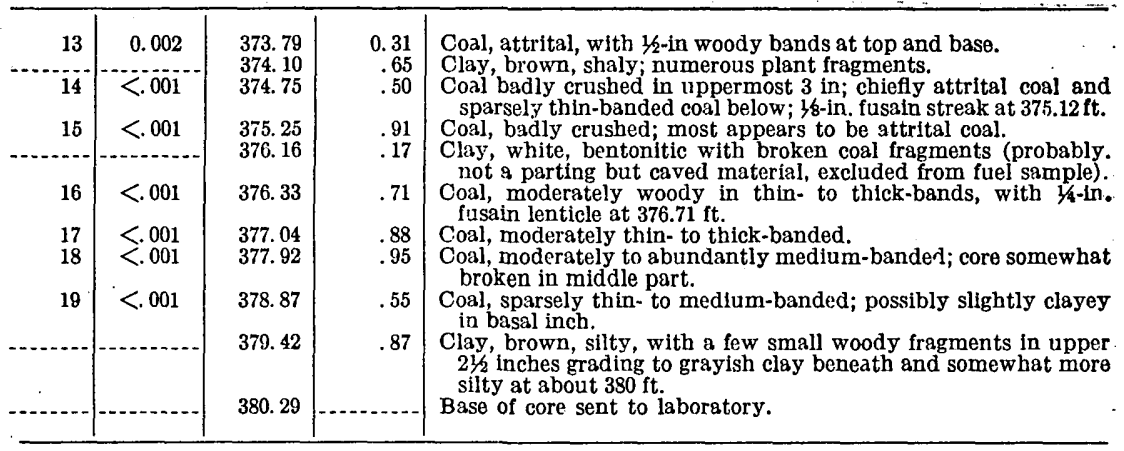

Fuel samples (U. S. Bureau of Mines): D-73909 includes TE samples 1-7. D-73910 includes TE samples 8-11. D-73911 includes TE samplo 12. D-73912 includes TE sample 14-19.

Core hole SD-8 (SE1/4NW1/4 sec. 36, T. 18 N., R 7 E.) elev. 3,330 ft.

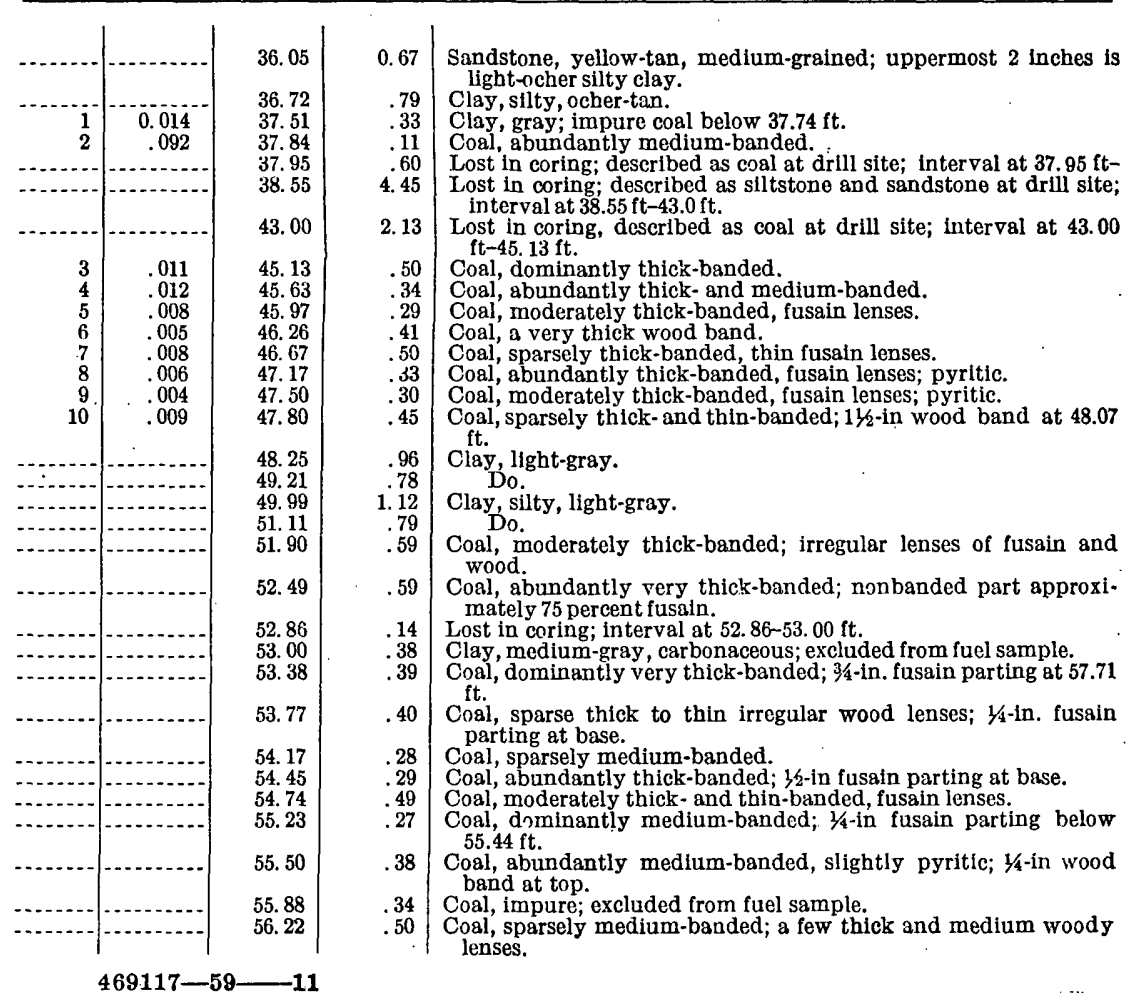


$\mathrm{T}_{\mathrm{ABLE}}$ 9.-Lithologic description of lignite cores from core holes $\mathrm{GS}-1-4,-16-18$, and $S D-8,-10$, and -19, Mendenhall area, Harding County, South Dakota-Continued

\begin{tabular}{c|c|c|c|c}
\hline $\begin{array}{c}\text { Core } \\
\text { hole } \\
\text { TE } \\
\text { sample } \\
\text { No. }\end{array}$ & $\begin{array}{c}\text { Uranium } \\
\text { (percent) }\end{array}$ & $\begin{array}{c}\text { Core section } \\
\text { Depth in } \\
\text { hole } \\
\text { (feet) }\end{array}$ & $\begin{array}{c}\text { Length } \\
\text { (feet) }\end{array}$ & Lithologic description and romarks \\
\hline
\end{tabular}

Core hole SD-8-Continued

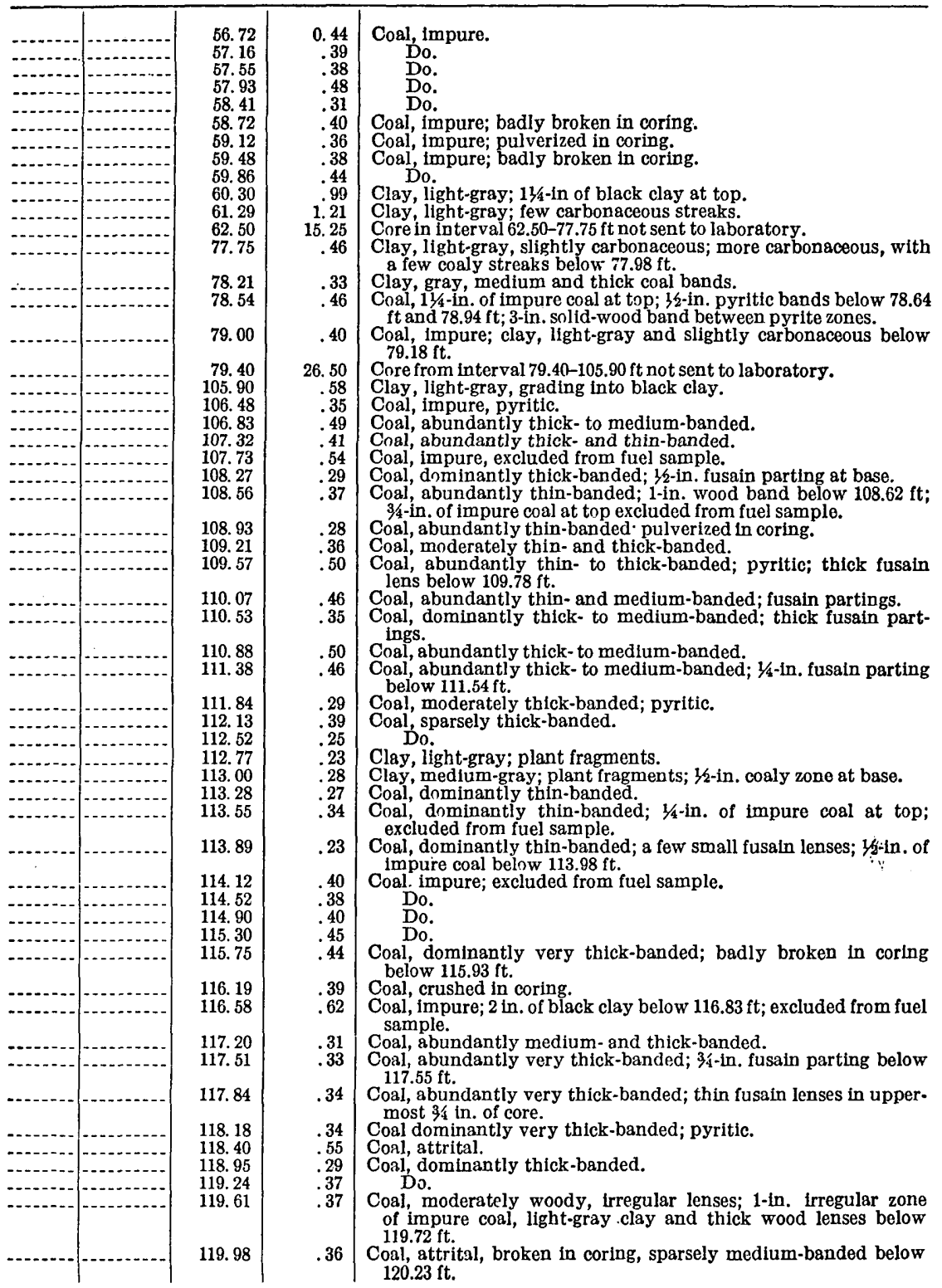


TABLE 9.-Lithologic description of lignite cores from core holes GS-1-4, -16-18, and $S D-8,-10$, and -19, Mendenhall area, Harding County, South Dakota-Continued

\begin{tabular}{c|c|c|c|c}
\hline $\begin{array}{c}\text { Core } \\
\text { hole } \\
\text { TE- } \\
\text { sample } \\
\text { No. }\end{array}$ & $\begin{array}{c}\text { Uranium } \\
\text { (percent) }\end{array}$ & $\begin{array}{c}\text { Core section } \\
\text { Depth in } \\
\text { hole } \\
\text { (feet) }\end{array}$ & $\begin{array}{c}\text { Length } \\
\text { (feet) }\end{array}$ & Lit hologic description and remarks \\
\hline
\end{tabular}

Core hole SD-8-Continued

\begin{tabular}{|c|c|c|c|c|}
\hline 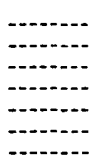 & $\mid-1+2-1$ & $\begin{array}{l}120.34 \\
120.76 \\
121.10 \\
121.44 \\
121.83 \\
122.56 \\
123.00\end{array}$ & $\begin{array}{r}0.42 \\
.34 \\
.34 \\
.39 \\
.73 \\
.44 \\
.4\end{array}$ & $\begin{array}{l}\text { Coal, sparsely medium-banded; irregular fusain lenses at } 120.45 \mathrm{ft} \text {. } \\
\text { Cosl. abundantly thick-banded. } \\
\text { Coal, impure. } \\
\text { Clay, dark-gray, coaly. } \\
\text { Clay, light-gray, silty. } \\
\text { Lost in coring; interval at } 122.56-123.00 \mathrm{ft} \text {. } \\
\text { Base of core sent to laboratory. }\end{array}$ \\
\hline
\end{tabular}

Fuel samples (U. S. Bureau of Mines): E-19298 includes TE sample 3-10. E-19299 includes core from interval $51.90 \mathrm{ft}-56.72 \mathrm{ft}$. E-19300 includes core from interval $106.83 \mathrm{ft}-112.77 \mathrm{ft}$. E-19301 includes core from interval $113.28 \mathrm{ft}-121.10 \mathrm{ft}$.

Core hole SD-10 (NE1/4 SE1/4 sec. 12, T. 17 N., R. 7 E.) elev. 3,630 ft.

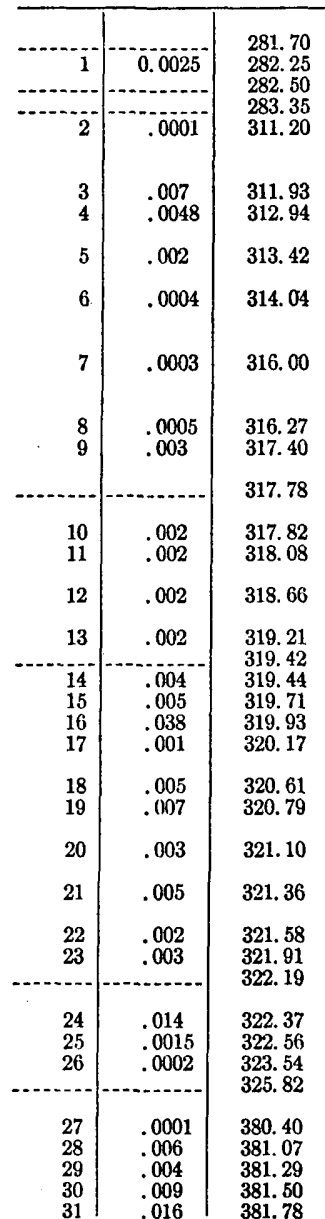

0. 55 Shale, sllty, light-gray, and buff, fine-grained, soft sandstone.

.25 Clay, hlack; a few interbedded light-buff sandy lenses.

.85 Siltstone, light-gray, moderately soft.

27. 85 Clay, siltstone and sandstone, not sent to laboratory.

.73 Clay, light-buff, fragmented; some light-gray interstitial clay; light-buff angular fragments larger in lower part, and with clay matrix more abundant.

1.01 Shale and clay, silty, gray to slightly limonitic.

.48 Clay, light-gray; abundant limonitic bands in upper part, less limonitic below.

.62 Clay, medium-gray to black, grading to impure attrital coal below the uppermost 2 inches.

1.96 Clay, silty, brown in upper part, becoming somewhat more drab below; very thin coaly streaks and 1/8-in limonitic band near the base.

Clay conglomerate; clay pebbles, light-tan to gray; one lignitic fragment occurs near the middle and larger more angular clay pieces at base; possibly caved from higher in core hole.

1. 13 Clay, brown, with scattered thin woody streaks.

.38 Coal, attrital coal in uppermost $11 / 2$ inch; dominantly woody below.

.04 Pyritic layer, coherent but somewhat earthy in appearance; excluded from fuel sample.

Coal, moderately woody; two $1 / 4$-in fusain lenticles near the middle.

.55 Coal, attrital or very thin-banded; a 1-in woody band below $318.84 \mathrm{ft}$.

.21 Coal, sparsely woody; $1 / 4$-in fusain layer at base.

$.021 / 4$-in. pyritic laminae; excluded from fuel sample.

.27 Coal, sparsely woody.

.22 Do

.24 Coal, attrital.

.44 Clay, coaly, black above $320.29 \mathrm{ft}$, grading to dark-gray, black with woody streaks below $320.27 \mathrm{ft}$; excluded from fuel sample. Coal, moderately woody.

Shale, black, clayey, 1/4-in hard siltstone band below $320.89 \mathrm{ft}$; excluded from fuel sample. excluded trom fuel sample bal, abundantly woody, thick bands; 1/8-in fusain parting below $321.49 \mathrm{ft}$.

.18 Clay, shaly, brown, with coaly fragments; excluded from fuel sample.

Coal, attrital, except for thick wood band in middle.

.98 Shale, brown, clayey.

2. 28 Siltstone, gray, clayey; few thin coaly streaks in lower part.

54. 58 Core in interval 325.82-380.40 $\mathrm{ft}$ not sent to laboratory; in. cludes shale and siltstone, as decsribed at drill site.

.67 Clay, silty, light-buft, soft; $1 / 4$-in carbonaceous streak at the base. .22 Coal, moderately woody.

.21 Do.

.28 Coal, abundantly woody; 1/4-in pyritic rosettes at base.

.29 Coal, mostly attrital; $13 / 2$ in woody band at base. 
$\mathrm{T}_{\mathrm{ABLE}}$ 9.-Lithologic description of lignite cores from core holes $G S-1-4,-16-18$, and SD-8, -10 , and -19 , Mendenhall area, Harding County, South Dakota-Continued

\begin{tabular}{|c|c|c|c|c|}
\hline \multirow{2}{*}{$\begin{array}{c}\text { Core } \\
\text { hole } \\
\text { TE- } \\
\text { sample } \\
\text { No. }\end{array}$} & \multirow[b]{2}{*}{$\begin{array}{l}\text { Uranium } \\
\text { (percent) }\end{array}$} & \multicolumn{2}{|c|}{ Core section } & \multirow{2}{*}{ Lithologic description and remarks } \\
\hline & & $\begin{array}{c}\text { Depth in } \\
\text { hole } \\
\text { (feet) }\end{array}$ & $\underset{\text { (feet) }}{\text { Length }}$ & \\
\hline
\end{tabular}

Core hole SD-10-Continued

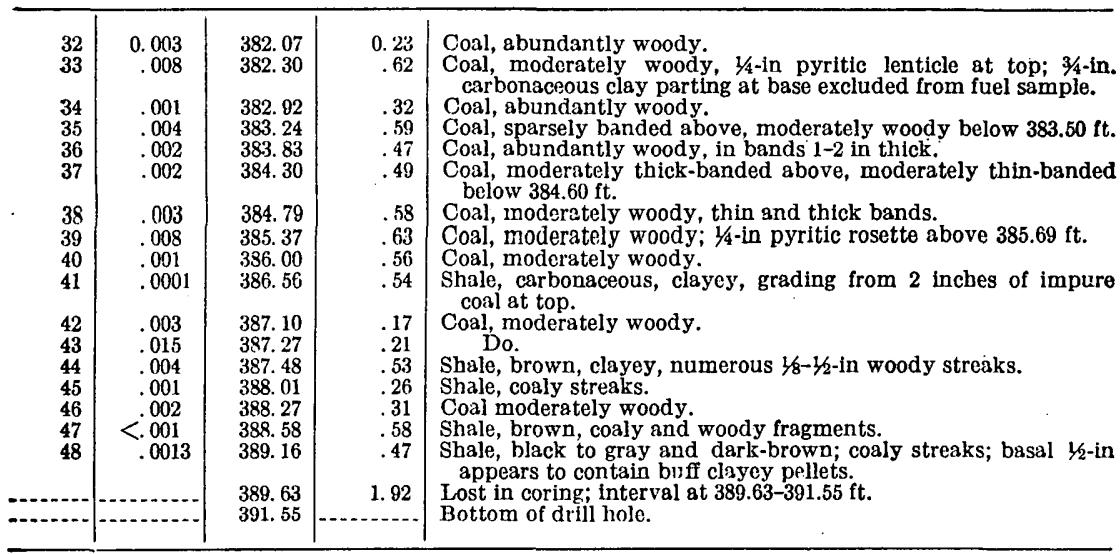

Fuel samples (U. S. Bureau of Mines): E-9832 includes TE samples 9-16, 18, 21-24. E-9833 includes TE samples $28-40$.

Core hole SD-19 (SW1/4SW1/4 sec 31, T. 18 N., R. 8 E.), elev 3,600 ft

\begin{tabular}{|c|c|c|c|c|}
\hline 1 & 0.0055 & 332.00 & 1.41 & $\begin{array}{l}\text { Siltstone, gray; a few 1/-in pyrite lenticles in upper part; coorser } \\
\text { silty bands stained with limonite below } 332.94 \mathrm{ft} \text {. }\end{array}$ \\
\hline 2 & .0039 & 333.41 & .31 & Siltstone, clayey, gray, dips about 8 degrees. \\
\hline 3 & & & .11 & Clay, carbonaceous, dark-brown and black; not coaly. \\
\hline 4 & .026 & 333.83 & .25 & $\begin{array}{l}\text { Coal, attrital, } 1 / 2 \text {-in woody band below } 333.91 \mathrm{ft} \text {; no dip appar- } \\
\text { ent in coal. }\end{array}$ \\
\hline 5 & .016 & 334.08 & .34 & Coal, dominantly attrital. \\
\hline 6 & 014 & & .33 & Coal, sparsely thin-banded. \\
\hline 7 & .006 & 334.75 & .34 & 1. \\
\hline 8 & .006 & 335.09 & .62 & $\begin{array}{l}\text { Coal, dominantly attrital, two } 1 / 2 \text {-in woody lenses in lower part; } \\
\text { thin pyritic facing on joint in upper part. }\end{array}$ \\
\hline 9 & .006 & 335.71 & .64 & Coal, moderately medium-banded. \\
\hline 10 & .010 & 336.35 & .29 & Coal, abundantly medium- and thin-banded. \\
\hline 11 & .015 & 336. 64 & .18 & Coal, a solid woody band. \\
\hline 12 & .006 & 336.82 & .12 & $\begin{array}{l}\text { Coal; 3,-in woody band at top; includes several pyritic rosettes } \\
1 / 4-\text { in-1/8-in thick, and one 1/8-in fusain lenticle. }\end{array}$ \\
\hline 13 & .015 & 336.94 & .18 & Coal, mostly woody; core is slightly broken. \\
\hline 14 & .007 & & .22 & Coal, moderately woody. \\
\hline 15 & .006 & 337.31 & .20 & Coal, dominantly woody; core is slightly broken. \\
\hline 16 & .006 & 337.54 & .56 & Coal, moderately thin-and medium-banded. \\
\hline 17 & .004 & 338.10 & .57 & $\begin{array}{l}\text { Coal, moderately thin-, medium-, and thick-banded including } \\
\text { a } 3 / 4 \text {-in woody band at } 338.20 \mathrm{ft} \text {. }\end{array}$ \\
\hline 18 & .003 & 338.67 & 19 & Coal, moderately medium-banded; core is somewhat broken. \\
\hline 19 & .005 & & .26 & Coal, moderately thin-banded; core is somewhat broken. \\
\hline O & .0008 & 339.12 & 1.80 & Clay, shaly, brown, a scattering of thin coaly plant fragments. \\
\hline 21. & .004 & 340.92 & .45 & $\begin{array}{l}\text { Coal, badly broken, perhaps slightly impure or broken by thin } \\
\text { partings. }\end{array}$ \\
\hline & & 341 & .63 & Lost in coring; interval at $341.37-34$ \\
\hline 22 & .005 & 342.00 & $.2 !$ & $\begin{array}{l}\text { Coal, dominantly woody, one woody band } 13 / 4 \text { inch thick; ap- } \\
\text { parently dipping } 6 \text { degrees. }\end{array}$ \\
\hline 23 & .003 & 342.21 & .30 & Coal, sparsely thin- and medium-banded; core is slightly broken. \\
\hline 24 & $<.001$ & 342 & .97 & $\begin{array}{l}\text { Coal, dominantly woody; one band } 23 \text { inches thick below } 342.63 \\
\text { ft; } 1 \text {-in fusain at } 342.56 \mathrm{ft} \text {; a few } 1 / 4 \text {-in pyritic blebs in lower } \\
\text { part. }\end{array}$ \\
\hline 25 & $<.001$ & 34 & .60 & Coal, dominantly woody. \\
\hline 26 & & & .23 & $\begin{array}{l}\text { Coal abundant wood bands; core is slightly broken; white clayey } \\
\text { specks appear in one woody band. }\end{array}$ \\
\hline 27 & $<.001$ & 344.31 & .50 & $\begin{array}{l}\text { Coal, attrital in upper part; moderately woody in lower part; } \\
\text { /1/ } \text {-in. fusain lenticle in a woody band near the base. }\end{array}$ \\
\hline 28 & $<: 001$ & 344.81 & 1.08 & $\begin{array}{l}\text { Coal, moderately thin-, medium-, and thick-banded; } 1 / 4 \text {-in fusain } \\
\text { band below } 3 \dot{4} 5.01 \mathrm{ft} \text {, and } 3 / 10 \text {-in fusain band below } 345.70 \mathrm{ft} \text {. }\end{array}$ \\
\hline
\end{tabular}


TABLE 9.-Lithologic description of lignite cores from core holes GS-1-4, -16-18, and $S D-8,-10$, and -19 , Mendenhall area, Harding County, South Dakota-Continued

\begin{tabular}{c|c|c|c}
\hline $\begin{array}{c}\text { Core } \\
\text { hole } \\
\text { TE- } \\
\text { sample } \\
\text { No. }\end{array}$ & $\begin{array}{c}\text { Uranium } \\
\text { (percent) }\end{array}$ & $\begin{array}{c}\text { Core section } \\
\text { Depth in } \\
\text { hole } \\
\text { (feet) }\end{array}$ & $\begin{array}{c}\text { Length } \\
\text { (feet) }\end{array}$
\end{tabular}$\quad$ Lithologic description and remarks

Core hole SD-19-Continued

\begin{tabular}{|c|c|c|c|c|}
\hline 29 & $<0.001$ & 345.89 & 1.00 & Coal, sparsely thin- and medium-banded; woody band with \\
\hline 30 & $<.001$ & 346.89 & 1.03 & $\begin{array}{l}\text { white clayey specks in middle part. } \\
\text { Coal, moderately medium- and thin-banded, coal is somewhat } \\
\text { broken in the middle part and possible more impure, largely } \\
\text { attrital coal in lower } 4 \text { inches. }\end{array}$ \\
\hline 31 & .0002 & 347.92 & 1.13 & $\begin{array}{l}\text { Clay, light-gray, with veinlike, vertical, black clay filling in upper } \\
\text { part; sparse to moderate number of woody streaks in lower } \\
51 / 2 \text { inches of this clay zone. }\end{array}$ \\
\hline 32 & $<.001$ & 349.05 & .58 & $\begin{array}{l}\text { Coal, impure, with } 11 / 4 \text { inches of coaly clay at top; lowest } 3 \text { inches } \\
\text { is woody. }\end{array}$ \\
\hline 33 & .0003 & 349.63 & 1. 07 & $\begin{array}{l}\text { Shale, clayey, dark-brown; sparse and very thin coaly streaks; } \\
\text { lowest two inches of sample is dark-brown to black. }\end{array}$ \\
\hline $\begin{array}{l}34 \\
35\end{array}$ & $<.001$ & $\begin{array}{l}350.70 \\
350.98\end{array}$ & $\begin{array}{l}.28 \\
.59\end{array}$ & $\begin{array}{l}\text { Coal, dominantly attrital; core is somewhat broken. } \\
\text { Coal, sparsely thin- and medium-banded. }\end{array}$ \\
\hline & & 351.57 & 1.95 & Lost in coring interval at $351.57-353.52 \mathrm{ft}$. \\
\hline 36 & 001 & 353.52 & 1.00 & $\begin{array}{l}\text { Coal, sparsely thin- and medium-banded; } 1 / 2 \text {-in. pyritic rosette } \\
\text { at } 353.70 \mathrm{ft} \text {; core is slightly broken in upper part. }\end{array}$ \\
\hline 37 & 001 & 354.52 & .29 & $\begin{array}{l}\text { Coal, dominantly woody; small white clay lenses in a } 1 \text {-inch } \\
\text { woody band at } 354.55 \mathrm{ft} \text {. }\end{array}$ \\
\hline 38 & <. 001 & 354.81 & .55 & $\begin{array}{l}\text { Coal, sparsely thin-banded; 1/4-in. pyritic lens at } 355.32 \mathrm{ft} \text {; core } \\
\text { somewhat broken in upper part. }\end{array}$ \\
\hline 39 & .001 & 355.36 & 1.96 & $\begin{array}{l}\text { Coal, moderately thin- to medium- and thick-banded; } 1 \text {-in. } \\
\text { woody band below } 356.85 \mathrm{ft} \text { and a } 11 / 2 \text {-in. band at } 357.10 \mathrm{ft} \text {; } \\
1 / 4-\mathrm{in} \text {. fusain band at } 356.34 \text {; core is slightly broken in upper } \\
\text { part. }\end{array}$ \\
\hline 40 & .001 & 357.32 & .61 & $\begin{array}{l}\text { Coal, abundantly thick-banded; } 1 / 4 \text {-in. fusain band below } 357.84 \mathrm{ft} \text {; } \\
\text { bedding of coal is apparently dipping about } 11 \text { degrees. }\end{array}$ \\
\hline 41 & 001 & 357.93 & 1. 22 & $\begin{array}{l}\text { Coal, dominantly thin-, medium-, and thick-banded, with 3/4-in. } \\
\text { bands of fusain in several thin- to medium-banded layers be- } \\
\text { low } 358.63 \mathrm{ft} \text {; apparent dip is about } 6 \text { degrees. }\end{array}$ \\
\hline 42 & .001 & 359.15 & 1. 30 & $\begin{array}{l}\text { Coal, predominantly woody; including two bands exceeding } 3 \\
\text { inches in thickness; apparent dip of } 5^{\circ}-9^{\circ} \text {. }\end{array}$ \\
\hline 43 & .0003 & 360.45 & 1.55 & $\begin{array}{l}\text { Shale, clayey, carbonaceous, dark-gray to black in uppermost } 4 \\
\text { inches, grading to medium-gray clayey shale below; two } 3 / 4 \text {-in. } \\
\text { pyritic rosettes occur between } 361.70 \mathrm{ft} \text { and } 361.80 \mathrm{ft} \text {; } 1 \text {-in. silty } \\
\text { layer below } 361.06 \mathrm{ft} \text {. }\end{array}$ \\
\hline & & 362.00 & 1. 00 & Lost in coring; interval at $362.00-363.00 \mathrm{ft}$. \\
\hline & & 363.00 & .90 & No core set to laboratory, described at drill site as siltstone. \\
\hline & & 372.75 & 9.25 & Lost in coring; interval at $372.00 \mathrm{ft}-372.75 \mathrm{ft}$. \\
\hline & & 382.00 & 1.08 & shale, black, carbonaceous and coaly; 1 -in. coal parting at 382.00 \\
\hline 45 & 001 & 383.08 & .73 & $\begin{array}{l}\text { Coal, sparsely thin-banded to attrital; very thick wood bands at } \\
383.38 \mathrm{ft} \text { and } 383.62 \mathrm{ft} \text {; 1/4-in. fusain parting with sand blebs at } \\
383.68 \mathrm{ft} \text { and thin fusain parting with pyrite nodule below } \\
383.35 \mathrm{ft} \text {; } 3 \text {-in clay parting at } 383.46 \mathrm{ft} \text {, excluded from fuel } \\
\text { sample. }\end{array}$ \\
\hline 46 & 001 & 383.81 & 1.15 & $\begin{array}{l}\text { Coal, dominantly attrital with } 3 \text {-in. wood band below } 384.68 \mathrm{ft} \text {; } \\
1 / 2 \text {-in coaly clay parting below } 384.50 \mathrm{ft} \text {, excluded from fuel } \\
\text { sample. }\end{array}$ \\
\hline 47 & 001 & 384.96 & .19 & $\begin{array}{l}\text { Coal, impure, thin lens of sand blebs below } 385.03 \mathrm{ft} \text {; excluded } \\
\text { from fuel sample. }\end{array}$ \\
\hline 48 & 001 & 385.15 & 1.44 & $\begin{array}{l}\text { Coal, abundantly thick-banded; irregular medium- to thick- } \\
\text { bands of wood in more attrital parts; uppermost } 21 / 2 \text { inches } \\
\text { contains clay blebs and fusain. }\end{array}$ \\
\hline 49 & 01 & 386.59 & .10 & Clay, black, carbonaceous; excluded from fuel sample. \\
\hline 50 & & 386.69 & 1.14 & Coal, moderately thick- to thin-banded. \\
\hline 51 & & 387.83 & 1. 10 & Coal, dominantly very thick-banded. \\
\hline 52 & .0003 & 388.93 & 2.46 & $\begin{array}{l}\text { Siltstone, carbonaceous, medium-gray; uppermost } 112 \text { inches is } \\
\text { black carbonaccous clay. }\end{array}$ \\
\hline & & 391.39 & .35 & Sandstone, fine-grained, light-gray, carbonaccous streaks. \\
\hline & & 391.74 & .64 & $\begin{array}{l}\text { Lost in coring, described at drill site as siltstone; interval at } 391.74 \\
-392.28 \mathrm{ft} \text {. }\end{array}$ \\
\hline 53 & .0002 & 392.38 & 2.40 & $\begin{array}{l}\text { Siltstone, brownish-gray, carbonaceous streaks and a few lenses } \\
\text { of light-tan sandstone; } 314 \text { inches of gray fine-grained sandstone } \\
\text { below } 392.38 \mathrm{ft} ; 1 / 2 \text {-in woody coal bands at } 393.23 \mathrm{ft} \text { and below } \\
394.75 \mathrm{ft} \text {. }\end{array}$ \\
\hline $\begin{array}{l}54 \\
5.5 \\
56\end{array}$ & $\begin{array}{l}<.001 \\
<.001 \\
<.001\end{array}$ & $\begin{array}{l}394.78 \\
395.06 \\
395.86\end{array}$ & $\begin{array}{l}.28 \\
.80 \\
.51\end{array}$ & $\begin{array}{l}\text { Coal, moderately thin- and thick-banded. } \\
\text { Coal, impure, very thick woody bands at } 395.31 \mathrm{ft} \text { and } 395.70 \mathrm{ft} \text {. } \\
\text { Clay, black to dark-gray, very carbonaceous. }\end{array}$ \\
\hline
\end{tabular}


$\mathrm{T}_{\mathrm{ABLE}}$ 9.-Lithologic description of lignite cores from core holes $G S-1-4,-16-18$, and $S D-8,-10$, and -19, Mendenhall area, Harding County, South Dakota-Continued

\begin{tabular}{|c|c|c|c|c|}
\hline \multirow{2}{*}{$\begin{array}{c}\text { Core } \\
\text { hole } \\
\text { TE- } \\
\text { sample } \\
\text { No. }\end{array}$} & \multirow[b]{2}{*}{$\begin{array}{l}\text { Uranium } \\
\text { (percent) }\end{array}$} & \multicolumn{2}{|c|}{ Core section } & \multirow{2}{*}{ Lithologic description and remarks } \\
\hline & & $\begin{array}{c}\text { Depth in } \\
\text { hole } \\
\text { (feet) }\end{array}$ & $\begin{array}{c}\text { Length } \\
\text { (feet) }\end{array}$ & \\
\hline
\end{tabular}

Core hole SD-19-Continued

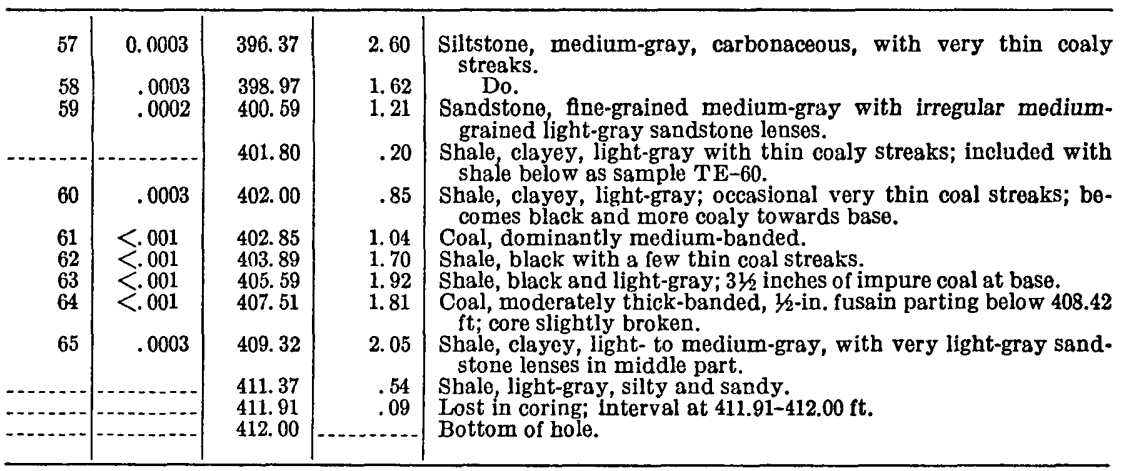

Fuel samples (U. S. Bureau of Mines): E-12615 includes TE samples 4-19. E-12616 includes TE samples 21-30. E-12617 includes TE samples 34-42. E-13500 includes TE samples 45-51. E-13501 includes TE sample 64 . 


\section{Uranium-Bearing Lignite}

In Southwestern

North Dakota

By GEORGE W. MOORE, ROBERT E. MELIN, and ROY C. KEPFERLE

URANIUM IN COAL IN THE WESTERN UNITED STATES

GE OL O G I A L S U R VEY B U L L E T I N $1055-\mathrm{E}$

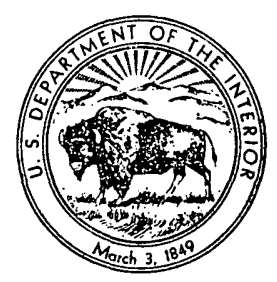





\section{CONTENTS}

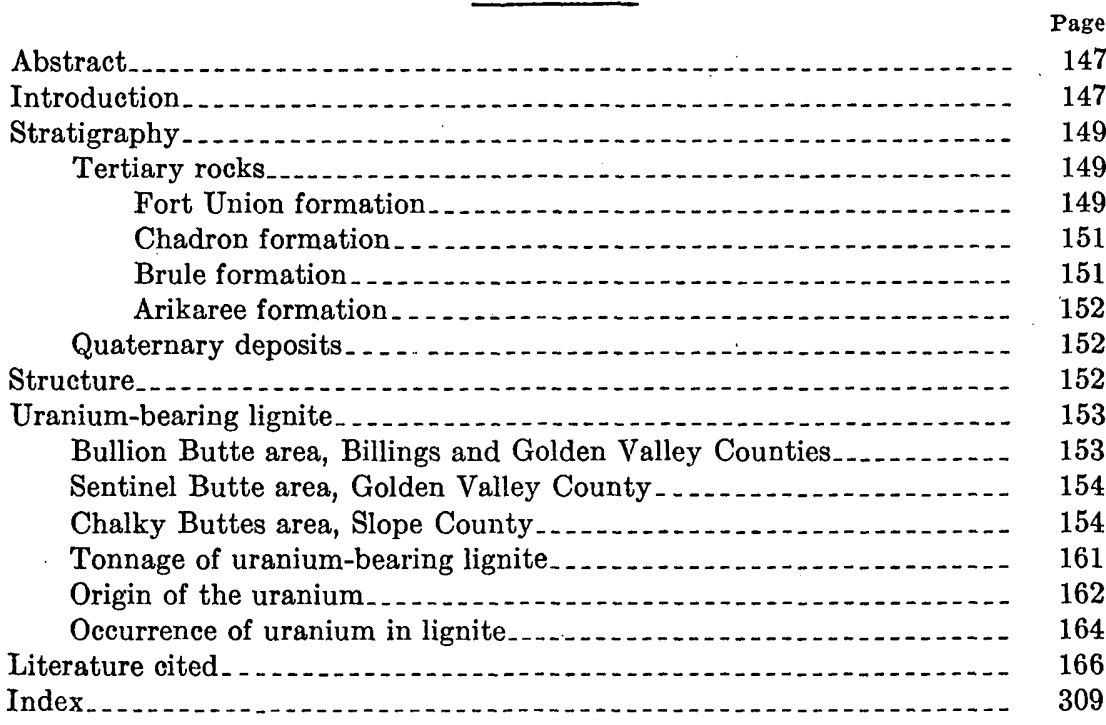

\section{ILLUSTRATIONS}

[Plates are in box]

Plate 30. Geologic map of the Chalky Buttes area.

31. Geologic map of the Sentinel Butte and Bullion Butte areas, and structure sections through Bullion, Sentinel, and Chalky Buttes.

32. Block diagram showing relationship of uranium-bearing lignite beds to base of the White River group.

Figure 19. Index map showing areas described in this report and other areas of uranium-bearing lignite

20. Stratigraphic sections of rocks associated with uraniumbearing lignite. . . .

21. Map showing areas underlain by uranium-bearing lignite in the Bullion Butte area............

22. Map showing area underlain by uranium-bearing lignite of beds 1 and 2 in the Sentinel Butte area

23. Map showing area underlain by uranium-bearing lignite of beds 3-5, Sentinel Butte area.............................

24. Map showing area underlain by uranium-bearing lignite in the northern part of the Chalky Buttes area.............

25. Map showing area underlain by uranium-bearing lignite in the southern part of the Chalky Buttes area .............

26. Map showing area underlain by uranium-bearing lignite in the HT Butte area. . . .

27. Graphic section of the Slide Butte lignite bed at Chalky Buttes. 
TABLE

Estimated tonnage of uranium-bearing lignite............. 


\title{
URANIUM IN
}

\section{URANIUM-BEARING LIGNITE IN SOUTHWESTERN NORTH DAKOTA}

\author{
By George W. Moore, Robert E. Melin, and Roy C. Kepferle
}

\begin{abstract}
Beds of uranium-bearing lignite were mapped and sampled in the Bullion Butte, Sentinel Butte, HT Butte, and Chalky Buttes areas in southwestern North Dakota; they occur at several stratigraphic positions in the Sentinel Butte member of the Fort Union formation of Paleocene age. A total of 261 samples from 85 localities were collected for uranium analysis. Lignite containing as much as 0.045 percent uranium, 10.0 percent ash, and 0.45 percent uranium in the ash was found; the average uranium content of the lignite is about 0.013 percent. About 27 million tons of lignite in beds about 2 feet thick underlie the four areas. Surface samples of the lignite average more than 30 percent ash.

The principal factor that seems to influence the concentration of uranium in the lignite beds is the stratigraphic position of the beds in relation to the base of the overlying White River group of Oligocene age. All uranium-bearing beds closely underlie the base of the White River group. The relative concentration of uranium is modified by other factors, however, as beds enclosed in permeable rocks are more uraniferous than beds in impermeable rocks, and thin beds have a greater uranium content than thick beds. In addition, a thick lignite bed commonly has a greater concentration in the top part of the bed. These and other factors suggest that the uranium is of secondary origin and that it was leached from volcanic ash in overlying rocks of Oligocene and Miocene age. Probably the uranium is held in the lignite as part of a metallo-organic compound.
\end{abstract}

\section{INTRODUCTION}

Beds of uranium-bearing lignite were examined in the Bullion Butte, Sentinel Butte, HT Butte, and Chalky Buttes areas in southwestern North Dakota during 1953 by the U. S. Geological Survey (fig. 19).

The common association of uranium with carbonaceous material has long been recognized, and one deposit of uranium-bearing coal at Leyden, Colo., has been known for 80 years (Berthoud, 1875). Other deposits of coal were found to be uranium-bearing in 1945 in the Red Desert, Sweetwater County, Wyo., by A. L. Slaughter and J. M. Nelson 
(written communication, 1946). Later work by D. G. Wyant and E. P. Beroni (written communication, 1950) resulted in the discovery of uranium in other lignite beds in North and South Dakota.

Each of the three areas investigated is dominated by one or more high buttes. Sentinel, Bullion, and HT (Black) Butte each rise more than 500 feet above surrounding gently rolling plains. One of the Chalky Buttes, with an altitude of 3,530 feet, is the highest point in North Dakota. The beds of uranium-bearing lignite lie at most places

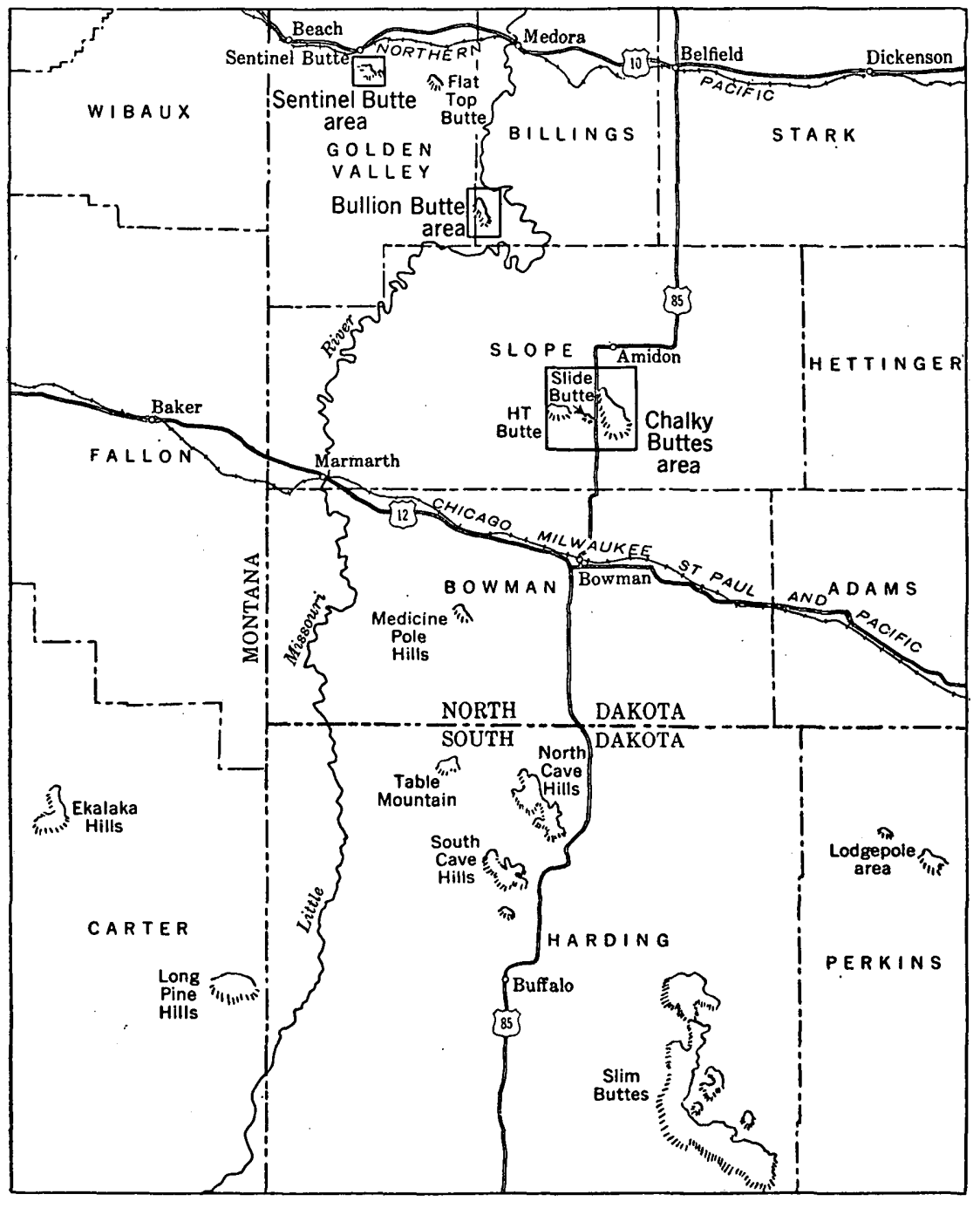

$10, \quad 0,20 \mathrm{M} 11 \mathrm{lles}$

Figure 19.--Index map showing areas described in this report and adjacent areas of uranium-bearing lignite in North Dakota, South Dakota, and Montana. 
near the tops of the buttes. The areas are all fairly accessible; U. S: Highway 85 passes through the Chalky Buttes area and U.S. Highway' 10 passes within 3 miles of Sentinel Butte. The nearest rail shipping. points are Bowman, N. Dak., 12 miles south of the Chalky Buttes area, and Sentinel Butte, N. Dak., 3 miles north of Sentinel Butte. Bullion: Butte is about 30 miles by county-maintained road from the latter town.

Earlier geologic mapping in these areas was done by Leonard (1908), Leonard and Smith (1909), and Hares (1928). Later E. P. Beroni and H. L. Bauer (written communication, 1952) sampled and described uranium-bearing lignite in the Sentinel and Bullion Butte areas. Deposits of such lignite in adjacent parts of South Dakota have a similar geologic setting and are described by Denson, Bachman, and Zeller (chapter B, this bulletin).

J. R. Gill organized the present field party and participated in the early stages of the work. Unpublished data on the uraniferous lignite deposits of South Dakota by Denson, Bachman, and Zeller were made available and permit the relating of the North Dakota deposits to their regional setting. Stratigraphic studies of rocks of Miocene age by Denson and Gill were also made available before they were published. Personnel of the U. S. Geological Survey analyzed the samples of rock and water collected during the present study.

\section{STRATIGRAPHY}

The rocks exposed in the Sentinel, Bullion, and Chalky Buttes areas are of continental origin. The beds of uranium-bearing lignite are in the upper part of the Fort Union formation of Paleocene age. The Fort Union formation is divided into the Ludlow, Tongue River, and Sentinel Butte members in ascending order. Only the latter two, the Tongue River and Sentinel Butte members, crop out in the mapped areas. The White River group of Oligocene age, made up of the Chadron and Brule formations, unconformably overlies the Fort Union formation. The White River group, in turn, is overlain unconformably by the Arikaree formation of Miocene age.

Stratigraphic sections of the rocks exposed in the Sentinel, Bullion, and Chalky Buttes areas are shown in figure 20.

\section{TERTIARY ROCKS}

\section{FORT UNION FORMATION}

.. Tongue River member.-The Tongue River member of the Fort Union formation of Paleocene age is the oldest rock unit exposed in each of the three areas mapped. A total thickness of 600 feet is assigned to the member by Hares $(1928$, p. 47). The Tongue River is made up predominantly of light yellowish gray very fine grained sand- 


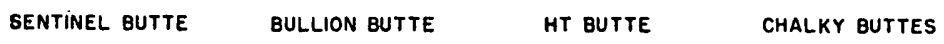

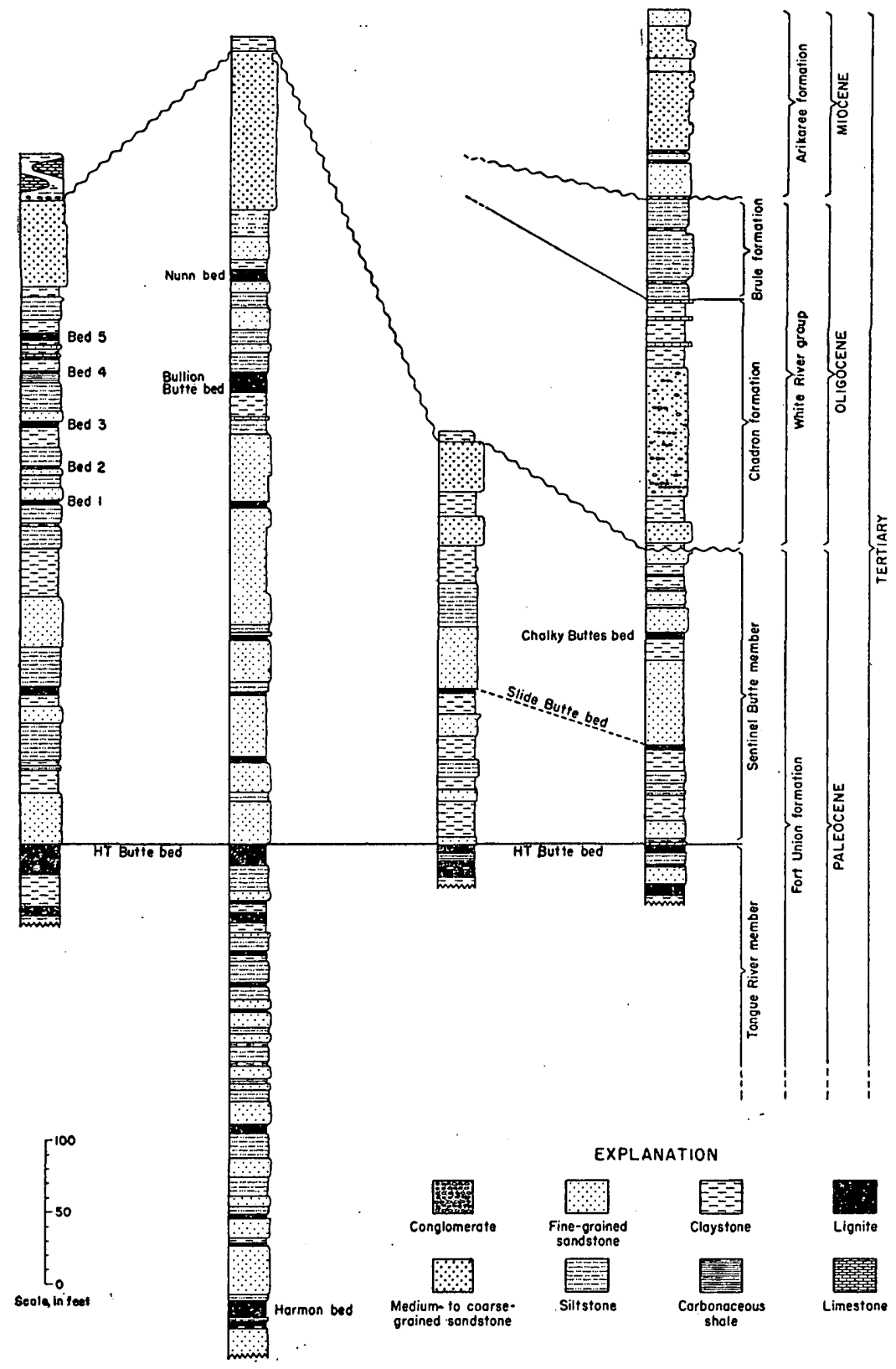

Figure 20.- Stratigraphic sections of rocks associated with uranium-bearing lignite in southwestern North Dakota. 
stone and siltstone and lesser amounts of claystone, carbonaceous shale, and lignite. The contact between the Tongue River and the overlying Sentinel Butte member is placed arbitrarily at the top of the HT Butte lignite bed.

Sentinel Butte member.-The uranium-bearing lignite deposits in the areas studied are in the Sentinel Butte member of the Fort Union formation. This unit overlies the Tongue River member and is considered to be of Paleocene age (Brown, 1948). It ranges in thickness from about 500 feet at Bullion Butte to 280 feet at HT Butte, owing to erosion which produced a surface that truncates progressively older rocks from northeast to southwest.

The Sentinel Butte member is composed principally of siltstone and very fine grained sandstone. In addition, claystone, lignite, and carbonaceous shale make up a somewhat larger part of the total than they do in the Tongue River member, and the overall color is darker than the Tongue River.

A vertebrate fossil identified by J. R. Macdonald of the South Dakota School of Mines as Champsosaurus sp. was found in the Chalky Buttes area about 180 feet stratigraphically above the base of the Sentinel Butte member and 18 feet below the overlying Chadron formation in the SE $1 / 4$ sec. 15, T. 134 N., R. 101 W. Champsosaurus is one of the last of a primitive order of water-dwelling reptiles that appeared in Permian time and did not survive the Eocene.

\section{CHADRON FORMATION}

The Chadron formation, the lower formation of the White River group of Oligocene age, is about 170 feet thick and in each of the areas investigated unconformably overlies the Sentinel Butte member of the Fort Union formation of Paleocene age. Twenty-five miles to the east, where a greater thickness of the underlying rocks has been preserved, the Chadron rests on the Golden Valley formation of Eocene age (Benson, 1951). At most places examined, the formation consists of a basal unit of light greenish gray sandy claystone, about 20 feet thick; a middle unit of yellowish-gray coarse-grained locally conglomeratic sandstone, about 100 feet thick; and an upper unit of light olive gray bentonitic claystone and white freshwater limestone, about 50 feet thick. Fossil fish have been described from some of the claystone beds (White, 1883). The top of the Chadron formation is marked by the uppermost limestone bed in the section.

\section{BRULE FORMATION}

The Brule formation, more than 70 feet thick, is the upper formation of the White River group and is exposed only in the Chalky Buttes. The formation is predominantly composed of grayish orange 
pink tuffaceous siltstone. Mammal remains were collected about 20 feet above the base of the Brule formation in the NW1/4 sec. 31, T. 134., R. $100 \mathrm{~W}$. These were identified by M. J. Hough of the U. S. Geological Survey. The collection is regarded as Whitneyan in age.

Miohippus sp., parts of two lower jaws

Hyracodon sp., lower molar

Eporeodon(?), lower jaw fragment

Protoceras (?), lower jaw fragment

Leptomeryx sp., parts of three lower jaws

Leptauchenia sp., anterior portion of skull and jaws, mandible, posterior portion of skull

Cedromus (?), upper tooth

Eumys sp., portions of three lower faws

Paleolagus sp., portions of four lower jaws

Paradjidaumo (?) sp. (?), portions of three lower jaws

Prosciurus sp., lower jaw fragment

\section{ARIKAREE FORMATION}

About 70 feet above the base of the Brule formation in the Chalky Buttes area, an erosion interval is marked by an unconformity at the base of a bed of conglomerate. Above this bed the rocks are principally dusky yellow green medium- to coarse-grained sandstone and are assigned to the Arikaree formation on the basis of their lithology. A fossil collection from the base of the Arikaree formation in the Ekalaka Hills, 70 miles to the southwest, indicates an early or middle Miocene age for the formation (J. R. Gill, written communication, 1953).

\section{QUATERNARY DEPOSITS}

Deposits of terrace gravel as much as 10 feet thick are present on the flanks of Bullion Butte at an altitude of 220 feet above the Little Missouri River. These deposits were not mapped. Landslide material derived mostly from massive sandstone of the Fort Union formation is common along the sides of the buttes. These deposits were mapped in the Chalky Buttes area but were not mapped in the Bullion Butte and Sentinel Butte areas. Deposits of alluvium and slope-wash occur along the major streams and on many of the hills, but none of this material was mapped.

\section{STRUCTURE}

The rocks in the areas investigated lie on the northeast flank of the Cedar Creek anticline, a low narrow uplift trending northwest through the southwest corner of North Dakota. The rocks dip to the northeast into the Williston basin at about 25 feet per mile. No faults have been recognized in the mapped areas. 


\section{URANIUM-BEARING LIGNITE}

All beds of uranium-bearing lignite in the three areas studied are in the Sentinel Butte member of the Fort Union formation. The relative stratigraphic position of the lignite beds is shown by figure 20 , and their areal distribution is shown by the geologic maps, plates 30 and 31. The discussion of uranium distribution is based on 261 samples collected for uranium analysis and on data from 85 measured sections of the uraniferous beds. Samples were also submitted for analysis from the underlying nonradioactive beds.

\section{BULLION BUTTE AREA, BILLINGS AND GOLDEN VALLEY COUNTIES}

Only two lignite beds in the Bullion Butte area (pl. 31) contain significant amounts of uranium. The most radioactive bed in this area is the Nunn lignite bed, being named from the Nunn Ranch in sec. 6, T. 137 N., R. 102 W. The bed crops out on the upper slopes of the butte and is about 400 feet stratigraphically above the base of the Sentinel Butte member. It is stratigraphically the highest lignite bed exposed in the area. The Nunn lignite bed ranges in thickness from 3 to 12 feet, the average being 4.8 feet, and underlies an area of about 500 acres. The greatest concentration of uranium found in the bed is 0.036 percent. The average uranium content of the bed is not uniform, being greatest at the places where the bed is thin and decreasing where it is thick. The quantity of uranium contained in the bed per square unit of area remains approximately the same, however, so that the thickness of the bed may be taken as an inverse measure of its relative grade. The uranium is not evenly distributed through the lignite bed but is commonly concentrated in the upper part, the grade decreasing downward. A similar progressive decrease downward in uranium content of thick radioactive lignite beds was noted by Denson, Bachman, and Zeller (chapter B, this bulletin) in nearby parts of South Dakota.

The other bed, the Bullion Butte lignite bed, 60 feet stratigraphically below the Nunn lignite bed, contains small amounts of uranium at some places in the Bullion Butte area. This bed ranges in thickness from 7-22 feet and averages 11 feet. The uppermost 1-2 feet of the Bullion Butte bed locally has as much as 0.007 percent uranium, but the lower part contains less than 0.001 percent. Other lignite beds in the Bullion Butte area are not uraniferous.

The Nunn lignite bed contains about 4.2 million short tons of lignite. The bed has an average thickness of 4.8 feet, and the average uranium content of the lignite is 0.007 percent. The average ash content of the lignite is about 20 percent and the ash contains an average of 0.037 percent uranium. The Bullion Butte bed contains more than 16 million tons of lignite, and it has an average uranium content of less $469117-59-12$ 
than 0.001 percent. Maps and sections showing uranium content and extent of the Nunn and Bullion Buttes beds are given in figure 21 .

\section{SENTINEL BUTTE AREA, GOLDEN VALLEY COUNTY}

Five beds of uranium-bearing lignite crop out near the top of Sentinel Butte. These beds, from oldest to youngest, are numbered from 1 through 5 (pl. 31). They are all in the upper part of the Sentinel Butte member of the Fort Union formation.

The uppermost, bed 5, which closely underlies the Chadron formation, has the greatest uranium content per unit area, though lower beds locally have a greater concentration of uranium. Within a bed the vertical distribution of uranium is somewhat irregular, the greatest concentrations occurring near the tops of the thicker beds, but in the beds 2 feet or less in thickness the greatest concentrations occur near the base.

Lignite beds in the lower part of the Sentinel Butte member and the underlying Tongue River member contain less than 0.001 percent uranium.

Lignite beds 1-5 contain about 5 million short tons of lignite. The lignite contains an average of about 0.007 percent uranium, 32 percent ash, and 0.022 percent uranium in the ash. The average thickness of the lignite beds is about 2.5 feet. Figures 22 and 23 show the extent of the individual lignite beds and the sampled sections and analytical data on which the estimates are based.

\section{CHALKY BUTTES AREA, SLOPE COUNTY}

In the Chalky Buttes area, Slope County, North Dakota, two beds of uranium-bearing lignite occur in the lower part of the Sentinel Butte member of the Fort Union formation. They are here named the Chalky Buttes lignite bed and the Slide Butte lignite bed (pl. 30) from exposures on the respective buttes. These beds underlie a total of 8 square miles.

The Chalky Buttes lignite bed underlies only the northern part of Chalky Buttes (fig. 24). In the southern part of the area the bed has been removed by pre-Chadron erosion. The bed ranges in thickness from 0.5 to 4 feet and averages about 2 feet. Its uranium content is not uniform, reaching a maximum of 0.018 percent near the place where the lignite bed is truncated by the Chadron formation. The Chalky Buttes lignite bed in the northern part of the Chalky Buttes area contains about 5,220,000 short tons of lignite containing an average of 0.008 percent uranium and 30 percent ash in which uranium averages about 0.023 percent.

The Slide Butte lignite bed is 80 feet stratigraphically below the Chalky Buttes lignite bed and 70 feet above the base of the Sentinel 
SOUTHWESTERN NORTH DAKOTA

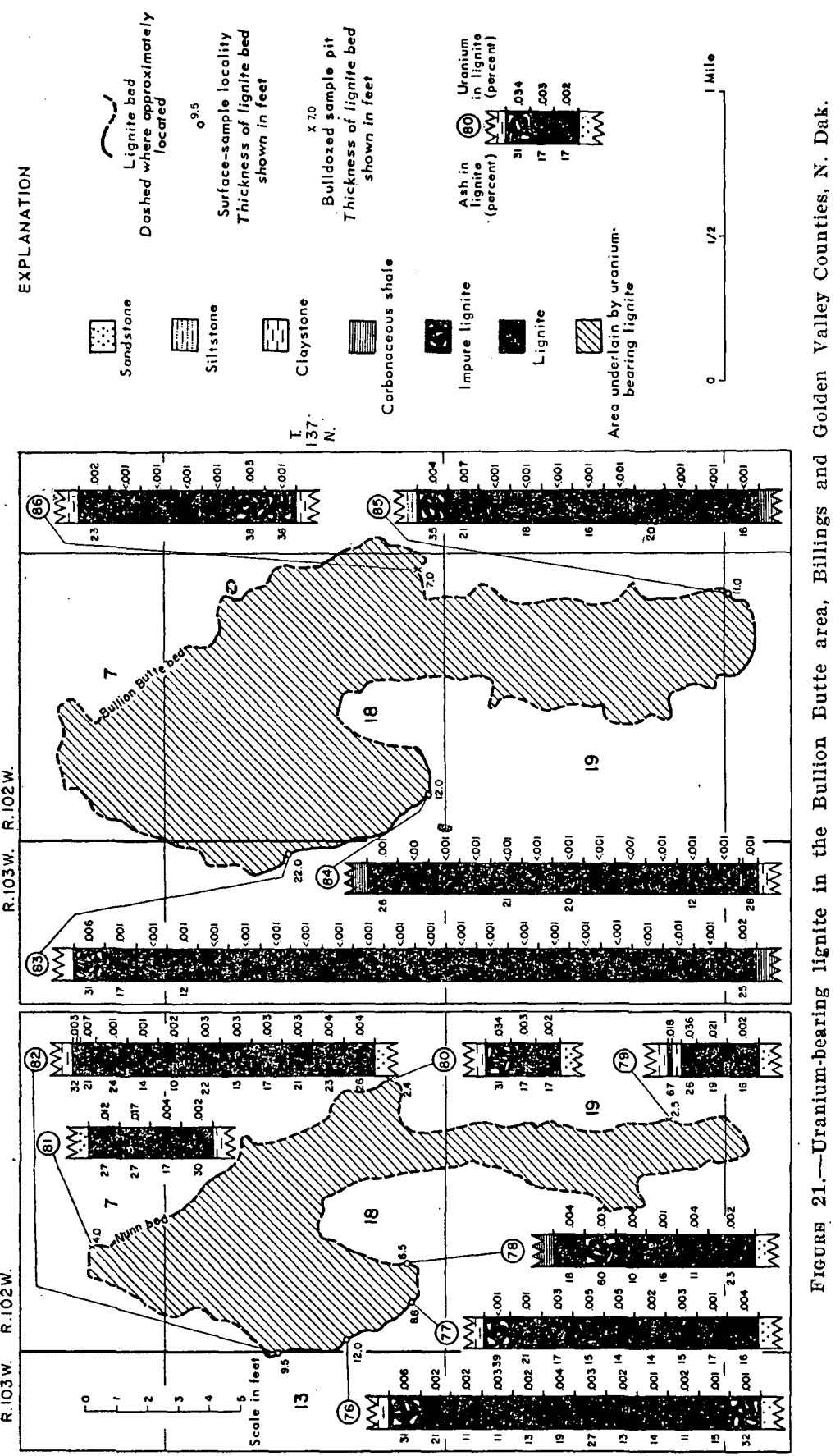



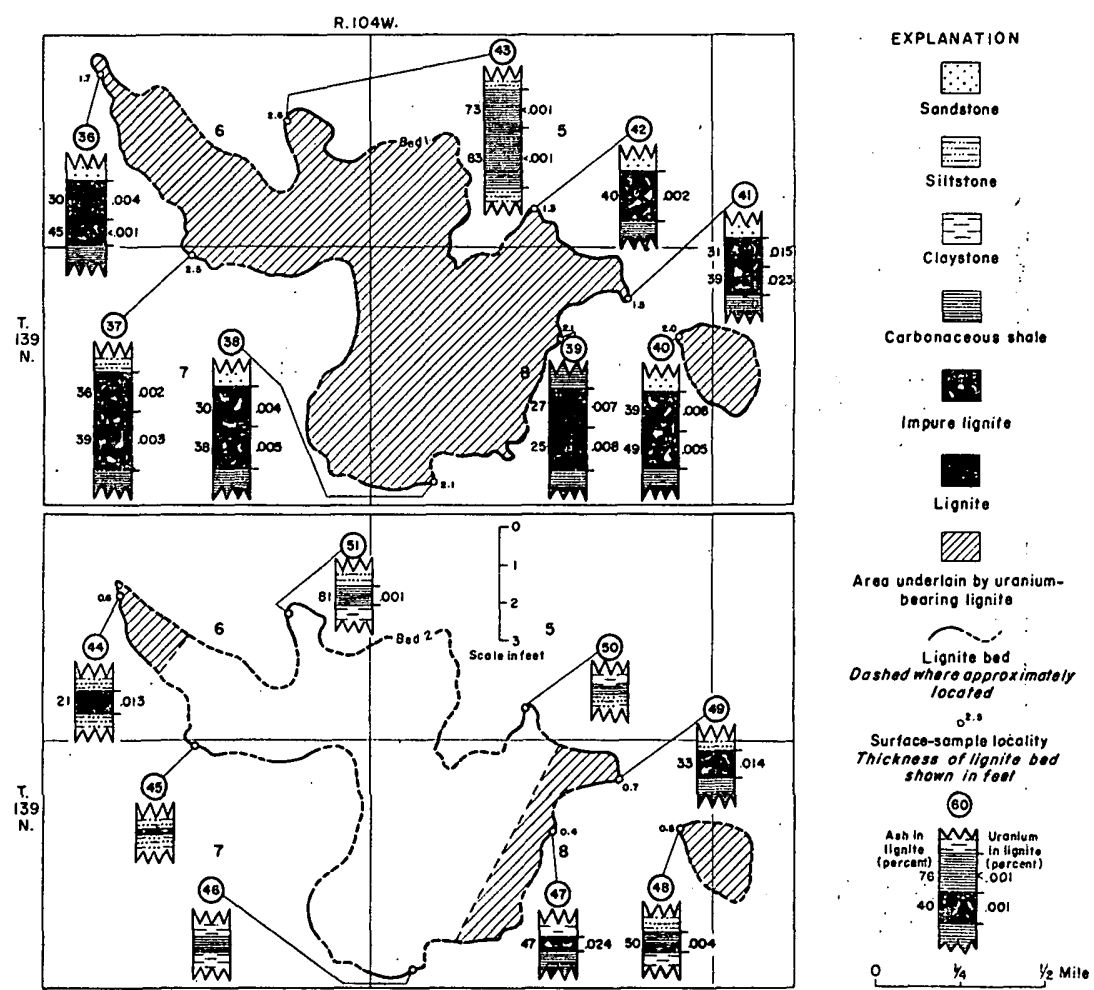

Figdre 22.-Uranium-bearing lignite in beds 1 and 2, Sentinel Butte area, Golden Valley County, N. Dak.

Butte member. It is the stratigraphically highest lignite bed at HT and Slide Buttes and in the southern part of Chalky Buttes. The maximum thickness of the bed is 7 feet and the average thickness, about 2 feet. A sample from this bed collected at the east end of HT Butte contains 0.045 percent uranium and 10 percent ash containing 0.45 percent uranium. The average uranium content of the bed, however, is considerably less, and in the northern part of Chalky Buttes, where the overlying Chalky Buttes lignite bed is present, the uranium content may be only 0.003 percent.

In the southern part of the Chalky Buttes area (fig. 25), the Slide Butte lignite bed contains a total of about 10 million short tons of lignite. The average uranium content of the lignite is about 0.022 percent; the ash content is about 30 percent, and the ash contains about 0.063 percent uranium. Of the above lignite, about $2,900,000$ short tons has an overburden of less than 30 feet and could be recovered by strip mining. The lignite that could be recovered by stripping averages about 2.6 feet in thickness and has an average uranium 

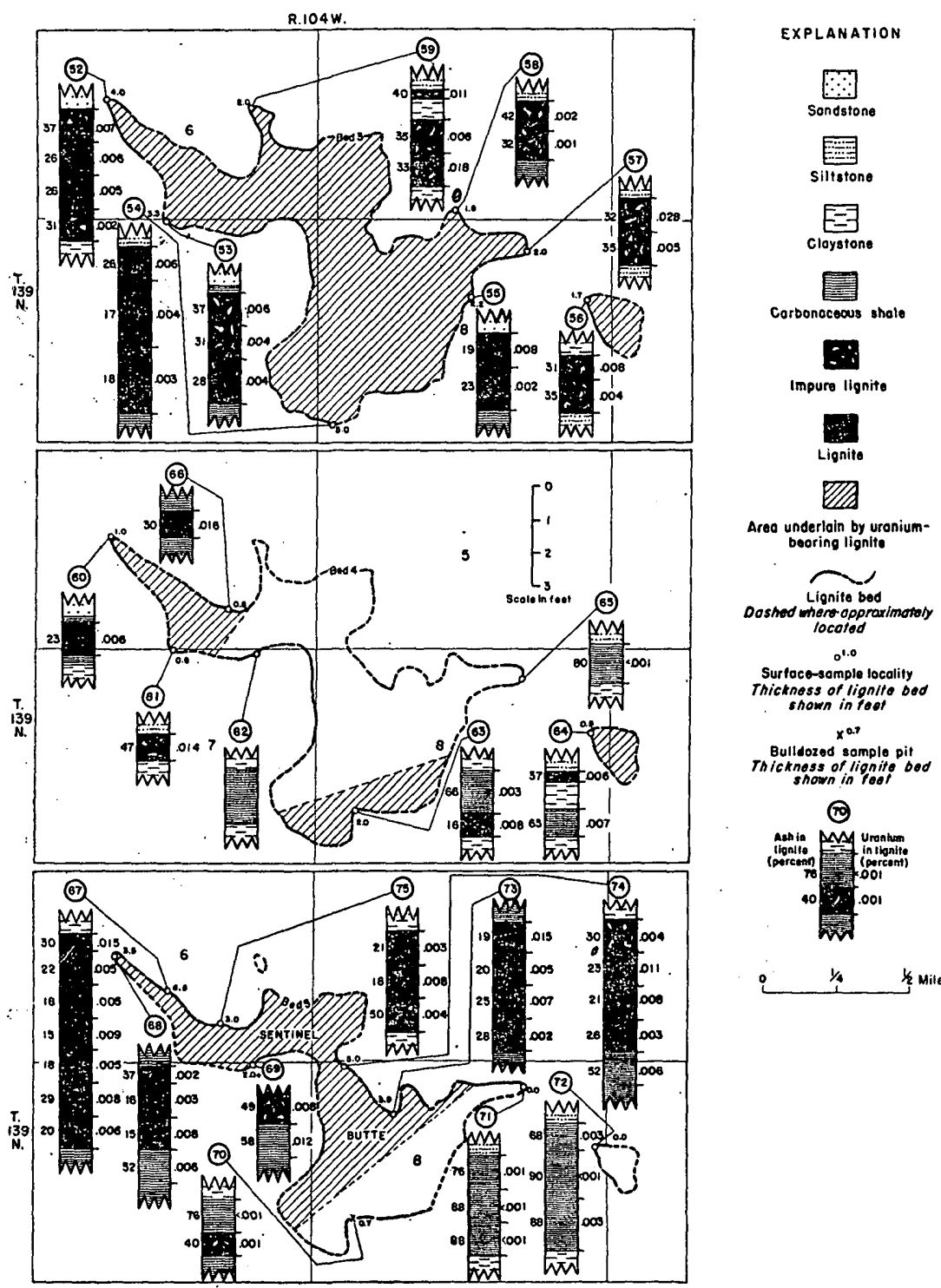

(2)
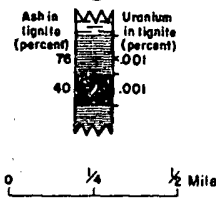

Frgure 23.-Uranium-bearing lignite in beds 3-5, Sentinel Butte area, Golden Valley County, N. Dak.

content of 0.016 percent. The average ash content is about 25 percent and the ash contains about 0.06 percent uranium.

In the HT Butte area, including both HT Butte and Slide Butte, the Slide Butte lignite bed contains about 2.5 million short tons of lignite (fig. 26). The bed is about 2 feet thick on both buttes and contains about 20 percent ash. On HT Butte the lignite contains about 


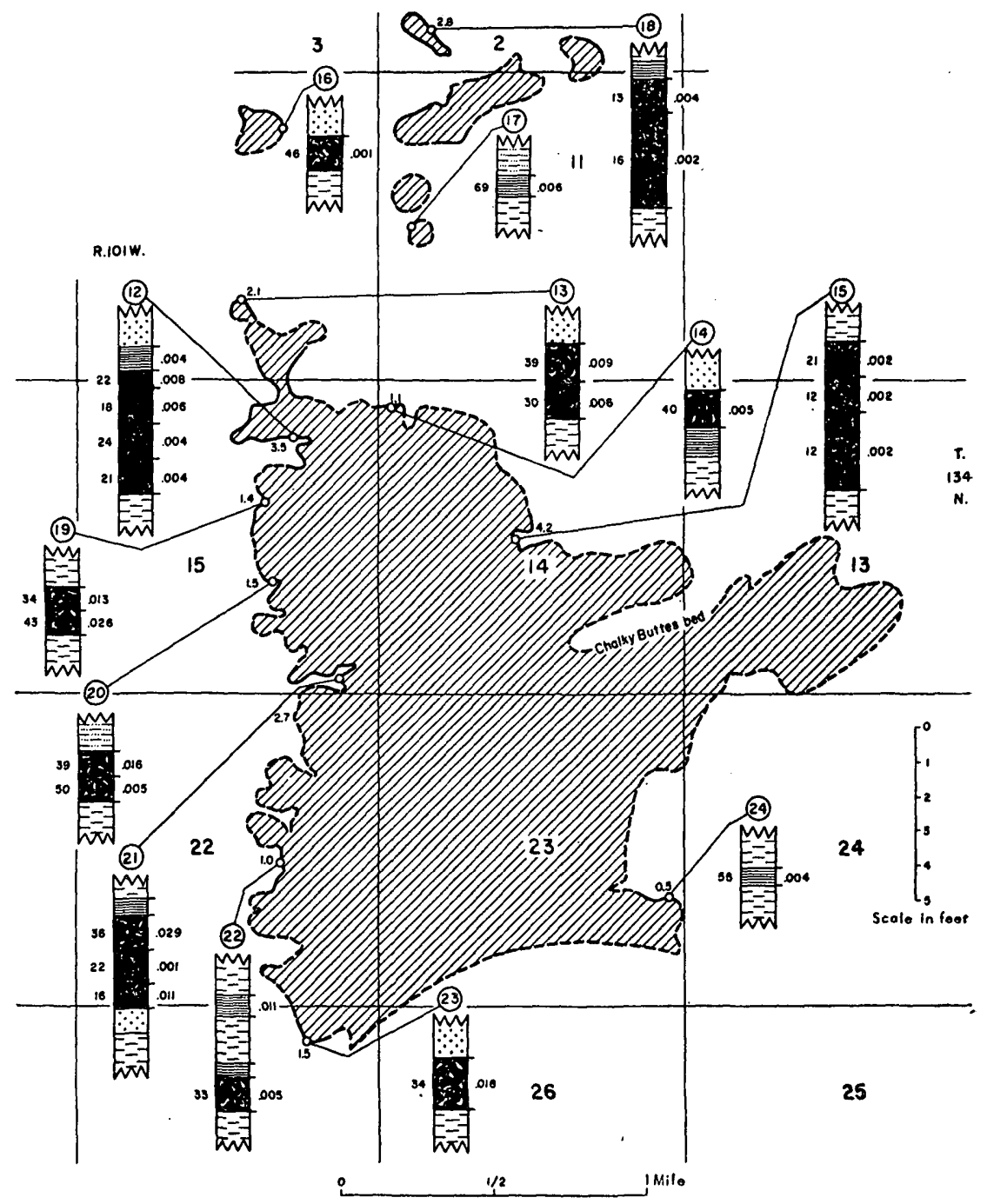

EXPLANATION

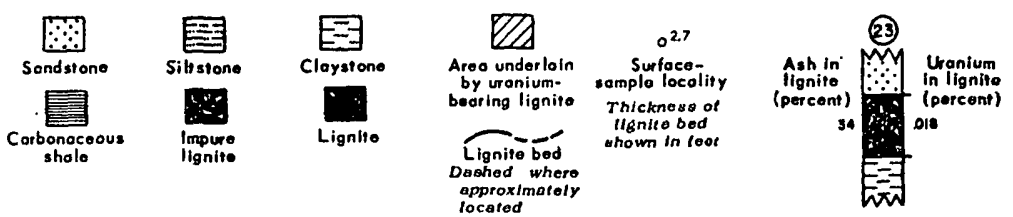

Figure 24.-Uranium-bearing lignite in the northern part of the Chalky Buttes area, Slope County, N. Dak. 


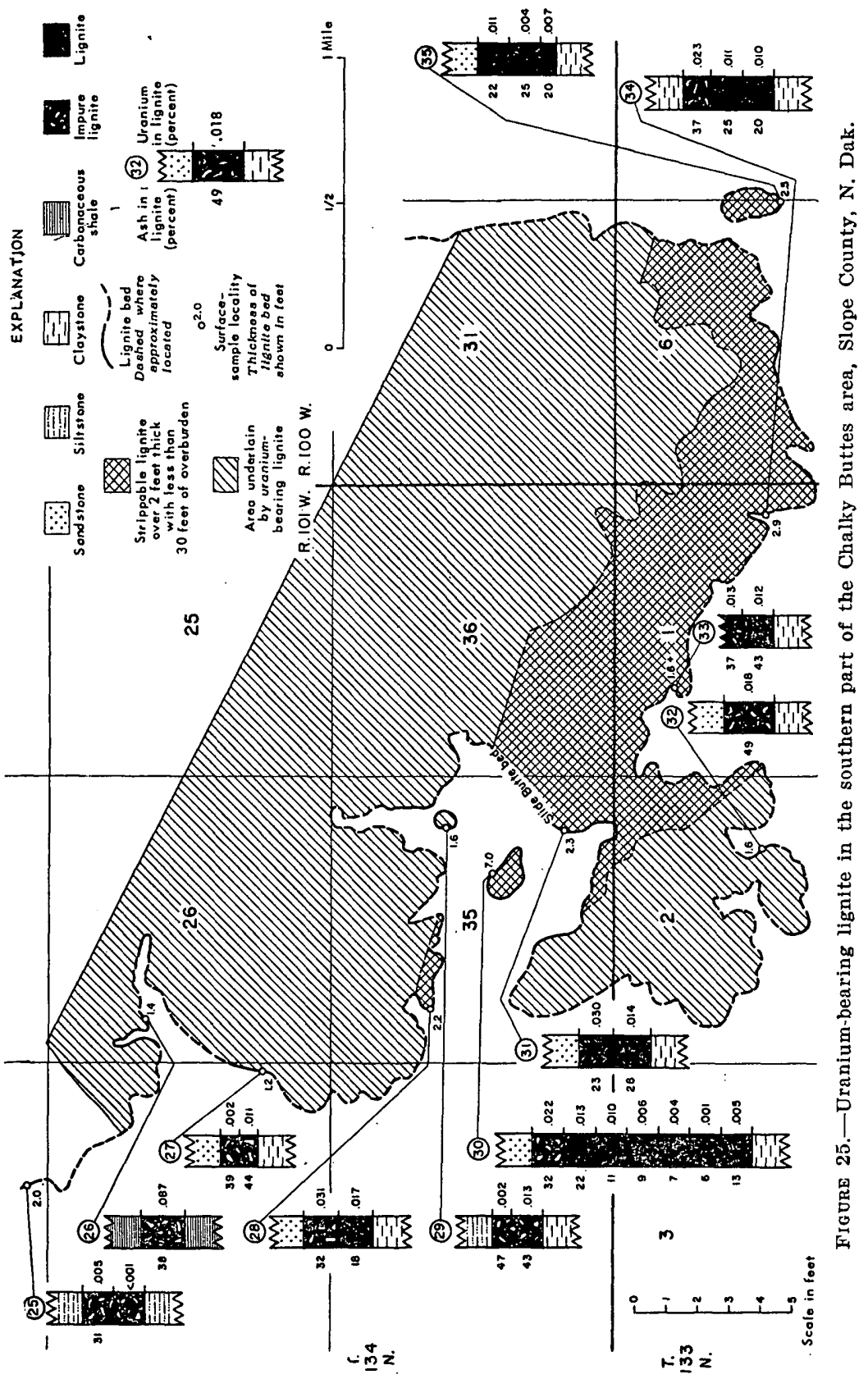




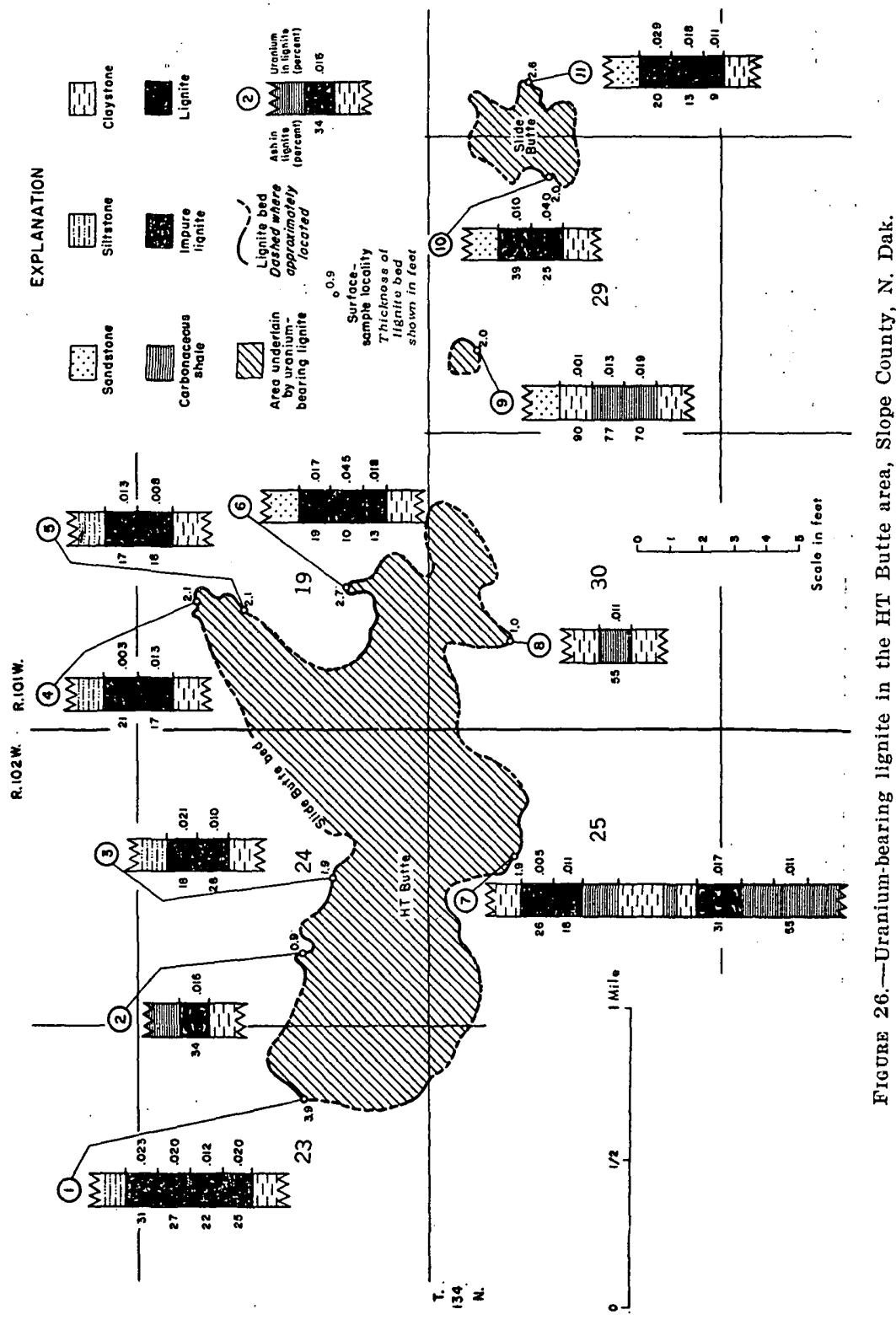


0.015 percent uranium and 0.075 percent uranium in the ash. On Slide Butte, where the bed contains about 230,000 short tons of lignite, the lignite contains about 0.024 percent uranium and 0.12 percent uranium in the ash.

\section{TONNAGE OF ORANIUM-BEARING LIGNITE}

The tonnage and uranium content of uranium-bearing lignite in the areas investigated in southwestern North Dakota are summarized in table 1. A total of 6,990 acres is underlain by $27,220,000$ tons of lignite in beds averaging 2.3 feet in thickness. This lignite contains an average of 0.013 percent uranium in the lignite and 0.045 percent uranium in the lignite ash. Except for a small area in the Chalky Buttes, all lignite beds examined would have to be mined by underground methods. About 2,900,000 tons of lignite in the Chalky Buttes area lie under less than 30 feet of overburden. A number of these lignite beds might be of interest as a possible future byproduct source of uranium.

TABLE 1.-Estimated tonnage of uranium-bearing lignite

\begin{tabular}{l|l|c|c|c|c|c|c|}
\hline Bed & Ares (acres) & $\begin{array}{c}\text { Average } \\
\text { thickness } \\
\text { (feet) }\end{array}$ & $\begin{array}{c}\text { Lignite } \\
\text { (short tons) }\end{array}$ & $\begin{array}{l}\text { in lignite } \\
\text { (percent) }\end{array}$ & $\begin{array}{l}\text { Uranium } \\
\text { in lignite } \\
\text { ash } \\
\text { (percent) }\end{array}$ \\
\hline
\end{tabular}

Bullion Butte area, Billings and Golden Valley Counties, N. Dak.

\begin{tabular}{l|r|r|r|r|r}
\hline Nunn lignite bed...................... & 501 & 4.8 & $.4,210,000$ & 0.007 & 0.037 \\
\hline
\end{tabular}

Sentinel Butte area, Golden Valley County, N. Dak.

\begin{tabular}{|c|c|c|c|c|c|}
\hline 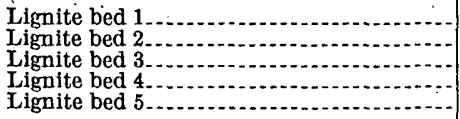 & $\begin{array}{r}502 \\
88 \\
370 \\
95 \\
159\end{array}$ & $\begin{array}{l}2.0 \\
0.5 \\
2.8 \\
1.1 \\
4.4\end{array}$ & $\begin{array}{r}1,760,000 \\
80,000 \\
1,810,000 \\
180,000 \\
1,220,000\end{array}$ & $\begin{array}{r}0.005 \\
.013 \\
.006 \\
.010 \\
.007\end{array}$ & $\begin{array}{l}0.017 \\
.041 \\
.020 \\
.028 \\
.028\end{array}$ \\
\hline Total & 1,214 & 2.4 & $5,050,000$ & .007 & .022 \\
\hline
\end{tabular}

Chalky Buttes area, Slope County, N. Dak.

\begin{tabular}{|c|c|c|c|c|c|}
\hline $\begin{array}{l}\text { silde Butte lignite bed } \\
\text { Chalky Buttes lignite bed. }\end{array}$ & $\begin{array}{l}2,913 \\
1,571\end{array}$ & $\begin{array}{l}2.0 \\
1.9\end{array}$ & $\begin{array}{r}10,200,000 \\
5,220,000\end{array}$ & $\begin{array}{r}0.022 \\
.008\end{array}$ & $\begin{array}{r}0.063 \\
.023\end{array}$ \\
\hline Total.. & 4,484 & 2.0 & $15,420,000$ & .017 & .049 \\
\hline
\end{tabular}

HT Butte area, Slope County, N. Dak.

\begin{tabular}{|c|c|c|c|c|c|}
\hline \multirow{2}{*}{$\begin{array}{l}\text { Slide Butte lignite bed } \\
\text { Grand total }\end{array}$} & 791 & 1.8 & $2,540,000$ & 0.016 & 0.078 \\
\hline & 6,990 & 2.3 & $27,220,000$ & .013 & .045 \\
\hline
\end{tabular}




\section{ORIGIN OF THE URANIUM}

Two principal hypotheses have been proposed to explain occurrences of uranium in the lignite beds of North and South Dakota. Denson, Bachman, and Zeller (chapter B, this bulletin), working in South Dakota, conclude that uranium was leached by ground water from volcanic ash of the White River group and the overlying Arikaree formation and was introduced into the lignite after its coalification. E. P. Beroni and H. L. Bauer (written communication, 1952), who studied the uranium-bearing lignite at Sentinel and Bullion Buttes, suggested that the uranium was extracted from surface water by organisms during their life cycle or shortly after burial; this material was subsequently carbonized to form lignite. They suggested that the uranium was derived from volcanic ash deposited contemporaneously with the lignite and now represented by beds of bentonitic claystone and siltstone found at several stratigraphic horizons within the Sentinel Butte member of the Fort Union formation. Evidence accumulated during the present investigation seems to support the hypothesis of origin advanced by Denson, Bachman and Zeller.

Plate 31 illustrates local variations in the areal distribution of uranium in lignite beds at Bullion, Sentinel, and Chalky Buttes. Generally, the lignite bed which directly underlies rocks of the White River group is more radioactive than other beds lower in the same stratigraphic sequence. Thus, at Bullion Butte, the Nunn lignite bed is uranium-bearing, the underlying Bullion Butte lignite bed contains but minor amounts of uranium and only locally, and beds below the Bullion Butte bed have no uranium. At Sentinel Butte, lignite bed 5 is the stratigraphically highest lignite bed and contains the most uranium at the west end of Sentinel Butte, but at the east end of the butte, where bed 5 lenses out, the uranium content of underlying lignite beds 3 and 1 is markedly increased. Similarly at Chalky Buttes, the Slide Butte lignite bed contains only small amounts of uranium where it is overlain by the Chalky Buttes lignite bed, but much larger amounts where the latter has been removed by pre-Chadron erosion.

Figure 27 is a graphic section of the Slide Butte bed showing the progressive decrease downward in uranium typically displayed by thick uranium-bearing lignite beds in the three areas studied. The distribution pattern suggests not only that the uranium is secondary, but that most of the uranium was introduced from above. A slight increase of uranium at the base of the bed is not uncommon, and many of the thinner lignite beds are most uraniferous at their bases. Such reversal of the distribution pattern may occur if the coal bed itself acted as an aquifer. 
SEI/4 sec. 35, T. 134 N., R. 101 W.

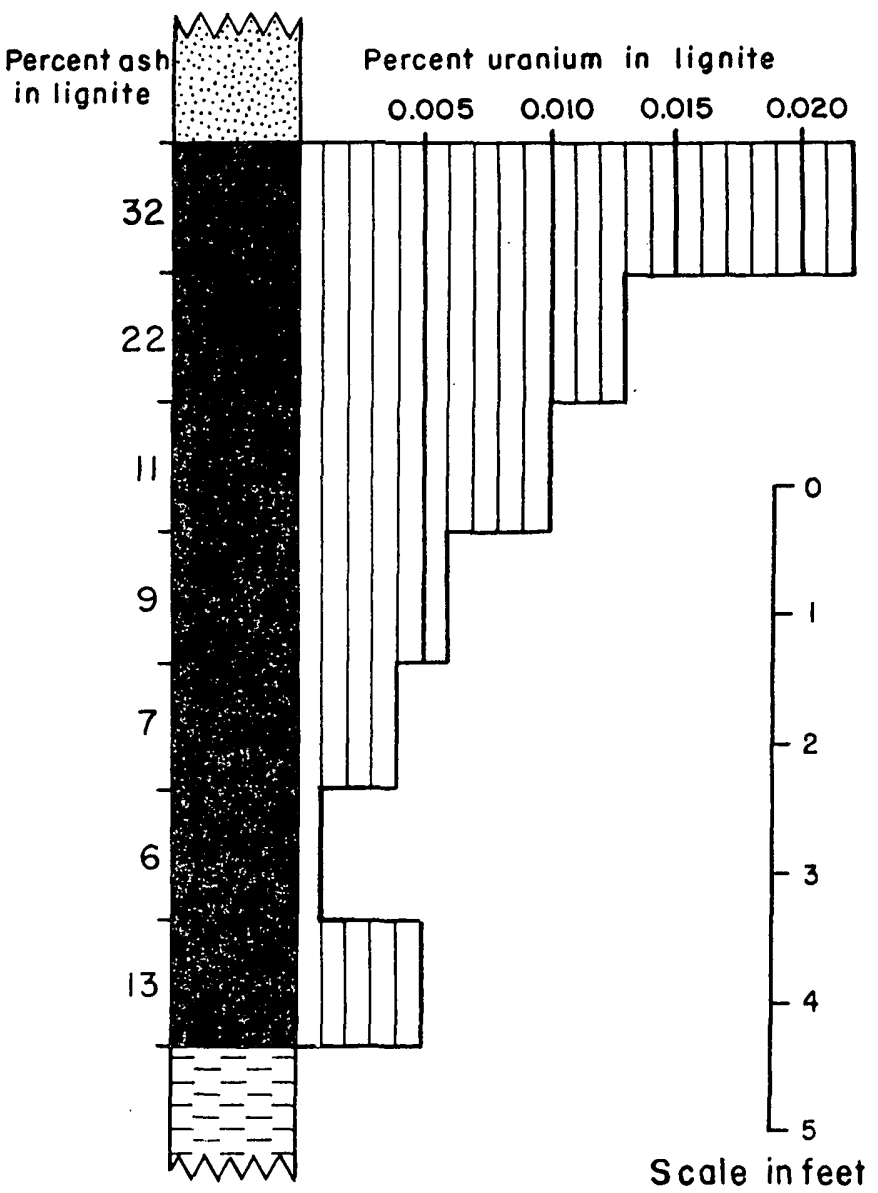

Figore 27.-Graphic section of the Slide Butte lignite bed at Chalky Buttes,

N. Dak, illustrating downward decrease in distribution of uranium.

The amount of uranium deposited seems to be due in part to the permeability of rocks enclosing the lignite beds. Beds with relatively large uranium content commonly are overlain by permeable beds of sandstone. One of the most uraniferous lignite beds studied, the Slide Butte lignite bed, is overlain by a bed of sandstone 60 feet thick where the lignite is most uraniferous, and the several thin beds of uraniumbearing lignite exposed in the Sentinel Butte area are associated with permeable rocks.

Perhaps the most convincing proof for the derivation of uranium from the rocks of the White River group and Arikaree formation is 
the regional relationship between the White River group and the underlying uranium-bearing lignite. Plate 32 is a block diagram showing the truncation of Paleocene and Upper Cretaceous rocks by the erosion surface at the base of the White River group, and the relation of uraniferous lignite to this unconformity. At Sentinel and Bullion Buttes, the White River group overlies the Sentinel Butte member of the Fort Union formation, and only the lignite in the upper part of the Sentinel Butte member contains uranium. As successively older beds of lignite are cut out beneath the pre-White River unconformity, the next lower bed in the stratigraphic sequence becomes uraniferous so that at Slim Buttes in South Dakota rocks of the White River group overlie a uranium-bearing bed near the base of the Ludlow member of the Fort Union formation. At the south end of Slim Buttes thin lenticular beds of lignite in the Hell Creek formation of Late Cretaceous age are also radioactive.

Northeast of the area shown by the diagram the White River group unconformably overlies the Golden Valley formation of Eocene age (Benson, 1951). In the NW1/4 sec. 31, T. 139 N., R. 97 E., Stark County, N. Dak., the Golden Valley formation contains a lenticular bed of lignite, 0.6 -foot thick, which crops out within 10 feet stratigraphically of the base of the White River group. This lignite bed contains 0.12 percent uranium, 6.1 percent ash, and 1.9 percent uranium in the ash. Thus, lignite beds having a stratigraphic range of more than 1,000 feet and ranging in age from Eocene to Late Cretaceous, may contain uranium, but they are uraniferous only where closely overlain by rocks of the White River group.

Denson, Bachman, and Zeller (see chapter B, this bulletin) note that ground water from the White River group contains unusually large amounts of uranium. Later detailed sampling of water in the Slim Buttes area added corroborative evidence (Gill and Moore, 1955). Two spring-water samples from the Chadron formation collected during the present investigation contain 29 and 10 parts per billion uranium at Chalky Buttes in the NW1/4 sec. 31, T. 134 N., R. 101 W., and at HT Butte in the SE $1 / 4$ sec. 24, T. 134 N., R. 102 W. By way of comparison, Sheldon Judson and Kenneth Osmond (written communication, 1953) obtained an average of only 0.4 parts per billion uranium from 42 well samples in Wisconsin, and the uranium content of the ocean is about 1 part per billion (Koczy, 1950).

\section{OCCURRENCE OF URANIOM IN LIGNITE}

R. A. Ewing and others (written communication, 1950) have shown that the uranium in lignite from Sentinel Butte, N. Dak., is not associated with mineral matter in the lignite but is related to organic con- 
stitutents. Breger, Deul, and Rubinstein (1955), on the basis of ionexchange studies of uranium-bearing lignite from Slim Buttes, S. Dak., have further demonstrated that the uranium is held as a metalloorganic compound. In additional laboratory studies, non-uraniferous lignite from Slim Buttes was found to extract 99 percent of the uranium from a 200 parts per million solution of uranyl sulfate (Moore, 1954). Under the same conditions wood (white pine) extracted only 40 percent of the uranium, which suggests that uncoalified organic material is less effective as an extracting agent for uranium than lignite.

The graphic section of the Slide Butte lignite bed shown by figure 27 indicates a notable relationship between the ash content and the uranium content of the lignite; the layers having the most ash also have the most uranium. A similar relationship between contents of ash and uranium seems to exist in many of the other uraniferous lignite beds studied. It is thought that other impurities were introduced into the lignite with the uranium, but because the ash content of the lignite is related directly to the freshness of the sample, and because all lignite beds were sampled at weathered outcrops, no consistent ash-uranium correlation can be demonstrated by the data from North Dakota.

The simple progressive downward decrease in uranium in thick lignite beds observed when 1-foot vertical samples through the beds are compared is in part modified when beds are sampled in greater detail. If samples are a fraction of a centimeter to several centimeters thick, variations in uranium content are found between individual samples which do not always reflect their position in the bed. This fact suggests that certain coal constituents may have a greater affinity for uranium than other components. J. M. Schopf and others have made extensive petrographic studies of lignite from the Slim Buttes area, South Dakota, to determine the nature of the uraniferous constituents. Preliminary results of these studies show that no quantitative correlation exists between uranium content and the coal petrologic constituents that are normally determined for coal classification (Schopf and Gray, 1954). They note, however, that the samples richest in uranium contain relatively large amounts of humic matter resulting from decomposition and microbial decay, an indication that plant material that has been most subjected to decay is the most favorable for extraction of uranium. It is also possible, however, that variations in permeability of the coal constituents may have controlled the movement of uranium-bearing solutions within the lignite beds thereby causing variations in uranium content not directly related to the chemical nature of the coal constituents. 


\section{LITERATURE CITED}

Benson, W. E., 1951, Geologic map of North Dakota southwest of the Missouri River: U. S. Geol. Survey.

Berthoud, E. L., 1875, On the occurrence of uranium, silver, and iron in the Tertiary formations of Colorado Territory: Acad. Nat. Sci. Philadelphia, Proc., v. 27, p. 363-365.

Breger, I. A., Deul, Maurice, and Rubinstein, Samuel, 1955, Geochemistry and mineralogy of a uraniferous lignite: Econ. Geology, v. 50, p. 206-226.

Brown, R. W., 1948, Correlation of Sentinel Butte shale in western North Dakota : Am. Assoc. Petroleum Geologists Bull., v. 32, p. 1265-1274.

Gill, J. R., and Moore, G. W., 1955, Carnotite-bearing sandstone in Cedar Canyon, Slim Buttes, Harding County, S. Dak.: U. S. Geol. Survey Bull. 1009-I., p. 249-264.

Hares, C. J., 1928, Geology and lignite resources of the Marmarth field, southwestern North Dakota: U. S. Geol. Survey Bull. 775.

Koczy, Gerta, 1950, Further uranium determinations on sea water samples: Akad. Wiss. Wien, math.-naturwiss. Kl., Sitzungsber., Abt. IIa, v. 158, p. 113-122.

Leonard, A. G., 1908, Geology of southwestern North Dakota with special reference to the coal : N. Dak. Geol. Survey 5th bienn. rept., p. 27-114.

Leonard, A. G., and Smith, C. D., 1909, The Sentinel Butte lignite field; U. S. Geol. Survey Bull. 341-A, p. 15-35.

Moore, G. W., 1954, Extraction of uranium from aqueous solution by coal and some other materials : Econ. Geology, v. 49, p. 652-657.

Schopf, J. M., and Gray, R. J., 1954, Microscopic studies of uraniferous coal deposits : U.S. Geol. Survey Circ. 343.

White, C. A., 1883, On the existence of a deposit in northeastern Montana and northwestern Dakota that is possibly equivalent with the Green River group : Am. Jour. Sci., ser. 3, v. 25, p. 411-414. 


\section{Reconnaissance for Uranium}

In the Ekalaka Lignite

Field, Carter County

Montana

By JAMES R. GILL

URANIUM IN COAL IN THE WESTERN UNITED STATES

GE OLOGICALS U R VEY B U L L E T I N $1055-\mathrm{F}$

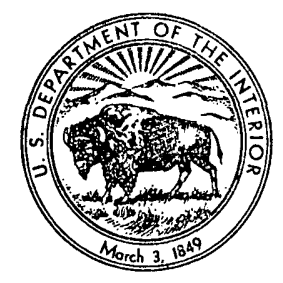





\section{CONTENTS}

\begin{tabular}{|c|c|}
\hline \multicolumn{2}{|l|}{ Ahstract } \\
\hline Abstract & \\
\hline & \\
\hline & \\
\hline & \\
\hline & \\
\hline & \\
\hline aceous) & \\
\hline - n- & \\
\hline (1) & \\
\hline 年 & \\
\hline 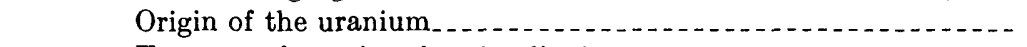 & \\
\hline bearing lignite $\ldots \ldots$ & \\
\hline ed & \\
\hline
\end{tabular}

\section{ILLUSTRATIONS}

Plate 33. Reconnaissance geologic map of the Ekalaka Hills, Carter County, Mont.

34. Correlation of lignite beds, Ekalaka Hills.

35. Concentration and distribution of uranium in lignite beds: Ekalaka Hills.

FIGURE 28. Index map of Carter County, Mont., showing location of the

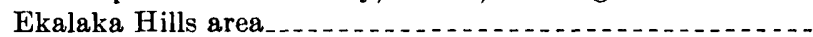

29. Area underlain by uranium-bearing lignite, Ekalaka Hills...-

\section{TABLES}

TABLE 1. Summary of analytical data for surface samples of uraniumbearing Jignite in the Ekalaka Hills area.................

2. Analyses of water samples from springs in the Arikaree formation, Ekalaka Hills area . . . . . . . . . . . . . . . . .

3. Tonnage of uranium-bearing lignite in the southern part of the Ekalaka Hills. 



\title{
URANIUM IN COAL IN THE WESTERN UNITED STATES
}

\section{RECONNAISSANCE FOR URANIUM IN THE EKALAKA LIGNITE FIELD, GARTER COUNTY, MONTANA}

\author{
By JaMES R. GILL
}

\section{ABSTRACT}

Beds of uranium-bearing lignite 1.5 to 8 feet thick occur in the Fort Union formation of the southern part of the Ekalaka Hills, Carter County, Mont. Data from surface outcrops indicate that an area of about 1,400 acres is underlain by 16.5 million tons of uranium-bearing lignite. The uranium content of the lignite beds ranges from 0.001 to 0.034 percent, the average being about 0.005 percent.

Ironstone concretions in the beds of massive coarse-grained sandstone in the upper part of the Fort Union formation contain 0.005 percent uranium in the northern and eastern parts of the area. These beds of standstone are favorable host rocks for uranium occurrences and are lithologically similar to beds of massive coarse-grained sandstone of the Wasatch formation in the Pumpkin Buttes area of the Powder River Basin.

\section{INTRODUCTION}

Uranium in lignite was discovered by the writer in the southern part of the Ekalaka Hills (fig. 28) in September 1953. An area of about 120 square miles was mapped in reconnaissance (pl. 33) and 127 samples were collected for uranium determinations.

\section{LOCATION AND ACCESSIBIUTTY}

The Ekalaka lignite field includes approximately 1,100 square miles in northeastern Carter and southern Fallon Counties in southeastern Montana. Uranium-bearing lignites are known in only about 120 square miles in Carter County in the southern part of the field. The area studied is largely within Custer National Forest. Ekalaka (popuulation 904), the county seat of Carter County, is the only town in the area. The nearest rail shipping point is Baker, about 36 miles to the north. The area is readily accessible by State Route 7, which crosses the area in a generally southeastward direction, and by graded county roads and Forest Service trails. 


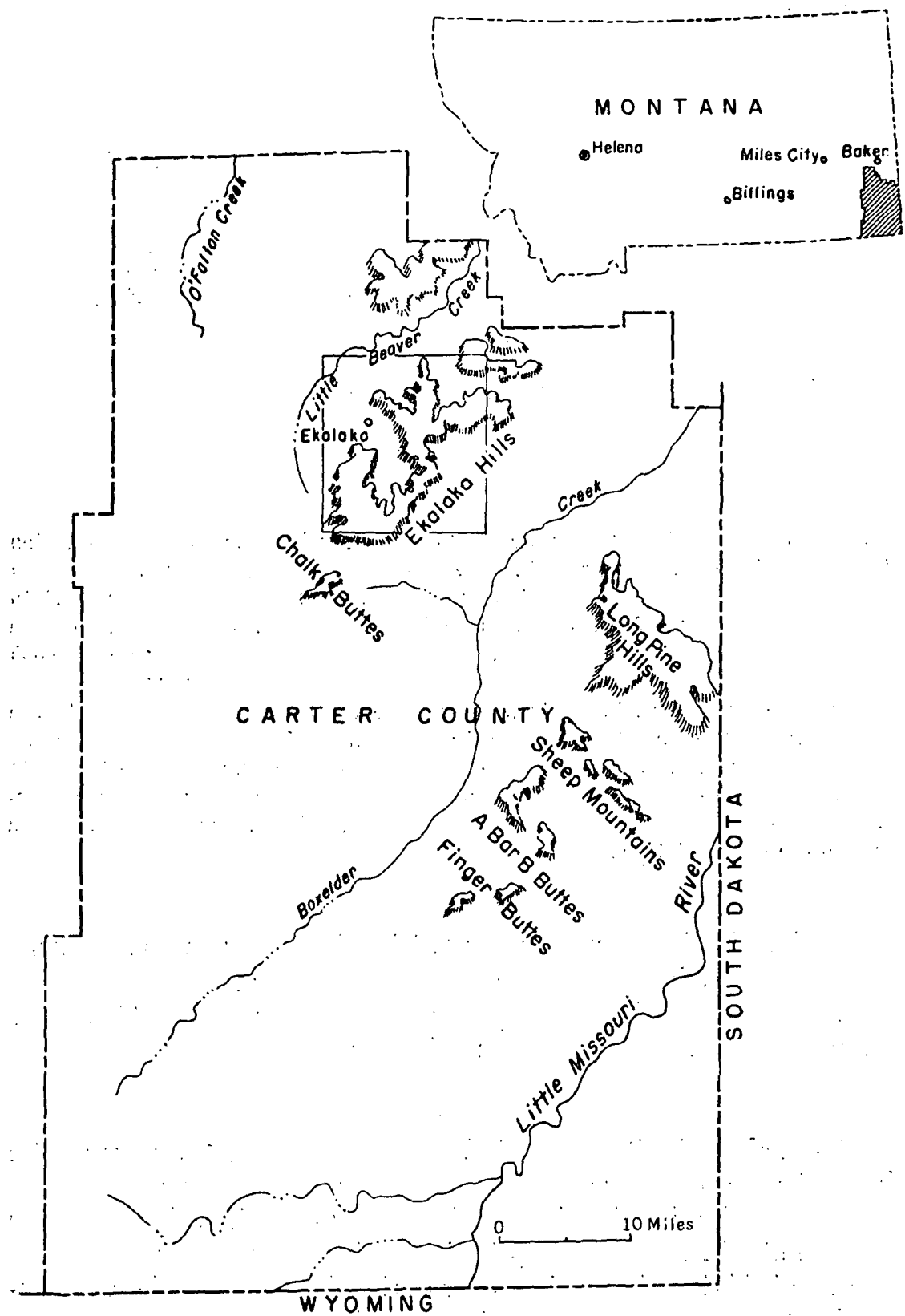

Figure 28.-Index map of Carter County, Mont., showing location of Lkalaka Hills area.

The Ekalaka Hills, rising 400 to 500 feet above the surrounding country, are the most imposing topographic feature in the area. Vegetation other than grass is sparse except on the steep slopes and 
relatively flat tops of these hills, where western yellow pine forms dense growths.

\section{GEOLOGIC WORK}

The geology and lignite resources of the Ekalaka Hills have been described by Bauer (1924) and the ground-water resources by Perry (1935). The investigation in the southern part of the Ekalaka Hills (fig. 28) on which this report is based was done by the writer in September 1953 as a part of a program of investigation of uraniumbearing coal and carbonaceous rocks in the western United States. An area of about 120 miles was mapped in reconnaissance (pl. 33). Some beds of lignite were found to be uranium bearing, and 127 samples from them and other rock material were collected for anlyses for uranium.

\section{GEOLOGY}

The Ekalaka Hills lie along the western margin of a broad shallow syncline between the northwest-trending extension of the Black Hills uplift on the southwest and the Cedar Creek anticline on the northeast. The Cretaceous Hell Creek formation and the Tertiary Fort Union (Paleocene) and Arikaree (Miocene) formations form the bedrock of the area. The lignite-bearing rocks, the Hell Creek and Fort Union formations, are equally slightly deformed; in the mapped area they dip from 1 to 3 degrees northeast. The flat-lying rocks of the Arikaree formation lie on the bevelled edges of these formations.

\section{STRATIGRAPHY}

\section{HELL CREEK FORMATION (UPPER CRETACEOUS)}

The oldest rocks exposed in the Ekalaka Hills are assigned to the Hell Creek formation of Late Cretaceous age. These rocks consist of gray to buff claystone with lenses of rusty-brown fine-grained poorly indurated sandstone and a few thin lenticular beds of lignite. Ellipsoidal concretions of sandstone ranging from one inch to more than five feet in diameter are common. The formation averages 500 feet in thickness (Bauer, 1924, p. 239) and is conformably overlain by the Fort Union formation. The soft, poorly indurated claystone and sandstone of the Hell Creek erode to form badland topography.

\section{FORT UNION FORMATION (PALEOCENE)}

The Fort Union formation of Paleocene age consists of light-yellow and gray fine- to medium-grained massive sandstone, gray shale, claystone, and thick lenticular beds of lignite. The formation ranges from 180 to 500 feet or more in thickness and is unconformably overlain by the Arikaree formation of Miocene age. 
In the southern part of the area of the Fort Union formation is exposed beneath the cliff-forming tuffaceous sandstones of the Arikaree formation that form the upper surface of the Ekalaka Hills. In the northern part of the area (T. 2 N., Rs. 58 and 59 E.) the massive, well-indurated sandstones of the upper part of the Fort Union formation form the upper surface of the Ekalaka Hills.

Ironstone concretions in beds of massive coarse-grained sandstone in the upper part of the Fort Union formation near Ekalaka contain 0.005 percent uranium. The sandstone is favorable as a host rock for possible deposits of uranium and is lithologically similar to the beds of massive, coarse-grained, uranium-bearing sandstone of the Wasatch formation in the Pumpkin Buttes area of the Powder River Basin (Love, 1952).

\section{ARIKAREE FORMATION (MIOCENE)}

Unconformably overlying the rocks of the Fort Union formation is the Arikaree formation of Miocene age. The formation is composed of more than 250 feet of slightly radioactive light-gray, fine-grained, tuffaceous sandstone. Samples of the sandstone contain an average of 0.002 percent uranium. It is thought that the uranium is in the volcanic material of which the formation is largely composed. The sandstone is one of the more resistant rock units in the area and causes the Ekalaka Hills to rise more than 500 feet above the surrounding country.

In the Long Pine Hills (fig. 28) and adjacent areas the Arikaree formation unconformably overlies rocks of the Brule formation of middle and late Oligocene age suggesting that the unconformity at the base of the Arikaree is younger than late Oligocene.

In southeastern Montana and adjacent parts of South Dakota few fossils have been found in this formation (Bauer, 1924, p. 245). The age of the Arikaree is based largely on a fossil beaver collected approximately 350 feet stratigraphically above the base of the formation on Fighting Butte, 9 miles southwest of the Ekalaka Hills, and described by Wood (1945) as of late Miocene age.

During the present investigation vertebrate fossils were collected from a bed of green fissile shale within 20 feet of the base of the formation in the $\mathrm{SW} 1 / 4 \mathrm{NW} 1 / 4 \mathrm{NW} 1 / 4$ sec. $24, \mathrm{~T} .1 \mathrm{~N}$., R. $57 \mathrm{E}$. These fossils were studied by G. E. Lewis who states: 
The specimens from locality DM-1F consist of (1) fragments of foot bones of equids of undetermined genus and species, and (2) fragments of entelodont milk teeth. The geologic age could be anything from late oligocene to middle Miocene.

In view of the regional stratigraphic relationship of the Arikaree formation and of the reported ages of the few fossils collected from it, it seems probable that the unit represents most of Miocene time.

\section{URANIUM-BEARING LIGNITE}

The lignite beds of the Ekalaka Hills are in the lower part of the Fort Union formation. The beds are best exposed in the southern part of the mapped area in secs. 35 and 36, T. 1 N., R. 58 E., and in sections 19 and 30, T. 1 N., R. 59 E. (pl. 33). Bauer (1924, p. 250) mapped three beds of lignite named, from oldest to youngest, the Keefer, Elder, and Wilder beds. The beds mapped are actually zones of lenticular beds of lignite. In the present study, a fourth zone, the Cleveland zone, was mapped between the Elder and Wilder zones, and the Elder was separated into upper and lower parts (pl. 34). The Cleveland zone is named after the Cleveland Ranch (NW1/4 sec. 30, T. 1 N., R. 59 E.) in Carter County, Mont., where these beds attain their greatest thickness. The stratigraphic relations of these zones are shown in the following generalized section.

Geologic unit or interval

Arikaree formation.

Unconformity.

Fort Union formation :

Thickness (feet)

sandstone and shale interval__._.

Wilder lignite zone (1-3 lignite beds)

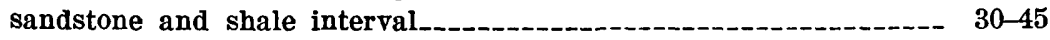

Cleveland lignite zone (1-3 lignite beds)

sandstonee and shale interval_._._.

Elder lignite zone :

upper part (1-4 lignite beds)

lower part (1-6 lignite beds)

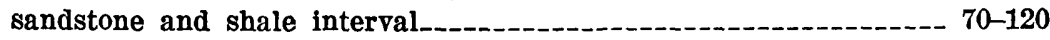

Keefer lignite zone (1-3 lignite beds)

Hell Creek formation.

Individual beds of lignite are lenticular and are difficult to trace for any great distance. The zones, however, are persistent mappable units, even though the beds at many places are represented by carbonaceous shale. Lignite sections were measured at 18 localities, and about 130 samples collected for uranium analyses (table 1, pl. 35). 
TABLE 1.-Summary of analytical data for surface samples of uranium-bearing lignite beds of the Elalaka Hills area, Carter County, Mont.

[Analysts: I. Barlow, H. Bivens, M. Delevaux, S. Furman, M. Joslyn, B. A. McCall and A. Pietsch, U. S. Geological Survey]

[Locality numbers refer to numbers on pl. 33; most samples containing less than 0.003 percent equivalent. uranium were not analyzed chemically for uranium

\begin{tabular}{|c|c|c|c|c|c|c|c|}
\hline \multicolumn{4}{|c|}{ Sample } & \multicolumn{4}{|c|}{ Analyses, in percent } \\
\hline \multirow{2}{*}{$\begin{array}{l}\text { Field } \\
\text { No. }\end{array}$} & \multirow{2}{*}{$\begin{array}{c}\text { Labo- } \\
\text { ratory } \\
\text { No. }\end{array}$} & \multirow{2}{*}{$\begin{array}{c}\text { Thick- } \\
\text { ness } \\
\text { (feet) }\end{array}$} & \multirow[b]{2}{*}{ Description } & \multirow{2}{*}{$\begin{array}{l}\text { Equiva- } \\
\text { lent } \\
\text { uranium }\end{array}$} & \multicolumn{2}{|c|}{ Uranium- } & \multirow[b]{2}{*}{ Ash } \\
\hline & & & & & $\underset{\text { sample }}{\text { in }}$ & in & \\
\hline
\end{tabular}

T. 1 S., R. 58 E.

Locality $1, \mathrm{SW}^{1} / 4 \mathrm{NE} 1 / 4 \mathrm{sec} 2$

\begin{tabular}{|c|c|c|c|c|c|c|c|}
\hline $\begin{array}{l}G M-138 . \\
G M-139 . \\
G M-140 \ldots \\
G M-141 . .\end{array}$ & $\begin{array}{l}201092 \\
201093 \\
201094 \\
201095\end{array}$ & $\begin{array}{l}1.1 \\
2.9 \\
1.0 \\
1.0\end{array}$ & $\begin{array}{l}\text { Carbonaceous sbale } \\
2-\mathrm{ft} \text { bed of lignite, uppermost } 1 \mathrm{ft} \\
2 \text {-ft bed lignite, basal } 1 \mathrm{ft}\end{array}$ & $\begin{array}{r}0.003 \\
.001 \\
.001 \\
.001\end{array}$ & 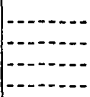 & 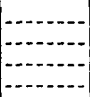 & 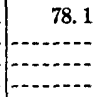 \\
\hline
\end{tabular}

T. 1 N., R. 58 E.

Locality $6, \mathrm{SW} 1 / 4 \mathrm{SE} 1 / 4 \mathrm{sec} 25$

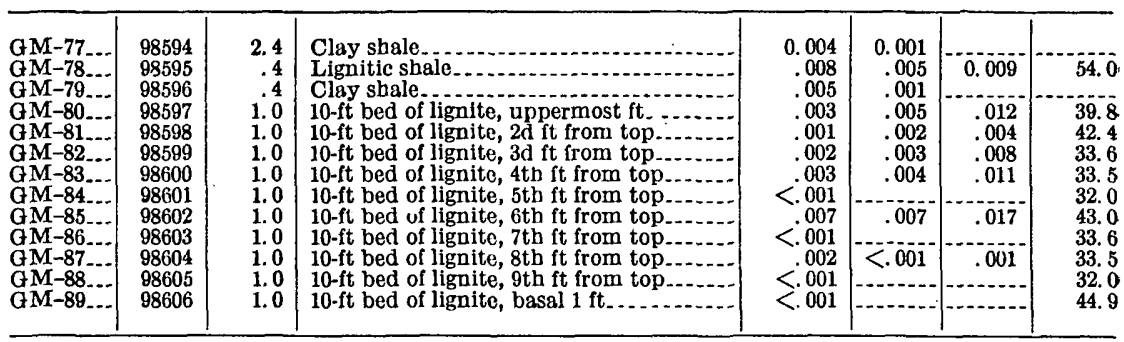

Locality 7, SE $1 / 4 \mathrm{SE}^{1} / 4$ sec 25

\begin{tabular}{|c|c|c|c|c|c|c|c|}
\hline 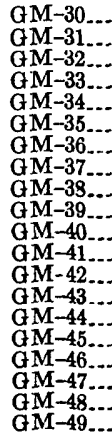 & $\begin{array}{l}95526 \\
95527 \\
95528 \\
95529 \\
95530 \\
95531 \\
95532 \\
95533 \\
95534 \\
95535 \\
95536 \\
95537 \\
95538 \\
95539 \\
95540 \\
95541 \\
95542 \\
95543 \\
95544 \\
95545\end{array}$ & $\begin{array}{r}0.5 \\
.5 \\
.5 \\
1.0 \\
.7 \\
.3 \\
1.0 \\
1.0 \\
.8 \\
.3 \\
1.0 \\
.5 \\
.5 \\
1.0 \\
1.0 \\
1.0 \\
1.0 \\
1.0 \\
1.2 \\
.8\end{array}$ & 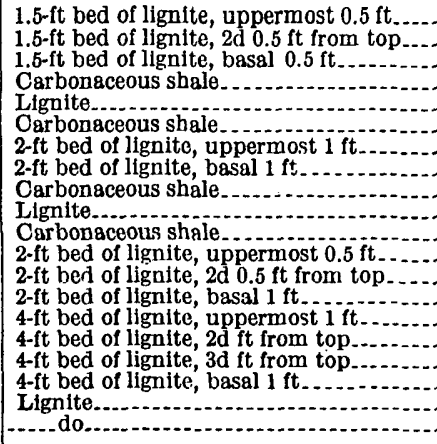 & $\begin{array}{l}0.006 \\
.021 \\
.007 \\
.004 \\
.004 \\
.003 \\
.002 \\
.003 \\
.010 \\
.011 \\
.005 \\
.011 \\
.002 \\
.001 \\
.002 \\
.002 \\
.005 \\
.005 \\
.003 \\
.002\end{array}$ & $\begin{array}{l}0.006 \\
.034 \\
.007 \\
.004 \\
.004 \\
.002 \\
.002 \\
.003 \\
.007 \\
.011 \\
.003 \\
.015 \\
.002 \\
.001 \\
.002 \\
.003 \\
.008 \\
.008 \\
.005 \\
.003\end{array}$ & $\begin{array}{r}0.017 \\
.014 \\
.015 \\
.004 \\
.012 \\
.002 \\
.005 \\
.008 \\
.008 \\
.027 \\
.003 \\
.045 \\
.005 \\
.004 \\
.006 \\
.007 \\
.024 \\
.018 \\
.018 \\
.012\end{array}$ & $\begin{array}{l}27.7 \\
24.0 \\
51.9 \\
71.8 \\
34.3 \\
86.9 \\
35.5 \\
38.2 \\
91.8 \\
39.3 \\
86.3 \\
33.7 \\
34.5 \\
30.7 \\
35.1 \\
40.5 \\
33.7 \\
44.6 \\
27.3 \\
25.4\end{array}$ \\
\hline
\end{tabular}


TABLE 1.-Summary of analytical data for surface samples of uranium-bearing lignite beds of the Ekalaka Hills area, Carter County, Mont.-Continued

\begin{tabular}{|c|c|c|c|c|c|c|c|}
\hline \multicolumn{4}{|c|}{ Sample } & \multicolumn{4}{|c|}{ Analyses, in percent } \\
\hline \multirow{2}{*}{$\begin{array}{l}\text { Field } \\
\text { No. }\end{array}$} & \multirow{2}{*}{$\begin{array}{l}\text { Labo- } \\
\text { ratory } \\
\text { No. }\end{array}$} & \multirow{2}{*}{$\begin{array}{l}\text { Thick- } \\
\text { ness } \\
\text { (feet) }\end{array}$} & \multirow[b]{2}{*}{ Description } & \multirow{2}{*}{$\begin{array}{l}\text { Equiva- } \\
\text { lent } \\
\text { uranium }\end{array}$} & \multicolumn{2}{|c|}{ Uranium- } & \multirow[b]{2}{*}{ Ash } \\
\hline & & & & & in & $\begin{array}{l}\text { in } \\
\text { ash }\end{array}$ & \\
\hline
\end{tabular}

T. 1 N., R. 58 E.-Continued

Locality $4, \mathrm{SE}^{1 / 4} \mathrm{SE}^{1} / 4, \sec 26$

\begin{tabular}{|c|c|c|c|c|c|c|c|}
\hline 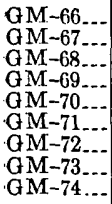 & $\begin{array}{l}98583 \\
98584 \\
98585 \\
98586 \\
98587 \\
98588 \\
98589 \\
98590 \\
98591\end{array}$ & $\begin{array}{r}1.0 \\
1.0 \\
1.0 \\
1.0 \\
1.0 \\
1.0 \\
.9 \\
.3 \\
1.5\end{array}$ & $\begin{array}{l}\text { 6-ft bed of lignite, uppermost 1-ft } \\
\text { 6-ft bed of lignite, } 2 \mathrm{~d} \text { ft from top. } \\
6 \text {-ft bed of lignite, 3d ft from top } \\
6 \text {-ft bed of lignite, 4ta ft from top. } \\
\text { 6-ft bed of lignite, 5th ft from top. } \\
\text { 6-ft bed of lignite, basal } 1 \text { ft } \\
\text { Clay shale } \\
\text { Lignitic shale. } \\
\text { Clay shale. }\end{array}$ & $\begin{array}{r}0.007 \\
.003 \\
.004 \\
.002 \\
.005 \\
.003 \\
.005 \\
.010 \\
.005\end{array}$ & $\begin{array}{l}0.010 \\
.004 \\
.004 \\
.002 \\
.005 \\
.003 \\
.002 \\
.006 \\
.002\end{array}$ & $\begin{array}{r}0.021 \\
.009 \\
.008 \\
.004 \\
.013 \\
.007 \\
.010\end{array}$ & $\begin{array}{r}46.4 \\
45.2 \\
47.1 \\
49.4 \\
38.8 \\
38.0 \\
60.0 \\
\\
-.-\end{array}$ \\
\hline
\end{tabular}

Locality $3, \mathrm{NW}^{1 / 4} \mathrm{NE} 1 / 4$, sec 35

\begin{tabular}{l|r|r|r|r|r|r}
\hline GM-75_.- & 98592 & 2.0 & Lignitic shale $\ldots \ldots \ldots \ldots$ & & \\
GM-76_.- & 98593 & 2.7 & .003 & $\ldots$ \\
\hline
\end{tabular}

Locality $2, \mathrm{NE}^{1} / 4 \mathrm{NW}^{1} / 4, \sec 35$

\begin{tabular}{|c|c|c|c|c|c|c|c|}
\hline $\begin{array}{l}\text { GM-147.- } \\
\text { GM-148.- } \\
\text { GM-149.- }\end{array}$ & $\begin{array}{l}201101 \\
201102 \\
201103\end{array}$ & $\begin{array}{r}1.1 \\
1.0 \\
.4\end{array}$ & $\begin{array}{l}\text { Lignite. } \\
\text { Carbonaceous shale } \\
\text { Lignite.... }\end{array}$ & $\begin{array}{r}0.001 \\
.003 \\
.002\end{array}$ & 0.002 & 0.003 & 65.9 \\
\hline
\end{tabular}

Locality $5, \mathrm{NW} 1 / 4 \mathrm{NE} 1 / 4, \sec 36$

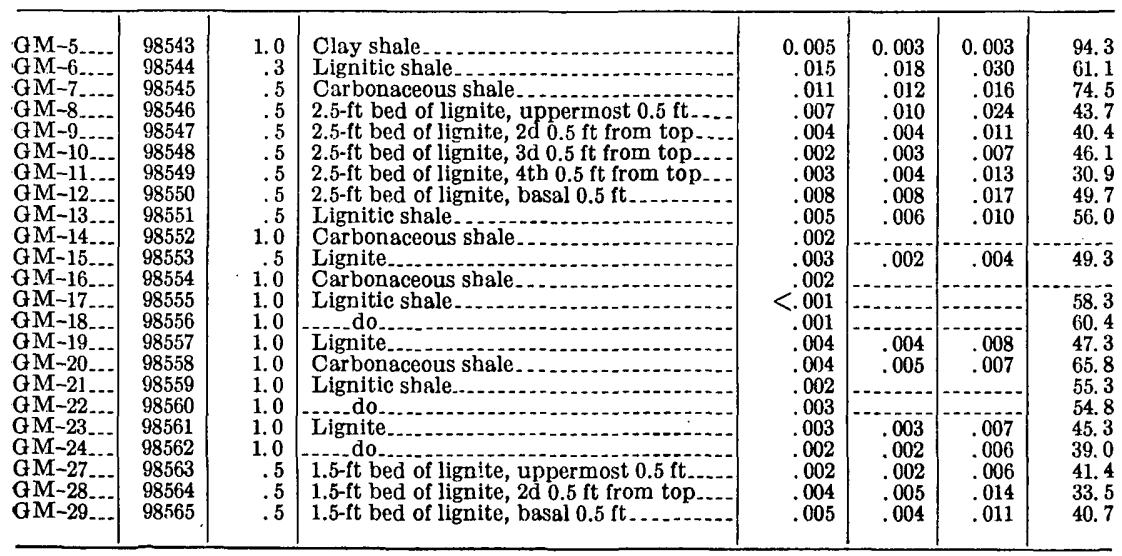


TABLE 1.-Summary of analytical data for surface samples of uranium-bearing. lignite beds of the Ekalaka Hills area, Carter County, Mont.-Continued

\begin{tabular}{|c|c|c|c|c|c|c|c|}
\hline \multicolumn{4}{|c|}{ Sample } & \multicolumn{4}{|c|}{ Analyses, in percent } \\
\hline \multirow{2}{*}{$\begin{array}{l}\text { Field } \\
\text { No. }\end{array}$} & \multirow{2}{*}{$\begin{array}{l}\text { Labo. } \\
\text { ratory } \\
\text { No. }\end{array}$} & \multirow{2}{*}{$\begin{array}{c}\text { Thick- } \\
\text { ness } \\
\text { (feet) }\end{array}$} & \multirow[b]{2}{*}{ Description } & \multirow{2}{*}{$\begin{array}{l}\text { Equiva- } \\
\text { lent } \\
\text { uranium }\end{array}$} & \multicolumn{2}{|c|}{ Uranium- } & \multirow[b]{2}{*}{ Ash } \\
\hline & & & & & $\underset{\text { sample }}{\text { in }}$ & $\begin{array}{l}\text { in } \\
\text { ash }\end{array}$ & \\
\hline
\end{tabular}

T. 1 N., R. 59 E.

Locality $15, \mathrm{NW}^{1} / \mathrm{SW} \mathrm{SW}^{1} / 4$ sec 3

\begin{tabular}{|c|c|c|c|c|c|c|c|}
\hline $\begin{array}{l}\text { GM-134.- } \\
\text { GM-135-- } \\
\text { GM-136.- } \\
\text { GM-137.- }\end{array}$ & $\begin{array}{l}201087 \\
201088 \\
201089 \\
201090\end{array}$ & $\begin{array}{l}3.4 \\
1.0 \\
1.5 \\
1.5\end{array}$ & $\begin{array}{l}\text { Lignite } \\
\text { Carbonaceous shale. } \\
3 \mathrm{ft} \text { bed of shale, uppermost } 1.5 \mathrm{ft} . \\
3 \mathrm{ft} \text { bed of shale, basal } 1.5 \mathrm{ft}\end{array}$ & $\begin{array}{l}0.004 \\
.002 \\
.002 \\
.004\end{array}$ & 0.001 & $\begin{array}{r}0.005 \\
\hdashline .001\end{array}$ & $\begin{array}{r}34.7 \\
\hdashline 79.4\end{array}$ \\
\hline
\end{tabular}

Locality 13, SE1/4NW1/4 sec 8

\begin{tabular}{|c|c|c|c|c|c|c|c|}
\hline $\begin{array}{l}G M-142 . \\
G M-143 .- \\
G M-144 .- \\
G M-145 .- \\
G M-146 .-\end{array}$ & $\begin{array}{l}201096 \\
201097 \\
201098 \\
201099 \\
201100\end{array}$ & $\begin{array}{r}1.8 \\
.9 \\
1.8 \\
1.3 \\
.4\end{array}$ & $\begin{array}{l}\text { Lignite... } \\
\text { Carbonaceous shale } \\
\text { Codo. do }\end{array}$ & $\begin{array}{r}0.002 \\
.001 \\
.001 \\
.002 \\
.002\end{array}$ & 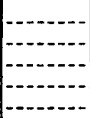 & 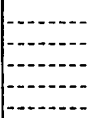 & 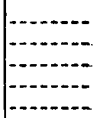 \\
\hline
\end{tabular}

Locality $14, \mathrm{SW}^{1} / 4 \mathrm{NE}^{1} / 4 \sec 8$

\begin{tabular}{|c|c|c|c|c|c|c|c|}
\hline $\begin{array}{l}\text { GM-108.- } \\
\text { GM-109-- } \\
\text { GM-110.- } \\
\text { GM-111.- } \\
\text { GM-112. }\end{array}$ & $\begin{array}{l}201061 \\
201062 \\
201063 \\
201064 \\
201065\end{array}$ & $\begin{array}{r}2.5 \\
.6 \\
.7 \\
.6 \\
.4\end{array}$ & $\begin{array}{l}\text { Llgnite.-10. } \\
\text { Analcite- } \\
\text { Carbonaceous shale }\end{array}$ & $\begin{array}{l}0.002 \\
.001 \\
.002 \\
.006 \\
.004\end{array}$ & $\begin{array}{r}0.002 \\
.002\end{array}$ & $\begin{array}{r}0.003 \\
.003\end{array}$ & $\begin{array}{r}86.0 \\
78.5\end{array}$ \\
\hline
\end{tabular}

Locality $9, \mathrm{SE}^{1 / 4} \mathrm{SW} 1 / 4$ sec 19

\begin{tabular}{|c|c|c|c|c|c|c|c|}
\hline $\begin{array}{l}\text { GM-96.-- } \\
\text { GM-97.-- } \\
\text { GM-98..- } \\
\text { GM-99.-- }\end{array}$ & $\begin{array}{l}98607 \\
98608 \\
98609 \\
98610\end{array}$ & $\begin{array}{r}1.1 \\
1.1 \\
1.0 \\
.7\end{array}$ & $\begin{array}{l}2.2 \mathrm{ft} \text { bed of lignite, uppermost } 1.1 \mathrm{ft} \\
2.2 \mathrm{ft} \text { bed of lignite, basal } 1.1 \mathrm{ft} \\
\text { Clay shale. } \\
\text { Lignite. }\end{array}$ & $\begin{array}{r}0.003 \\
.006 \\
.003 \\
.002\end{array}$ & $\begin{array}{r}0.003 \\
.007 \\
.002\end{array}$ & $\begin{array}{r}0.009 \\
.020 \\
.005\end{array}$ & $\begin{array}{r}38.2 \\
36.6 \\
48.0\end{array}$ \\
\hline
\end{tabular}

Locality 11, SW1/4NW1/4 sec 24

\begin{tabular}{|c|c|c|c|c|c|c|c|}
\hline $\begin{array}{l}G M-50 \\
G M-51 \\
G M-52\end{array}$ & $\begin{array}{l}98566 \\
98567 \\
98568\end{array}$ & $\begin{array}{l}1.0 \\
1.0 \\
3.8\end{array}$ & $\begin{array}{l}5.8 \mathrm{ft} \text { bed of lignite, uppermost } 1 \mathrm{ft} \\
5.8 \mathrm{ft} \text { bed of lignite, } 2 \mathrm{~d} \mathrm{ft} \text { from top.... } \\
5.8 \mathrm{ft} \text { bed of lignite, basal } 3.8 \text { feet. }\end{array}$ & $\begin{array}{r}0.004 \\
.004 \\
.001\end{array}$ & $\begin{array}{r}0.004 \\
.004 \\
.002\end{array}$ & $\begin{array}{r}0.011 \\
.008 \\
.007\end{array}$ & $\begin{array}{l}39.2 \\
47.0 \\
30.7\end{array}$ \\
\hline
\end{tabular}

Locality $12, \mathrm{NW} / / \mathrm{NE} / 4 \sec 24$

\begin{tabular}{|c|c|c|c|c|c|c|c|}
\hline $\begin{array}{l}\text { GM-100.- } \\
\text { GM-101.- } \\
\text { GM-102.- } \\
\text { GM-103.- } \\
\text { GM-104.- } \\
\text { GM-105.- }\end{array}$ & $\begin{array}{l}98611 \\
98612 \\
98613 \\
98614 \\
98615 \\
98616\end{array}$ & $\begin{array}{l}1.0 \\
1.0 \\
1.0 \\
1.0 \\
1.0 \\
1.0\end{array}$ & $\begin{array}{l}6 \mathrm{ft} \text { bed of lignite, uppermost } 1 \mathrm{ft} \\
6 \mathrm{ft} \text { bed of lignite, } 2 \mathrm{~d} \mathrm{ft} \text { from top. } \\
6 \mathrm{ft} \text { bed of lignite, 3d ft from top. } \\
6 \mathrm{ft} \text { bed of lignite, 4th ft from top. } \\
6-\mathrm{ft} \text { bed of lignite, 5th ft from top. } \\
6-\mathrm{ft} \text { bed of lignite, basal } 1 \mathrm{ft} .\end{array}$ & $\begin{array}{r}0.005 \\
.002 \\
.001 \\
.001 \\
.001\end{array}$ & $\begin{array}{r}0.005 \\
.002 \\
.001 \\
.002 \\
.001\end{array}$ & $\begin{array}{r}0.020 \\
.006 \\
.002 \\
.014 \\
.005\end{array}$ & $\begin{array}{l}26.6 \\
36.0 \\
41.9 \\
14.1 \\
17.1 \\
16.4\end{array}$ \\
\hline
\end{tabular}


TABLE 1.-Summary of analytical data for surface samples of uranium-bearing lignite beds of the Ekalaka Hills area, Carter County, Mont.-Continued

\begin{tabular}{|c|c|c|c|c|c|c|c|}
\hline \multicolumn{4}{|c|}{ Sample } & \multicolumn{4}{|c|}{ Analyses, in percent } \\
\hline \multirow{2}{*}{$\begin{array}{l}\text { Field } \\
\text { No. }\end{array}$} & \multirow{2}{*}{$\begin{array}{c}\text { Labo- } \\
\text { ratory } \\
\text { No. }\end{array}$} & \multirow{2}{*}{$\begin{array}{c}\text { Thick- } \\
\text { ness } \\
\text { (feet) }\end{array}$} & \multirow{2}{*}{ Description } & \multirow{2}{*}{$\begin{array}{l}\text { Equiva- } \\
\text { lent } \\
\text { uranium }\end{array}$} & \multicolumn{2}{|c|}{ Uranlum- } & \\
\hline & & & & & $\underset{\text { sample }}{\text { in }}$ & $\underset{\text { ish }}{\text { in }}$ & \\
\hline
\end{tabular}

T. 1 N., R. 59 E.-Continued

Locality $17, \mathrm{SW} 1 / 4 \mathrm{SE} 1 / 4 \sec 29$

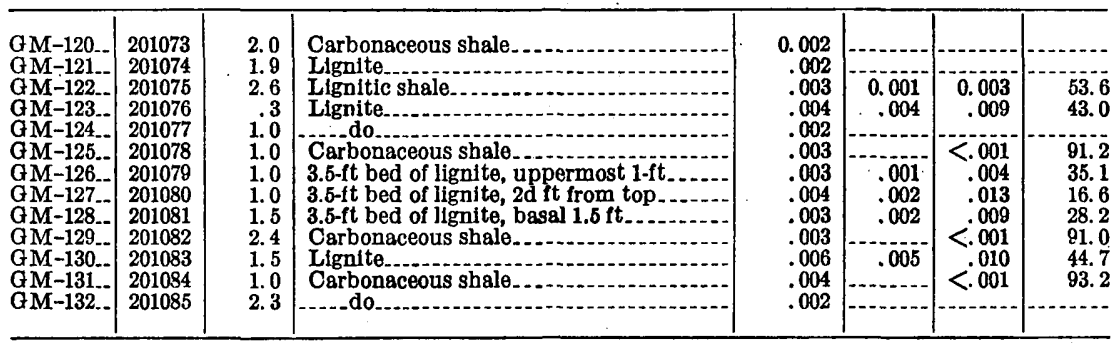

Locality 8, center of west line, sec 30

\begin{tabular}{|c|c|c|c|c|c|c|c|}
\hline $\begin{array}{l}G M-53 \ldots \\
G M-54 \ldots \\
G M-55 \ldots \\
G M-56 \ldots \\
G M-57 \ldots \\
G M-58 \ldots \\
G M-59 \ldots \\
G M-62 \ldots \\
G M-60 \ldots \\
G M-61 \ldots \\
G M-63 \ldots \\
G M-64 \ldots \\
G M-64 A . \\
G M-65 \ldots\end{array}$ & $\begin{array}{l}98569 \\
98570 \\
98571 \\
98572 \\
98573 \\
98574 \\
98575 \\
98578 \\
98576 \\
98577 \\
98579 \\
98580 \\
98581 \\
98582\end{array}$ & $\begin{array}{r}1.0 \\
1.0 \\
1.0 \\
1.0 \\
.4 \\
.2 \\
.8 \\
1.0 \\
1.0 \\
1.0 \\
.5 \\
.7 \\
.3 \\
.3\end{array}$ & $\begin{array}{l}\text { Lignitic shale } \\
\text { 2-ft bed of lignite, uppermost 1-ft. } \\
\text { 2-ft bed of lignite, basal 1-ft } \\
\text { Lignite... } \\
\text { Carbonaceous shale. } \\
\text { Carbonaceous shale } \\
\text { Shale } \\
2.5 \text {-ft bed of lignite, basal ft } \\
2.5 \text {-ft bed of lignite, 2d ft above base } \\
\text { 2.5-ft bed of lignite, uppermost } 0.5 \mathrm{ft} \\
\text { Carbonaceous shale. }\end{array}$ & $\begin{array}{r}0.005 \\
.003 \\
.002 \\
.007 \\
.007 \\
.011 \\
.008 \\
.004 \\
.007 \\
.002 \\
.005 \\
.003 \\
.008 \\
.003\end{array}$ & $\begin{array}{r}0.007 \\
.004 \\
.004 \\
.009 \\
.010 \\
.009 \\
.008 \\
.001 \\
.005 \\
.003 \\
.004 \\
.006 \\
<.001\end{array}$ & $\begin{array}{r}0.012 \\
.010 \\
.011 \\
.019 \\
.012 \\
.014 \\
.009 \\
.014 \\
.007 \\
.008 \\
.007 \\
.001\end{array}$ & $\begin{array}{l}56.2 \\
41.4 \\
39.1 \\
48.9 \\
81.0 \\
63.5 \\
86.6 \\
--.5 \\
37.8 \\
42.6 \\
52.2 \\
72.1 \\
90.1 \\
41.6\end{array}$ \\
\hline
\end{tabular}

Locality $16, \mathrm{SE}^{1} / 4 \mathrm{NW} / \mathrm{4}$ sec 33

\begin{tabular}{|c|c|c|c|c|c|c|c|}
\hline GM-133. & 201086 & 1.5 & Ironstone concretion. & 0.008 & 0.005 & 0.005 & 81.0 \\
\hline
\end{tabular}

T. 2 N., R. $58 \mathrm{E}$.

Locality $18, \mathrm{NE}^{1 / 4} \mathrm{NW}^{1 / 4} / 4 \mathrm{sec} 30$

\begin{tabular}{|c|c|c|c|c|c|c|c|}
\hline & 201068 & 0.7 & Lignite......... & 0.001 & & & \\
\hline GM-116.- & $\begin{array}{l}201069 \\
201070\end{array}$ & 1.5 & 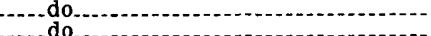 & .002 & 0 & 0 & \\
\hline GM-118.- & 201071 & .9 & Carbonaceous sh & .004 & 0.001 & & $\begin{array}{l}50.0 \\
92.1\end{array}$ \\
\hline GM-120.- & 201072 & 1.2 & Lignite ash.............. & .002 & & & \\
\hline
\end{tabular}

Locality $19, \mathrm{NW}^{1} / 4 \mathrm{NW}^{1} / 4 \sec 13$

\begin{tabular}{|c|c|c|c|c|c|c|c|}
\hline $\begin{array}{l}\text { GM-113.- } \\
\text { GM-114.. }\end{array}$ & $\begin{array}{l}201066 \\
201067\end{array}$ & $\begin{array}{l}2.1 \\
1.0\end{array}$ & $\begin{array}{l}\text { Carbonaceous shale } \\
\text { Lignite.... }\end{array}$ & $\begin{array}{r}0.003 \\
.001\end{array}$ & 0.001 & 0.001 & 76.1 \\
\hline
\end{tabular}


- The uranium content of the lignite beds ranges from 0.001 to 0.034 percent, the average being 0.005 percent. The greatest concentration of uranium is in the beds of the Wilder, Cleveland, and upper part of the Elder lignite zones in the southern part of the area at localities 4-12 (pl. 35), where they are unconformably overlain by the mildly radioactive tuffaceous sandstone of the Arikaree formation. Elsewhere in the area to the north and east, the same lignite beds are separated from the overlying Arikaree formation by younger rocks of the Fort Union formation and the lignite is less radioactive.

In the southern part of the area at localities 11 and 12, the Wilder lignite zone contains an average of about 0.003 percent uranium throughout its entire thickness of 5.9 feet and the Cleveland lignite zone contains several thin beds ranging from 1.5 to 3.5 feet in thickness that contain an average of 0.006 percent uranium. The upper part of the Elder lignite zone is highly lenticular, ranging from less than one foot to more than 20 feet in thickness. A maximum thickness of 8 feet contains 0.005 percent uranium.

Fresh, unweathered samples suitable for fuel analysis could not be collected from outcrops and there are no mines in the area. Determinations made on weathered samples containing the visible impurities, analcite, barite and gypsum, show 14 to 50 percent ash. Because some of these impurities probably were introduced during the weathering of the lignite, it is not unreasonable to assume that unweathered lignite will have a much lower ash content and will have a heating value comparable to most lignite.

\section{ORIGIN OF THE URANIUM}

Investigations of uranium-bearing lignite deposits in North and South Dakota by Denson, Bachman, and Zeller (see chapter B, this bulletin) suggest that the uranium in the lignite was brought by ground water from the uranium-bearing tuff in the overlying White River group of Oligocene age and Arikaree formation of Miocene age. Subsequently, secondary minerals of uranium were found in Oligocene rocks in the Slim Buttes area (Gill and Moore, 1955) and in the IBigBadlands of South Dakota (Moore and Levish, 1955).

Some of the conditions that seem to control the concentration of uranium in the lignite are: stratigraphic proximity of the lignite to the base of the potential source rock, permeability of rocks overlying the lignite, and the adsorptive properties of the lignite. In general, the stratigraphically highest lignite bed beneatb the source rock contains the most uranium, and the greatest concentration of uranium is in the upper part of beds three feet or more thick. Beds less than 3 feet thick may contain uranium equally distributed through their entire thickness. 
The distribution of uranium in the lignite beds is shown on plate 35 . The effect of permeability of rocks overlying the lignite is indicated at localities 11 and 12 where the Wilder lignite zone is directly overlain by impervious shale. The uranium content is low despite the fact that the lignite closely underlies the source rocks of the Arikaree formation. At localities 4, 5, 7 and 8 (pl. 34) the upper part of the Elder lignite zone is overlain by a thick sandstone and though the lignites are 90 to 150 feet stratigraphically below the base of the Arikaree formation the upper parts of the lignite bed are more than twice as uraniferous as the Wilder zone at localities 11 and 12 (pl. 35).

Minor variations in the distribution of urarium within the lignite bed can be expected where the lignite is directly overlain by an impervious shale and underlain by a permeable sandstone, as for example, the Cleveland lignite zone at locality 8 (pl. 35). There, an increase at the base rather than a downward decrease from the top suggests that the uranium may have been introduced under hydrostatic pressure into the base of the lignite from the underlying sandstone.

Where the lignite beds are separated from the Arikaree formation by impervious overlying rocks of the Fort Union formation, as in the northern and eastern parts of the area, the beds are not radioactive.

Analyses of spring waters from the Arikaree formation in the Ekalaka Hills indicate that uranium is being leached from this formation and is being transported by ground waters. The uranium content in parts per billion of six representative ground-water samples from springs in the area are listed below. Some of the springs shown on the map as being in the uppermost part of the Fort Union actually are in small unmapped alluvial deposits, but the springs derive their water from the Arikaree formation.

TABLE 2.-Analyses of water samples from springs in the Arikaree formation, Ekalaka Hills, Carter County, Mont.

\begin{tabular}{|c|c|c|c|c|c|c|}
\hline \multirow{2}{*}{$\begin{array}{c}\text { Field } \\
\text { No. }\end{array}$} & \multirow{2}{*}{$\begin{array}{l}\text { Labora- } \\
\text { tory } \\
\text { No. }\end{array}$} & \multirow{2}{*}{ Name of spring } & \multicolumn{3}{|c|}{ Location } & \multirow{2}{*}{$\underset{(p p b)}{\text { Uranium }}$} \\
\hline & & & (Tp.) & (R.) & (Sec.) & \\
\hline $\begin{array}{r}G M-138 \\
-152 \\
-153 \\
-154 \\
-155 \\
-156\end{array}$ & $\begin{array}{l}201091 \\
201106 \\
201107 \\
201108 \\
201109 \\
201110\end{array}$ & $\begin{array}{l}\text { Kinsey } \\
\text { Dugan Draw } \\
\text { Sugar Bowl } \\
\text { Stagville_. } \\
\text { Ben Russell } \\
\text { Martin }\end{array}$ & $\begin{array}{l}1 \mathrm{~N} \\
1 \mathrm{~N} \\
1 \mathrm{~N} \\
1 \mathrm{~N} . \\
1 \mathrm{~N} .\end{array}$ & $\begin{array}{l}59 \mathrm{E} . \\
58 \mathrm{E} . \\
58 \mathrm{E} . \\
58 \mathrm{E} . \\
58 \mathrm{E} . \\
58 \mathrm{E} .\end{array}$ & $\begin{array}{r}6 \\
19 \\
33 \\
21 \\
24 \\
13\end{array}$ & $\begin{array}{l}6 \\
4 \\
7 \\
3 \\
3 \\
8\end{array}$ \\
\hline
\end{tabular}

\section{TONNAGE OF URANIUM-BEARING LIGNTTE}

Approximately 16.5 million tons of uranium-bearing lignite having an average uranium content of about 0.0045 percent underlie the southern part of the Ekalaka Hills (fig. 29) in beds of the Wilder, 


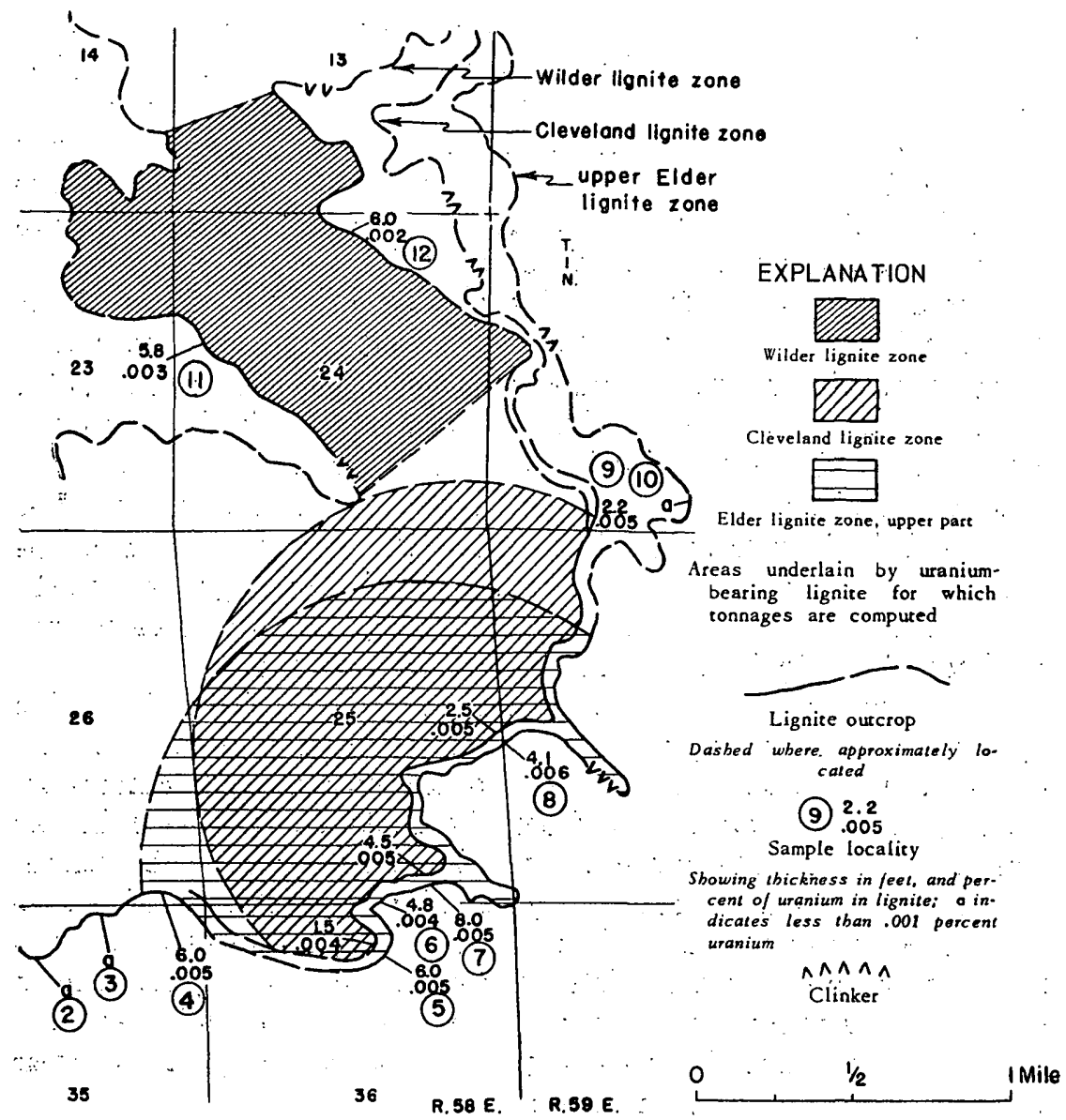

FIGURb 29.-Map showing area underlain by uranium-bearing lignite, Ekalaka Hills, Carter County, Mont.

Cleveland and upper part of the Elder lignite zones. The uraniumbearing lignite beds have an average ash content of 37 percent; these ash determinations were made of weathered lignite samples and may not reflect correctly the ash content of unweathered lignite.

A summary of tonnage estimates of uranium-bearing lignite for the Wilder, Cleveland, and upper part of the Elder liznite zones in the southern part of the Ekalaka Hills is given in the following table: 
EKALAKA LIGNITE FIELD, CARTER COUNTY, MONTANA 179

TABLE 3.-Tonnage of uranium-bearing lignite in the southern part of the Ekalaka Hills, Carter County, Mont.

\begin{tabular}{|c|c|c|c|c|c|}
\hline Lignite zone & $\begin{array}{c}\text { Average } \\
\text { thickness } \\
\text { (feet) }\end{array}$ & $\begin{array}{c}\text { Average } \\
\text { ash content } \\
\text { (percent) }\end{array}$ & $\begin{array}{l}\text { Uranium } \\
\text { in lignite } \\
\text { (percent) }\end{array}$ & $\begin{array}{c}\text { Area } \\
\text { (acres) }\end{array}$ & $\begin{array}{l}\text { Lignite } 1 \\
\text { (short } \\
\text { tons) }\end{array}$ \\
\hline $\begin{array}{l}\text { Wuller } \\
\text { Cleveland } \\
\text { Elder, upper part... }\end{array}$ & $\begin{array}{l}5.9 \\
2.7 \\
5.9\end{array}$ & $\begin{array}{l}30 \\
43 \\
40\end{array}$ & $\begin{array}{l}0.003 \\
.006 \\
.005\end{array}$ & $\begin{array}{l}560 \\
760 \\
700\end{array}$ & $\begin{array}{l}5,782,000 \\
3,591,000 \\
7,105,000\end{array}$ \\
\hline Total.. & & & 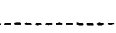 & 2,020 & $16,478,000$ \\
\hline
\end{tabular}

1 Based on 1,750 tons per acre-foot, net result rounded to nearest 1,000 tons.

\section{LITERATURE CITED}

Bauer, C. M., 1924, The Ekalaka lignite field, southeastern Montana: U. S. Geol. Survey Bull. 751.

Gill, J. R., and Moore, G. W., 1955, Carnotite-bearing sandstone in Cedar Canyon, Slim Buttes, Harding County, S. Dak.: U. S. Geol. Survey Bull. 1009-I.

Love, J. D., 1952, Preliminary report on uranium deposits in the Pumpkin Buttes area, Powder River Basin, Wyo.: U. S. Geol. Survey Circ. 176.

Moore, G. W., and Levish, Murray, 1955, Uranium-bearing sandstone in the White River Badlands, Pennington County, S. Dak.: U. S. Geol. Survey Circ. 359.

Perry, E. S., 1935, Geology and ground-water resources of southeastern Montana: Montana Bur. Mines and Geology Mem. 14.

Wood, H. E. 2d, 1945, Late Miocene beaver from southeastern Montana: Am. Mus. Novitates 1299, 


\section{Uranium-Bearing Coal}

\section{in the Red Desert Area}

Sweetwater County

\section{Wyoming}

By HAROLD MASURSKY and GEORGE N. PIPIRINGOS

URANIUM IN COAL IN THE WESTERN UNITED STATES

GEOLOGICAL SURVEY BULLETIN $1055-\mathrm{G}$ 



\section{CONTENTS}

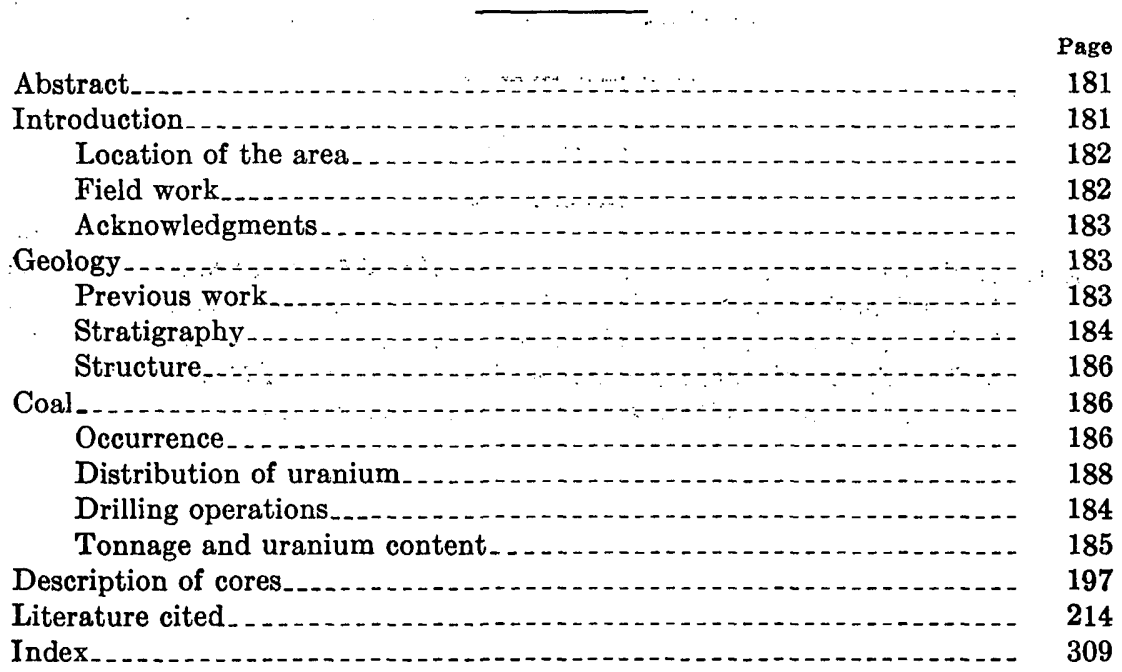

\section{ILLUSTRATIONS}

[Plates are in box]

Plate 36. Geologic map of the Red Desert area, and section showing lithofacies and position of coal beds.

37. Stratigraphic chart showing uranium content and heating value of coal from Red Desert area.

38. Distribution and concentration of uranium in coal cores.

39. Thickness and uranium content of coal beds, locations 1-40.

40. Thickness and uranium content of coal beds, locations 41-95.

41. Thickness and uranium content of coal beds, locations 96-125.

42. Thickness and uranium content of coal beds, locations 126-176.

43. Thickness and uranium content of coal beds, locations 177-214.

44. Thickness and uranium content of coal beds, locations 215-235.

45. Sketch map showing location of core holes, areas of strippable coal, and structure contours in northern part of Red Desert area.

Figure 30. Index map of Wyoming 182

31. Diagram showing intertonguing of Eocene rocks_.......... 184

32. Composite columnar section showing stratigraphic position

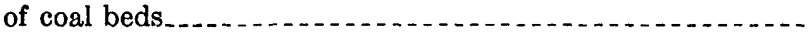

33. Graph showing interrelation of thickness, contents of ash and uranium in coal, and permeability of rocks in the Luman zone 
Figure 34. Graphs showing influence of stratigraphic position and permeability of enclosing rocks on the distribution of uranium within the Sourdough No. 2 coal bed.

35. Geologic section showing the two types of favorable geologic association in prospecting for uranium-bearing coal in the Red Desert area.

\section{TABLES}

TABLe 1. Proximate and ultimate fuel analyses of coal from cores......

3. Tonnage of uranium-bearing coal ....................... 196

4. Description of cores from the Red Desert area, and PMG values, equivalent-uranium, and uranium content of coal......... 


\title{
URANIUM IN COAL IN THE WESTERN UNITED STATES
}

\section{URANIUM-BEARING COAL IN THE RED DESERT AREA, SWEETWATER COUNTY, WYOMING}

\author{
By Harold Masursery and George N. Pipiringos
}

\begin{abstract}
Uranium-bearing coal occurs in the Red Desert area of Sweetwater County, Wyo., in a zone 15 miles wide which extends in a northwesterly direction for 30 miles north of Wamsutter, Wyo. The thickest coal is found along the transition zone between the fluviatile sandstone of the Wasatch formation and the lacustrine shale of the Green River formation, both of Eocene age. Each coal bed is lenticular and grades into shale to the northeast and southwest.

The greatest concentrations of uranium in the coal occur locally where the beds are overlain by conglomerate of possible Miocene age. Widespread but lesser concentrations of uranium occur in coal where a bed is in proximity to intercalations of coarse-grained, permeable, fluviatile sandstone which were derived from a source area to the northeast. The close relationship between uranium in the coal and the permeability of the adjacent beds indicates that the uranium is of epigenetic origin.

Preliminary estimates indicate that the rocks in the mapped area contain about 700 million short tons of subbituminous B coal in beds not less than 2.5 feet thick and overlain by not more than 75 feet of overburden. The Luman No. 1 coal bed, the principal objective of a drilling program in 1952, contains about 12 million short tons of subbituminous coal that averages 3.9 feet in thickness, under not more than $\mathbf{7 5}$ feet of overburden. The uranium content of the Luman No. 1 bed averages about 0.006 percent, the ash content averages about 20 percent, and the uranium content of the ash averages about 0.030 percent. The average heating value of the coal in the "as received" condition is 7,600 Btu. The average uranium content of other coal in the rest of the area is about 0.003 percent, although locally, as at Creston Ridge in the southeastern part of the area, impure coal contains as much as 0.051 percent uranium.

The study indicates that the coal in the Red Desert area is of interest primarily as a fuel resource and contains only small concentrations of uranium. Thin carbonaceous shale interbedded with coarse-grained sandstone to the north and east of the principal area underlain by coal, however, may contain high. grade deposits of uranium.
\end{abstract}

\section{INTRODUCTION}

A study was made in 1951 of uranium-bearing coal along the northeast margin of the Red Desert area, in the Great Divide Basin, Sweet- 
water County, Wyo. As a result, exploratory core drilling was carried on for the U. S. Geological Survey in 1952 to determine more accurately the areal distribution, thickness, and uranium content of the coal in the northern part of the area. Another objective of the investigation was to determine the origin of the uranium in the coal and use the knowledge as a guide to exploration for other deposits.

Preliminary results based on this work are herein presented. Extensive additional core drilling in the eastern part of the area, carried out in 1953, has considerably modified the correlation of coal beds and the estimation of tonnage of uranium-bearing coal in the southeastern part of the area.

\section{LOCATION OF THE AREA}

The Red Desert area, in Sweetwater County, Wyo., lies in the central part of the Great Divide Basin, a structural and topographic basin lying between the Rawlins and Rock Springs uplifts on the east and west, respectively, and the Green Mountains and the Laney Rim of the Washakie Basin on the north and south. The area of this report includes about 600 square miles and extends from the town of Wamsutter for 30 miles to the north (fig. 30). The altitude ranges from 6,500 to 7,200 feet. Owing to the semiarid climate, only

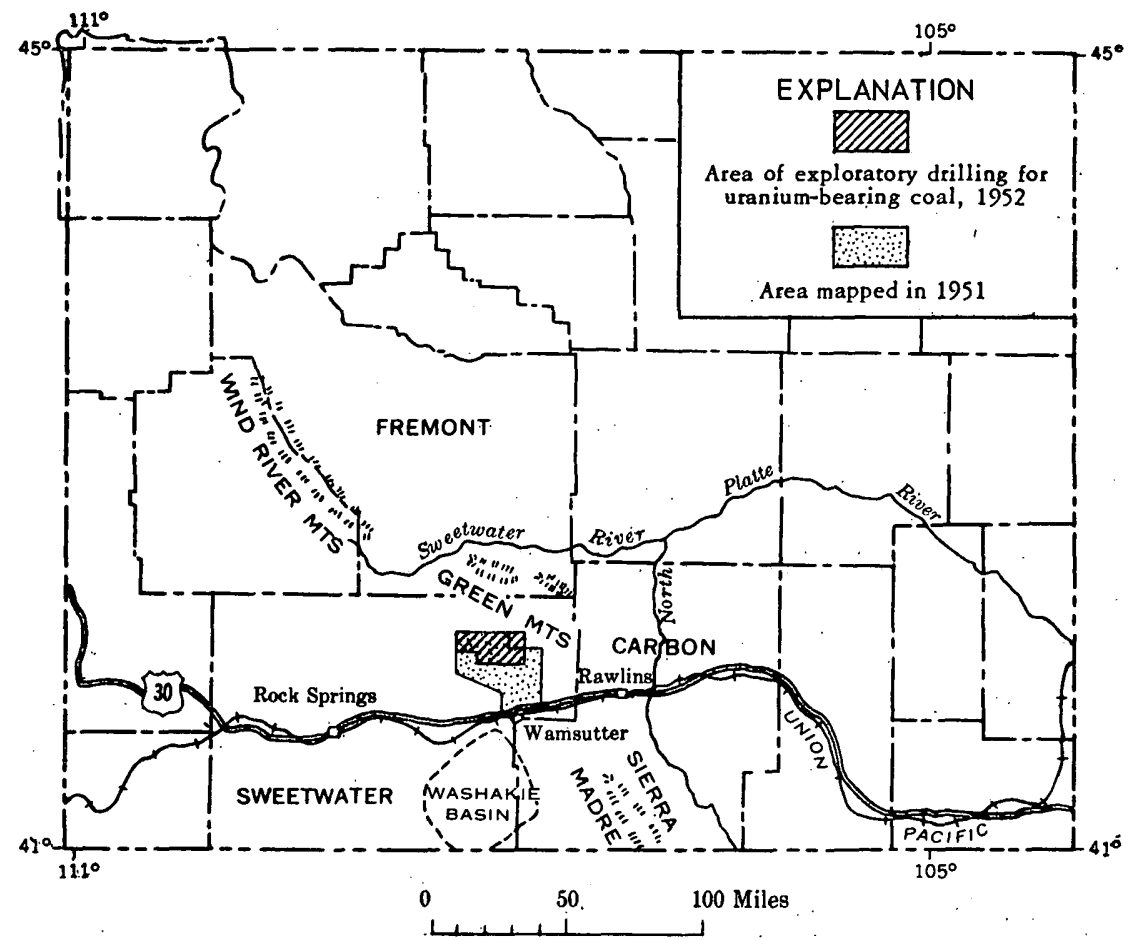

Figurb 30.-Index map of Wyoming, showing location of the Red Desert area, Sweetwater County. 
intermittent streams and playa lakes are present; the Sweetwater River on the north side of the Green Mountains, 25 miles north of the area, is the nearest perennial stream. The nearest shipping point is Wamsutter, on the Union Pacific Railroad which crosses the southern part of the area. Many graded dirt roads and trails make other parts of the area easily accessible by automobile.

\section{FIELPWORK}

July to December of 1951 was spent in mapping the coal beds in the central part of the area. At that time, channel samples were collected with pick and shovel at exposures of coal, and a truckmounted auger was used to establish the persistence of coal beds into covered areas. From June to November 1952 a four-man party mapped and sampled the coal beds in more detail. Core drilling in the northern part of the area (fig. 30) was done in September and October 1952 by the Minerals Engineering Co.

Geology was mapped and General Land Office section-corner markers were plotted on aerial photographs at a scale of about $1: 36,000$ and compiled at a scale of $1: 31,680$ on a grid constructed from township plats of the General Land Office resurvey of 1937.

\section{ACKNOWLEDGMENTS}

In the fieldwork of 1952 the writers were assisted by Arthur E. Burford, Howard D. Gower, George W. Moore, J. R. Pierson, Jr., and James Sindelar. Gower also assisted the writers in the office for several months after the fieldwork. Theodore Botinelly, Maurice Deul, and Irving Breger of the Geological Survey contributed helpful discussions in the field on the mineralogy of the coal; Roland Brown and H. R. Christner collected and identified plant fossils.

James M. Schopf processed and made detailed descriptions of all coal cores. Chemical analyses for uranium and determinations of equivalent uranium were made in Geological Survey laboratories, and proximate and ultimate fuel analyses of the coal from cores were done by the U.S. Bureau of Mines.

The writers are especially indebted to Raymond Larsen and Kaj Hansen for providing housing facilities for Geological Survey personnel during the 1952 fieldwork.

\section{GEOLOGY}

\section{PREVIOUS WORK}

The geology of the coal-bearing rocks in the Red Desert area was described by Smith (1909). Studies of adjacent areas were made by Schultz (1907) and Ball (1909). Tertiary strata, especially in relation to the occurrence of oil shale, was investigated and described by Sears and Bradley (1924), and Bradley $(1926,1945)$. Oil and gas 
possibilities along the east and west margins of the Great Divide Basin were discussed by Schultz (1920), Fath (1924), and Dobbin $(1928,1929)$.

Uranium in coal was discovered in the Red Desert area by A. L. Slaughter and J. M. Nelson (written communication, 1946), while investigating the Lost Creek schroeckingerite deposit. Subsequent studies of the uranium deposits of the area were made by R. A. Nelson, W. N. Sharpe, and F. W. Stead (written communication, 1951), D. M. Sheridan, J. T. Collier, and R. S. Sears (written communication, 1952), and D. G. Wyant, W. N. Sharpe, and D. M. Sheridan. (1957). A preliminary copy of the map by Wyant and Sharpe of part of the coal-bearing rocks was available to the writers before fieldwork started in 1951.

\section{STRATIGRAPHY}

The Wasatch and Green River formations of Eocene age are the only stratigraphic units studied in detail in the mapped area (pl. 36) pertinent to this report. The Wasatch formation is divided into two parts in ascending order: the main body of the Wasatch formation (the Hiawatha member of local usage, Nightingale, 1930; Wood and others, 1941; Wyo. Geol. Assoc. Nomenclature Committee, 1951), and the Cathedral Bluffs tongue of the Wasatch formation (fig. 31).

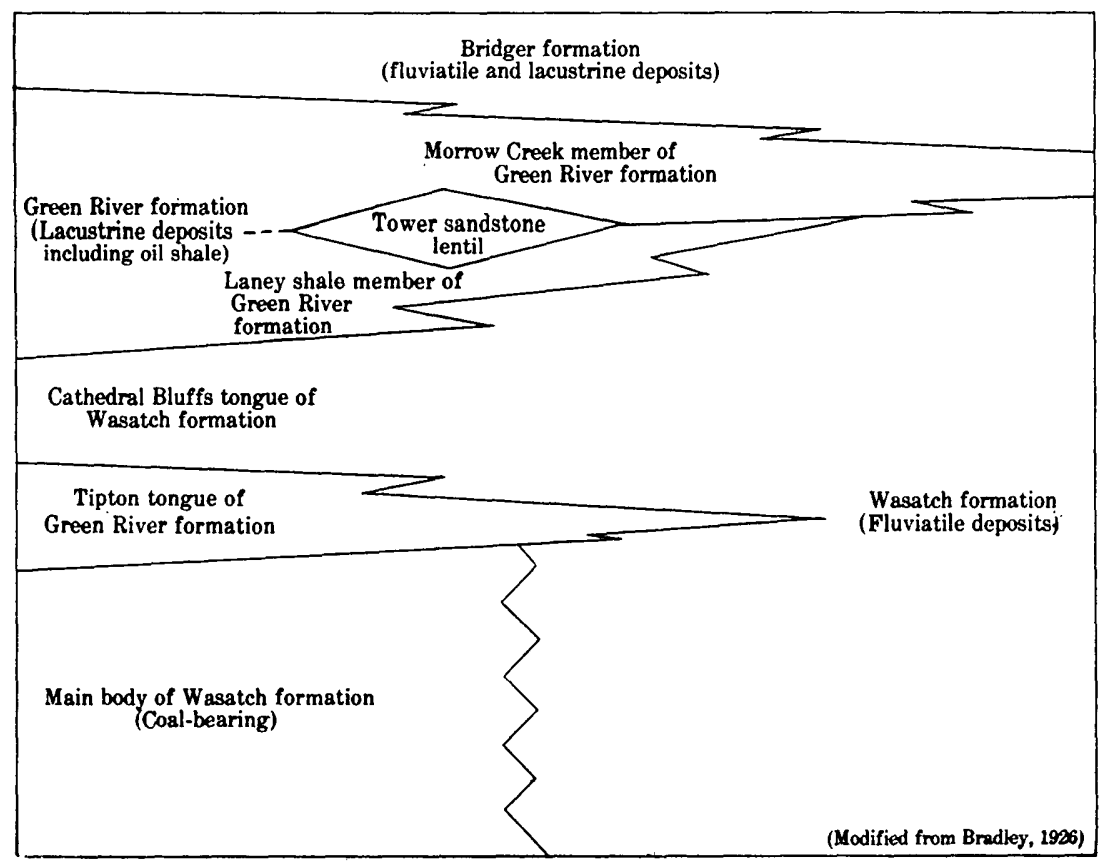

FraURD 31.-Diagrammatic section showing intertonguing of Eocene rocks in the Red Desert area, Sweetwater County, Wyo., and adjoining areas. 
The units of the Green River, in ascending order, are the Tipton tongue, the Laney shale member, and the Morrow Creek member. Only the upper part of the main body of the Wasatch formation, the lower part of the Cathedral Bluffs tongue, and the Tipton tongue of the Green River formation are exposed in the mapped area and have an aggregate thickness of more than 1,200 feet. Younger rocks of Eocene, Miocene, and Pliocene(?) age were examined in reconnaissance in adjacent areas. Pleistocene and Recent lake deposits, alluvium, and sand dunes mantle the bedrock over large areas of the Red Desert.

The Wasatch formation of the northeastern part of the area is composed of coarse-grained arkose and sandy claystone; both rock types commonly are buff to tan but are variegated at some localities. They are irregularly bedded and cross-laminated and probably of fluviatile origin. To the southwest the rocks of the main body of the Wasatch formation are finer grained, more evenly bedded, very light gray in color, and coal bearing. Rocks of the Cathedral Bluffs tongue also become finer grained and even bedded to the southwest but are variegated and weather to typical badland forms. The Wasatch rocks represent floodplain and swamp deposits and intertongue with rocks of lacustrine origin, consisting of papery organic shale, laminated siltstone, and fossiliferous calcareous sandstone belonging to the Green River formation. The restored section (pl. 36) shows the stratigraphic relations of the interfingering units within the mapped area. Similar relationships in adjacent areas have been described by many workers, including Schultz (1909), Sears and Bradley (1924), Bradley (1926, 1945, and 1948), Nightingale (1930), and Nace (1939).

Plant and vertebrate fossils indicate an early Eocene age for the main coal-bearing sequence of the Wasatch formation. They are listed in the table on the following page.

Beds of lacustrine shale and siltstone similar to rocks of the Green River formation are mapped separately in the central and northwestern part of the area and are tentatively included in the main body of the Wasatch formation. Brown limy sandstone containing freshwater fossils is common in these lacustrine rocks. Two key zones were helpful in mapping: a 10-foot zone near the top of the Tipton tongue, which includes calcareous onion-layered algal balls about 0.5 foot in diameter, and a 5-foot zone of pastel-weathering limestone concretions, each about 2 feet in diameter, that is usually present at the base of the shale tongue above the Battle No. 3 coal bed.

High level terraces in the southern part of the area are covered by conglomerate that is tentatively correlated with the basal conglomerate of the Browns Park formation of Miocene age. However, conglomerate also occurs in nearby areas in beds of Oligocene and Pliocene age, and gravels of Pleistocene age occur locally. The possible 
Fossil collections from the main body of the Wasatch formation in the Red Desert area

\begin{tabular}{|c|c|c|c|}
\hline Map locality (pl:37) & Location & Identifications & Age \\
\hline \multicolumn{4}{|c|}{ Plants [identified by R. W. Brown] } \\
\hline 186 & $\begin{array}{l}\text { SE1/4SW1/4 sec. } 24, \text { T. } 24 \\
\text { N., R. } 96 \text { W. } \\
\text { SW1/4SW1/4 sec. 4, T. } 21 \\
\text { N., R. } 94 \text { W. }\end{array}$ & $\begin{array}{l}\text { Eguisetum sp..... } \\
\text { Lygodium kaulfussi Heer } \\
\text { Salvinia preauriculata Berry } \\
\text { Lemna scutata Dawson } \\
\text { Salvinia preauriculata Berry } \\
\text { Sparganium antiquum (Newberry) } \\
\text { Berry. } \\
\text { Platanus raynoldsi Newberry......... }\end{array}$ & $\begin{array}{c}\text { Earlier half } \\
\text { of Eocene. } \\
\text { Do. } \\
\text { Do. } \\
\text { Do. } \\
\text { Eocene. } \\
\text { Do. } \\
\text { Do. }\end{array}$ \\
\hline
\end{tabular}

Invertebrates [identified by Teng-Chien Yen]

\begin{tabular}{|c|c|c|c|}
\hline $49 \ldots \ldots$ & $\begin{array}{l}\text { SW1/4SE1/4 sec. } 36, \text { T. } 23 \\
\text { N., R. } 95 \text { W. } \\
\text { SW1/4SW1/4 sec. } 15 \text {, T. } 22 \\
\text { N., R. } 94 \text { W. }\end{array}$ & $\begin{array}{l}\text { Unio sp. undet. } \\
\text { Sphaerium sp. undett } \\
\text { Viviperus sp. undet. } \\
\text { Valvata s, undet. und } \\
\text { Goniobasis nodulifera (Meek) } \\
\text { Goniobasis cf. G. tenera (Hail) } \\
\text { Gyraulus sp. undet. } \\
\text { Unio sp. undet } \\
\text { Valvata sp. undet } \\
\text { Viviparus cf. V. paludinaeformus } \\
\text { (Hall). } \\
\text { Goniobasis cf. } G . \text { tenera (Hall) } \\
\text { Gyraulus cf. } G . \text { militarus (White) }\end{array}$ & $\begin{array}{l}\text { Early Eocene. } \\
\text { Do. } \\
\text { Do. } \\
\text { Do. } \\
\text { Do. } \\
\text { Do. } \\
\text { Do. } \\
\text { Do. } \\
\text { Do. } \\
\text { Do. } \\
\text { Do. } \\
\text { Do. }\end{array}$ \\
\hline
\end{tabular}

Miocene age of these beds is based on intermittently exposed similar terrace deposits that extend to the east and pass under tuffaceous sandstone of the Browns Park formation in the vicinity of Rawlins.

\section{STRUCTURE}

The Red Desert area is generally one of low structural relief; however, two large structures are recognizable in the area of core drilling. One is a basin, the southern limit of which is marked by the Eagles Nest Rim, at the northern edge of the mapped area (pl. 36), and which is here called the Niland basin. The other, a syncline, continues southeastward from the Niland basin and is probably continuous with the Red Desert syncline of Schultz (1920, p. 40); it is shown by structure contours on plate 45 . The axis of the syncline trends about $\mathrm{N} .30^{\circ} \mathrm{W}$.

Along the north margin of Lost Creek Flat are several minor folds that trend $\mathrm{N} .30^{\circ} \mathrm{E}$, and an anticline trends N. $75^{\circ} \mathrm{E}$. at Chain Lakes Flat.

High-angle faults of minor displacement and trending N. $75^{\circ} \mathrm{E}$. occur at many places; faults of lesser importance trend N. $30^{\circ} \mathrm{E}$.

\section{COAL}

\section{OCCURRENCE}

The coal beds are thickest, 5-20 feet (fig. 32), in a northwest-trending zone about 30 miles long in the central part of the area. The zone coincides with the transition zone between the. Wasatch formation of 
fluviatile origin and the Green River formation of lacustrine origin. Each coal bed is lens-shaped in cross section and thins within a few miles to the northeast and southwest of the zone, grading into carbonaceous shale which in turn grades into green-clay shale. Not only

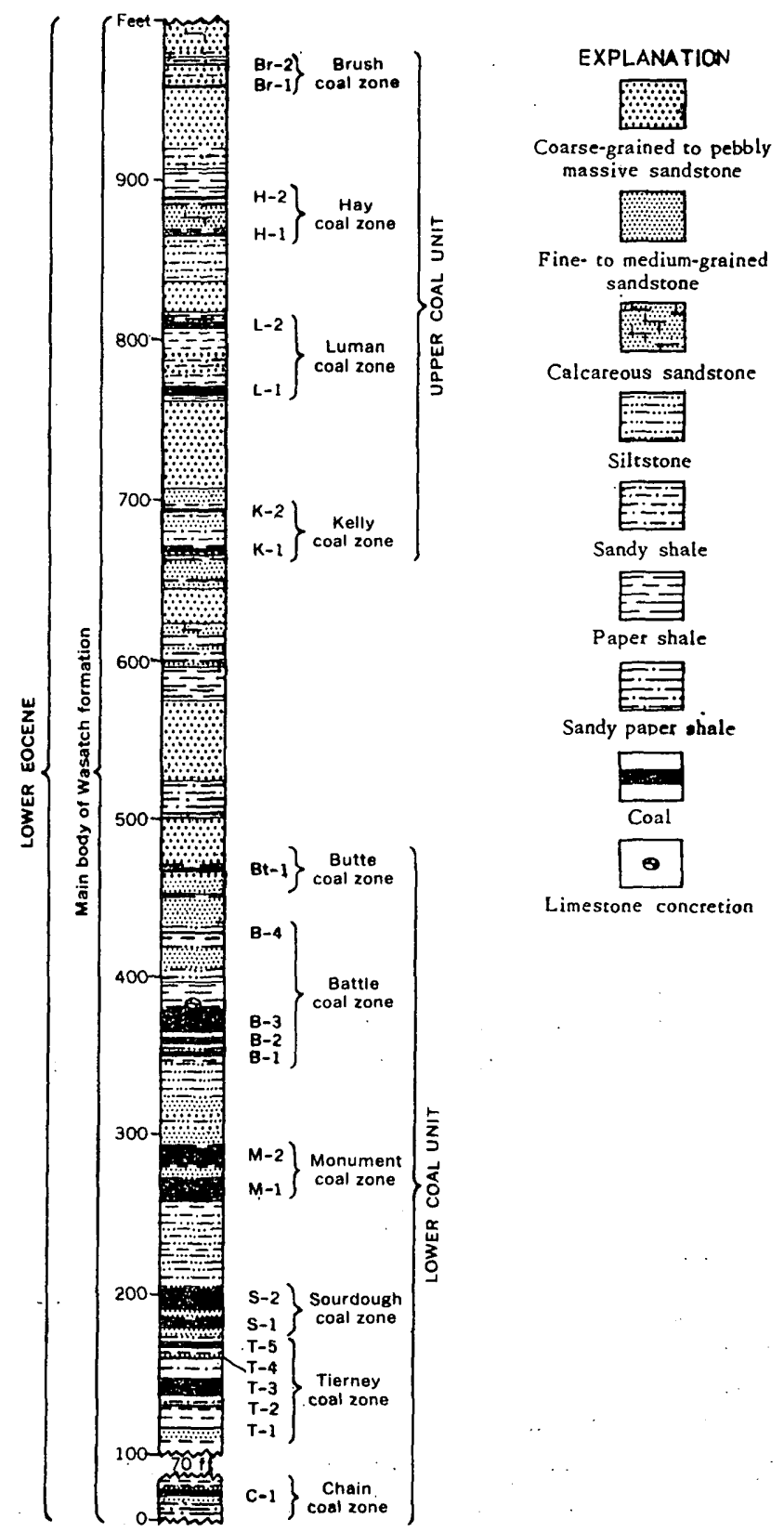

Figdre 32-Generalized columnar section, showing relative positions of principal coal beds, Red Desert area, Sweetwater County, Wyo. 
the coal beds but the entire stratigraphic sequence is thickest along this transition zone and thins considerably to the west and slightly to the east (pl. 36).

The coal in outcrop ranges in physical character from hard, banded, black coal having conchoidal fracture to light-weight, soft porous coal containing many fragments of carbonized wood. On weathering the coal breaks down into small fragments. It has burned along the outcrop at many places, but the burning did not extend far back underground from the outcrop. Evidently the soft siltstone overlying the coal caved and smothered the fires.

In the area of core drilling there are four zones of uranium-bearing coal of potential economic interest: the Sourdough, Monument, Battle, and Luman zones, and several minor zones of coal and carbonaceous shale in which beds are thin and of little or only local importance (fig. 32). In the central part of the area of drilling the thickest carbonaceous zone is 21 feet in thickness and the thickest coal bed, 9 feet; in the southern part of the Red Desert area the thickest zone, the Tierney, is as much as 16 feet thick. Fuel analyses by the U. S. Bureau of Mines, 30 proximate and 12 ultimate, are given in table 1. Calculations from these analyses, based on the Parr formula (ASTM, 1938), indicate that the coal is subbituminous B grade. The average heating value in the "as received" condition is 7,600 $\mathrm{Btu}$; in the moisture- and ash-free condition, it is 9,900 Btu. The average ash content is 15.5 percent, and the average sulfur content is 1.8 percent. Detailed descriptions of the coal cores by James M. Schopf are listed in table 4 (see page 198). Plate 37 shows the generalized graphic logs of the core holes.

\section{DISTRIBUTION OF URANIUM}

The uranium content of the coal reached by the 11 core holes is shown in detail in plate 38, which also shows the percent of ash and uranium in the ash. The distribution of uranium in individual coal beds, as determined from surface and auger samples, is shown in plates 39-44, each figure showing stratigraphic sections of the coal beds in an east-west tier of townships.

The greatest concentrations of uranium in coal occur locally in the topographically higher parts of the area, at an unconformity where the coal beds are overlain by conglomerate of possible Miocene age. Along the south rim of Bison Basin, 20 miles north of the mapped area, a coal bed in the Fort Union formation of Paleocene age, directly below the unconformably overlying conglomerate, contains 0.056 percent uranium; a bed 12 feet below it contains 0.005 percent, and a bed 40 feet below it contains 0.001 percent. At Creston Ridge, in the southeastern part of the area, a coal bed in the main body of the Wasatch formation of early Eocene age, and immediately 
URANIUM-BEARING COAL, RED DESERT AREA, WYO. 189

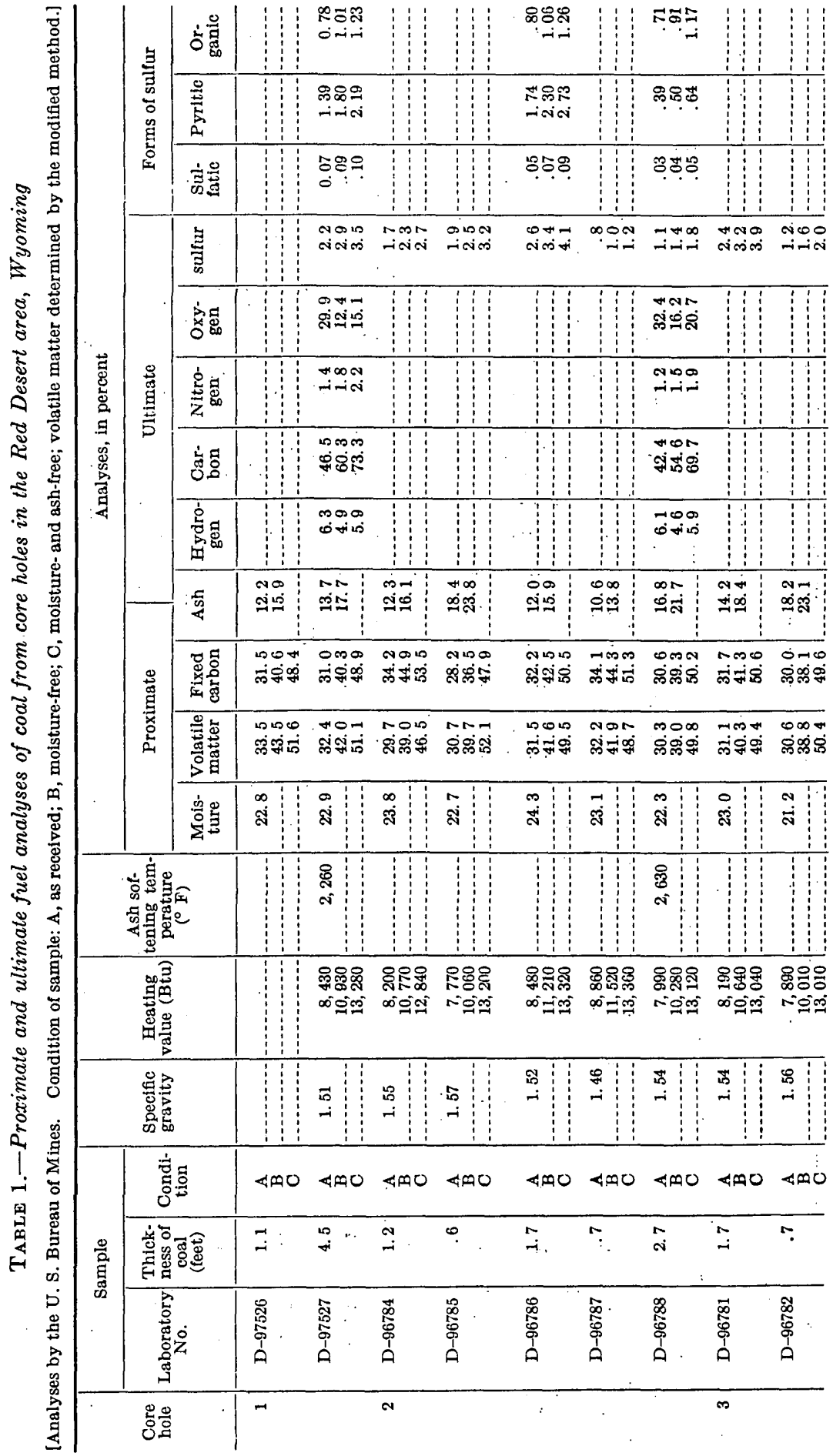




\begin{tabular}{|c|c|c|c|c|c|c|c|c|c|c|c|c|}
\hline \multirow{12}{*}{ 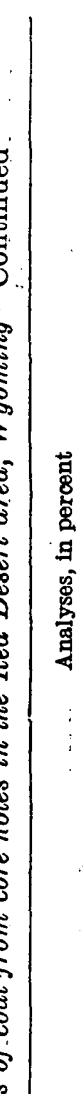 } & \multirow{3}{*}{ 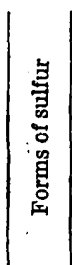 } & 施 & 저ㅇㅠㅠ & 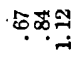 & 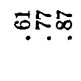 & & 郘요. & 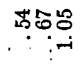 & 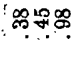 & R๐. & & \\
\hline & & 惫 & శ్ర0 & $\because \%$ & 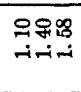 & & 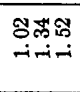 & ๑ొస్ & & ్ా요 & & \\
\hline & & 㝘营 & 양하. & 항요요 & $8 \%$ & & 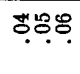 & 훙유. & 훙ํำ & ชి\%ฺ & & \\
\hline & \multirow{6}{*}{ 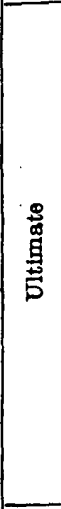 } & 壱 & 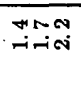 & 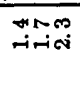 & 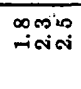 & & 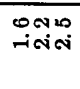 & $\because \square$ & $\because \underset{\sim}{\longrightarrow \infty}$ & 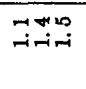 & 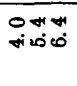 & ind \\
\hline & & 它桇 & 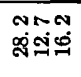 & सं०० & $\begin{array}{l}\infty \infty 0 m \\
\text { simp: }\end{array}$ & & 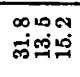 & 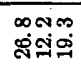 & $\begin{array}{l}000 \\
\text { సึఖ }\end{array}$ & 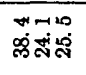 & & \\
\hline & & 室要 & $\begin{array}{l}\text { NoO } \\
\text { ITiN }\end{array}$ & Tुmo & Hifi & & mitio & ๑. & $\because$ & $\begin{array}{l}\infty 000 \\
\text { ifin }\end{array}$ & & \\
\hline & & 宛。 & 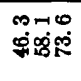 & 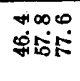 & $\begin{array}{l}-\infty 0 \\
\text { 섬: }\end{array}$ & & $\begin{array}{l}700 \\
80801\end{array}$ & क्ष & 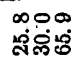 & 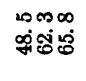 & & \\
\hline & & 离要 & $\begin{array}{c}-\infty 00 \\
0 * \forall i d\end{array}$ & $\begin{array}{l}\infty 100 \\
15 \text { tio }\end{array}$ & Nom & & 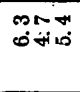 & 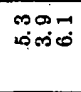 & $\begin{array}{l}x \rightarrow \infty \\
\text { Fin }\end{array}$ & $\begin{array}{l}\text { mon } \\
\text { bivins }\end{array}$ & & \\
\hline & & 量 & $\begin{array}{l}\infty-1 \\
\dot{\Phi} \overline{\text { त }}\end{array}$ & 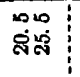 & $\infty=$ & 무 & 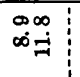 & 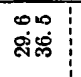 & 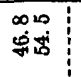 & $\begin{array}{l}\text { Th } \\
\text { Sine }\end{array}$ & $\begin{array}{l}\infty n \\
\dot{q} \Phi\end{array}$ & लेंजे \\
\hline & \multirow{3}{*}{$\begin{array}{l}\text { 兽 } \\
\text { 基 } \\
\text { 品 }\end{array}$} & 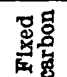 & 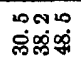 & 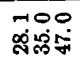 & $\begin{array}{l}0 \rightarrow \infty \\
\text { क्षंक्ष. }\end{array}$ & गुंक्ष & 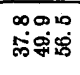 & 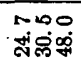 & 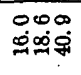 & 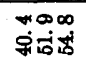 & 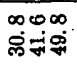 & $\begin{array}{l}-100 \\
\text { సิ요요 }\end{array}$ \\
\hline & & 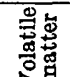 & 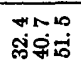 & लि0 & 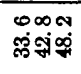 & 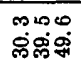 & 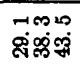 & $\begin{array}{l}\infty 00 \\
\dot{8}: 50\end{array}$ & జ்- & 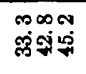 & $\begin{array}{l}000 \\
\text { मेंज्ञ }\end{array}$ & 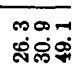 \\
\hline & & 产至 & क̊ & 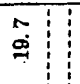 & $\hat{\vec{a}}$ & ฌุ & ì & $\underset{\infty}{\infty}$ & $\exists$ & $\overrightarrow{\text { ม }}$ & & \\
\hline \multicolumn{3}{|c|}{ 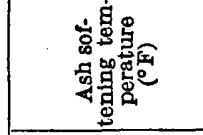 } & $\begin{array}{l}\not{8} \\
\text { o }\end{array}$ & $1: 1$ & $\frac{9}{5}$ & & $\underset{8}{\stackrel{8}{0}}$ & 111 & 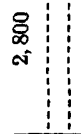 & 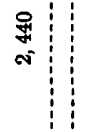 & & \\
\hline \multicolumn{3}{|c|}{ 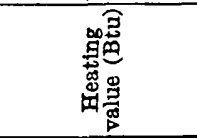 } & 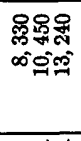 & 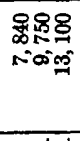 & 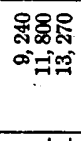 & & 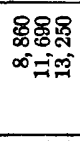 & 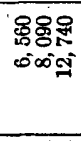 & 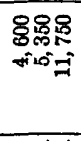 & $\begin{array}{l}\text { 유용 } \\
\infty \\
\infty=1\end{array}$ & 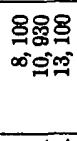 & 용요 \\
\hline \multicolumn{3}{|c|}{ 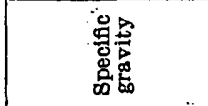 } & \begin{tabular}{l|l}
$\mathscr{B}$ & \\
\hdashline
\end{tabular} & $\stackrel{\mathscr{0}}{\stackrel{0}{-}}$ & 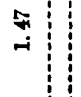 & & $\stackrel{9}{+9}$ & $\underset{-i}{\mathscr{B}}$ & $\vec{\sigma}$ & 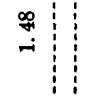 & 苛 & \\
\hline \multirow{3}{*}{ 总 } & \multicolumn{2}{|c|}{ 䒿苛 } & ४mO & $<\infty$ & $4 M O$ & ४MO & 4MO & 4MO & ४⿻ & 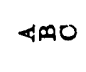 & ४MO & ४⿻ \\
\hline & \multicolumn{2}{|c|}{ 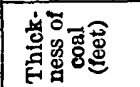 } & $\stackrel{\infty}{\infty}$ & $\vec{\omega}$ & a: & $\stackrel{4}{-}$ & مै & $\stackrel{0}{*}$ & $\stackrel{0}{*}$ & $\stackrel{\infty}{*}$ & $\stackrel{\circ}{*}$ & $\bar{i}$ \\
\hline & \multicolumn{2}{|c|}{ 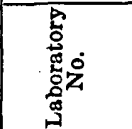 } & 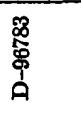 & 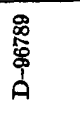 & $\begin{array}{l}\text { 蛋 } \\
\text { \$ } \\
\text { م }\end{array}$ & 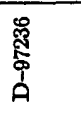 & $\begin{array}{l}\text { 勇 } \\
\text { p } \\
0\end{array}$ & 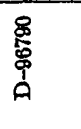 & 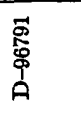 & 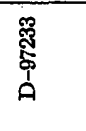 & 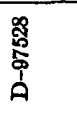 & 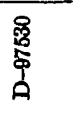 \\
\hline \multicolumn{3}{|c|}{ 용요 } & $\infty$ & $\omega$ & & & & $\infty$ & 0 & 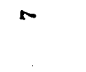 & $\infty$ & $\infty$ \\
\hline
\end{tabular}


URANIUM-BEARING COAL, RED DESERT AREA, WYO. 191

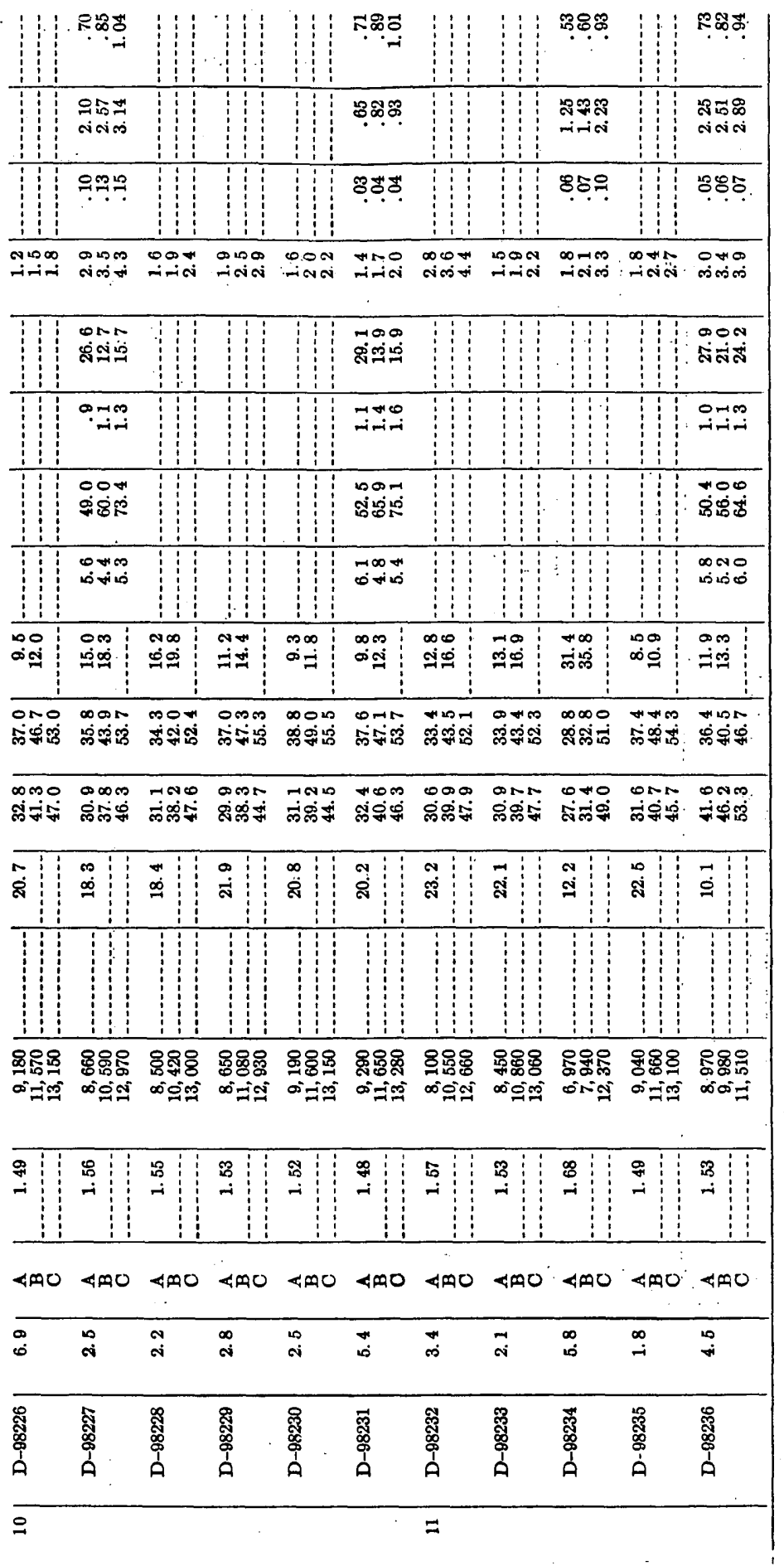


below a conglomerate contains as much as 0.051 percent uranium, whereas a bed 40 feet below it contains less than 0.001 percent.

The graphs in figure 33 show the thickness, uranium content, and percent ash of the coal, and the permeability of the rocks enclosing the coal bed, and are based on data from six core holes reaching the Luman No. 1 coal bed. These data show that in the less intensely

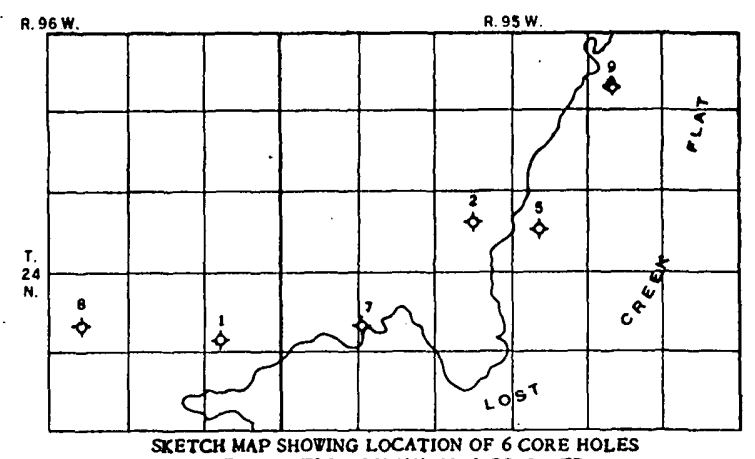

SKETCH MAP SHOVING LOCATION OF 6 CORE HOLES PENETRATING LUMAN NO. 1 COAL BED
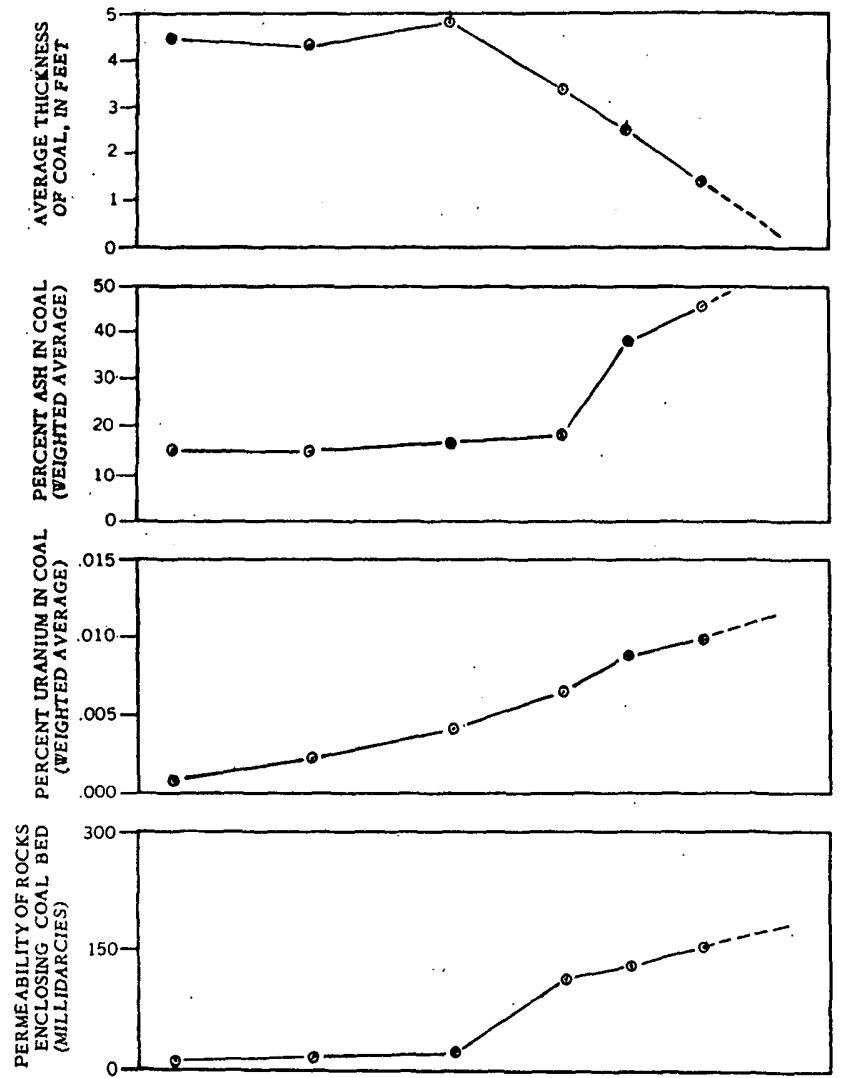

FiguRe 33.-Graphs showing the interrelation of thickness, ash content aud uranium content of coal, and the permeability of assoclated rocks in the Luman No. 1 coal bed, Red Desert area, Sweetwater County, Wyo. 
mineralized parts of the coal bed the uranium content increases from west to east and closely coincides with the change in facies of the rocks from less permeable lacustrine shale and coal-bearing shale; siltstone, and fine-grained sandstone in the western part of the area to coarse-grained, more permeable, fluviatile sandstone in the eastern part. The uranium content of the Luman No. 1 coal bed appears to be directly related to the presence of tongues of coarse-grained sandstone extending from the northeast.

That the distribution of uranium within a coal bed is related to the permeability of the associated rocks is shown by figure 34 , in which the uranium content of the Sourdough No. 2 coal bed is plotted at two localities. In core hole 11, where the coal bed is underlain by sandstone, the uranium content is greatest at the base of the bed. At locality 134, where the coal bed is underlain and overlain by sandstone, the uranium content is greatest at the top and base of the bed; adjacent to the sandstone.
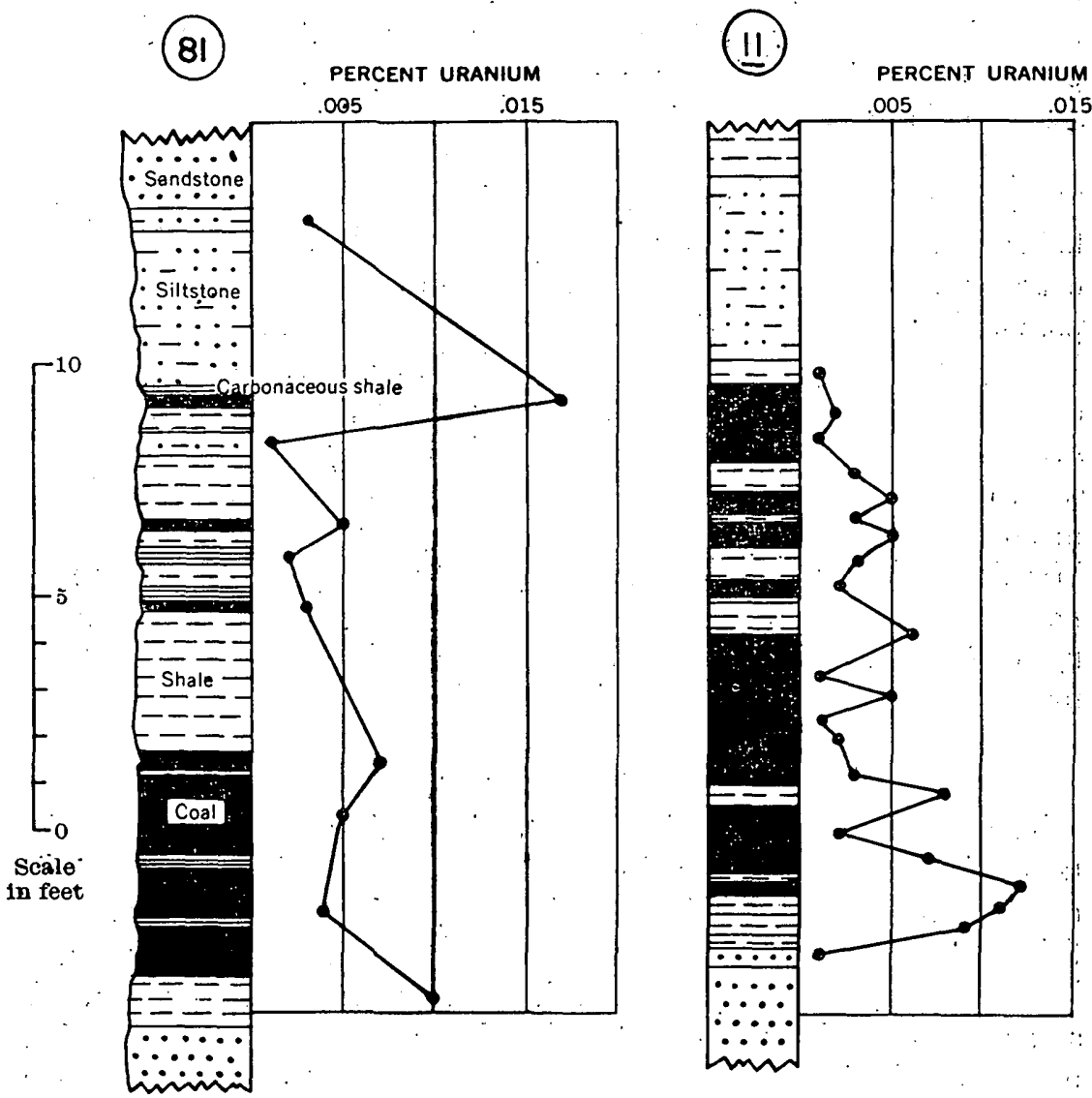

Fiadiz 34.-Graphs showing influence of stratigraphic position and permeability of enclosing rocks on the distribution of uranium within the Sourdough No. 2 coal bed. 
At Eagles Nest, at the northern border of the mapped area, beds of low-grade oil shale are interbedded with coarse-grained, permeable sandstone. At the contact of the shale with the sandstone there is a fourfold increase in the uranium content of the shale. North of Eagles Nest, there is a three- to four-fold increase in uranium content of sandy claystone at the contact with well-sorted channel sandstone.

The close relationship between the uranium content of the coal, organic shale, and claystone, and the permeability of the adjacent beds indicates that the uranium is of epigenetic origin.

This relationship suggests that geologic associations favorable for uranium-bearing coal occur not only where coal beds that can be mineralized with uranium are in contact with overlying source rocks furnishing uranium to mineralizing ground-water (type $A$, fig. 35), as is postulated for the lignite beds in the Dakotas (Denson, Bachman, and Zeller, chapter B, this bulletin), but also where such coal beds are perhaps miles from source rocks but are in contact with beds of permeable sandstone that can act as conduits for uraniumbearing ground water moving laterally and downward from areas of source rocks (type $B$, fig. 35 ).

Figure 35 illustrates both types of favorable geologic association. Type $A$ is typical of the areas of uranium-bearing lignite in the Dakotas and is found where source rocks directly overlie coal, which extracts uranium leached from source rocks and carried downward by percolating ground water. Type $B$ is more common in the Red Desert area and is found where coal is in association with beds of coarse-grained permeable sandstone through which uranium-bearing groundwater has moved downward and laterally for miles from the source rocks. The coal beds are more intensely mineralized with uranium adjacent to overlying and underlying permeable sandstone. Uranium-bearing coal in areas of type $A$ or $B$ may be found by prospecting along coal exposures or by shallow drill holes. In areas of type $B$, where there is no surface indication of mineralization, uranium-bearing coal may also be found by deep:drill holes.

\section{DRILLING OPERATIONS}

The primary objective of the 1952 core-drilling program was to obtain samples of unweathered coal for analyses on which to base estimates of tonnage of uranium-bearing coal in beds more than 2.5 feet thick in the areas in which geological factors discussed in the preceding paragraph were most favorable for uranium mineralization. A secondary objective was to determine the relationship of distribution of uranium in the coal beds to permeable zones and to major and minor tectonic. structures, and its value as a guide in search for uranium deposits of higher grade in the Red Desert area. 

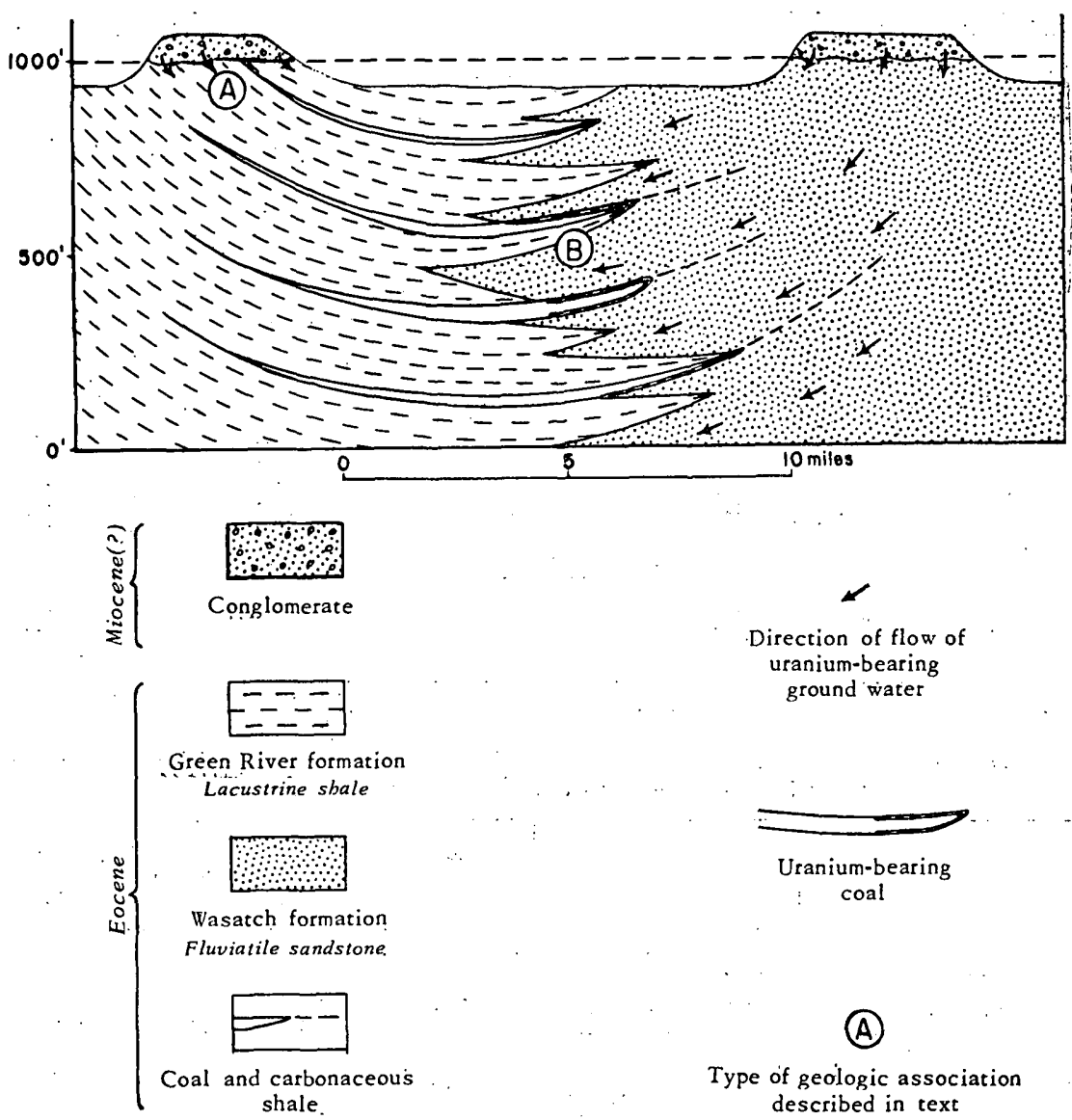
Direction of flow of uranium-bearing ground water

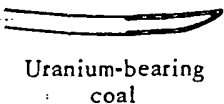

(A)

Type of geologic association described in text

Figure 35.-Idealized geologic section showing two types of geologic association favorable for prospecting for uranium-bearing coal, Red Desert area, Wyoming.

Core holes were drilled in two adjacent areas (pls. 36 and 45); 9 holes penetrated the beds in the upper coal unit in the vicinity of the Eagles Nest Rim in the northern part of the area; 2 holes, drilled about 8 miles to the southeast near the southern margin of Battle Springs Flat, tested the lower coal unit which is about 250 feet stratigraphically lower. Hole 4, in the northern part of the area, was drilled to a depth of 600 feet to determine the interval between the two coal units, to confirm the geologic mapping, and to provide data for estimation of tonnage of coal in this part of the mapped area. The average drill-hole depth was 227 feet; the deepest core hole being 600 feet; the shallowest, 55 feet (table 2). With a few exceptions, core recovery was good.

\section{TONNAGE AND URANIUM CONTENT}

Tonnage of uranium-bearing coal in beds at least 2.5 feet thick and under not more than 75 feet of overburden have been estimated and tabulated by townships. Thickness and uranium content of the coal 
are based on weighted averages of 425 analyses for uranium on samples from core holes and 770 analyses of samples from surface sections and auger holes.

About 700 million short tons of coal underlie the mapped area (table 3 ), of which about 300 million contain at least 0.003 percent uranium.

TABLE 2.-Statistical data on core holes, Red Desert area, Sweetwater County, Wyo.

\begin{tabular}{|c|c|c|c|c|}
\hline Core & Location & $\begin{array}{c}\text { Elevation } \\
\text { (feet above } \\
\text { sea level) }\end{array}$ & $\begin{array}{c}\text { Aggregate } \\
\text { thickness } \\
\text { of cosl (feet) }\end{array}$ & $\begin{array}{l}\text { Depth } \\
\text { of hole } \\
\text { (feet) }\end{array}$ \\
\hline \multirow[t]{2}{*}{$\begin{array}{r}1 \\
1 \\
3 \\
4 \\
5 \\
5 \\
6 \\
7 \\
8 \\
9 \\
10 \\
11\end{array}$} & \multirow[t]{2}{*}{ 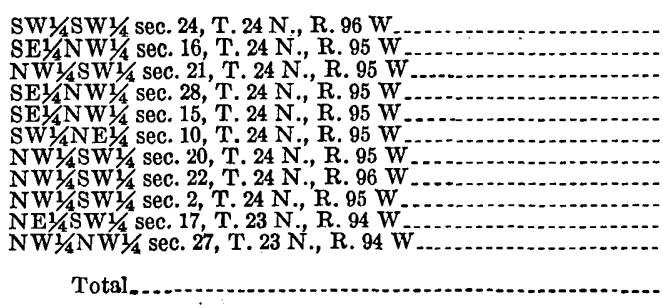 } & $\begin{array}{l}6,645 \\
6,630 \\
6,610 \\
6,610 \\
6,580 \\
6,605 \\
6,560 \\
6,715 \\
6,620 \\
6,510 \\
6,660\end{array}$ & $\begin{array}{r}6.9 \\
9.5 \\
8.2 \\
26.4 \\
3.7 \\
6.2 \\
5.1 \\
4.7 \\
4.7 \\
26.8 \\
26.1\end{array}$ & $\begin{array}{r}142 \\
266 \\
173 \\
600 \\
202 \\
263 \\
55 \\
119 \\
206 \\
245 \\
226\end{array}$ \\
\hline & & & 3 & 2,497 \\
\hline
\end{tabular}

TABLE 3.-Tonnage of uranium-bearing coal in beds at least 2.5 feet thick and under no more than 75 feet of overburden, Red Desert area, Wyo.

\begin{tabular}{|c|c|c|c|c|c|}
\hline Township & Coal bed & $\begin{array}{c}\text { Area } \\
\text { (acres) }\end{array}$ & $\begin{array}{c}\text { Thickness } \\
\text { (feet) }\end{array}$ & $\begin{array}{l}\text { Uranium } \\
\text { (percent) }\end{array}$ & $\begin{array}{l}\text { Tonnage of } \\
\text { coala } \\
\text { (short tons) }\end{array}$ \\
\hline \multicolumn{6}{|c|}{ Northern part of Red Desert area } \\
\hline $\begin{array}{l}\text { T. } 24 \text { N., R. } 96 \text { W. } \\
\text { T. } 24 \text { N., R. } 95 \text { W } \\
\text { T. } 23 \text { N., R. } 95 \text { W. } \\
\text { Do } \\
\text { T. } 23 \text { N., R. } 94 \text { W. } \\
\text { Do } \\
\text { Do } \\
\text { Do }\end{array}$ & $\begin{array}{l}\text { Luman No. } \\
\text { Luman No. } \\
\text { Monument No. 2. } \\
\text { Monument No. 1 } \\
\text { Battle No. 3 } \\
\text { Monument No. } 2 \\
\text { Monument No. } 1 \\
\text { Sourdough No. 2 }\end{array}$ & $\begin{array}{r}1,477 \\
1,705 \\
152 \\
5,183 \\
2,583 \\
499 \\
3,642 \\
1,587 \\
\end{array}$ & $\begin{array}{r}3.5 \\
3.9 \\
4.0 \\
4.3 \\
10.9 \\
2.6 \\
5.8 \\
3.5 \\
\end{array}$ & $\begin{array}{l}0.002 \\
.006 \\
.002 \\
.002 \\
.004 \\
.004 \\
.005 \\
.006\end{array}$ & $\begin{array}{r}9,151,000 \\
11,770,000 \\
1,076,000 \\
39,448,000 \\
49,834,000 \\
2,296,000 \\
37,388,000 \\
9,831,000 \\
\end{array}$ \\
\hline Totalb, northe & of Red Desert are & 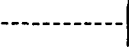 & & & $160,800,000$ \\
\hline \multicolumn{6}{|c|}{ Southern part of Red Desert area } \\
\hline 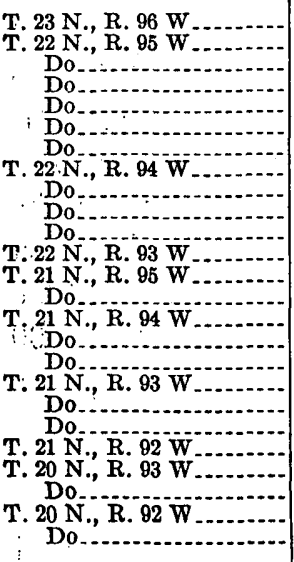 & 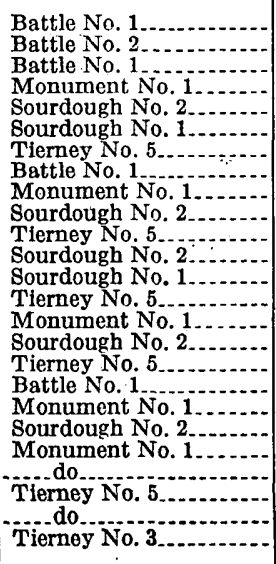 & $\begin{array}{r}640 \\
640 \\
810 \\
1,440 \\
1,340 \\
1,528 \\
1,080 \\
2,080 \\
6,719 \\
11,627 \\
3,248 \\
877 \\
205 \\
528 \\
653 \\
5,675 \\
760 \\
934 \\
3,939 \\
2,095 \\
640 \\
256 \\
2,285 \\
488 \\
1,798 \\
\end{array}$ & $\begin{array}{r}2.5 \\
2.5 \\
3.0 \\
6.5 \\
3.5 \\
4.5 \\
3.0 \\
3.0 \\
9.5 \\
6.4 \\
4.0 \\
5.0 \\
2.5 \\
5.0 \\
3.0 \\
4.3 \\
.5 .0 \\
4.5 \\
5.4 \\
5.2 \\
4.0 \\
4.5 \\
16.0 \\
16.0 \\
5.7 \\
\end{array}$ & $\begin{array}{l}0.001 \\
.001 \\
.003 \\
.001 \\
.001 \\
.001 \\
.002 \\
.001 \\
.001 \\
.003 \\
.001 \\
.003 \\
.001 \\
.002 \\
.010 \\
.001 \\
.001 \\
.006 \\
.009 \\
.002 \\
.003 \\
.002 \\
.001 \\
.001 \\
.001 \\
\end{array}$ & $\begin{array}{r}2,832,000 \\
2,832,000 \\
4,301,000 \\
9,360,000 \\
8,301,000 \\
12,171,000 \\
5,735,000 \\
11,045,000 \\
112,979,000 \\
131,688,000 \\
22,992,000 \\
7,761,000 \\
907,000 \\
4,673,000 \\
3,467,000 \\
43,188,000 \\
6,726,000 \\
7,439,000 \\
37,494,000 \\
19,275,000 \\
4,531,000 \\
2,039,000 \\
64,711,000 \\
13,820,000 \\
18,139,000 \\
\end{array}$ \\
\hline . Total b, so & of Red D & & & & $558,400,000$ \\
\hline
\end{tabular}

a Tonnage estimates based on 1,770 tons of coal per acre foot. b Rounded. 
The Luman No. 1 coal bed, the most favorable potential source of uranium in the area, contains about 12 million short tons of coal averaging 3.9 -feet in thickness and containing an average of 0.005 percent uranium and 20 percent ash; with 0.030 percent-uranium in the ash. Areas of potentially strippable coal in the northern part of the Red Desert area are shown in plate 45.- Estimates for the northern part of the area; Tps. 23 and 24 N., Rs. 94 and $95 \mathrm{~W}$, are based on data obtained by core drilling in 1952. Estimates of tonnage and uranium content of coal in the other townships of the area are based on samples from surface sections and auger holes obtained in 1951. These latter estimates are probably less reliable, owing to the weathering effects and concealed beds in surface sections and to contamination of the auger hole samples by caving from the sides of the holes.

\section{DESCRIPTION OF CORES}

Lithologic descriptions of coal cores and PMG determinations were made by James M. Schopf at the Geological Survey laboratory at Columbus, Ohio.

PMG values, which are a measure of the beta-gamma radiation in pulses per minute per gram, were made for all sampled intervals using a cup-mounted IB85 GM tube connected to an AEC CGM-3B scaler. The nature and significance of PMG values are explained by Schopf (1954).

Fuels samples listed below each core hole were analyzed by the U.S. Bureau of Mines and data are shown in table 1.

The samples labeled "TE" were analyzed by the Geological Survey. for equivalent uranium, uranium, ash, and uranium in ash. Equivalent uranium is an expression of percent uranium that a sample would contain if all the radioactivity were due only to uranium and its daughter products in equilibrium.

The coals discussed in this report are dominantly banded. The banding is primarily a function of the occurrence of elongate lenses of large fragments of woody trunks and roots of ancient plants. In describing banded coals the important features are (1) the thickness of bands, and (2) the frequency of occurrence of these bands. Thickness and frequency are described using the terms according to the following definitions: 
(1) Thickness of woody bands: ${ }^{1}$

Approx. thickness

Banding

(inches)

Thin $1 / 50^{-1 / 12}$

Medium _-_.-.- 1/12-1/5

Thick -.... 1/5-2

Very thick

(2) Frequency of occurrence-

Percentage of the layer.

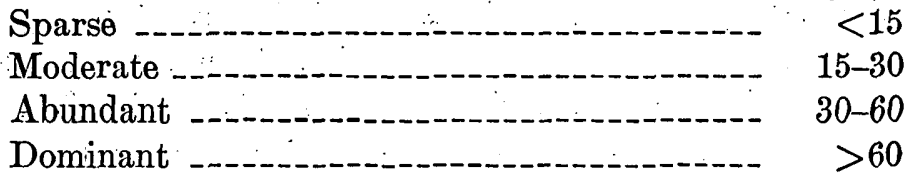

TABLE 4.-Lithologic descriptions of coal cores from the Red Desert area, Sweetwater County, Wyo., showing comparison of PMG values, equivalent uranium, and uranium content of coal

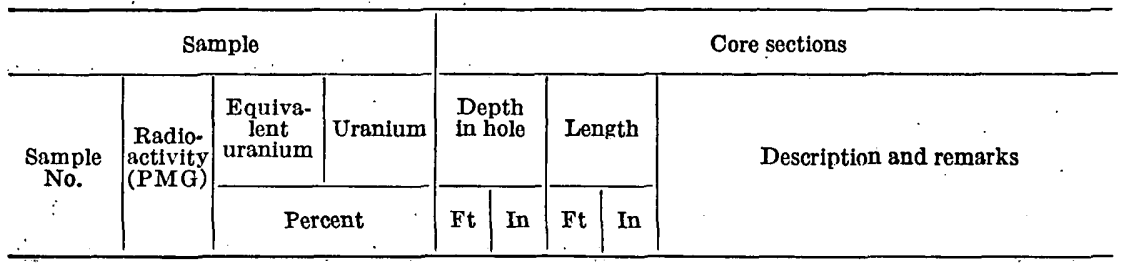

Core hole 1 (SW1/4 SW1/4 sec. 24 , T. 24 N., R. 96 W.) elev, $6,645 \mathrm{ft}$

\begin{tabular}{|c|c|c|c|c|c|c|c|c|}
\hline TE S1.. & 0.4 & 0.001 & $<0.001$ & 63 & $51 / 4$ & & $48 / 4$ & $\begin{array}{l}\text { (Top of core sent to laboratory.) Shale, } \\
\text { medium-and dark-gray; abundant shell } \\
\text { fragments; } 1 / 2 \text {-in of slightly. coaly shale } \\
\text { at } 63 \mathrm{ft} 91 / 2 \text { in. }\end{array}$ \\
\hline TE S2 & $\begin{array}{l}2.4 \\
1.6\end{array}$ & .004 & .002 & $\begin{array}{l}63 \\
64\end{array}$ & $\begin{array}{r}10 \\
0\end{array}$ & & $\begin{array}{l}2 \\
6\end{array}$ & Shale, coaly, grading to shaly coal. \\
\hline TE $\mathbf{S 4}$ & .2 & $<.001$ & $<.001$ & 64 & 6 & & $41 / 4$ & $\begin{array}{l}\text { Coal, moderately thin- and medium- } \\
\text { banded. }\end{array}$ \\
\hline TE S5. & .4 & .001 & .001 & $\begin{array}{l}64 \\
65\end{array}$ & $\begin{array}{c}101 / 4 \\
11 / 4\end{array}$ & & 8 & $\begin{array}{l}\text { Coal, abundantly thin- and medium- } \\
\text { banded. } \\
\text { (Loss in coring interval from } 64 \mathrm{ft} \text { to } 65 \mathrm{ft}\end{array}$ \\
\hline Lab $\mathbf{s} 6 .$. & .5 & & & 65 & 2 & & $91 / 2$ & Shale, light- to medium-gray ; carbonaceous \\
\hline $\begin{array}{l}\text { Lab } S \\
\text { Lab } 8\end{array}$ & .4 & & & $\begin{array}{l}65 \\
66\end{array}$ & $11 \frac{1}{4} / 2$ & ${ }^{i}$ & $\begin{array}{l}51 / 4 \\
71 / 4\end{array}$ & to light-gray, $;$ edium-gray; $1 / 2$-in of coal \\
\hline $\mathbf{T E}$ & .9 & .003 & .001 & 67 & 0 & & 7 & Shale, medium- and dark-gray, carbona- \\
\hline 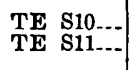 & $\begin{array}{r}1.9 \\
.7\end{array}$ & $\begin{array}{l}.005 \\
.004\end{array}$ & $\begin{array}{l}.005 \\
.001\end{array}$ & $\begin{array}{l}67 \\
67\end{array}$ & 7 & & $7^{21 / 2}$ & $\begin{array}{l}\text { Shale, medium to dark-gray, coaly. } \\
\text { Shale, medium-gray, carbonaceous; } 1 \text {-in } \\
\text { dark-gray clay at } 68 \mathrm{ft} 31 / 2 \text { in. }\end{array}$ \\
\hline $\begin{array}{l}\text { TE } \\
\text { TE } \\
13\end{array}$ & $\begin{array}{l}1.1 \\
1.4\end{array}$ & $\begin{array}{l}.003 \\
.003\end{array}$ & .002 & $\begin{array}{l}68 \\
68\end{array}$ & $\begin{array}{r}41 / 2 \\
101 / 2\end{array}$ & & $\begin{array}{l}6 \\
6\end{array}$ & $\begin{array}{l}\text { Coal, abundantly thin-banded. } \\
\text { Coal, abundantly thin- and medium- } \\
\text { banded. }\end{array}$ \\
\hline $\begin{array}{l}\text { TE S14-.. } \\
\text { TE S15 }\end{array}$ & .7 & $\begin{array}{l}.001 \\
.004\end{array}$ & $\begin{array}{l}.001 \\
.003\end{array}$ & $\begin{array}{l}69 \\
69\end{array}$ & $\begin{array}{l}41 / 2 \\
91 / 2\end{array}$ & & $\begin{array}{l}5 \\
51 / 2\end{array}$ & $\begin{array}{l}\text { Coal, abundantly thin-banded. } \\
\text { Coal, moderately thin- and medium- } \\
\text { banded. }\end{array}$ \\
\hline & .9 & .001 & .001 & 70 & 3 & & 6 & $\begin{array}{l}\text { Coal, abundantly thin- and medium- } \\
\text { banded, } 1 / 4 \text { to } 1 / 2 \text { in pyritic nodules; core } \\
\text { is broken. }\end{array}$ \\
\hline TE & .8 & .001 & .001 & 70 & 9 & & $51 / 4$ & $\begin{array}{l}\text { Coal, abundantly / medium and thin- } \\
\text { banded; slightly pyritic throughout; core } \\
\text { is broken. }\end{array}$ \\
\hline $\mathbf{T E}$ & .9 & .002 & .002 & 71 & $21 / 4$ & & $31 / 4$ & $\begin{array}{l}\text { ndantly thin-banded; } 1 / 4 \text { in } \\
\text { ns at } 71 \text { ft } 28 / 4 \text { in. }\end{array}$ \\
\hline $\mathbf{E}$ & .8 & .001 & .001 & 71 & $61 / 2$ & & 5 & Coal, abundantly thin-banded. \\
\hline
\end{tabular}

1 Woody bands less than $1 / 50$ inch are regarded as a part of attrital coal. 
TABLE 4:- Lithologic descriptions of coal cores from the Red Desert area, Sweetwater County, Wyo., showing comparison of $P M G$ values, equivalent uranium, and uranium content of coal-Continued

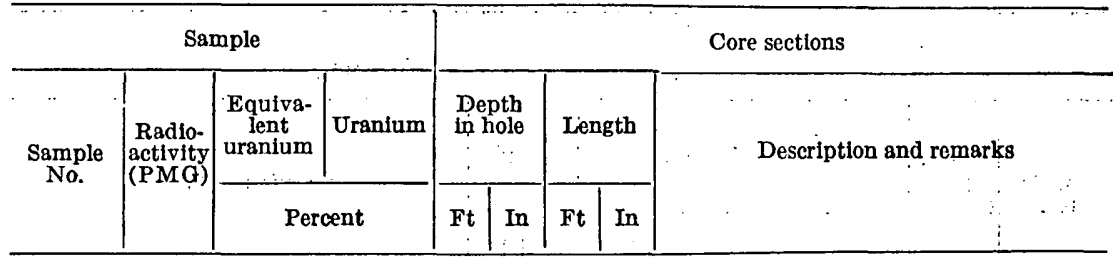

Core hole 1-Continued

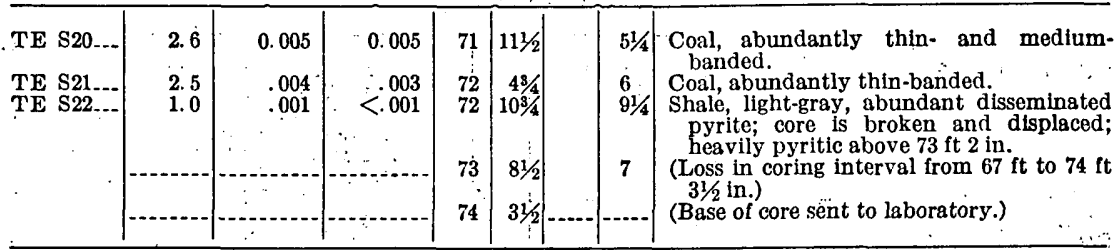

Fuel samples (U. S. Bureau of Mines) from core hole 1:

D-97526 includes TE samples S3-S5.

D-97527 includes TE samples S12-S21.

Core hole $2(\mathrm{SE} 1 / 4$ NW1/4 sec. 16, T. 24 N., R. 95 W.) elev. $6,630 \mathrm{ft}$

\begin{tabular}{|c|c|c|c|c|c|c|c|c|}
\hline CGL 1. & 1.5 & & & 38 & 0 & & $108 / 4$ & $\begin{array}{l}\text { (Top of core sent to laboratory.) Sand- } \\
\text { stone, clayey, light- to medium-gray; } \\
\text { abundant plant impressions; irregular } \\
\text { yellow-brown stains; upper 1/4-in } \\
\text { includes coarse sand grains loosely; } \\
\text { cemented. }\end{array}$ \\
\hline GL 2. & 1.1 & & & 38 & $108 / 4$ & 1 & $11 / 4$ & $\begin{array}{l}\text { Sandstone, clayey, as in above sample; } \\
\text { zone of coarse sand grains, loosely }\end{array}$ \\
\hline GL & 1.4 & & & 40 & 0 & 1 & 0 & $\begin{array}{l}\text { Sandstone, clayey, as in above samples; } \\
1 / 4 \text {-in. gypsum lens in uppermost } 1 / 2 \text { in } \\
\text { and in } 1 / 2 \text {-in loosely cemented coarse- } \\
\text { sand layer at } 39 \mathrm{ft} 111 / 4 \text { in. }\end{array}$ \\
\hline $\begin{array}{l}\text { GL and } \\
\text { TE } 4 .\end{array}$ & 2.0 & 0.005 & 0.003 & 41 & 0 & 1 & 1 & $\begin{array}{l}\text {, carbonaceous } \\
\text { ly broken and }\end{array}$ \\
\hline $\begin{array}{l}\text { CQL and } \\
\text { TE } 5 .\end{array}$ & 1.4 & .003 & .001 & 42 & 1 & 1 & 1 & $\begin{array}{l}\text { Sandstone, clayey, to } 42 \mathrm{ft} 4 \mathrm{in} \text {, then grad- } \\
\text { ing to sandy, light-gray clay; core is } \\
\text { badly broken and dislocated above } 42 \mathrm{ft} \text {. } \\
111 / 2 \text { in; clay is saindy, very carbonaceous, } \\
\text { medium to dark-gray; lowest } 8 / 4 \text { in of } \\
\text { clay is carbonaceous, dark-gray, } 1 / 16-\text { in } \\
\text { coal streaks. }\end{array}$ \\
\hline ." & & & & 43 & 2 & 4 & 10 & $\begin{array}{l}1 \text { ft } 7 \text { in to } \\
\text { t about the } \\
\text { e. The } 42 \\
\text { ay directly. }\end{array}$ \\
\hline E 1... & 1.9 & .004 & .003 & 48 & 0 & & $61 / 4$ & $\begin{array}{l}\text { Coal, abundantly thin- } \\
\text { banded; } 1 / 4 \text {-in discontinuo } \\
11 / 2 \text { in below top. }\end{array}$ \\
\hline E 2... & 3.1 & .005 & .005 & 48 & $61 / 4$ & & $.81 / 2$ & $\begin{array}{l}\text { Coal, sparsely thin- an } \\
\text { a few thick vitrain } \\
\text { streaks at base. }\end{array}$ \\
\hline 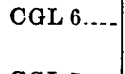 & .4 & & & 49 & $28 / 4$ & & $91 / 4$ & $\begin{array}{l}\text { Sandstone, clayey, and ss } \\
\text { buff, soft, irregularly bec } \\
\text { coaly streaks below } 49 \mathrm{ft}\end{array}$ \\
\hline$G L_{1}$ & .5 & & & 50 & 0 & & 10 & $\begin{array}{l}\text { Ciay, sandy, light-gray to buff; } 1 / 4 \text {-in vitrain } \\
\text { streak at top; } 1 / 4 \text {-in nodules of pyrite at } \\
50 \mathrm{ft} 51 / 2 \text { in and } 50 \mathrm{ft} 7 \mathrm{in} \text {. }\end{array}$ \\
\hline 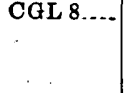 & .9 & & & $\begin{array}{l}50 \\
51\end{array}$ & 10 & & 6 & $\begin{array}{l}\text { Sandstone, clayey, light-buff to light-gray. } \\
\text { crumbly, poorly cemented. } \\
\text { (Loss in coring interval from } 48 \mathrm{ft} \text { to } 51^{\mathrm{l}} \mathrm{ft}\end{array}$ \\
\hline$x_{1} y_{2 .}$ & .7 & & & $\begin{array}{r}51 \\
140\end{array}$ & $\begin{array}{l}6 \\
0\end{array}$ & 88 : & $\begin{array}{r}6 \\
11\end{array}$ & $\begin{array}{l}\text { Shale, clayey, medium-gray, hard; } \\
\text { dant invertebrate fossils and som } \\
\text { scales (?). }\end{array}$ \\
\hline
\end{tabular}


TABde 4.-Lithologic descriptions of coal cores from the Red Deserit area, Sweetwater County, Wyo., showing comparison of $P M G$ values, equivalent iranium, and uranium content of coal-Continued

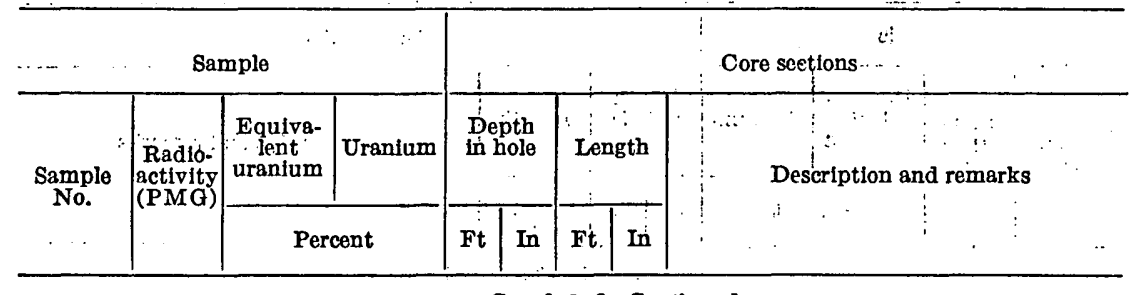

Core hole 2-Continued

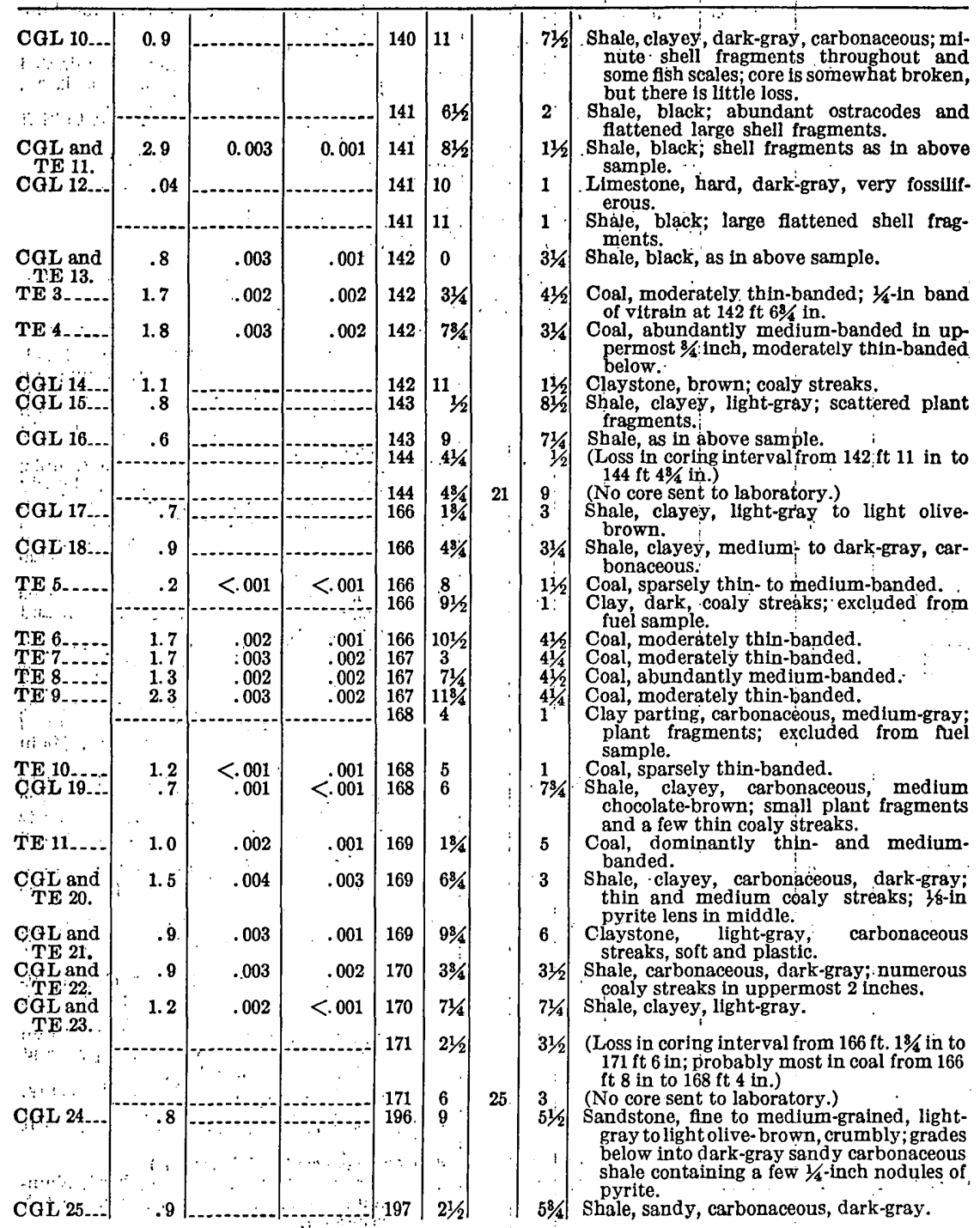


URANIUM-BEARING COAL, RED DESERT AREA, WYO. 201

TABLE 4.-Lithologic descriptions of coal cores from the Red Desert area, Sweetwater County, Wyo., showing comparison of PMG values, equivalent uranium, and uranium content of coal-Continued

\begin{tabular}{|c|c|c|c|c|c|c|c|c|}
\hline \multicolumn{4}{|c|}{ Sample } & \multicolumn{5}{|c|}{ Core sections } \\
\hline \multirow{2}{*}{$\begin{array}{c}\text { Sample } \\
\text { No. }\end{array}$} & \multirow{2}{*}{$\begin{array}{l}\text { Radio- } \\
\text { actir 1ty } \\
\text { (PMG) }\end{array}$} & \multirow{2}{*}{$\frac{\begin{array}{c}\text { Equiva- } \\
\text { lent } \\
\text { uranium }\end{array}}{\text { Perc }}$} & \multirow{2}{*}{$\frac{\text { Uranium }}{\text { cent }}$} & \multicolumn{2}{|c|}{$\begin{array}{l}\text { Depth } \\
\text { in hole }\end{array}$} & \multicolumn{2}{|c|}{ Length } & \multirow[t]{2}{*}{ Description and remarks } \\
\hline & & & & Ft & In & Ft & In & \\
\hline
\end{tabular}

Core hole 2 - Continued

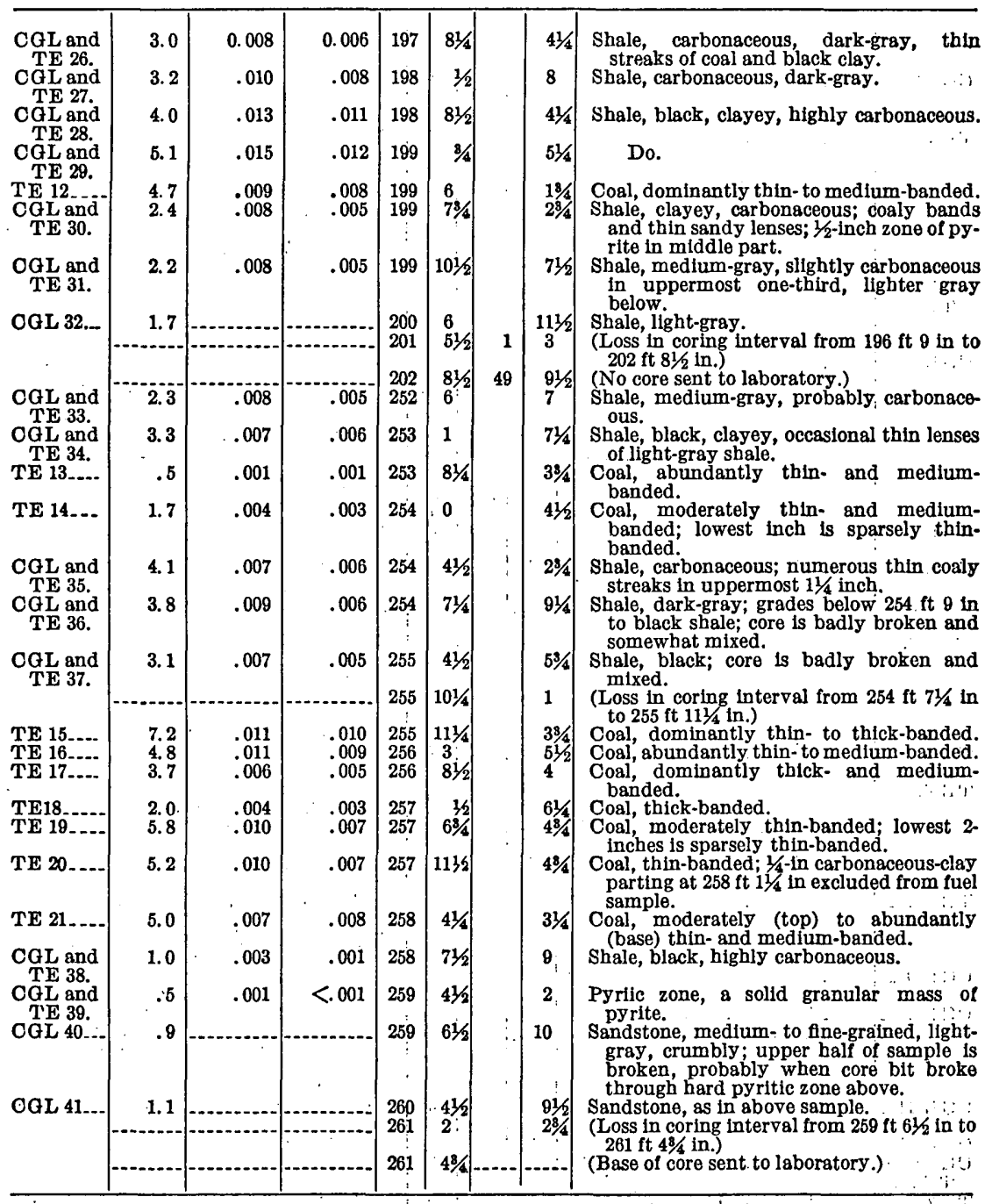

Fuel samples (U. S. Bureau of Mines) from core hole 2:

D-96784 includes TE samples 1-2.

D-96785 includes. TE samples 3-4.

D-96786 includes TE samples 5-10.

D-96787. includes TE samples 13-14.

D-96788 includes TE samples 15-21. 
TABLE 4.-Lithologic descriptions of coal cores from the Red Desert area,"Sweetwater County, Wyo., showing comparison of. PMG values, equivalent uranium, and uranium content of coal-Continued

\begin{tabular}{|c|c|c|c|c|c|c|c|c|}
\hline \multicolumn{4}{|c|}{ Sample } & \multicolumn{5}{|c|}{ Core sections } \\
\hline \multirow{2}{*}{$\begin{array}{c}\text { Sample } \\
\text { No. }\end{array}$} & \multirow{2}{*}{$\begin{array}{l}\text { Radio- } \\
\text { activity } \\
\text { (PMG) }\end{array}$} & \multirow{2}{*}{$\frac{\begin{array}{c}\text { Equiva- } \\
\text { lent } \\
\text { uranium }\end{array}}{\text { Per }}$} & \multirow[t]{2}{*}{ Uranium } & \multicolumn{2}{|c|}{$\begin{array}{l}\text { Depth } \\
\text { in hole }\end{array}$} & \multicolumn{2}{|c|}{ Length } & Description and remarks \\
\hline & & & & $\mathbf{F t}$ & In & $\mathrm{Ft}$ & In & 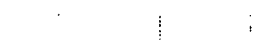 \\
\hline
\end{tabular}

Core hole 3 (NW1/4SW1 $\frac{4}{4}$ sec. 21 ; T. 24 N., R. 95 W.) elev. 6,610 ft.

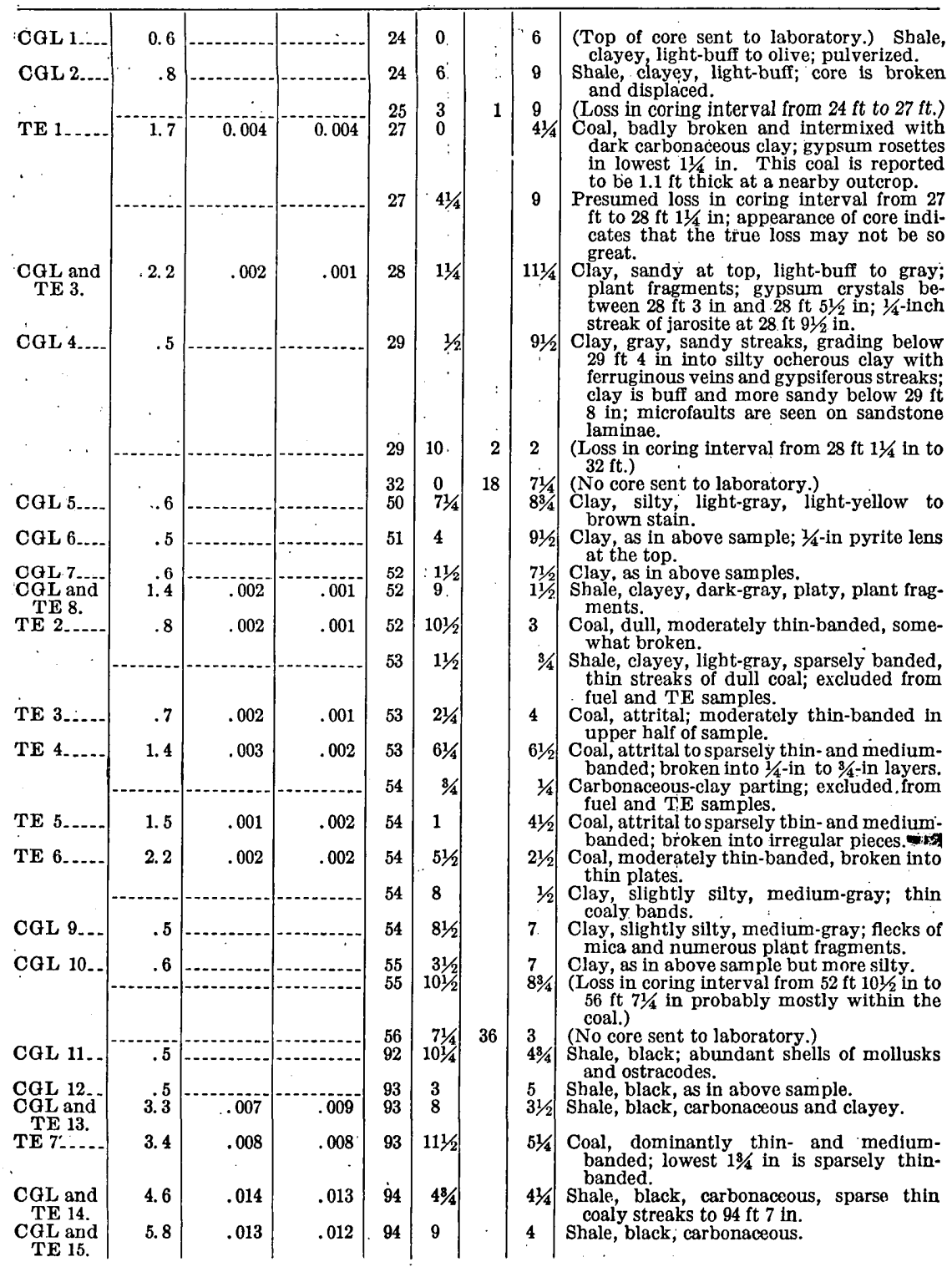


TABLE 4.-Lithologic descriptions of coal cores from the Red Desert area, Sweetwater County, Wyo., showing. comparison of PMG values, equivalent uranium, and uranium content of coal-Continued

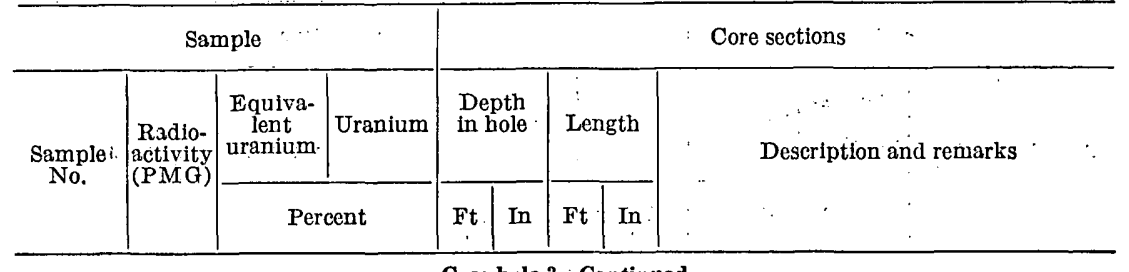

Core hole 3 -Continued

\begin{tabular}{|c|c|c|c|c|c|c|c|c|}
\hline $\begin{array}{l}\text { CGL and } \\
\text { TE } 16 .\end{array}$ & 1.6 & 0.006 & 0.004 & 95 & 1 & & $101 / 2$ & $\begin{array}{l}\text { Clay, medium-gray, grading into shale be- } \\
\text { low } 95 \mathrm{ft} 4 \text { in; core is badly broken and } \\
\text { somewhat mixed. }\end{array}$ \\
\hline CGL and & 1.4 & .005 & .004 & 95 & $111 / 2$ & & $91 / 2$ & Shale, clayey, medium-gray. \\
\hline $\begin{array}{l}\text { TE } 17 \\
\text { CGL and } \\
\text { TE } 18 .\end{array}$ & 2.2 & .007 & .005 & 96 & 9 & & 5 & $\begin{array}{l}\text { Shale, carbonaceous, medium-gray, thin } \\
\text { light-gray laminae; thin coaly streaks } \\
\text { below } 97 \mathrm{ft} 11 / 2 \text { in. }\end{array}$ \\
\hline $\begin{array}{l}\text { CGL and } \\
\text { TE } 19 .\end{array}$ & 1.2 & .005 & .004 & 97 & 2 & & $41 / 2$ & Shale, clayey, light- to medium-gray. \\
\hline & & & & 97 & $61 / 2$ & 3 & $11 / 4$ & $\begin{array}{l}\text { (Loss in coring interval from } 95 \mathrm{ft} 1 \text { in to } \\
97 \mathrm{ft} 73 / 4 \text { in.) } \\
\text { (No core sent to laboratory.) }\end{array}$ \\
\hline $\begin{array}{l}\text { CGL and } \\
\text { TE } 20 .\end{array}$ & 1.4 & .004 & .004 & 100 & $10^{3} / 4$ & & $58 / 4$ & Shale, medium-gray, slightly carbonaceous. \\
\hline $\begin{array}{l}\text { CGL and } \\
\text { TE } 21 .\end{array}$ & 3.2 & .006 & .007 & 101 & $41 / 2$ & & $41 / 2$ & $\begin{array}{l}\text { Shale, medium-gray; occasional thin streaks } \\
\text { of vitrain; darker and carbonaceous be- } \\
\text { low } 101 \mathrm{ft} .6 \% 4 \text { in, scattered coarse quart } \\
\text { grains. }\end{array}$ \\
\hline $\begin{array}{l}\text { CGL and } \\
\text { TE } 22 .\end{array}$ & 1.3 & .005 & .003 & 101 & 9 & & 4 & $\begin{array}{l}\text { Shale, gray to light-brown, silty; grading } \\
\text { to sandstone below } 102 \mathrm{ft} \text {. }\end{array}$ \\
\hline & & & & 102 & 1 & 2 & $3 \%$ & $\begin{array}{l}\text { (Loss in coring apparently accumulated in } \\
\text { interval from } 100 \mathrm{ft} 103 / 4 \text { in to } 104 \mathrm{ft} 48 / 4 \\
\text { in.) }\end{array}$ \\
\hline & & & & $\begin{array}{l}104 \\
128\end{array}$ & $\begin{array}{l}48 / 4 \\
91 / 2\end{array}$ & 24 & $\begin{array}{l}48 / 4 \\
31 / 2\end{array}$ & $\begin{array}{l}\text { (No core sent to laboratory.) } \\
\text { (Core section apparently omitted from }\end{array}$ \\
\hline CGiL and & i. 5 & .005 & .004 & 129 & 1 & & $51 / 2$ & Shale, medium-gray, light-gray streaks. \\
\hline CGL and & 3.1 & .006 & .005 & 129 & $61 / 2$ & & 2. & $\begin{array}{l}\text { Shale, dark-gray, carbonaceous, lighter } \\
\text { streaks at top; lowest } 1 / 8 \text { in is coaly. }\end{array}$ \\
\hline TE $8 \ldots$ & 1.4 & .003 & .002 & 129 & $81 / 2$ & & 4: & $\begin{array}{l}\text { Coal, sparsely thin-banded above and } \\
\text { abundantly thin-banded below } 129 \mathrm{ft} \\
10 \text { in. }\end{array}$ \\
\hline TE 9 & 4.3 & .007 & .006 & 130 & $1 / 2$ & & 4 & Coal, moderately thin- and medium. \\
\hline CGL and & .3 .0 & .008 & .007 & 130 & $41 / 2$ & & $31 / 4$ & Shale, black; uppermost $11 / 2$ in is coaly. \\
\hline CGL and & 1.4 & .004 & .003 & 130 . & $78 / 4$ & & $41 / 2$ & Shale, carbonaceous, dark-gray. \\
\hline CGL and & 2.9 & .007 & .005 & 131 & $1 / 4$ & & $21 / 4$ & Shale, black; thin coaly streaks. \\
\hline $\begin{array}{l}\text { CGL and } \\
\text { TE } 28 .\end{array}$ & 1.5 & .005 & .003 & 131 & $21 / 2$ & & $3^{3} / 4$ & $\begin{array}{l}\text { Shale, carbonaceous, dark-gray; core is } \\
\text { somewhat broken and displaced. }\end{array}$ \\
\hline $\begin{array}{l}\text { CGL and } \\
\text { TE } 29 .\end{array}$ & 2.3 & .006 & .006 & 131 & $61 / 4$ & & 6 & $\begin{array}{l}\text { Shale, coaly or carbonaceous; core is badly } \\
\text { broken and mixed. }\end{array}$ \\
\hline $\begin{array}{l}\text { CGL and } \\
\text { TE } 30 \text {. }\end{array}$ & 1.9 & .006 & .004 & 132 & $1 / 4$ & & $41 / 2$ & $\begin{array}{l}\text { Shale, medium-gray; core is badly broken } \\
\text { and mixed. }\end{array}$ \\
\hline CGL and & 2.5 & .006 & .004 & 132 & $48 / 4$ & & $41 / 4$ & $\begin{array}{l}\text { Shale, carbonaceous, dark- to light-gray; } \\
\text { core is badly broken and mixed. }\end{array}$ \\
\hline TE 1 & 2.2 & .004 & .004 & 132 & 9 & & $48 / 4$ & $\begin{array}{l}\text { Coal, and carbonaceous shale; core is badly } \\
\text { broken and mixed. }\end{array}$ \\
\hline $\begin{array}{l}\text { TE } 11 \\
\text { TE } 12 \text {. }\end{array}$ & $\stackrel{1}{1.5}$ & $\begin{array}{r}<.001 \\
.003\end{array}$ & $\begin{array}{r}<.001 \\
.002\end{array}$ & $\begin{array}{l}133 \\
133\end{array}$ & $\begin{array}{l}18 / 4 \\
43 / 4\end{array}$ & & $\begin{array}{l}3 \\
51 / 4\end{array}$ & $\begin{array}{l}\text { Coal, moderately thin- and thick-banded. } \\
\text { Coal, sparsely thin-and thick-banded; core }\end{array}$ \\
\hline $\begin{array}{l}\text { TE } 13 \\
\text { CQL and } \\
\text { TE } 32 .\end{array}$ & $\begin{array}{l}4.2 \\
2.8\end{array}$ & $\begin{array}{r}.006 \\
.009\end{array}$ & .005 & $\begin{array}{l}133 \\
134\end{array}$ & $\begin{array}{r}10 \\
0\end{array}$ & ? & $\begin{array}{l}2 \\
63 / 4\end{array}$ & $\begin{array}{l}\text { Coal, sparsely thin-banded. } \\
\text { Shale, carbonaceous, clayey, dark- to me- } \\
\text { dium-gray; sparse thin coal streaks; ex- }\end{array}$ \\
\hline TE 14 & 2.4 & .006 & .005 & 134 & $68 / 4$ & & $61 / 4$ & Coal, sparsely thin-banded; 1-16-in pyritic \\
\hline TE 15 . & 3.9 & .009 & .008 & 135 & 1 & & 5 & $\begin{array}{l}\text { Coal, sparsely thin- and medium-banded, } \\
\text { pyritic facings; } 1 / 2 \text {-in vitrain band at } 135\end{array}$ \\
\hline TE 16 & 1.6 & $.008^{\circ}$ & .008 & 135 & 6 & & $53 / 4$ & Coal, moderately thin-banded, a total of \\
\hline TE 17 & 1.4 & .003 & .003 & 135 & $118 / 4$ & & $61 / 4$ & Coal, dominantly thin- to medium-banded; \\
\hline TE 18 & 2.7 & .004 & $\because: 005$ & 136 & 6 & & $41 / 2$ & Coal, abundantly thin- and medium- \\
\hline $\mathbf{T}$ & 5.2 & 007 & .007 & 136 & $101 / 2$ & & $48 / 4$ & Coal, dominantly bright; three $1 / 4$-in \\
\hline TE $20 \ldots$ & 2.4 & .004 & $\therefore \cdot .004$ & 137 & $31 / 4$ & & $38 / 4$ & $\begin{array}{l}\text { Codl; wioderately thin- and medium- } \\
\text { banded. }\end{array}$ \\
\hline
\end{tabular}




\section{URANIUM IN COAL IN THE WESTERN UNITED STATES}

TABLE 4.-Lithologic descriptions of coal cores from the Red Desert area, Sweetwater County, Wyo., showing. comparison of PMG values, equivalent uranium, and uranium content of coal-Continued

\begin{tabular}{|c|c|c|c|c|c|c|c|c|}
\hline \multicolumn{4}{|c|}{ Sample } & \multicolumn{5}{|c|}{ Core sections } \\
\hline \multirow{2}{*}{$\begin{array}{l}\text { Sample. } \\
\text { No. }\end{array}$} & \multirow{2}{*}{$\begin{array}{l}\text { Radio- } \\
\text { activity } \\
\text { (PMG) }\end{array}$} & \multirow{2}{*}{$\frac{\begin{array}{c}\text { Equiva- } \\
\text { lent } \\
\text { uranlum }\end{array}}{\text { Perc }}$} & \multirow[t]{2}{*}{ Uranium } & \multicolumn{2}{|c|}{$\begin{array}{l}\text { Depth } \\
\text { in hole }\end{array}$} & \multicolumn{2}{|c|}{ Length } & \multirow{2}{*}{ Description and remarks } \\
\hline & & & & Ft & In & Ft & In & \\
\hline
\end{tabular}

Core hole 3-Continued

\begin{tabular}{|c|c|c|c|c|c|c|c|c|}
\hline $\begin{array}{l}\text { CGL and } \\
\text { TE 33. } \\
\text { CGL 34..- } \\
\text { CGL 35... } \\
\text { CGL 36..- } \\
\text { CGL 37..- } \\
\text { CGL 38... } \\
. .\end{array}$ & $\begin{array}{r}0.9 \\
\\
.5 \\
.4 \\
.5 \\
.9 \\
.7\end{array}$ & 0.003 & $\begin{array}{c}0.002 \\
0 \\
0 \\
0\end{array}$ & $\begin{array}{r}137 \\
138 \\
138 \\
139 \\
140 \\
140 \\
1 \\
142\end{array}$ & \begin{tabular}{c|}
7 \\
1 \\
8 \\
9 \\
10 \\
$108 / 4$ \\
0
\end{tabular} & 1 & $\begin{array}{c}1 \\
8 / 4 \\
11 / 4 \\
\vdots\end{array}$ & $\begin{array}{l}\text { Shale, black, occasional coaly streaks. . } \\
\text { Shale, medium-gray, light-gray streaks. } \\
\text { Shale, as in above sample, becoming darker, } \\
\text { merging with sample below. } \\
\text { Shale, carbonaceous, dark-gray; 1-in. } \\
\text { pyritic nodule at } 139 \text { ft } 101 / 2 \text { in. } \\
\text { Pyritic zone, granular. } \\
\text { Sandstone, fine- to. medium-grained, } \\
\text { crumbly, loosely. cemented; a few } 1 / 4-\text {-in. } \\
\text { pyritic nodules. } \\
\text { (Base of core sent to laboratory.) }\end{array}$ \\
\hline
\end{tabular}

Fuel samples (U. S. Bureau of Mines) from core hole 3:

D-96781 includes TE samples 2-6.

D-96782 includes TE samples 8-9.

D-86783 includes TE samples 11-20 and 32.

Core hole 4 (SE $1 / 4$ NW1/4 sec. 28 , T. 24 N., R. 95 W.) elev. 6,610 ft.

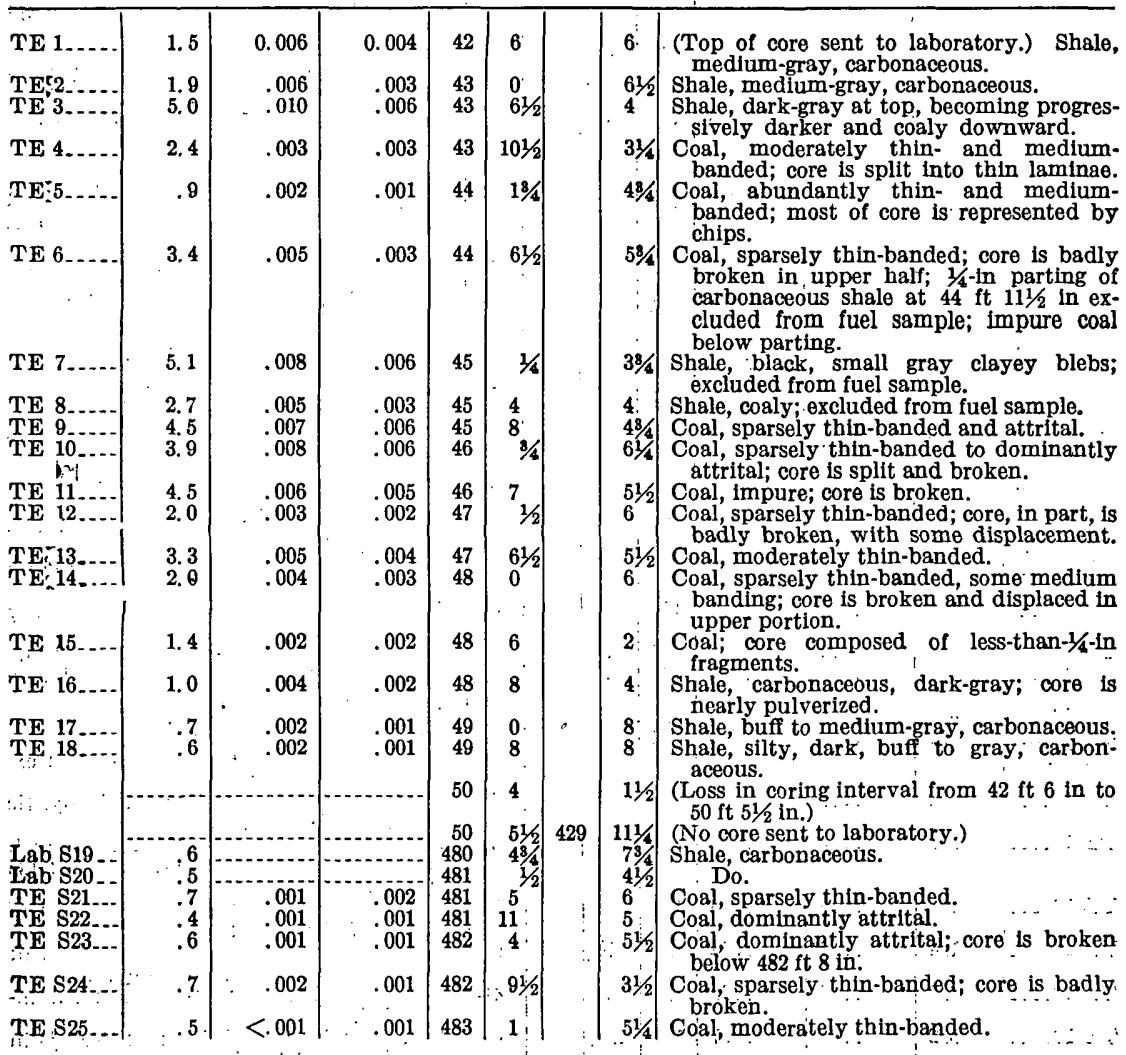


TABLE 4--Lithologis descriptions of coal cores from the Red Desert area, Sweetwater County; Wyo., showing comparison of PMG values, equivalent uranium, and uranium content of coal-Continued

\begin{tabular}{|c|c|c|c|c|c|c|c|c|c|}
\hline \multicolumn{4}{|c|}{ Sample : } & \multicolumn{6}{|c|}{ Core sections } \\
\hline \multirow{2}{*}{$\begin{array}{l}\text { Sample } \\
\text { No. }\end{array}$} & \multirow{2}{*}{$\begin{array}{l}\text { Radio- } \\
\text { activity } \\
\text { (PMG) }\end{array}$} & \multirow{2}{*}{$\begin{array}{r}\begin{array}{c}\text { Equiva. } \\
\text { lent } \\
\text { uranium }\end{array} \\
\text { Per }\end{array}$} & \multirow{2}{*}{$\frac{\text { Uranium }}{\text { cent }}$} & \multicolumn{2}{|c|}{$\begin{array}{l}\text { Depth } \\
\text { in hole }\end{array}$} & \multicolumn{2}{|c|}{ Length } & \multirow{2}{*}{$\begin{array}{l}\text { Description and remarks, } \\
\because \quad \cdots\end{array}$} & $\because$ \\
\hline & & & & Ft & In. & Ft & In & & \\
\hline
\end{tabular}

Core hole 4-Continued

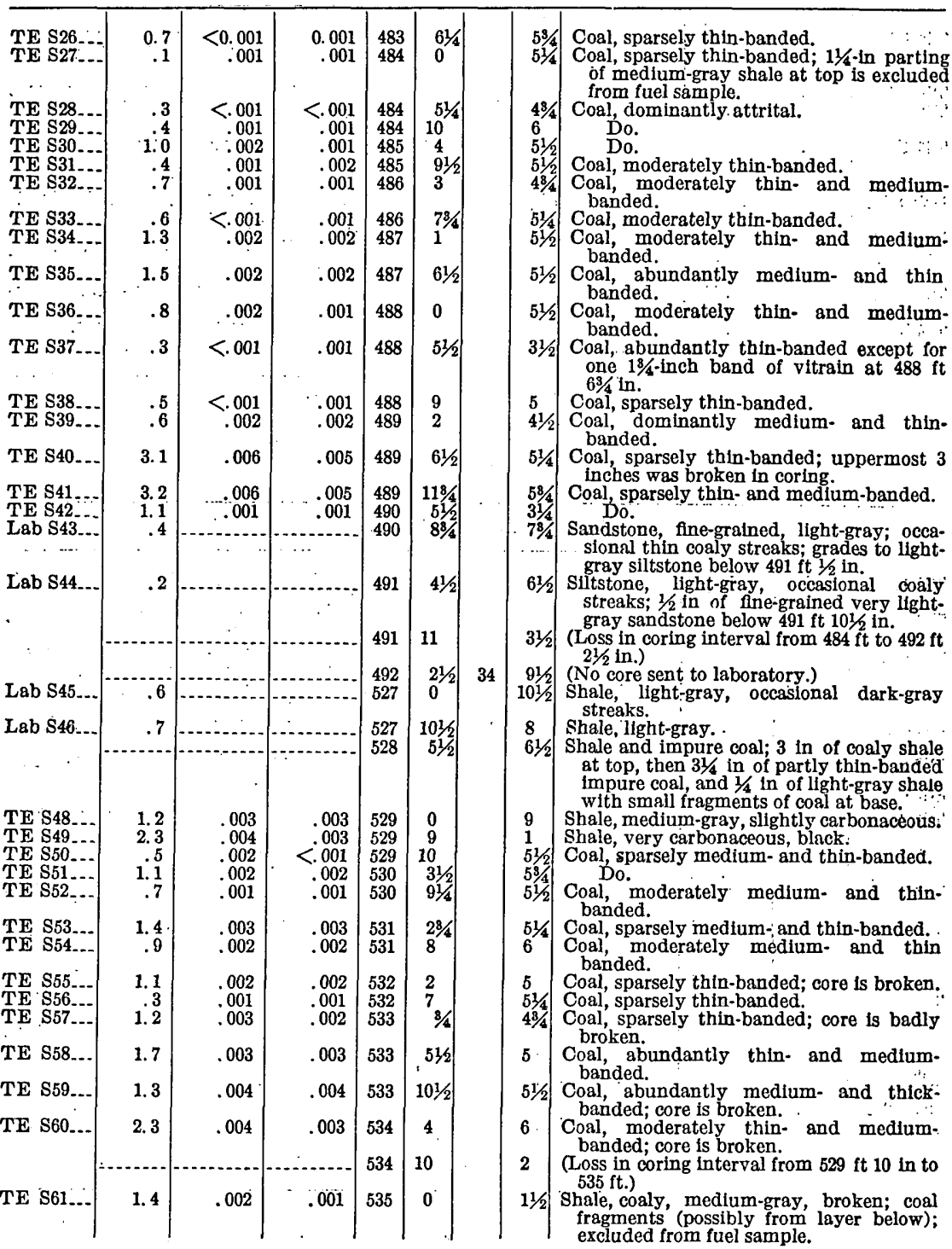


TABLE 4.-Lithologic descriptions of coal cores from the Red Desert area, Sweetwater County, Wyo., showing.comparison of PMG values, equivalent uranium, and uranium content of coal-Continued

\begin{tabular}{|c|c|c|c|c|c|c|c|c|}
\hline \multicolumn{4}{|c|}{ Sample } & \multicolumn{5}{|r|}{ ' Core sections } \\
\hline \multirow{2}{*}{$\begin{array}{l}\text { Sample } \\
\text { No. }\end{array}$} & \multirow{2}{*}{$\begin{array}{l}\text { Radio- } \\
\text { activity } \\
\text { (PMG) }\end{array}$} & \multirow{2}{*}{$\frac{\begin{array}{c}\text { Equiva- } \\
\text { lent } \\
\text { uranium }\end{array}}{\text { Per }}$} & \multirow[t]{2}{*}{ Uranium } & \multicolumn{2}{|c|}{$\begin{array}{l}\text { Depth } \\
\text { in hole }\end{array}$} & \multicolumn{2}{|c|}{ Length } & \multirow[t]{2}{*}{ Description and remarks } \\
\hline & & & & Ft & In & $\mathrm{Ft}$ & In & \\
\hline
\end{tabular}

\section{Core hole 4-Continued}

\begin{tabular}{|c|c|c|c|c|c|c|c|c|}
\hline TE S62... & 1.0 & 0.002 & 0.002 & 535 & $11 / 2$ & & $41 / 2$ & $\begin{array}{l}\text { Coal, abundantly medium- and thin- } \\
\text { banded; upper } 1 \frac{1}{2} \text { in was broken in cor- } \\
\text { ing. }\end{array}$ \\
\hline $\begin{array}{l}\text { TE S63.-. } \\
\text { TE S64... }\end{array}$ & .7 & .001 & .001 & $\begin{array}{l}535 \\
535\end{array}$ & $\begin{array}{l}6 \\
93 / 4\end{array}$ & & $\begin{array}{l}33 / 4 \\
6\end{array}$ & $\begin{array}{l}\text { Coal, sparsely thin-banded; core is broken. } \\
\text { Shale, silty, light-gray, slightly carbonace- }\end{array}$ \\
\hline TE S65 & .7 & .003 & .001 & 536 & $33 / 4$ & & $81 / 4$ & $\begin{array}{l}\text { Shale, silty, light-gray, occasional coal frag. } \\
\text { ments. }\end{array}$ \\
\hline Lab S66.. & .6 & & & $\begin{array}{l}537 \\
584\end{array}$ & $\begin{array}{l}0 \\
9\end{array}$ & 47 & 9 & $\begin{array}{l}\text { (No core sent to laboratory.) } \\
\text { Shale, silty, light-gray; lower } 1 / 4 \text { in is }\end{array}$ \\
\hline $\begin{array}{l}\text { Lab } S 67 .- \\
\text { Lab } \mathbf{S} 68 .\end{array}$ & .1 & & & $\begin{array}{l}585 \\
585\end{array}$ & $\frac{11 / 2}{71 / 2}$ & & $\begin{array}{l}6 \\
6\end{array}$ & $\begin{array}{l}\text { Coal, moderately thin-banded. } \\
\text { Coal, abundantly thin- and medium- }\end{array}$ \\
\hline TE S69 & 1.4 & .003 & .004 & 586 & $11 / 2$ & & $48 / 4$ & $\begin{array}{l}\text { Coal, moderately medium- and thin- } \\
\text { banded. }\end{array}$ \\
\hline TE S70 & .8 & .003 & .001 & $\begin{array}{l}586 \\
587\end{array}$ & $\begin{array}{l}61 / 4 \\
2\end{array}$ & & $78 / 4$ & $\begin{array}{l}\text { Shale, medium-gray; slightly coaly. } \\
\text { (Base of core sent to laboratory.) }\end{array}$ \\
\hline
\end{tabular}

Fuel samples (U. S. Bureau of Mines):

D-96789 includes TE samples 4-15.

D-97235 includes TE samples S21-S42.

D-97237 includes TE samples S50-S63.

D-97236 includes TE samples S67-S69.

Core hole 5 (SE1/4N W1/4 sec. 15 , T. 24 N., R. 95 W.) elev. $6,580 \mathrm{ft}$

\begin{tabular}{|c|c|c|c|c|c|c|c|}
\hline TE 1. & 3.5 & 0.007 & 0.006 & 99 & 313 & 238 & (Top of core sent to laboratory.) Coal, \\
\hline TE & $\begin{array}{l}2.4 \\
4.0 \\
2.2\end{array}$ & $\begin{array}{l}.006 \\
.009 \\
.006\end{array}$ & $\begin{array}{l}.005 \\
.007 \\
.005\end{array}$ & $\begin{array}{l}99 \\
99 \\
99\end{array}$ & \begin{tabular}{c|}
6 \\
9 \\
$111 / 2$
\end{tabular} & $\begin{array}{l}3 \\
21 / 2 \\
6\end{array}$ & $\begin{array}{l}\text { Shale, clayey, slightly carbonaceous, coaly. } \\
\text { Shale, black, coaly. } \\
\text { Coal, sparsely thin- and medium-banded; }\end{array}$ \\
\hline E 5 & 3.9 & .011 & .008 & 100 & $51 / 2$ & $41 / 2$ & Shale, black, coaly; becomes shaly coal \\
\hline CGL & 2.7 & .008 & .005 & 100 & 10 & $31 / 2$ & Shale, medium-gray, slightly carbona- \\
\hline TE 6 & 3.9 & .008 & .006 & 101 & $11 / 2$ & $61 / 2$ & Shale, black, coaly streaks; more coaly \\
\hline $\begin{array}{l}\text { TE } 7 \\
\text { TE } 8\end{array}$ & $\begin{array}{l}4.2 \\
3.8\end{array}$ & .011 & $\begin{array}{l}.008 \\
.014\end{array}$ & $\begin{array}{l}101 \\
102\end{array}$ & $\begin{array}{l}8 \\
0\end{array}$ & $\begin{array}{l}4 \\
5\end{array}$ & $\begin{array}{l}\text { Coal, abundantly thin-banded. } \\
\text { Coal, moderately thin- and medium- } \\
\text { banded; attritol-coal zone from } 102 \mathrm{ft} 1 \frac{2}{2} \\
\text { in to } 102 \mathrm{ft} .21 / 2 \mathrm{in} \text {. }\end{array}$ \\
\hline $\begin{array}{l}\text { TE } 9 \\
\text { TE } 1\end{array}$ & $\begin{array}{l}5.7 \\
6.9\end{array}$ & .011 & .008 & $\begin{array}{l}102 \\
102\end{array}$ & $\begin{array}{r}5 \\
11\end{array}$ & $\begin{array}{l}6 \\
6\end{array}$ & Coal, mostly sparsely thin-banded. \\
\hline TE & 3.1 & .006 & .006 & 103 & 5 & 5 & $\begin{array}{l}\text { Coal, moderately thin- and medium. } \\
\text { banded; } 1 / 4-\mathrm{ln} \text { band of vitrain at } 103 \mathrm{ft} \\
83 / 4 \text { in. }\end{array}$ \\
\hline $\begin{array}{l}\mathrm{TE} \\
\mathrm{TE}\end{array}$ & $\begin{array}{l}3.0 \\
3.7\end{array}$ & $\begin{array}{l}.006 \\
.015\end{array}$ & $\begin{array}{l}.006 \\
.013\end{array}$ & $\begin{array}{l}103 \\
104\end{array}$ & $\begin{array}{c}10 \\
23 / 4\end{array}$ & $\begin{array}{l}43 / 4 \\
51 / 4\end{array}$ & $\begin{array}{l}\text { Coal, attrital or sparsely thin-banded. } \\
\text { Clay, dark-gray, soft, carbonaceous; grad- } \\
\text { ing to dark-gray carbonaceous shale } \\
\text { below } 104 \mathrm{ft} 5 \text { in; some disturbance of top } \\
\text { clay during drilling. }\end{array}$ \\
\hline $\begin{array}{l}\text { TE } 14 \\
\text { TE } 15 \\
\text { CGL } 2\end{array}$ & $\begin{array}{r}3.2 \\
2.5 \\
.6\end{array}$ & $\begin{array}{r}012 \\
.010\end{array}$ & $\begin{array}{r}.009 \\
.008\end{array}$ & $\begin{array}{l}104 \\
105 \\
105\end{array}$ & $\begin{array}{l}8 \\
2 \\
71 / 2\end{array}$ & $\begin{array}{l}6 \\
51 / 2 \\
81 / 2\end{array}$ & $\begin{array}{l}\text { Shale, clayey, dark-gray, carbonaceous. } \\
\text { Shale, dark-gray, carbonaceous. } \\
\text { Sandstone, poorly sorted, greenish. }\end{array}$ \\
\hline & & & & 106 & & & $\begin{array}{l}106 \mathrm{ft} 43 / 4 \text { in.) } \\
\text { (Base of core sent to laboratory.) }\end{array}$ \\
\hline
\end{tabular}

Fuel sample (U. S. Bureau of Mines):

D-96790 includes TE samples 7-12. 
TABLE 4.-Lithologic descriptions of coal cores from the Red Desert area; Sweet-: water County, Wyo., showing comparison of PMG values, equivalent uranium, and uranium content of coal-Continued

\begin{tabular}{|c|c|c|c|c|c|c|c|c|c|}
\hline \multicolumn{4}{|c|}{ Sample } & \multicolumn{6}{|c|}{ Core sections } \\
\hline \multirow{2}{*}{$\begin{array}{c}\text { Sample } \\
\text { No. }\end{array}$} & \multirow{2}{*}{$\begin{array}{l}\text { Radio- } \\
\text { activity } \\
\text { (PMG) }\end{array}$} & \multirow{2}{*}{$\frac{\begin{array}{c}\text { Equiva- } \\
\text { lent } \\
\text { uranium }\end{array}}{\text { Per }}$} & \multirow[t]{2}{*}{ Uranium } & \multicolumn{2}{|c|}{$\begin{array}{l}\text { Depth } \\
\text { in hole }\end{array}$} & \multicolumn{2}{|c|}{ Length } & Description and remarks & \\
\hline & & & & Ft & In & Ft & In & . & \\
\hline
\end{tabular}

Core hole 6 (SW $1 / 4$ NE $1 / 4$ sec. 10, T. 24 N., R. 95 W.) elev. 6,605 ft

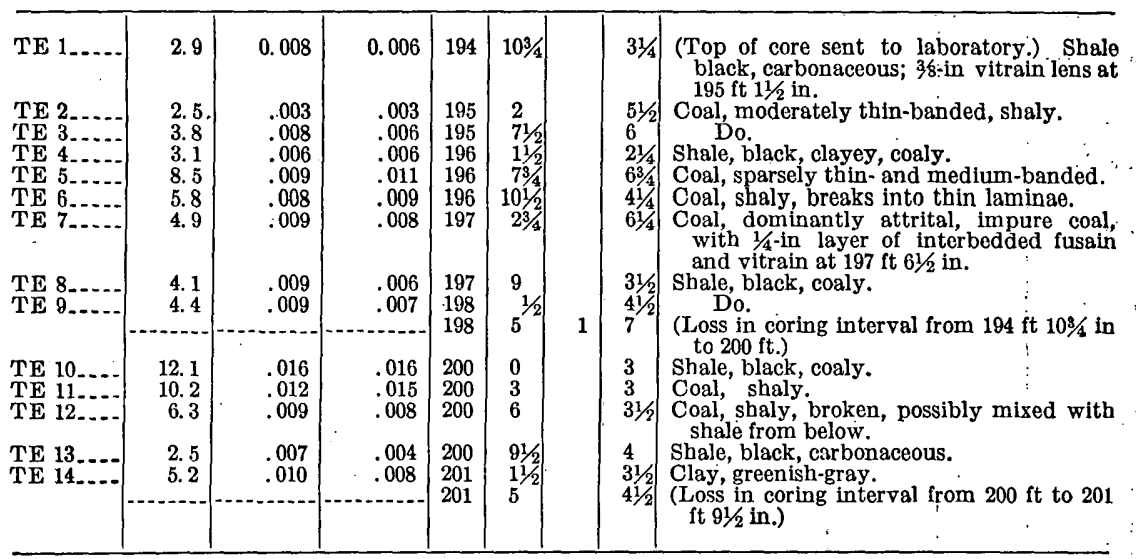

Fuel sample (U.S. Bureau of Mines) from core hole 6:

D-96791 includes TE samples 2-12.

Core hole 7 (NW1/4SW1/4 sec. 20, T. 24 N., R. 95 W.) elev. 6,560 ft

\begin{tabular}{|c|c|c|c|c|c|c|c|}
\hline TE S1.... & 1.7 & 0.005 & 0.003 & 37 & $1 / 2$ & $61 / 2$ & $\begin{array}{l}\text { (Top of core sent to laboratory.) Shale, } \\
\text { dark-gray, carbonaceous; } 1 / 2 \text {-in black and }\end{array}$ \\
\hline - & & & & & & & coaly shale at $37 \mathrm{ft} 61 / 2$ in. \\
\hline E S2.. & 2.7 & .003 & .003 & 37 & 7 & $31 / 2$ & Coal, dominantly attrital. \\
\hline S3.... & 2.0 & .002 & .002 & 37 & $101 / 2$ & 4 & Coal, sparsely thin-banded. \\
\hline E S4 & & .007 & .004 & 38 & $21 / 2$ & $31 / 2$ & Shale, black, coaly, uppermost $1 / 4$ in is \\
\hline TÉ S5.. & 1.3 & .002 & .002 & 38 & 6 & 6 & $\begin{array}{l}\text { Coal, sparsely thin-banded, } 1 / 2 \text {-in band } \\
\text { of vitrain at } 38 \mathrm{ft} 81 / 4 \text { in.; core is broken } \\
\text { into } 1 / 2 \text {-in. layers and disarranged. }\end{array}$ \\
\hline TE $S 6 \ldots$ & 3.8 & .004 & .003 & 39 & 0 & 2 & Coal, sparsely thin-banded. \\
\hline T & 2.8 & .007 & .004 & 39 & 2 & 2 & $\begin{array}{l}\text { Shale, carbonaceous, dark-gray; excluded } \\
\text { from fuel sample. }\end{array}$ \\
\hline $\begin{array}{l}\text { TE S8 } \\
\text { TE S9. }\end{array}$ & $\begin{array}{l}2.5 \\
1.4\end{array}$ & .004 & $\begin{array}{l}.003 \\
.003\end{array}$ & $\begin{array}{l}39 \\
39\end{array}$ & 4 & $\begin{array}{l}4 \\
4\end{array}$ & $\begin{array}{l}\text { Coal, dominantly attrital. } \\
\text { Do. }\end{array}$ \\
\hline TE S10... & 2.6 & .004 & .004 & 40 & 0 & 6 & $\begin{array}{l}\text { Coal, uppermost } 21 / 2 \text { in abundantly thin- } \\
\text { and medium-banded; lower } 31 / 2 \text { in is } \\
\text { dominantly attrital coal. }\end{array}$ \\
\hline TE S11..- & 2.0 & .005 & .005 & 40 & 6 & $61 / 2$ & Coal, dominantly attrital. \\
\hline $\begin{array}{l}\text { TE S12_..- } \\
\text { TE S13.. }\end{array}$ & $\begin{array}{l}1.2 \\
1.6\end{array}$ & .008 & .008 & $\begin{array}{l}41 \\
41\end{array}$ & $61 / 2$ & $\begin{array}{l}6 \\
6\end{array}$ & Coal, sparsely thin-banded. \\
\hline TE S14.- & 1.0 & .002 & .002 & 42 & $1 / 2$ & $71 / 2$ & $\begin{array}{l}\text { Coal, dominantly attrital. } \\
\text { Coal, dominantly attrital; } 1 / 2 \text {-in clayey. } \\
\text { shale parting at } 42 \mathrm{ft} 41 / 4 \text { in excluded }\end{array}$ \\
\hline TE & & & 02 & & & & from fuel sample. \\
\hline $\mathrm{LabS}$ & .7 & .002 & .002 & 42 & 11 & & $\begin{array}{l}\text { Coal, dominantly attrital. } \\
\text { Shale, dark-buff; uppermost } 1 \text { in is car- }\end{array}$ \\
\hline $\begin{array}{l}\text { Lab } \$ 17 . . . \\
\text { Lab S18... } \\
\text { Lab } \$ 19 \ldots\end{array}$ & .9 & & & $\begin{array}{r}43 \\
43 \\
44\end{array}$ & $\begin{array}{l}5 \\
9 \\
5 \\
7\end{array}$ & $\begin{array}{l}4 \\
8 \\
21 / 2\end{array}$ & $\begin{array}{l}\text { Shale, clayey, Iight- and medium-gray. } \\
\text { Shale, dark- to medium-buff. } \\
\text { Shale, dark-buff. }\end{array}$ \\
\hline Lat & .8 & & & 45 & 0 & $51 / 2$ & $\begin{array}{l}\text { (Loss in coring interval from } 40 \mathrm{ft} \text { to } 45 \mathrm{ft} \text {. } \\
\text { Shale, buff. }\end{array}$ \\
\hline Lab & & & & $\begin{array}{l}45 \\
45\end{array}$ & $11^{51 / 2}$ & $51 / 2$ & $\begin{array}{l}\text { Do. } \\
\text { (Base of core sent to laboratory.) }\end{array}$ \\
\hline
\end{tabular}

Fuel samples (U. S. Bureau of Mines) from core hole 7: D-97233 includes TE samples S2-S3, S5-S6, and 
TABLE 4.-Lithologic descriptions of coal cores from the Red Desert area, Sweetwater County, Wyo., showing comparison of PMG values, equivalent uranium, and uranium content of coal-Continued

\begin{tabular}{|c|c|c|c|c|c|c|c|c|c|}
\hline \multicolumn{4}{|c|}{ Sample } & \multicolumn{6}{|c|}{ Core sections } \\
\hline \multirow{2}{*}{$\begin{array}{l}\text { Sample } \\
\text { No. }\end{array}$} & \multirow{2}{*}{$\begin{array}{l}\text { Radio- } \\
\text { activity } \\
\text { (PMG) }\end{array}$} & \multirow{2}{*}{$\frac{\begin{array}{c}\text { Equiva- } \\
\text { lent } \\
\text { uranium }\end{array}}{\text { Perc }}$} & \multirow{2}{*}{ Uranium } & \multicolumn{2}{|c|}{$\begin{array}{l}\text { Depth } \\
\text { in hole }\end{array}$} & \multicolumn{2}{|c|}{ Length } & \multirow[t]{2}{*}{. } & \multirow{2}{*}{$\begin{array}{c}\text { Description and remarks } \\
:\end{array}$} \\
\hline & & & & Ft & In & Ft & In & & \\
\hline
\end{tabular}

Core hole 8 (NE $1 / 4$ SWt/4 sec. 22, T. 24 N., R. 96 W.) elev. $6.716 \mathrm{ft}$

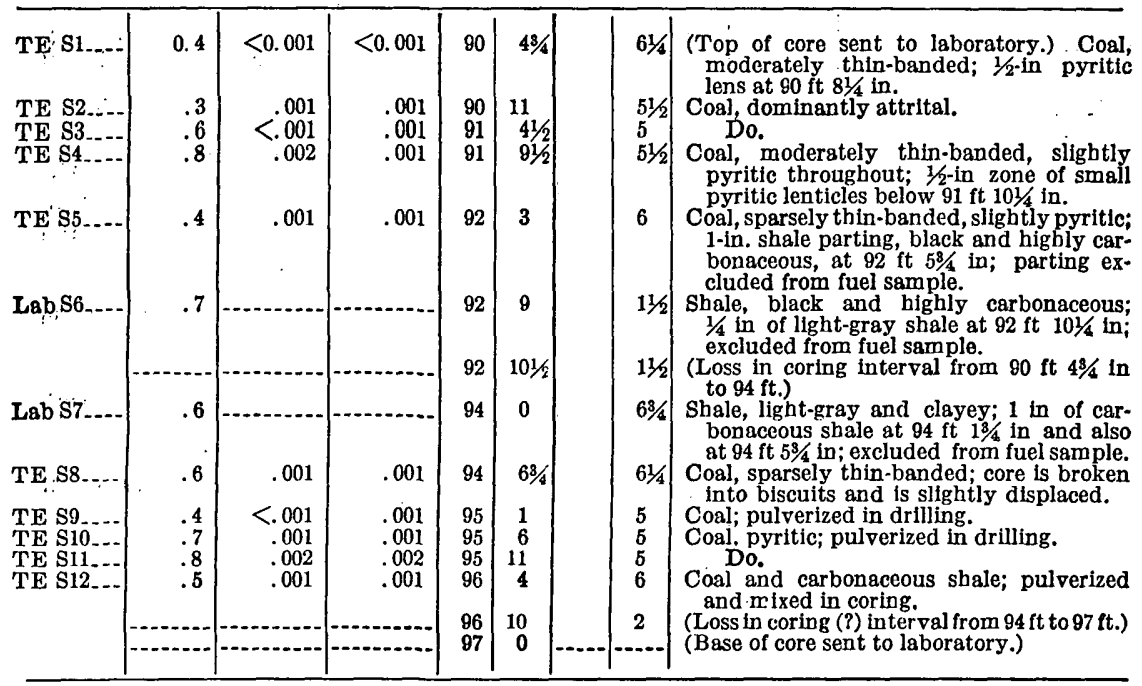

Fuel sample (U. S. Bureau of Mines) from core bole 8:

D-97528 includes TE samples S1-S5 and S8-S11.

Core hole $9\left(\mathrm{NE}^{1} / 4 \mathrm{SW}^{1} / 4\right.$ sec. 2 , T. 24 N., R. 95 W.) elev. $6.620 \mathrm{ft}$

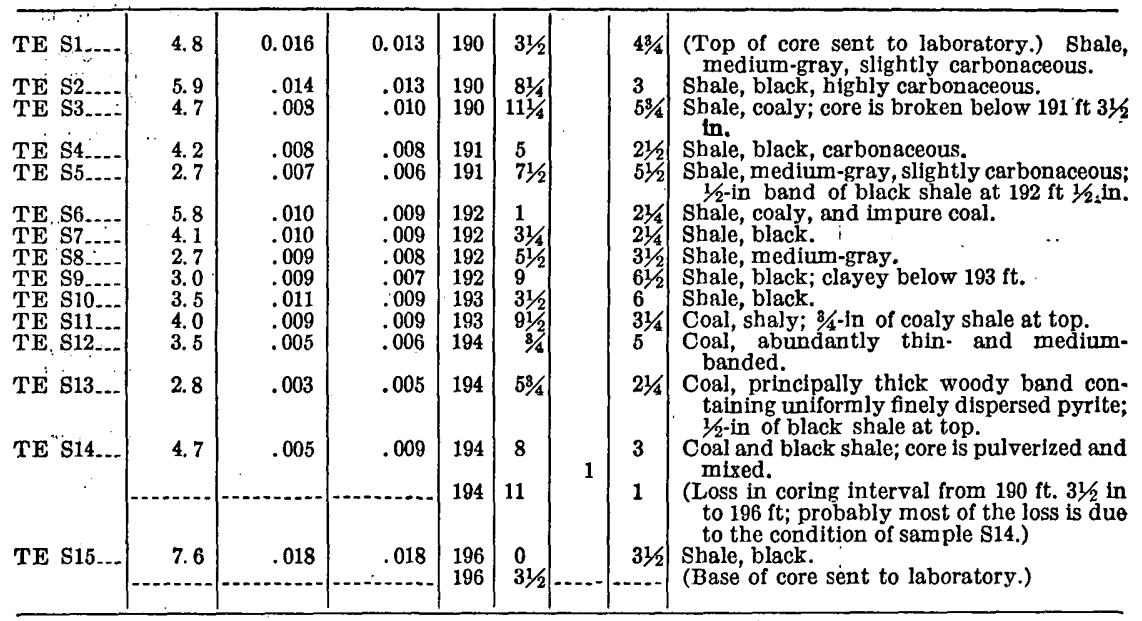


TABLE 4.-Lithologic descriptions of coal cores from the Red Desert area, Sweetwater County, Wyo., showing comparison of PMG values, equivalent uranium, and uranium content of coal-Continued

\begin{tabular}{|c|c|c|c|c|c|c|c|c|}
\hline \multicolumn{4}{|c|}{ Sample } & \multicolumn{5}{|c|}{ Core sections } \\
\hline \multirow{2}{*}{$\begin{array}{c}\text { Sample } \\
\text { No. }\end{array}$} & \multirow{2}{*}{$\begin{array}{c}\text { Radio- } \\
\text { activity } \\
\text { (PMG) }\end{array}$} & \multirow{2}{*}{$\frac{\begin{array}{c}\text { Equiva- } \\
\text { lent } \\
\text { uranium }\end{array}}{\text { Perc }}$} & \multirow{2}{*}{$\frac{\text { Uranium }}{\text { cent }}$} & \multicolumn{2}{|c|}{$\begin{array}{c}\text { Depth } \\
\text { in hole } \\
\vdots\end{array}$} & \multicolumn{2}{|c|}{ Length } & \multirow[t]{2}{*}{ Description and remarks } \\
\hline & & & & Ft & In & Ft & In & \\
\hline
\end{tabular}

Core hole 10 (NE1/4SW1/4 sec. 17, T. 23 N., R. 94 W.) elev. 6,510 ft

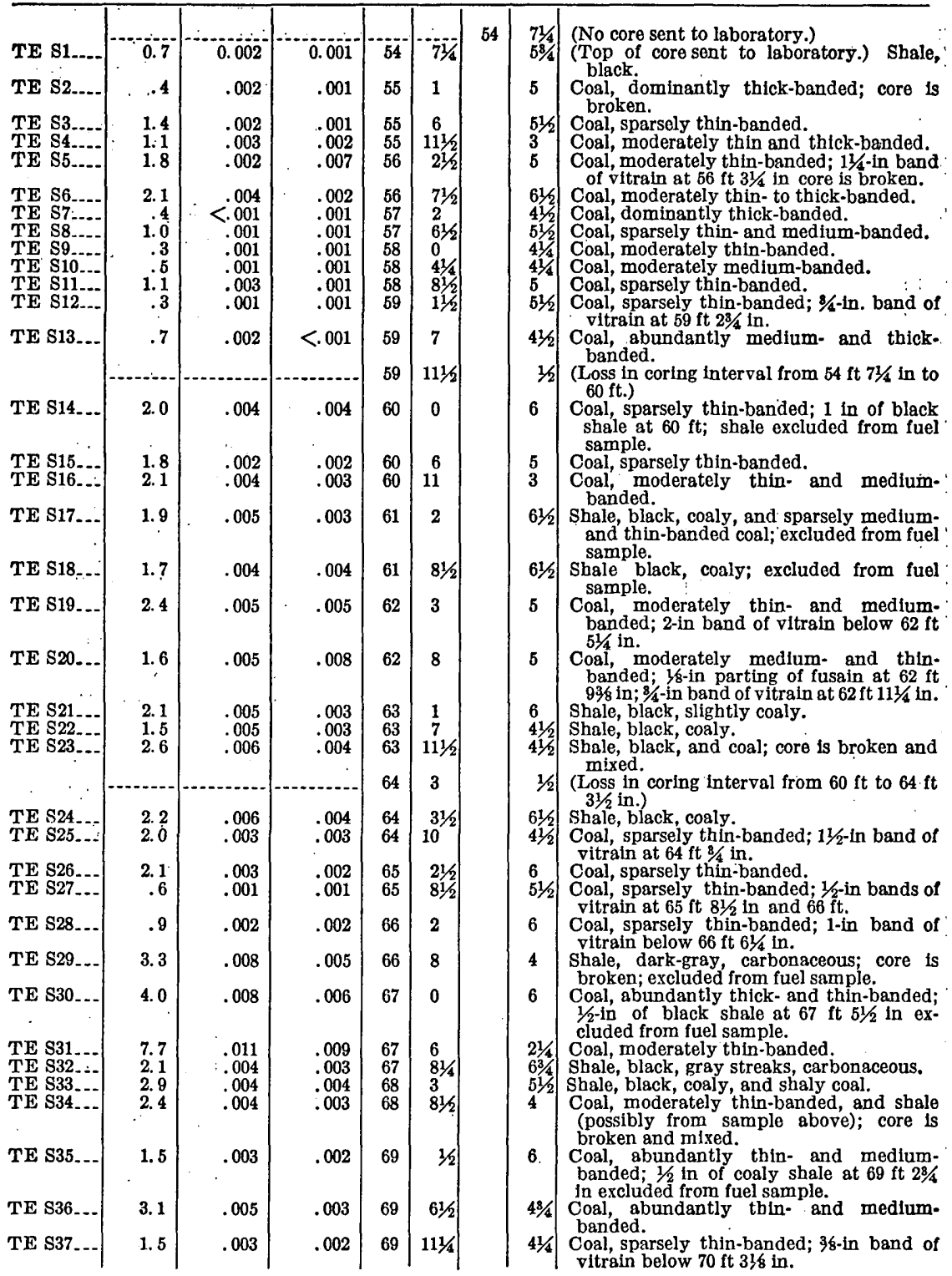


TABLE 4.-Lithologic descriptions of coal cores from the Red Desert area, Sweetwater County, Wyo.; showing comparison of PMG values, equivalent uranium, and uranium content of coal-Continued

\begin{tabular}{|c|c|c|c|c|c|c|c|c|}
\hline \multicolumn{4}{|c|}{ Sample } & \multicolumn{5}{|r|}{ Core sections } \\
\hline \multirow{2}{*}{$\begin{array}{c}\text { Sample } \\
\text { No. }\end{array}$} & \multirow{2}{*}{$\begin{array}{l}\text { Radio- } \\
\text { activity } \\
(\mathrm{PMG})\end{array}$} & \multirow{2}{*}{$\frac{\begin{array}{c}\text { Equiva- } \\
\text { lent } \\
\text { uranium }\end{array}}{\text { Perc }}$} & \multirow{2}{*}{ Uranium } & \multicolumn{2}{|c|}{$\begin{array}{l}\text { Depth } \\
\text { in hole }\end{array}$} & \multicolumn{2}{|c|}{ Length } & \multirow[t]{2}{*}{ Description and remarks } \\
\hline & & & & Ft & In & $\mathrm{Ft}$ & In & \\
\hline
\end{tabular}

Core hole 10-Continued

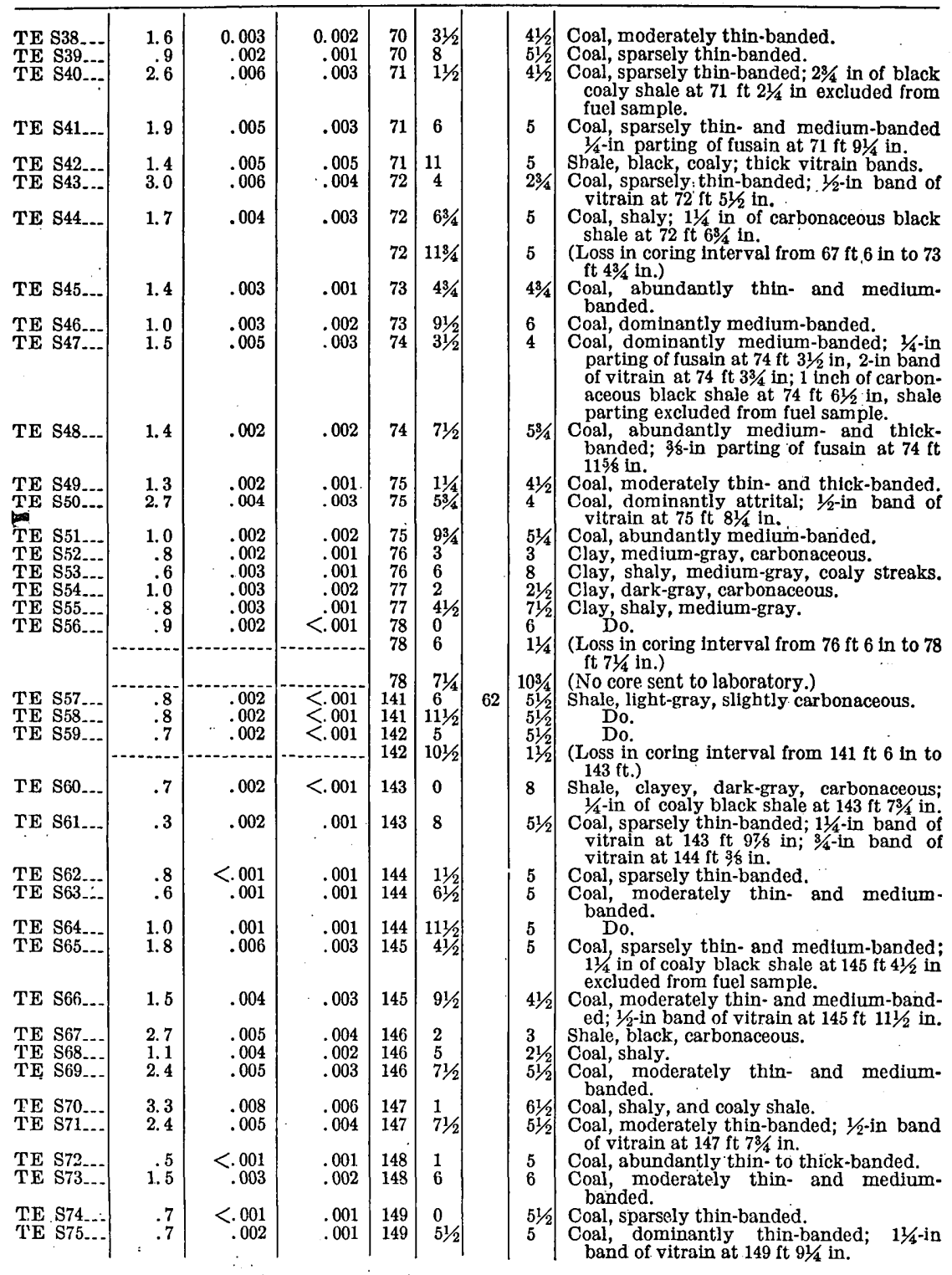


TABLE 4.-Lithologic descriptions of coal cores from the Red Desert area, Sweetwater County, Wyo., showing comparison of PMG values, equivalent uranium, and uranium content of coal-Continued

\begin{tabular}{|c|c|c|c|c|c|c|c|c|}
\hline \multicolumn{4}{|c|}{ Sample } & \multicolumn{5}{|c|}{ Core sections } \\
\hline \multirow{2}{*}{$\begin{array}{c}\text { Sample } \\
\text { No. }\end{array}$} & \multirow{2}{*}{$\begin{array}{c}\text { Radio- } \\
\text { activity } \\
\text { (PMG) }\end{array}$} & \multirow{2}{*}{$\frac{\begin{array}{c}\text { Equiva- } \\
\text { lent } \\
\text { uranium }\end{array}}{\text { Per }}$} & \multirow{2}{*}{$\frac{\text { Urạium }}{\text { tent }}$} & \multicolumn{2}{|c|}{$\begin{array}{l}\text { Depth } \\
\text { in hole }\end{array}$} & \multicolumn{2}{|c|}{ Length } & \multirow{2}{*}{$\begin{array}{c}\text { Description and remarks } \\
\vdots\end{array}$} \\
\hline & & & & Ft & In & Ft & In & \\
\hline
\end{tabular}

Core hole 10-Continued

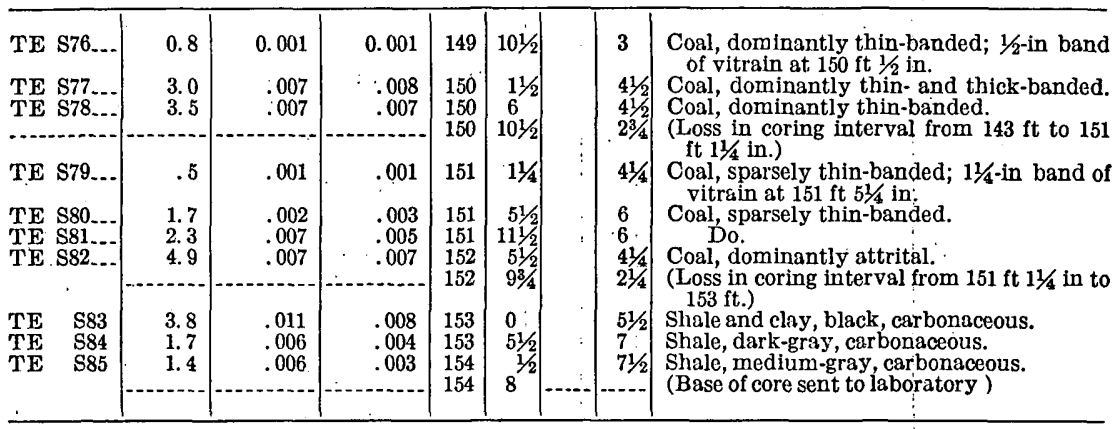

Fuel samples (U. S. Bureau of Mines) from core hole 10:

D-98226 includes TE samples S2-S11, S13-S16, and S19-S20

D-98227 includes TE samples S25-S28 and S30.

D-98228 includes TE samples S35-S41.

D-98229 includes T.E samples S45-S51.

D-98230 includes TE samples S61-S66.

D-98231 includes TE samples S71-S82.

Core hole 11 (NW1/4 NW1/4 sec. 27, T. 23 N., R. 94 W.) elev, 6,660 ft

\begin{tabular}{|c|c|c|c|c|c|c|c|c|}
\hline & & & & & & 30 & & (No core sent to laboratory.) \\
\hline $\mathrm{E} \mathrm{S1}$. & 0.8 & $0.000^{-}$ & 0.001 & 30 & $31 / 2$ & 1 & & $\begin{array}{l}\text { (Top of core sent to laboratory.) Silt } \\
\text { stone, very fine-grained, tan, uncon- } \\
\text { solidated. }\end{array}$ \\
\hline $\mathrm{E}$ S2. & .8 & .004 & .002 & 31 & $\begin{array}{l}38 / 4 \\
41 \%\end{array}$ & & $21 / 4$ & Siltstone, light-gray. \\
\hline TE S4. & 1.1 & .002 & .003 & 31 & $41 / 2$ & & $21 / 2$ & $\begin{array}{l}\text { and mixed coal fragments, possibly from } \\
\text { sample below. } \\
\text { Shale, black, and gypsiferous coal; core is } \\
\text { badly broken and mixed. }\end{array}$ \\
\hline $\mathrm{E}$ & 1.1 & .002 & .002 & 32 & 0 & & 5 & Coal; core is badly broken. \\
\hline E & 1.2 & .003 & .003 & 32 & 5 & & 6 & $\begin{array}{l}\text { Coal; core is badly broken; components of } \\
\text { one thick band of vitrain were noted in } \\
\text { the fragments. }\end{array}$ \\
\hline TE S7. & 1.6 & .004 & .004 & 32 & 11 & & 6 & $\begin{array}{l}\text { Coal, sparsely thin-banded; core is badly } \\
\text { broken. }\end{array}$ \\
\hline TE S8. & 2.3 & .004 & .004 & 33 & 5 & & $5, / 4$ & $\begin{array}{l}\text { Coal, sparsely thin-banded; } 1 / 2 \text { in of black } \\
\text { shale at } 33 \text { ft } 71 / 2 \text { in excluded from fuel } \\
\text { sample. }\end{array}$ \\
\hline TE S9. & 3.7 & .008 & .009 & 33 & $101 / 4$ & & $33 / 4$ & $\begin{array}{l}\text { Coal, moderately thin- to thick-banded; } 1 \\
\text { in of coaly black shale at } 34 \cdot \mathrm{ft} 1 \text { in }\end{array}$ \\
\hline TE $\mathrm{S10}$ & 2.8 & .008 & $: 010$ & .34 & 2 . & i & 5 & $\begin{array}{l}\text { excluded from fuel samplé. } \\
\text { Coal and coaly shale, broken and mixed; }\end{array}$ \\
\hline TE S11... & 1.7 & .003 & .003 & $\begin{array}{l}34 \\
34\end{array}$ & $\begin{array}{l}7 \\
93 / 4\end{array}$ & 2 & $23 / 4$ & Coal, moderately thin- and thick-banded. \\
\hline TE S12 & .4 & .002 & .002 & 36 & 0 & & $41 / 2$ & Coal, abundantly thịn- and medium. \\
\hline TE S13 & 1.3 & .003 & .003 & 36 & $41 / 2$ & . & 0 & Coal, sparsely thin-banded. \\
\hline TE S14. & 1.7 & .005 & .006 & 36 & $91 \% 2$ & t & $41 / 2$ & $\begin{array}{l}\text { Coal, sparsely thin-banded; core is badly } \\
\text { broken and includes } \dot{a} \text { few } 1 / 4 \text {-in tan } \\
\text { silty nodules. }\end{array}$ \\
\hline${ }_{\mathrm{TE}}^{\mathrm{T}}$ & $\begin{array}{l}2.7 \\
1.4\end{array}$ & $\begin{array}{l}.009 \\
.005\end{array}$ & .006 & 37 & $\begin{array}{l}2 . \\
81 / 2\end{array}$ & & $61 / 2$ & Clay, shaly, black, carbonaceous. \\
\hline & & & & & & & & \\
\hline
\end{tabular}


Table 4.-Lithologic descriptions of coal cores from the Red Desert area, Sweetwater County, Wyo., showing comparison of $P M G$ values, equivalent uranium. and uranium content of coal-Continued

\begin{tabular}{|c|c|c|c|c|c|c|c|c|}
\hline \multicolumn{4}{|c|}{ Sample } & \multicolumn{5}{|r|}{ Core sections } \\
\hline \multirow{2}{*}{$\begin{array}{l}\text { Sample } \\
\text { No. }\end{array}$} & \multirow{2}{*}{$\begin{array}{l}\text { Radio- } \\
\text { activity } \\
\text { (PMQ) }\end{array}$} & \multirow{2}{*}{$\frac{\begin{array}{c}\text { Equiva- } \\
\text { lent } \\
\text { uranium }\end{array}}{\text { Per }}$} & \multirow{2}{*}{ Uranium } & \multicolumn{2}{|c|}{$\begin{array}{l}\text { Depth } \\
\text { in hole } \\
\vdots\end{array}$} & \multicolumn{2}{|c|}{ Length } & \multirow{2}{*}{$\begin{array}{c}\cdots \\
\vdots \\
\vdots\end{array}$} \\
\hline & & & & $\mathrm{Ft}$ & In & In & Ft & \\
\hline
\end{tabular}

Core hole 11-Continued

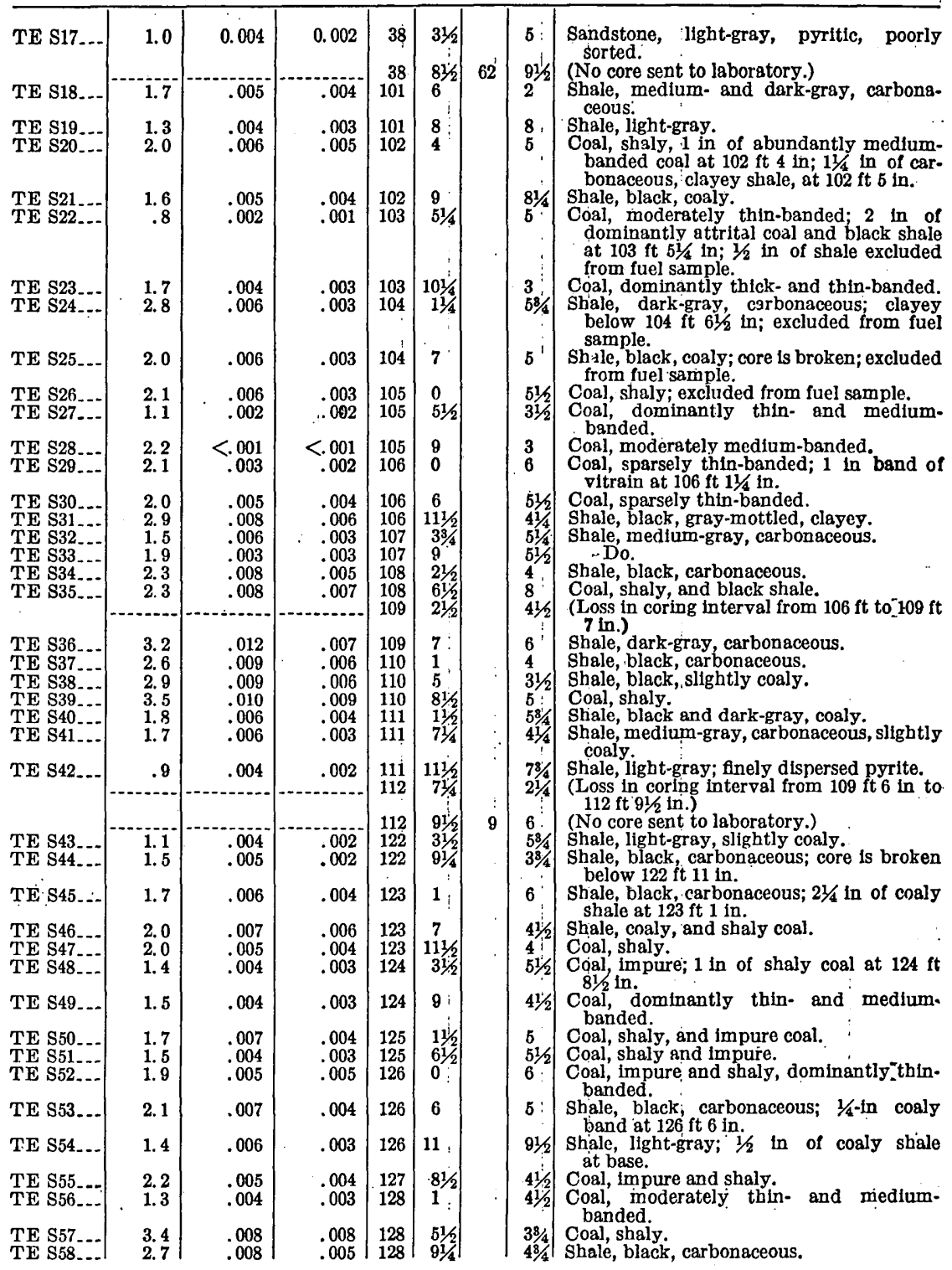


TABLE 4.-Lithologic descriptions of coal cores from the Red Desert area, Sweetwater County, Wyo., showing comparison of PMG values, equivalent uranium, and uranium content of coal-Continued

\begin{tabular}{|c|c|c|c|c|c|c|c|c|}
\hline \multicolumn{4}{|c|}{ Sample } & \multicolumn{5}{|r|}{ - Core sections } \\
\hline \multirow{2}{*}{$\begin{array}{c}\text { Sample } \\
\text { No. }\end{array}$} & \multirow{2}{*}{$\begin{array}{l}\text { Radio- } \\
\text { activity } \\
\text { (PMG) }\end{array}$} & \multirow{2}{*}{$\frac{\begin{array}{c}\text { Equiva } \\
\text { lent } \\
\text { uranium }\end{array}}{\text { Per }}$} & \multirow{2}{*}{$\frac{\text { Uranium }}{\text { cent }}$} & \multicolumn{2}{|c|}{$\underset{\text { in hole }}{\text { Depth }}$} & \multicolumn{2}{|c|}{ Length } & \multirow{2}{*}{ Description and remarks } \\
\hline & & & & $\mathrm{Ft}$ & In & Ft & In & \\
\hline
\end{tabular}

Core hole 11-Continued

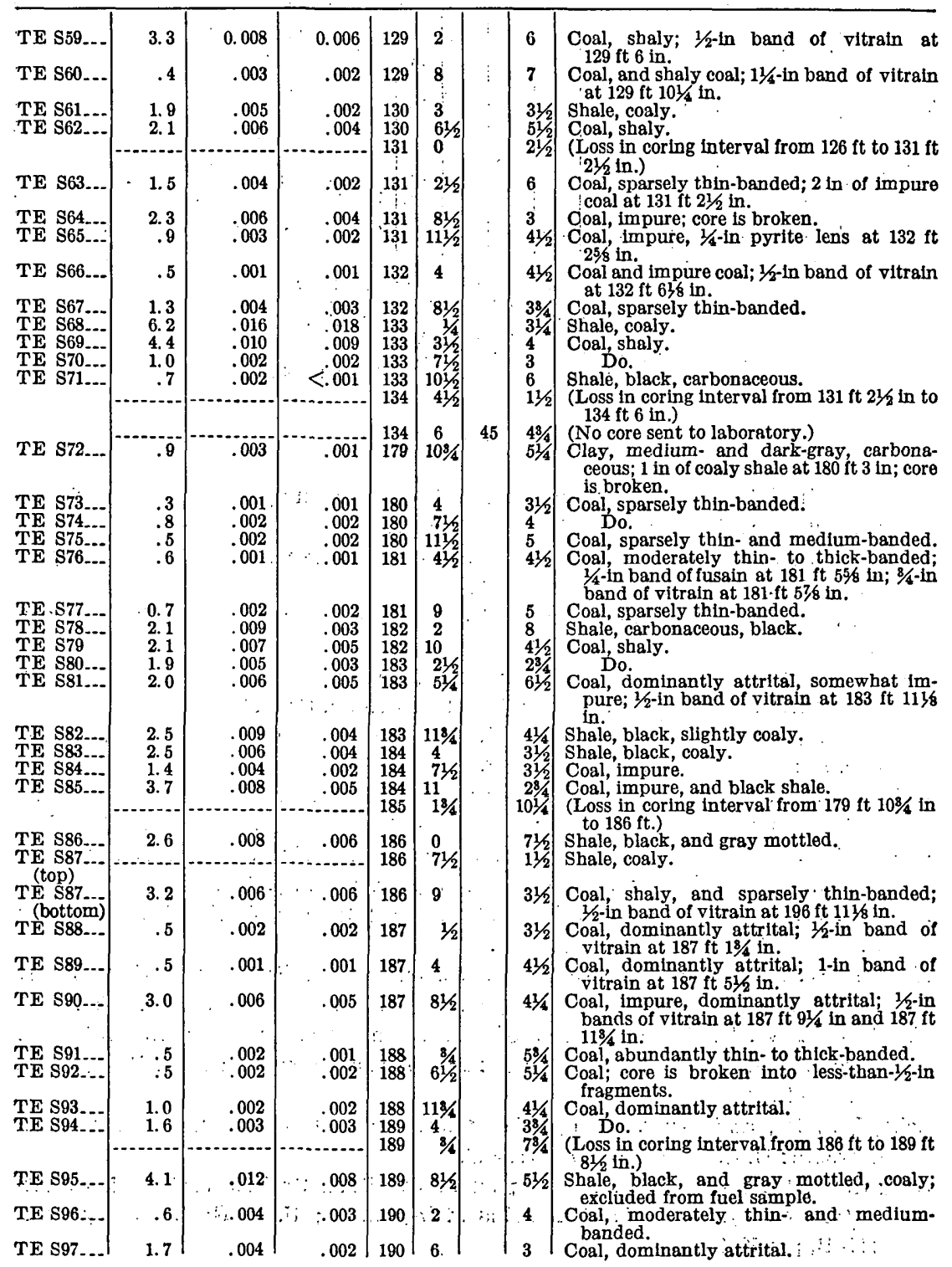


TABLE 4.-Lithologic descriptions of coal cores from the Red Desert area, Sweetwater County, Wyo., showing comparison of PMG values, equivalent uranium, and uranium content of coal-Continued

\begin{tabular}{|c|c|c|c|c|c|c|c|c|c|}
\hline \multicolumn{4}{|c|}{ Sample } & \multicolumn{6}{|c|}{ Core sections } \\
\hline \multirow{2}{*}{$\begin{array}{c}\text { Sample } \\
\text { No. }\end{array}$} & \multirow{2}{*}{$\begin{array}{r}\text { Radio- } \\
\text { activity } \\
\text { (PMG) }\end{array}$} & \multirow{2}{*}{$\frac{\begin{array}{c}\text { Equiva- } \\
\text { lent } \\
\text { uranium }\end{array}}{\text { Per }}$} & \multirow{2}{*}{$\frac{\text { Uranium }}{\text { cent }}$} & \multicolumn{2}{|c|}{$\begin{array}{l}\text { Depth } \\
\text { in hole }\end{array}$} & \multicolumn{2}{|c|}{ Length } & \multirow{2}{*}{ Description and remarks } & \\
\hline & & & & Ft & In & Fit. & In & & \\
\hline
\end{tabular}

Core hole 11-Continued

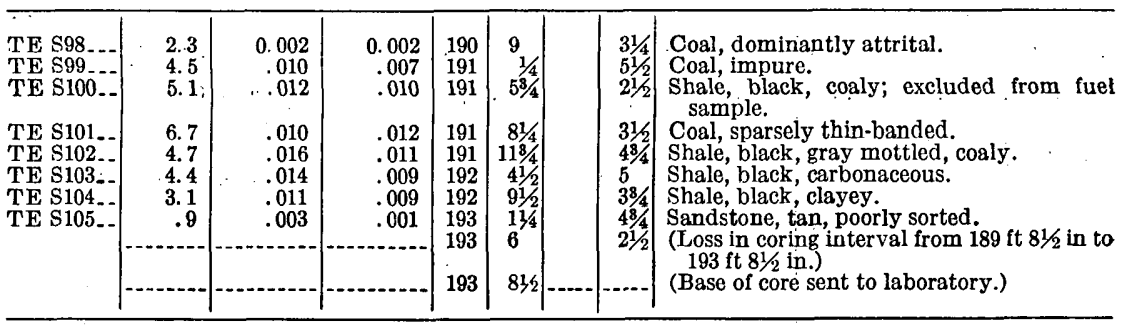

Fuel samples (U. S. Bureau of Mines) from core hole 11:

D-98232 includes TE samples S5-S9 and S11-S14.

D-98233 includes TE samples S22-S23 and S27-S30.

D-98234 includes TE samples S56-S70.

D-98235 includes TE samples S73-S77.

D-98236 includes TE samples S87 (bottom)-S94, S96-S99, and S101.

\section{LTTERATURE CITED}

American Society for Testing Materials, 1938, Standard specifications for classification of coals by rank : D 388-38, p. 652-657.

Ball, M. W., 1909, The western part of the Little Snake River coal. field, Wyo. : U. S. Geol. Survey Bull. 341, p. 243-255.

Bradley, W. H., 1926, Shore phases of the Green River formation in northern Sweetwater County, Wyo.: U. S. Geol. Survey Prof. Paper 140-D, p. 121-131:

1945, Geology of the Washakie Basin, Sweetwater and Carbon Counties, Wyo.: U. S. Geol. Survey Oil and Gas. Inv. Prelim. Map 32.

- 1948, Limnology and Eocene lakes of the Rocky Mountain region: Geol. Soc. America Bull., v. 59, p. 635-648.

Dobbin, C. E., 1928, Geology and oil and gas possibilities of the Bell Springs district, Carbon County, Wyo. : U. S. Geol. Survey Bull. 796-D, p. 171-197.

1929, Geology and coal and oil resources of the Hanna and Carbon basins, Carbon County, Wyo.: U. S. Geol. Survey Bull. 805, p. 1-187.

Fath, A. E., 1924, Oil and gas fields of the Lost Soldier-Ferris district, Wyo.: U. S. Geol. Survey Bull. 756, p. 1-57.

Nace, R. L., 1939, Geology of the northwest part of the Red Desert, Sweetwater and Fremont Counties, Wyo.: Wyoming Geol. Survey Bull. 27, p. 1-51.

Nightingale, W. T., 1930, Geology of Vermilion Creek gas area in southwest Wyoming and northwest Colorado: Am. Assoc. Petroleum Geol. Bull., v. 14, p. 1013-1040.

Schopf, J. M., and Gray, .R. J., 1954, Microscopic studies of uraniferous coal deposits : U. S. Geol. Survey Circ. 343.

Schultz, A. R., 1909, The northern part of the Rock Springs coal field, Sweetwater County, Wyo., in Coal fields of Wyoming: U. S. Geol. Survey Bull. 341-B, p. 256-282. 
Schultz, A. R., 1920, Oil possibilities in and around Baxter Basin, in the Rock Springs uplift, Sweetwater County, Wyo.: U. S. Geol. Survey Bull. 702, p. 1-107.

Sears, J. D., and Bradley, W. H., 1924, Relations of the Wasatch and Green River formations in northwestern Colorado and southwestern Wyoming, with notes on oil shale in the Green River formation: U. S. Geol. Survey Prof. Paper 132-F, p. 93-105.

Smith, E. E., 1909, The eastern part of the Great Divide Basin coal field, Wyoming, in Coal fields of Wyoming: U. S. Geol. Survey Bull. 341-B, p. 220-242.

Wood, H. E., 2nd, and others, 1941, Nomenclature and correlation of the North American continental Tertiary : Geol. Soc. America Bull., v. 52, p. 1-48.

Wyoming Geological Association Nomenclature Committee, 1951, Wyoming stratigraphic nomenclature chart: Wyoming Geol. Assoc. Guidebook, 6th Ann. Field Conference, p. 11. 
Tertiary Geology of the Goose Creek District Cassia County, Idaho Box Elder County, Utah And Elko County, Nevada By WILLIAM J. MAPEL and WILLIAM J. HAIL, JR. URANIUM IN COAL IN THE WESTERN UNITED STATES GEOLOGICAL S URVEY B ULLETIN $1055-\mathrm{H}$ 



\section{CONTENTS}

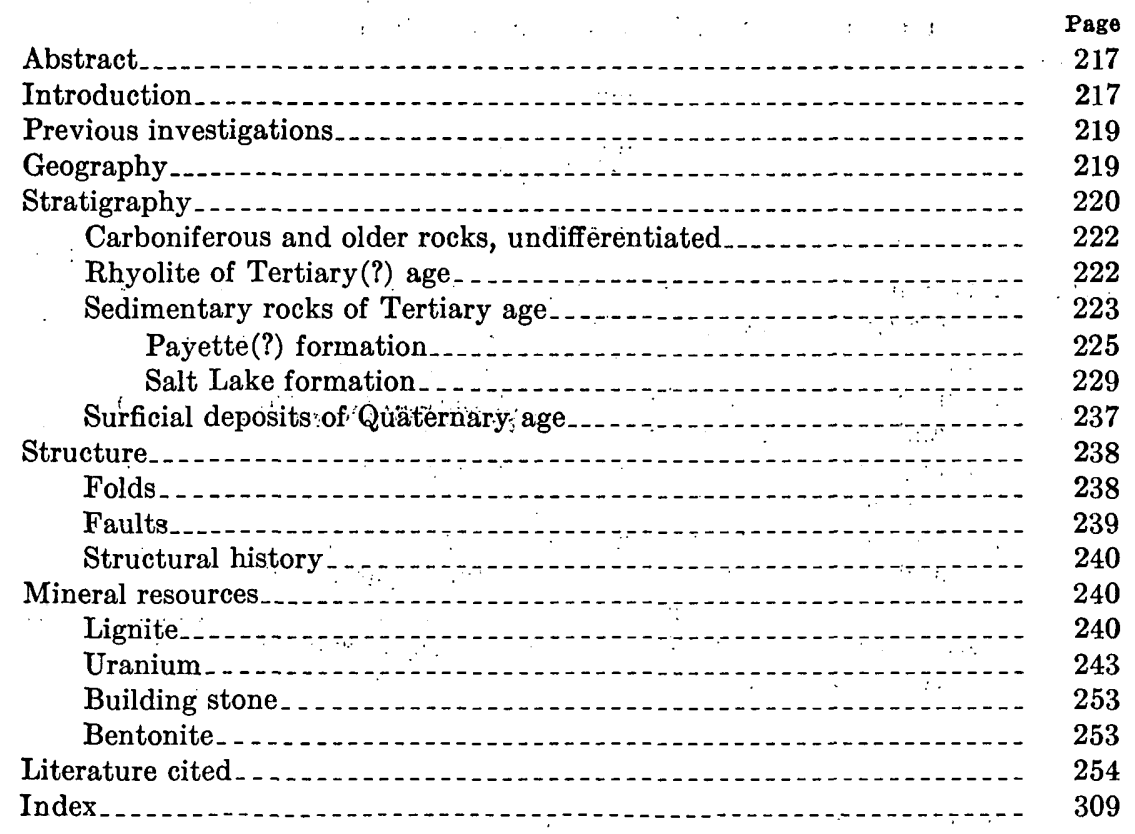

\section{ILLUSTRATIONS}

[Plates 46, 47, and 50 are in box]

Plate 46. Geologic map, structure-contour map, and geologic sections, Goose Creek district.

47. Columnar sections showing correlation of beds in Payette(?) and Salt Lake formations.

48. $A$, Lower part of the Salt Lake formation; $B$, Rhyolite in volcanic ash of the Salt Lake formation............ Facing

49. Volcanic rocks of the Salt Lake formation: $A$, Welded tuff; $B$, Photomicrograph of volcanic ash; $C$, Photomicrograph of

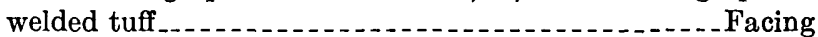

50. Stratigraphic sections showing thickness and uranium content of carbonaceous shale and lignite beds.

FIGURE 36. Index map showing location of the Goose Creek district.....-

37. Diagram showing thickness and maximum uranium content of carbonaceous shale from core holes

38. Map of part of T. 16 S., R. 21 E., Idaho, showing areas that may be underlain by carbonaceous shale in beds at least 1 foot thick containing at least 0.01 percent uranium...... 


\section{CHARTS}

Chart 1. Rocks exposed in the Goose Creek district

2. Stratigraphic names used by various writers for Tertiary rocks exposed in the Goose Creek district. . . . . . . . . . .

3. Approximate correlation of some Tertiary and Quaternary rocks in southern Idaho and northeastern Nevada

\section{TABLES}

TABLE 1. Chemical analyses of welded tuff and volcanic ash, Goose Creek district, Cassia County, Idaho

2. Fuel analyses of lignite and lignitic shale, Goose Creek district.-

3. Analyses for uranium in selected samples of carbonaceous shale and lignite, Goose Creek district.

4. :Analyses for uranium in samples of miscellaneous rock types, Goose Creek district

5. Potential resources of uranium in beds of carbonaceous shale and lignite at least 1 foot thick containing at least 0.01 percent uranium, Goose Creek district.

6. Analyses for uranium (in parts per billion) in samples of water, Goose Creek district...... 


\title{
TERTIARY GEOLOGY OF THE GOOSE GREEK DISTRIGT, CASSIA COUNTY, IDAHO, BOX ELDER COUNTY, UTAH, AND ELKO COUNTY, NEVADA
}

\author{
By William J. Mapel and William J. Hail, Jr.
}

ABSTRACT

The Goose Creek district is an area of about 260 square miles in the northern and central parts of an intermontane basin in southern Idaho and adjacent parts of Utah and Nevada and is drained by Goose Creek, a large perennial tributary of the Snake River. Tertiary rocks exposed in the district include the Payette(?) formation, of Miocene or Pliocene age, and the overlying Salt Lake formation, of Pliocene age. The Payette(?) formation is at least 900 feet thick and consists mainly of greenish-gray shale and white volcanic ash. The Salt Lake formation is at least 2,300 feet thick and consists largely of volcanic ash and welded rhyolitic tuff. Both formations contain thin beds of carbonaceous shale and lignite, and at various stratigraphic levels there are numerous beds of sandstone and conglomerate derived from the disintegration and erosion of older rocks exposed on adjacent highlands. The Tertiary sedimentary rocks rest unconformably on a large body of Tertiary(?) rhyolite exposed in the mountains bordering the district on the southeast, and on a thick undifferentiated sequence of Carboniferous and older rocks, limestone, quartzite, and shale, exposed in the mountains to the west and northeast. Quaternary deposits of gravel, slope wash, alluvium, and landslide material overlie the older rocks locally.

The Payette(?) and Salt Lake formations are tilted in a general easterly direction, with an average dip of about 3 degrees. Shallow folds and structural terraces modify the eastward tilting, particularly along the eastern margin of the district, where dips in the Tertiary rocks locally are reversed. Normal faults with displacements ranging from a few feet to as much as 900 feet cut the Tertiary sequence at various places. Most of the faults trend northward or northeastward, and' some may be traced for several miles.

Lignite has been mined for local use from both the Payette and Salt Lake formations, but most of the lignite has a large content of ash and is of little commercial value. Concentrations of as much as 0.1 percent uranium occur locally in lignite and carbonaceous shale in the lower part of the Salt Lake formation. Most of the uranium-rich beds are on the flanks and in the trough of a shallow syncline in T. $16 \mathrm{~S}$., R. $21 \mathrm{E}$., Idaho. Other mineral resources include building stone and bentonite.

\section{INTRODUCTION}

The Goose Creek district is an area of about 260 square miles in southern Cassia County, Idaho, and adjacent parts of Box Elder 
County, Utah, and Elko County, Nevada (fig. 36). Tertiary rocks in the area were mapped during the summer of 1952 by the U. S. Geological Survey on behalf of the Atomic Energy Commission. The work was directed chiefly toward the location - of uranium deposits; however, the area was examined for other mineral resources, and some data were gathered on deposits of lignite, building stone, and bentonite.

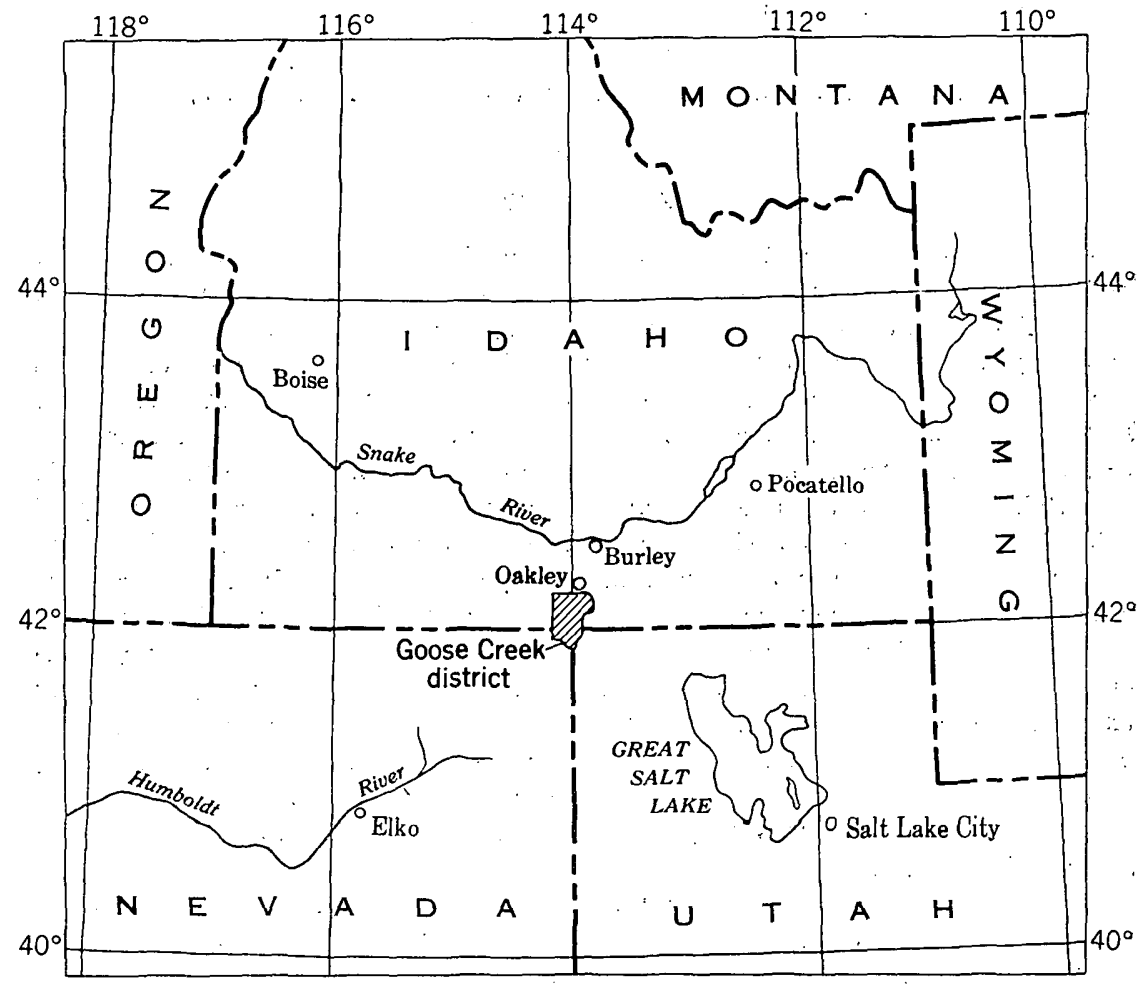

FIGCRE 36.-Index map showing the location of the Goose Creek district.

The investigations began in September and October 1951, with a reconnaissance survey of the district by D: C. Duncan, W. J. Hail, Jr., and J. R. Gill. During the following summer, the writers, assisted by J. E. Conkin and J. N. Babcock, mapped the Tertiary rocks of the district on aerial photographs at a scale of about $1: 30,000$. The fieldwork was followed in August and September of 1953 by the rotary core-drilling of 13 shallow test holes in the central part of the district. Drilling was done by a private company under contract to the Geological Survey, and the drilling program was supervised by M. L. Troyer. Rock and water samples collected during the investigation were analyzed for uranium in the Geological Survey laboratories. . J. M. Schopf and R. J. Gray studied the microscopic: characteristics of the cores of radioactive lignite and carbonaceous 
shale from two of the drill holes and the results of their study have been reported separately (Schopf and Gray, 1954).

The base on which the geologic map was compiled was prepared by methods involving a radial plot. Control was established by planetable triangulation tied to U. S. Coast and Geodetic Survey triangulation points and Bureau of Land Management land corners.

\section{PREVIOUS INVESTIGATIONS}

Previous geologic investigations in the Goose Creek district include a reconnaissance survey of the lignite beds of the area by C. F. Bowen (1913); a study of the ground-water resources of the Goose Creek drainage basin by A. M. Piper (1923); and an investigation of the geology of the northeastern part of the district as a part of a geologic reconnaissance of eastern Cassia County, Idaho, by A. L. Anderson (1931).

\section{GEOGRAPHY}

The Goose Creek district covers the northern and central parts of an elongate northward-trending intermontane basin bordered on the west by an unnamed mountain range, on the southeast and east by the Goose Creek and South Mountains, and on the north by the Snake River Plain.

Steep-sided, even-topped buttes and mesas, and deep, narrow canyons characterize the land surface in the northern and central parts of the district. The surface in the southern part has less relief and in places is gently rolling, although locally it is intricately dissected by gullies and washes. Steep mountain slopes border the district on the east and southwest, but in the northwestern part the rough topography of the basin merges with that of the mountains, with no clear demarcations. Altitudes range from 7,450 feet on Hudson Ridge, in the northwestern corner of the district, to about 4,550 feet at the point where Goose Creek crosses the northern boundary.

Goose Creek, a large perennial tributary of the Snake River, flows northeastward across the area, and is the principal stream. Its chief tributary is Trapper Creek which drains much of the northern part of the district and enters Goose Creek near the northeastern corner. The valleys of both streams are narrow canyons near their confluence, but upstream they became broad and open. . Both streams discharge into the Lower Goose Creek reservoir, which occupies the narrowest part of the Goose Creek valley and is about 4 miles long and $1 / 2$ mile wide. Other perennial streams in the district, all tributary to Goose Creek, include Jay and Trout Creeks, which join Goose Creek from the west, and Cold, Little Pole, Birch, and Pole Creeks which join it from the east. Beaverdam Creek in the west-central part of the district and Hardister Creek in the southern part are the main intermittent streams. 
Both the climate and the vegetation in the Goose Creek district are similar to those of other parts of northeastern Nevada and southern Idaho. The mean annual precipitation is about $101 / 2$ inches, and the mean temperature at Oakley ranges from about $29^{\circ} \mathrm{F}$. in January to $71^{\circ} \mathrm{F}$. in July. The vegetation reflects the aridity of the climate: sagebrush grows abundantly; juniper trees, growing singly or in clumps and thickets, are common; aspen and willows are found on high slopes or along the stream courses. Grass is sparse, but it is sufficient to provide grazing for sheep, cattle, and horses, and much of the land is utilized for this purpose. Some hay is grown on irrigated meadow lands in the valleys of Goose and Trapper Creeks, most of it being used for feed within the district.

The district is sparsely settled, having few permanent residents and no towns. Oakley, Idaho, with a population of about 800 is 3 miles north of the district. Burley, Idaho, with a population of about 6,000 is 22 miles north of Oakley and is the county seat of Cassia County.

A branch line of the Oregon Short Line (Union Pacific system) Railroad, and a paved highway connect Oakley and Burley. Graveled roads lead from Oakley up the valleys of Goose and Trapper Creeks. These roads and a network of dirt roads and trails provide access to most parts of the area.

\section{STRATIGRAPHY}

The present investigation was devoted primarily to a study of the Tertiary strata of the Goose Creek district. These rocks include the Payette(?) formation of Miocene or Pliocene age, and the overlying Salt Lake formation of Pliocene age. Older rocks were examined only where it was necessary to determine their structural and stratigraphic relations to the Tertiary sequence. They include a massive rhyolite porphyry of Tertiary (?) age, exposed in the mountains bordering the district on the southeast, and an undifferentiated pre-Tertiary sequence of limestone, quartzite, and shale, together with their metamorphic equivalents exposed in the mountains and hills bordering the district on the northeast, south, and west. Younger deposits of Quaternary age consist of alluvium along the present streams, slope wash, landslide material, and gravel deposits on high erosion surfaces.

The thickness and character of the rock formations exposed in the district are summarized in chart 1. Plate 46 shows their distribution. 
TERTIARY GEOLOGY, GOOSE CREEK DISTRICT

Chart 1.-Rocks exposed in the Goose Creek district

\begin{tabular}{|c|c|c|c|c|c|}
\hline System & Series & \multicolumn{2}{|c|}{$\begin{array}{l}\text { Rock type or } \\
\text { formation }\end{array}$} & Character & $\begin{array}{l}\text { Thick- } \\
\text { ness } \\
\text { (feet) }\end{array}$ \\
\hline \multirow{2}{*}{ Quaternary } & \multirow{2}{*}{$\begin{array}{l}\text { Recent } \\
\text { and } \\
\text { Pleisto- } \\
\text { cene(?) }\end{array}$} & \multicolumn{2}{|c|}{$\begin{array}{l}\text { Alluvium and } \\
\text { slope wash }\end{array}$} & $\begin{array}{l}\text { Surficial deposits of } \\
\text { silt, sand, and gravel } \\
\text { on the flood plains of } \\
\text { present streams or } \\
\text { adjacent to steep } \\
\text { mountain slopes. }\end{array}$ & $0-80 \pm$ \\
\hline & & \multicolumn{2}{|c|}{$\begin{array}{l}\text { Gravel deposits on } \\
\text { high erosion sur- } \\
\text { faces }\end{array}$} & $\begin{array}{l}\text { Surficial deposits of } \\
\text { stream-worn pebbles } \\
\text { and boulders, mainly } \\
\text { of rhyolite and } \\
\text { quartzite; lenses of } \\
\text { sand and silt. }\end{array}$ & $0-15$ \\
\hline \multirow[b]{2}{*}{$\begin{array}{l}\because \\
\text { Tertiary }\end{array}$} & \multirow[b]{2}{*}{ Pliocene } & \multicolumn{2}{|l|}{$\stackrel{9}{\circ}$} & $\begin{array}{l}\text { Interbedded white and } \\
\text { grayish-orange vol- } \\
\text { canic ash, with a few } \\
\text { lenticular beds of } \\
\text { conglomerate; a } \\
\text { thick, persistent bed } \\
\text { of welded tuff is at } \\
\text { the base. }\end{array}$ & $700 \pm$ \\
\hline & & \multicolumn{2}{|c|}{ 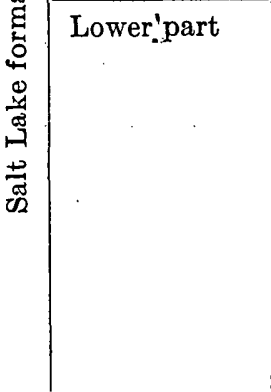 } & $\begin{array}{l}\text { Mainly white volcanic } \\
\text { ash containing a few } \\
\text { beds of shale, sand- } \\
\text { stone, and conglom- } \\
\text { erate; conspicuous } \\
\text { beds of black to } \\
\text { dark-reddish-brown } \\
\text { welded tuff in the } \\
\text { upper half; lenticu- } \\
\text { lar beds of uranium- } \\
\text { bearing carbonaceous } \\
\text { shale and lignite in } \\
\text { the lower half. }\end{array}$ & $1550 \pm$ \\
\hline$\therefore$ & Miocene & \multicolumn{2}{|c|}{$\begin{array}{l}\text { Payette(?) forma- } \\
\text { tion. }\end{array}$} & $\begin{array}{l}\text { Interbedded shale and } \\
\text { volcanic ash, with } \\
\text { some thin beds of } \\
\text { sandstone and con- } \\
\text { glomerate; a few } \\
\text { lenticular beds of } \\
\text { carbonaceous shale } \\
\text { and lignite. }\end{array}$ & $900_{ \pm}$ \\
\hline Tertiary (?) & & \multicolumn{2}{|c|}{$\begin{array}{l}\text { Uncontormity- } \\
\text { Rhyolite }\end{array}$} & $\begin{array}{l}\text { Massive dark-reddish- } \\
\text { brown rhyolite } \\
\text { porphyry. }\end{array}$ & \\
\hline $\begin{array}{l}\text { Carbonifer- } \\
\text { ous and } \\
\text { older } \\
\text { systems } \\
\ldots\end{array}$ & & & & $\begin{array}{l}\text { Bluish-gray and light- } \\
\text { gray cherty lime- } \\
\text { stone; light-gray } \\
\text { quartzite, quartz- } \\
\text { mica schist, and } \\
\text { marble; some dark } \\
\text { shale. }\end{array}$ & \\
\hline
\end{tabular}




\section{CARBONIFEROUS AND OLDER ROCKS, UNDIFFERENTIATED}

Anderson (1934, p. 377) assigns the rocks that crop out in the mountains along the northeastern margin of the district to the Albion Range group of Precambrian age. North of Cold Creek, these rocks consist of well-stratified quartzite containing much muscovite; to the south, between Cold and Little Pole Creeks, the rocks are predominantly light-gray limestone or marble. Light-tan and dark-bluishgray limestone, containing much dark chert, and some dark-gray to black shale crops out in the hills and mountains on the western side of the district, and in the vicinity of Birch and Hardister Creeks on the southeastern side. Similar rocks in nearby areas have been assigned by Anderson (1931, p. 30-35) to the Brazer limestone of Mississippian age, or to the Wells formation of Pennsylvanian age.

\section{RHYOLITE OF TERTIARY(?) AGE}

A thick massive rhyolite of porphyritic texture, much shattered by joints and fractures, crops out in the southeastern part of the mapped area from the vicinity of Birch Creek southward almost to Hardister Creek. Rhyolite is exposed also near the crest of a low hill in the southwestern part of the area between Jay and Trout Creeks. Samples collected from this formation by Piper were studied by E. S. Larsen who gives the following description (Piper, 1923, p. 27):

These specimens are rather dense red-brown banded tridymite-quartz latites. * * They carry about 20 percent of phenocrysts as much as 3 millimeters across, most of which are oligoclase feldspar. Quartz in resorbed crystals is abundant, and orthoclase, also resorbed is less abundant. Dark minerals are absent, though they may have been present in small amounts but are now decomposed. Magnetite and zircon are fairly abundant, and apatite is present. The groundmass in one specimen from Pole Creek is mostly a very fine spongelike intergrowth of feldspar and tridymite with some coarser intergrowths and some unusually large crystals of tridymite in the porous parts. A little quartz is closely associated with the coarse tridymite in the porous parts, and the two look as if they were contemporaneous.

Although the specimens examined by Larsen were identified as quartz latites, Piper (1923) used the field term "rhyolite" for the rocks as a whole and this practice is continued in this report.

The rhyolite probably intrudes Carboniferous and older limestone beds north of Birch Creek, as evidenced by a sill of rhyolite in these older strata in secs. 21 and 28, T. 16 S., R. 22 E., Idaho. Peterson (1942, p. 471-472) described the rhyolite as intrusive into Paleozoic and older rocks in the Ashbrook silver mining district, about 3 miles east of the mapped area in the northwestern part of T. 14 N., R. 17 W., Utah.

The rhyolite is older than Pliocene, as it unconformably underlies sedimentary rocks of Pliocene age. Piper (1923, p. 26) regards it as early Miocene(?) in age, noting that a similar body of rhyolite of 
probable Miocene age was described by Schrader (1912, p. 35-47) in the Jarbidge mining district, about 50 miles to the west.

\section{SEDIMENTARY ROCKS OF TERTIARY AGE}

Sedimentary rocks of Tertiary age exposed in the district consist of a basal series of Miocene or Pliocene age, made up mostly of shale and volcanic ash in about equal amounts, and an overlying predominantly pyroclastic series of Pliocene age made up mostly of volcanic ash and welded rhyolitic tuff. On the basis of lithology, stratigraphic position, and age, the lower sequence is tentatively correlated with the Payette formation as described by Kirkham (1931a, p. 232-234) in the Boise area of southwestern Idaho; and on the basis of lithology and stratigraphic position, the upper pyroclastic sequence is tentatively correlated with the Pliocene Salt Lake formation as described by Mansfield (1920, p. 54-55; 1927, p. 110-112) in and near the Fort Hall Indian Reservation in southeastern Idaho. Anderson (1931, p. 41-44) has pointed out the similarity in lithology and stratigraphic position of the Tertiary rocks of the Goose Creek area to both the Payette and Salt Lake formations. According to Anderson, welded tuffs in the upper part of the Tertiary sequence near Goose Creek are part of an essentially continuous sheet of rhyolitic rocks which overlies the lacustrine and fluviatile sediments of the Payette formation south of Boise in southwestern Idaho, and are interbedded with volcanic ash and clastic rocks in the upper part of the Salt Lake formation near the Fort Hall Indian Reservation and adjacent parts of southeastern Idaho. Kirkham (1931b, p. 580-581) notes the same stratigraphic relations of the Payette and Salt Lake formations, and both writers conclude that the two formations are essentially equivalent. In a more recent paper, Mansfield $(1952$, p. 46,59$)$ reported the discovery of two species of plants (Phragmites sp. and Castalia sp.) in beds of carbonaceous shale associated with welded rhyolitic tuffs near Idaho Falls. F. H. Knowlton, who identified the fossils, considered them to be Pleistocene in age, although his conclusion was not based on positive criteria. If the conclusion is correct, it indicates that the welded tuffs which are interbedded with and overlie the Salt Lake formation in parts of southeastern Idaho may be younger than those in the Goose Creek district and in nearby parts of south-central and southwestern Idaho.

In Cache Valley, eastern Box Elder County, Utah, and the adjacent part of Idaho-about 90 miles east of the Goose Creek districtseveral writers have described a sequence of as much as 9,000 feet of light-colored tuff, limestone, sandstone, and conglomerate of middle and late Pliocene age called the Salt Lake group and divided by Adamson, Hardy, and Williams (1955) into the Collinston con- 
glomerate, Cache Valley formation, and Mink Creek conglomerate. These rocks apparently are mostly younger than the Salt Lake formation in the Goose Creek district.

On the basis of lithologic similarity and age, the Tertiary rocks of the Goose Creek district might also be correlative with some part of the Humboldt formation, which, as described by Sharp (1939) in the vicinity of Elko and Wells in northeastern Nevada, includes a sequence of fluviatile, lacustrine, and pyroclastic deposits, at least 5,000 feet thick, of Miocene and possibly early Pliocene age. Sharp (p. 150) suggests that the Humboldt formation crops out as far north as Contact, Nev., which is about 40 miles southwest of the Goose Creek district.

The stratigraphic names that have been used for the Tertiary rocks of the Goose Creek district in earlier reports, and the approximate correlation of the Tertiary sequence with some rocks of Miocene and Pliocene age described in other parts of southern Idaho and northeastern Nevada, are summarized by charts 2 and 3. The lithologies of the Payette (?) and Salt Lake formations and the correlation of beds at various places within the district are shown by plate 47 .

\section{PAYETTE(?) FORMATION}

Rocks similar in many respects to the Payette formation crop out in the western part of the Goose Creek district in the valley of Trapper Creek, and in a wide band between the Right Hand Fork of Beaverdam Creek and Jay Creek. These rocks, here designated the Payette(?) formation, consist of interbedded tuffaceous shale and volcanic ash, with lesser amounts of conglomerate, sandstone, and

Chart 2.-Stratigraphio names used by various writers for the Tertiary rocks exposed in the Goose Creek district.

\begin{tabular}{|c|c|c|c|c|c|c|c|}
\hline Lithology & \multicolumn{2}{|c|}{$\begin{array}{l}\text { Bowen } \\
\text { (1913). }\end{array}$} & \multicolumn{2}{|c|}{$\begin{array}{l}\text { Piper } \\
\text { (1923) }\end{array}$} & $\begin{array}{c}\text { Anderson } \\
\text { (1931) }\end{array}$ & \multicolumn{2}{|c|}{ This report } \\
\hline $\begin{array}{l}\text { Volcanic ash and } \\
\text { conglomerate }\end{array}$ & \multicolumn{2}{|c|}{ Not described } & \multicolumn{2}{|c|}{ Not described } & Not described & \multirow{3}{*}{ 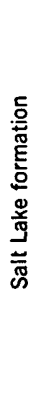 } & 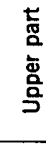 \\
\hline $\begin{array}{l}\text { Volcanic ash } \\
\text { and welded } \\
\text { tuff; some } \\
\text { conglomerate }\end{array}$ & \multirow{3}{*}{ 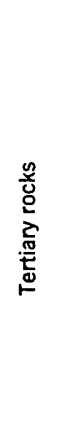 } & 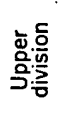 & \multirow{3}{*}{ 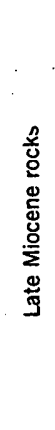 } & 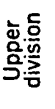 & \multirow{2}{*}{ Quartz } & & \\
\hline $\begin{array}{l}\text { Mostly volcanic } \\
\text { ash; some shale, } \\
\text { sandstone, and } \\
\text { conglomerate }\end{array}$ & & \multirow{2}{*}{ 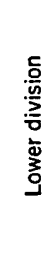 } & & \multirow{2}{*}{ 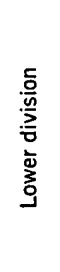 } & & & 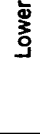 \\
\hline $\begin{array}{l}\text { Mostly shale and } \\
\text { volcanic ash; } \\
\text { some sandstone } \\
\text { and conglomerate }\end{array}$ & & & & & & \multicolumn{2}{|c|}{$\begin{array}{l}\text { Payette(?) } \\
\text { formation }\end{array}$} \\
\hline
\end{tabular}


CharT 3,-Approximate correlation of some racks of Tertiary and Quaternary age in southern Idaho and northeastern Nevada, as described by several writers.

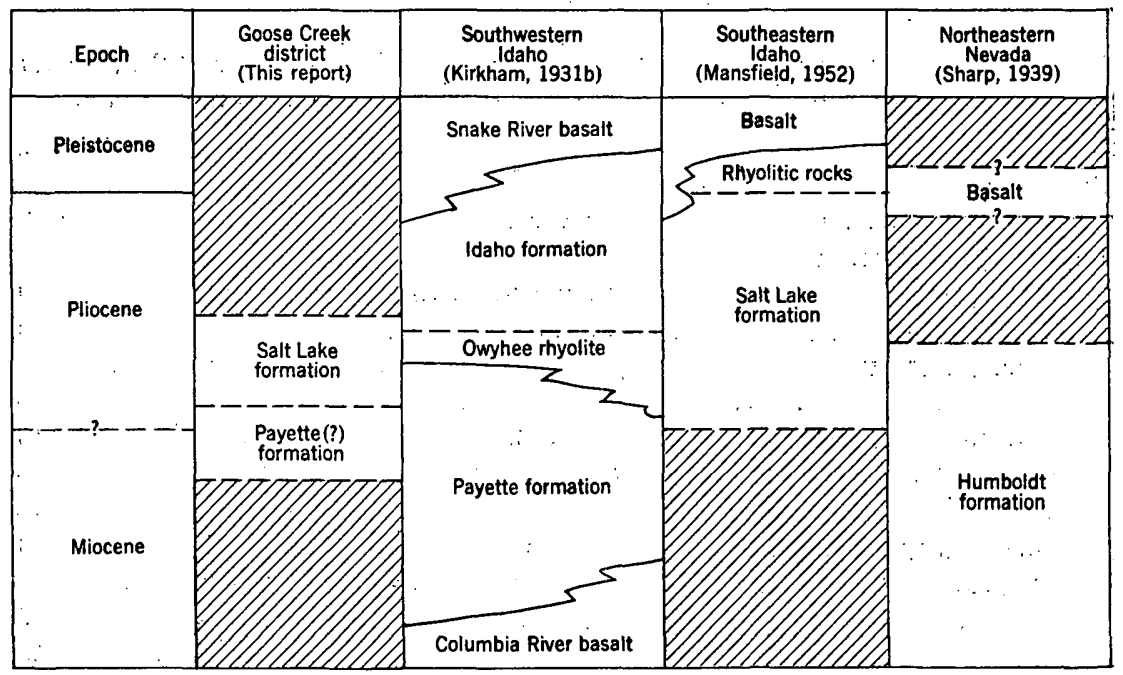

lignite. The thickness of the Payette(?) is not uniform, owing to its deposition on an uneven surface of Carboniferous and older rocks, but it is at least 900 feet thick near Dry Gulch in the west-central part of the mapped area, where all but the basal part was measured. About 200 feet of strata assigned to the Payette(?) formation crops out in the valley of Trapper Creek, but there only the upper part of the formation is exposed. Except for some of the beds of conglomerate, the formation erodes easily. and forms gentle slopes and flats.

About 50 percent of the Payette(?) formation is slabby, evenly bedded, light greenish gray and yellowish-gray tuffaceous shale." At some placès the shale is diatomaceous; fossil leaves and seeds are abundant in some beds, and the formation contain several lenses and thin beds of brown carbonaceous shale and lignite. Interbedded with the shale and making up most of the rest of the formation are beds of friable light-gray to white volcanic ash which range in thickness from a few inches to more than 100 feet. Beds of sandstone or conglomerate, locally as much as 40 feet thick, occur at various levels in the formation; their resistance to erosion makes them useful key beds for mapping and correlation. The coarse fragments in the beds of conglomerate are subrounded pebbles and cobbles of limestone and chert, commonly 1-4 inches in their longest dimension, derived from the older formations cropping out to the west of the area. Many of the conglomerate beds are lenses that pinch out within a few hundred yards, but a few are more widespread and may be traced for several miles. 
The following stratigraphic section (see columnar section 2 of plate 47) shows the character of the Payette(?) formation.

Section of part of the Payette(?) formation exposed near Dry Gulch, eenter of sec. 10 to NW1/4 sec. 19, T. 16 S., R. 20 E., Cassia County, Idaho

Salt Lake formation :

Feet

Volcanic ash, light-gray, partly covered._-_._- 20+

Payette(?) formation:

Shale, greenish-gray, fissile; contains plant and fish remains_...... 14

Mostly covered; probably volcanic ash

Shale, light-gray, flssile, tuffaceous; grades downward to silty lightgray claystone.

Volcanic ash, light-gray, partly covered

Shale, olive-brown, slightly carbonaceous; contains fossil leaves..--

Covered

Shale, grayish-green, fissile, tuffaceous

Claystone and shale, grayish-green to brown; contains Equisetum sp_.

Mostly covered; in part light-gray volcanic ash.

Shale, greenish-gray, weathers white, fissile, tuffaceous; abundant fish vertebrae

Claystone, light-gray, tuffaceous

Mostly covered; in part, light-gray volcanic ash

Shale, light-gray, fissile, brittle, tuffaceous, abundant Equisetum sp_-

Siltstone, brown, carbonaceous

Volcanic ash, brownish-gray and light-gray, friable, nonresistant_-

Sandstone, light-gray, fine- to medium-grained, tuffaceous; forms a ledge.

Siltstone, yellowish-gray, very tuffaceous; contains plant fragments and some interbedded shale 15

Volcanic ash, light-gray, contains lenses and partings of sandstone and siltstone

Shale, yellowish-gray, tuffaceous, fissile, slightly carbonaceous; 4 foot bed of light-gray volcanic ash near middle-

Shale, brown, carbonaceous.

Sandstone, gray, very fine grained, micaceous, grades upward to gray shale

Shale, brown, carbonaceous

Shale, grayish-green and brown, tuffaceous, fissile; contains numerous fish bones.

Sandstone, yellowish-gray, fine- to medium-grained, tuffaceous....--

Shale, brown, carbonaceous; contains a few streaks of dark-brown to black lignite; uppermost 1 foot is silty

Claystone, yellowish-gray, tuffaceous; contains a 1-foot bed of brown carbonaceous shale near the base

Volcanic ash, light-gray to white, massive; forms a bluff-...---.--.-

Shale, light grayish-green, tuffaceous, silty in upper part; contains

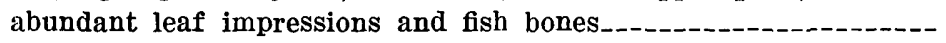


Section of part of the Payette $(\varphi)$ formation exposed near Dry Gulch, center of sec. 10 to NW1/4 sec. 1S, T. 16 S., R. 20 E., Cassia County, Idaho-Continued

\section{Payette(?) formation-Continued}

Worthington zone:

Feet

Shale, brown, carbonaceous._._. 3

Sandstone, yellowish-brown; fine-grained, tuffaceous; contains a

few partings of brown carbonaceous shale

Shale, medium- to dark-brown, carbonaceous

Volcanic ash, light-gray.

Shale, brown, carbonaceous

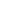

Shale and volcanic ash, in alternating thin to medium beds, lightgray.

Volcanic ash, light-gray ; upper part forms a ledge

Covered

Shale, light-gray, very tuffaceous; contains a few fish bones and leaf impressions.

Covered

Volcanic ash, light-gray ; poorly exposed

Shale, brown, carbonaceous; grades downward to gray shale_-_.--_--

Volcanic ash, light-gray

Covered

Conglomerate, pebbles of limestone, chert, and shale in a matrix of volcanic ash; forms a ledge.

Shale, gray and yellowish-gray, very tuffaceous_

Shale, brown, carbonaceous; contains a few streaks of dark-brown to black lignite.

Volcanic ash, light-gray, shaly and sandy________-_ 24

Siltstone, brown, carbonaceous_-_-_-_-_- 4

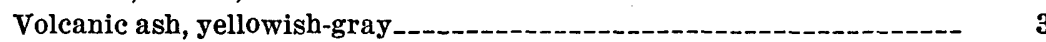

Conglomerate, pebbles of chert, limestone, silicified wood, and shale

in a matrix of tuffaceous sandstone; forms a ledge

Volcanic ash, tuffaceous siltstone, and sandstone, interbedded, light-

gray ; contains a few partings of brown carbonaceous shale-_..----

\section{Covered}

Shale, grayish-brown, slightly carbonaceous

Sandte

Shale, gray, tuffaceous; contains abundant plant fossils

Volcanic ash, light-gray

Claystone, greenish-gray

Total, measured part of the Payette(?) formation

Fossils collected from the Payette(?) formation include wellpreserved diatoms, leaves and seeds, and some spores and pollen. K. E. Lohman regards the age of the diatoms as early Pliocene, and R. W. Brown regards the age of the leaves and seeds as late Miocene. Spores and pollen that were collected are undiagnostic. The fossils are listed below.

Diatoms collected 5-75 feet stratigraphically below the top of the Payette (?) formation near Trapper Creek in the NE1/4 sec. 2, T. 15 S., R. 20 E., Idaho (fossil locality 1, pl. 46) ; identified by K. E. Lohman: 
[Relative abundance : $:$ C, commoñ ; F; frequent ;..R, rare]

Relative abundance

Relative abundance

Achnanthes lanceolata Brebisson

A. lanceolata var. elliptica Cleve..- $\mathrm{F}$

A. sp......... $\mathrm{R}$

Amphora commutata Grunow_..._- $\mathbf{R}$

Cocconeis sp...... $\mathbf{R}$

Coscinodiscus ef. C. subaulaco-

discoidalis Rattray-_._-_-_-_- $\mathrm{C}$

C. sp..--_-

Cymbella tumida (Brebisson:)! :

Van Heurck

Eunotia valida Hustedt_.._._._._... $\mathbf{R}$

F'ragilaria construens.. (Ehren-

berg) Grunow _._.

$F$. pinnata Ehrenberg._......... $\mathrm{F}$

$F$. sp._-_-__._-_._- $\mathbf{R}$

Melosira distans (Ehrenberg)

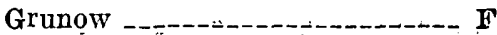

Gyrosigma sp.....-. $\mathrm{R}$

Melosira distans (Ehrenberg)

Kützing
M. distans var. alpigena Grunow_..- R

M. distans var. lineata (Ehren-:

berg) Bethge_..._._.......... F

M. granulata (Ehrenberg) Ralfs_- C

M. granulata var. procera

(Ehrenberg) Grunow

$M$. italica (Ehrenberg) Kützing _-- $\mathbf{R}$

$M$. sp._-_._-_._.

Navicula discephala (Ehrenberg)

Wm. Smith

N. scutelloides. Wm. Smith___._._. $\mathbf{F}^{\prime}$

N. subhexagona Hustedt________. $\mathrm{R}$

$N$. sp._._._. $\mathrm{R}$

opephora martyi Heribaud_._.....- F

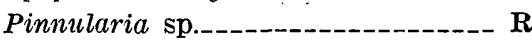

Tetracyclus cf. T. javanicus Hus-

tedt

$R$

T. lacustris Ralfs_._._._._. $\mathrm{F}$

$T$. cf. $T$. pagesi Hergaud____._-_-_ $\mathbf{R}$

T. rupestris (Brun) Grunow -...- $\mathbf{R}$

Leaves and seeds collected from the same locality as above (fossil locality 1); identified by R. W. Brown :

Abies laticarpus MacGinitie

Pinus sp.

Picea sp.

Pseudotsuga masoni MacGinitie

Sequoia affinis Lesquereaux

Populus eotremuloides Knowiton

Alnus carpinoides Lesquereaux

Pterocarya? sp.

Zelkova oregoniana (Knowlton) Brown
Quercus browni Brooks

Q. consimilis Newberry

Q. simulata Knowlton

Acer bendirei Lesquereaux

A. glabroides Brown

A. osmonti Knowlton

A. scottiae MacGinitie

Fraxinus idahoensis Brown

Leaves and seeds collected about 450 feet stratigraphically below the top of the Payette(?) formation near the Worthington mine in the SW1/4 sec. 23 , T. 16 S., R. 20 E., Idaho (fossil locality 2, pl. 46); identified by $R$. W. Brown:

Pseudotsuga masoni MacGinitie

Alnus carpinoides Lesquereaux
Acer bendirei Lesquereaux

A. scottiae MacGinitie

Commenting on the diatoms, Lohman states (written communication, 1953) :

This assemblage of diatoms was probably deposited in a cool fresh-water lake of moderate depth. It bears a striking resemblance to an assemblage obtained from a lower Pliocene diatomite on the east slope of the Cedar Mountains, Nye County, Nevada. The age of the Cedar Mountain beds was established by a large lower Pliocene vertebrate fauna obtained there by the University of California. Coscinodiscus spp. from the Goose Creek district are identical with two of the new species known from the Cedar Mountain beds. The same is true of several of the other unidentified species. Based on comparison with the diatom floras from the Cedar Mountains and elsewhere, I 
believe that the shale from the Goose Creek district represented by the sample submitted is early Pliocene in age.

Brown makes the following statement regarding the leaves and seeds (written communication, Jan. 26, 1954) :

The species here identified are individually, but not necessarily collectively, found in the Latah and Payette floras of Washington and Idaho, the Hog Creek flora of western Idaho, the Trout Creek, Sucker Creek, and Mascall floras of central and eastern Oregon. Some of the species have also been found in the Alvord Creek flora of southeastern Oregon, which is said to be early Pliocene in age. Perhaps there is not enough evidence here for drawing a sharp line between late Miocene and early Pliocene, but my inclination, after seeing the stratigraphic relations in the field, is to regard the flora as latest Miocene in age.

\section{SALT LAKE FORMATION}

The Salt Lake formation forms the surface of most of the district. It consists largely of friable volcanic ash, with several beds of welded rhyolitic tuff near the middle, and, at various levels, some beds of shale, sandstone, conglomerate, lignite, and limestone. For convenience in showing its distribution, the formation is divided into two parts at the base of the stratigraphically highest persistent bed of welded tuff. The formation is at least 2,300 feet thick, and about $1,200-1,600$ feet of the sequence is assigned to the lower part (pl. $48, A)$.

Most of the welded tuff in the Salt Lake formation occurs in four main beds, which range in thickness from less than 10 feet to as much as 250 feet. In general, the beds of welded tuff are thickest in the northern part of the district, where, north of Trapper Creek, they tend to merge. They thin gradually and irregularly southward. They are resistant to erosion and crop out as ledges and steep cliffs in the northern part of the district and as hogbacks in the southern part.

Previous investigators in the Goose Creek district referred to the beds of welded tuff as rhyolite flows. However, the rock is not a crystalline rhyolite, but is composed largely of glass shards and the texture is similar in all respects to the welded rhyolitic tuffs described by Mansfield and Ross (1935) in and near the Fort Hall Indian Reservation. Commonly, the basal part of each of the beds of welded tuff is a layer of black obsidian that ranges in thickness from a few inches to as much as 10 feet. At many places its contact with the underlying beds of volcanic ash is gradational within an interval of 1-6 inches. The obsidian commonly grades upward to a dense, stony, black to dark reddish-brown rock which locally is highly vesicular (pl. 49, $A$ ). Fragments of feldspar and spherical aggregates of tridymite occur in both rock types.

Ross (in Mansfield, 1952, p. 51-52) gives the following description of the composition, texture, and arigin of welded tuffs in southeastern 
Idaho which probably applies equally well to the welded tuffs of the Goose Creek district:

Most of the pyroclastic rhyolitic materials show various degrees of welding and distortion of the tuff fragments, due to various degrees of accommodation of the shape of one grain to another while still in a plastic condition. That is, the rhyolitic materials from the Idaho region show a typical eutaxitic texture as described and pictured by Iddings (1909, v. 1, p. 331-333) from the Yellowstone region.

The degree of plasticity of the grains after their fall varied greatly. In many specimens the plasticity was so great that the tuff fragments have become completely welded and are very greatly elongated in one direction. There is, however, no indication of more than slight flowage after fall and welding. In a few specimens there is welding, but only slight accommodation of the shape of one grain to another. In other specimens, the original porosity has been partially eliminated and in many of them it has been almost completely eliminated.

Tuff grains are commonly fragments of broken bubbles and glassy plates; moon-shaped fragments, Y-shapes and occasional hollow spheres are to be observed. * * The completely collapsed and welded fragments are now in the form of wavy plates or grotesquely distorted forms, but occasionally even these show a typical Y-shaped form. ** *

The completeness of devitrification, the character of the minerals formed (feldspar and tridymite), and the terminated crystals projecting into cavities, are all phenomena indicative of crystallization in the presence of hot gases *** The strong evidence of a gas-phase control of crystallization and heat adequate to maintain the tuff fragments in a plastic condition during wide dispersion from their volcanic vent suggests comminution and distribution under the influence of a blast of hot gases (nuées ardentes) as described by Lacroix (1904), at Pelée, and by Fenner (1923) for the Valley of Ten Thousand Smokes. However, the eutaxitic tuffs of the Idaho region do not show that heterogeneity that is supposed to characterize nuées ardentes deposits. A large proportion of the fragments are fairly well sorted with only an occasional grain or phenocryst markedly exceeding average size. It, therefore, seems probable that the eutaxitic material of the Idaho region was distributed by blasts of hot gas, but was blown so high and so far from the vent that a very fair degree of sorting occurred. In much of the material that fell under these conditions there was welding of the grains, very commonly a complete fusion together of the grains, and elimination of porosity. Commonly, enough hot gas was present after the fall and welding of the grains to promote devitrification.

Photomicrographs of friable volcanic ash and welded tuff from the Goose Creek district are shown together for comparison on plate 49 $B$ and $C$. Chemical analyses of the ash and welded tuff are shown by table 1.

A few thin beds of hard resistant welded tuff in the upper part of the Salt Lake formation are light gray to white. Unlike the welded tuffs described above, the pyroclastic texture of the rock is evident in hand specimens and these beds grade laterally into friable volcanic ash within a few hundred yards.

In most parts of the district, the thick beds of welded tuff maintain relatively uniform stratigraphic positions and so are useful for struc- 


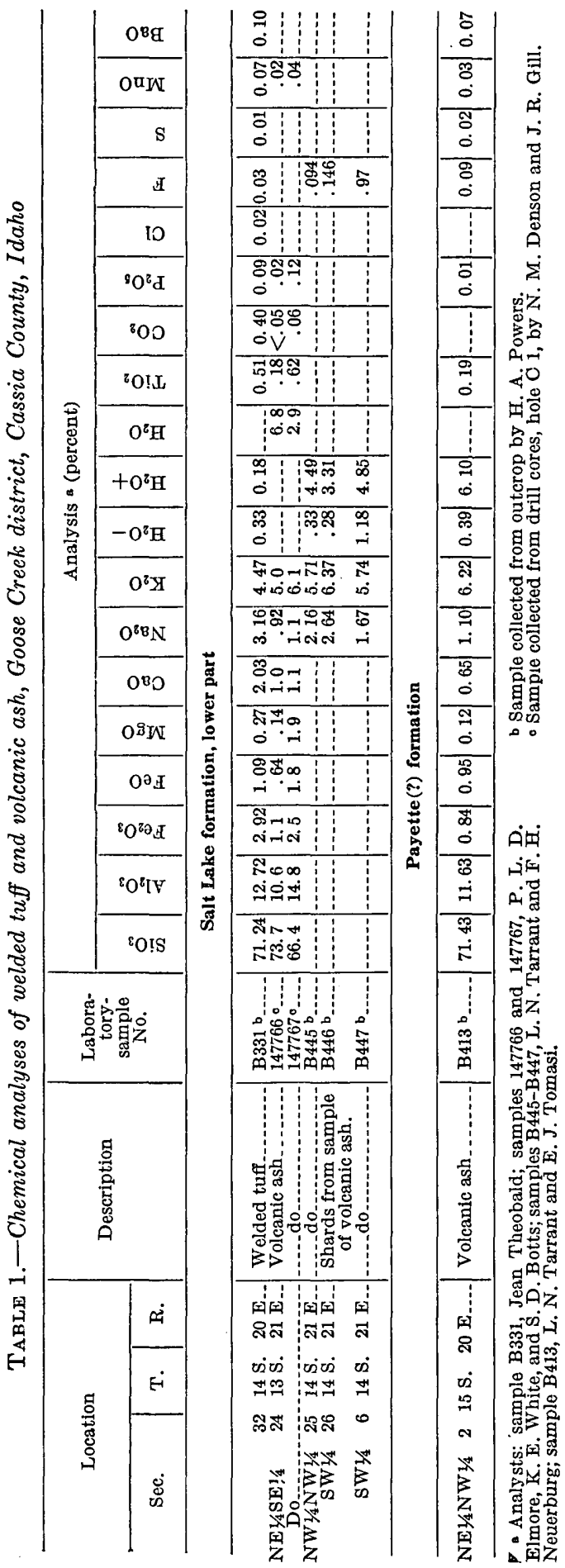


tural control. At some places, however, the welded tuff at the base of the upper part of the Salt Lake formation rests on an uneven surface that locally may have a relief of as much as 400 feet in 2 to 3 miles. Thus in secs. 19 and 20, T. 15 S., R. 22 E., and in secs. 13, 14, and 28 , T. 15 S., R. 21 E., Idaho, the uppermost bed of welded tuff merges with the bed of tuff normally 200 to 300 feet stratigraphically below it; and at Flatiron Butte, in secs. 33 and 34, T. 16 S., R. 21 E., Idaho, the thickness of the interval between the welded tuff which caps the butte and the next lower bed of tuff exposed on the side of the butte is nearly 400 feet less than its thickness between the equivalent beds about 3 miles to the northwest.

The volcanic ash which, together with welded tuff, makes up a large part of the Salt Lake formation is white to light gray and fairly well stratified in the lower part of the formation, becoming predominantly grayish orange and poorly stratified in the upper part. Some of the beds are thinly laminated, others are massive, and a few are crossbedded. Fine-grained shards make up most of the beds, but a few contain, in addition, numerous small fragments of spongy white pumice. The ash is friable, and small pieces may be crushed between the fingers; however, some of the beds are fairly resistant to erosion, and locally the ash stands in rounded ledges or in nearly vertical cliffs (pl. 48A).

In the vicinity of Birch and Pole Creeks, the darker ash in the upper part of the formation locally contains numerous angular fragments of welded tuff as much as 1 foot in the longest dimension. These fragments are unsorted and are scattered in the ash matrix with only the crudest alinement in beds. Parts of these deposits, including the tuff fragments, may have been eroded from rising fault blocks of the lower part of the Salt Lake formation to the east, carried westward, and reincorporated in the upper part of the formation as mud flows or alluvium. In the SE1/4 sec. 31, T. 16 S., R. 22 E., beds of white volcanic ash in the Salt Lake formation contain scattered subrounded boulders of Tertiary (?) rhyolite as much as 3 feet in diameter (pl. $48 B$ ). Adjacent to this deposit is Tertiary (?) rhyolite separated from the Salt Lake formation by a fault. Movement along this fault during deposition of the Salt Lake formation may have produced a scarp from which the boulders were shed as talus.

Lenticular beds of conglomerate, ranging in thickness from a few inches to 50 feet occur in both the lower and upper parts of the Salt Lake formation. In general, the beds are thickest and most numerous, and their constituent rock fragments are largest, near the mountains bordering the district on the east. Pebbles of quartzite, limestone, and chert make up most of the conglomerate in the lower part of the formation; pebbles and cobbles of rhyolite predoritinate in conglomerate in the upper part. 


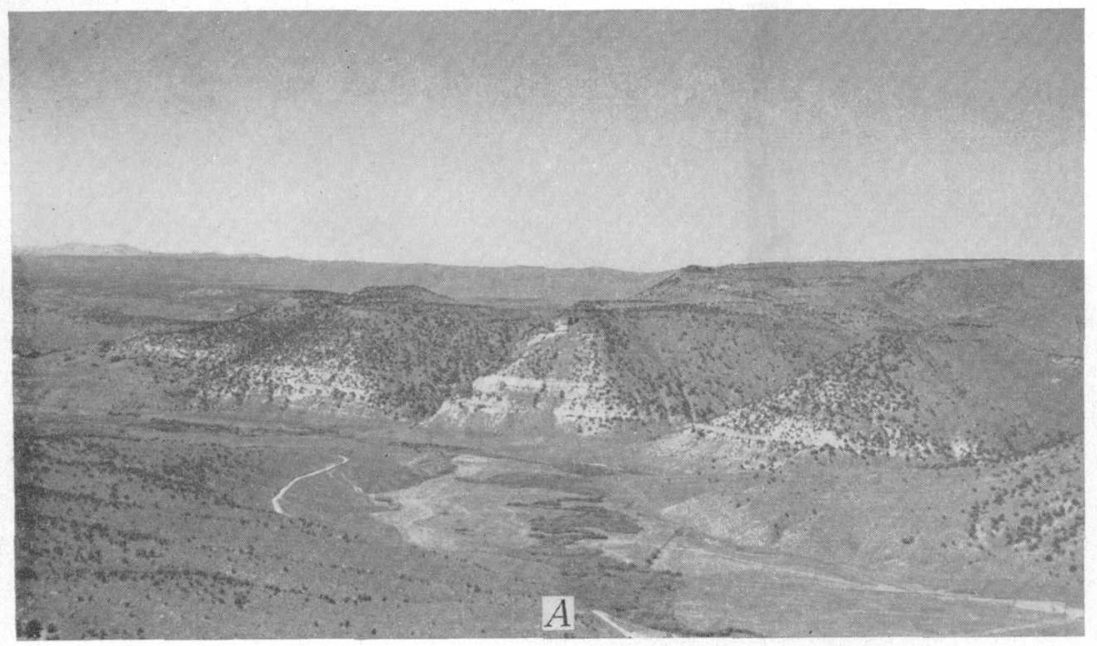

A. LOWER PART OF THE SALT LAKE FORMATION EXPOSED IN THE VALLEY OF GOOSE CREEK, T. 16 S., R. 21 E., IDAHO Beds of welded tuff cap the high bluffs on the far side of the stream.

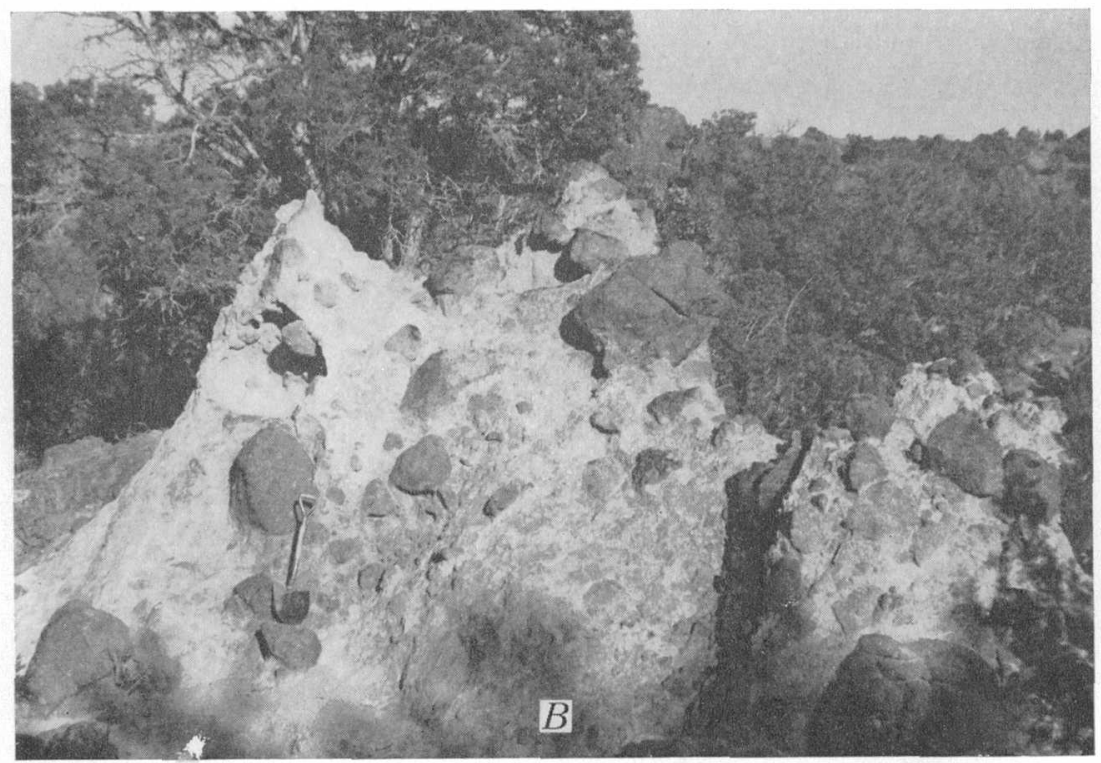

B. BOULDERS OF TERTIARY(?) RHYOLITE IN VOLCANIC ASH OF THE SALT LAKE FORMATION, SE1/4 SEC. 31, T. 16 S., R. 22 E., IDAHO 

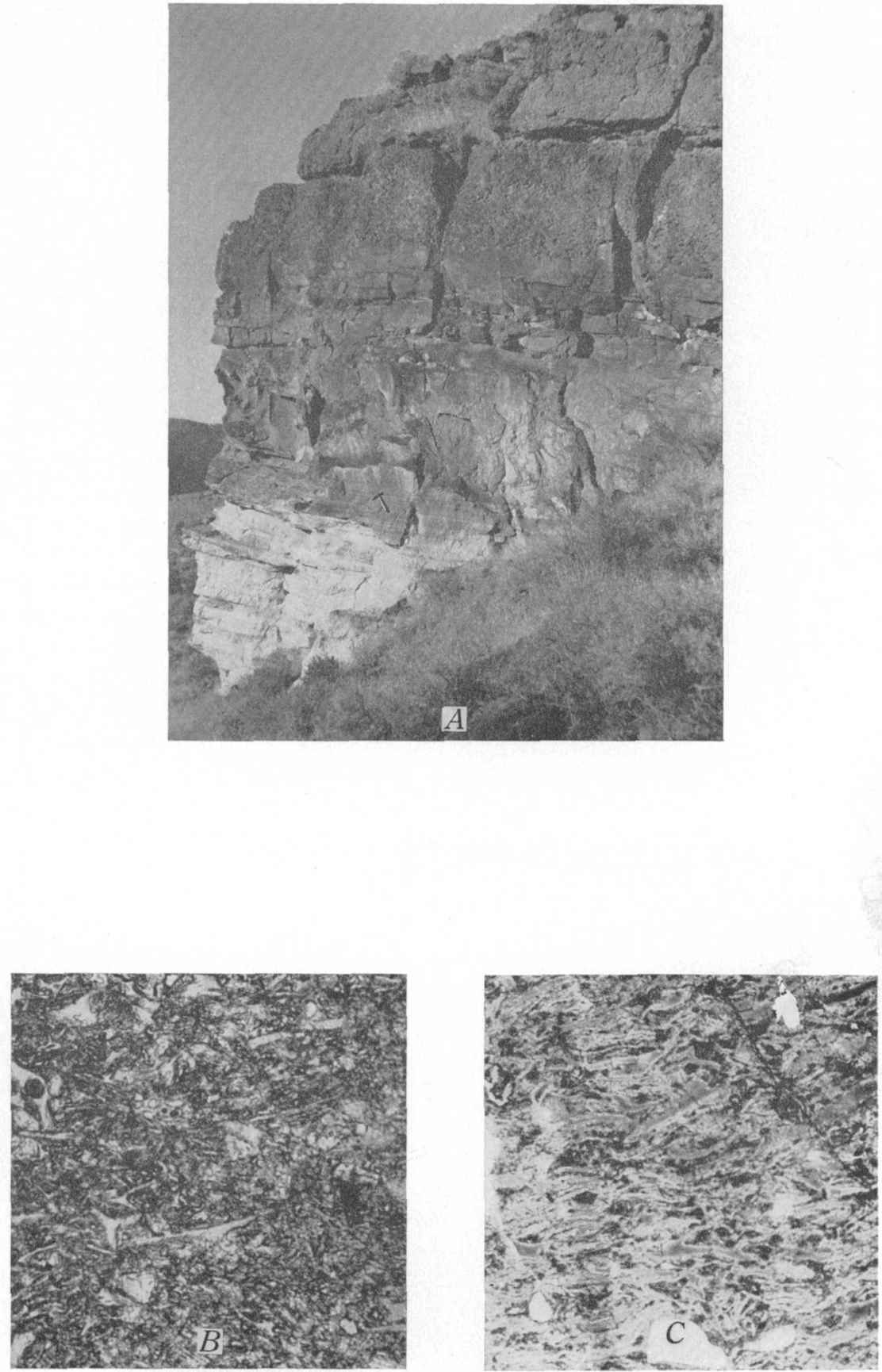

VOLCANIC ROCKS OF THE SALT LAKE FORMATION

$A$, Welded tuff; hammer is at the contact of glassy welded tuff with underlying friable volcanic ash; the glassy tuff grades upward to stony vesicular tuff at the top of the ledge. $B$, Photomicrograph of volcanic ash, showing undeformed glass shards ( $\times 35$, plain light). $C$, Photomicrograph of welded tuff, showing eutaxitic texture ( $\times 35$, plain light $)$. 
Grayish-green shale similar to that which makes up much of the underlying Payette(?) formation occurs also in the Salt Lake formation, particularly in the lower part, in the area south of Beaverdam Creek. Beds of brown carbonaceous shale and lignite also occur in the lower part of the formation at several horizons.

Light-colored argillaceous limestone in beds as much as 3 feet thick crop out locally in the lower part of the formation near Hardister Creek. None of the beds of limestone is persistent for more than a few hundred yards, and limestone is a very minor constituent of the formation.

Bentonite and bentonitic volcanic ash resulting from the devitrification of volcanic glass and its alteration to clay occur in the lower part of the formation, particularly in the central and southern parts of the district. Much of the bentonite and bentonitic volcanic ash have a granular texture, and in hand specimens shardlike outlines are plainly visible, but some of the bentonite is a dense homogeneous clay in which individual grains cannot be distinguished. The bentonite beds range in thickness from a few inches to as much as 20 feet.

The base of the Salt Lake formation in the vicinity of Trapper Creek is a thick sequence of friable volcanic ash which rests on the underlying shale of the Payette(?) formation with a slight angular unconformity. Southward from the Right Hand Fork of Beaverdam Creek, the basal part of the Salt Lake becomes increasingly shaly; and the position of the contact, which here appears conformable, was determined arbitrarily by the correlation of conglomerates. The Salt Lake formation overlaps the Payette(?) formation along the western, southern, and eastern sides of the district, and locally parts of the Salt Lake formation rest directly on Carboniferous and older rocks or on Tertiary (?) rhyolite.

The following stratigraphic sections of the upper part (columnar section 8 , pl. 47) and the lower part (columnar section 8, pl. 47) of the Sal take formation show its general character.

Composite stratigraphic section of the upper part of the Salt Lake formation west of Pole Creele, SE1/4 sec. 26 and NE1/4 sec. 35, T. N., R. 19 W., Box Elder County, Utah

Top of hill.

Feet

Surficial gravel deposit consisting of pebbles, cobbles, and boulders of rhyolite, chert, and limestone.

Upper part of the Salt Lake formation (part) :

Volcanic ash, grayish-orange, irregularly bedded; beds of light-gray volcanic ash, each about 3 feet thick, occur 40 feet, 70 feet, and 240 feet above base

Conglomerate, pebble-sized fragments of black and light-gray welded tuff in a matrix of grayish-orange volcanic ash; forms a lenticular ledge.

Partly covered; mostly light-gray volcanic ash grading upward to grayish-orange volcanic ash in the uppermost 20 feet. 
Composite stratigraphic section of the upper part of the Salt Lalke formation west of Pole Creel, SE1/4 sec. 26 and NE1/4 sec. 35, T. 15 N., R. 19 W., Box Elder County, Utah-Continued

Upper part of the Salt Lake formation (part) - Continued

Welded tuff, grayish-white ; 2 -foot bed of less-resistant grayish-white volcanic ash in middle of the unit; upper and lower parts form irregular, pitted ledges.

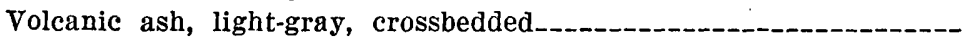

Volcanic ash, grayish-orange; contains angular fragments of white pumice and gray and black welded tuff, the largest of which are 2 inches in maximum dimension

Partly covered; mostly friable grayish-white volcanic ash.......-.--

Welded tuff, grayish-white; weathers to a rough, pitted surface; forms a ledge.

(Section is offset $1 / 2$ mile north on the base of above unit.)

Poorly exposed; in part, friable grayish-white volcanic ash

Welded tuff, grayish-white; forms a jagged cavernous ledge

Covered interval

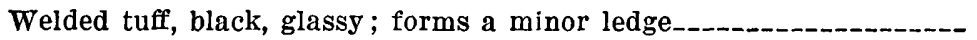

Mostly covered; in part, friable grayish-white volcanic ash.--_-.----

Welded tuff, black and dark reddish-brown, stony ; forms a conspicuous blocky ledge. The base of this unit is covered and is the base of the upper part of the Salt Lake formation

Total measured section, upper part of the Salt Lake formation

Composite stratigraphic section of the lower part of the Salt Lake formation near Hardister Creel, sec. 21, T. 14 N., R. 19 W., Box Elder County, Utah, and secs. 29, 30, and 31 (approx.), T. 47 N., R. 70 E., Elko County, Nevada

Upper part of the Salt Lake formation (part) :

Feet

Welded tuff, dark-gray to black, weathers dark reddish-brown, dense,

blocky ; forms the crest of a narrow ridge

Lower part of the Salt Lake formation:

Covered interval

Volcanic ash, grayish-white, friable, thin- to medium-bedded, in part crossbedded.

Volcanic ash, grayish-orange and grayish-white

Volcanic ash, grayish-white; a few thin beds of grayish-orange volcanic ash in the upper part; in part crossbedded

Welded tuff, black, stony to glassy; basal 1 foot grades downward to grayish-white volcanic ash; forms a minor ledge

Partly covered ; mostly friable grayish-white volcanic ash.-.-.--.-.-.

Limestone, grayish-white, argillaceous, abundantly fossiliferous; forms a ledge

Volcanic ash, grayish-white, friable, thin- to medium-bedded

(The part of the section described below is offset $3 / 4$ mile south at top of its uppermost unit.)

Welded tuff, uppermost $1 / 2$-foot is pink and pumiceous; lower 2 feet is black, stony, and blocky ; forms a ledge

Volcanic ash, grayish-white; contains several thin layers composed largely of sand-sized fragments of black welded tuff

Welded tuff, black; uppermost 3 feet is stony and slabby, lower 8 feet is glassy and perlitic; forms a prominent ledge 
Composite stratigraphic section of the lower part of the Salt Lake formation near Hardister Creek, sec. 21, T. 14 N., R. 19 W., Box Elder County, Utah, and secs. 29, 30, and 31 (approx.), T. 47 N., R. 70 E., Elko County, Nevada-Continued

Lower part of the Salt Lake formation-Continued

Feet

Volcanic ash, grayish-white, thin- to thick-bedded, some beds are crossbedded.

Bentonite, light-gray to light yellowish-gray

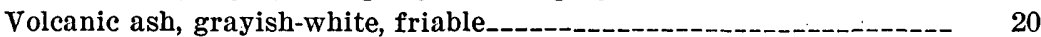

Covered _._._.

Volcanic ash, grayish-white, friable_-_-_-_._-_._- $\quad 30$

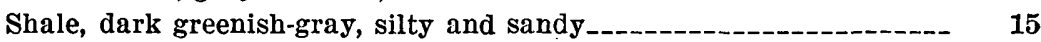

Barrett zone :

Shale, brown, carbonaceous $1 / 2$

Shale, greenish-gray ; contains a few thin seams of brown carbonaceous shale in the lower part.

Limestone, light-tan, grading downward to greenish-gray, argillaceous; contains abundant small gastropods ; forms a ledge.

Bentonite, yellow

Limestone, light-tan, argillaceous ; contains abundant small gastropods

Shale and siltstone, interbedded; dark-greenish-gray; contains a few thin beds of yellowish-gray bentonite and 2 thin beds of light-tan argillaceous limestone

Sandstone, dark grayish-yellow, fine-grained

Partly covered; in part, grayish-green shale, siltstone, and sandstone; shale at the top of the interval contains small gastropods and pelecypods

Shale, greenish-gray, fissile, brittle ; contains a few leaf impressions_-

Sandstone, light-gray, fine-grained, tuffaceous, crossbedded; forms a ledge

Volcanic ash, light-gray; and light yellowish-gray bentonite; thin bedded ; contains a few thin beds of grayish-green bentonite.

Bentonite, light yellowish-gray

Covered

Total measured section, lower part of the Salt Lake formation_- 1, 120 Carboniferous and older rocks, undifferentiated :

Limestone, grayish-brown, finely crystalline; contains stringers of gray and brown chert.

Fossils found in the Salt Lake formation include fresh-water mollusks, a few vertebrate remains, pollen and spores, some unidentified diatoms, and a few poorly preserved leaves and seeds. The mollusks and vertebrate remains indicate a Pliocene age and the formation is classified here as Pliocene, although the spores and pollen suggest that at least part of the formation may be older.

Fragments of vertebrate teeth and bones were collected from the basal part of the Salt Lake formation in sec. 1 (approximate location), T. 46 N., R. 69 E., Nev., on the lower slopes of a pair of gravelcapped buttes about $11 / 2$ miles southeast of the Trout Creek ranch (fossil locality $3, \mathrm{pl} .46$ ). The tooth fragments were identified by Jean Hough as parts of the upper molars of the horse Neohipparion, 
probably Neohipparion occidentale (Leidy), indicating an early or middle Pliocene age.

Fresh-water mollusks collected from the lower part of the formation were identified by $\mathrm{D}$. W. Taylor as follows:

U. S. G. S. Cenozoic loc. 20942 (fossil locality 4, pl. 46), fossiliferous shale in the upper part of carbonaceous shale zone $B$ (about 160 feet stratigraphically below the Barrett zone), north side of Birch Creek in the SW1/4 sec. 25, T. 16 S., R. 21 E., Idaho. ${ }^{1}$

\section{Sphaerium \\ Valvata referable to Valvata humeralis (Say) \\ Lymnaea albiconica Taylor \\ Lymnaea cf. L. megasoma Say \\ Planorbidae indet. \\ Physa}

U. S. G. S. Cenozoic loc. 20927 (fossil locality 5, pl. 46), light-tan limestone at the base of the Barrett carbonaceous shale zone, 1 mile southeast of the Goose Creek ranch in sec. 30 (approx.), T. 47 N., R. 70 E., Nevada.

\section{Sphaerium}

Lymnaea cf. L. megasoma Say

U. S. G. S. Cenozoic loc. 20924 (fossil locality 6, pl. 46), light-gray limestone about 450 feet above the Barrett carbonaceous shale zone in sec. 29 (approx.), T. 47 N., R. 70 E., Nevada.

\section{Sphaerium}

Planorbarius? n. sp.

Taylor notes (written communication, 1958) in regard to the collection from locality 20942 that Lymnaea albiconica, Lymnaea cf. L. megasoma Say, the Valvata, and the indeterminate planorbid all occur in the Teewinot formation of western Wyoming and southeastern Idaho (Taylor, 1956, p. 123-125), and that the mollusks of that area are dated at two localities by mammals of middle Pliocene age. Taylor also considers the fossils from locality 20927 as middle Pliocene in age although he states that the assemblage is not diagnostic. The fossils from locality 20924 represent a distinctly different type of assemblage, according to Taylor, and he comments:

The two species *** are clearly similar to very good material from several places in the Rockland Valley area, south of American Falls, Idaho. *** On the basis of what is known of the late and middle Pliocene of southern Idaho, the collection from loc. 20924 and the Rockland Valley assemblage are more reasonably called late middle Pliocene than early late Pliocene.

Spores and pollen collected from the lower part of the Salt Lake formation were identified by Estella B. Leopold as follows:

Samples D1208-1 and -2 , carbonaceous shale from the Barrett carbonaceous shale zone at the Barrett prospect, center of the N1/2 sec. 5, T. 15 S., R. 21 E., Idaho : pollen of juniper, sedges, poplar, and many unidentified monocots, spores of Polypodiaceae (fern) and remains of Botrycoccus (alga).

\footnotetext{
1 Fossils from this locality as identified by T. C. Yen were listed in an earlier report (Mapel and Hail, 1956, p. 15-16). Yen's list of species is here modified as a result of a reexamination by $D$. W. Taylor.
} 
Samples D12028-3 and -4, carbonaceous shale and lignite from the Barrett carbonaceous shale zone at a coal prospect along Coal Banks Creek, SW $1 / 4$, sec. 34, T. 15 S., R. 21 E., Idaho, contains pollen of Zelkova (abundant), Carya, Sarcobatus vermiculatus, Cyperaceae, Pinus (abundant), Alnus?, Abies, Potamogeton, Betula, Sparganium or Potamogeton, Onagraceae (cf. Ludwigia), Ephedra cf. viridis, $E$. cf. nevadensis, fern spores, fungal spores.

Miss Leopold notes (written communication, 1958) a close similarity of the assemblage in samples D12028-3 and -4 to material from the Creede formation (Miocene) of southwestern Colorado, especially the abundance of Zelkova and Carya, the presence of a fir species, and the absence of pollen of the family Compositae. She points out that Zelkova and Carya are rare or absent in collections of the Miocene-Pliocene Hog Creek flora, Idaho, from the middle Pliocene Teewinot formation, Wyoming, and from middle Pliocene rocks in the Teton region, Wyoming. She states: "The generic composition of this assemblage indicates a Miocene or Pliocene age. The strong representation of the exotic genus Zelkova suggests a late Miocene rather than a Pliocene age."

Fossil leaves were collected at several horizons in the lower part of the formation, but those which could be identified (Equisetum sp. and Salio sp.) do not help in determining the age of the enclosing rocks.

\section{SURFICIAI DEPOSITS OF QUATERNARY AGE}

Surficial deposits of Quaternary age include deposits of alluvium, slope wash, landslide material, and gravel on high surfaces.

Alluvial deposits consisting of silt, sand, and gravel floor the valley of Goose Creek in a band as much as half a mile wide. The thickness of these deposits is unknown at most places; however, a core hole drilled near the mouth of Coal Banks Creek went through 80 feet of alluvium at a point not more than 100 feet horizontally from exposures of bedrock on the adjacent valley wall. Near the axis of the valley the alluvium may be thicker. Alluvium also borders a few of the other large streams in the district, but for the most part it occurs in bands that are too narrow to be shown on the geologic map.

A large deposit of slope wash, consisting of soil and rock detritus that conceals the underlying bedrock, covers about 9 square miles in the northeastern corner of the district. Much of the material is bouldery rubble derived from the adjacent slopes of quartzite. Streams have eroded gullies and washes in the deposit at various places, but in general its upper surface is a broadly sloping flat that merges with steeper mountain slopes cut on Carboniferous and older rocks along its upper boundary and with more gentle slopes cut on the Salt Lake formation at its lower boundary.

Three large landslides and two small ones were mapped during the present investigation. The largest landslide covers an area of about 
1 square mile near the headwaters of Squaw Creek in the northwestern part of the district; others border Goose Creek in the northeastern, central, and southwestern parts; and one lies at the foot of mountain slopes a few hundred yards south of the Idaho-Nevada boundary in the western part. The displaced material comprising all the landslide masses is from the Salt Lake formation.

Deposits of sand and gravel as much as 15 feet thick cover several high, broad surfaces in the southern part of the district. The surfaces extend from the mountains east of the mapped area toward Goose Creek with a gentle gradient, and near Goose Creek are about 200 feet above the present stream level. Streamworn pebbles, cobbles, and boulders of rhyolite, quartzite, and limestone derived from the mountains to the east make up the coarser fragments in these deposits.

\section{STRUCTURE}

The Goose Creek district occupies a topographic and structural basin in the northern part of the Basin and Range province. The Tertiary rocks are faulted, gently folded, and rest unconformably on a complexly folded and faulted basement of Tertiary (?) and preTertiary rocks. Both the Tertiary and older rocks of the district plunge northward beneath relatively undeformed Pliocene and Pleistocene basaltic lava flows of the Snake River plain.

Plate 46 shows the structure of the Salt Lake and Payette(?) formations by means of structure contours drawn at 100-foot intervals on the top of the Barrett carbonaceous shale zone. In general the Tertiary strata have a gentle easterly dip that averages about 3 degrees, but the eastward tilting is modified locally by shallow folds and structural terraces, and the rocks are disrupted at many places by normal faults. The structural relief in the district is at least 3,000 feet, with the structurally highest part west of Ibex Peak in T. 15 S., R. 20 E., Idaho, and the structurally lowest part south of Pole Creek in the northern part of T. 14 N., R. 19 W., Utah.

\section{FOLDS}

The main structural feature in the northern part of the district is the Goose Creek syncline, a northerly trending fold, the axis of which coincides roughly with the valley of Goose Creek. Near the upper end of the Goose Creek reservoir, the syncline is a structural basin having a closure of about 200 feet. The welded tuff at the base of the upper part of the Salt Lake formation crops out at the level of Goose Creek in the trough of this fold. The Goose Creek syncline dies out southward against a low anticlinal ridge that extends eastward for about 2 miles in the vicinity of Little Pole Creek. South of this ridge, the Salt Lake formation is folded into a second, broad, poorly defined syncline, the axis of which extends southwestward for about 
5 miles, almost to the Idaho-Utah boundary, where it is terminated by a series of northeastward-trending normal faults.

Along Hardister Creek, in the southern part of the district, the welded tuff at the base of the upper part of the Salt Lake formation may be traced around a broad northerly trending syncline and sharply folded anticline that is faulted along its crest. Dips on the steep west flank of the anticline are as much as $50^{\circ} \mathrm{W}$.

The Tertiary rocks in the northwestern part of the district are arched into a low anticlinal fold or structural terrace breached by the valley of Trapper Creek. The Payette(?) formation is exposed in a narrow strip near the crest of this fold.

Undulating folds and local flattening or steepening of the general easterly dip are shown by the structure-contour map, plate 46 , at various other places in the district.

\section{FAULTS}

Many normal faults, some with displacements of several hundred feet, cut the Salt Lake and Payette(?) formations. Most of the larger faults trend northward or northeastward. A few may. be traced for several miles.

A normal fault brings the upper part of the Salt Lake formation against Carboniferous and older limestone and quartzite along the eastern side of the district, from Birch Creek northward for at least 10 miles. Because of the slope wash and talus, the fault surface was not observed; however, the upper part of the Salt Lake formation dips eastward into Carboniferous and older rocks at angles ranging from $5^{\circ}$ to $46^{\circ}$ adjacent to its inferred trace. The Salt Lake formation covers a small area on the upthrown side of the fault in sec. $22, \mathrm{~T}$. 15 S., R. 22 E., where welded tuff at the base of the upper part of the formation rests directly on quartzite. The bed of tuff at this locality is nearly flat lying and is about 300 feet topographically higher than the equivalent bed exposed on the opposite side of the fault half a mile to the west. Vertical displacement along the fault, therefore, may have been as much as 300 feet, after the deposition of the tuff. Some movement and erosion may have occurred along the fault before deposition of the welded tuff, inasmuch as several hundred feet of volcanic ash and other rocks of the lower part of the Salt Lake formation crop out beneath the tuff on the west side of the fault, but are absent east of it.

Near Birch Creek, and extending from Birch Creek southward to Pole Creek, the upper bed of welded tuff of the Salt Lake formation is brought to the surface in a complex series of faulted wedges bounded by northerly or northeasterly trending normal faults. The displacement across the faulted zone is at least 900 feet, down on the east, along Birch Creek in sec. 25, T. 16 S., R. 21 E. Bordering this 
faulted area on the east and extending from Birch Creek southward to Hardister Creek, the lower and upper parts of the Salt Lake formation are faulted against Tertiary (?) rhyolite along a system of parallel northerly trending high-angle normal faults, downthrown on the west. The displacement of any one of the faults was not determined, but across the fault system the displacement may be several hundred feet.

Several faults cut the Tertiary rocks in the central and western parts of the district. The largest of these, with a displacement of about 500 feet upthrown on the west, is near the junction of Idaho, Utah, and Nevada. The fault trace extends for about $31 / 2$ miles with a north-easterly trend in the lower part of the Salt Lake formation. Other faults in the Salt Lake or Payette(?) formations have displacements of less than 250 feet.

\section{STRUCTURAT HISTORY}

Sharp (1939, p. 156-158) has proposed that in parts of northeastern Nevada the Miocene basins of deposition originated as a result of downwarping or faulting, and that faulting continued during later Tertiary time. Although folding and faulting in the Goose Creek district may not have been strictly contemporaneous with that noted by Sharp in nearby areas in Nevada, a similar structural history can be postulated as follows: (1) folding or faulting which originated the basin of deposition of the Payette(?) formation, (2) faulting during deposition of the Payette(?) and Salt Lake formations with progressive deepening of the basin and rejuvenation of the adjacent highlands, and (3) renewed faulting and folding after deposition of the Salt Lake formation, perhaps in adjustment to downwarping of the Snake River plains to the north.

\section{MINERAL RESOURCES}

\section{LIGNITE}

Thin seams and beds of dark-brown to black lignite and beds of brown carbonaceous shale occur in both the Salt Lake and Payette(?) formations. Small prospects and mines have been opened on the lignite beds at various places in the district, and Bowen (1913, p. 258) reports that lignite from one of these mines, the Worthington mine in sec. 23 , T. 16 S., R. 20 E., Idaho, was marketed at Oakley before 1911. The other lignite prospects in the district were never worked as commercial mines.

The lignite is dark brown to black when fresh; on weathering, it disintegrates rapidly to brown flakes and scales. It is commonly high in ash and is of doubtful commercial value for fuel. The grade of some of the better lignite and lignitic shale in the district is shown by fuel analyses made by the U. S. Bureau of Mines and given in table 2 . 


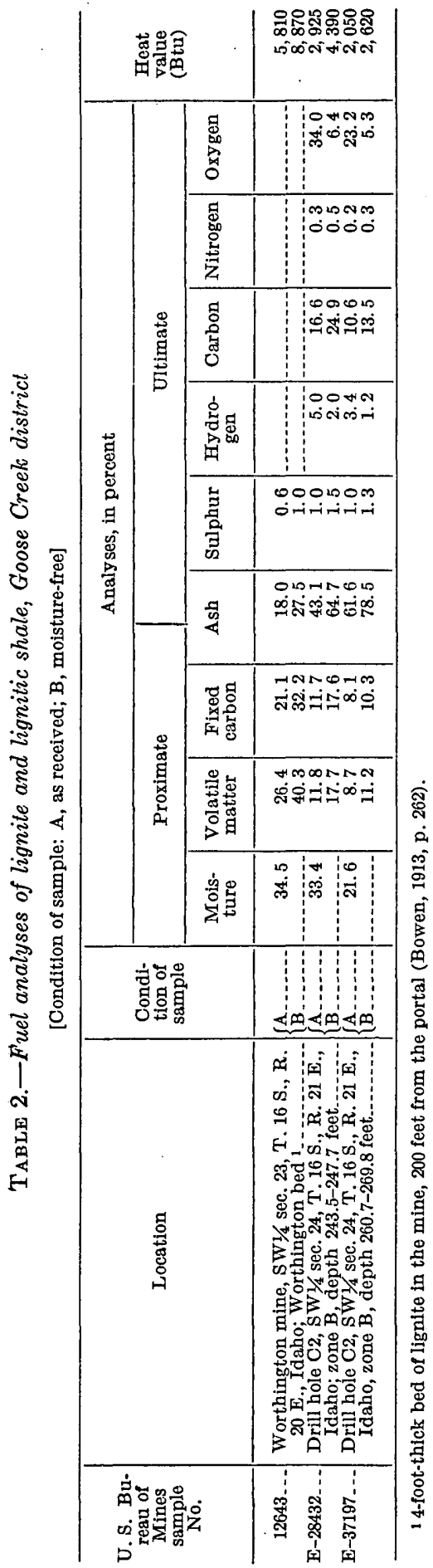


The carbonaceous shale and lignite beds are interbedded with volcanic ash, greenish-gray shale, bentonite, sandstone, and conglomerate in fairly well defined zones, some of which can be traced for tens of miles. Individual beds of lignite and carbonaceous shale, however, are lenticular and may pinch out or be replaced by noncarbonaceous material within a few hundred feet. Carbonaceous zones have been examined at about 100 localities in the district. Detailed sections at 39 of these localities are shown graphically on plate 50 .

On both sides of the Coal Banks Creek-Beaverdam Creek divide, beds of lignite in the lower part of the Salt Lake formation have burned underground, and the heat has fused and baked the overlying rocks to conspicuous masses of bright-red clinker.

Two main beds, or zones, and several less persistent lenses of carbonaceous shale and lignite occur in the Payette(?) formation. The Grant zone, here named for its occurrence at the Grant prospect in NW $1 / 4$ sec. 2 , T. 15 S., R. 20 E. (locality $35^{2}$ ), crops out about 125 feet below the top of the formation in the valley of Trapper Creek. The zone contains as many as 6 thin lenticular beds of carbonaceous shale and lignite interbedded with shale, sandstone, and volcanic ash in a stratigraphic interval of as much as 60 feet. The Worthington bed, named by Bowen (1913, p. 257) from the Worthington mine in sec. 23, T. 16 S., R. 20 E. (locality 38), crops out about 500 feet below the top of the formation near South Beaverdam Creek, where it consists of one bed of carbonaceous shale, locally lignitic, 2-5 feet thick. Nearby, in section 11 of this township (locality 37), 3 beds of carbonaceous shale in an interval of 45 feet are mapped as the Worthington zone.

The lower part of the Salt Lake formation contains four main carbonaceous shale zones. Their relative stratigraphic positions and thicknesses are summarized in the generalized section below :

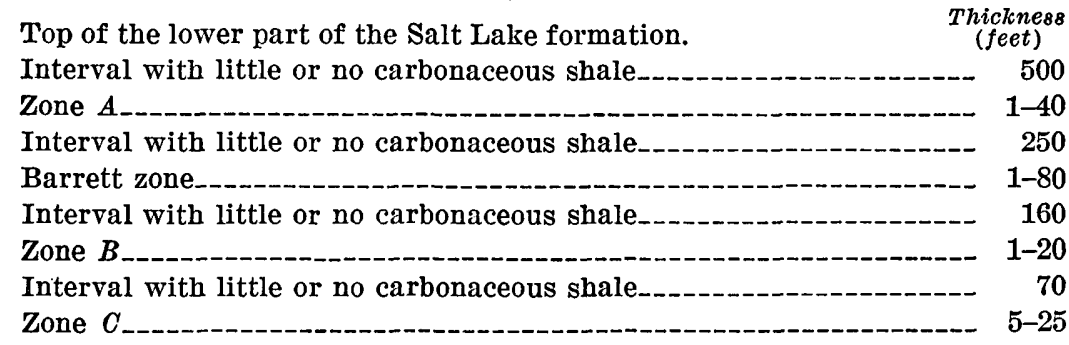

Of these four zones, the Barrett zone is the thickest and most persistent. It was named by Bowen (1913, p. 257) from its occurrence at the Barrett prospect in sec. 5, T. 15 S., R. 21 E. (locality 3), where it crops out 30 feet below the lowest bed of welded tuff in the lower part of the Salt Lake formation. The Barrett zone may be traced

\footnotetext{
2 Numbers given are the locality numbers shown on plates 46 and 50 .
} 
almost continuously from Trapper Creek southward to Hardister Creek, or for almost the length of the mapped area. It is thickest on the sides of the Coal Banks Creek-Beaverdam Creek divide in T. 16 S., R. 21 E., where the zone contains as many as 10 beds of carbonaceous shale and thin stringers of lignite ranging in thickness from less than 1 foot to 10 feet in a stratigraphic interval of 50-80 feet. The beds of lignite in the Barrett zone have been mined at the Barrett prospect, and also near the head of Coal Banks Creek in sec. 34, T. 15 S., R. 21 E. (locality 17).

\section{URANIUM}

Most of the Tertiary rocks sampled in the Goose Creek districtincluding beds of volcanic ash, welded tuff, sandstone, and carbonaceous and noncarbonaceous shale-are slightly radioactive. At some places, however, beds of carbonaceous shale, lignite, or lignite ash in the lower part of the Salt Lake formation contain concentrations of uranium in amounts many times that of the enclosing strata. The thickness and uranium content of some of the more radioactive of these carbonaceous beds, as determined by examination and sampling of outcrops and drill cores, are shown by fig. 37 and pl. 50, and analyses for uranium in some of these beds are given in table 3 . No uranium minerals were identified, and the mineralogic nature of the occurrences is unknown.

The Barrett zone contains nearly all known deposits of uranium in the district assaying more than 0.005 percent. The zone is most uraniferous at locality 28 , sec. 26 , T. 16 S., R. 21 E., Idaho, where the uppermost 1-foot of a bed, at least 8 feet thick, of carbonaceous shale contains 0.12 percent uranium. Beds of carbonaceous shale or lignite in the Barrett zone contain at least 0.01 percent uranium at several other places in the same vicinity. Zone $B, 160$ feet below the Barrett zone, is also radioactive, and where tested by drilling in the SE $1 / 4$ SW $1 / 4$ sec. 24 , T. 16 S., R. 21 E. (core hole 2), a zone 0.5 foot thick near the top of a bed of lignitic shale 5.5 feet thick contains 0.101 percent uranium.

The principal area in which the Barrett zone and zone $B$ are mineralized is a northeasterly trending strip, about 4 miles wide and 6 miles long, near Goose Creek, in T. 16 S., R. 21 E. Isolated concentrations of uranium occur also north of this area in the valley of Trapper Creek, where a carbonaceous bed in the Barrett zone contains 0.045 percent uranium at the Barrett prospect (locality 3), and 0.034 percent uranium about $2 \frac{1}{2}$ miles to the southwest at locality 4. As shown by the structure-contour map, pl. 46, the mineralized area in T. 16 S., R. 21 E., is on the flanks and along the trough of a syncline, the axis of which trends northeastward across the southeastern part of the township. 
244 URANIUM IN C COAL IN THE WESTERN UNITED STATES

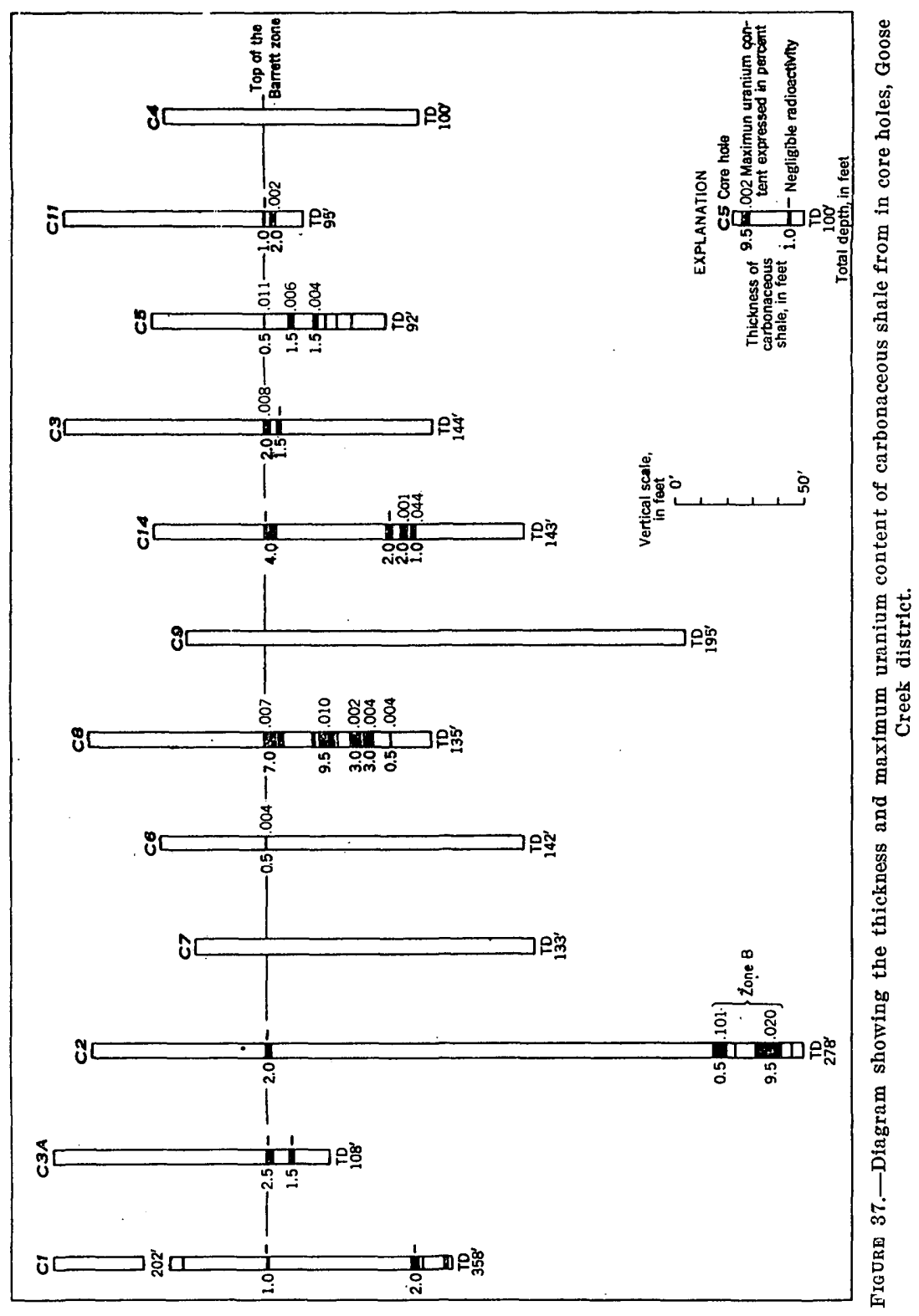


$\mathrm{T}_{\mathrm{ABLE}}$ 3.-Analyses for uranium in selected samples of carbonaceous shale and lignite, Goose Creelc district

[Analyses by the U. S. Geological Survey]

\begin{tabular}{|c|c|c|c|c|c|c|c|}
\hline $\begin{array}{c}\text { Locality } \\
\text { No: (pls: } \\
\mathbf{4 6} \text { and } \\
50 \text { ) }\end{array}$ & $\begin{array}{c}\text { Description } \\
\ldots \\
. .\end{array}$ & & $\begin{array}{c}\text { Labora- } \\
\text { tory } \\
\text { sample } \\
\text { No. }\end{array}$ & $\begin{array}{c}\text { Equiv- } \\
\text { alent } \\
\text { uranium } \\
\text { (percent) }\end{array}$ & $\begin{array}{l}\text { Uranium } \\
\text { (pcrcent) }\end{array}$ & $\underset{\text { (percent) }}{\text { Ash }}$ & $\begin{array}{c}\text { Üranium } \\
\text { in ash } \\
\text { (percent) }\end{array}$ \\
\hline
\end{tabular}

SALT LAKE FORMATION

Barrett zone

3 4.0-ft bed, top $1.0 \mathrm{ft}$

$8.5 \mathrm{ft}$ bed, top $1.0 \mathrm{ft}$

next $1.0 \mathrm{ft}$

next $0.4 \mathrm{ft}$

next $1.5 \mathrm{ft}$

next $1.0 \mathrm{ft}$

next $1.0 \mathrm{ft}$.

4 3.0-ft bed

8.3-ft bed, top $0.5 \mathrm{ft}$ :

next $0.4 \mathrm{ft}$.

8 2.0-ft bed.

7.5 -ft bed, top $0.7 \mathrm{ft}$

next $2.3 \mathrm{ft}$

next $2.6 \mathrm{ft}$

bottom $1.9 \mathrm{ft}$

9 1.5-ft bed

3.0-ft bed

5.0-1t bed.

2.1-ft bed.

3.0-ft bed

2.8-ft bed

11

4.0-ft bed, top $0.8 \mathrm{ft}$

middle $0.8 \mathrm{ft}$.

bottom $0.8 \mathrm{ft}$

1.1-ft bed

0.5 -ft bed

13.7-ft bed, top $0.8 \mathrm{ft}$

next $0.8 \mathrm{ft}$

next $0.8 \mathrm{ft}$.

-

next $0.8 \mathrm{ft}$

next $0.8 \mathrm{ft}$

next $0.9 \mathrm{ft}$ below $0.9-\mathrm{ft}$ part-

ing of volcanic ash

next $0.9 \mathrm{ft}$.

next $0.9 \mathrm{ft}$

next $0.9 \mathrm{ft}$.

next $1.0 \mathrm{ft}$

next $1.0 \mathrm{ft}$.

next $1.0 \mathrm{ft}$

bottom 1.0

1.8-ft bed, top $0.9 \mathrm{ft}$ bottom $0.9 \mathrm{ft}$

2.2-ft bed, top $1.1 \mathrm{ft}$

bottom $1.1 \mathrm{ft}$

2.7-ft bed, top $0.9 \mathrm{ft}$ middle $0.9 \mathrm{ft}$ : bottom $0.8 \mathrm{ft}$

3.4-ft bed, top $1.4 \mathrm{ft}$

bottom $2.0 \mathrm{ft}$

2.5-ft bed, top $1.0 \mathrm{ft}$

bottom $1.5 \mathrm{ft}$

9.6-ft bed, top $1.5 \mathrm{ft}$.

next $1.5 \mathrm{ft}$

next $1.5 \mathrm{ft}$

next $1.5 \mathrm{ft}$

9.6-ft bed, bottom $1.5 \mathrm{ft}$

7.2-ft bed, top $1.4 \mathrm{ft}$.

next $1.5 \mathrm{ft}$.

next $1.0 \mathrm{ft}$.

next $1.3 \mathrm{ft}$

1.4-ft bed

bottom $2.0 \mathrm{ft}$

2.5-ft bed, top $1.2 \mathrm{ft}$

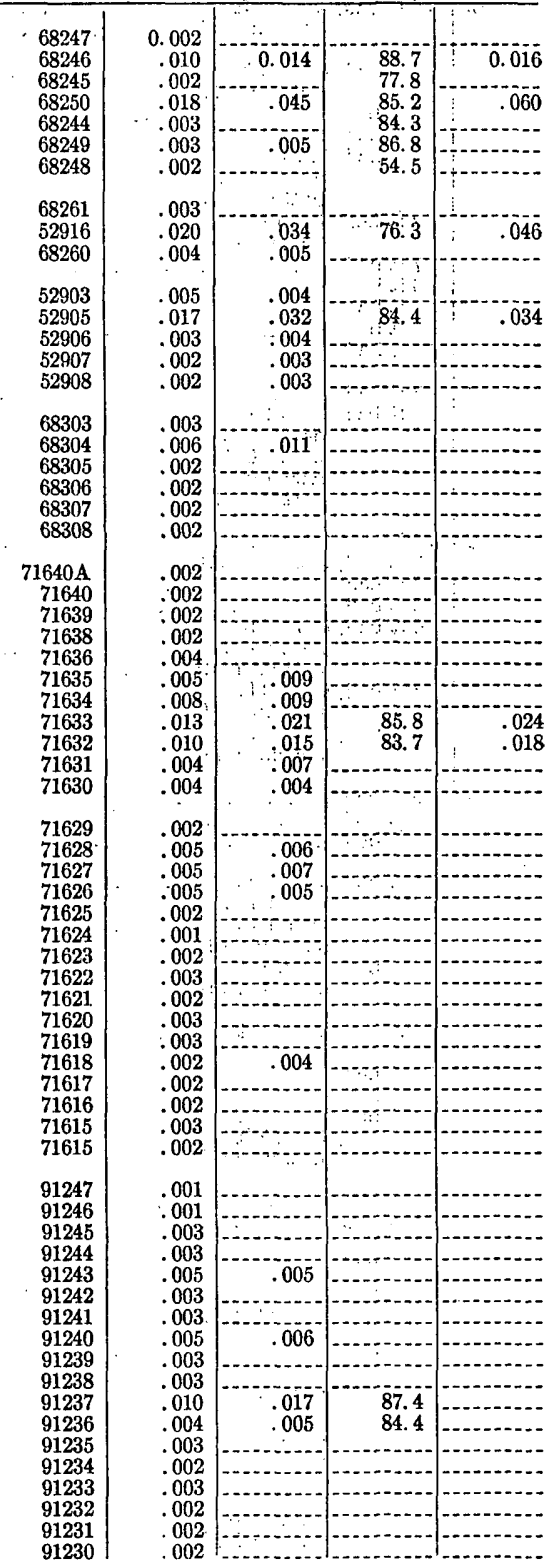




\section{URANIUM IN COAL IN THE WESTERN UNITED STATES}

TABLE 3.-Analyses for uranium in selected samples of carbonaceous shale and lignite, Goose Creek district-Continued

\begin{tabular}{|c|c|c|c|c|c|c|}
\hline $\begin{array}{c}\text { Locality } \\
\text { No. (pls. } \\
46 \text { and } \\
50 \text { ) }\end{array}$ & Description & $\begin{array}{c}\text { Labora- } \\
\text { tory } \\
\text { sample } \\
\text { No. }\end{array}$ & $\begin{array}{l}\text { Equiv- } \\
\text { alent } \\
\text { uranium } \\
\text { (percent) }\end{array}$ & $\begin{array}{l}\text { Uranium } \\
\text { (percent) }\end{array}$ & $\underset{\text { (percent) }}{\text { Ash }}$ & $\begin{array}{c}\text { Uranium ash } \\
\text { (percent) }\end{array}$ \\
\hline
\end{tabular}

SALT LAKE FORMATION-continued

Barrett zone-Continued

12

14

17

18

3. 3 - bed bottom 1.3 ft.

1.3-ft bed

1.8-ft bed

3.0-ft bed, top $0.6 \mathrm{ft}$

next $1.2 \mathrm{ft}$

1.7-ft bed, top $1.0 \mathrm{ft}$

bottom $0.7 \mathrm{ft}$

2.6-ft bed, top $1.3 \mathrm{ft}$

20

1.6-ft bed

1.1-ft bed

23

1.0-ft bed

4.4-ft bed, top $1.1 \mathrm{ft}$

next $1.1 \mathrm{ft}$

bottom $1.1 \mathrm{ft}$

1.1-ft bed, top $0.7 \mathrm{ft}$

bottom $0.4 \mathrm{ft}$

26

1.5-ft bed, top $0.5 \mathrm{ft}$

bottom $1.0 \mathrm{ft}$

0.4-ft bed.

0.6-ft bed

0.3-ft bed

1.7 -ft bed, top $0.7 \mathrm{ft}$.

bottom $1.0 \mathrm{ft}$

27 1.0-ft bed.

$1.9-\mathrm{ft}$ bed, top $0.9 \mathrm{ft}$.

0.7-ft bed

bottom $1.0 \mathrm{ft}$

1.0 -ft bed

2.8-ft bed, top $1.0 \mathrm{ft}$

2.0-ft bed

bottom $1.8 \mathrm{ft}$

8.0-ft bed, top $1.0 \mathrm{ft}$

next $1.0 \mathrm{ft}$

next $1.0 \mathrm{ft}$

next $1.0 \mathrm{ft}$.

next $1.0 \mathrm{ft}$

next $1.0 \mathrm{ft}$

bottom $1.0 \mathrm{ft}$

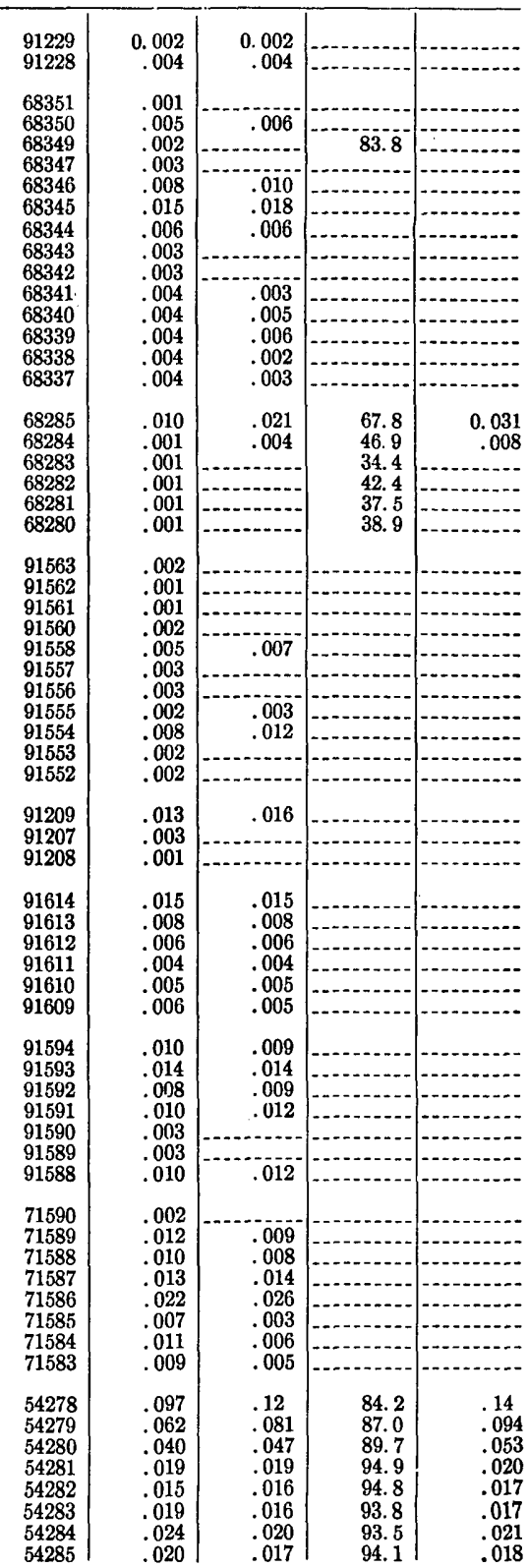


TABLE 3.-Analyses for uranium in selected samples of carbonaceous shale and lignite, Goose C'reek district-Continued

\begin{tabular}{|c|c|c|c|c|c|c|}
\hline $\begin{array}{c}\text { Locality } \\
\text { No. (pls. } \\
46 \text { and } \\
50)\end{array}$ & Description & $\begin{array}{c}\text { Labora- } \\
\text { tory } \\
\text { sample } \\
\text { No. }\end{array}$ & $\begin{array}{c}\text { Equiv- } \\
\text { alent } \\
\text { uranium } \\
\text { (percent) }\end{array}$ & $\begin{array}{l}\text { Uranium } \\
\text { (percent) }\end{array}$ & $\underset{\text { (percent) }}{\text { Ash }}$ & $\begin{array}{l}\text { Uranium } \\
\text { in ash } \\
\text { (percent) }\end{array}$ \\
\hline
\end{tabular}

SALT LAKE FORMATION-continued

Barrett zone-Continued

\begin{tabular}{|c|c|c|c|c|c|c|}
\hline 29 & 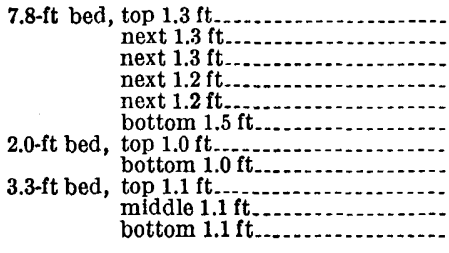 & $\begin{array}{l}71612 \\
71611 \\
71610 \\
71609 \\
71608 \\
71607 \\
71605 \\
71604 \\
71603 \\
71602 \\
71601\end{array}$ & $\begin{array}{r}0.003 \\
.008 \\
.008 \\
.005 \\
.004 \\
.005 \\
.006 \\
.008 \\
.021 \\
.017 \\
.013\end{array}$ & $\begin{array}{r}0.007 \\
.004 \\
.003 \\
.002 \\
.001 \\
.004 \\
.006 \\
.035 \\
.023 \\
.013\end{array}$ & 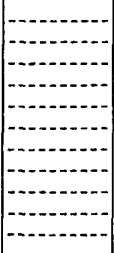 & 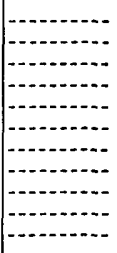 \\
\hline C5 & $\begin{array}{l}0.7-\mathrm{ft} \text { bed } \\
1.4 \text {-ft bed, top } 1.0 \mathrm{ft} \\
\text { bottom } 1.4 \mathrm{ft} \text {-ft bed, top } 1.0 \mathrm{ft} \\
0.7 \text {-ft bed, bottom } 0.7 \mathrm{ft} \\
0.3 \text {-ft bed } \\
0.3 \text {-ft bed. }\end{array}$ & $\begin{array}{l}115802 \\
115803 \\
115804 \\
115805 \\
115806 \\
115807 \\
115808 \\
115809\end{array}$ & $\begin{array}{l}.011 \\
.008 \\
.005 \\
.006 \\
.003 \\
.004 \\
.004 \\
.004\end{array}$ & $\begin{array}{r}.011 \\
.005 \\
.006 \\
.004 \\
002 \\
.002 \\
.002 \\
.002\end{array}$ & $\begin{array}{c}- \\
- \\
-- \\
-- \\
-- \\
--\end{array}$ & 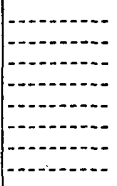 \\
\hline C8 & 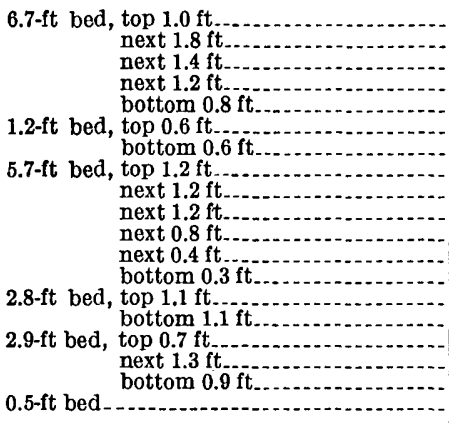 & $\begin{array}{l}115814 \\
115815 \\
115816 \\
115817 \\
115818 \\
115819 \\
115820 \\
115821 \\
115822 \\
115823 \\
115824 \\
115825 \\
115826 \\
115827 \\
115828 \\
115829 \\
115830 \\
115831 \\
115832\end{array}$ & $\begin{array}{l}.005 \\
.007 \\
.007 \\
.004 \\
.004 \\
.009 \\
.009 \\
.005 \\
.003 \\
.003 \\
.003 \\
.008 \\
.002 \\
.002 \\
.003 \\
.003 \\
.002 \\
.005 \\
.005\end{array}$ & $\begin{array}{r}.004 \\
.004 \\
.007 \\
.003 \\
.003 \\
.009 \\
.010 \\
.004 \\
.001 \\
.002 \\
.002 \\
.009 \\
.002 \\
.002 \\
.004 \\
.004\end{array}$ & 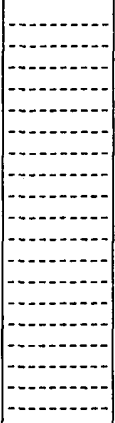 & \begin{tabular}{|c|} 
\\
\end{tabular} \\
\hline $\mathrm{C} 14$ & $\begin{array}{l}2.5-\mathrm{ft} \text { bed, bottom } 0.6 \text { foot } \\
0.7-\mathrm{ft} \text { bed }\end{array}$ & $\begin{array}{l}115833 \\
115834\end{array}$ & $\begin{array}{l}.003 \\
.038\end{array}$ & .001 & - & $\ldots$ \\
\hline
\end{tabular}

Zone B

\begin{tabular}{|c|c|c|c|c|c|c|}
\hline C2 & 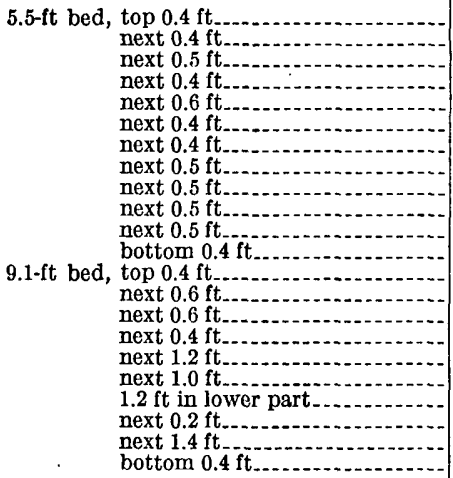 & $\begin{array}{l}120773 \\
120774 \\
120775 \\
120776 \\
120777 \\
120778 \\
120779 \\
120780 \\
120781 \\
120782 \\
120783 \\
120784 \\
120791 \\
120792 \\
120793 \\
120794 \\
120795 \\
120796 \\
120797 \\
120798 \\
120799 \\
120800\end{array}$ & $\begin{array}{r}0.053 \\
.026 \\
.076 \\
.057 \\
.088 \\
.041 \\
.018 \\
.028 \\
.022 \\
.020 \\
.012 \\
.010 \\
.021 \\
.014 \\
.010 \\
.007 \\
.004 \\
.008 \\
.010 \\
.007 \\
.020 \\
.006\end{array}$ & $\begin{array}{l}0.050 \\
.022 \\
.101 \\
.055 \\
.085 \\
.053 \\
.033 \\
.028 \\
.036 \\
.035 \\
.018 \\
.014 \\
.022 \\
.019 \\
.013 \\
.010 \\
.002 \\
.007 \\
.014 \\
.006 \\
.017 \\
.009\end{array}$ & $\begin{array}{l}84.2 \\
70.1 \\
59.7 \\
47.7 \\
67.4 \\
62.1 \\
57.3 \\
63.1 \\
73.3 \\
71.2 \\
51.4 \\
60.1 \\
65.2 \\
78.3 \\
88.8 \\
80.5 \\
91.4 \\
78.2 \\
72.8 \\
85.4 \\
57.1 \\
61.0\end{array}$ & $\begin{array}{l}0.059 \\
.031 \\
.170 \\
.116 \\
.126 \\
.082 \\
.057 \\
.044 \\
.050 \\
.048 \\
.039 \\
.025 \\
.033 \\
.025 \\
.014 \\
.012 \\
.002 \\
.009 \\
.019 \\
.006 \\
.030 \\
.014\end{array}$ \\
\hline
\end{tabular}


TABLE 3.-Analyses for uranium in selected samples of carbonaceous shale and lignite, Goose Creek diștrict-Continued

\begin{tabular}{c|c|c|c|c|c|c}
\hline $\begin{array}{c}\text { Locality } \\
\text { No. (pls. } \\
46 \text { and } \\
\text { 50) }\end{array}$ & $\therefore$ & $\begin{array}{c}\text { Description } \\
\text { nabora- } \\
\text { tory } \\
\text { sample } \\
\text { No. }\end{array}$ & $\begin{array}{c}\text { Equir- } \\
\text { alent } \\
\text { uranium } \\
\text { (percent) }\end{array}$ & $\begin{array}{c}\text { Uranium } \\
\text { (percent) }\end{array}$ & $\begin{array}{c}\text { Ash } \\
\text { (percent) }\end{array}$ & $\begin{array}{c}\text { Uranium } \\
\text { in ash } \\
\text { (percent) }\end{array}$ \\
\hline
\end{tabular}

PAYETTE (?) FORMATION

Worthington zone

\begin{tabular}{|c|c|c|c|c|c|c|}
\hline 38 & 2.7-ft bed, top $1.2 \mathrm{ft}$ & $\begin{array}{l}68316 \\
68317\end{array}$ & $\begin{array}{r}0.001 \\
.001\end{array}$ & & $\begin{array}{l}20.0 \\
29.3\end{array}$ & 0.007 \\
\hline
\end{tabular}

The vertical distribution of uranium in the carbonaceous beds is irregular. In the thicker and more mineralized beds ( 3 feet or more in thickness and containing 0.01 percent or more uranium), the uranium content is generally greatest in the upper part of the bed and decreases progressively downward (see sections at localities 3, $8,11,12,23,28$, and $C 2, \mathrm{pl} .47$ ). Thinner and less mineralized beds show no regular pattern of vertical distribution.

The uranium content of the carbonaceous beds is very irregular at different places along the same bed, and in different beds in the same zone. For this reason, and because the beds themselves are lenticular, no individual uranium-rich beds could be traced continuously for more than a few hundred feet.

Tertiary (?) rhyolite exposed in the southeastern part of the district was sampled north of Birch Creek in the SW1/4 sec. 32, T. $16 \mathrm{~N}$., R. 22 E., Idaho, and near Pole Creek in the NW1/4 sec. 18, T. $14 \mathrm{~N}$., R. $18 \mathrm{~W}$., Utah, where it contains 0.007 and 0.006 percent uranium, respectively. Samples of volcanic ash from the Salt Lake formation contain 0.001 percent or less uranium, but equivalent uranium in the same samples ranges from 0.001 to 0.005 percent. Dark shale and limestone of Carboniferous age have negligible radioactivity where tested at various places along the margins of the district.

Analyses of noncarbonaceous rocks in the district are given in table 4.

TABLE 4.-Analyses for uranium in samples of miscellaneous rock types, Goose Creek district

[Analyses by the U. 8. Geological Survey]

\begin{tabular}{|c|c|c|c|c|c|c|c|}
\hline \multicolumn{4}{|c|}{ Location } & \multirow{2}{*}{ Description } & \multirow{2}{*}{$\begin{array}{l}\text { Labora- } \\
\text { tory-sam- } \\
\text { ple No. }\end{array}$} & \multirow{2}{*}{$\mid \begin{array}{c}\text { Equiva- } \\
\text { lent } \\
\text { uranium } \\
\text { (percent) }\end{array}$} & \multirow{2}{*}{$\begin{array}{l}\text { Uranium } \\
\text { (percent) }\end{array}$} \\
\hline State & Sec. & $\mathrm{T}$. & R. & & & & \\
\hline \multicolumn{8}{|c|}{ Salt Lake formation, upper part } \\
\hline Utab. & 35 & $15 \mathrm{~N}$. & $19 \mathrm{w}$. & $\begin{array}{l}\text { Grayish-orange volcanlc ash, upper } \\
2 \mathrm{ft} \text { of f-ft bed... } \\
\text { Light-gray volcanic ash, grab sam- } \\
\text { ple- } \\
\text { Grayish-white volcanic ash, } 2 \text {-ft bed } \\
\text { Grayish-orange volcanic ash, 2-ft } \\
\text { bed } \\
\text { Grayish-orange volcanic ash, 2-ft } \\
\text { bed }\end{array}$ & $\begin{array}{l}\text { D-76310 } \\
\text { D-76311 } \\
\text { D-76312 } \\
\text { D-76313 } \\
\text { D-76314 }\end{array}$ & $\begin{array}{l}0.002 \\
.003 \\
.002 \\
.002 \\
.003\end{array}$ & $\begin{array}{r}0.0003 \\
.0002 \\
.0001 \\
.0001 \\
.0003\end{array}$ \\
\hline
\end{tabular}


TABLE 4.-Analyses for uranium in samples of miscellaneous rock types, Goose Creek district-Continued

\begin{tabular}{c|c|c|c|c|c|c}
\hline \multicolumn{3}{c|}{ Location } & & Description & $\begin{array}{c}\text { Labora- } \\
\text { tory-sam- } \\
\text { ple No. }\end{array}$ & $\begin{array}{c}\text { Equiva- } \\
\text { lent } \\
\text { uranium: } \\
\text { (percent) }\end{array}$ \\
\hline State & Sec. & T. & R. & (percent) \\
\hline
\end{tabular}

Salt Lake formation, lower part

\begin{tabular}{|c|c|c|c|c|c|c|c|}
\hline Utah.. & $\begin{array}{r}1 \\
5 \\
5 \\
5 \\
6 \\
12 \\
22 \\
23 \\
26 \\
21 \\
33\end{array}$ & $\begin{array}{l}15 \mathrm{~S} . \\
15 \mathrm{~S} . \\
15 \mathrm{~S} . \\
15 \mathrm{~S} . \\
15 \mathrm{~S} . \\
16 \mathrm{~S} . \\
16 \mathrm{~S} . \\
16 \mathrm{~S} . \\
16 \mathrm{~S} . \\
14 \mathrm{~N} . \\
15 \mathrm{~N} .\end{array}$ & $\begin{array}{l}20 \mathrm{E} . \\
20 \mathrm{E} . \\
20 \mathrm{E} . \\
21 \mathrm{E} . \\
21 \mathrm{E} . \\
20 \mathrm{E} . \\
21 \mathrm{E} . \\
21 \mathrm{E} . \\
21 \mathrm{E} . \\
19 \mathrm{~W} . \\
19 \mathrm{~W} .\end{array}$ & 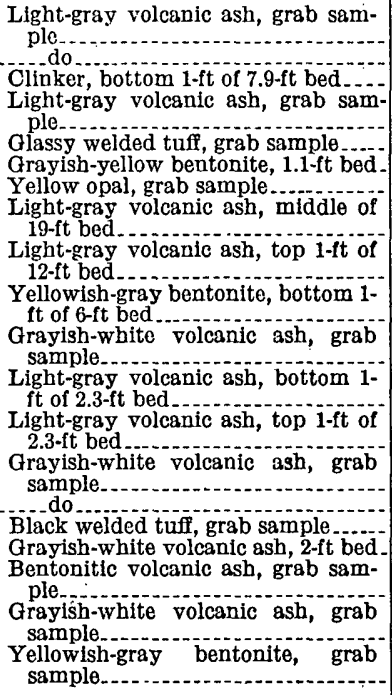 & $\begin{array}{l}54767 \\
54772 \\
68318 \\
54768 \\
54766 \\
100250 \\
\text { D-70178 } \\
87776 \\
87767 \\
71612 A \\
\text { D-76316 } \\
100352 \\
100353 \\
\text { D-76315 } \\
\text { D-76317 } \\
\text { D-76318 } \\
\text { D-76319 } \\
\text { D-76320 } \\
\text { D-76321 } \\
\text { D-76322 }\end{array}$ & $\begin{array}{r}0.001 \\
.003 \\
.004 \\
.005 \\
.004 \\
.002 \\
.001 \\
.002 \\
.003 \\
.003 \\
.005 \\
.002 \\
.001 \\
.003 \\
.004 \\
.004 \\
.003 \\
.003 \\
.004 \\
.002\end{array}$ & $\begin{array}{l}.0002 \\
.0001 \\
.0003 \\
.0002 \\
.0005 \\
.0001 \\
.0001 \\
.0006 \\
.0013\end{array}$ \\
\hline
\end{tabular}

Rhyolite of Tertiary (?) age

\begin{tabular}{|c|c|c|c|c|c|c|c|}
\hline $\begin{array}{l}\text { Idaho..... } \\
\text { Utah...... }\end{array}$ & $\begin{array}{l}32 \\
18\end{array}$ & $\begin{array}{ll}16 & \mathrm{~S} . \\
14 & \mathrm{~S} .\end{array}$ & $\begin{array}{l}22 \mathrm{E} . \\
18 \mathrm{~W} .\end{array}$ & $\begin{array}{l}\text { Light-gray rhyolite, grab sample...- } \\
\text { Reddish-brown rhyolite, grab sam- } \\
\text { ple. }\end{array}$ & $\begin{array}{l}87790 \\
D-85547\end{array}$ & $\begin{array}{r}0.005 \\
.003\end{array}$ & $\begin{array}{r}0.007 \\
.006\end{array}$ \\
\hline
\end{tabular}

Carboniferous and older rocks

\begin{tabular}{|c|c|c|c|c|c|c|c|}
\hline $\begin{array}{l}\text { Idaho..... } \\
\text { Nerada... }\end{array}$ & $\begin{array}{r}9 \\
15\end{array}$ & $\begin{array}{l}15 \mathrm{~S} . \\
15 \mathrm{~S} . \\
47 \mathrm{~N} .\end{array}$ & $\begin{array}{l}20 \mathrm{E} . \\
20 \mathrm{E} . \\
69 \mathrm{E} .\end{array}$ & $\begin{array}{l}\text { Gray limestone, grab sample. } \\
\text { Dark-gray shaie, grab sample } \\
\text { Gray limestone, grab sample }\end{array}$ & $\begin{array}{l}D-70176 \\
D-70177 \\
D-76326 \\
D-76327\end{array}$ & $\begin{array}{l}0.001 \\
.001 \\
.002 \\
.001\end{array}$ & $\begin{array}{r}0.0003 \\
.0001 \\
.0004 \\
.0001\end{array}$ \\
\hline
\end{tabular}

The potential low-grade resources of uranium in the district total about 100 short tons in beds at least 1 foot thick containing at least 0.010 percent uranium. Estimates are listed on table 5, and the areas for which estimates were calculated are shown on figure 38. A weight of 1,100 short tons of carbonaceous shale per acre-foot, used in calculations for the Barrett zone, was based on an average specific gravity of 0.83 for 6 samples from outcrops. A weight of 2,700 short tons of carbonaceous shale and lignite per acre-foot, used in calculations for zone $B$, was based on an average specific gravity of 2.0 for 2 samples from drill holes. 


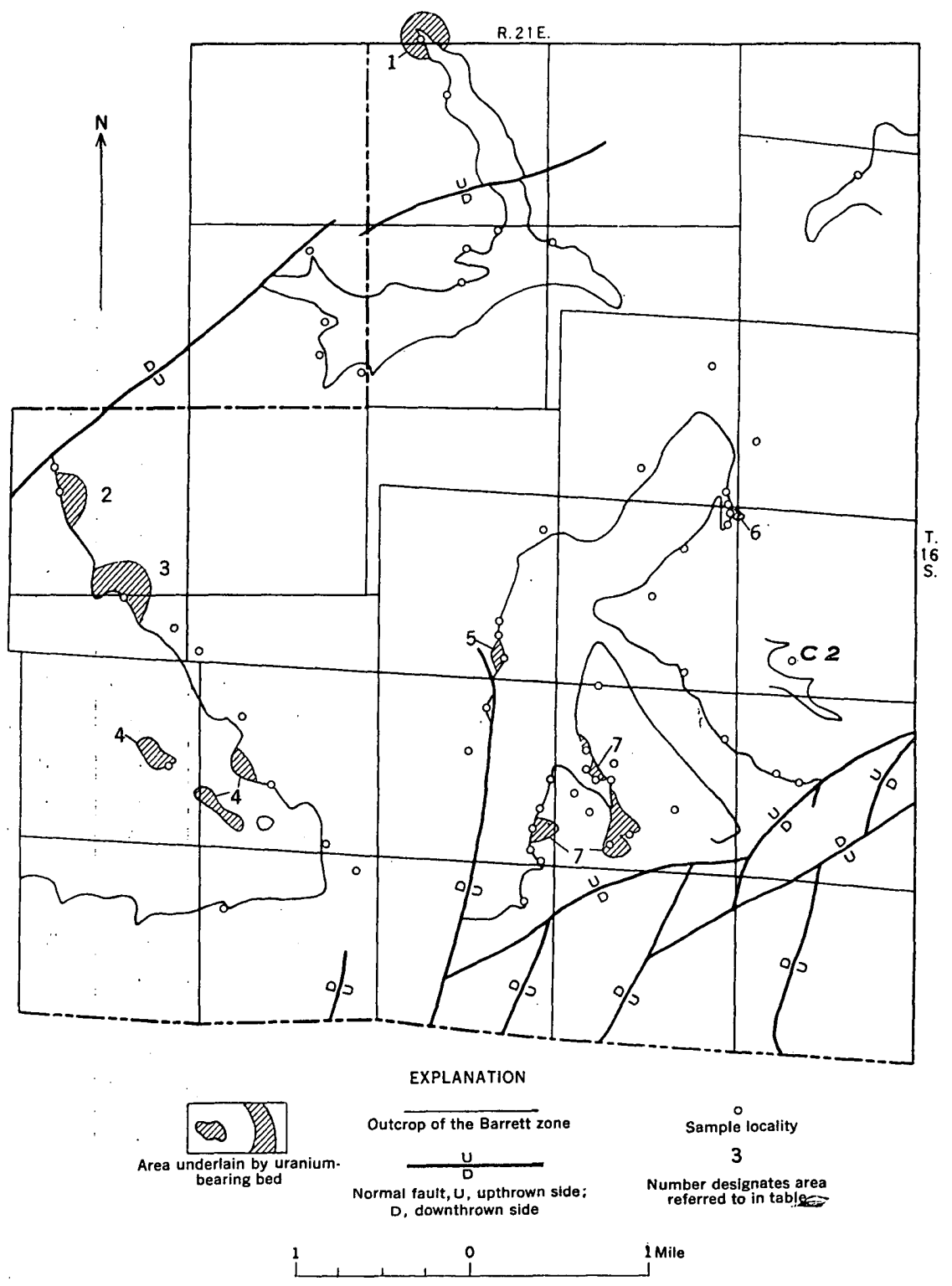

Frgore 38.-Map of part of T. 16 S., R. 21 E., Idaho, showing areas that may be underlain by carbonaceous shale in beds at least 1 foot thick containing at least 0.01 percent uranium.

Several lines of evidence support a hypothesis that uranium now concentrated in the beds of carbonaceous shale and lignite was derived by ground water from volcanic ash in the Salt Lake formation. The excess of equivalent uranium in samples of volcanic ash from the Salt Lake formation suggests that significant amounts of uranium have been removed from the ash and either carried away or 
TABLE 5.-Potential resources of uranium in beds of carbonaceous shale and lignite at least 1 foot thick containing at least 0.01 percent uranium, Goose Creel district

\begin{tabular}{|c|c|c|c|c|c|}
\hline \multirow[b]{2}{*}{ Locality (reference nos. on fig. 38) } & \multirow[b]{2}{*}{$\begin{array}{c}\text { Area } \\
\text { (acres) }\end{array}$} & \multirow{2}{*}{$\begin{array}{l}\text { Thickness } \\
\text { of bed a } \\
\text { (feet) }\end{array}$} & \multirow[b]{2}{*}{$\underset{\text { (percent) }}{\text { Uranium }}$} & \multicolumn{2}{|c|}{ Tonnage } \\
\hline & & & & $\begin{array}{l}\text { Carbona- } \\
\text { ceous shale } \\
\text { and lignite }\end{array}$ & $\begin{array}{l}\text { Uranium } \\
\text { content }\end{array}$ \\
\hline
\end{tabular}

SALT LAKE FORMATION

Barrett zone

\begin{tabular}{|c|c|c|c|c|c|}
\hline Sec. 5, T. 15 S., R. 21 E., Idaho. R. Idaho. & $\begin{array}{r}25 \\
20 \\
40 \\
25 \\
10 \\
3 \\
44 \\
14 \\
66\end{array}$ & $\begin{array}{l}1.7 \\
1.0 \\
3.0 \\
6.1 \\
2.5 \\
1.6 \\
2.3 \\
1.5 \\
1.0\end{array}$ & $\begin{array}{r}0.022 \\
.024 \\
.011 \\
.010 \\
.013 \\
.013 \\
.015 \\
.024 \\
.020\end{array}$ & $\begin{array}{r}47,000 \\
22,000 \\
130,000 \\
170,000 \\
27,000 \\
5,300 \\
110,000 \\
24,000 \\
73,000\end{array}$ & $\begin{array}{r}10 \\
5 \\
14 \\
17 \\
4 \\
1 \\
17 \\
6 \\
15\end{array}$ \\
\hline Total or averageb & 247 & 2.2 & .015 & 610,000 & 89 \\
\hline
\end{tabular}

Zone B

$\begin{array}{r}\begin{array}{r}\text { Vicinity of core hole 2, sec. 24, T. } 16 \mathrm{~S} ., \mathrm{R} .21 \\ \text { E., Idaho.... }\end{array} \\ \hline\end{array}$

a Weighted average.

b Rounded.

redeposited in other beds. The affinity of uranium for carbonaceous material is well known and Moore (1954) has shown that lignite and carbonaceous shale extract large percentages of uranium 'from dilute cold-water solutions. Inasmuch as ground water tends to percolate downward, or to travel laterally on top of impervious beds of shale, beds of shale in synclines would seem favorably located for exposure to large volumes of moving water carrying uranium. The principal mineralized area in the district is on the flanks and in the trough of a syncline. Moreover, the thicker mineralized beds tend to be richest in uranium at the top of the bed suggesting that the uranium was introduced from above, as might be expected if the downward movement of uranium-bearing solutions was deflected by the shale.

The availability of uranium to ground water would probably depend partly on the degree of devitrification and weathering of glass shards comprising the ash. Most of the ash in the district appears relatively fresh and unweathered, but at some places the ash is almost completely devitrified and altered to bentonite. Commonly the beds of bentonite are associated with beds of uranium-rich carbonaceous shale.

Table 6 gives the uranium content, in parts per billion, of water from streams and springs at 18 localities in the district. Content ranges from less than 2 parts per billion ( 3 samples) to 5 parts 
per billion (3 samples). In comparison, Rona (1943, p. 137-138) reports that sea water contains about 0.7 parts uranium per billion, and water from the Mississippi, Hudson, and St. Lawrence Rivers contains about 0.04 parts per billion. The analyses suggest that more than average amounts of uranium are being carried by the present surface and ground waters of the district, although the data are too scant to indicate that any one formation is a principal contributor of uranium to the water.

TABLE 6.-Analyses for uranium (in parts per billion) in samples of water, Goose Creek district

[Analyses by the U. S. Geological Survey]

\begin{tabular}{|c|c|c|c|c|c|c|}
\hline \multicolumn{3}{|c|}{ Location } & \multirow{2}{*}{ Description } & \multirow{2}{*}{$\begin{array}{c}\text { Labora- } \\
\text { tory } \\
\text { sample } \\
\text { No. }\end{array}$} & \multirow{2}{*}{$\mathrm{pH}$. } & \multirow{2}{*}{$\underset{\text { ump }}{\text { Urant- }}$} \\
\hline Sec. & $\mathrm{T}$. & R. & & & & \\
\hline
\end{tabular}

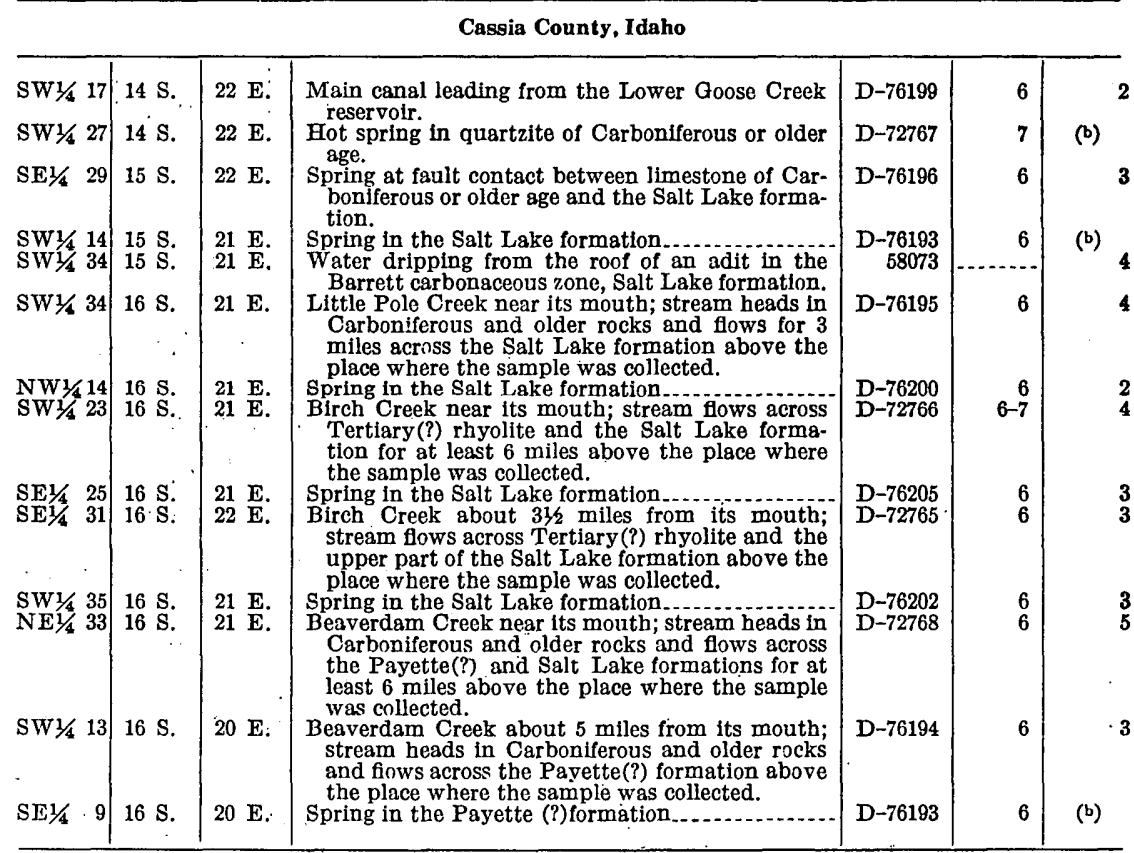

Elko County, Nev.

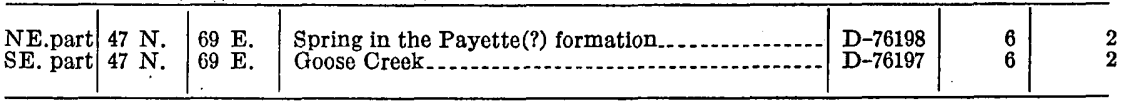

Box Elder County, Utah

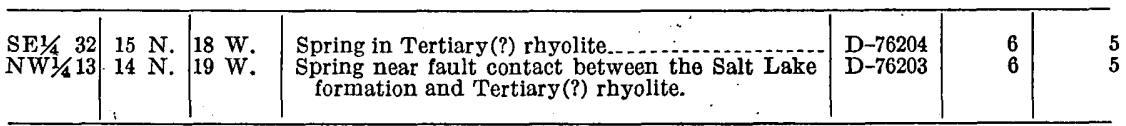

a $\mathrm{pH}$ determined with $\mathrm{pH}$-indicator paper in the field.

b Less than $2 \mathrm{ppb}$. 


\section{BUIIDING STONE}

Large amounts of rock suitable for building stone are available in the district. Blocks cut from beds of dark reddish-brown welded tuff or from the lighter colored volcanic ash of the Salt Lake formation are used successfully for the outside walls of schools, churches, stores, and houses in many of the towns in the region. In Oakley, the exteriors of two-story buildings made with blocks of welded tuff and volcanic ash show no signs of deterioration after many years of service. Anderson (1931, p. 141-150) describes in detail the use and physical properties of these materials as building stones.

Small amounts of Precambrian quartzite and marble, similar to that found in the mountains that border the district on the northeast, have been quarried and used locally for foundations and trim.

\section{BENTONITE}

Bentonite occurs in the lower part of the Salt Lake formation in relatively pure beds which range in thickness from a few inches to as much as 20 feet. The lateral extent of individual beds was not determined, but some of them may be traced for several hundred yards. Commonly the bentonite is white, grayish white, or light grayish yellow. Small lumps of the rock placed in water swell to about twice their original volume. Much bentonite is associated with beds of carbonaceous shale and sandstone in the central part of the district in T. 16 S., R. 21 E., Idaho, and other beds crop out in the southern part in Utah and Nevada. None of the bentonite has been mined commercially, although a small prospect has been opened on a bed in the NW1/4 sec. 26, T. 14 N., R. 19 W., Utah.

The bentonite was formed by the devitrification and alteration of volcanic ash to the clay mineral montmorillonite. Much of the bentonite retains the texture of the ash with great perfection. Some of the bentonite, however, is a dense homogeneous rock in which pyroclastic textures are largely destroyed. Such deposits may have resulted from partial devitrification and reworking of the ash before burial with consequent obliteration of much of the texture of the original material.

A. J. Gude analyzed by X-ray diffraction two samples of bentonite collected in the southern part of the district: one sample was from a bed about 20 feet thick a mile southeast of the junction of Goose and Hardister Creeks, T. 47 N., R. 70 E., Nev., and the other was from a bentonite prospect in a bed at least 10 feet thick in the NW1/4 sec. 26, T. 14 N., R. 19 W., Utah. Both samples consisted almost entirely of montmorillonite. The first sample contained, in addition, minor amounts of quartz; the second contained almost no quartz but was contaminated with small amounts of some unidentified mica mineral or minerals.

$469117-59-19$ 


\section{LITERATURE CITED}

Adamson, R. D., Hardy, C. T., and Williams, J. S., 1955, Tertiary rocks of Cache Valley, Utah and Idaho: Utah Geol. Soc. Guidebook, no. 10, p. 1-22.

Anderson, A. L., 1931, Geology and mineral resources of eastern Cassia County, Idaho: Idaho Bur. of Mines and Geology Bull. 14.

1934, Contact phenomena associated with the Cassia batholith, Idaho: Jour. Geology, v. 42, no. 4, p. 376-392.

Bowen, C. F., 1913, Lignite in the Goose Creek district, Cassia County, Idaho: U. S. Geol. Survey Bull. 531, p. 252-262.

Fenner, C. N., 1923, The origin and mode of emplacement of the great tuff deposit in the Valley of Ten Thousand Smokes: Natl. Geog. Soc. Contributed Tech. Papers, Katmai ser., no. 1.

Iddings, J. P., 1909, Igneous rocks, composition, texture and classification, description and occurrence : v. 1, New York, John Wiley and Sons.

Kirkham, V. R. D., 1931a, Revision of the Payette and Idaho formations: Jour. Geology, v. 39, no. 3, p. 193-239.

1931b, Igneous geology of southwestern Idaho: Jour. Geology, v. 39, no. 6, p. 564-591.

Lacroix, Alfred, 1904, La Montagne Pelée et ses eruptions, Paris.

Mansfield, G. R. 1920, Geography, geology, and mineral resources of the Fort Hall Indian Reservation, Idaho: U. S. Geol. Survey Bull. 713.

1927, Geography, geology, and mineral resources of part of southeastern Idaho: U. S. Geol. Survey Prof. Paper 152.

- 1952, Geography, geology, and mineral resources of the Ammon and Paradise Valley quadrangles, Idaho: U. S. Geol. Survey Prof. Paper 238.

Mansfield, G. R., and Ross, C. S., 1935, Welded rhyolite tuffs in southeastern Idaho: Am. Geophys. Union Trans. 16th Ann. Mtg. pt. 1, p. 308-321.

Mapel, W. J., and Hail, W. J., Jr., 1956, Tertiary stratigraphy of the Goose Creek district, Cassia County, Idaho, and adjacent parts of Utah and Nevada: Utah Geol. Soc. Guidebook, no. 11, p. 1-16.

Moore, G. W., 1954, Extraction of uranium from aqueous solution by coal and some other materials : Econ. Geology, v. 49, no. 6, p. 652-658.

Peterson, V. E., 1942, A study of the geology and ore deposits of the Ashbrook silver mining district, Utah: Econ. Geology, v. 37, no. 6, p. 466-502.

Piper, A. M., 1923, Geology and water resources of the Goose Creek basin, Cassia County, Idaho: Idaho Bur. of Mines and Geology Bull. 6.

Rona, Elizabeth, 1943, Radioactivity of sea water: Am. Philos. Soc. Yearbook 1943, p. 136-138.

Schopf, J. M., and Gray, R. J., 1954, Microscopic studies of uraniferous coal deposits : U. S. Geol. Survey Circular 343.

Schrader, F. C., 1912, A reconnaissance of the Jarbidge, Contact, and Elk Mountain mining districts, Elko County, Nevada: U. S. Geol. Survey Bull. 497.

Sharp, R. P., 1939, The Miocene Humboldt formation in northeastern Nevada: Jour. Geology, v. 47, no. 2, p. 133-160.

Taylor, D. W., 1956, Pliocene mollusks from Jackson Hole, Grand Valley, and Star Valley, Wyoming and Idaho: Wyoming Geol. Assoc. Guidebook 11th Ann. Field Conf., p. 123-125. 


\section{Geology and Uranium}

Deposits in Carbonaceous Rocks of the Fall Creek Area, Bonneville

\section{County, Idaho}

By JAMES D. VINE

URANIUM IN COAL IN THE WESTERN UNITED STATES

GE L O G.ICAL S U R VEY B U L L T I N 1055 - I

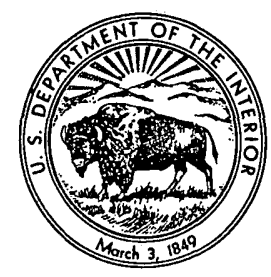





\section{CONTENTS}

\begin{tabular}{|c|c|}
\hline & \\
\hline & \\
\hline ion. & \\
\hline (n-1 & 250 \\
\hline ssibility _ _ _ & 25 \\
\hline ter supply_-.-.-.-- & 256 \\
\hline - & 258 \\
\hline 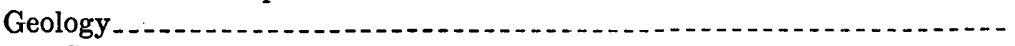 & 258 \\
\hline - & 258 \\
\hline 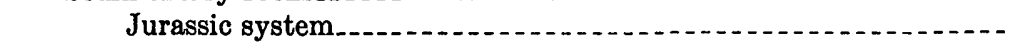 & 260 \\
\hline stem & 260 \\
\hline Igneol & 264 \\
\hline----- & 264 \\
\hline nt of the Bear River formation & 265 \\
\hline $20-20-120-2$ & 266 \\
\hline - & 266 \\
\hline (n-1 & 267 \\
\hline nts_-_. & 272 \\
\hline leposits & 275 \\
\hline$-n-n-1$ & 278 \\
\hline $\mathrm{D}$ & 278 \\
\hline$\cdots+$ & 278 \\
\hline & 281 \\
\hline 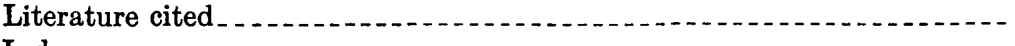 & 294 \\
\hline & 30 \\
\hline
\end{tabular}

\section{ILLUSTRATIONS}

[Plates are in box]

Plate 51. Geologic map of the Fall Creek area, Bonneville County, Idaho.

52. Longitudinal section and distribution of uranium in samples from the Fall Creek coal prospect, Bonneville County, Idaho.

FrgURE 39. Index map of southeastern Idaho showing location of the Fall Creek area and adjacent areas in which samples were collected

40. Stratigraphic section of the upper part of the Bear River formation and the lower part of the Wayan formation, as measured at the Fall Creek coal prospect.

41. Comparison of uranium, molybdenum, and germanium content in the ash of coal.

42. Sketch map of part of Fall Creek area, Bonneville County, Idaho, showing location of core holes and areas underlain by uranium-bearing rock

43. Stratigraphic sections of cores from Fall Creek area, Idaho_- 


\section{TABLES}

TABLE 1. Coal analyses of samples from the Fall Creek coal prospect.-.

2. Tonnage estimate of uranium-bearing rocks, Fall Creek area..

3. Analyses of sedimentary rocks in the Fall Creek and adjacent

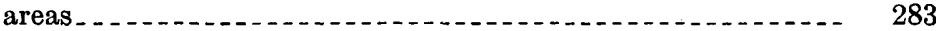

4. Analyses of silicic volcanic rocks _...

5. Analyses of natural waters .

6. Analyses of core samples. .

7. Standard sensitivities for the elements determined by the semiquantitative spectrographic method in the U. S. Geological Survey laboratory, May 1952

8. Semiquantitative spectrographic analyses for other elements in the ash and chemical analyses for uranium and ash of selected carbonaceous-rock samples, Fall Creek area, Bonneville County, Idaho

CHART

Sedimentary rocks exposed in the Fall Creek area 


\title{
URANIUM IN COAL IN THE WESTERN UNITED STATES
}

\section{GEOLOGY AND URANIUM DEPOSITS IN GARBONAGEOUS ROCKS OF THE FALL GREEK AREA, BONNEVILLE COUNTY, IDAHO}

\author{
BY JAMES D. VINE
}

\begin{abstract}
Uranium occurs in carbonaceous rocks of the Bear River formation, of Early Cretaceous age, in the Fall Creek area, Bonneville County, Idaho. The principal deposit is at the Fall Creek coal prospect in sec. 4, T. 1 S., R. 42 E., where impure coal contains an average of about 0.02 percent uranium. Geologic mapping and sampling have demonstrated that the zone of uranium-bearing rocks is widespread in the area and is repeated in outcrop several times, owing to folding and faulting of the enclosing strata, although exposures suitable for sampling and analysis are few. Analytic data suggests a possible geochemical relation between uranium, germanium, and molybdenum. Four general hypotheses are advanced for the origin of uranium in carbonaceous rocks, but comparison of the deposits with other occurrences of uranium-bearing carbonaceous rocks suggests that an epigenetic hypothesis of deposition by downward percolating meteoric water seems best able to explain the occurrence of uranium in the Fall Creek area. Core drilling was inconclusive in demonstrating the areal extent of the radioactive units. Most of the holes did not reach the uraniumbearing strata, because the area is one of structural complexity, with faulting, thinning of incompetent strata, and increasingly steep dips at depth.

About $61 / 2$ million tons of coaly shale, carbonaceous shale, and carbonaceous limestone with an average grade of about 0.02 percent uranium is believed to be in the area. This estimate is based on the average thickness and grade of uranium-bearing strata exposed in the Fall Oreek coal prospect, by drill-hole data, and by the inferred extent of these strata over an area of slightly more than 400 acres.
\end{abstract}

\section{INTRODUCTION}

In the course of reconnaissance for uranium-bearing coal and carbonaceous materials during the 1951 field season George W. Moore and the author made many radioactivity measurements in coal mines in Idaho, Colorado, and Utah, especially where coal was associated with silicic volcanic rocks because this association was suggested as a favorable one for the occurrence of uranium in the lignites of western South Dakota by Denson, Bachman, and Zeller (see chapter B, 
this bulletin). Several deposits were found in which the uranium content was too small to be of interest. However, investigations in the Fall Creek area, where Mansfield (1920) had reported several coal prospects closely associated with volcanic rocks, resulted in the discovery of a significant concentration of uranium.

Field work was carried on during July and August 1952 to determine the areal extent, structural setting, and nature of the occurrence of uranium in the Fall Creek area. Core drilling to determine the thickness and grade of the uranium-bearing zone was done during June, July, and August 1953.

\section{ACKNOWLEDGMENTS}

The field investigations were greatly facilitated by the use of an advance copy of a geologic map of the Irwin and part of the Hell Creek quadrangles prepared by Louis S. Gardner of the U. S. Geological Survey. The author is indebted to George W. Moore who assisted in the reconnaissance in 1951, Robert F. Flege, Jr., who assisted with the geologic mapping during the 1952 field season, and Max L. Troyer, who supervised the drilling program. All analytical work was performed in U. S. Geological Survey laboratories.

\section{IOCATION AND ACCESSIBIIITY}

The uranium-bearing strata of the Fall Creek area are on the west flank of the Caribou Mountains in Bonneville County, Idaho, in Tps. $1 \mathrm{~N}$. and $1 \mathrm{~S} .$, R. $42 \mathrm{E}$. (fig. 39). The area is about 16 miles southwest of Swan Valley, Idaho, and is easily accessible in good weather. The principal exposure is in the NE1/4 sec. 4, T. 1 S., R. 42 E., at an abandoned, inclined shaft dug for coal, adjacent to the Fall Creek road in the Caribou National Forest. This shaft, referred to in this report as the Fall Creek coal prospect, may be reached as follows: drive 3 miles northwest on U. S. Highway 26 from the town of Swan Valley and cross the bridge that spans the Snake River. At the west side of the bridge turn left onto a graveled road and proceed about a mile along the Snake River to the junction of the Fall Creek road. Turn right and travel about 12 miles up the Fall Creek Road. The entrance to the Fall Creek coal prospect is marked by a timbered entry on the south side of the road about a mile beyond the Fall Creek Ranger Station (pl.51).

\section{TOPOGRAPHY AND WATER SUPPLY}

The U. S. Geological Survey topographic maps of the Hell Creek and Irwin quadrangles show altitudes in the Fall Creek area that 


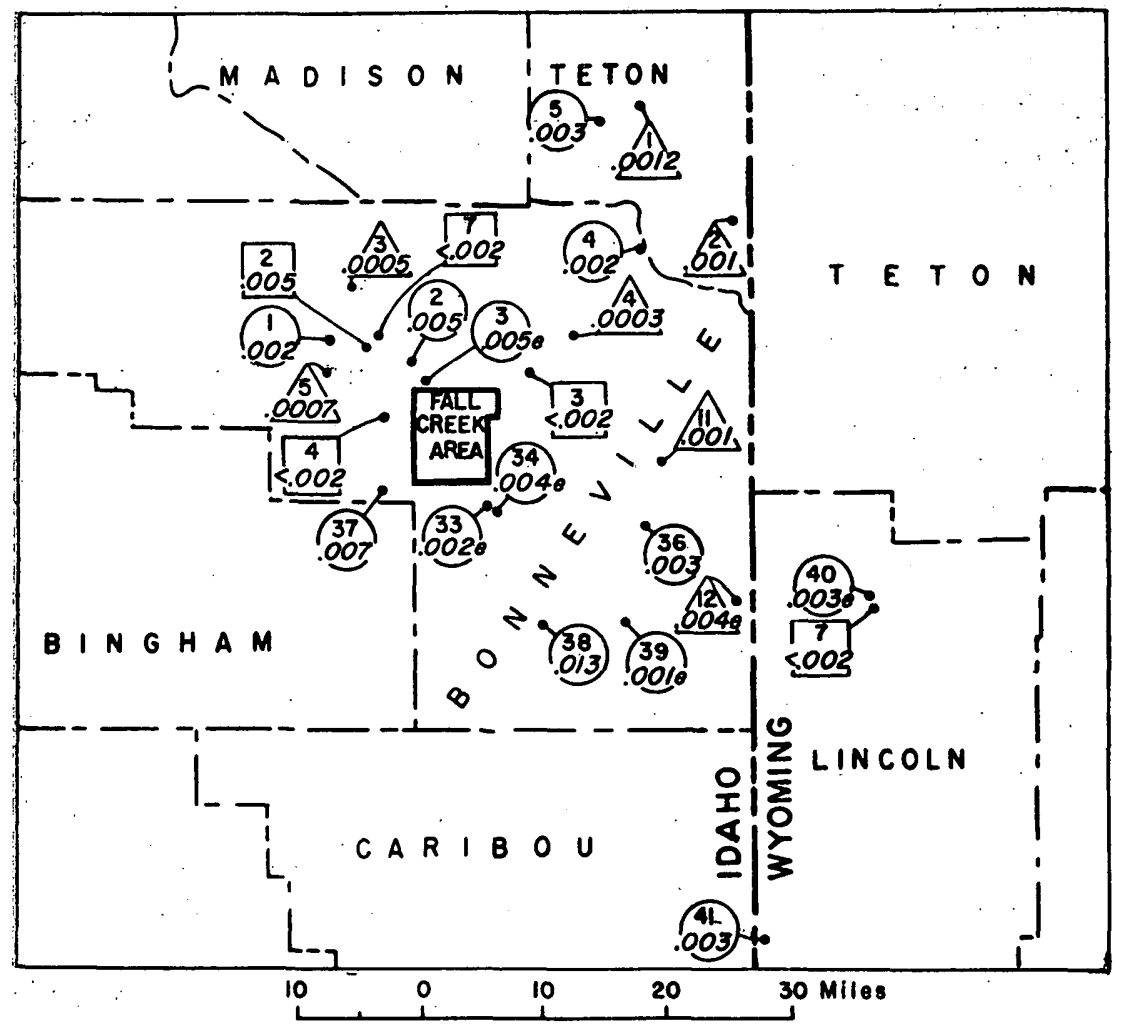

EXPLANATION

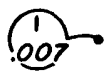

Carbonoceous-rock-somple locality. Upper figure is locality number. Lower flgure is moximum-percent uranium (or equivalent uranium if followed by "e") in somple

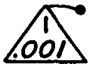

Silicic-volconic-rock somple locality. Upper figure is locolity number. Lower figure is maximum percent uronium (or equivalent uranium if followed by " $"$ ")

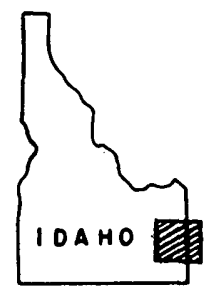
in somple

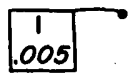

Water-somple locolity. Upper figure is locality number.

Lower flgure is amount of uranium in parts per million

Figdae 39.-Index map of southeastern Idaho, showing location of the Fall Creek area, Bonneville County, and adjacent areas in which samples were collected. 
range from about 5,600 feet, in the valley of Fall Creek, to 7,600 feet, along the drainage divide between Fall Creek and Pritchard Creek in the northern part of the area. Fall Creek, flowing northeast to the Snake River, drains most of the area, although Hell Creek, which flows northwestward into the Snake River, drains the southwestern part of the area (pl. 51). Fall, Pritchard, and Hell Creeks and many of their tributaries are permanent streams.

\section{LAND OWNERSHIP}

Except for a tier of sections along its west side, most of the area mapped lies within the boundary of the Caribou National Forest. Several small tracts of privately owned land, however, lie within the National Forest. These tracts are shown on the U. S. Department of Agriculture map of the Caribou National Forest, dated 1949.

\section{GEOLOGY}

\section{SEDIMENTARY ROCKS}

Strata of Mesozoic and Paleozoic age are present in the Caribou Mountains, but only Cretaceous and Jurassic rocks crop out in the area mapped; therefore, only the rocks of these systems are described. A summary of the sedimentary rocks exposed in the area is shown in the chart. The following descriptions are adapted from Kirkham (1924, p. 20-29), with important modifications in the descriptions of the Tygee and Wayan formations in order to include Louis S. Gardner's usage (oral communication, 1952) of the Bear River formation. 
Sedimentary rocks exposed in the Fall Creek area ${ }^{1}$

\begin{tabular}{|c|c|c|c|c|}
\hline & \multicolumn{2}{|r|}{ Formation } & $\begin{array}{l}\text { Thickness } \\
\text { (feet) }\end{array}$ & Description \\
\hline 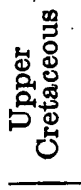 & \multicolumn{2}{|c|}{ Wayan formation } & $\begin{array}{r}3,000-4,000 \\
\text { (estimate) }\end{array}$ & $\begin{array}{l}\text { Shale, red and purple, and sandstone, } \\
\text { gray, medium- to coarse-grained, } \\
\text { crossbedded, friable; sandstone beds } \\
\text { form prominent ledges in the softer } \\
\text { shales. }\end{array}$ \\
\hline \multirow{6}{*}{ 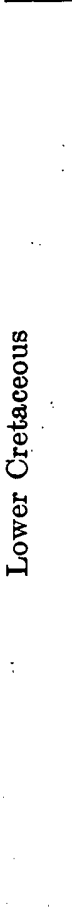 } & \multicolumn{2}{|c|}{$\begin{array}{l}\text { Bear River } \\
\text { formation }\end{array}$} & $300-500$ & $\begin{array}{l}\text { Siltstone, dark-gray, carbonaceous, fer- } \\
\text { ruginous; and brown, thin-bedded } \\
\text { sandstone in lower two-thirds; over- } \\
\text { lain in upper third by brown to gray } \\
\text { medium-grained quartzite or sand- } \\
\text { stone that is very resistant to } \\
\text { weathering. Uranium-bearing coaly } \\
\text { shale and carbonaceous limestone } \\
\text { occur near the top of the formation. }\end{array}$ \\
\hline & \multirow{5}{*}{ 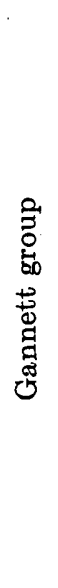 } & $\underset{\text { sandstone }}{\text { Tygee }}$ & $285-300$ & $\begin{array}{l}\text { Shale, red, interbedded with gray to } \\
\text { brown, fine-grained sandstone; some } \\
\text { sandstone is gray, medium grained, } \\
\text { crossbedded and friable; the sand- } \\
\text { stone beds form ledges in the shales. }\end{array}$ \\
\hline & & $\begin{array}{l}\text { Draney } \\
\text { limestone }\end{array}$ & $175-300$ & $\begin{array}{l}\text { Limestone, gray, fine- to coarse- } \\
\text { grained; weathers very light gray; } \\
\text { fossiliferous at top. }\end{array}$ \\
\hline & & $\begin{array}{l}\text { Bechler } \\
\text { redbeds }\end{array}$ & $225-300$ & Shale, red, weathers to a red soil. \\
\hline & & $\begin{array}{l}\text { Peterson } \\
\text { limestone }\end{array}$ & $50-100$ & $\begin{array}{l}\text { Limestone, fine-grained, dark gray; } \\
\text { weathers very light gray. }\end{array}$ \\
\hline & & $\begin{array}{l}\text { Ephraim con- } \\
\text { glomerate }\end{array}$ & $360-400$ & $\begin{array}{l}\text { Conglomerate and sandstone, reddish- } \\
\text { gray, coarse-grained, gritty; some } \\
\text { reddish-gray shale and purplish- } \\
\text { gray limestone. }\end{array}$ \\
\hline \multirow{2}{*}{ 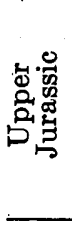 } & \multicolumn{2}{|c|}{ Stump sandstone } & $220-300$ & $\begin{array}{l}\text { Sandstone, gray to greenish-gray, fine-- } \\
\text { grained and shaly; some sandstione is } \\
\text { massive and coarse grained. }\end{array}$ \\
\hline & \multicolumn{2}{|c|}{ Preuss sandstone } & $425-500$ & $\begin{array}{l}\text { Shale, red and green with green "salt } \\
\text { and pepper" sandstone and thin beds } \\
\text { of limestone. }\end{array}$ \\
\hline 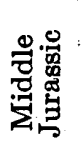 & \multicolumn{2}{|c|}{$\begin{array}{r}\text { Twin Creek } \\
\text { limestone }\end{array}$} & $970-1,200$ & $\begin{array}{l}\text { Limestone, gray, impure; weathers } \\
\text { yellowish-gray, forms small splintery } \\
\text { fragments. }\end{array}$ \\
\hline 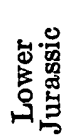 & \multicolumn{2}{|c|}{ Nugget sandstone } & 1,000 & $\begin{array}{l}\text { Quartzite and sandstone, red to :pink } \\
\text { or white, very resistant; weathers } \\
\text { into large blocks which form exten- } \\
\text { sive talus slopes. }\end{array}$ \\
\hline
\end{tabular}

1 Modifled from Kirkham (1924) and unpublished data of L. S. Gardner (oral communication, 1952). 


\section{JURASSIC SYSTEM}

Nugget sandstone.-The base of the Nugget sandstone is not exposed in the mapped area, but the formation is probably about 1,000 feet thick. It consists of fine-grained, white to pink or red sandstone and quartzite, generally thin-bedded, though locally crossbedded. The entire formation is highly resistant and weathers to blocks which cover extensive talus slopes.

Twin Creek limestone.-Lying with apparent conformity on the Nugget sandstone, the Twin Creek limestone forms a unit 970 to 1,200 feet thick that is easily recognizable by its lithology. The Twin Creek consists chiefly of gray, impure limestone that weathers into yellowishgray splintery fragments or flakes of characteristic appearance. The formation forms rounded, gentle slopes with sparse vegetation.

Preuss sandstone.-The Preuss sandstone is probably about 425 feet thick and separated from the Twin Creek limestone by a minor unconformity. The Preuss consists of interbedded shale, sandstone, and limestone ranging in color from red and green to brown and gray. The difficulty in distinguishing this formation from the overlying Stump sandstone and Ephraim conglomerate made it necessary to map all three formations as a single unit.

Stump sandstone.-No distinctive lithologic contact separates the Stump sandstone from the underlying Preuss sandstone. The Stump is probably about 220 feet thick and consists chiefly of fine- to coarsegrained gray sandstone, which is commonly ripple marked and weathers to yellowish or brownish gray.

\section{CReTaceous system}

Gannett group.-Five formations totaling 1,100 to 1,400 feet of strata at the base of the Cretaceous make up the Gannett group. They are, from oldest to youngest, the Ephraim conglomerate, Peterson limestone, Bechler redbeds, Draney limestone, and Tygee sandstone. A striking cyclic repetition of units of similar lithology is represented by the Peterson and Draney limestones, each of which is overlain by the red shale and sandstone, Bechler redbeds or Tygee sandstone.

Ephraim conglomerate.-Conformably overlying the Stump sandstone and forming the basal unit of the Gannett group is the Ephraim conglomerate, at least 360 feet thick. The Ephraim consists of interbedded red to gray sandstone, conglomerate, reddish limestone, and reddish shale. The difficulty in distinguishing the Ephraim from the underlying Stump and Preuss sandstones made it necessary to map all three formations as a single unit. 
Peterson limestone.-Lying conformably on the Ephraim conglomerate, the Peterson limestone is about 50 to 100 feet thick and forms prominent ledges. The Peterson consists of gray massive fine-grained limestone, which weathers into characteristic whitish outcrops. The formation makes an excellent horizon marker.

Bechler redbeds. - The Bechler redbeds lie conformably over the Peterson limestone and are at least 225 feet thick. The Bechler consists of red shale, which weathers into a red soil and forms a valley or saddle between the underlying and overlying limestone formations.

Draney limestone.-Conformably overlying the Bechler redbeds is the Draney limestone, about 175 feet thick. The weathered appearance of the Draney limestone is very similar to that of the Peterson limestone and where not seen in continuous sequence is sometimes indistinguishable from the Peterson limestone. The Draney consists chiefly of gray massive fine-grained limestone, with coarse-grained fossiliferous dark-colored limestone at the top. The limestone weathers into whitish outcrops that stand out as ridges between the enclosing red shale and sandstone.

Tygee sandstone.-Lying with apparent conformity on the underlying Draney limestone is the Tygee sandstone, 285 feet thick where measured on Skyline Ridge. The formation consists of interbedded red shale and gray to brown sandstone. The sandstone is commonly medium grained, crossbedded, and friable, resembling sandstone in the Wayan.

The following section of the Tygee sandstone was measured on Skyline Ridge in sec. 27, T. 1 S., R. 42 E. The strata in this section are overturned and dip $85^{\circ}$ to the northeast. The intense deformation may have caused the formation to be thinner here than in a normal section. The limits of the formation differ greatly from the limits described by Kirkham (1924, p. 26-28) who included beds in the Tygee that are here called the Bear River formation. Apparently Kirkham measured his section east of the Fall Creek Ranger Station, where faulting has duplicated the strata. 
Section of the Tygee sandstone, sec. 2\%, T. 1 S., R. 42 E., Bonneville County, Idaho

[The dip is about $85^{\circ} \mathrm{NW}$. , beds are overturned]

Bear River formation: shale and siltstone, dark-gray, ferruginous (not measured).

Tygee sandstone:

Unit

Thickness

1. Covered, red soil

6 . 0

2. Sandstone, fine-grained; dark-gray to brown, hard-_-_-_ $\quad 1 \quad 8$

3. Covered, red soil

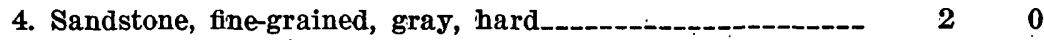

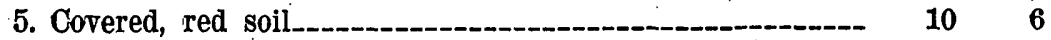

6. Sandstone, fine-grained, gray, hard, calcareous__-_-_-_-_-_ 10

7. Covered, red soil, probably red shale______-_-_-_ $52 \quad 0$

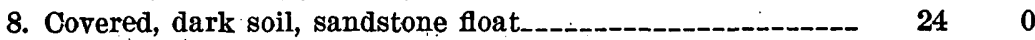

9. Sandstone, fine- to medium-grained, gray, crossbedded, friable, calcareous; similar to sandstone in the Wayan formation

10. Covered, red soil, probably red shale

260

540

11. Sandstone, reddish-brown, calcareous___-_-_-__-_-_-_ 2 . 0

12. Covered, reddish-brown soil__-_-_-_-_-_-_-_-_-_-- $35 \quad 0$

13. Sandstone, fine-grained, gray, numerous black grains, calcareous

14. Covered, reddish-gray soil and a thin ledge of gray siltstone

15. Sandstone, fine-grained, gray, massive, calcareous_-_-_-_---

16. Covered, reddish-gray soil

17. Sandstone, fine-grained, gray, massive, calcareous_-------

18. Covered, light-gray soil

19. Sandstone, fine-grained, brown, thin-bedded, calcareous_-_--

20. Covered, light-gray soil, limestone float.

Total, Tygeè sandstone.

Draney limestone: Limestone, dark bluish-gray, fossiliferous (not measured).

Bear River formation.-The Bear River formation, lying with apparent conformity on the Tygee sandstone, is about 300 to 500 feet thick. The upper and lower contacts of the formation, as described herein, follow the usage of Louis S. Gardner (oral communication, 1952). The lower two-thirds of the formation consists of dark-gray, ferruginous, carbonaceous shale and siltstone interbedded with thin beds of dark-brown sandstone. The upper third of the formation consists of a prominent ledge of medium-grained gray to brown quartzite or sandstone 75 feet thick, overlain by black shale, thin beds of fine-grained brown sandstone, coaly shale, and black fossiliferous granular limestone probably of brackish-water origin. The limestone and coaly shale are the uranium-bearing strata in the Fall Creek 
area. The Bear River formation does not contain any of the beds of the red or green shale that are so characteristic of nearly all the other Jurassic and Cretaceous clastic sedimentary rocks in this area. The thick ledge-forming quartzite or sandstone in the upper third of the formation is the principal marker bed in this part of the section. The dark somber color of soils derived from the formation as a whole is fairly characteristic and helps to identify the formation where exposures are poor. The Bear River formation is generally poorly exposed and the outcrops are commonly complicated by faulting or folding, so that no complete section of the formation was measured. The following section of the lower part of the formation was measured near the divide between Blacktail, Porcupine, and Pritchard Creeks.

Section of the lower part of the Bear River formation in sec. 22, T. 1 N., R. $42 \mathrm{E}$., Bonneville County, Idaho

[The strata here dips $40^{\circ}-45^{\circ} \mathrm{NE}$ ]

Bear River formation (the upper part of the formation is not exposed) :

Unit

Thickness (feet)

1. Quartzite, fine-grained, brown, thin-bedded to massive, noncalcareous -_-_-_-_.-_- 22

2. Covered, quartzite float_._._._-_._- 35

3. Sandstone, fine-grained, gray, thin-bedded to massive, calcareous; weathers brown_......

4. Covered, dark-gray soil covered with small chips of dark-gray to brown siltstone float

5. Sandstone, fine-grained, quartzitic, dark-brown, ferruginous_-_.--

6. Covered, dark-gray soil covered with small chips of dark-gray to brown siltstone float

Total, lower part of Bear River formation

Tygee sandstone : covered, red soil (not measured).

A section of the upper part of the Bear River formation and part of the lower Wayan formation is described later in the text under the heading Fall Creek coal prospect.

Wayan formation.-An unconformity probably separates the Wayan formation from the underlying Bear River, though proof of its existence in this area depends primarily on the variation in the interval between the massive ledge of quartzite in the Bear River and the first appearance of red shale above the quartzite. The variation in the interval may also be dependent on primary depositional differences and unequal deformation at the time of folding. The formation is estimated to be at least $3,000-4,000$ feet thick where involved in a series of folds in Fall Creek basin, but the top of the formation is not exposed. No attempt was made to measure a stratigraphic section of the Wayan formation, but various exposures of it consist 
chiefly of red and purple shale interbedded with medium- to coarsegrained, gray, crossbedded, friable sandstone in beds up to 20-30 feet. thick. The sandstone beds commonly form prominent ledges in slopes. developed on the otherwise nonresistant strata. A characteristic of the sandstone beds is crossbedding; this feature is very useful in determining the sequence of strata and therefore the structure, particularly in areas where folds are overturned.

\section{IGNEOUS ROCKS}

Tertiary volcanic flows and tuffs lie unconformably on the folded and faulted strata of Mesozoic and Paleozoic age in the Caribou: Mountains. Several hills within the mapped area are capped by remnants of volcanic rocks. These remnants occur at different altitudes. Large remnants in the northern part of the area, in secs. 20, 29, and 30, T. 1 N., R. 42 E., lie at altitudes ranging from 7,000 to 7,600 feet; whereas, similar remnants in the southwestern part of the area, in secs. 29, 30, and 31, T. 1 S., R. 42 E., lie at about 6,600 to 6,700 feet. This difference in altitude would seem to indicate at least 1,000 feet of topographic relief at the time the volcanic rocks were deposited and may indicate that the original thickness of tuffs and flows was: much greater than is represented in any of the present remnants. Ross and Forrester (1947) assign the tuffs and flows to the oldest of a series of three volcanic groups recognized in southeastern Idaho. This oldest group consists of Miocene and Pliocene silicic volcanic rocks (beds of welded tuff and flows resembling rhyolitic lava) associated with the Snake River basalt. In the Fall Creek area this group of volcanic rocks is made up of hard, dense, gray and tan to red, felsite porphyry containing small feldspar phenocrysts. Black and gray obsidian rocks with microlites and spherulites are also present.

\section{STRUCTURAL SETTING}

The Caribou Mountains in southeastern Idaho are at the northern end of a system of parallel mountain ranges that form an arcuate belt along the Idaho-Wyoming border. The Caribou Mountains are characterized by complex structural features that trend northwest and ultimately plunge beneath the lavas of the Snake River Plain, which surrounds the northern end of the range. Closely spaced, parallel folds, overturned at many places and broken by faults, are the principal structural features of the range.

Cross section $\mathbf{A}-\mathrm{A}^{\prime}$ (pl. 51) shows the principal structural features in the area mapped. Folds in the southwestern part of the area are overturned to the northeast, whereas, folds in the northeastern part of the area are overturned towards the southwest. The Fall Creek 
coal prospect is located on the flank of a nearly symmetrical anticline between the two areas of overturning. Both longitudinal and transverse faults are superimposed on the pattern on the folds. Most of the longitudinal faults are normal faults, but the faults along Skyline Ridge and the next ridge to the southwest are thrust faults. In sec. 12, T. 1 S., R. 42 E., a longitudinal normal fault is offset by a transverse normal fault. At this place the relation between two types of faulting can be clearly determined. A northeast-trending joint pattern at right angles to the folding is suggested in the Fall Creek basin by the trellislike drainage pattern so characteristic of the area.

Folding in the area ranges in magnitude from minor drag folds to folds involving thousands of feet of strata in which the horizontal distance from the axis of one fold is several miles from the axis of an adjacent fold.

\section{STRUCTURE AND EXTENT OF THE BEAR RIVER FORMATION}

The Bear River formation is exposed along the flanks of most of the synclines and anticlines in the area mapped and also in many of the surrounding areas. The prominent synclinal trough at the northeastern corner of the area mapped (pl. 51) is divided into two synclines by a small faulted anticline. The Bear River formation occurs along the flanks of both the major and the minor folds, but exposures of the coal-bearing zone are very poor. Along the overturned southwest flank of the major anticlinal structure east of the Fall Creek Ranger Station the Bear River formation is duplicated by faulting. Exposures of the coal-bearing zone are poor, and the zone itself is thin, apparently owing to stretching which was a part of the intense deformation. A faulted anticline broken by transverse faults to form a horstlike structure brings the Bear River formation to the surface at the Fall Creek coal prospect. Elsewhere along the strike of the same anticlinal feature the zone of radioactive rocks is not exposed.

The Fall Creek basin is a broad area of gentle relief eroded from folded strata in the Wayan formation. Between the Fall Creek coal prospect and Skyline Ridge, an anticline overturned to the northeast has exposed strata older than the Wayan formation. However, the northeast flank of this anticline is so steep, the strata so thin, and the exposures so poor that the radioactive zone could not be found. The southwest flank of the anticline, however, has a relatively gentle dip and the coal-bearing zone appears to be quite similar to that at the Fall Creek coal prospect, though the exposures are poor. Southwest of this overturned anticline is a thrust sheet that parallels the crest of Skyline Ridge. A belt of very complex structure including recumbent folds and imbricate thrust sheets occurs between Skyline

$469117-59-20$ 
Ridge and Hell Creek. Within this belt of complex structure the Bear River formation is repeated at least three times, but the exposures of the coal-bearing zone are very poor. The intense deformation has probably caused the thinning of incompetent strata including the coal-bearing strata:

A relatively gentle syncline and anticline occupy the southwest corner of the area mapped, but soil and vegetation cover the coalbearing zone and no outcrops could be found. An area near the heads of Camp, Haskin, Trap, and Beaver Creeks, in the southcentral part of the mapped area, is one of complex and indeterminate structure. Soil cover, heavy regetation, and hillwash mask the exposures. Locally, outcrops of the Bear River formation were recognized, but the structural setting is poorly understood.

\section{URANIUM-BEARING ROCKS}

\section{GENERAL DISTRIBUTION}

Uranium in coal and carbonaceous rocks was discovered in September 1951 at the entrance to the Fall Creek coal prospect, sec. 4, T. 1 S., R. 42 E. (pl. 51). Most of the uranium-bearing rocks are restricted to a single stratigraphic zone in the upper part of the Bear River formation, which is present throughout much of the northern part of the Caribou Mountains. Limestone pebble. conglomerates containing about 0.01 percent uranium were also found locally in the Wayan formation. One of these yielded a fossil-bone fragment that contains 0.17 percent úranium (locality 16 , table 3 ). The Phosphoria formation of Permian age also contains uranium, but a study of this formation in the Caribou Mountains was not included in this investigation.

The exposure of uranium-bearing strata in the Fall Creek coal prospect (locality 13, pl. 51) is discussed in the next section. Elsewhere exposures of the uranium-bearing strata are rare. 'Trenches (localities 9, 10, 11 and 12, pl. 51 and table 3) were dug to expose these strata at intervals along the strike northwest of the coal prospect for nearly half a mile. Together these five exposures supply the best information available on the lithology and uranium content of the uranium-bearing strata. Exposures elsewhere serve chiefly to demonstrate the widespread distribution of the uranium-bearing strata. The locations of the exposures discussed below are shown on figure 39. Roadcuts have exposed uraniferous strata at locality 36 (sec. 18, T. 2 S., R. 45 E.) and locality 38 (sec. 23, T. 3 S., R. 43 E.), both outside the area mapped and about 17 to 18 miles from the Fall Creek coal prospect. A select grab sample of coal from the dump of 
the Croley coal prospect, locality 37 (sec. 27 , T. 1 S., R. 41 E.), contains 0.007 percent uranium in the coal and 0.03 percent uranium in the ash. The mine itself is not accessible and so the thickness and nature of the strata are not known. Carbonaceous shale on the dump of an abandoned coal prospect in sec. 5, T. 32 N., R. 119 W., near Auburn, Wyo., 47 miles to the southeast (fig. 39, locality 41) contains 0.0035 percent uranium in the sample and 0.0053 percent uranium in the ash. Elsewhere a slight radioactivity was detected in material on the dumps of abandoned coal prospects, including the Brinson prospect, locality 1 (sec. 34, T. 2 N., R. 40 E.), the Pine Creek Pass prospect, locality 4 (sec. 25, T. 3 N., R. 44 E.), which is 21 miles distant, and at a mine in the Bear River formation about 12 miles west of Driggs (locality 5). However, the radioactivity measured in these areas indicated no more than 0.003 percent equivalent uranium. At several other localities radioactivity was detected in rocks exposed by trenches, auger holes, or from limestone float, but fresh samples of the zone of coaly shale were not obtainable and the analyses of these samples can serve only in a qualitative way to show the general distribution of uranium (fig. 39, pl. 51, and table 3).

\section{FALL CREEK COAL PROSPECT}

The Fall Creek coal prospect is an inclined shaft that extends about 83 feet down the dip of a bed of coaly shale in the Bear River formation. The shaft was sunk about 1922 by J. H. Smith of Rigby, Idaho, who reports that he mined down the dip of the bed for a distance of about 98 feet and ceased operations when he reached water. A firm limestone roof and good timbering have helped to keep the shaft open, though the floor is covered with rubble and the lowest 15 feet are filled with rubble. Plate 52 is a diagrammatic longitudinal section of the shaft showing the distribution of uranium in the samples.

The prospect lies on the northeast flank of a faulted anticline (pl. 51). The beds here dip $33^{\circ}$ northeast and strike northwest. A fault system transverse to the general strike has uplifted the Bear River formation for about half a mile along the axis of the anticline. The inclined shaft has been driven in a zone of incompetent strata which have been sheared by differential movement and are characterized by drag folds.

Uranium in measurable amounts at the Fall Creek coal prospect is confined to a stratigraphic zone of brackish or fresh-water organicrich strata-units 16 through 21 in the stratigraphic section as described below and represented graphically in figure 40 . 


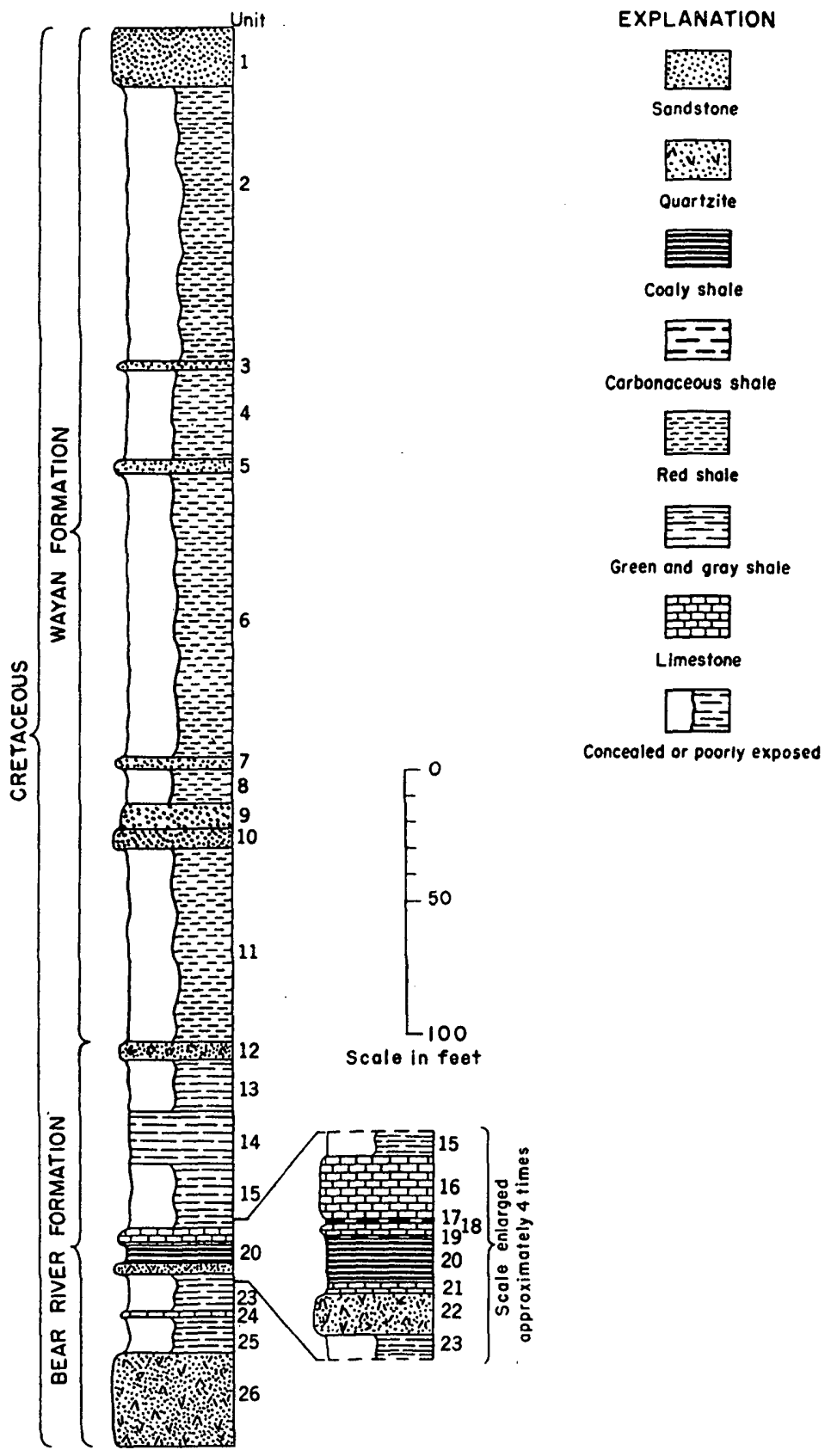

Figore 40.- Stratigraphic section of the upper part of the Bear River formation and the lower part of the Wayan formation, as measured at the Fall Creek coal prospect. 
Stratigraphic section of the upper part of the Bear River formation and the lower part of the Wayan formation, measured at the Fall Creek coal prospect in sec. 4, T. 1 S., R. 42 E., Bonneville County, Idaho

[The dip here is about $30^{\circ}-35^{\circ}$ to the northeast]

Wayan formation:

Upper part (not measured).

Lower part:

Unit

1. Sandstone, light-gray, medium-grained, thin- to thickbedded, crossbedded ; forms prominent ledge

2. Covered; probably contains red shale; forms slope...-

3. Sandstone, bulish-gray, fine- to medium-grained------

4. Covered ; probably contains red shale; forms slope----

5. Sandstone, bluish-gray, fine-grained

6. Covered; probably contains red shale; forms slope...--

7. Sandstone, greenish-gray, fine-grained

8. Covered; probably contains red shale; forms slope...-

9. Sandstone, light-gray, fine- to medium-grained, forms ledge locally

10. Sandstone, light-gray, fine- to medium-grained, crossbedded, thin-bedded, slightly friable; forms ledge; the lower 6-8 inches contain a siltstone-pebble conglomerate

340

50

1080

40

130

100

11. Covered, reddish soil; probably contains red shale, forms slope.

Total, lower part of Wayan formation (measured)

Bear River formation:

Unit

12. Quartzite, greenish-gray, fine-grained to dense

60

13. Covered ; probably contains green nonfissile shale_-..-.-

14. Shale, greenish- to purplish-gray, not fissile; forms slope

15. Covered by road fill; probably contains green nonfissile shale

16. Limestone, carbonaceous, gray to black, weathers gray, dense to finely crystalline; contains fossil fragments, including smooth gastropod shells, uraniferous.----

17. Shale, carbonaceous, dark greenish gray, uraniferous_-

18. Limestone, carbonaceous, dark-gray to black, weathers gray ; contains fossil fragments ; fresh fragments give off fetid odor; uraniferous

19. Shale gouge, carbonaceous, contains lenses of clay, coal, and limestone; uraniferous

20. Coaly shale and thin lenses of coal, clay, and limestone; sheared. This unit contains the highest percent of uranium.

21. Shale, carbonaceous; carbonaceous limestone and uraniferous coal

22. Quartzite, greenish-gray to brown, fine-grained; forms ledge 
Stratigraphic section of. the upper part of the Bear River formation and the lower part of the Wayan formation, measured at the Fall Creek coal prospect in sec. 4, T. 1 \&., R. 42 E., Bonneville County, Idaho-Continued

Bear River formation-Continued

Unit

23. Mostly covered slope-forming unit; probably gray to black, fissile shale

24. Limestone, impure, dark-brown, weathers brown, dense to finely crystalline; fresh fragments give off a fetid odor; contains fossil fragments including. smooth gastropod shells.

25. Mostly covered, slope-forming unit; probably contains gray to black fissile shale

26. Quartzite, greenish-gray to brown, fine-grained; cross-. bedded in part; forms massive ledge, the most prominent marker bed in this part of the section. The lower part of the Bear River formation is not exposed

Total, Bear River formation exposed (measured)

Units 16,17 , and 18 in the above section are considered as a relatively resistant limestone zone with a thin shale parting. The limestone ranges from a gray, fine-grained limestone that is not uraniferous to a black, medium- to coarse-grained limestone rich in carbonaceous material, macerated fossil fragments, and some gastropod and pelecypod shells. This type of organic-rich limestone is commonly, though not invariably, uranium bearing throughout a widespread area. The roof of the Fall Creek coal prospect is formed by the base of this limestone. It has a wavy lower surface and contains cavernous joints which may have been enlarged by groundwater circulation. A group of incompetent strata underlying the limestone has been sheared by differential movement and is characterized by shear structure rather than bedding features.

Unit 19 in the stratigraphic section at the Fall Creek prospect is a gouge zone of variable thickness and lithology in which the shear structure is roughly parallel to the bedding of the overlying limestone units. This unit is composed of varying proportions of carbonaceous shale, carbonaceous and calcareous clay gouge, thin limestone lenses, and thin lenses of coal. A sample of black vitreous coal from a 2-inch-thick lens was insoluble in carbon disulfide. Pyrite occurs in the lenses of coal. The unit ranges in thickness from 4 inches to 2 feet and contains an average of about 0.02 percent uranium.

Unit 20, the most highly uraniferous unit of the group, consists of sheared coaly shale with thin lenses of coal, clay, and limestone; it is approximately 4 feet thick. Unit 20 is characterized by drag folds in 
which lenses of yellow and gray clay, coal, and limestone have been dragged into the sheared coaly shale. Gypsum, calcite, and jarosite commonly occur as secondary encrustations on fractures, joints, and shear planes. A bulk sample of unit 20 was collected about 35 feet from the entrance to the inclined shaft for proximate and ultimate analysis by the U. S. Bureau of Mines. The results are shown in table 1, together with the analysis of a sample collected in 1923 from the same or a nearby prospect. The ash content of this bulk sample is too great for commercial use of the material as fuel. However, sufficient carbonaceous matter is present to make the material comparable to coal. The ratio of carbon to hydrogen is similar to that of subbituminous coal, but the ratio of volatile matter to fixed carbon is higher than for most coals except certain unusual varieties such as cannel coal. This high proportion of volatile matter indicates that this unit may originally have been more similar to canneloid shale than to a true coal. The top foot of unit 20 contains an average of about 0.04 percent uranium and a maximum of about 0.13 percent uranium. The basal 3 feet contain an average of about 0.01 percent uranium.

Underlying the coaly shale of unit 20 is unit 21 , which, like unit 19 , consists of carbonaceous shale, with lenses of limestone, clay, and jetblack coal. The shear planes in this unit are wavy but roughly parallel the bedding. The unit ranges in thickness from about 6 inches to 2 feet; the base is poorly exposed. The uranium content of this unit is relatively small and averages slightly less than 0.006 percent.

TABLE 1.-Proximate and ultimate analyses of coaly-shale samples from the Fall Creek coal prospect, Bonneville County, Idaho

[Analyses by the U. S. Bureau of Mines. Form of analysis: A, as received; B, air dried; C, moisture-free; $\dot{D}$, moisture- and ash-free]

\begin{tabular}{|c|c|c|c|c|c|c|c|c|c|c|c|c|c|}
\hline Sample & & & & & Analys & s, in & percen & & & & & bility & \\
\hline & & & Proxi & mate . & & & . & Ultim & ate & & & & \\
\hline $\begin{array}{c}. \\
\text { Laboratory } \\
\text { No. }\end{array}$ & 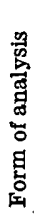 & 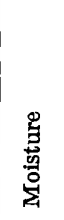 & 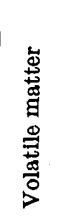 & 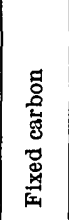 & प्चี & 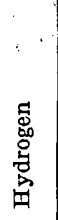 & 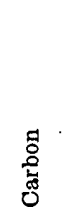 & 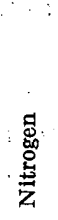 & $\begin{array}{l}\text { 总 } \\
\text { 获 } \\
0\end{array}$ & 急 & 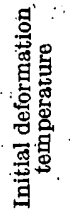 & 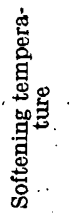 & 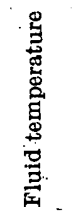 \\
\hline D-78075 $1 \ldots$ & $\begin{array}{l}\mathbf{A} \\
\mathbf{C} \\
\mathbf{D}\end{array}$ & \begin{tabular}{l}
2.9 \\
2.9 \\
\hdashline 4.6 \\
\hdashline-
\end{tabular} & $\begin{array}{l}25.4 \\
25.4 \\
26.1 \\
60.4 \\
20.7 \\
21.2 \\
72.4\end{array}$ & $\begin{array}{r}16.6 \\
16.5 \\
17.1 \\
39.6 \\
7.7 \\
8.0 \\
27.6\end{array}$ & $\begin{array}{r}55.1 \\
55.2 \\
56.8 \\
-67.5 \\
70.8\end{array}$ & $\begin{array}{l}2.7 \\
2.7 \\
2.4 \\
5.6 \\
2.5 \\
2.0 \\
7.0\end{array}$ & $\begin{array}{l}28.8 \\
28.9 \\
29.7 \\
68.7 \\
19.2 \\
20.1 \\
68.7\end{array}$ & $\begin{array}{r}0.5 \\
.5 \\
.5 \\
1.2 \\
.3 \\
.3 \\
1.0\end{array}$ & $\begin{array}{r}9.9 \\
9.7 \\
7.5 \\
17.3 \\
7.2 \\
3.4 \\
11.6\end{array}$ & $\begin{array}{r}3.0 \\
3.0 \\
3.1 \\
7.2 \\
3.3 . \\
3.4 \\
11.7\end{array}$ & $\begin{array}{r}2,170 \\
2,180\end{array}$ & $\begin{array}{r}2,300 \\
2,340\end{array}$ & $\begin{array}{l}2,530 \\
2,390\end{array}$ \\
\hline
\end{tabular}

Analyzed January 2, 1952

2 Analyzed September 24, 1923. From Cooper and others (1947, p. 38). 
The average percent ash of samples from the Fall Creek coal prospect (exclusive of the limestone in the roof of the shaft) is greater than 50 percent. A sample of jet-black vitreous coal (sample 2, table 3, pl. 52) from a small lens contained 17.3 percent ash, the least of all the samples collected. This and other samples relatively low in ash contained considerably more uranium than most samples with higher ash contents. At localities 9 (pl. 51) and 37.(fig. 39), grab samples VI-371 and VI-1140 from abandoned prospect dumps had relatively low ash contents of 37 and 21.7 percent and uranium contents of 0.08 and 0.007 percent respectively (table 3).

\section{DISTRIBUTION OF URANIUM AND OTHER ELEMENTS}

Carbonaceous rocks are a complex mixture of organic and inorganic compounds and characteristically contain a large suite of minor elements in trace quantities. The ash of coal that has burned represents a concentration of those constituents which are noncombustible and nonvolatile, though not necessarily in the same form as in the unburned coal. The elements present in the ash include at least two and probably three distinct suites, according to their mode of origin (Katchenkov, 1952). The extraneous ash is generally the most abundant and includes several of the common rock-forming elements which were carried into the coal swamp as constituents of sand and clay prior to burial. The extraneous ash probably includes such elements as silicon, aluminum, calcium, iron, magnesium, and possibly, sodium, potassium, manganese, and titanium, most of which are likely to be abundant in those carbonaceous rocks having a high ash content. The intrinsic ash consists of those elements that were part of the mineral constituents in the plant bodies from which the coal was formed. These elements generally include several of the common metals, such as barium, strontium, lead, nickel, zinc, and cobalt-present commonly only in trace amounts, plus many minor metals such as boron, beryllium, scandium, gallium, germanium, lanthanum, niobium, yttrium, molybdenum, and silver-also present only in trace amounts. Several additional elements including sulfur and phosphorus are common constituents of raw coal, but may or may not be present in the ash depending on the original form of the element present in coal. Elements not normally abundant in plant tissues or common rock minerals are sometimes found in considerable abundance in coal ash. Germanium is one such element, and it has been pointed out by Haught ${ }^{2}$ that such an accumulation is difficult to explain except as the result of secondary enrichment. Thus, secondary enrichment may produce a third possible distinct suite of

\footnotetext{
1 Haught, O. L., 1954, On the occurrence and distribution of rare elements in coal : Paper read at meeting of the Appalachlan Geol. Soc., Charleston, W. Va., April 5, 1954.
} 
elements in carbonaceous rocks. Any specific element may be introduced by any one or a combination of the three methods.

Until recently uranium was not considered to be important as a trace element in coaly rocks because it is normally present only in extremely small amounts, probably in the range of $0.000 \mathrm{X}$ percent or less. It is now known, however, that the ash of coal may contain as much as 1 percent uranium (Bachman and others, chapter $J$, this bulletin). The nature of the occurrence of uranium in coaly matter is not clearly understood. Investigations by Tolmachev (1943) suggest that uranium may be associated with carbonaceous material in the form of an adsorbed ion held by the platy structure of the carbon molecules. Ion-exchange studies by Breger and Deul (1955) suggest that uranium may occur as a metallo-organic compound in lignite from South Dakota. Autoradiographic studies by E. F. Koppe and others (written communication, 1954) suggest that uranium or one of its radioactive daughter products is concentrated in an unidentified crystalline material that forms the pore filling of fossil cell lumens in coal. No uranium minerals have been recognized in the carbonaceous material of the Fall Creek area, though an autoradiograph made by exposing ortho-type film for three weeks to a cut section of coal, sample 2-(table 3 ), shows numerous point sources of radiation in a clouded background and indicates a concentration of radioactive material in microscopic units within a mass of less intensely disseminated radioactive substance.

Semiquantitative spectographic analyses were obtained on a select group of ashed carbonaceous rock samples from the Fall Creek area. The analyses of samples in table 8 are arranged by lithologic types, as follows: coal, less than 50 percent ash; coaly shale, 50-80 percent ash; carbonaceous shale, more than 80 percent ash; and limestone, in which the ash content is not significant. Within each group the samples are arranged by locality, and where possible in order of decreasing percent uranium in the ash. This results in the list having, in general, an order of decreasing percent uranium in the ash. In other words, the percent uranium in the ash shows a general inverse proportion to the percent ash in the sample.

The essential rock-forming elements are listed at the left in table 8 and the accessory elements are grouped to the right. according to chemical affinities. Most of the elements occur in what may be considered normal quantity (Goldschmidt, 1937, p. 669), but there are several which deviate from the normal. Uranium, of course, has a range of approximately 50 to one, and even the sample with the least uranium probably contains on the order of 10 times that normally found in rocks of this type. Molybdenum and germanium correlate remarkably well with the uranium (fig. 41), for the samples which are high in uranium also contain one or two orders of magnitude times the 


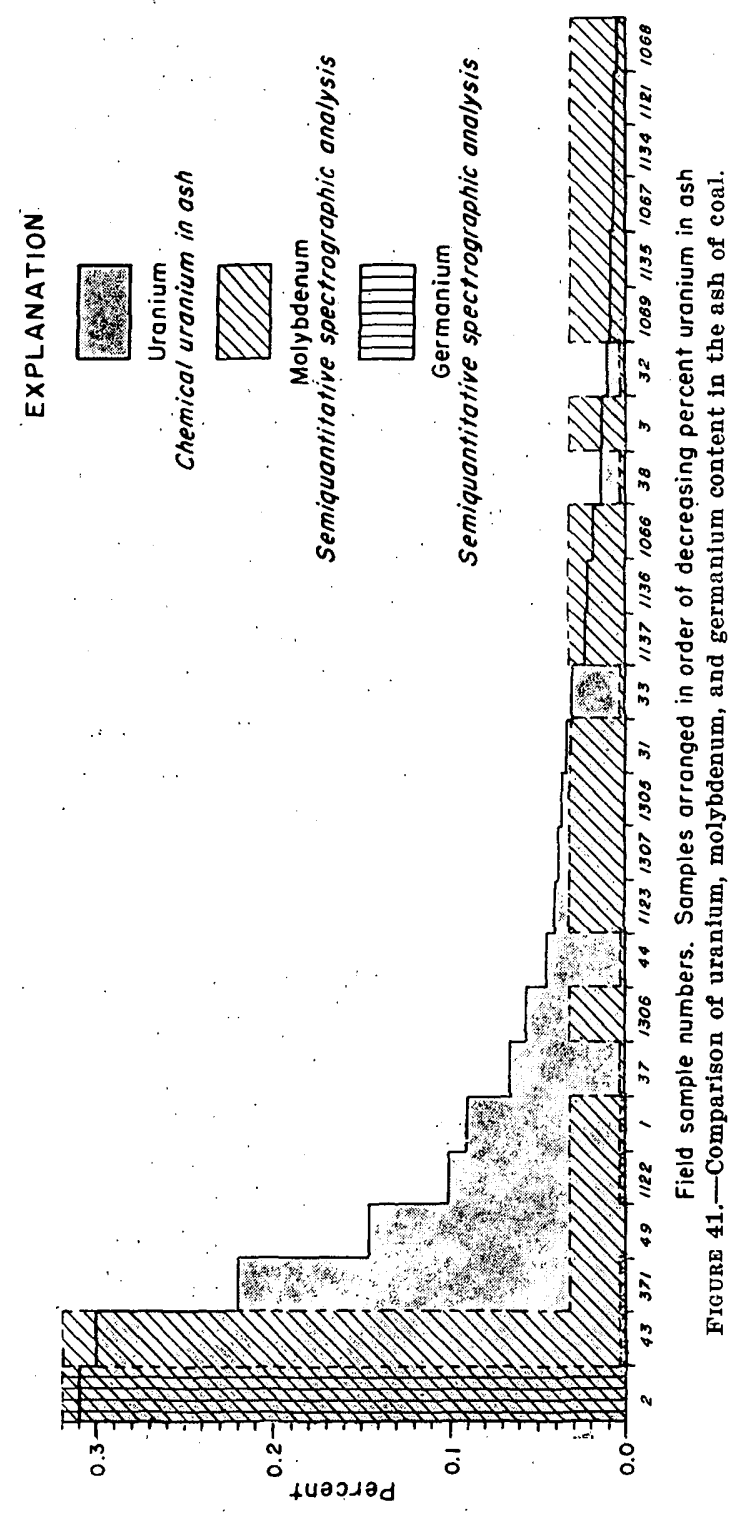


normal quantity of molybdenum and germanium, although the germanium and molybdenum contents are not consistently proportional to the uranium content. This correlation of the three elements, which is apparent in the samples with the greatest amount of uranium and less apparent in the samples with less uranium, suggests a geochemical relation and possibly a common origin. Several elements, including beryllium, zinc, gallium, yttrium, and lead, appear to be less abundant in the Fall Creek material than in average coal though the significance of this fact is not apparent.

Uranium in the carbonaceous rocks of the Fall Creek area occurs most abundantly in the units that contain the most carbonaceous material (pl. 52). These units include coal, coaly shale, carbonaceous shale, and black carbonaceous limestone, in a general decreasing order of uranium content. However, even within each unit the uranium content is far from uniform. This is perhaps best shown within the unit of sheared coaly shale, because of the greater number of samples collected. The percent of uranium within this unit at the Fall Creek coal prospect ranges from 0.004 (sample 16) to 0.131 (sample 43). In general, the uranium content is small near the weathered surface exposure and increases to a maximum at about 60 feet down the dip of the bed. The weighted-average content of uranium in samples from this unit at the entrance to the inclined shaft is 0.015 percent uranium, whereas the weighted average for the same unit 60 feet from the entrance is 0.043 percent uranium. There is also a pronounced vertical pattern to the distribution of uranium. The top 1 foot of this coaly shale unit contains an average of about 0.044 percent uranium, in contrast to only about 0.008 percent uranium contained in the basal 1 foot of the unit.

\section{ORIGIN OF URANIUM DEPOSITS}

Four general hypotheses for the origin of uranium in coal and carbonaceous materials warrant consideration. These may be classed according to the time and manner of emplacement of the contained uranium, as follows:

1. Syngenetic: simultaneous emplacement of the uranium with the sedimentary material in which it occurs by concentration in living plant tissues.

2. Diagenetic : emplacement of the uranium after the deposition of the sediment but before the consolidation or deep burial of the sedimentary material by concentration in decaying plant remains.

3. Epigenetic: emplacement of the uranium long after the consolidation or deep burial of the sedimentary material:

(a) By invasion of carbonaceous rocks with uranium-bearing hydrothermal solutions and removal of uranium from solution by reaction with the organic material. 
(b) By migration through carbonaceous rocks of uranium-bearing meteoric waters under the force of gravity and removal of the uranium from solution by reaction with the organic material.

For each hypothesis there is general agreement that the organic material in some way causes concentration of the uranium derived from a source that is relatively dilute. It is not known whether the organic material concentrates uranium by reduction, ionic adsorption, chemical combination with the organic constituents, or by other related processes.

It should be possible to deduce the origin of the uranium from the size and shape of the deposit, the distribution of uranium within it, and the type of gangue minerals which characterize the deposit. A syngenetic or diagenetic origin should result in a blanket deposit showing no structural control and being relatively uniform and widespread, similar to those in the uraniferous black Chattanooga shale of Devonian and Mississippian age or the black shales and phosphorite of the Phosphoria formation of Permian age. Hydrothermal solutions should be expected to form small local deposits of uranium concentrated near veins or fissures through which the solutions rose and uranium minerals should be associated with gangue minerals and altered wall rock characteristic of hydrothermal mineralization. On the other hand, deposits of epigenetic origin formed by migrating meteoric waters may be large or small, depending on (1) the size of the area and the content of uranium available from the source; (2) the factors that influence the flow of groundwater from the source to the host rock: regional structure, local structure, and the permeability of the rocks; and (3) the organic content of the host rock. They should contain the type of gangue minerals which are deposited by meteoric waters.

Although hydrothermal gold deposits have been found on Caribou Mountain, an igneous intrusion more than 20 miles away, there is no evidence of hydrothermal activity near the Fall Creek coal prospect. The radioactivity of the Bear River formation throughout a widespread area is somewhat suggestive of a syngenetic or diagenetic origin of the uranium accumulations. However, the uranium content of samples from this widespread area is far from being uniform, and some of the samples from the Fall Creek coal prospect contain several times more uranium than that normally found in the Chattanooga shale or Phosphoria formation, which have been mentioned as examples of deposits of syngenetic origin. Also, there is an apparent relation between the grade of the deposit and structure. The top of the zone of sheared coaly shale has the largest content of uranium, and there is an apparent increase in the percent of uranium below prominent cavernous joints and fissures in the overlying bed of lime- 
stone. Where vertical strata were examined and sampled (localities 1 and 39) they were found to contain less uranium than elsewhere. These factors are difficult to explain by a syngenetic or diagenetic origin and are suggestive of an epigenetic origin of the uranium in which the mineralizing solutions were introduced from above. More data are necessary before the structural control of the deposit can be established with certainty.

A definite structural control has been demonstrated in other areas of uraniferous coals and lignites where additional field relationships can be observed that indicate an epigenetic origin by migrating meteoric waters. These areas include those of the uranium-bearing lignite in western North and South Dakota (chapter B), the La Ventana area in Sandoval County, N. Mex. (chapter J), the Red Desert area of Wyoming (chapter G), and the Goose Creek area of southern Idaho (chapter $\mathrm{H})$. From the limited evidence available at the Fall Creek coal prospect and from comparison with other deposits of uraniferous coal and lignite, the epigenetic origin of the uranium from migrating meteoric water seems most plausible in the Fall Creek area.

There still remains the problem of the ultimate source of the uranium which is transported to the deposit by meteoric water. In the Dakota areas of uraniferous lignite the ultimate source is thought to be the tuffaceous sandstones of the White River group of Oligocene age and the Arikaree formation of Miocene age which directly overlie the uraniferous lignite, and in the La Ventana area, New Mexico, the ultimate source is believed to be the Bandelier rhyolite tuff of Smith (1938) of Quaternary age. In the Goose Creek area, Idaho, the source is believed to be the rhyolitic tuffs of the Salt Lake formation of Pliocene age which are interbedded with the lignite. In each example the ultimate source is believed to be a rock of volcanic origin, either a tuffaceous sandstone or a volcanic tuff containing uranium in a highly disseminated form.

A similar potential source for the uranium was present in the Fall Creek area, when the entire area was covered by the silicic volcanic rocks of Miocene or Pliocene age of which only a few small remnants remain, as shown on the geologic map (pl. 51). Samples of these rocks contain 0.002-0.004 percent equivalent uranium and about 0.0012 percent uranium.

Analyses of spring waters issuing from source rocks have helped to demonstrate the leaching action of ground water in other areas. Some spring waters from the White River group in South Dakota and Wyoming contain 40 or more parts per billion of uranium. This compares with considerably less than 1 part per billion for most waters from nontuffaceous rocks that have been tested. No springs could be found in the Fall Creek area issuing directly from the silicic volcanic rocks, but water from a spring at the Fall Creek Ranger 
Station, which is near the trough of a syncline, part of which is overlain by silicic volcanic rocks contained 8 parts uranium per billion.

The origin of the uranium is of considerable economic importance because the approach to be used in physical exploration depends on the interpretation of the size and shape of the occurrence, which in turn is related to the mode of origin. If the uranium is of epigenetic origin, then exploration for ore-grade material should be conducted in areas structurally favorable for the concentration and flow of ground water solutions, such as along synclinal troughs. On the other hand, if it is of syngenetic or diagenetic origin, then the deposit should be relatively uniform over a large area and exploration should be conducted in areas most easily mined.

\section{CORE-DRILLING PROGRAM}

\section{DRILLING OPERATIONS}

Core drilling in the Fall Creek area, Bonneville County, Idaho, was conducted to obtain information about the subsurface areal extent, thickness, and grade of unweathered uranium-bearing carbonaceous rocks. It was hoped that information might also be obtained on the relation between uranium content and the structural position of the uraniferous strata. Drilling was done for the Geological Survey under contract by a private company.

Six core holes were drilled at three different structural settings (fig. 42) to obtain information on the reserves of uranium in three blocks, as follows:

1. Core holes 1 and 2 were drilled on the northeast limb of an anticline in the northern part of sec. 4, T. 1 S., R. $42 \mathrm{E}$.

3. Core holes 3, 3A, and 4 were drilled on the southwest limb of an anticline near the center of the same section.

2. Core hole 5 was drilled on the southwest limb of an anticline at the northeast corner of sec. 8, T. 1 S., R. 42 E.

All holes were planned to test the same sheared stratigraphic zone exposed in the Fall Creek coal prospect.

\section{DESCRIPTION OF CORE HOLES}

The six core holes have a combined total footage of 1,618 feet (figs. 42 and 43 ). The average hole depth was 270 feet, the deepest being 472 and the shallowest, 55 feet.

Core recovery of rocks other than the coaly shale was good, but core recovery of the coaly shale was poor. The structure of the area was much more complex than anticipated, and only one hole reached the uranium-bearing carbonaceous rocks. The other holes did not reach them owing to faulting and to increasing dip of the strata at depth. 


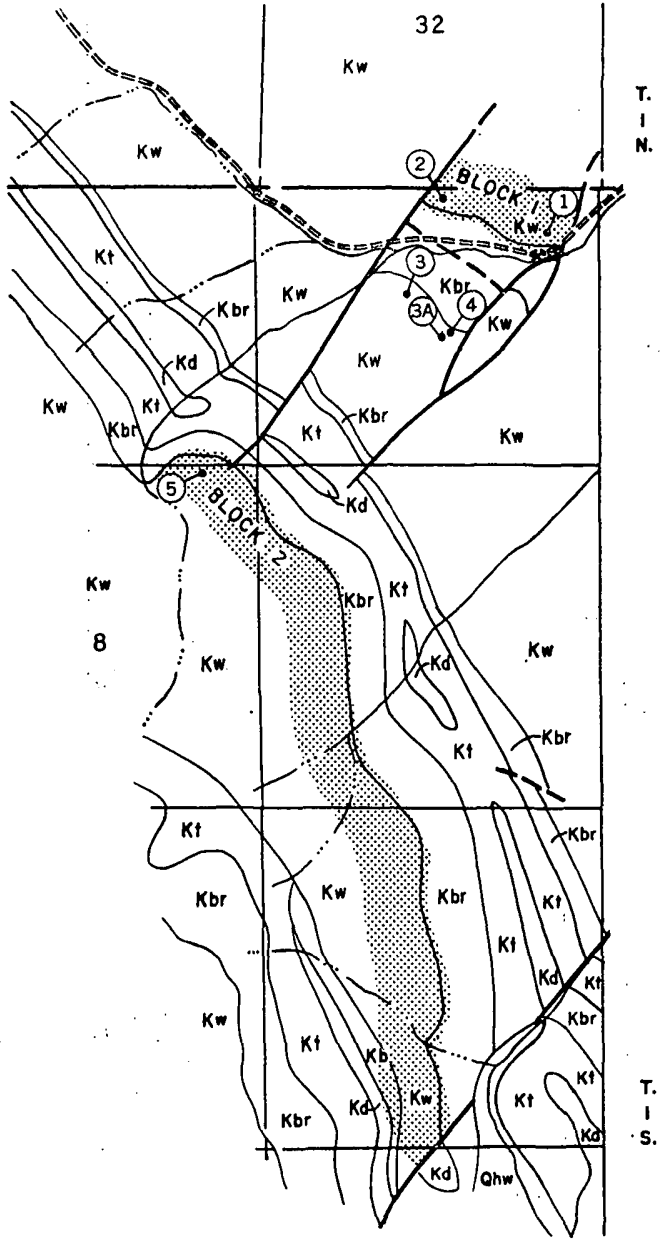

0 I Mile I milo

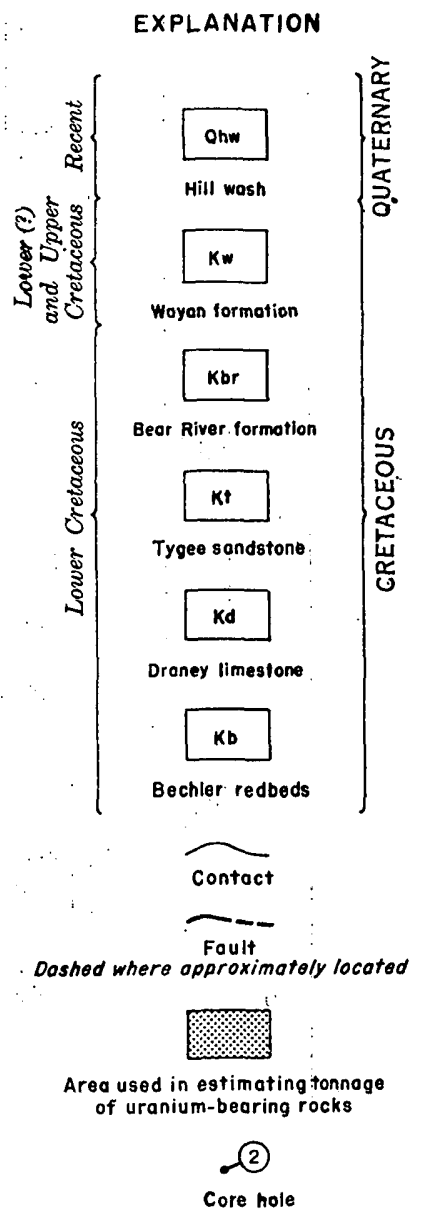

FigdRa 42.- Sketch map of part of Fall Creek area, Bonneville County, Idaho, showing location of core holes and areas underlain by uranlum-bearing rock.

Core hole 1 was drilled to a depth of 293 feet from a location about 300 feet northeast and 60 feet higher than the exposure of uraniumbearing rocks at the Fall Creek coal prospect. A zone of uraniferous limestone and carbonaceous shale is present in the interval penetrated from 264-270.9 feet. Analyses of 8 samples, VI-1300 to VI-1307 (table 6), from this zone ranged from 0.003 to 0.036 percent uranium in the sample. The highest grade sample, VI-1306, with 70.0 percent ash, contained 0.056 percent uranium in the ash. This is the only hole in which the anticipated thickness of uranium-bearing rock was found. 


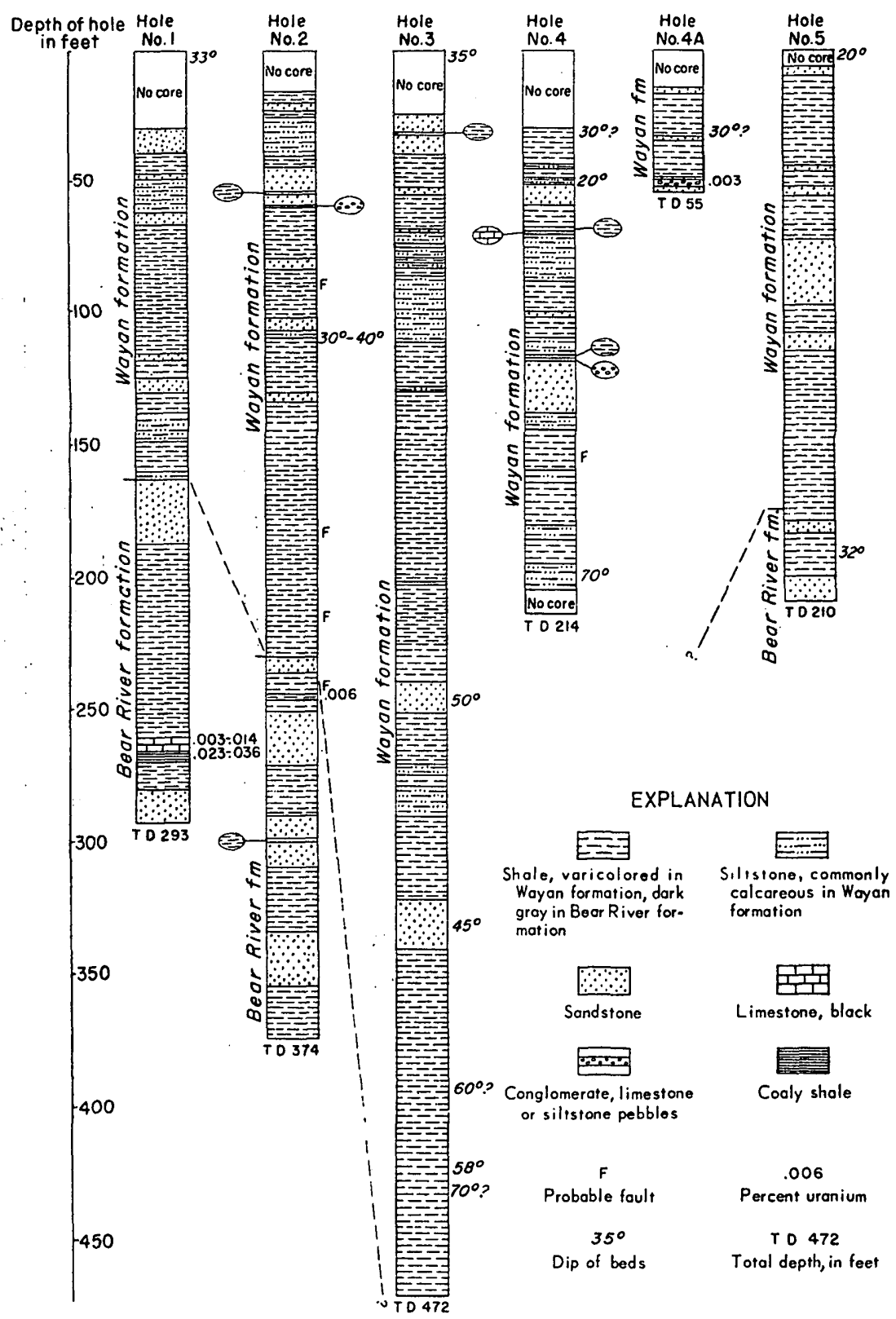

8

FIGURE 43.-Stratigraphic sections of cores from Fall Creek area, Idaho.

Core hole 2 was drilled to a depth of 374 feet from a point about 350 feet northeast and 100 feet higher than the outcrop of uraniferous rock sampled at lncality 9 (pl. 51). If the surface dip of about $35^{\circ}$ had been maintained at depth, the uranium-bearing zone should have been reached at about 345 feet. However, a thin zone of dark-gray 
carbonaceous shale from core-hole depths of 246 to 248 feet analyzed 0.006 percent equivalent uranium (sample VI-1308). Below this zone the core more nearly resembles the carbonaceous, ferruginous siltstone present in the lower two-thirds of the Bear River formation. Therefore, if the thin zone from 246 to 248 feet represents the uraniumbearing zone exposed at the Fall Creek coal prospect, it has apparently been squeezed and deformed because of its proximity to a fault.

Core hole 3 was drilled to a depth of 472 feet from a point about 430 feet southwest and at the same altitude as the outcrop of radioactive soil and limestone sampled at locality 14 . Here too, if the surface dip of about $35^{\circ}$ had been maintained, the uranium-bearing zone should have been reached at a depth of about 295 feet. However, the dip of the rocks, as shown from the core, gradually increased to as much as $70^{\circ}$, and the red shale characteristic of the Wayan formation was present at the bottom of the hole. No reliable estimate can be made as to the depth required to reach the uraniferous zone in the Bear River formation at this locality.

Core hole 4 was drilled to a depth of 214 feet at a point 140 feet south and level with the outcrop of radioactive soil and limestone near carbonaceous-rock-sample locality 15 . Dip readings at the surface in this area range from $20^{\circ}$ to $45^{\circ}$, so the uranium-bearing zone should have been reached at a depth between 50 and 135 feet. Radioactive rock was present at a depth of 53-54 feet, but no core was recovered and below this interval no other radioactivity was detected in the wall rock of red shale characteristic of the Wayan formation. Strata in the core from the bottom of the hole had dips of $70^{\circ}$.

Core hole $4 \mathrm{~A}$ was drilled at a point offset about 3 feet from core hole 4 to a depth of 55 feet to obtain a sample of core from the radioactive rock for which no core was obtained in core hole 4 . At a depth of 51.5-52 feet a uranium-bearing limestone-pebble conglomerate was cored that is similar to beds of limestone-pebble conglomerate observed in outcrops of the Wayan formation.

Core hole 5 was drilled to a depth of 210 feet at a location about 330 feet south and 42 feet below the outcrop of limestone in radioactive soil that is half a mile northwest of carbonaceous-rock-sample locality 24. Dips at the surface near the hole range from $20^{\circ}$ to $22^{\circ}$, so the uranium-bearing zone should have been reached at a depth between 75 and 90 feet. However, dips as much as $32^{\circ}$ were measured on the core. The bottom of the hole was in the Bear River formation, probably within 50 feet of the objective.

\section{TONNAGE OF URANIUM-BEARING ROCK}

Carbonacous rocks containing 0.01 to 0.04 percent uranium are believed to underlie parts of two areas in secs. $4,5,8,9$, and $16, \mathrm{~T} .1 \mathrm{~S}$., $469117-59-21$ 
R. 42 E., and sec. 32, T. 1 N., R. 42 E., Bonneville County, Idaho. These areas are shown in two blocks on figure 42 . The blocks were determined by assuming that the uranium-bearing strata extend 1000 feet down dip from the known outcrop. Block 1, on the northeast, as shown in figure 42, contains 57 acres and was sampled at the Fall Creek coal prospect, at core hole 1 and at surface sample localities $9,10,11$, and 12. Because of the small number and variable quality of the samples from this block, the estimate of amount of uraniumbearing rock in block 1 is considered to be subject to large error. However, because core hole 2, at the northwest end of the block, did not reach the anticipated thickness of uranium-bearing strata, the size of block 1 for the purpose of estimating tonnage of uranium-bearing rock was arbitrarily reduced to 50 acres. Block 2, on the southwest, as shown on figure 42 , is 356 acres in size and was sampled at the surface at sample localities 24,27 , and 28 . Core hole 5 at the northwest end of block 2 did not reach the uranium-bearing strata, but the existence of a block having uranium-bearing rock is not invalidated. However, because of the inadequacy of the surface samples to provide a means of evaluating the thickness and grade of the uranium-bearing strata the estimates of tonnage for block 2 is considerably less reliable than that for block 1 .

Because of the excellent exposure and number of samples collected in the Fall Creek coal prospect, these data alone were considered in estimating the average thickness and grade of the various units used in calculating tonnage for both blocks 1 and 2. The estimates are in error to whatever extent the average thickness and grade throughout blocks 1 and 2 differ from that in the Fall Creek coal prospect.

For these reasons, it is estimated there are about $61 / 2$ million tons of rock containing about 0.02 percent uranium underlying about 400 acres of the Fall Creek area, as shown in table 2.

TABLE 2.-Tonnage estimate of uranium-bearing carbonaceous rock, Fall Creek area, Bonneville County, Idaho

[Block 1 lies on the northeast flants of the anticline north of the Fall Creek coal prospect. Block 2 lies in an outcrop band midway between the Fall Creek coal prospect and Skyline Ridge]

\begin{tabular}{|c|c|c|c|c|c|}
\hline \multirow[t]{2}{*}{ Rock type } & \multirow[t]{2}{*}{$\underset{\text { (feet) }}{\text { Thickness }}$} & \multirow[t]{2}{*}{$\begin{array}{l}\text { Tons per } \\
\text { acre-foot }\end{array}$} & \multirow[t]{2}{*}{$\begin{array}{l}\text { Uranium } \\
\text { (percent) }\end{array}$} & $\begin{array}{c}\text { Block 1 } \\
\text { (50 acres) }\end{array}$ & $\underset{\text { (356 acres) }}{\text { Block 2 }}$ \\
\hline & & & & \multicolumn{2}{|c|}{ Tonnage } \\
\hline $\begin{array}{l}\text { Limestone } \\
\text { Carbonaceous shale } \\
\text { Coaly shale (top) } \\
\text { Coaly shale (base) }\end{array}$ & $\begin{array}{l}1.5 \\
1.5 \\
1.5 \\
3.6\end{array}$ & $\begin{array}{l}3,600 \\
2,600 \\
1,750 \\
1,750\end{array}$ & $\begin{array}{l}0.02 \\
.024 \\
.045 \\
.011\end{array}$ & $\begin{array}{r}270,000 \\
195,000 \\
87,500 \\
262,500\end{array}$ & $\begin{array}{r}1,920,000 \\
1,390,000 \\
623.000 \\
1,870,000\end{array}$ \\
\hline Total & & & & 815,000 & $5,803,000$ \\
\hline
\end{tabular}


TABLE 3.-Analyses of sedimentary rocks in the Fall Creek and adjacent areas, Idaho and Wyoming

All samples are carbonaceous rocks from the Bear River formation except for samples from locality 16 (Wayan formation) and from localittes 23 and 35 (Draney limestone). All locallties are in Bonnevlle County, Idaho, except localities 40 and 41 , which are in Lincoln County, Wyo. Description of sample : the following arbitrary limits of ash content were used : coal, less than 50 percent; coaly shale, 50-80 percent; carbonaceous shale, more than 80 percent. Oranlum: most samples contalning less than 0.004 percent equivalent uranium were not analyzed for uranium.

[Analysts: Maryse Delevaux, Harry Levine, Audry Pietsch, Joseph Budinsky, R. Dufour, W. P. Tucker; Carmen R. Hoy, S. Lundine, B. A. McCall, S. Furman, U.S. Geological Survey.]

\begin{tabular}{|c|c|c|c|c|c|c|c|c|}
\hline \multicolumn{5}{|c|}{ Sample } & \multicolumn{4}{|c|}{ Analyses, in percent } \\
\hline \multirow[b]{2}{*}{$\begin{array}{l}\text { Field } \\
\text { No. }\end{array}$} & \multirow{2}{*}{$\begin{array}{c}\text { Labora- } \\
\text { tory } \\
\text { No. }\end{array}$} & \multirow[b]{2}{*}{ Type } & \multirow[b]{2}{*}{ Material } & \multirow{2}{*}{$\begin{array}{l}\text { Thick- } \\
\text { ness } \\
\text { (in.) }\end{array}$} & \multirow{2}{*}{$\begin{array}{l}\text { Equiv- } \\
\text { alent } \\
\text { ura- } \\
\text { nium }\end{array}$} & \multicolumn{2}{|c|}{ Uranium- } & \multirow[b]{2}{*}{$\begin{array}{l}\text { Ash in } \\
\text { sample }\end{array}$} \\
\hline & & & & & & $\underset{\text { sample }}{\text { In }}$ & $\begin{array}{c}\text { In ash } \\
\text { of } \\
\text { sample }\end{array}$ & \\
\hline
\end{tabular}

LOCALITY 1, BRINSON COAL PROSPECT, SEC. 34, T. 2 N., R. 40 E. (FIG. 39)

\begin{tabular}{|c|c|c|c|c|c|c|c|c|}
\hline VI-1170 & 95499 & Grab.- & Coaly shale. & & 0.001 & & & 70.1 \\
\hline 1171 & D74343 & ......do... & do & 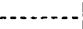 & .003 & 0.0015 & 0.0012 & 74.65 \\
\hline 1172 & D74324 & ..... do & Limestone. & & .003 & .0019 & & \\
\hline
\end{tabular}

LOCALITY 2, SEC. 2, T. 1 N., R. 41 E. (FIG. 39)

\begin{tabular}{|c|c|c|c|c|c|c|c|c|}
\hline $\begin{array}{l}\text { VI- } 1045 \\
\quad 1046\end{array}$ & $\begin{array}{l}87722 \\
87723\end{array}$ & Grab.......... & $\begin{array}{l}\text { Llmestone } \\
\text { Black clay soil }\end{array}$ & - & $\begin{array}{r}0.006 \\
.002\end{array}$ & 0.005 & 0.008 & $\begin{array}{l}59.6 \\
81.6\end{array}$ \\
\hline
\end{tabular}

LOCALITY 3, SEC. 13, T. 1 N., R. 41 E. (FIG. 39)

\begin{tabular}{l|c|c|c|c|c|c|c|c}
\hline VII-1044 & 87721 & Grab......... & Limestone....................... & 0.003 & $\ldots 1.7$ \\
\hline
\end{tabular}

LOCALITY 4, PINE CREEK PASS PROSPECT, SEC. 25, T. 3 N., R. 44 E. (FIG. 39)

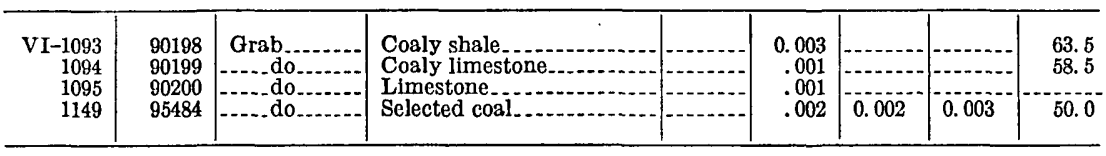

LOCALITY 5, HORSESHOE DISTRICT, SEC. 32, T. 5 N., R. 44 E. (FIG. 39)

\begin{tabular}{|c|c|c|c|c|c|c|c|c|}
\hline $\begin{array}{r}\text { VI-1153 } \\
1154\end{array}$ & $\begin{array}{l}95486 \\
95487\end{array}$ & Grab & $\begin{array}{l}\text { Coal on dump } \\
\text { Fosslis in coal }\end{array}$ & & $\begin{array}{r}0.003 \\
<.001\end{array}$ & 0.003 & 0.009 & $\begin{array}{l}36.2 \\
79.0\end{array}$ \\
\hline
\end{tabular}

LOCALITY 6, SEC. 16, T. 1 N., R. 42 E. (PL. 51)

\begin{tabular}{|c|c|c|c|c|c|c|c|c|}
\hline VI-1043 & 87720 & Grab. & Black clay soil. & & 0.004 & & & 84.4 \\
\hline 1166 & 95495 & Auger.- & .....do do... & 8 & .004 & 0.005 & 0.006 & 84.4 \\
\hline 1167 & 95496 & .....do... & -...-do & 8 & .004 & .003 & .004 & 85.7 \\
\hline 1168 & 95497 & $\therefore$ do. & $\therefore$ do. & 4 & .003 & ...... & 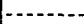 & 86.7 \\
\hline 1169 & 95498 & Channel..... & Limestone & 2 & .003 & & $\ldots$ & 80.8 \\
\hline
\end{tabular}

LOCALITY 7, SEC. 25, T. 1 N., R. 42 E. (PL. 51)

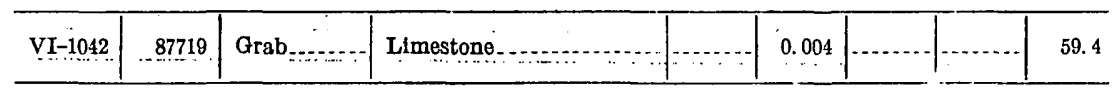


TABLE 3.-Analyses of sedimentary rocks in the Fall Creek and adjacent areas, Idaho and Wyoming-Continued.

\begin{tabular}{c|c|c|c|c|c|c|c|}
\hline & Sample & \multicolumn{2}{c}{ Analyses, in percent } \\
\hline $\begin{array}{c}\text { Field } \\
\text { No. }\end{array}$ & $\begin{array}{c}\text { Labora- } \\
\text { tory } \\
\text { No. }\end{array}$ & Type & Material & & $\begin{array}{c}\text { Thick- } \\
\text { ness } \\
\text { (in.) }\end{array}$ & $\begin{array}{c}\text { Equiv- } \\
\text { alent } \\
\text { ura- } \\
\text { nium }\end{array}$ & Uranium- \\
sample & $\begin{array}{c}\text { In ash } \\
\text { of } \\
\text { sample }\end{array}$ & Ash in \\
sample
\end{tabular}

LOCALITY 8, SEC. 36, T. 1 N., R. 41 E. (PL. 51)

\begin{tabular}{|c|c|c|c|c|c|c|c|}
\hline VI-1080 & 90185 & Grab......... & Limestone & & $<0.001$ & & \\
\hline
\end{tabular}

LOCALITY 9, SEC. 4, T. 1 S., R. 42 E. (PL. 51)

\begin{tabular}{|c|c|c|c|c|c|c|c|c|}
\hline $\begin{array}{r}\text { VI-371 } \\
372 \\
373\end{array}$ & $\begin{array}{l}66858 \\
66859 \\
66860\end{array}$ & $\mid$\begin{tabular}{l} 
Grab \\
\hdashline do
\end{tabular} & $\begin{array}{l}\text { Selected coal on dump } \\
\text { Coaly soil } \\
\text { Black clay soll }\end{array}$ & & $\begin{array}{r}0.066 \\
.021 \\
.002\end{array}$ & $\begin{array}{c}0.08 \\
.016 \\
. .0\end{array}$ & $\begin{array}{l}0.22 \\
.028\end{array}$ & $\begin{array}{l}37.0 \\
58.1\end{array}$ \\
\hline
\end{tabular}

LOCALITX 10, SEC. 4, T. 1 s., R. 42 E. (PL. 51)

\begin{tabular}{|c|c|c|c|c|c|c|c|c|}
\hline $\begin{array}{r}\text { VI-1036 } \\
1033 \\
1034 \\
1035\end{array}$ & $\begin{array}{l}87713 \\
87710 \\
87711 \\
87712\end{array}$ & \begin{tabular}{|c} 
Channel. \\
\\
\hdashline do
\end{tabular} & $\begin{array}{l}\text { Limestone } \\
\text { Coaly shale }\end{array}$ & $\begin{array}{r}18 \\
9 \\
9 \\
17\end{array}$ & $\begin{array}{l}0.013 \\
.008 \\
.011 \\
.010\end{array}$ & $\begin{array}{l}0.010 \\
.006 \\
.011 \\
.008\end{array}$ & $\begin{array}{r}0.017 \\
.009 \\
.014 \\
.011\end{array}$ & $\begin{array}{l}61.5 \\
70.2 \\
75.1 \\
71.2\end{array}$ \\
\hline
\end{tabular}

LOCALITY 11, SEC. 4, T. 1 s., R. 42 E. (PL. 51)

\begin{tabular}{|c|c|c|c|c|c|c|c|c|}
\hline VI-1138 & 90223 & Grab & Limestone. & & 0.008 & 0.007 & & \\
\hline 1134 & 90219 & Channel. & Carbonaceous clay & 6 & .008 & .006 & 0.007 & 83.6 \\
\hline 1135 & 90220 & .....do do.... & do & 6 & .013 & .007 & .009 & 83.3 \\
\hline 1136 & 90221 & ............ & Coaly shale... & 6 & .017 & .015 & .021 & 69.8 \\
\hline 1137 & 90222 & & .....do & 6 & .021 & .015 & .023 & 66.8 \\
\hline
\end{tabular}

LOCALITY 12, SEC. 4, T. 1 S., R. 42 E. (PL. 51)

\begin{tabular}{|c|c|c|c|c|c|c|c|c|}
\hline VI-1133 & 90218 & Grab........... & Limestone .... & (n..... & 0.013 & 0.012 & & \\
\hline 1132 & 90217 & _. do & Coaly shale.. & & .009 & .006 & 0.008 & 74.4 \\
\hline
\end{tabular}

LOCALITY 13, FALL CREEK COAL PROSPECT, SEC. 4, T. 1 S., R. 42 E. (PLS. 51 AND 52)

Samples collected at entry of inclined shaft

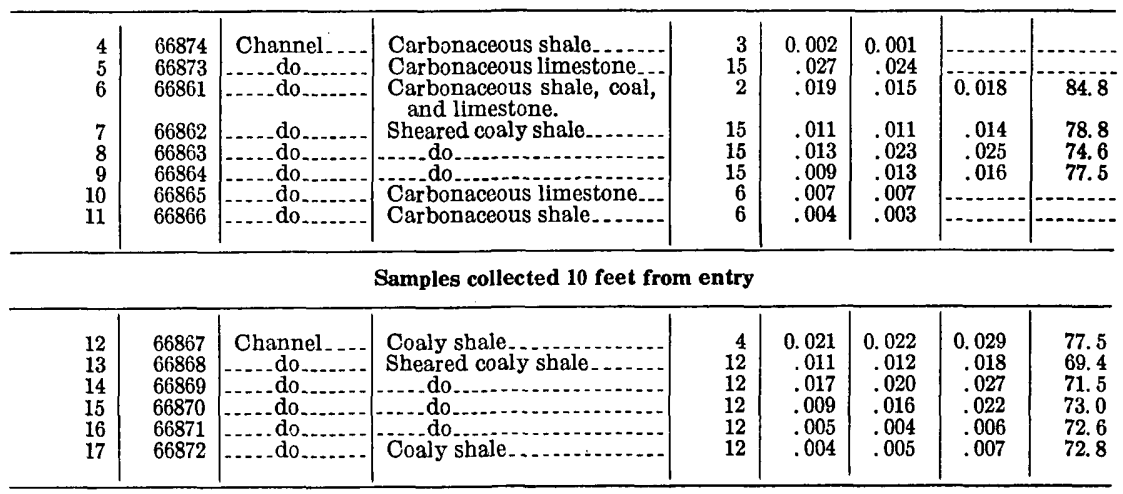


TABLE 3.-Analyses of sedimentary rocks in the Fall Creek and adjacent areas, Idaho and Wyoming-Continued

\begin{tabular}{|c|c|c|c|c|c|c|c|c|}
\hline \multicolumn{5}{|c|}{ Sample } & \multicolumn{4}{|c|}{ Analyses, in percent } \\
\hline \multirow[b]{2}{*}{$\begin{array}{c}\text { Field } \\
\text { No. }\end{array}$} & \multirow{2}{*}{$\begin{array}{c}\text { Labora- } \\
\text { tory } \\
\text { No. }\end{array}$} & \multirow[b]{2}{*}{ Type } & \multirow[b]{2}{*}{ Material } & \multirow{2}{*}{$\begin{array}{l}\text { Thick- } \\
\text { ness } \\
\text { (in.) }\end{array}$} & \multirow{2}{*}{$\begin{array}{l}\text { Equiv- } \\
\text { alent } \\
\text { ura- } \\
\text { nium }\end{array}$} & \multicolumn{2}{|c|}{ Uranium- } & \multirow[b]{2}{*}{$\begin{array}{l}\text { Ash in in } \\
\text { sample }\end{array}$} \\
\hline & & & & & & $\underset{\text { sample }}{\operatorname{In}}$ & $\begin{array}{l}\text { In ash } \\
\text { of } \\
\text { sample }\end{array}$ & \\
\hline
\end{tabular}

LOCALITY 13, FALL CREEK COAL PROSPECT-continued Samples collected 20 feet from entry

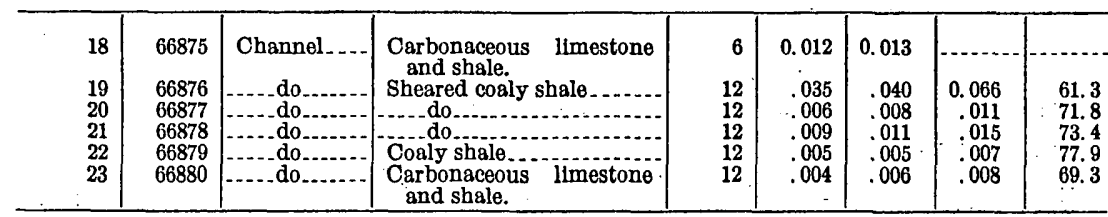

Samples collected 30 feet from entry

\begin{tabular}{|c|c|c|c|c|c|c|c|c|}
\hline $\begin{array}{l}24 \\
25 \\
26 \\
27 \\
28\end{array}$ & $\begin{array}{l}66881 \\
66882 \\
66883 \\
66884 \\
66885\end{array}$ & \begin{tabular}{|} 
Channel. \\
$\ldots$ do \\
$\ldots$ do
\end{tabular} & $\begin{array}{l}\text { Carbonaceous shale..... } \\
\text { Sheared coaly shale. }\end{array}$ & $\begin{array}{l}12 \\
16 \\
16 \\
16 \\
15\end{array}$ & $\begin{array}{l}0.024 \\
.008 \\
.006 \\
.007 \\
.007\end{array}$ & $\begin{array}{r}0.028 \\
.010 \\
.008 \\
.010 \\
.007\end{array}$ & $\begin{array}{r}0.014 \\
.011 \\
.014 \\
.009\end{array}$ & $\begin{array}{l}72.0 \\
68.3 \\
69.7 \\
74.4\end{array}$ \\
\hline
\end{tabular}

Samples collected 40 feet from entry

\begin{tabular}{|c|c|c|c|c|c|c|c|c|}
\hline $\begin{array}{l}29 \\
30\end{array}$ & $\begin{array}{l}66886 \\
66887\end{array}$ & Channel.... & Carbonaceous shale........ & $\begin{array}{r}6 \\
10\end{array}$ & $\begin{array}{r}0.026 \\
.028\end{array}$ & $\begin{array}{r}0.032 \\
.031\end{array}$ & 0.044 & 70.8 \\
\hline $\begin{array}{l}31 \\
32 \\
33 \\
34\end{array}$ & $\begin{array}{l}66888 \\
66889 \\
66890 \\
66891\end{array}$ & \begin{tabular}{|l} 
\\
\\
\hdashline
\end{tabular} & $\begin{array}{l}\text { shale, and coal. } \\
\text { Sheared coaly shale. }\end{array}$ & $\begin{array}{l}16 \\
16 \\
16 \\
16\end{array}$ & $\begin{array}{l}.021 \\
.006 \\
.018 \\
.005\end{array}$ & $\begin{array}{l}.024 \\
.007 \\
.021 \\
.007\end{array}$ & $\begin{array}{l}.033 \\
.010 \\
.030 \\
.009\end{array}$ & $\begin{array}{l}72.3 \\
74.6 \\
71.4 \\
78.2\end{array}$ \\
\hline
\end{tabular}

Samples collected 50 feet from entry

\begin{tabular}{|c|c|c|c|c|c|c|c|c|}
\hline 35 & 66892 & Channel.... & Carbonaceous shale and & 12 & 0.026 & 0.030 & & \\
\hline 36 & 66893 & .....do. & limestone. & 8 & .025 & .027 & & \\
\hline $\begin{array}{l}37 \\
38 \\
39 \\
40\end{array}$ & $\begin{array}{l}66894 \\
66895 \\
66896 \\
67239\end{array}$ & 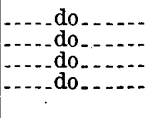 & $\begin{array}{l}\text { Sheared coaly shale } \\
\begin{array}{c}\text { Carbonaceous shale and } \\
\text { coal. }\end{array}\end{array}$ & $\begin{array}{l}15 \\
15 \\
15 \\
12\end{array}$ & $\begin{array}{l}.033 \\
.007 \\
.005 \\
.006\end{array}$ & $\begin{array}{l}.040 \\
.009 \\
.007 \\
.006\end{array}$ & $\begin{array}{r}0.066 \\
.013 \\
.010 \\
.008\end{array}$ & $\begin{array}{l}60.4 \\
66.0 \\
70.8 \\
70.8\end{array}$ \\
\hline
\end{tabular}

Samples collected 60 feet from entry

\begin{tabular}{|c|c|c|c|c|c|c|c|c|}
\hline 41 & 67240 & Channel. & Carboriaceous shäle & 8 & 0.016 & 0.020 & & \\
\hline 42 & 67241 & -...do........ & Carbonaceous limestone & 15 & .018 & $\because 022$ & & \\
\hline $\begin{array}{l}43 \\
44 \\
45 \\
46\end{array}$ & $\begin{array}{l}67242 \\
67243 \\
67244 \\
67245\end{array}$ & 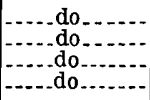 & $\begin{array}{l}\text { Sheared coal } \\
\text { Sheared coaly shale }\end{array}$ & $\begin{array}{l}15 \\
15 \\
15 \\
15\end{array}$ & $\begin{array}{l}.096 \\
.025 \\
.006 \\
.007\end{array}$ & $\begin{array}{l}.131 \\
.029 \\
.008 \\
.007\end{array}$ & $\begin{array}{r}0.300 \\
.044 \\
.010 \\
.009\end{array}$ & $\begin{array}{l}43.7 \\
66.2 \\
75.9 \\
77.4\end{array}$ \\
\hline
\end{tabular}

\section{Samples collected 75 feet from entry}

\begin{tabular}{|c|c|c|c|c|c|c|c|c|}
\hline 47 & 67246 & Channel.... & Carbonaceous shale and & 4 & 0.003 & 0.003 & & \\
\hline $\begin{array}{l}48 \\
49 \\
50 \\
51\end{array}$ & $\begin{array}{l}67247 \\
67248 \\
67249 \\
67250\end{array}$ & 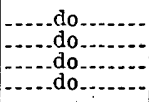 & $\begin{array}{l}\text { Carbonsceous limestone } \\
\text { Sheared coaly shale. }\end{array}$ & $\begin{array}{l}17 \\
13 \\
13 \\
13\end{array}$ & $\begin{array}{l}.010 \\
.064 \\
.007 \\
.008\end{array}$ & $\begin{array}{l}.011 \\
.089 \\
.006 \\
.009\end{array}$ & $\begin{array}{r}0.145 \\
.009 \\
.012\end{array}$ & $\begin{array}{l}58.4 \\
64.9 \\
72.4\end{array}$ \\
\hline
\end{tabular}


TABLE 3.-Analyses of sedimentary rocks in the Fall Creek and adjacent areas, Idaho and Wyoming-Continued

\begin{tabular}{|c|c|c|c|c|c|c|c|c|c|}
\hline \multicolumn{6}{|c|}{ Sample } & \multicolumn{4}{|c|}{ Analyses, in percent } \\
\hline \multirow[b]{2}{*}{$\begin{array}{l}\text { Field } \\
\text { No: }\end{array}$} & \multirow{2}{*}{$\begin{array}{c}\text { Labora- } \\
\text { tory } \\
\text { No. } \\
\vdots\end{array}$} & \multirow{2}{*}{\multicolumn{2}{|c|}{ Туре }} & \multirow[b]{2}{*}{ Material } & \multirow{2}{*}{$\begin{array}{c}\text { Thick } \\
\text { ness } \\
\text { (in.) }\end{array}$} & \multirow{2}{*}{$\begin{array}{l}\text { Equiv- } \\
\text { alent } \\
\text { ura- } \\
\text { nium }\end{array}$} & \multicolumn{2}{|c|}{ Uranium- } & \multirow[b]{2}{*}{$\begin{array}{l}\text { Ash in } \\
\text { sample }\end{array}$} \\
\hline & & & & & & & $\underset{\text { sample }}{\text { In }}$ & $\begin{array}{l}\text { In ash } \\
\text { of } \\
\text { sample }\end{array}$ & \\
\hline
\end{tabular}

LOCALITY 13, FALL CREEK COAL PROSPECT-continued Samples typical of the lithologic unitg represented in and near the Fall Creek coal prospect

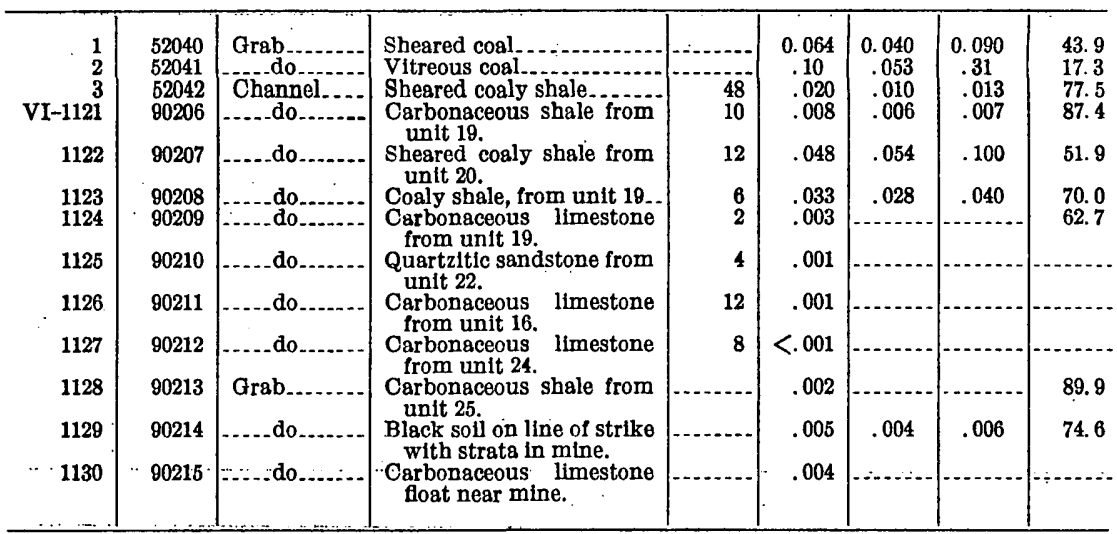

LOCALITY 14, SEC. 4, T. 1 S., R. 42 E. (PL. 51)

\begin{tabular}{|c|c|c|c|c|c|c|c|c|}
\hline VI-1120 & 90205 & Grab......... & Limestone & . & $<0.001$ & & & \\
\hline
\end{tabular}

LOCALITY 15, SEC. 4, T. 1 S., R. 42 E. (PL. 51)

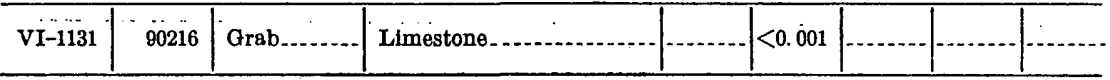

LOCALITY 16, SEC. 3, T. 1 s., R. 42 E. (PL. 51)

\begin{tabular}{l|l|l|l|l|l|l|l|l}
\hline VI-1031 & 87708 & Grab........ & $\begin{array}{l}\text { Fossil bone (Wayan for- } \\
\text { mation). }\end{array}$ & $0 . . . . .16$ & 0.17 & 0.21 & 82.3 \\
\hline
\end{tabular}

LOCALITY 17, SEC. 33, T. 1 N., R. 42 E. (PL. 51)

\begin{tabular}{|c|c|c|c|c|c|c|c|c|}
\hline VI-1075 & 80180 & Grab......... & Limestone & $\ldots$ & 0.001 & & & \\
\hline
\end{tabular}

LOCALITY 18, SEC. 33, T. 1 N., R. 42 E. (PL. 61)

\begin{tabular}{|c|c|c|c|c|c|c|c|c|}
\hline VI-1074 & 80179 & Grab. & Limestone. & & 0.001 & & & \\
\hline 1071 & 88112 & Auger & Gray clay soil. & 10 & .004 & & & 91.5 \\
\hline 1072 & 90117A & -do...... & do do & 16 & .001 & $\cdots$ & $\ldots$ & 88.1 \\
\hline 1073 & 90118 & $\therefore-\therefore d \quad r$ & $\ldots$ do & 16 & .002 & & & 86.2 \\
\hline
\end{tabular}

LOCALITY 10, SEC. 34, T. 1 N., R. 42 E. (PL. 61)

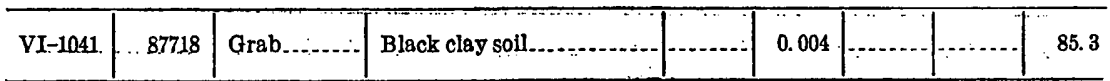

LOCALITY 20, SEC. 34, T. 1 N.; R. 42 E. (PL. 51)

\begin{tabular}{|c|c|c|c|c|c|c|c|c|}
\hline VI-1032 & 87709 & Grab & Limestone & \begin{tabular}{cc}
$\vdots$ & $\cdots$ \\
\hdashline-2 & -
\end{tabular} & 0.006 & 0.004 & 0.007 & 61.1 \\
\hline
\end{tabular}


TABLE 3.-Analyses of sedimentary rocks in the Fall Creek and adjacent areas, Idaho and Wyoming-Continued

\begin{tabular}{|c|c|c|c|c|c|c|c|c|}
\hline \multicolumn{5}{|c|}{ Sample } & \multicolumn{4}{|c|}{ Analyses, in percent } \\
\hline \multirow[b]{2}{*}{$\begin{array}{c}\text { Field } \\
\text { No. }\end{array}$} & \multirow{2}{*}{$\begin{array}{l}\text { Labora- } \\
\text { tory } \\
\text { No. }\end{array}$} & \multirow[b]{2}{*}{ Type } & \multirow[b]{2}{*}{ Material } & \multirow{2}{*}{$\begin{array}{l}\text { Thick- } \\
\text { ness } \\
\text { (in.) }\end{array}$} & \multirow{2}{*}{$\begin{array}{l}\text { Equiv- } \\
\text { alent } \\
\text { ura- } \\
\text { nium }\end{array}$} & \multicolumn{2}{|c|}{ Uranium- } & \multirow[b]{2}{*}{$\begin{array}{l}\text { Ash in } \\
\text { sample }\end{array}$} \\
\hline & & & & & & $\underset{\text { sample }}{\text { In }}$ & $\begin{array}{c}\text { In ash } \\
\text { of } \\
\text { sample }\end{array}$ & \\
\hline
\end{tabular}

LOCALITY 21, SEC. 34, T. 1 N., R. 42 E. (PL. 51)

\begin{tabular}{|c|c|c|c|c|c|c|c|c|}
\hline VI-1040 & 87717 & Grab.......... & Sandy clay soll & & 0.001 & & & .92 .3 \\
\hline \multicolumn{9}{|c|}{ LOCALITY 22, SEC. 2, T. 1 S., R. 42 E. (PL. 51) } \\
\hline $\begin{array}{r}\text { VI-1ก38 } \\
1039\end{array}$ & $\begin{array}{l}87715 \\
87716\end{array}$ & Channel...-. & Black clay soll & $\begin{array}{r}6 \\
\ldots 6\end{array}$ & $\begin{array}{l}0.007 \\
.007\end{array}$ & $\begin{array}{l}0.004 \\
.006\end{array}$ & $\begin{array}{l}0.005 \\
.007\end{array}$ & $\begin{array}{r}86.4 \\
-\quad 86.6\end{array}$ \\
\hline
\end{tabular}

LOCALITY 23, SEC. 7, T. 1 8., R. 12 E. (PL. 51)

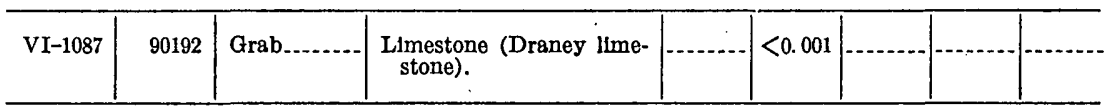

LOCALITY 24, SEC. 9, T. 1 S., R. 42 E. (PL. 51)

\begin{tabular}{|c|c|c|c|c|c|c|c|c|}
\hline VI-1047 & 87724 & Grab. & Limestone & & 0.003 & & & 61.9 \\
\hline 1048 & 88089 & ..... do. & Black clay soll. & & .012 & 0.011 & 0.013 & 84. 6 \\
\hline 1052 & 88093 & .....do.. & {$[\ldots$} & & .010 & .008 & .010 & 83.2 \\
\hline 1049 & 88090 & Auger... & ....... do & 7 & .006 & .004 & .005 & 84.0 \\
\hline 1050 & 88091 & ......do.. & .....do do & 14 & .005 & .003 & .004 & 85.4 \\
\hline 1051 & 88092 & .....do.. & - & 28 & .003 & ......... & $-\cdots$ & 86.3 \\
\hline
\end{tabular}

LOCALITY 26, SEC. 12, T. 1 S., R. 12 E. (PL. 61)

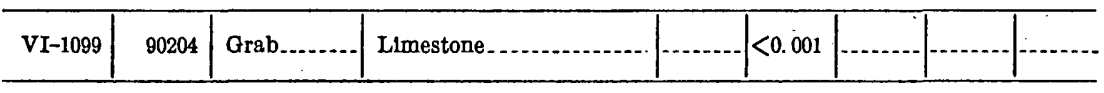

LOCALITY 20, Bnc. 7, T. 1 S., R. 43 E. (PL. 51)

\begin{tabular}{|c|c|c|c|c|c|c|c|c|}
\hline VI-1098 & 90203 & Grab... & Limestone & $\begin{array}{c}\cdot \\
\cdots\end{array}$ & $<0.001$ & (n) & $\cdots$ & $\ldots$ \\
\hline
\end{tabular}

LOCALITY 27, SEC. 16, T. 1 S., R. 42 E. (PL. 51)

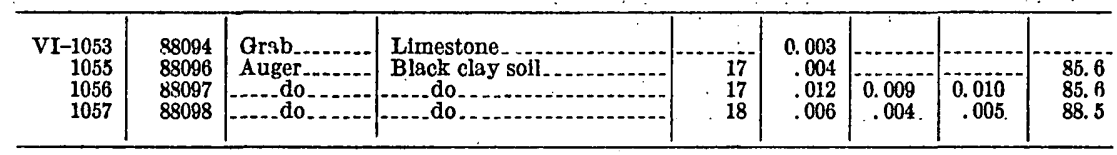

LOCALITY 28, SEC. 16, T. 1 S., R. 42 E. (PL. 51)

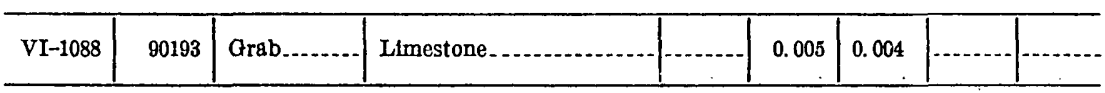

LOCALITY 29, SEC. 22, T. 1 S., R. 42 E. (PL. 61)

\begin{tabular}{|c|c|c|c|c|c|c|c|c|}
\hline $\begin{array}{r}\text { VI-1092 } \\
1091\end{array}$ & $\begin{array}{l}90197 \\
90196\end{array}$ & Grab & $\begin{array}{l}\text { Limestone } \\
\text { Black clay soill }\end{array}$ & $\mid-\ldots-1$ & $\begin{array}{r}0.004 \\
.003\end{array}$ & & & $-\cdots$ \\
\hline
\end{tabular}


TABLE 3.-Analyses of sedimentary rocks in the Fall Creek and adjacent areas, Idaho and Wyoming-Continued.

\begin{tabular}{|c|c|c|c|c|c|c|c|c|}
\hline \multicolumn{5}{|c|}{ Sample } & \multicolumn{4}{|c|}{ Analyses, in percent } \\
\hline \multirow[b]{2}{*}{$\begin{array}{l}\text { Fleld } \\
\text { No. }\end{array}$} & \multirow{2}{*}{$\begin{array}{l}\text { Labora- } \\
\text { tory } \\
\text { No. }\end{array}$} & \multirow[b]{2}{*}{ Type } & \multirow[b]{2}{*}{ Material } & \multirow{2}{*}{$\begin{array}{l}\text { Thick- } \\
\text { ness } \\
\text { (in.) }\end{array}$} & \multirow{2}{*}{$\begin{array}{l}\text { Equiv- } \\
\text { alent } \\
\text { ura- } \\
\text { nium }\end{array}$} & \multicolumn{2}{|c|}{ Uranium- } & \multirow[b]{2}{*}{$\begin{array}{l}\text { Ash in } \\
\text { sample }\end{array}$} \\
\hline & & & & & & $\underset{\text { sample }}{\text { In }}$ & $\begin{array}{l}\text { In ash } \\
\text { of } \\
\text { sample }\end{array}$ & \\
\hline
\end{tabular}

LOCALITY 30, BEC. 27, T. 1 S., R. 42 E. (PL. 51)

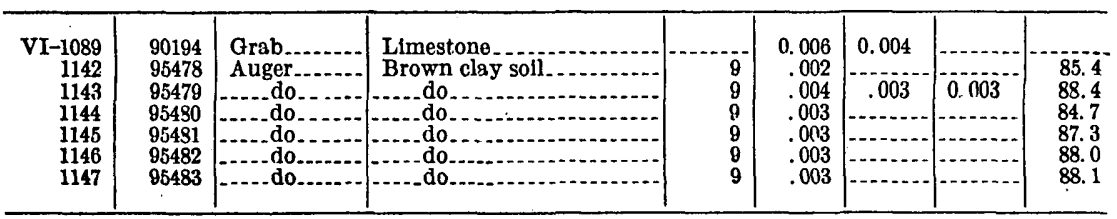

LOCALITY 31, SEC. 23, T. 1 B., R. 42 E. (PL. 51)

\begin{tabular}{|c|c|c|c|c|c|c|c|c|}
\hline VI-1090 & 90195 & Grab.......... & Limestone & & 0.002 & & & \\
\hline
\end{tabular}

LOCALITY 32, SEC. 25, T. 1 S., R. 42 E. (PL. 61)

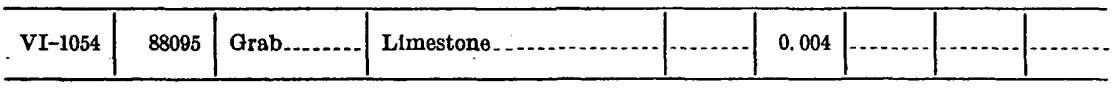

LOCALITY 33, SEC. 1, T. 2 S., R. 42 E. (FIG. 39)

\begin{tabular}{|c|c|c|c|c|c|c|c|c|}
\hline VI-1058 & 88090 & Grab......... & Black soll & $\ldots$ & 0.002 & & & 87.7 \\
\hline
\end{tabular}

LOCALITY 34, SEC. 6, T. 2 S., R. 43 E. (F1G. 39)

\begin{tabular}{|c|c|c|c|c|c|c|c|c|}
\hline VI-1060 & 88101 & Grab. & Limestone. & & 0.004 & & & \\
\hline 1059 & 88100 & Channel. .... & Black clay soll. & 18 & .003 & & & 83.4 \\
\hline 1061 & 88102 & Auger...... & do................ & 8 & .002 & |-- & - n...... & 80.6 \\
\hline 1062 & 88013 & .....do... & do............ & 8 & .002 & & & 80.7 \\
\hline 1063 & 88014 & ...... do.. & Gray clay soll & 8 & .003 & & & 82.7 \\
\hline 1064 & 88015 & & Sandy clay soll. & 8 & .002 & & & 90.0 \\
\hline
\end{tabular}

LOCALITY 35, SEC. 17, T. 2 S., R. 43 E. (FIG. 39)

\begin{tabular}{l|r|c|c|c|c|c|c|}
\hline VI-1065 & 88016 & Grab........ & $\begin{array}{l}\text { Limestone (Draney lime- } \\
\text { stone). }\end{array}$ & $\ldots 0.001$ & $\ldots \ldots \ldots$ \\
\hline
\end{tabular}

LOCALITY 36, SEC. 18, T. 2 S., R. 45 E. (FIG. 39)

\begin{tabular}{|c|c|c|c|c|c|c|c|c|}
\hline $\begin{array}{r}\text { VI-1174 } \\
1173\end{array}$ & $\begin{array}{l}\text { D74326 } \\
\text { D74325 }\end{array}$ & Channel.... & $\begin{array}{l}\text { Limestone } \\
\text { Coaly shale }\end{array}$ & $\begin{array}{l}24 \\
12\end{array}$ & $\begin{array}{r}0.002 \\
.004\end{array}$ & $\begin{array}{r}0.0011 \\
.0033\end{array}$ & 0.0042 & 77.53 \\
\hline
\end{tabular}

LOCALITY 37, CROLEY COAL PROSPECT, SEC. 27, T. 1 S., R. 41 E. (FIG. 39)

\begin{tabular}{|c|c|c|c|c|c|c|c|c|}
\hline $\begin{array}{r}\text { VI- } 1140 \\
1141\end{array}$ & $\begin{array}{l}95476 \\
95477\end{array}$ & Grab....................... & $\begin{array}{l}\text { Selected coal on dump.... } \\
\text { A verage material on coal } \\
\text { dump. }\end{array}$ & & $\begin{array}{r}0.005 \\
.003\end{array}$ & $\begin{array}{r}0.007 \\
.002\end{array}$ & $\begin{array}{r}0.030 \\
.004\end{array}$ & $\begin{array}{l}21.7 \\
48.6\end{array}$ \\
\hline
\end{tabular}

LOCALITY 38, SEC. 23, T. 3 S., R. 43 E. (FIG. 39)

\begin{tabular}{|c|c|c|c|c|c|c|c|c|}
\hline $\begin{array}{r}\text { VI-1066 } \\
1067 \\
1068 \\
1069\end{array}$ & $\begin{array}{l}88107 \\
88108 \\
88109 \\
88110\end{array}$ & 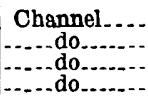 & $\begin{array}{l}\text { Coaly shale } \\
\text { Carbonaceous clay }\end{array}$ & $\begin{array}{l}9 \\
9 \\
9 \\
9\end{array}$ & $\begin{array}{l}0.011 \\
.006 \\
.005 \\
.006\end{array}$ & $\begin{array}{r}0.013 \\
.006 \\
.005 \\
.007\end{array}$ & $\begin{array}{r}0.019 \\
.007 \\
.006 \\
.009\end{array}$ & $\begin{array}{l}69.9 \\
81.6 \\
83.1 \\
79.9\end{array}$ \\
\hline
\end{tabular}


URANTUM DÉPOSITS, FALL ĊREEK AREA, IDAHO 289

TABLE 3-Analyses of sedimentary rocks in the Fall Creek and adjacent areas, Idaho and Wyoming-Continued

\begin{tabular}{|c|c|c|c|c|c|c|c|c|}
\hline \multirow[b]{3}{*}{$\begin{array}{c}\text { Field } \\
\text { No. }\end{array}$} & \multirow{3}{*}{$\begin{array}{c}\text { Labora- } \\
\text { tory } \\
\text { No. }\end{array}$} & \multicolumn{2}{|c|}{ Sample } & ; & \multicolumn{4}{|c|}{ Analyses; in percent } \\
\hline & & \multirow[b]{2}{*}{$\begin{array}{c}\text { Type } \\
\text {. }\end{array}$} & \multirow{2}{*}{ Materfal } & \multirow{2}{*}{$\begin{array}{l}\text { Thick- } \\
\text { !ness } \\
\vdots \text { (in.) } \\
\vdots\end{array}$} & \multirow{2}{*}{$\begin{array}{c}\text { Equiv- } \\
\text { alent } \\
\text { ura- } \\
\text { nium }\end{array}$} & \multicolumn{2}{|c|}{ Uranium- } & \multirow[b]{2}{*}{$\begin{array}{l}\text { Ash in } \\
\text { sample }\end{array}$} \\
\hline & & & & & & $\underset{\text { sample }}{\text { In }}$ & $\begin{array}{l}\text { In ash } \\
\text { of } \\
\text { sample }\end{array}$ & \\
\hline
\end{tabular}

LOCALITY 39, SEC. 24 , T. 3 S., R. 44 E. (FIG. 39)

\begin{tabular}{|c|c|c|c|c|c|c|c|c|}
\hline VI-1070 & 88111 & Channel.... & Carbonaceous shale & 12 & 0.001 & .. & 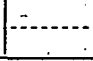 & 82.4 \\
\hline \multicolumn{9}{|c|}{ LOCALITY 40, SEC. 4, T. 37 N., R. 117 W. (FIG. 39) } \\
\hline $\begin{array}{r}V W-1082 \\
1083 \\
1084\end{array}$ & $\begin{array}{l}90187 \\
90188 \\
90189\end{array}$ & $\begin{array}{l}\text { Grab } \\
\text { Channel. }\end{array}$ & $\begin{array}{l}\text { Limestione } \\
\text { Black shale } \\
\text { Conglomerate }\end{array}$ & 12 & $\begin{array}{r}0.003 \\
.001 \\
<.001\end{array}$ & $\mid \cdots$ & (1) & $\begin{array}{r}91.9 \\
85.7\end{array}$ \\
\hline
\end{tabular}

LOCALITY 41, AUBURN COAL PROSPECT, SEC. 5, T. $32 \mathrm{~N}$, R. 119 W. (FÍG. 39)

\begin{tabular}{l|c|c|c|c|c|c|c|c}
\hline $\mathrm{VW}-1.190$ & $D 74342$ & Grab........ & Carbonaceous shale....... & $\ldots . .$. & 0.004 & 0.0035 & 0.0053 & 88.01 \\
\hline
\end{tabular}

TABLE 4.-Analyses of silicic volcanic rocks, Fall Creek and adjacent areas, Idaho: [Analyses by W. Niles, W. Montjoy, R. Dufour and S. Furman, U. S. Geological Survey]

\begin{tabular}{|c|c|c|c|c|c|c|c|}
\hline \multicolumn{3}{|c|}{ Locality } & \multirow{2}{*}{$\begin{array}{l}\text { Field } \\
\text { No. }\end{array}$} & \multirow{2}{*}{$\begin{array}{l}\text { Labora- } \\
\text { tory } \\
\text { No }\end{array}$} & \multirow{2}{*}{ Rock type } & \multirow{2}{*}{$\begin{array}{l}\text { Equiva- } \\
\text { lent } \\
\text { uranilim } \\
\text { (percent) }\end{array}$} & \multirow{2}{*}{$\begin{array}{l}\text { Uranium } \\
\text { in sample } \\
\text { (percent) }\end{array}$} \\
\hline $\begin{array}{l}\text { No. and } \\
\text { map }\end{array}$ & Sec. & $\mathbf{T}$ & & & & & \\
\hline $\begin{array}{l}1 \text { (fig. 39) } \ldots . . \\
2 \text { (fig. 39) } \ldots . \\
3 \text { (fig. 39) } \ldots \\
4 \text { (fig 39) } \ldots \\
5 \text { (fig. 39) } \ldots \\
6 \text { (pl. 51) } \\
7 \text { (pl. 51) } \\
9 \text { (pl. 51) } \\
9 \text { (pl. 51) } \\
10 \text { (pl. 51) } \ldots \\
11 \text { (flg. 39) } \\
12 \text { (fig. 39) }\end{array}$ & $\begin{array}{r}25 \\
19 \\
1 \\
1 \\
25 \\
11 \\
21 \\
30 \\
29 \\
8 \\
29 \\
16 \\
16\end{array}$ & 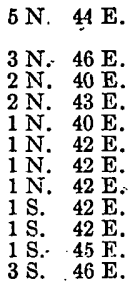 & $\begin{array}{r}\text { VI-367 } \\
368 \mathrm{a} \\
1096 \\
1151 \\
1148 \\
366 \mathrm{a} \\
1030 \\
1037 \\
370 \mathrm{a} \\
1081 \\
1139 \\
369 \mathrm{a} \\
1085 \\
1086\end{array}$ & $\begin{array}{r}66854 \\
\text { D } 84780 \\
\text { D } 84787 \\
\text { D73712 } \\
\text { D73711 } \\
\text { D } 84779 \\
\text { D } 84785 \\
87714 \\
\text { D84782 } \\
\text { D } 84786 \\
90224 \\
\text { D } 84781 \\
90190 \\
90191\end{array}$ & $\begin{array}{l}\text { Vesicular lava } \\
\text { Tuff. } \\
\text { Rhyolite. } \\
\text { Tuff } \\
\text { Pumiceous loess. } \\
\text { Rhyolitic tuff } \\
\text { Obsidian } \\
\text { Rhyolitic tuff. } \\
\text { do do } \\
\text { Tuffaceous sand } \\
\text { Tuffaceous sand } \\
\text { Tuff.... }\end{array}$ & $\begin{array}{l}0.004 \\
.004 \\
.004 \\
.002 \\
.001 \\
.003 \\
.004 \\
.004 \\
.004 \\
.004 \\
.004 \\
.004 \\
.004 \\
.001\end{array}$ & $\begin{array}{r}0.0012 \\
.0010 \\
.0005 \\
.0003 \\
.0007 \\
.0012 \\
.0010 \\
.0012 \\
.0010 \\
\\
\end{array}$ \\
\hline
\end{tabular}


TABLE 5.-Analyses of natural waters, Fall Creek and adjacent areas, Idaho and Wyoming

[Analyses by W. Niles and W. Montjoy, U. S. Geological Survey]

\begin{tabular}{|c|c|c|c|c|c|c|c|}
\hline \multicolumn{4}{|c|}{ Locality } & \multirow{2}{*}{$\begin{array}{l}\text { Fleld } \\
\text { No. }\end{array}$} & \multirow{2}{*}{$\begin{array}{l}\text { Labora- } \\
\text { tory No. }\end{array}$} & \multirow{2}{*}{$\underset{(\mathrm{ppm})}{\text { Uranium }}$} & \multirow{2}{*}{ Description } \\
\hline $\begin{array}{l}\text { No. and } \\
\text { map }\end{array}$ & Sec. & T. & R. & & & & \\
\hline $\begin{array}{l}1 \text { (fig. 39) } \\
2 \text { (fig. 39) }\end{array}$ & $\begin{array}{l}32 \\
31\end{array}$ & $2 \stackrel{2}{2}$ N. & $41 \mathrm{E}$ & $\begin{array}{r}\text { VI-1105 } \\
1104\end{array}$ & $\begin{array}{l}\text { D73708 } \\
\text { D73707 }\end{array}$ & $\begin{array}{r}<0.002 \\
.005\end{array}$ & $\begin{array}{l}\text { Spring at base of silicic volcanic rocks. } \\
\text { Spring in Wayan formation just below }\end{array}$ \\
\hline $\begin{array}{l}3 \text { (fig. 39) } \ldots \\
4 \text { (fig. 39) } \ldots\end{array}$ & $\begin{array}{r}8 \\
28\end{array}$ & $1 \mathrm{~N}$. & $43 \mathrm{E}$ & $\begin{array}{l}1106 \\
1103\end{array}$ & $\begin{array}{l}\text { D73709 } \\
\text { D73706 }\end{array}$ & $<.002$ & $\begin{array}{l}\text { Mineral spring on Fall Creek. } \\
\text { Spring in Wayan formation just below }\end{array}$ \\
\hline $5(\mathrm{pl} .51) \ldots$ & 32 & $1 \mathrm{~N}$. & $42 \mathrm{E}$. & 1101 & D73704 & .003 & $\begin{array}{l}\text { Spring in Wayan formation about } 500 \\
\text { feet below contact with silicic vol- }\end{array}$ \\
\hline $6(\mathrm{pl} .51) \ldots$ & 33 & $1 \mathrm{~N}$. & $42 \mathrm{E}$. & 1102 & D73705 & .008 & $\begin{array}{l}\text { Spring at Fall Creek Ranger Station } \\
\text { along a synclinal axis in the Wayan } \\
\text { formation. A remnant of silicic } \\
\text { volcanic rocks overlies the synclinal } \\
\text { axis about } 136 \text { miles to the northwest. }\end{array}$ \\
\hline 7 (fig. 39) & & $\begin{array}{l}37 \mathrm{~N} . \\
\text { Wyom }\end{array}$ & $117 \mathrm{~W}$. & 1100 & D73703 & $<.002$ & Water from the Snake River. \\
\hline
\end{tabular}

TABLE 6.-Analyses of core samples from Fall Creek area, Idaho

[Analyses by Alice Padgett and B. A. McCall, U. S. Geological Survey]

\begin{tabular}{|c|c|c|c|c|c|c|c|c|}
\hline \multicolumn{4}{|c|}{ Sample } & \multirow{3}{*}{$\begin{array}{l}\text { Depth of } \\
\text { interval } \\
\text { sampled } \\
\text { (feet) }\end{array}$} & \multicolumn{4}{|c|}{ Analyses, in percent } \\
\hline \multirow{2}{*}{$\begin{array}{l}\text { Field } \\
\text { No. }\end{array}$} & \multirow{2}{*}{$\begin{array}{l}\text { Labora- } \\
\text { tory No. }\end{array}$} & \multirow{2}{*}{ Rock type } & \multirow{2}{*}{$\begin{array}{c}\text { Thick- } \\
\text { ness } \\
\text { (feet) }\end{array}$} & & \multirow{2}{*}{$\begin{array}{l}\text { Equiva- } \\
\text { Ient } \\
\text { uranium }\end{array}$} & \multicolumn{2}{|c|}{ Uranium- } & \multirow{2}{*}{$\begin{array}{l}\text { Ash in } \\
\text { sample }\end{array}$} \\
\hline & & & & & & $\operatorname{In}_{\text {sample }}$ & $\begin{array}{c}\text { In ash of } \\
\text { sample }\end{array}$ & \\
\hline \multicolumn{9}{|c|}{ Core hole 1} \\
\hline $\begin{array}{r}\text { VI-1300 } \\
1301 \\
1302 \\
1303 \\
1304 \\
1305 \\
1306 \\
1307\end{array}$ & $\begin{array}{l}113580 \\
113581 \\
113582 \\
113583 \\
113584 \\
113585 \\
113586 \\
113587\end{array}$ & 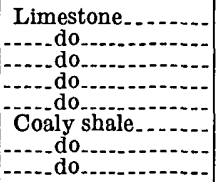 & $\begin{array}{l}0.6 \\
1.0 \\
1.0 \\
1.0 \\
1.0 \\
1.2 \\
.5 \\
1.0\end{array}$ & $\begin{array}{r}261.9-262.5 \\
262.5-263.5 \\
263.5-264.5 \\
264.5-265.5 \\
265.5-266.5 \\
1266.5-267.7 \\
269.0-269.5 \\
269.5-270.5\end{array}$ & $\begin{array}{l}0.003 \\
.003 \\
.003 \\
.007 \\
.013 \\
.020 \\
.025 \\
.023\end{array}$ & $\begin{array}{l}0.003 \\
.004 \\
.003 \\
.007 \\
.014 \\
.028 \\
.039 \\
.028\end{array}$ & $\begin{array}{r}0.036 \\
0.056 \\
.039\end{array}$ & $\begin{array}{r}7.1 \\
70.0 \\
69.0\end{array}$ \\
\hline
\end{tabular}

\begin{tabular}{r|r|r|r|r|r|r|r|r}
\hline VI-1308 & 113588 & $\begin{array}{l}\text { Carbonaceous } \\
\text { shale_. }\end{array}$ & 0.9 & $246.3-247.2$ & 0.006 & \\
\hline
\end{tabular}

1 No core recovered, interval at $267.7-269.0$ feet.

TABLE 7.-Standard sensitivities for the elements determined by the semiquantitative spectrographic method in the U.S. Geological Survey Laboratory, May 1952

\begin{tabular}{|c|c|c|c|c|c|}
\hline Elements & Percent & Elements & Percent & Elements & Percent \\
\hline 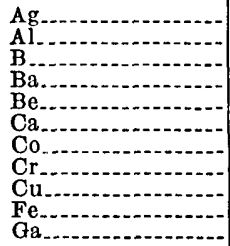 & $\begin{array}{l}0.0001 \\
.001 \\
.005 \\
.0001 \\
.0001 \\
.001 \\
.0005 \\
.0005 \\
.0001 \\
.001 \\
.001\end{array}$ & $\begin{array}{l}\text { Ge } \\
\mathrm{K} \\
\mathrm{La} \\
\mathrm{Mg} \\
\mathrm{Mo} \\
\mathrm{Mn} \\
\mathrm{Na} \\
\mathrm{Nb} \\
\mathrm{N} \mathrm{B}\end{array}$ & $\begin{array}{l}0.0005 \\
1.0 \\
.005 \\
.005 \\
.001 \\
.001 \\
.01 \\
.1 \\
.01\end{array}$ & 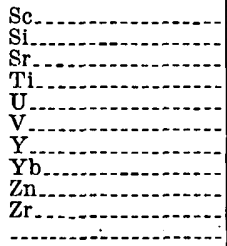 & $\begin{array}{l}0.001 \\
.001 \\
.0005 \\
.001 \\
.05 \\
.001 \\
.001 \\
.0001 \\
.05 \\
.001\end{array}$ \\
\hline
\end{tabular}



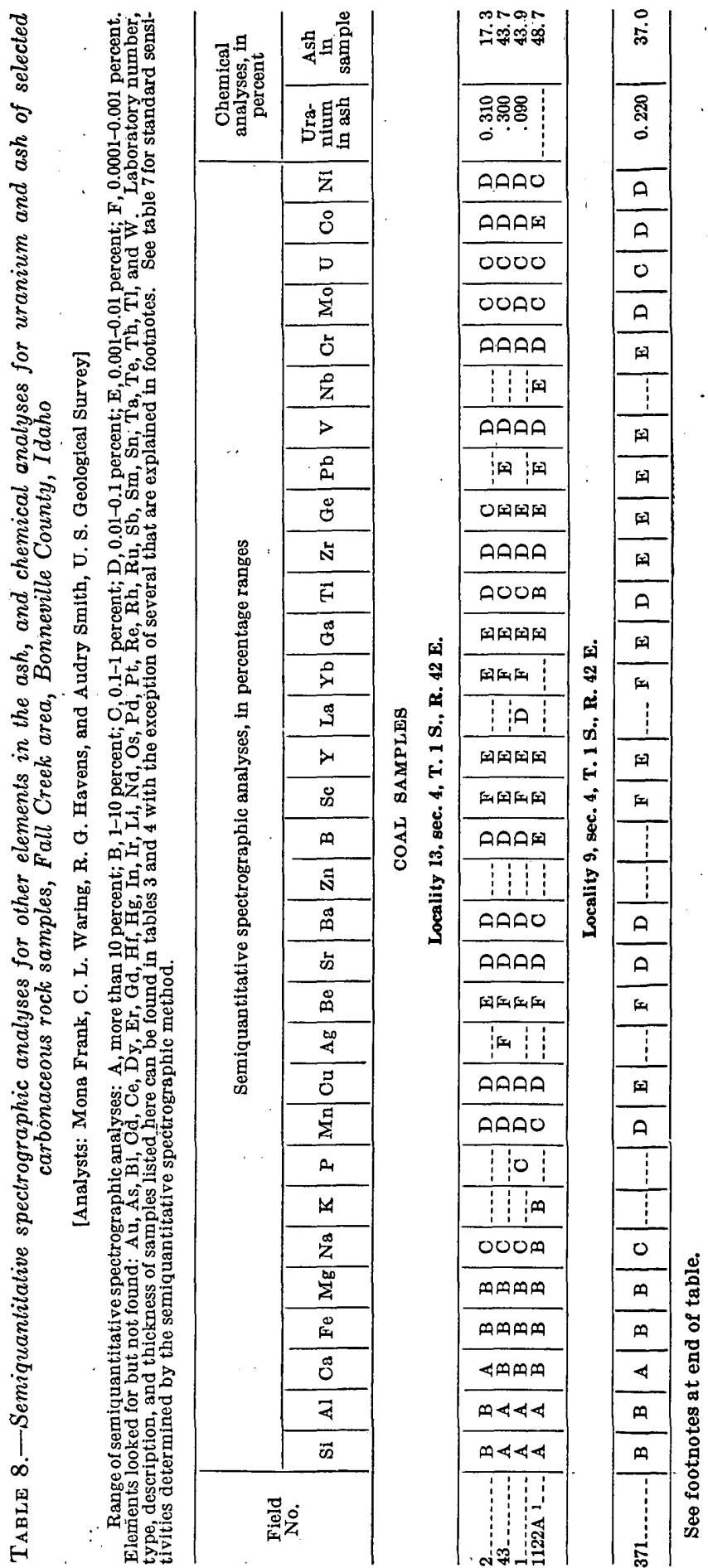


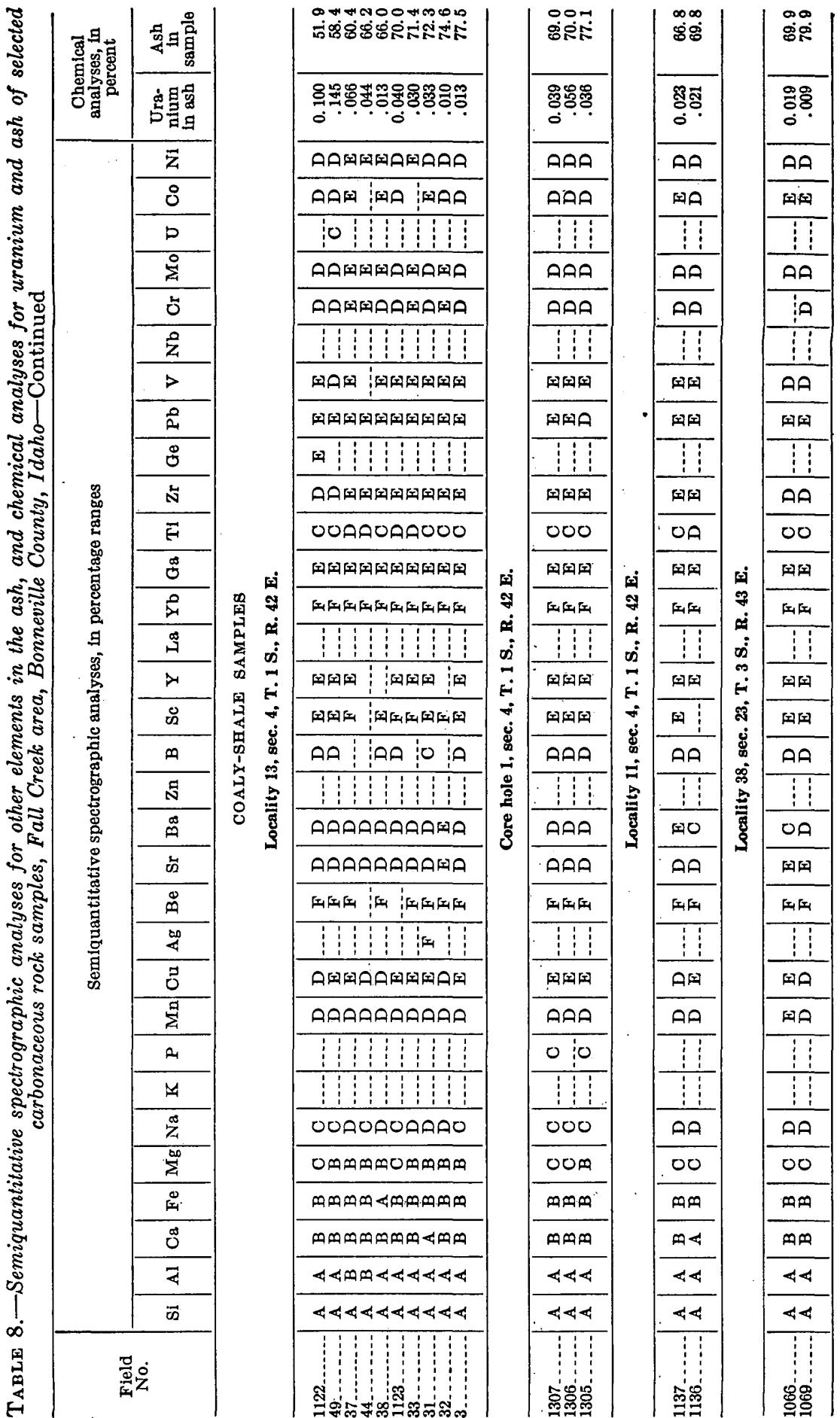


URANIUM DEPOSITS, FALL CREEK IAREA, "IDAHO

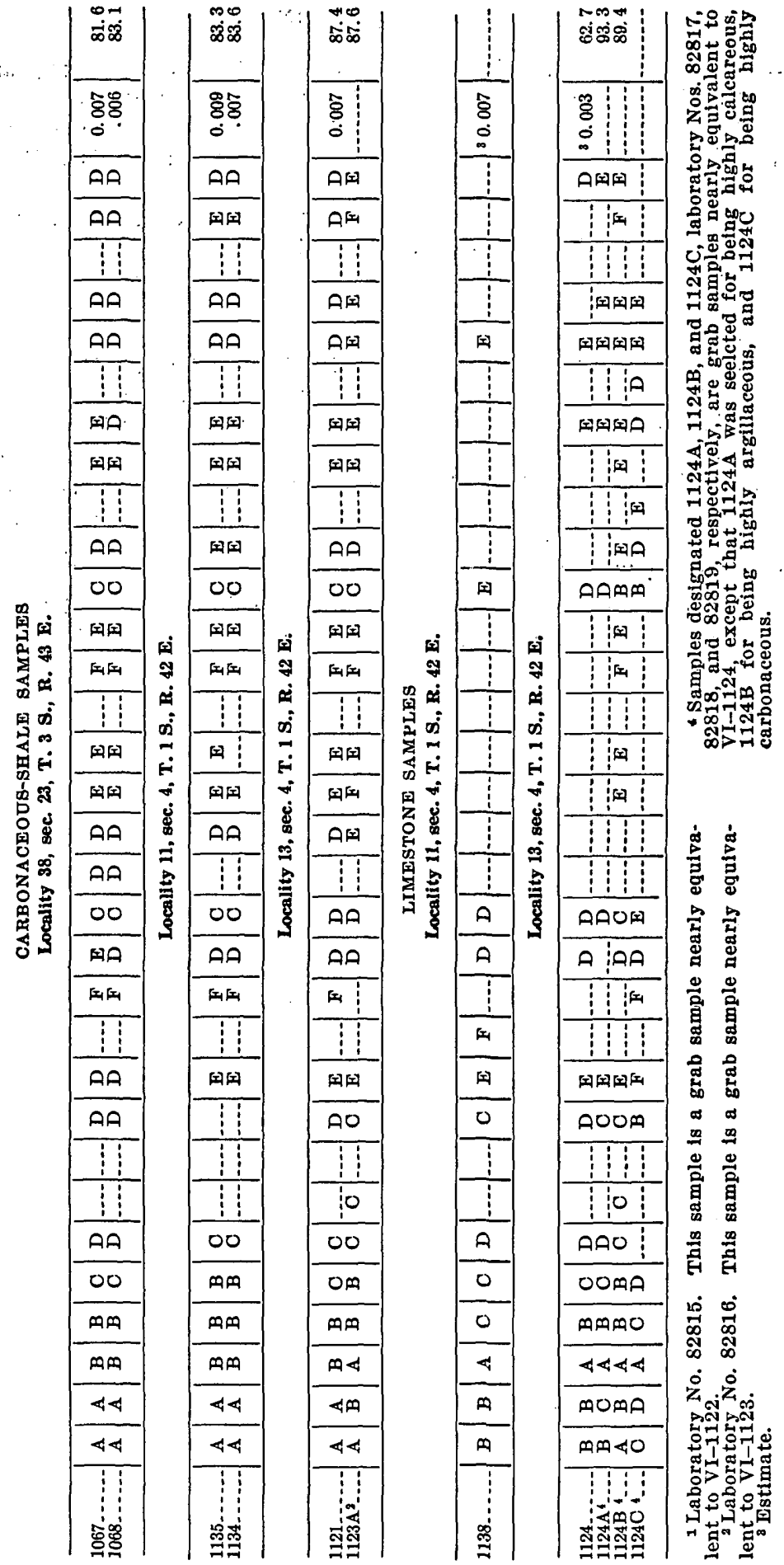




\section{LITERATURE CITED}

Breger, I. A., Deul, Maurice, and Rubinstein, Samuel, 1955, Geochemistry and mineralogy of a uraniferous lignite : Econ. Geology, v. 50, no. 2, p. 220-224.

Cooper, H. M., Snyder, N. H., Abernethy, R. F., Tarpley, E. C., and Swingle, R. J., 1947, Analyses of mine, tipple and delivered samples: U. S. Bur. Mines Tech. Paper 696, p. 38.

Goldschmidt, V. M., 1937, The principles of distribution of chemical elements in minerals and rocks: Chem. Soc. Jour., p. 655-673.

Katchenkov, S. M., 1952, On some general regularities of the accumulation of mineral elements in petroleum and hard coals : Akad. Nauk SSSR Doklady, v. 86, no. 4, p. 805-808, Moscow, 1952.

Kirkham, V. R. D., 1924, Geology and oil possibilities of Bingham, Bonneville, and Caribou Counties, Idaho: Idaho Bur. Mines and Geology Bull. 8.

Mansfield, G. R., 1920, Coal in eastern Idaho: U. S. Geol. Survey Bull. 716-F, p. 123-154.

Ross, C. P., and Forrester, J. S., 1947, Geologic map of Idaho, scale 1: 500,000: published by the U S. Geol. Survey and the Idaho Bur. Mines and Geology.

Smith, H. T. U., 1938, Tertiary geology of the Abiquiu quadrangle, New Mexico: Jour. Geology, v. 46, no. 7, p. 933-965.

Tolmachev, I. M., 1943, Adsorption of uranyl salts on solid adsorbents: Izvestiia Akad. Nauk SSSR, Otd. Khim. Nauk, no. 1, p. 28-34 (U. S. S. R. Acad. Sci. Bull. no. 1, p. 28-34). 


\section{Uranium-Bearing Coal}

and Carbonaceous Shale

\section{in the La Ventana Mesa}

Area, Sandoval County

New Mexico

By GEORGE O. BACHMAN, JAMES D. VINE, CHARLES B. READ, and GEORGE W. MOORE

URANIUM IN COAL IN THE WESTERN UNITED STATES

GEOLOGICAL S URVEY BULLETIN $1055-\mathrm{J}$

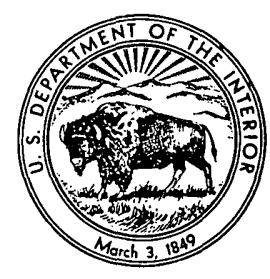





\section{CONTENTS}

$\begin{aligned} \text { Page } & \\ \text { Abstract } & 295\end{aligned}$

Introduction

Purpose and scope of the report

Geography

Fieldwork

Previous investigations._. 296

General geology

Structural setting

Stratigraphy _.._.

Uranium deposits...... 298

La Ventana Mesa.

Hogback area east of La Ventana Mesa....

Area west of La Ventana Mesa....... 300

Structural control _. . .

Stratigraphic control

Origin

Tonnage and grade of the deposits.... 304

Literature cited... 307

\section{ILLUSTRATIONS}

[Plates 53, 55, and 57 are in box]]

Plate 53. Geologic and structure-contour map of the region surrounding La Ventana Mesa.

54. View of La Ventana Mesa.

55. Geologic map of La Ventana Mesa area.

56. North butte of La Ventana Mesa ............. Follows 302

57. Stratigraphic sections of uranium-bearing zone, La Ventana Mesa.

58. Uranium-bearing zone showing minor structures and concentration of uranium: $A$, Tent-shaped thickening of beds; $B$, Minor syncline below sandstone body _._- Follows 302

59. Weathered outcrop of 3 -foot bed of uranium-bearing coal.

Figure 44. Variation of uranium content in coal bed......... 2

\section{TABLES}

TABLE 1. Analyses of samples from the La Ventana Mesa area........

2. Tonnage and grade of uranium-bearing material 1 foot or more thick and containing 0.1 percent or more uranium.....-

3. Tonnage and grade of uranium-bearing material 1 foot or more thick and containing 0.01-0.1 percent uranium......... 

URANIUM IN COAL IN THE WESTERN UNITED STATES

\section{URANIUM-BEARING COAL AND GARBONACEOUS SHALE IN THE LA VENTANA MESA AREA, SANDOVAL COUNTY, NEW MEXICO}

By George O. Bachman, James D. Vine, Charles B. Read, and GeORge W. MOORE

\section{ABSTRACT}

Uranium-bearing coal, carbonaceous shale, and carbonaceous sandstone of Late Cretaceous age occur on and adjacent to La Ventana Mesa, Sandoval County, N. Mex. The uranium is present in three lenticular beds forming a mineralized zone several feet thick at the base of the La Ventana tongue of the Cliff House sandstone. An epigenetic origin for the uranium from groundwater solutions that ultimately derived the uranium from the Pleistocene Bandelier rhyolite tuff of Smith (1938) is suggested. The content of uranium in the coal is as much as 0.62 percent and in the coal ash is as much as 1.34 percent. It is estimated that 132,000 tons of coal and carbonaceous shale containing an average of 0.10 percent uranium are present on La Ventana Mesa.

\section{INTRODUCTION}

\section{PURPOSE AND SCOPE OF THE REPORT}

Uranium in coal, carbonaceous shale, and carbonaceous sandstone was discovered on La Ventana Mesa, Sandoval County, N. Mex., during the summer of 1951. The area has since been carefully mapped, 125 samples have been collected and analyzed for uranium, and it is now possible to describe and evaluate the deposits in some detail. This report describes the occurrances and discusses the possible source of uranium and its deposition in coal.

\section{GEOGRAPHY}

La Ventana Mesa is 1 mile east of La Ventana, N. Mex., on State. Route 44, between Cuba and San Ysidro, and about 65 miles northwest of Albuquerque, N. Mex. (pl. 53). It is 151 miles by primary road from Durango, Colo., and approximately 115 miles from Grants, N. Mex.

La Ventana Mesa culminates in a north and a south butte, located in secs. $28,29,32,33$, and 34 , T. 19 N., R. 1 W., on the west side of the 
Nacimiento Mountains. The north butte ranges in altitude from 7,200 to 7,400 feet above sea level, and the south butte, from 7,400 to 8,000 feet. As the highway adjacent to La Ventana is about 6,000 feet above sea level, the topographic relief of the area is approximately 2,000 feet. The surface of the mesa is a relatively broad area of gentle relief (pl. 54).

The climate of the area is semiarid and the lowest areas are only sparsely vegetated. Juniper forests grow in the intermediate uplands and forests of yellow pine in the mountains. The entire area is drained by the Rio Puerco, which has an intermittent flow. Potable water is available at Cuba, about 12 miles to the north, and at Warm Springs, about 12 miles south of the mesa.

\section{FIELDWORK}

Fieldwork was done during the summer and fall of 1951. One hundred and eight samples for analysis were collected from 70 localities along the outcrop of the uranium-bearing zone around the periphery of the two buttes, and 17 samples were collected from 7 localities in the hogback area to the east and the area west of the mesa, many at natural exposures, others at localities where excavation was necessary. Geologic mapping was done on aerial photographs at a scale of about $1: 36,000$ and, where greater detail was needed, on enlargements at a scale of about 1:9,600. The geologic data were transferred to a topographic map at a scale of $1: 12,000$ that was compiled from aerial photographs with vertical and horizontal control established by plane table mapping.

\section{PREVIOUS INVESTIGATIONS}

The area described herein has been studied and mapped previously in connection with investigations of the water resources (Renick, 1931); the coal resources (Dane, 1936); and the potential oil and gas resources (Wood and Northrop, 1946, fig. 1).

\section{GENERAL GEOLOGY}

\section{STRUCTURAL SETTING}

The most prominent topographic and geologic feature in the area is the Nacimiento Mountains, a high mountainous area of Precambrian rocks, which is 2 to 3 miles east of La Ventana Mesa (pl. 53). The west flank of the Nacimiento Mountains is characterized by hogbacks of steeply dipping Paleozoic and Mesozoic strata. Beneath La Ventana Mesa, however, the rocks dip gently towards the San Juan Basin to the west. The mesa lies along the axis of a broad syncline, plunging gently to the northwest (pl. 53) and called the La Ventana syncline in this report. 


\section{STRATIGRAPHY}

The sequence of sedimentary strata exposed in the area is shown in the following chart (adapted from Dane, 1936, p. 92-108; and Beaumont, Dane, and Sears, 1956).

\begin{tabular}{|c|c|c|c|}
\hline System & \multicolumn{2}{|c|}{ Geologic units } & $\begin{array}{c}\text { Thickness } \\
\text { (feet) }\end{array}$ \\
\hline \multirow[b]{3}{*}{ Cretaceous - } & Lewis shale_....... & & $80-1,600$ \\
\hline & \multirow{3}{*}{ Mesaverde group...- } & $\left\{\begin{array}{r}\text { La Ventana tongue of } \\
\text { Cliff House sandstone:- }\end{array}\right.$ & $60-80$ \\
\hline & & $\left\{\begin{array}{c}\text { Allison member and } \\
\text { Cleary coal member of } \\
\text { Menefee formation }\end{array}\right.$ & 640 \\
\hline \multirow[t]{3}{*}{. } & & Point Lookout sandstone & 100 \\
\hline & Mancos shale...... & $-1--1-1-1-1$ & 2,000 \\
\hline & Dakota sandstone & 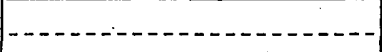 & 200 \\
\hline $\begin{array}{l}\text { Jurassic and } \\
\text { older rocks. }\end{array}$ & $\begin{array}{l}\text { Morrison and older } \\
\text { : formations. }\end{array}$ & - & \\
\hline
\end{tabular}

Of these, the strata of importance for the purpose of this report are those of the Mesaverde group and the Dakota sandstone. Following the revised nomenclature of Beaumont, Dane, and Sears (1956), the Mesaverde group is divisible into three units, in ascending order: the Point Lookout sandstone, the Menefee formation, and the: La Ventana tongue of the Cliff House sandstone. The Point Lookout sandstone, 100 feet or more in thickness, consists chiefly of pale-yellow to brown sandstone interbedded with one or more thin beds of carbonaceous shale or coal. It is difficult to distinguish the Cleary coal member and the Allison member of the Menefee formation (Beaumont, Dane, and Sears, 1956) in this area and they are not differentiated on the geologic map.: The Menefee consists of about 640 feet of lenticular sandstone, clay, carbonaceous shale, and many coal beds: The geologic map of the La Ventana area (pl. 55) shows a contact drawn on the top of a locally prominent sandstone about 250 feet: below the base of the La Ventana tongue of the Cliff House sand-: stone. This contact divides the Menefee into two parts, which in this report are referred to as the upper and lower parts of the Menefee: formation: The La Ventana tongue consists of about $60-80$ feet of light-yellow to brown, cliff-forming sandstone which contains shark's' teeth and is of marine origin. It forms the resistant caprock at the top of La Ventana Mesa (pl.56). 


\section{URANIUM DEPOSITS}

Uranium occurs in coal, carbonaceous shale, and carbonaceous sandstone in the La Ventana area. The principal deposit is just below the La Ventana tongue of the Cliff House sandstone on La Ventana Mesa. Minor deposits are present in the Point Lookout sandstone and the Dakota sandstone in the hogback area east of La Ventana Mesa, and at the base of the La Ventana tongue in the area west of La Ventana Mesa.

\section{LA VENTANA MESA}

Uranium occurs erratically within a zone several feet thick immediately below the base of the cliff-forming La Ventana tongue of the Cliff House sandstone near the top of La Ventana Mesa (pls. 55 and 57): The uranium-bearing zone of strata includes three beds: an upper bed, 6 inches to 6 feet thick, of friable gray sandstone containing fragments of carbonaceous debris, silt, and shale (fig. 44 and pl. 58A); a middle bed, 2 inches to 4 feet thick, of coal and impure coal; and a lower bed, as much as 10 feet thick, of carbonaceous shale. The upper bed, friable sandstone, contains as much as 0.065 percent uranium; the middle bed, coal and impure coal, contains as much as 0.62 percent uranium and with as much as 1.34 percent uranium in the ash; and the upper part of the lower bed, carbonaceous shale, as much as 0.062 percent uranium. These three beds are somewhat lenticular and not always distinct. Locally, the upper bed interfingers with the overlying more indurated La Ventana tongue. Both the middle and upper beds pinch out to the southeast and are absent on the southeastern part of the south butte. The uranium-bearing zone varies greatly even in relatively short horizontal distances. At locality 59, shown in detail in figure 44 , the uranium content of the impure-coal bed ranges from 0.005 to 0.3 percent within less than 50 feet. Elsewhere, exposures are inadequate to determine the variability in such detail. There is also considerable variation vertically. The greatest concentration of uranium is confined to the stratigraphically highest bed of coal or carbonaceous material, which is the middle bed, of impure coal, at the base of the La Ventana tongue on $\mathrm{La}$ Ventana Mesa. Stratigraphically lower coal beds are essentially barren of uranium as is shown by a sample collected from an abandoned coal mine, locality 71 (pl. 55), near the base of La Ventana Mesa. Locally, within the uranium-bearing impure-coal bed the uranium content is in inverse ratio to the ash content of the coal. For example; in an exposure of 3 feet of coal at locality 4 (pl. 59), the uppermost foot of impure coal has an ash content of 59 percent and contains 0.065 percent uranium; the middle foot of coal has an ash content of 39 percent and contains 0.16 percent uranium; whereas the lowest foot of coal and bone has an ash content of 50 percent and contains 0.08 percent uranium. 


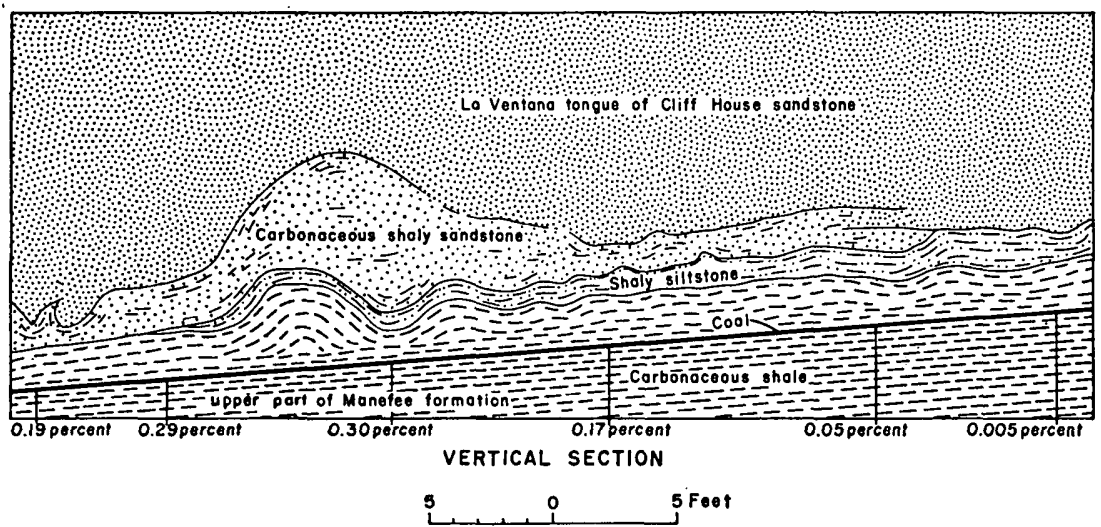

Fraurg 44.-Variation of uranium content in a coal bed below a minor structure.

Areas of greater than average uranium content are present on both the north and south buttes. The largest of such areas is on the southwest and west sides of the north butte. The next largest area is on the westernmost tip of the south butte, and several small localities, though east of the westernmost tip of the south butte, that are on the narrow segment of the butte that extends west from its main area. The area on the west side of the north butte represents the most favorable area for production of uranium, for the west end of the north butte is underlain by 1-4 feet of mineralized coal, whereas the maximum thickness of mineralized coal on the south butte is only 6 inches and the average is only about 3 inches.

\section{HOGBACK AREA EAST OF LA VENTANA MESA}

In the hogback area, uranium-bearing shale beds occur in the Dakota sandstone at San Miguel Mine Canyon (locality 76 pl. 53) and Arroyo Dedos Gordos (locality 78). According to Renick (1931, p. 35-36), the Dakota sandstone at San Miguel Mine Canyon is approximately 188 feet thick and is divisible into three units, two of

Sandstone, fine- to medium-grained; carbonaceous material

Mancos shale (not measured).

Dakota sandstone:

ft $\quad$ in

Sandstone, fine-to medium-grained; carbonaceous material (wood fragments) disseminated throughout; contains streaks of carbonaceous sandstone; massive at base, medium- to thin-bedded at top

Carbonaceous shale, sandy shale and shaly carbonaceous sandstone; most concealed

Sandstone, massive; thin layers of grit, conglomerate coal, carbonaceous sandstone, and shale

Total

$188 \quad \dot{2}$

Morrison formation (not measured). 
A 6-inch bed of carbonaceous shale in the upper part of the lower sandstone unit at San Miguel Mine Canyon contains 0.02 percent uranium. Uranium is also present in less persistent lenses of carbonaceous material in this part of the unit. One associated small lens of impure coal contains 0.088 percent uranium, and 0.10 percent uranium is present in the ash. Interbedded sandstone that contains fragments of carbon contains 0.004 percent uranium.

In Arroyo Dedos Gordos, about 51/2 miles south of San Miguel Mine Canyon, the section of the Dakota sandstone is similar in character to the section just described. A bed of radioactive carbonaceous shale 18 inches thick occurs. near the base of the middle unit. The equivalent-uranium content of the carbonaceous shale is 0.007 percent but the uranium content is only 0.002 percent. The Dakota sandstone has been examined in the other water gap canyons in the hogbacks between San Miguel Mine Canyon and Arroyo Dedos Gordos, but no radioactivity has been detected. This suggests that the uranium deposits in the Dakota sandstone east of La Ventana Mesa are not continuous, but future prospecting in the Dakota sandstone should not be discouraged because, at present, the data are inadequate to permit appraisal of the possibilities of this outcrop belt.

Three uranium-bearing zones, each about 1 foot in thickness and consisting of carbonaceous shale, are present east of La Ventana Meșa in a hogback formed by the Point Lookout sandstone (locality 77). These zones have an average uranium content of about 0.05 percent and each underlies a bed of permeable sandstone.

\section{AREA WEST OF LA VENTANA MESA}

West of New Mexico State Route 44 the La Ventana tongue of the Cliff House sandstone forms a prominent escarpment for several miles north and south of La Ventana. The strata in this escarpment have been examined at many. localities, but the uranium content is negligible. Several samples were collected from coal and natural coal ash which occurs at the base of the La Ventana tongue north and northwest of La Ventana. The location of these samples is shown on plate 53. The greatest uranium content is 0.009 percent, which occurs in a natural coal ash at locality 74 , north of La Ventana. . The other samples average about 0.003 percent uranium.

\section{STRUCTURAL CONTROI}

The two largest deposits of uranium-bearing material on La Ventana Mesa are near the axis of the La Ventana syncline (pl. 53). This suggests that movement of uranium-bearing solutions may have been concentrated along the axis of the syncline.

The relationship of structural features to concentrations of uranium suggests they have played an important part in localizing min- 
eralization. Three types of minor structural features on La Ventana Mesa that show close relationships with the uranium deposits are:

1. Tent-shaped thickening of beds in the upper part of the unit of the undifferentiated Menefee formation below the La Ventana tongue of the Cliff House sandstone (fig. 44 and pl. 58A).

2. Minor synclines in the uranium-bearing zone (pl. $58 B$ ).

3. Joints in the La.Ventana tongue directly above the uraniumbearing zone.

Tent-shaped thickening of beds in the uranium-bearing zone is common. These structures are probably the result of plastic deformation and are caused by the overload of the more competent La Ventana tongue. The tent-shaped beds are best exposed on the south butte, where they are usually associated with prominent joints in the overlying La Ventana tongue and with the greatest concentrations of uranium. In a similar structural feature (fig. 44) the carbonaceous sandstone that overlies the coal thickens from an average of about 1 foot to about 6 feet. The uranium content of the coal increases correspondingly from 0.005 percent to 0.3 percent along a 50 -foot exposure. The mechanism for the structural control is not known, but it appears that minor structures have controlled the movement of the mineralizing solutions.

The second type of structural feature is due to a lens of indurated sand above the coal, which has caused the uranium-bearing zone to be compressed into a minor syncline (pl. $58 B)$. : The greatest concentration of uranium is in the trough of the syncline.

The third type of minor structural feature that seems to have influenced mineralization is the joint system commonly present in the La Ventana tongue of the Cliff House sandstone. For example, at locality 8 (pl. 55) a joint contains a deposit of uranium-bearing opal. The uranium content of the coal bed downdip from the intersection of the joint with the coal bed averages 0.3 percent; updip from the joint it averages 0.047 percent uranium. This relationship suggests that the uranium-bearing solutions which deposited the siliceous material in the joint entered the coal bed along the joint and percolated downdip from it. On the other hand, the La Ventana tongue has such a high permeability that joints, although possibly important in localizing mineralization at some places, may be insignificant in others. :

The configuration of the base of the La Ventana tongue may be a significant factor in concentrating or localizing the uranium, but at present, data are inadequate to evaluate its importance.

\section{STRATIGRAPHIC CONTROL}

Two stratigraphic features appear to be important in the concentration of uranium in La Ventana area. All major concentrations' of

$469117-59-1$ 
uranium observed are in, or adjacent to, beds of carbonaceous sediments or porous sandstone.

The physical and chemical conditions which account for the concentration of uranium in carbonaceous material are poorly understood. Likewise, little is known of the nature of the uranium compounds that occur in carbonaceous material. However, the association of uranium with fossil wood in carnotite deposits has long been established (Boutwell, 1904, p. 200). The occurrence of uranium in lignite, cóal, and similar carbonaceous sediments has been reported in widespread areas.

Though no uranium minerals are visible in coal from La Ventana Mesa, J. W. Gruner (oral communication) has reported the presence of coffinite, a uranium silicate of undetermined chemical composition.

Adsorption of uranium by carbonaceous material is the most plausible' explanation' known by the writers for the association of uranium with carbon as found in nature. Tolmachev (1943) demonstrated in the laboratory that activated charcoal and carbonaceous shale remove uranium from a uranyl nitrate solution. Experiments performed by G. W. Moore (1954) demonstrate that coal also will remove uranium from solution.

The writers made autoradiographs of both polished sections and thin sections of the uranium-bearing coal in an attempt to determine the nature of the mineralization. Autoradiographs of polished sections of the coal demonstrate that the most intense radioactivity is associated with fractures and joints in the coal. Less intenise radioactivity is found in certain layers parallel with the bedding planes: These layers, which are faintly visible bands on the polished sections, are brown and may represent clay or shale partings stained brown by humic colloids. The radioactivity associated with these bands could be due to greater adsorbency of the material but is probably due to greater permeability along the band. A faint gray fog on the film over the entire area covered by the coal specimen indicates mild radioactivity uniformly distributed throughout the specimen. Autoradiographs of thin sections of the coal examined under high magnification demonstrate that most of the radioactivity is from opaque constituents in the coal.

These studies indicate that the uranium is in close association with carbonaceous material, that uranium-bearing solutions entered the coal along fractures and joints in the coal, and that certain constituents of the coal are better adsorbents of uranium than others.

The close association of the uranium deposits in the La Ventana area with beds of permeable sandstone suggests that the sandstone beds have served as aquifers through which uranium-bearing solutions have migrated. This is especially evident for uranium-bearing beds in the hogback area east of La Ventana Mesa, where carbonaceous shale and sandstone are in contact with permeable sandstone 


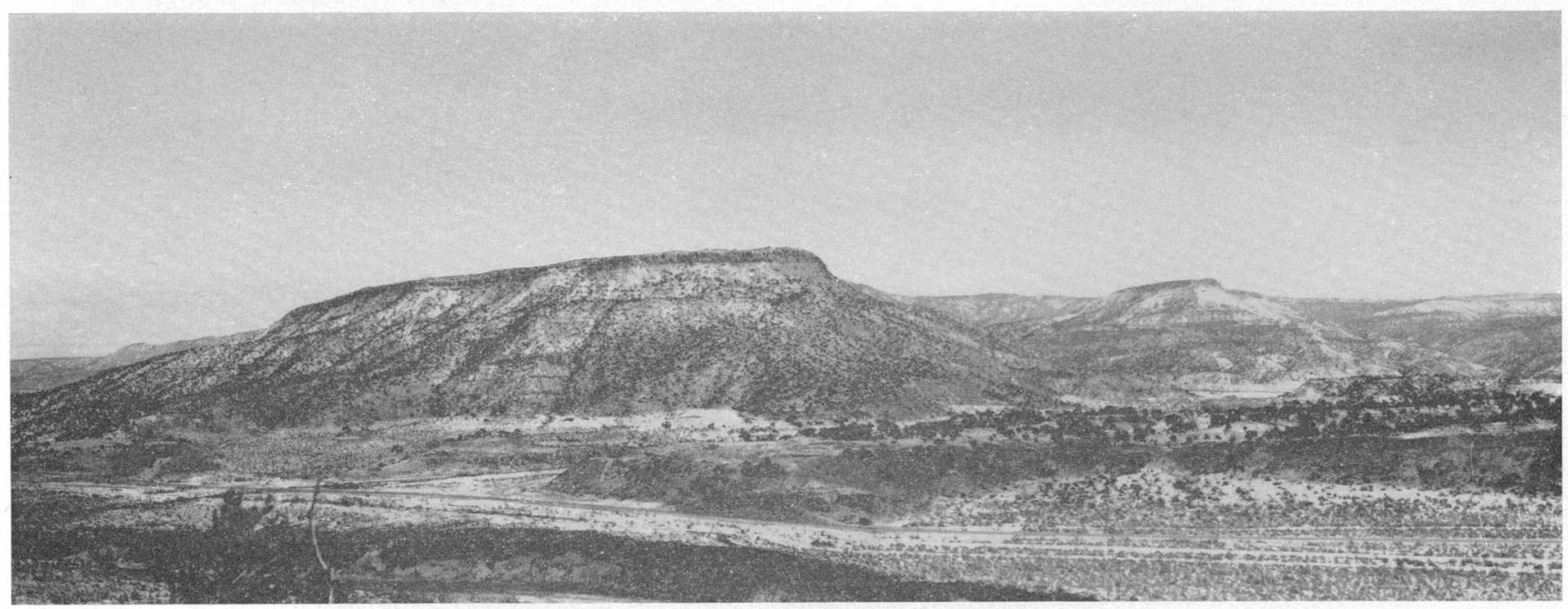

LA VENTANA MESA, SANDOVAL COUNTY, NEW MEXICO

View is east across the Río Puerco, showing the north butte, on the left, and the south butte, on the right. State Route 44 in foreground. 


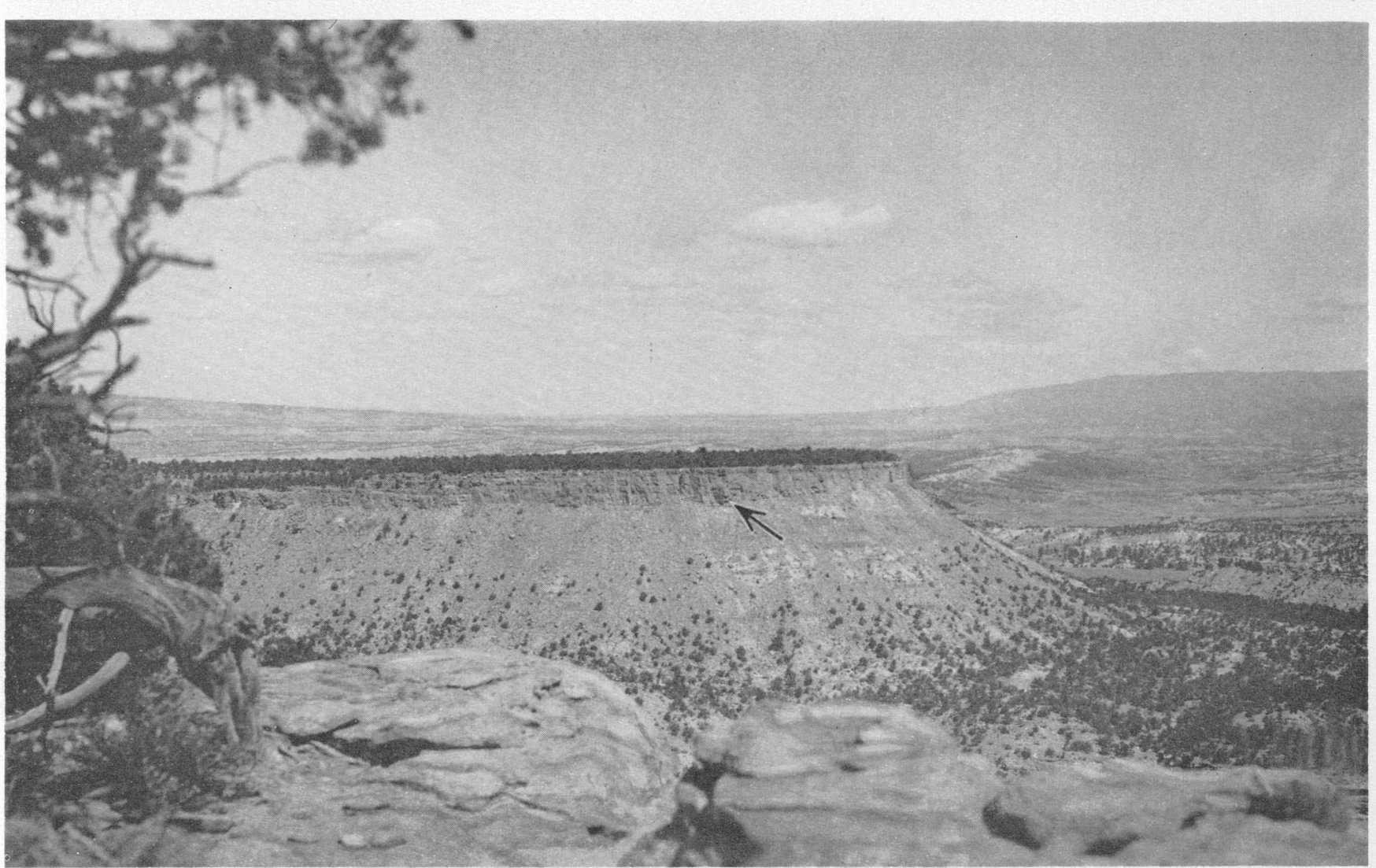

NORTH BUTTE OF LA VENTANA MESA VIEWED FROM THE SOUTH BUTTE

Arrow indicates the coal bed of the uranium-bearing zone directly below the cliff-forming La Ventana tongue of the Cliff House sandstone. 


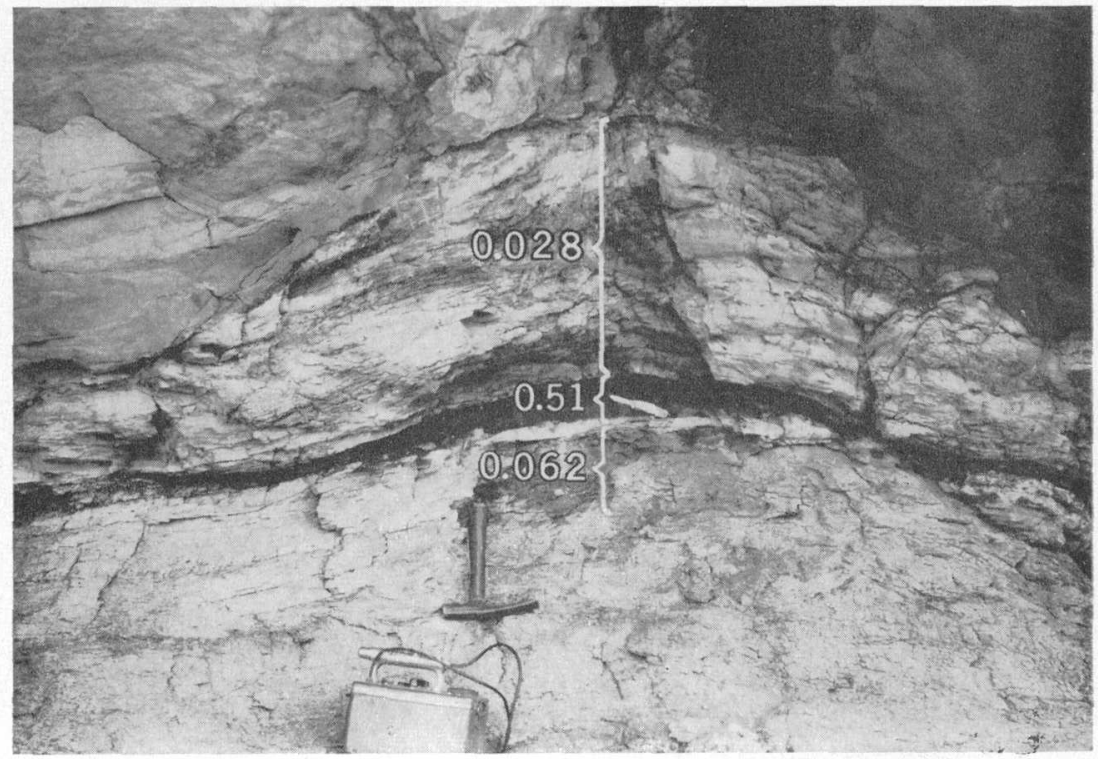

A. Tent-shaped thickening of beds at locality 46 on south butte of $\mathrm{La}$ Ventana Mesa, showing content of uranium in percent.

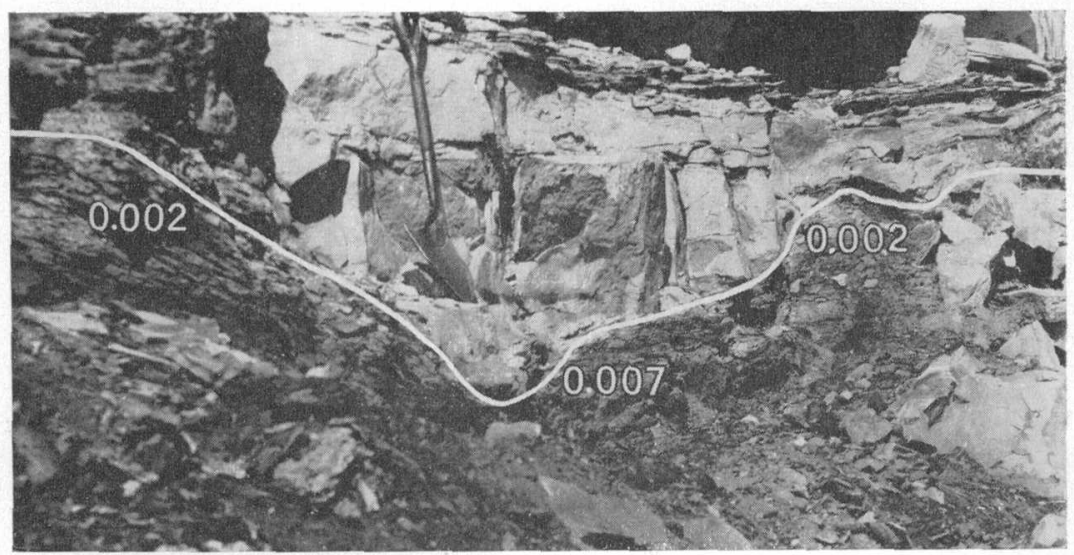

$B$. Effect of minor syncline in coal below a sandstone body at the base of the La Ventana tongue of the Cliff House sandstone. Value of equivalent uranium, in percent, indicates more intense mineralization in trough of syncline than on flanks.

URANIUM-BEARING ZONE ON LA VENTANA MESA, SHOWING MINOR STRUCTURES ASSOCIATED WITH URANIUM IN COAL 


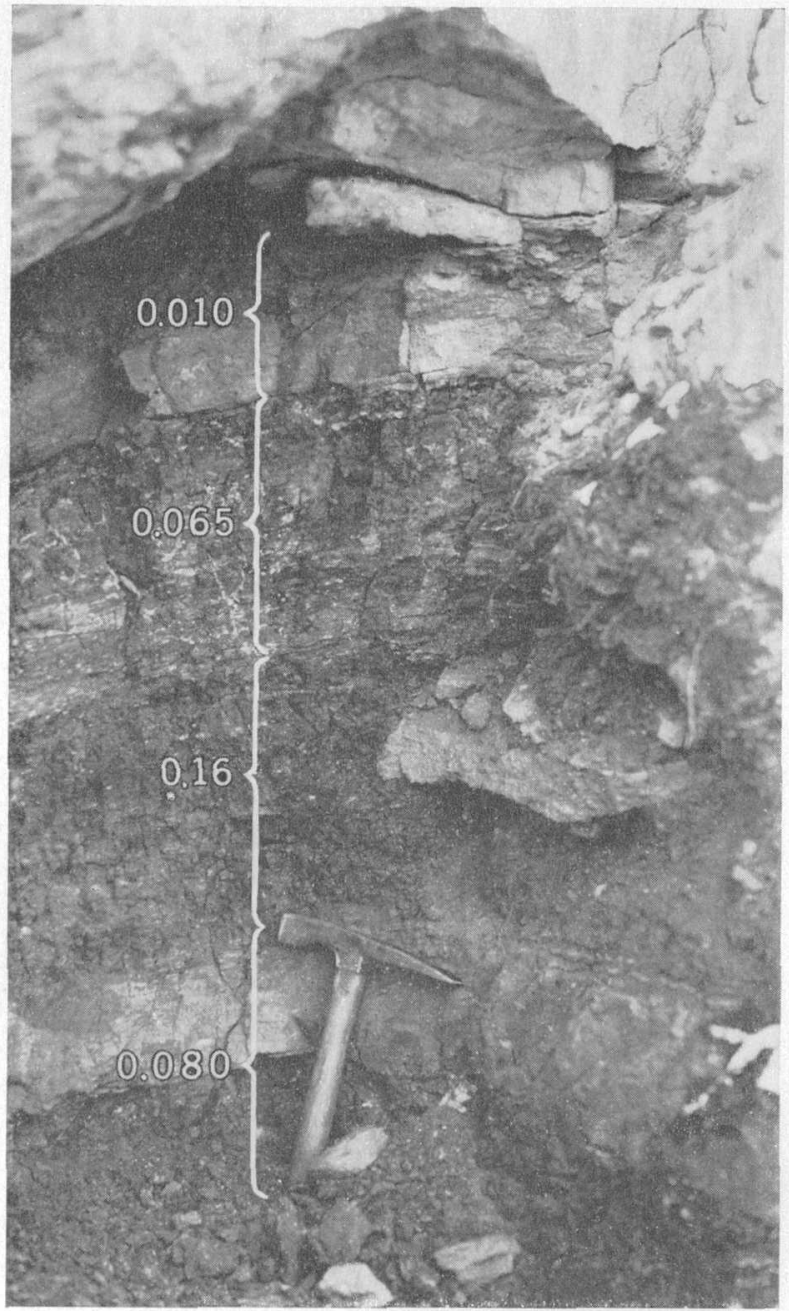

THE WEATHERED OUTCROP OF A 3.FOOT BED OF URANIUM.BEAR. ING COAL AT LOCALITY 4. THE URANIUM CONTENT IS INDICATED IN PERCENT. 
beds of the Dakiota sandstone and the Point Lookout sandstone. On La Ventana Mesa the uranium-bearing zone is directly overlain by the La Ventana tongue of the Cliff. House sandstone, in which permeability has been increased by numerous joints. The coal bed of this zone is the only coal bed that is uranium bearing, though many coal beds are present at lower stratigraphic horizons.

\section{ORIGIN}

At the present time any hypothesis of the origin of the uranium at La Ventana Mesa is unproved because direct evidence is lacking. The possibility that the uranium could have been introduced into the carbonaceous rocks by thermal, or juvenile, solutions has been considered because'slightly: radioactive;ground water is present:within the Jemez Mountain region. At Warm Springs, 15 miles south of La Ventana, slightly radioactive travertine is being deposited around a. well from which warm water flows: However, the Quaternary travertine deposits in the SW1/4 sec. 32, T. 19 N., R. 1 W., in the vicinity of a fault, were checked radiometrically but were found to be non-radioactive. . Likewise, strata in the vicinity of the fault, as well as numerous coal beds in the stratigraphic sequence below the uranium-bearing coal beds at La Ventana Mesa were examined without finding additional radioactivity. The absence of abnormal radioactivity in rocks at places: where juvenile waters:would be expected to travel normally and the absence of radioactivity in rocks directly below the uranium-bearing coal suggests that uranium has not been carried upward into the rocks by such waters. There is very strong evidence that there has been lateral transportation of uranium within. the mineralized areas, but there is little evidence to indicate that these mineralized areas are closely associated with fault systems.

Therefore the writers believe that the uranium deposits at La Ventana Mesa are of epigenetic origin and were derived from groundwater solutions and that a source of the uranium was the Bandelier rhyolite tuff of Smith (1938) of Pleistocene age. The Bandelier rhyolite tuff is widespread on the Jemez volcanic plateau to the east of the Nacimiento Mountains. It contains an average of 0.003 percent uranium and a variation of 0.003 to 0.006 percent equivalent uranium. This concentration of uranium, by itself, is probably of little significance; but the great quantity' of disseminated uranium represented by the Bandelier is worthy of consideration.

The Bandelier rhyolite tuff was deposited on a surface of considerable relief and it is conceivable that the tuff formerly extended across the area of the Nacimiento Mountains into the La Ventana Mesa area. However, a careful search has been made in the La Ventana area for erosional remnants of the Bandelier but at present none 
have been discovered. This fact causes the epigenetic hypothesis of origin to be speculative. The process of release of uranium from volcanic tuff and concentration of the uranium in carbonaceous material is discussed by Denson, Bachman, and Zeller in chapter B.

\section{TONNAGE AND GRADE OF THE DEPOSITS}

A total of 125 samples was collected from the La Ventana area and analyzed in the laboratory for uranium content. A detailed list of the results of sampling is given in table 1 . Local variations in both thickness and uranium content of the mineralized zone make calculations of tonnage and grade difficult. Isopach maps were prepared of areas where the zone contains 0.1 percent uranium in the mesa area. The thickness at each locality was determined by combining material having more than 0.1 percent uranium with that having less than 0.1 percent until the average equals $0: 1$ percent uranium. On the basis of geometric constructions derived from relative spacing of sample stations and of geologic inference as to the continuity of the uranium-bearing zone behind the outcrop, the writers estimate that two major mineralized areas contain about 132,000 tons of material containing an average of 0.10 percent uranium. These estimates are summarized in table 2.

Many parts of the La Ventana area appear to have lower grade uranium-bearing material, containing between 0.01 and 0.10 percent uranium. In addition to those of the north and south buttes of the mesa, deposits are in the Dakota sandstone and the Point Lookout sandstone in the hogback area to the east of La Ventana. A summary of tonnage and grade of these low grade resources is given in table 3.

TABLE 1.-Analyses of samples from the La Ventana Mesa area, New Mexico'

\begin{tabular}{|c|c|c|c|c|c|c|c|}
\hline \multirow{3}{*}{$\begin{array}{c}\text { Locality } \\
\text { No. } \\
.\end{array}$} & \multicolumn{3}{|c|}{ Sample } & \multicolumn{4}{|c|}{ Analyses, in percent } \\
\hline & \multirow{2}{*}{ Field No. } & \multirow{2}{*}{$\begin{array}{l}\text { Thickness } \\
\text { (inches) }\end{array}$} & \multirow{2}{*}{. Material } & \multirow{2}{*}{$\begin{array}{c}\text { Equiv- } \\
\text { alent } \\
\text { uranium }\end{array}$} & \multicolumn{2}{|c|}{ Uranium } & \multirow{2}{*}{ Ash } \\
\hline & & & & & $\underset{\text { sample }}{\text { In }}$ & $\underset{\text { ash }}{\text { In }}$ & \\
\hline
\end{tabular}

La Ventana Mesa (pl. 55)

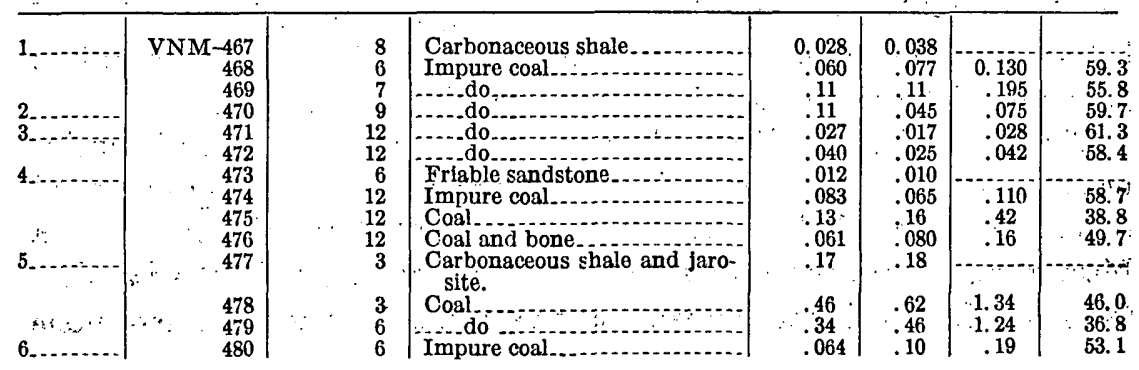


TABLE 1.-Analyses of samples from the La Ventana Mesa area, New Mexico-Con.

\begin{tabular}{|c|c|c|c|c|c|c|c|}
\hline \multirow{3}{*}{$\begin{array}{c}\text { Locality } \\
\text { No. } \\
\therefore:\end{array}$} & \multicolumn{3}{|c|}{ Sample } & \multicolumn{4}{|c|}{ Analyses, in percent } \\
\hline & \multirow{2}{*}{ Field No. } & \multirow{2}{*}{$\begin{array}{c}\text { Thickness } \\
\text { (inches) }\end{array}$} & \multirow{2}{*}{ Material } & \multirow{2}{*}{$\begin{array}{l}\text { Equiv- } \\
\text { alent } \\
\text { uranium }\end{array}$} & \multicolumn{2}{|c|}{ Uranium } & \multirow{2}{*}{ Ash } \\
\hline & & & & & $\begin{array}{c}\text { In } \\
\text { sample }\end{array}$ & $\underset{\text { ash }}{\text { In }}$ & \\
\hline
\end{tabular}

La Ventana Mesa (pl. 55)-Continued

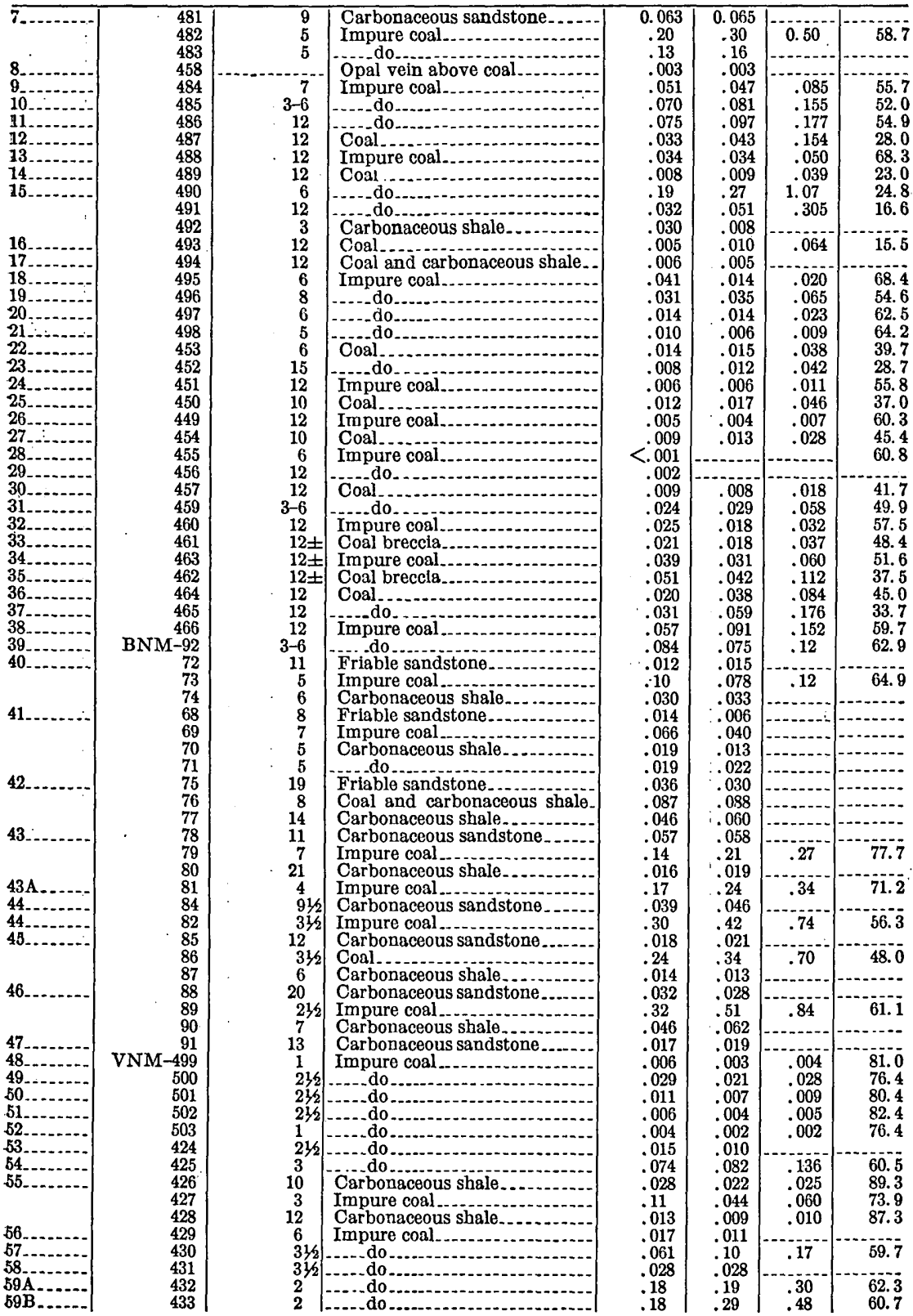


TABLE 1.-Analyses of:samples from the La Ventana:Mesa area; New Mexico-Con:

\begin{tabular}{|c|c|c|c|c|c|c|c|}
\hline \multirow{3}{*}{$\begin{array}{c}\text { Locality } \\
\text { No. }\end{array}$} & \multicolumn{3}{|c|}{ Sample } & \multicolumn{4}{|c|}{ Analyses, in percent } \\
\hline & \multirow[b]{2}{*}{ Field No. } & \multirow{2}{*}{$\begin{array}{l}\text { Thickness } \\
\text { (inches) }\end{array}$} & \multirow[b]{2}{*}{ Material } & \multirow{2}{*}{$\begin{array}{c}\text { Equiv- } \\
\text { alent } \\
\text { uranium }\end{array}$} & \multicolumn{2}{|c|}{ Uranium } & \multirow[b]{2}{*}{ Ash } \\
\hline & & & & & $\underset{\text { sample }}{\text { In }}$ & $\underset{\text { ash }}{\text { In }}$ & \\
\hline
\end{tabular}

La Ventana Mesa (pl. 55)-Continued

\begin{tabular}{|c|c|c|c|c|c|c|c|}
\hline 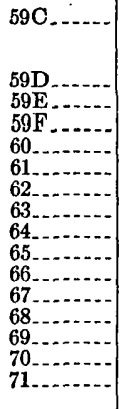 & $\begin{array}{l}438 \\
434 \\
439 \\
435 \\
436 \\
437 \\
442 \\
443 \\
444 \\
445 \\
446 \\
447 \\
448 \\
423 \\
422 \\
441 \\
440\end{array}$ & $\begin{array}{r}12 \\
2 \\
12 \\
2 \\
2 \\
2 \\
12 \\
12 \\
12 \\
12 \\
18 \\
6 \\
4 \\
6 \\
4 \\
6 \\
6 \\
12\end{array}$ & $\begin{array}{l}\text { Carbonaceous sandstone. } \\
\text { Impure coal. } \\
\text { Carbonaceous shale. } \\
\text { Impure coal } \\
\text { Coal } \\
\text { Carbonaceous shale } \\
\text { do do }\end{array}$ & $\begin{array}{c}0.014 \\
.21 \\
.027 \\
.096 \\
.034 \\
.013 \\
.004 \\
.005 \\
.006 \\
.004 \\
.002 \\
.003 \\
.003 \\
.003 \\
.001 \\
.007 \\
.007 \\
.002\end{array}$ & $\begin{array}{c}0.013 \\
.30 \\
.036 \\
.17 \\
.05 \\
.005 \\
.002 \\
.003 \\
.002 \\
* .001 \\
* .001 \\
.001 \\
.01 \\
.001 \\
.003 \\
.005 \\
.001\end{array}$ & $\begin{array}{c}0.48 \\
.30 \\
.11 \\
.014 \\
\end{array}$ & $\begin{array}{r}61.1 \\
56.3 \\
45.2 \\
38.9 \\
\\
\end{array}$ \\
\hline
\end{tabular}

Area west of La Ventana Mesa and Hogback area (pl. 53)

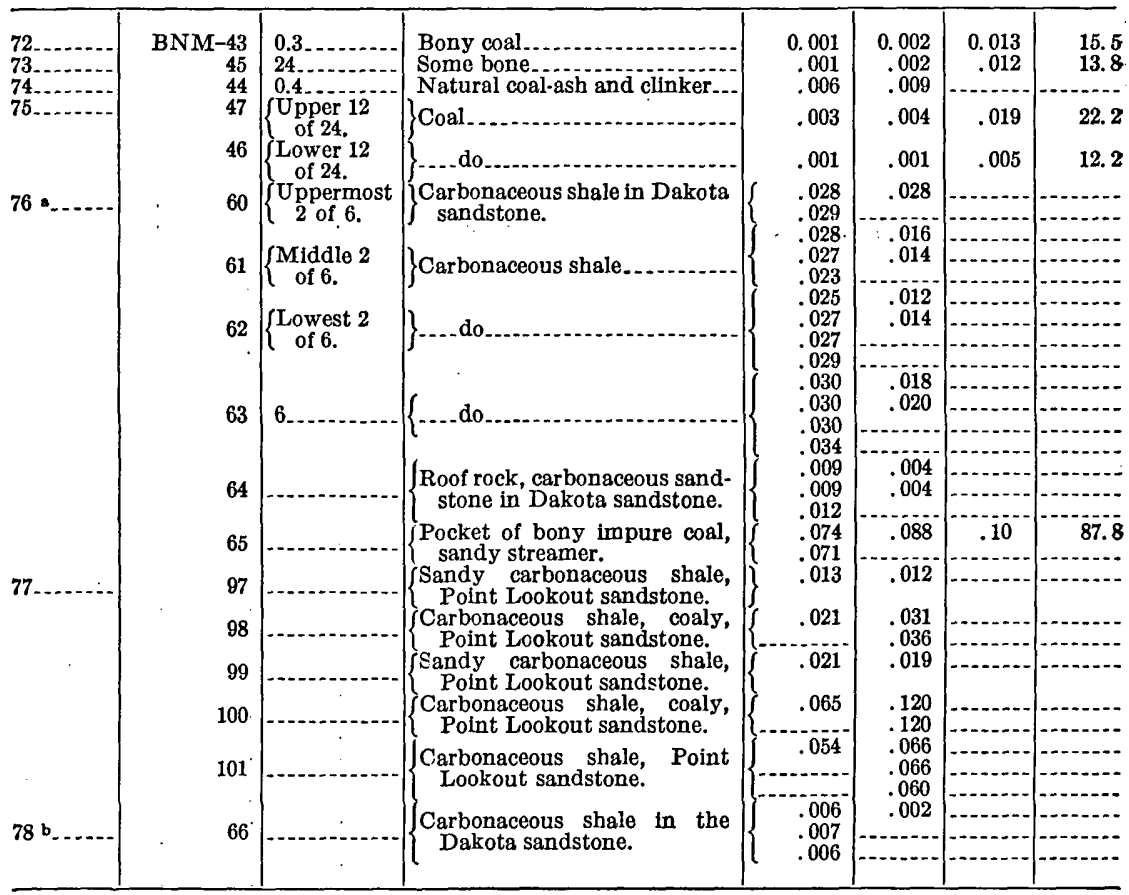

- San Miguel Canyon.

b Arroyo Dedos Gordos. 
TABLE 2.-Tonnage of uranium-bearing coal and carbonaceous shale at least 1 foot thick and containing at least 0.10 percent uranium, La Ventana Mesa

\begin{tabular}{|c|c|c|c|c|c|c|c|}
\hline \multirow{3}{*}{ Area } & \multirow{3}{*}{ Location in area } & \multirow{3}{*}{$\begin{array}{l}\text { Thick- } \\
\text { ness } \\
\text { (feet) }\end{array}$} & \multirow{3}{*}{ Ash } & \multicolumn{2}{|c|}{ Uranium content } & \multicolumn{2}{|c|}{ Tonnage } \\
\hline & & & & In coal & In ash & Coal & Ash \\
\hline & & & & \multicolumn{2}{|c|}{ (percent) } & \multicolumn{2}{|c|}{ (short tons) } \\
\hline $\begin{array}{l}\text { North butte. } \\
\text { Do } \\
\text { South butte. }\end{array}$ & $\left\{\begin{array}{l}\text { NE } 14 \text { NE1/4 sec. } 32, \text { and SE1/4 } \\
\text { sec. } 29, T .19 \text { N., R. } 1 \text { W. } \\
\text { Locality } 15 \text { (pl. } 55) \\
\text { N1/2SE1/4 and S16 of NE1/4 } \\
\text { sec. 33, T. } 19 \text { N., R. } 1 \text { W. }\end{array}\right.$ & $\begin{array}{r}1-3 \\
1.5 \\
1-1.5\end{array}$ & $\begin{array}{l}50 \\
20 \\
88\end{array}$ & $\begin{array}{r}0.10 \\
.12 \\
.10\end{array}$ & $\begin{array}{r}0.20 \\
.56 \\
.11\end{array}$ & $\begin{array}{c}120,000 \\
1,000+ \\
12,000\end{array}$ & $\begin{array}{l}60,000 \\
200+ \\
10,000\end{array}$ \\
\hline
\end{tabular}

TABLE 3.-Estimates of tonnage and grade of uranium-bearing rocks at least 1 foot thick and containing $0.01-0.10$ percent uranium

\begin{tabular}{|c|c|c|c|c|}
\hline Locality & Geologic occurrence & $\underset{\text { (feet) }}{\text { Thickness }}$ & $\underset{\text { (percent) }}{\text { Uranium }}$ & $\begin{array}{l}\text { Tonnage of } \\
\text { uranium- } \\
\text { bearing rocks } \\
\text { (short tons) }\end{array}$ \\
\hline $\begin{array}{l}\text { La Ventana Mesa: } \\
\text { North butte }\end{array}$ & \multirow{3}{*}{$\begin{array}{l}\left\{\begin{array}{l}\text { Uranium-bearing zone at base of La Ven- } \\
\text { tana tongue of Cliff House sandstone. }\end{array}\right. \\
\text { Point Lookout sandstone. } \\
\text { Dakota sandstone.s. }\end{array}$} & \multirow{2}{*}{\} $\begin{array}{c}1-1.5 \\
1-1.5 \\
1 \\
1\end{array}$} & \multirow{2}{*}{$\begin{array}{r}0.04 \\
.02 \\
.05 \\
.02\end{array}$} & \multirow{2}{*}{$\begin{array}{r}336,000 \\
57,000 \\
13,000 \\
8,000\end{array}$} \\
\hline $\begin{array}{l}\text { South butte } \\
\text { Hogback area- } \\
\text { Do }\end{array}$ & & & & \\
\hline Total tonnage... & & $-\ldots$ & $\ldots$ & 414,000 \\
\hline
\end{tabular}

\section{LITERATURE CITED}

Beaumont, E. C., Dane, C. H., and Sears, J. D., 1956, Revised nomenclature of Mesaverde group in San Juan Basin, New Mexico: Am. Assoc. Petroleum Geologists Bull., v. 40, p. 2149-2162.

Boutwell, J. M., 1905, Carnotite deposits in the San Rafael Swell: U. S. Geol. Survey Bull. 260, p. 200-210.

Dane, C. H., 1936, Geology and fuel resources of the southern part of the San Juan Basin, New Mexico, pt. 3, The La Ventana-Chacra Mesa coal field: U. S. Geol. Survey Bull. 860-C, p. 81-166.

Moore, G. W., 1954, Extraction of uranium from aqueous solution by coal and some other materials: Econ. Geology, v. 49, p. 652-658.

Renick, B. C., 1931, Geology and ground-water resources of western Sandoval County, New Mexico: U. S. Geol. Survey Water-Supply Paper 620.

Smith, H. T. U., 1938, Tertiary geology of the Abiquiu quadrangle, New Mexico: Jour. Geology, v. 46, no. 7, p. 933-965.

Tolmachev, I. M., 1943, Adsorption of uranyl salts on solid adsorbents: U. S. S. R. Acad. Sci. Bull., no. 1, p. 28-34.

Wood, G. H., and Northrop, S. A., 1946, Geology of Nacimiento Mountains, San Pedro Mountain, and adjacent plateaus in parts of Sandoval and Rio Arriba Counties, New Mexico: U. S. Geol. Survey Oil and Gas Inv. Prelim. Map 57. 



\section{INDEX}

$\mathbf{A}$

Acknowledgments 13, 88, 149, 183, 218, 256 Adamson, R. D., Hardy, C. T., and Willams, J. S., cited.

Alluvial fans, Mendenhall area - 104

Alluvium, Goose Creek district 221,237 Analcite, relation to uranium. 31,37 Ekalaka Hills

176 Analyses, chemical, Arikare $\theta$ formation...... 27,36 ground water, Ekalaka Hills.

Fall Creek area....................... 277-278

White River group............... . 22, 36,164

lignite, $\mathrm{Bar} \mathrm{H}$ area. . . . . . . . .

Ekalaka Hills. . . .................... 172-175

Johnson outlier........................ 78

Lodgepole area................. 54, 55, 76-78

Long Pine Hills....................... 54

Medicine Pole Hills. . .................. 78-79

North Cave Hills...................... 50,51

Slim Buttes.............52-54, 71-76, 118-127

South Cave Hills...................... 51, 52

Table Mountain

lignite and carbonaceous shale, Goose Creek district

49

tuff and volcanic ash, Goose Creek district $245-249$

White River group.

fuel, Bar $\mathrm{H}$ area. 27,36

coaly shale, Fall Creek district

$80-81$
271

comparison of weathered and unweath. ered lignite, Mendenhall area..... 108

Goose Creek district.

Johnson outlier

Lodgepole area

Medicine Pole Hills.

Mendenhall area. $107-108,128-135$

Slim Buttes (See Bar H and Mendenhall areas).

Red Desert area....................... 189-191

semiquantitative spectrographic, Arikaree formation

carbonaceous-rocks and coal ash, Fall Creek area................... 273, 291-293

lignite ash, Bar H $\mathrm{H}$ area................ 39, 71-76

Johnson outlier.......................... 76-78

Lodgepole area . ............................... 76-78

Medicine Pole Hills.................... 78-79

Mendenhall area.................... 118-127

theshold values of elements...... 70,117,290

White River group X-ray
Anderson, A. L., cited........... 219, 222, 223, 224, 253 Anomalies, distribution of uranium....... 33,68

Anticline, faulted............................ 265, 267

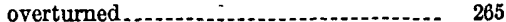

Areas of uranlum-bearing coal, western United States, Idaho, Fall Creek area.6, 256-293 Goose Creek district.................. 6, 217-253 Montana, Ekalaka Hills................. 167-179 Nevada, Goose Creek district.......... 6, 217-253 New Mexico, La Ventana Mesa area. 6, 295-307 North Dakota, Bullion Butte area........... 153, $155,161,162,164$ Chalky Buttes area...................... 148, $154,155,156,158,161-163$

Medicine Pole Hills . . . . . . . . ............. 65-66 Sentinel Butte area

South Dakota, Bar H area............... 64-65 Cave Hills.................12, 14, 19, 20, 28, 50, 52 Lodgepole area........................... 45, 65

Mendenhall area........................ 97-116

the Slim Buttes......................... 18, $22-25,27,28,30,35,37,45-46,48,64-66,87-116$

Wyoming, Powder River Basin........... 6

Red Desert area..................... 6, 181-215

Areas that may contain uranium-bearing coal, Western Canada, Cypress Hills _... $\quad 8,8$

Colorado, Denver basin ................... 8, 8

Montana, Flaxville Highlands............. $\quad 8,8$

Tertiary intermontane basins........... $8, \mathbf{8}$

North Dakota, Killdeer-Knife River area.. $\quad 8,9$

South Dakota, Fox Ridge area............. $\quad 8,9$

Killdeer-Knife River area................ 8,8

Utah, north flank of Uintah Mountains.. $\quad 8,8$

Wyoming, north flank of Uinta Mountains. 8,9 west flank of Big Horn Mountains..... $\quad 8,9$

Arikaree formation.... 14, 15, 23-27, 37, 61, 64, 150, 152

Ekalaka Hills ............................ 170-171

Mendenhall area.................... 104, 113-116

radioactivity in Mendenhall area. $59,62,113-115$ Arroyo Dedos Gordos, La Ventana Mesa area. $\quad 300$ Arsenic........................................... 7,29

Ash, coal, elements in..................... 272 extrinsic...................................... 272 intrinsic ................................. 271 relation to uranium content............. 273 volcanic.................................... 4, 22,30 as source of uranium in the Dakotas...- 162 Goose Creek district....................... 223, $225,229,232,233,242,248,250,251,253$ Ash content, average, in uranium-bearing Dakota lignite. 70 coaly shale, Fall Creek area............... 271, 272 lignite, Goose Creek district................. 240 
Ash content, uranium-bearing lignite, Ekalaka Hills................................ 178 southwestern North Dakota.......... 153, $154,156,157,162,164,165$ relationship to uranium content, La Ventana Mesa

Ash-leach theory

Attrital coal, description of, Mendenhall area.- 106 Autoradiographs........................ 31, 273, 362 Autunite.

\section{$\mathbf{B}$}

Bachman, G. O., Denson, N. M., and Zeller, work cited

Banded coal, description of terms, Menden-

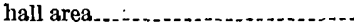

Bandelier rhyolite tuff of Smith, as possible source of uranium

Bar H mine

Bar H lignite bed.

$35,36,62$

Bar $\mathrm{H}$ rider lignite bed . . . . . . . . . . 62, 63

Barite, in lignite, Ekalaka Hills............ 176

Barrett carbonaceous zone, Goose Creek district $242-243,249$

Basins, structural, Goose Creek district_...... 238

Bates, T. F., cited.

Bauer, H. L., and Beroni, E. P., cited. 3, 30, 31, 37, 98 work cited. 148

Bear River formation, Fall Creek area .... 262-263, 265-266, 269-270, 281 structure

Bechler redbeds, Fall Creek area ........... 261

Bentonite, Goose Creek district _...... 233, 251, 253 composition, Goose Creek district........ 253 Mendenhall area . ................ 101, 102,115

Beroni, E. P., and Bauer, H. L., cited. 3, 30, 31, 37, 98

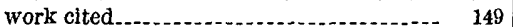

Beroni, E. P., Gott, G. B., and Wyant, D. G., cited.

Boutwell, J, M., work cited

Bowen, C. F., work cited...... . 219, 224, 240, 241, 242

Breger, I. A., and Deul, Maurice, cited._115 work cited

Breger, I. A., Deul, Maurice, and Rubenstein, S., work cited............. 171

Brown, R. W., cited....... 16, 19, 228, 229

Browns Park formation, Red Desert area....- 185

Brule formation, Mendenhall area.......... 102, 103

Chalky Buttes area.................. 151-152

Bullion Butte area, Billings and Golden Valley Counties, N. Dak............. 153, $155,161,162,164$

Bullion Butte lignite bed $15,150,153,162$

\section{C}

Calcium

Cannonball member, Fort Union formation.-- 11, $13,14,17,101$

Caprock 40,42

Carbonaceous material, association with uranium.......................... 2,29

affinity for uranium 251

relation to uranium concentration, La Ventans Mesa area............. 298, 302
Carbonaceous rocks, uranium-bearing, Fall

Creek area.

Goose Creek district.................... 262, 270

La Veńtắna Mèsà

Carbonaceous zones, Goose Creek district_... 238 , 242-243, 249

Carboniferous and older rocks, Goose Creek district................. 221, 222, 239

Cathedral Bluffs tongue, Wasatch formation, Red Desert area.................. 185 Cave Hills, South Dakota.... 12, 14, 19, 20, 28, 40-43 Cedar Creek anticline................... 152 Chadron formation, Mendenhall area........ 102$103,104,110,115,116$

southwestern North Dakota. . . ...........151, 154 springs in, Mendenhall area ......... 103,115

Chalky Buttes area, Slope County, North Dakota..... 148, 154-155, 156, 158, 161, 163

Chalky Buttes lignite bed................ 154

Chuning lignite mine, lignite at. .............. 47

Clay, bentonitic................ 20, 115 Mendenhallarea ..................... 102

Claystone ........... 151, 162

Cleveland lignite zone, Ekalaka Hills . . 171, 176-179

Clinker Goose Creek district. . . . .......... 242

Red Desert area....... 188

Coal, uranium-bearing

Fall Creek area_............ 270, 272, 273, 275

La Ventana Mesa............ 298, 300,302, 303

Red Desert area................. 192-194

Coal prospects Fall Crcek area . . . .......... 267

Coal zone, Bear River formation, Fall Creek area. . . . . 265, 266

Coal zones Red Desert area $\ldots \ldots \ldots . . .188$

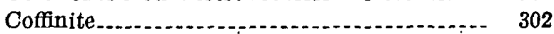

Concretions...................... 14, 16, 18, 21

Concretionary zone, Arikaree formation. ..... 23, 25 ironstone, Ekalaka Hills................. 170 sandstone, Ekalaka Hills.............. 169

Conglomerate. . . . . . . . . . 20, 24, 42, 260, 281 Arikaree formation, Mendenhall area..... 103 Goose Creek district _... 223-224, 225, 229, 232, 233 limestone pebble, uranium-bearing ...... 266 Contact, Hell Creek-Ludlow members........ 17 Sentinel Butte-Tongue River members.- 151

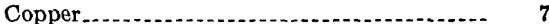
Core-drilling, Fall Creek area......... 278 Mendenhall area

Red Desert area. . . . . 194-195

Core holes, data ...................61, 100, 196 Core loss, determination of, Mendenhall area $\quad 102$ Cores, disposition of samples, Mendenhall area lithologic description, Bar H area....... 84-91 Johnson outlier..................... 93-94

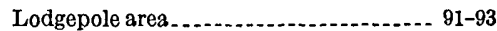
Medicine Pole Hills area . . ............ 94-95 Mendenhall area ................... 106, 136-146 Red Desert area....... 197-214 sampling procedure, Mendenhall area _ 100, 106 Coring, procedure, Mendenhall area ........ 100 Correlation, of lignite beds.... 41 of other chemical elements with uranium. 7,29, 272,275 
Page

Correlation, reliability of, Mendenhall area:

Cretaceous rocks, Ekalika:Hills.

Croley coal prospect Fal lCrek' area

\section{D}

Daniels, Farrington, cited. $36-37,39,40$

Davidson, C. F., and Ponsford, D. R. A., cited.

Denson, N. M., Bachman, G. O., and Zeller, H. D., cited.

38

3

Deul, Maurice, and Breger, I. A., cited..... 115, 273

and Rubenstein,.S., work cited........... $\quad 165$

Diatoms, Goose Creek district............... 227-228

Dip, regional.................... 28, 44, 63, 64, 65, 104

Discovery, uranium-bearing carbonaceous material.

$2,7,181,266,295$

uranium-bearing coal

2, $7,181,266$

uranium-bearing lignite.

Distribution of uranium, in carbonaceous rocks, Goose Creek district.... 248, 251

in coal, Fall Creek area.................... 275

Red Desert area............... 188, 192, 193, 194

La Ventana Mesa...................... 298, 301

in lignite ................................ 4, 32, 35

Ekalaka Hills.......................... 176-177

Mendenhall area, controlling factors.. 115-116

Mendenhall mine. . ................... 32-33

northwestern South Dakota .............. 63, 65

relation to thickness .................... 153

Slide Butte bed. ...................... 163, 165

southwestern North Dakota........ 68, 153,162

in shale, Red Desert area ................. 194

progressive downward decrease............ $\quad 33$

Drag folding, Fall Creek area............... 270-271

Draney limestone, Fall Creek area............. 261

\section{$\dot{\mathbf{E}}$}

Economic value, uranium-bearing coal

5,48

Ekalaka Hills, Mont................... 6, 49, 167-177

Elder lignite zone, Ekalaka Hills . ...... 171, 176-178

Elements, chemical, associated with uranium

in coal.......... $7,29,68-69,106,273-275$

Ephraim conglomerate, Fall Creek area ...... 260

Ewing, R. A., work cited................... 170

Extraction of uranium from solution by lignite.

28,165

relation of coal constitutents............. 165

relation of coal permeability .............. 165

\section{F}

Fall Creek area, Idaho location

$6,255-293$

256

spect....................... 256,

$264-265,266,267,270,282$

Faulting, Goose Creok district............ 238, 239, 240

Faults ................................. 28, 39, 46, 158

displacement, Goose Creek district...... 239-240

normal, Fall Creek area . ........... 265

Goose Creek district.................. 239-240

the Slim Buttes.......................... 62

relation to uranium deposition, La Ventana Mesa

thrust, Fall Creok area.
Favorable host material.

Page

Fenner, C. N., cited....................... 230

Feicht, F. L., and Foster, W.D., cited..._... 37

Fluviatile deposits.............................. 13

Folds, Fall Creek area..................... 264-265

Fort Union formation. . ............. 17-20, 149, 151

Ekalaka Hills. . . .

Mendenhall area................... 101, 102, 104

Fossils, Ekalaka Hills. ...................... 170-171

Fall Creek area........................ 270

fish, Chadron formation................. 157 invertebrate, Goose Creek district...... 235-236

La Ventana Mesa..................... 297

plant, Goose Creek district. 227, 229, 235, 236-237

Mendenhall area ....................... 107

Tongue River formation............... $\quad 21$

Red Desert area.......................... 185

uranium-bearing ....................... 104, 266

vertebrate, Brule formation............ 103, 158

Chadron formation.................... 23

Goose Creek district...................... 235

Sentinel Butte member................... 151

Foster, W. D., and Feicht, F. L. cited...... 37

Fox Hills sandstone. . ........................ 15, 16, 21

Fractures, relation to uranium in cosl $\mathrm{La}$

Ventana Mesa.................... 302

G

Gannett group Fall Creek area............. 260

Gardner, L. S. cited...................... 262

Gazin, C. L. cited.

Geologic associations, favorable, for uranlum.

bearing coal...................... 31,194

Germanium ............................. 272, 273-275

Gill, J. R., cited............................ 28,41, 43

work cited.................................... 149

Gill, J. R., and Moore, G. W., cited......... 22, 36

Golden Valley formation...................... 32

uranium-bearing lignite................. 164

Goose Creek district, Idaho, Utah, and Nevada location.................... 217-218, 219

Gott, G. B., Beroni, E. P., and Wyant, D. G., cited........................... 3

Grade, average, uranium in coal

uranium in Dakota lignite............... $\quad 70$

uranium deposits, La Ventana Mesa... 304, 307

Grant carbonaceous zone, Goose Creek district............................. 242

Gray, R. J., and Schopf, J. M., cited... 165, 218-219

Green River formation, Red Desert area...... 184

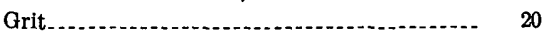

Ground water, analyses................ 7, 22, 36, 164

as mineralizing agent.................... 194, 276

average uranium content.................. 4, 7,164

role in formation of uranium deposits... 276

transportation of uranium.............. 31, 33, 37

Ground-water sampling, use in prospecting..- 7

Gruner, J. W., cited........................ 302

303 Gude, A. J., 3d, work cited................... 253

264 Gypsum in lignite, Ekalaka Hills............ 179 
:Hail, W. J., Jr., and Mapel, W. J., clted .... 236 Harmon lignite bed.......... 19;44; 45, 65, 67, 68, 69, 70 Harmon rider lignite bed................... 65, 67, 68 Haught, O. L., cited...................... 272 Hell Creek formation.................... 15, 16, 169 Hiawatha member, Wasatch formation....... 184 Hogback area near La Ventana.Mesa..- 299-300, 302 Hough, M. J., work cited................... 152 HT Butte.......... 156, 157 HT lignite bed............................. 15 Humic matter, relation to uranium extraction. 165

Iddings, J. P., cited

Impurities, lignite, Ekalaka Hills.............. 176

Inverted pattern of uranium concentration . - 33, 34,

Investigation of uranium-bearing coal.

$$
\mathbf{J}
$$

Johnson outlier, South Dakota.

Joints. . . ........................... 38, 43, 265, 301, 303 relation to uranium concentration, Fall Creek area.

La Ventana Mesa.

Judson, Sheldon, and Osmond, Kenneth, work cited.

\section{$\mathbf{K}$}

Kaolinite 37,147

Keefer lignite zone, Ekalaka Hills.......... 171 Kirkham, V. R. D., cited.............. 223, 225, 261 Koberlin, F. R., cited.

Koppe, E. F., work cited................... 273

\section{L}

Lacrolx, Alfred, cited...................... $\quad 230$

Landslide debris, Mendenhall area.......... 101, 104

Landslides. .................................. 45

Landslides, Goose Creek district............. 237-238 pre-Arikaree............................. 20,46 Mendenhall area....................... 102-104

Larsen, E. S., cited........................ 222

La Ventana Mesa area, New Mexico, location. 295

La Ventana tongue of Cliffhouse sandstone. 297, 300

La Ventana syncline........................ 296, 300

Leaching of uranium........................ 4,37

Lead............ 29

Leopold, E. B., work cited. ........... 236-237

Lignite..................................... 15, 16,17 bulk samples, Mendenhall area.......... 108-110 Ekalaka Hills. . . . . . . Goose Creek district..................... 240-243 Hell Creek formation, Ekalaks: Hills..... 169 microfossils in, Mendenhall area.......... 107 quality, Goose Creek district............ 240, 241

Mendenhall area...................... 107-108

North and South Dakota............ 63,65, 68 strippable uranium-bearing, Mendenhall area. southwestern North Dakota.... 69, 70, 153, 161
Lignite, uranium-bearing $14,28,38,40$ Ekalaka Hills $171-176$ Sentinel Butte member, southwestern North Dakota................... 13, 20, 21, 148, 149, 153-161

geochemistry of, Mendenhall area...... 115 Golden Valley formation, North Dakota.

164

Hell Creek formation, northwestern South Dakota................. 13, 16, 21

Ludlow member, northwestern South Dakota $. . . . . . . . . . . . . .13,17,21,41,43,44$ Tongue River member:.... 13, 19, 21, 64, 65, 68 weathered, Mendenhall area......... 107-108,116 Lignite bed $B$.............................. 15 C. D. $E$. $5 \ldots \ldots \ldots$ Lignite beds, Mendenhall area. . . Lignite zones, Ekalaka Hills................... 177 Limestone, freshwater............ 18, 20,151, 229, 233 marine, Fall Creek area......... 260, 261, 262, 290 marine, Goose Creek district. 220, 222, 229, 233, 248 uranium-bearing, Fall Creek area......... 270 Lithology, lignite-bearing rocks.............. 13-14 Lodgepole area, South Dakota.............. 14,45,65 Lohman, K. E., work cited................. 227-229 Long Pine Hills........... 12, 14, 20, 21, 24, 28, 46, 176 Ludlow member, Fort Union formation. $15,17,40,62$ Mendenhall area.................... 101-102, 104 Luman No. 1 coal bed, Red Desert area.... 193, 197

\section{$\mathbf{M}$}

Mansfield, G. R., cited.............. 223, 225, 229, 256 Mapel, W. J., and Hall, W. J., Jr., cited...... 236 Marker beds, Fall Creek area.................. 263 McDonald, J. R., cited...................... $\quad 151$ McKensie Butte.............. 40,41 Medicine Pole Hills, N. Dak ........... 14, 43, 65-68 Mendenhall area of the Slim Buttes, Harding

County, S. Dak ................. 97-116 Mendenhall lignite bed..... 104-105, 113, 119-127, 128 Mendenhall mine............ 32-33, 35, 46, 48, 105, 111 Mendenhall rider lignite bed, Mendenhall area................. 104, 108, 119, 128-129

Menefee formation, La Ventana Mesa area .. 297,300 Mesaverde group, La Ventana Mesa area...- 297 Microbial decay, relation to uranium extrac-

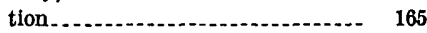

Mineralizing solutions, conduits for........... 4 tuffaceous sandstone of Arikaree formation................................... 24-25 uranium, coating fossils, Mendenhall area. $\quad 103$ in coal................................. 1, 7, 302 in lignite ................ 28, 29, 30,41,43 in volcanic rocks........................ 4 in White River group............ 36 Mines, lignite, Goose Creek district........-... $\quad 240$ Molybdenum, relation to uranium.......... 7 , $29,68-69,106,273$ Moore, G. W., work cited_._._._._. 165, 251, 255, 302 and Gill, J. R., cited 
Nelson, J. M., and Slaughter, A. L., work cited.

Nickel.

North Cave Hills $21,42-43$

Nugget sandstone, Fall Creek ares............. 260 Nunn lignite bed. 153,162

\section{0}

Obsị̂dian 229,264

Olesrud lignite bed, Mendenhall area........ 104-105, $108,124-127,131-134$

Origin of uranium in coal, diagenetic theory epigenetic theory... $3,30,31,162,194,275,277,278$ evidence for .......... 31-36, 250-251, 276, 303-304 Goose Creek district..................... 250-251 La Ventana Mesa area.................... 303-304 syngenetic theory evidence for

Origin of uranium in lignite, Ekalaka Hills. .- 176-177 Mendenhall area........................... 115-116 Osmond, Kenneth, and Judson, Sheldon, cited 164 Overburden 156-161

\section{$\mathbf{P}$}

Payette formation, Goose Creek district....... 220, $223,224-229,233,239,240,242$

Permeability, relation to distrubution and concentration of uranium 33,35 , $38,43,46,116,163,165,177,193,194$

Peterson limestone, Fall Creek area.

Peterson, V. E., cited.

Phosphorus.

Photomicrographs.

Pierre shale.

Piper, A. M., cited 261

Point Lookout sands area.

Polished sections sandstone, La Ventana Mesa Mesa
$297,300,303$

Ponsford, D. R. A., and Davidson, C. F., cited.

Powder River Basin

Powers, H. A., cited.......................... 25-29

Preuss sandstone, Fall Creek area.............- 260

Progressive downward decrease of uranium... $\quad 65$, $153,162,165,275$

Prospecting for uranium-bearing coal..........- ' $5-7$ Purpose of investigation.............. 59 Quartzite 'Quaternary deposits.......................... 28

\section{$\mathbf{R}$}

Radioactivity, coal of La Ventana Mesa...... White River group and Arikaree formation. rock of dumps of coal prospects, Fall

Creek area.......... 267

Red Desert area, Wyoming................ 6, 181-214

Reserves, uranium-bearing coal and other rocks. See tonnages.

Rhyolite, Goose Creek district...... 220, 222-223, 248 boulders
Ross, C. S., cited........................... 229

Rubenstein, S., Preger, I. A., and Deui,

Maurice, work cited.

Salt Lake formation, Goose Creek district........220, $223,229-237,238,239,240,242,243,250,253$

Sampling, Fall Creek area .................. 267;271

Red Desert area....................... 183

Sandstone . . . . ................... 14, 16, 17, 18, 19, 20, $23,28,42,151,152,260,261,262,264,297,299,300$

Arikaree formation....................... 45

composition ............................. 25-26

as conduits for uranium-bearing solutions. 4 ,

$33,194,302$

basal Chadron, Mendenhall area ......... 106 carbonaceous............................. 37

Goose Creek district._....... 223, 224, 225, 229, 242

Ludlow member........................... 47

possible uranium deposits in.............. 47, 170

Red Desert area..................... 185, 193, 194

Tongue River member. .................... 44

tuffaceous... 20, 23, 25, 45, 62, 102-104, 115, 170, 176

uranium-bearing, La Ventana Mesa ..... 298, 300 .

South Dakota............................ 36, 47

San Miguel Mine Canyon, La Ventana Mesa

area

Schopf, J. M., work cited................ 165

and Gray, R. J., cited..............165; 218-219

Schrader, F. C., cited........................ 223

Semiquantitative spectrographic analyses...... . 7 ,

$26,27,29$

Sentinel Butte area, North.Dakota............ 154

Sentinel Butte member, Fort. Union forma-

tion ......................... 15, 20, 151

Shale_...... 17, 18, 20, 40, 260, 261, 262, 263, 264, 281, 299

carbonaceous......................... 20, 297

Goose Creek district... 225, 233, 240, 241, 243, 250

uranium-bearing, LaVentana Mesa.. 298, 300

clay ................................. 105, 151

coaly, uranium-bearing, Fall Creek area.. 262 ,

$267,270,271-272,275,278,282$

Red Desert area

tuffaceous, Goose Creek district. ........ 225 Shape of uranium deposits in relation to origin. 276 Shards, glass............................. $2 n, 27$ Sharp, R. P., cited...................... 224, 240 Shearing, Fall Creek area....................... 270 Short Pine Hills.................... 12, 13, 14, 21, 24, 28 Siltstone................. 107, 157, 158, 162, 185, 261, 281 Slaughter, A. L., and Nelson, J. M., work cited............................ 2, 147 Slide Butte lignite bed, southwestern North Dakota ...-. 154, 156-157, 159-161, 162-163 distribution of uranium.in.............. 162-163 relation of ash to uranium content......... 171 Slide Butte, N. Dak $\ldots . . . . . . . . . . . . . . . . .157,161$ Slim Buttes, the, S. Dak. (See also Bar H and Mendenhall areas) .............. 12, 14 , $22,23,24,25,27,28,30,35,37,45-46,102$

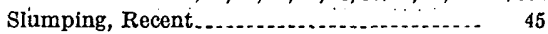
Sodium Solubility, uranium in ground water......... 7 
Page
Pourats Ekalaka Hills_. . . .

La Ventana Mesa area................... 303

Source of uranium, relation of weathering of volcanic ash.

silicic volcanic material

Sourdough No. 2 coal bed, Red Desert area, distribution of uranium............ 193

South, Cave Hills ....................... 21, 40

Specimens, hand, Arikaree formation......... 25

Springs............................................. 45

uranium content, Ekalaka Hills........- 177

uranium-content, Mendenhall area... 103, 115

southwestern North Dakota.............. 164

Stratigraphic contral, uranium deposits, La Ventana-Mesa.................. 301-303

Stratigraphic sections, Bear River formation,

lower part

upper part............................. 269, 270

Stratigraphic sections, Ekalaka Hills, Mont._ $\quad 171$

Dakota sandstone....................... : 299

Payette formation....................... 226-227

Salt Lake formations. ................ 223-235, 242

Tygee sandstone......................... 262

Wayan formation, lower part............. 269

Strippable lignite................ 48, 69, 70, 111, 162, 167

Structural control, uranium deposits, La Ventana Mesa.................. 300

synclines_............................... 301

joints................................ 301, 302, 303

tent-shaped thickening of beds........... 302

Structure, Bar H area, South Dakota......... $\quad 62$

Ekalaka Hills.......................... 169

Fall Creek area....................... 265, 266

Goose Creek district...................... 238-240

La Ventana Mesa...................... 296

Mendenhall area........................... 104

Red Desert........................... 186-194

Structure, regional, northwestern South Dakota..

Structure, regional, southwestern North Da-

kota.................................. 152

Stump sandstone, Fall Creek area............. 260

Synclines, Goose Creek district..... 238, 239, 243, 251

$\mathbf{T}$

Table Mountain

Taylor, D. W., work cited...................... 236

Terrace deposits............................ 108, 152

Tertiary rocks, Ekalaka Hills................. 169-171 rocks of Fall Creek area. ............ 260, 261, 263

Payette formation.................... 225

Salt Lake formation........................ $\quad 229$

Sentinel Butte member..................... 157 uranium-bearing lignite ........... 41, 44, 46, 47-55 uranium-bearing zones, La Ventana Mesa area.

Thin sections, coal

Thrust sheets

Tolmachev, I. M., work cited.
Tongue River member, Fort Union formation Page $17,18-20,64-65,149$

Tonnages, uranium-bearing coal, Red Desert

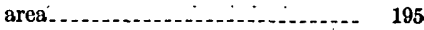
uranium-bearing lignite, Bullion Butte area.

Chalky Buttes area................. 154, 161

Dakotas and Montana............... 49-51,69

Ekalaka Hills. . . . . . . . .

HT Butte area................... 157, 161

McKensie Butte .................... 42

Mendenhall area...................... 111-112

North Cave Hills........................ 42

southwestern North Dakota............. 161

Slim Buttes. .................. 46, 111-112

South Cave Hills.................... 42

Table Mountain

uranium-bearing rock, Fall Creek area_ 281-283

Goose Creek district................... 249, 251

La Ventana Mesa area.................. 307

Topography, areas of uranium-bearing lignite_ 40 ,

Torbernite . 42,148

Transition zone, Wasatch-Green River forma-

tions, Red Desert area.......... 186, 188

Transportation of uranium by ground water.. 4,

Travertine, radioactive $\quad 33,176$

Trenching ........................................... 266

Tuff -...- 303

uranium-bearing.......................... 176

welded, Goose Creek district............. 223,

$229-230,232,238,239$

Tuffaceous rocks. ..................... 24, 25-27, 31

leaching of uranium, Mendenhall area _ 115-116

Twin Creek limestone, Fall Creek area

Tygee sandstone, Fall Creek area............... 261

\section{U}

Unconformity, contact of Bear River and Wayan formations................. 263

pre-Arikaree, Ekalaka Hills............. 169, 170

pre-Arikaree, southwestern North Dakota. 152 pre-Oligocene, at base of White River group.................................. 14,

relation to uranium-bearing lignite...... 21, $31-32,37,39,46,164$

Mendenhall area.................. 101, 102, 110

Uranium, affinity for carbonaceous material.....2, 29,

165,275

average concentration, earth's crust........ $\quad 115$

average concentration, sedimentary rocks. 115

concentration in carbonaceous material,

La Ventana Mesa.............. 302

concentration in lignite, Ekalaka Hills...-. 176

factors controlling occurrence in lignite,

Mendenhall area................... 115

fixation in coal.......................... 273

Uranium-bearing strata, Fall Creek area...... $\quad 270$

Uranium-bearing zone, La Ventana Mesa.. 298, 299

Uranium-bearing zones, hogback area near La

Ventana Mesa..................... 300 
Uranium content, Arikaree formation, Mendenhall area.................... 104,115

Brule formation, Mendenhall area...... 103-104 carbonaceous shale, Fall Creek area. ...... 267

La Ventana, Mesa area $298,299,300$

Chadron formation, Mendenhall area.... 103,

104,115

coal, western United States $267,270,271$

Fall Creek area

$298,300,301$

La Ventana Mesa area.

193

coaly shale, Fall Creek area............. 271, 275 concretions in sandstone, Ekalaka Hills .- 170 coal ash, Fall Creek area. . . ................ 267

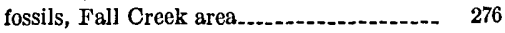
ground water............................. 4, 36

Arikaree formation, Ekalaka Hills.....- 179

Chadron formation................... 164

Mendenhall area.

103,115

lignite

Ekalaka Hills

$34,35,47-55$

northwestern South Dakota

176-179

southwestern North Dakota

63,65

$153,154,156,157,161,163$

microscopic coal constituents.

relation to coal ash

163

relation to coal permeability

relation to mineral matter.

sandstone of La Ventana Mesa area......-.

source beds......................................

springs, Mendenhall area

uncoalified wood.

water samples.

Uranium minerals, in coal

\section{V}

Vanadium

Volcanic fows, Goose Creek district

$7,29,68,79$

Volcanic material, Arikaree formation

Mendenhall area. 24,36

White River group.

101,104

rocks

tuffs, Goose Creek district
W

Page

Walker, Glen, work cited..................... $\quad 97$

Wasatch formation, Red Desert area_....... 184-185

key zones................................... 185

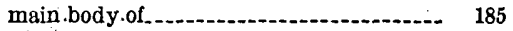

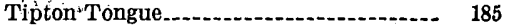

Water samples, as guide to uranium-bearing

coal

northwestern South Dakota................ 22, 36

uranium content, Ekalaka Hills........... 183

Goose Creek district.................. 251-252

Water table, perched, Slim Buttes---- 20-22, 114-116

Wayan formation, Fall Creek area.......... 263,

$264,265,266,268,281$

White River group...................... 14, 15, 20-23,

$24,37,42,46,59,62,65$, , 102-103, :115, 151

analyses of

water samples from

Wilder lignite zone, Ekalaka Hills...... 177, 176-178

Worthington carbonaceous zone.............. 242

Wood, H. E., cited....................... 22, 23

Wyant, D. G., and Beroni, E. P., cited...... 2,27

Wyant, D. G., Beroni, E. P., and Gott, G. B. cited.

$\mathrm{Y}$

$Y$ lignite bed, Mendenhall area

105

$$
\text { Z }
$$

$Z$ lignite bed, Mendenhall area. 101,104

Zeller, H. D., Denson, N. M., and Bachman,

G. O., work cited....... 3

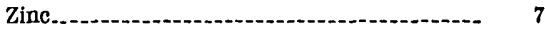

Zone, uranium-bearing, La Ventana Mesa. 298-300 Fall Creek district....................... 266,

$267,268,269,279,280,281$ coal-bearing, Bear River formation, Fall

Creek area....................... 265, 266

Zones, carbonaceous, Goose Creek district...- 238,

242-243, 249

coal, Red Desert area.................-..- 188

lignite, Ekalaka Hills...................... 171 